$$
\text { UNIVERSIDADE DE SÃO PAULO }
$$

FACULDADE DE FILOSOFIA, LETRAS E CIÊNCIAS HUMANAS DEPARTAMENTO DE LETRAS CLÁSSICAS E VERNÁCULAS ÁREA DE FILOLOGIA E LÍNGUA PORTUGUESA

\title{
A DESCORTESIA NA REDE SOCIAL FACEBOOK
}

\author{
Katiuscia Cristina Santana
}


UNIVERSIDADE DE SÃO PAULO

FACULDADE DE FILOSOFIA, LETRAS E CIÊNCIAS HUMANAS DEPARTAMENTO DE LETRAS CLÁSSICAS E VERNÁCULAS ÁREA DE FILOLOGIA E LÍNGUA PORTUGUESA

\section{A DESCORTESIA NA REDE SOCIAL FACEBOOK}

\section{Katiuscia Cristina Santana}

Tese apresentada ao Programa de Pós-Graduação em Filologia e Língua Portuguesa, do Departamento de Letras Clássicas e Vernáculas da Faculdade de Filosofia, Letras e Ciências Humanas da Universidade de São Paulo, para obtenção do título de Doutor em Letras.

Orientador: Prof. Dr. Luiz Antônio da Silva 
Autorizo a reprodução e divulgação total ou parcial deste trabalho, por qualquer meio convencional ou eletrônico, para fins de estudo e pesquisa, desde que citada a fonte.

Catalogação na Publicação Serviço de Biblioteca e Documentação Faculdade de Filosofia, Letras e Ciências Humanas da Universidade de São Paulo

S194d

SANTANA, Katiuscia Cristina

A descortesia na rede social Facebook / Katiuscia Cristina SANTANA; orientador Luiz Antônio da SILVA. - São Paulo, 2019. $262 \mathrm{f}$.

Tese (Doutorado) - Faculdade de Filosofia, Letras e Ciências Humanas da Universidade de São Paulo. Departamento de Letras Clássicas e Vernáculas. Área de concentração: Filologia e Língua Portuguesa.

1. INTERAÇ̃̃O USUÁRIO-COMPUTADOR . 2. INTERAÇÃO VERBAL. 3. CONVERSAÇÃO. I. SILVA, Luiz Antônio da, orient. II. Título. 


\section{ENTREGA DO EXEMPLAR CORRIGIDO DA DISSERTACÃO/TESE \\ Termo de Ciência e Concordância do (a) orientador (a)}

Nome do (a) aluno (a): Katiuscia Cristina Santana

Data da defesa: 30/09/2019

Nome do Prof. (a) orientador (a): Luiz Antônio da Silva

Nos termos da legislação vigente, declaro ESTAR CIENTE do conteúdo deste EXEMPLAR CORRIGIDO elaborado em atenção às sugestões dos membros da comissão Julgadora na sessão de defesa do trabalho, manifestando-me plenamente favorável ao seu encaminhamento e publicação no Portal Digital de Teses da USP.

São Paulo, 29/11/2019

Prof. Dr. Luiz Antonio da Silva 
Dedico este trabalho ao professor Hudinilson Urbano, meu inesquecível orientador de mestrado, e ao meu querido marido, Pedro W. Cunha, presente em todos os momentos.

À minha família e à Kamunjin Tanguele, pelo apoio em momentos difíceis. 


\section{Agradecimentos}

O presente trabalho foi realizado com apoio da Coordenação de Aperfeiçoamento de Pessoal de Nível Superior - Brasil (CAPES) - Código de Financiamento 001.

Agradeço aos amigos, Kamunjin, Ana Albarelli, Ramiro e Yedda pelas frequentes discussões teóricas acerca desta pesquisa e pelo apoio durante o meu percurso acadêmico.

Ao professor Dr. Luiz Antônio da Silva pela paciência e oportunidade dada para a realização e o desenvolvimento desta pesquisa.

À professora Dra. Vanessa Martins do Monte pela generosidade em compartilhar experiência e conhecimento durante o meu estágio PAE.

Ao professor Artarxerxes Tácito Modesto pelas importantes contribuições e sugestões dadas na banca de qualificação.

A todos os professores membros da banca de exame de doutoramento.

À professora Claudia Amigo Pino pelo apoio na realização do estágio PAE.

Ao meu querido marido, Pedro W. Cunha, e aos meus pais, pelo incentivo e força em momentos difíceis.

À amiga Sandra Gomes pela amizade e apoio em momentos difíceis.

À vizinha, Cássia, pelo carinho sempre.

A todos os integrantes do grupo Pragmática (inter)linguística, cross-cultural e intercultural. 


\section{Resumo}

O presente trabalho propõe um estudo das estratégias linguísticas e não linguísticas que expressam a descortesia na rede social Facebook, em especial o fenômeno de mock-politeness, doravante pseudocortesia, tal como entende Leech $(1983 ; 2014)$. De acordo com o estudioso, mock-politeness (ou pseudocortesia) é um enunciado ofensivo que pode parecer simpático e polido, mas não o é. Assim como em uma interação face a face, é possível encontrar, no mundo virtual, desentendimentos entre os interactantes. Um dos meios para se evitar um possível conflito na interação é o emprego da cortesia, entendida, em geral, como a adequação social a um contexto determinado que preserva o caráter harmonioso de uma relação interpessoal. A noção de cortesia se desenvolveu com base no conceito de face introduzido por Goffman (1967) e aprofundado, mais tarde, por Brown \& Levinson (1978;1987). Salienta-se que o ritual de cortesia é um aspecto fundamental no processo de interação social, visto que os interactantes procuram evitar, geralmente, qualquer tipo de agressão em relação ao outro. A respeito disso, Brown \& Levinson desenvolveram a ideia de face, entendida como a imagem que se constrói na vida social e que necessita ser defendida pelos interactantes. Por meio dos estudos teóricos de Brown \& Levinson, o estudo da cortesia tem se destacado e se desenvolvido nas pesquisas acadêmicas nos últimos anos, tal como ocorre com o fenômeno da descortesia. Nesta pesquisa, evidenciamos, sobretudo, os tipos de manifestações descorteses na rede social digital Facebook, tal como o uso recorrente da pseudocortesia no mundo virtual. Tal como já exposto, entendemos por pseudocortesia a aparente cortesia inserida em um contexto interacional descortês. Levando em consideração as pesquisas já desenvolvidas a respeito da teoria da preservação das faces e a respeito da cortesia, a pesquisa busca fazer uma releitura dos estudos de Leech (1983;2014) e Grice (1982 [1975]), tendo como embasamento teórico a Análise da Conversação, a Pragmática e a Sociolinguística Interacional na análise do corpus escolhido para o estudo, e a Teoria da Enunciação para o estudo da organização enunciativa na rede social digital. Além do uso de recursos verbais, apontam-se os usos de elementos visuais, tais como memes e emoticons como principais estratégias de (des)cortesia utilizadas pelos interactantes na interação virtual. Para o estudo do corpus, serão analisados aproximadamente quinhentos comentários de um grupo da Faculdade de Filosofia, Letras e Ciências Humanas da Universidade de São Paulo. Espera-se que esta análise possa contribuir para o desenvolvimento teórico das interações em meios digitais, em especial, para o estudo de estratégias da descortesia em rede.

Palavras-chave: descortesia; rede social digital; Análise Conversacional; interação; cortesia. 


\section{ABSTRACT}

The present work proposes a study of the linguistic and non-linguistic strategies that express the impoliteness in the social network Facebook, especially the phenomenon of mock-politeness, henceforth pseudocortesia, as understood by Leech $(1983,2014)$. According to the scholar, mock-politeness (or pseudopoliteness) is an offensive statement that may seem sympathetic and polite, but it is not. As in a face-to-face interaction, it is possible to find, in the virtual world, disagreements between the interactants. One way to avoid a possible conflict in interaction is the use of politeness, generally understood as social adequacy to a given context that preserves the harmonious character of an interpersonal relationship. The notion of politeness developed on the basis of the concept of the face introduced by Goffman (1967) and further elaborated later by Brown \& Levinson (1978; 1987). It is emphasized that the politeness ritual is a fundamental aspect in the process of social interaction, since the interacting ones try to avoid, generally, any type of aggression with respect to the other. In this respect, Brown \& Levinson developed the idea of face, understood as the image that is built in social life and that needs to be defended by the interactants. Through the theoretical studies of Brown \& Levinson, the study of politeness has stood out and developed in academic research in recent years, as with the phenomenon of impoliteness. In this research, we highlight, above all, the types of impoliteness manifestations in the digital social network Facebook, such as the recurrent use of pseudo-politeness in the virtual world. As already explained, we mean by pseudo-politeness the apparent politeness inserted in an impoliteness interactional context. Taking into account the research already developed regarding the face preservation theory and politeness, the research seeks to reread the studies of Leech $(1983,2014)$ and Grice (1982 [1975]), having as theoretical background the Conversational Analysis, Pragmatics and Interactional Sociolinguistics in the analysis of the corpus chosen for the study, and Enunciation Theory for the study of enunciative organization in the digital social network. In addition to the use of verbal resources, the use of visual elements such as memes and emoticons as the main strategies of (im) politeness used by the interactants in the virtual interaction are pointed out. For the study of the corpus, almost five hundred comments from a group of the Faculty of Philosophy, Letters and Human Sciences of the University of São Paulo will be analyzed. It is hoped that this analysis may contribute to the theoretical development of interactions in digital media, especially for the study of network impoliteness strategies.

Keywords: Impoliteness; digital social network; Conversational Analysis; interaction; politeness. 


\section{SUMÁRIO}

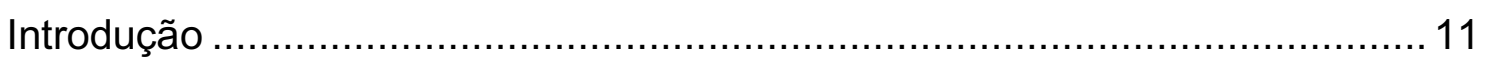

CAPÍTULO 1: A (DES)CORTESIA LINGUÍSTICA ….................................... 16

1.1 As contribuições dos Filósofos da Linguagem no estudo da cortesia

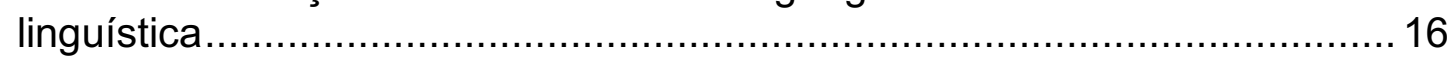

1.2 A abordagem interacionista: Goffman (1967); Brown \& Levinson (1987

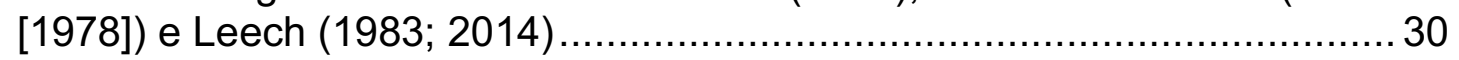

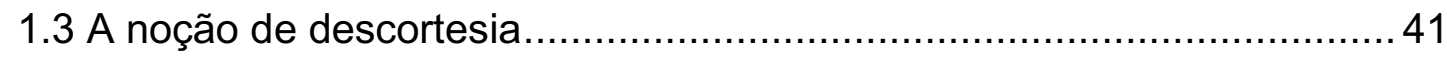

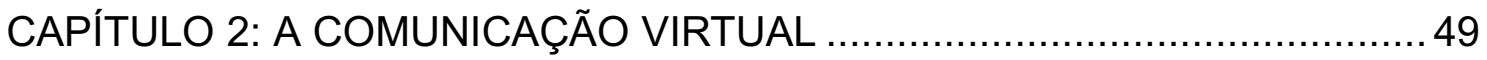

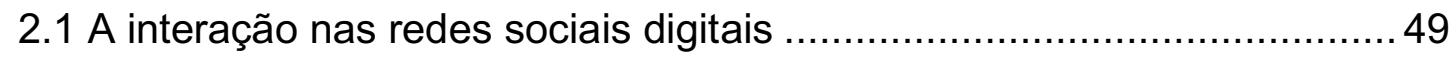

2.2 A enunciação na rede social digital Facebook .....................................54

2.3 A interação não-verbal ou híbrida: Memes, emoticons e Gifs ................. 65

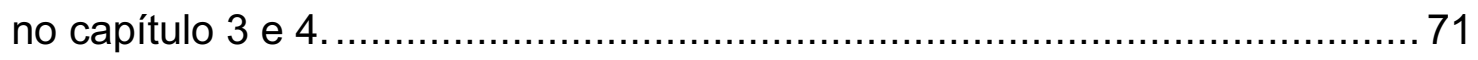

CAPÍTULO 3: AS MANIFESTAÇÕES DESCORTESES NA INTERAÇÃO ......72

3.1 Tipos de descortesia na interação virtual ........................................... 72

2.2 Atenuadores e intensificadores da descortesia ..................................... 94

2.3 O fenômeno da ironia e do gracejo na interação................................... 123

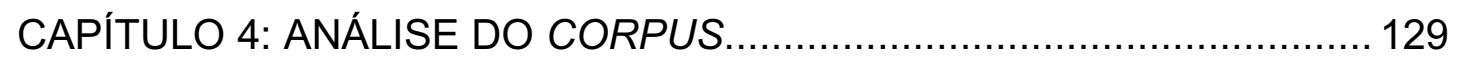

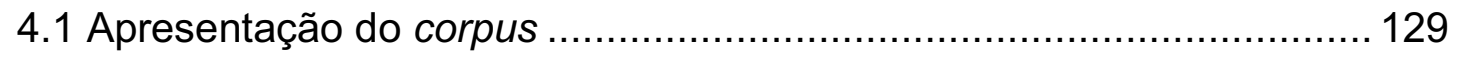

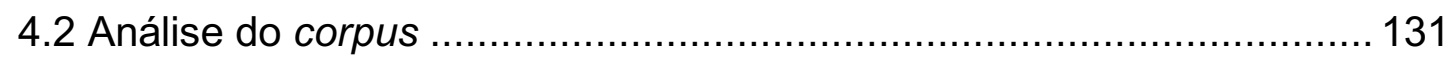

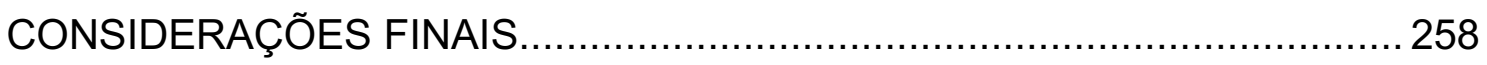

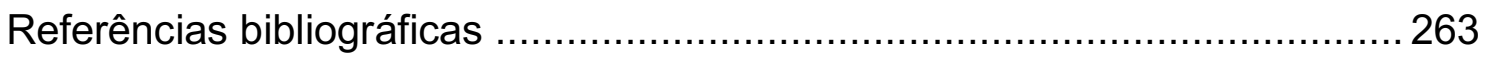




\section{LISTA DE TABELAS}

Tabela 1: As Estratégias Gerais da Cortesia de Leech (2014, p. 91) traduzida e adaptada.

Tabela 2: As categorias de condições de infração da Estratégia Geral da Descortesia de Leech, traduzida e adaptada (2014, p. 221).

Tabela 3: As categorias de condições de infração da estratégia geral da descortesia no Inquérito 1

Tabela 4: As categorias de condições de infração da estratégia geral da descortesia no Inquérito 2

Tabela 5: As categorias de condições de infração da estratégia geral da descortesia no Inquérito 3

Tabela 6: As categorias de condições de infração da estratégia geral da descortesia no Inquérito 4

Tabela 7: As categorias de condições de infração da estratégia geral da descortesia no Inquérito 5

Tabela 8: As categorias de condições de infração da estratégia geral da descortesia no Inquérito 6

Tabela 9: As categorias de condições de infração da estratégia geral da descortesia no Inquérito 7 .

Tabela 10: As categorias de condições de infração da estratégia geral da descortesia no Inquérito 8 


\section{Introdução}

A relação com o outro sempre causa um problema, nunca é um dado natural. Temos dificuldade em aceitar que o outro seja um problema, e é por isso que nos protegemos sob rituais de civilidade, como as fórmulas de polidez, de saudação e as normas sociais de saber viver. (Patrick Charaudeau) ${ }^{1}$

O advento da internet e de novas formas de comunicação têm mudado a relação estabelecida entre o sujeito e o mundo. Neste sentido, as redes sociais na internet surgem como uma nova possibilidade de participação e interação social, onde tempo e espaço se confundem. Devido a essas características, esta pesquisa tem como objetivo apresentar as especificidades discursivas da enunciação na rede social digital Facebook. Trata-se de uma rede social virtual que conecta pessoas e empresas do mundo inteiro por meio de perfis institucionais e perfis de pessoas. Os usuários criam um perfil e produzem conteúdo, e a rede social digital possibilita que os participantes publiquem ou republiquem mensagens pessoais, notícias ou imagens. Desta maneira, as redes sociais virtuais criam um ambiente cooperativo de interação, onde a troca comunicativa e a construção de laços sociais são instauradas.Partindo da premissa que a comunicação mediada pelo computador se assemelha à conversação real, estabelecemos a organização do processo enunciativo entre um emissor e um receptor virtual com base nos estudos da Análise da Conversação e da Pragmática. Observamos que a conversação virtual também é guiada por rituais comunicativos semelhantes à conversação face a face, entretanto são mais dependentes do contexto específico de interação, uma vez que a interpretação de uma mensagem depende do contexto específico de comunicação e do efeito causado no receptor. O receptor virtual deve, assim, mobilizar sua competência linguística e cultural para interagir de maneira bemsucedida na rede social digital.

Devido à presença de várias culturas pelo mundo, não há uma teoria universal a respeito da cortesia. Traçaremos um panorama de diferentes

\footnotetext{
${ }^{1}$ CHARAUdEAU, 2016, p. 26
} 
perspectivas de vários teóricos para, enfim, adotar a noção de cortesia e descortesia que julgamos adequada para nossa pesquisa.

\section{Justificativa}

As manifestações de cortesia e de descortesia têm sido estudadas tanto no âmbito da conversação face a face quanto na conversação virtual. No entanto, percebe-se ainda uma lacuna nos estudos no que diz respeito à descortesia, sobretudo no mundo virtual. Nota-se a ausência de um estudo dos elementos verbais e dos não-verbais nas interações on-line que a desencadeiam. Os exemplos transcritos neste trabalho, provenientes da rede social Facebook, reproduzem a escrita original do emissor e do receptor. Como critério de escolha do corpus, buscou-se exemplos de descortesia em um grupo da rede social Facebook e, com base nele, percebeu-se a necessidade de rediscutir as questões das Máximas de Grice (1982 [1975]) e do Princípio de Cortesia e das Estratégias Gerais da Cortesia de Leech (1983; 2014) nos exemplos selecionados para este trabalho, uma vez que se trata de um ambiente conversacional virtual, guiado também por rituais comunicativos. Muitos exemplos recolhidos para o corpus colaboram para o estabelecimento e enriquecimento de novas ideias e conceitos.

Assim, são necessárias novas reflexões a respeito dos estudos de Leech (1983; 2014) e um estudo dos elementos verbais e não-verbais presentes nas interações conflituosas virtuais, levando sempre em consideração o contexto comunicativo em que elas acontecem. Com base no levantamento realizado na Plataforma Sucupira, percebeu-se que os estudos pragmáticos enfatizaram a cortesia e a cooperatividade em vez da hostilidade nos atos de fala.

\section{Objeto e Objetivos}

Os objetivos gerais deste trabalho serão situar os conceitos teóricos relacionados ao estudo da cortesia e da descortesia na interação social, propondo uma análise das manifestações descorteses em um grupo na rede social digital Facebook. Os objetivos específicos consistem em investigar e sistematizar as estratégias de ataque e defesa dos interactantes em casos de descortesia virtual no grupo objeto de nosso estudo no Facebook. Por meio da Estratégia Geral de Cortesia de Leech (2014) e das Máximas de Grice (1982 
[1975]), além de fatores socias desencadeadores de descortesia elencados por Fuentes Rodríguez (2013) e Kaul de Marlangeon (2012), observaremos como recursos verbais ou não-verbais são usados na rede social digital para gerar uma intenção e um efeito descortês entre um locutor e um interlocutor. Por meio do contexto específico de cada interação exemplificada na teoria e no corpus coletado para este trabalho, identificaremos quais são as situações em que a pseudocortesia e a pseudodescortesia se manifestam por meio da interação virtual na rede social digital em questão.

\section{Materiais e Métodos}

A Pragmática fornecerá o suporte teórico para esta pesquisa, já que ela considera a linguagem como uma ação e como produto de uma intenção dentro de um contexto sociocultural e situacional específico. Para compreender a dinâmica de uma conversação virtual, encontramos amparo teórico na Teoria dos Atos de Fala, de Austin (1990 [1969]) e de Searle (2002 [1979]). Austin (1990 [1969]) sustenta que a linguagem não só descreve a realidade, mas também sinaliza a intenção do emissor. Searle (2002 [1979]) acrescenta que uma proposição pode ser interpretada diferentemente de um sentido literal, de acordo com as circunstâncias e propósito da enunciação, tais como os atos de fala indiretos, como a metáfora e a ironia.

Esses estudos podem colaborar com a teoria da descortesia, já que um simples enunciado pode ser interpretado como uma ordem, uma ameaça ou uma intimidação, de acordo com o contexto de interação. Uma enunciação descortês, por exemplo, pode estar diretamente ligada à intenção comunicativa ofensiva ou ameaçadora por parte do emissor. Desta forma, o fenômeno da descortesia está ligado à noção de contexto, que incluem também aspectos extralinguísticos, além das particularidades dos interactantes no ato de fala.

Com base nos estudos de Austin (1990 [1969] e Searle (2002 [1979]) e levando em consideração a situação comunicativa dentro de um contexto específico, consideramos neste trabalho o termo atos de fala descorteses em situações onde a descortesia impera em um ato ilocutório. Este conceito leva em consideração a explícita intenção do locutor ou interlocutor no ato comunicativo de ser descortês e isso, muitas vezes, gerará também por parte do interlocutor um ato perlocutório descortês. Logo, os atos de fala descorteses afetam tanto o 
emissor quanto o receptor. Sendo assim, o estudo dos atos de fala nos traz as ferramentas de análise dentro da interação conflituosa. É necessário considerar o contexto da situação e os elementos extralinguísticos presentes no ato comunicativo, além do contexto sociocultural, que indica o comportamento adequado ou inadequado de acordo com as circunstâncias da troca comunicativa. Também é possível considerar o contexto sob o enfoque sociolinguista, considerando informações como tempo, espaço, gênero, hierarquia, classe social e idade dos participantes.

Não deixaremos de considerar a importância do significado e o sentido literal do uso do léxico que colaboram no nosso estudo juntamente com a teoria dos atos de fala na identificação do significado intencional do emissor em determinados contextos. O uso de um léxico com uma carga negativa de significado também depende do contexto comunicativo.

Pretende-se fazer uma pesquisa de abordagem qualitativa no corpus selecionado. Depois do levantamento da bibliografia referente ao tema da descortesia e ao da interação virtual, exemplificaremos e explicaremos os elementos verbais e não-verbais desencadeantes da descortesia. Os elementos linguísticos serão classificados por categorias, tais como atenuadores e intensificadores de descortesia. A partir de uma releitura dos estudos de Grice (1982 [1975]) e Leech (1983; 2014), pretende-se discutir o conceito de cooperação linguística e descortesia no mundo virtual, analisando os exemplos contidos no corpus. Elegemos como material de pesquisa aproximadamente quinhentos comentários de um grupo na rede social Facebook para a análise de interações mediadas pelo computador. Todo o material será analisado de forma a considerar os recursos verbais e não-verbais utilizados nas interações de acordo com os aspectos situacionais e temporais.

No âmbito desta pesquisa, objetivamos discutir, sobretudo, a manifestação da descortesia em um grupo na rede social Facebook. Trata-se de um grupo da Faculdade de Filosofia, Letras e Ciências Humanas da Universidade de São Paulo, a FFLCH/USP. Para fins de análise, serão mantidos os prenomes dos participantes, no entanto, ocultaremos os sobrenomes e as fotografias de perfil. Caso a mesma letra se repita na mesma interação, a próxima letra do nome será transcrita. 
O grupo foi criado com o intuito de reunir alunos da faculdade de Letras da USP, ou seja, muitos participantes podem ou não se conhecer pessoalmente, uma vez que a cada ano ingressam mais de oitocentos alunos no curso de Letras, nos períodos matutino e noturno. Atualmente, o grupo conta com aproximadamente doze mil integrantes no ano de 2019. Foram selecionados oito inquéritos que se destacaram pelos diferentes tipos de descortesia estudados nesta pesquisa.Muitos foram extraídos da rede social digital de forma integral, o que justifica a diferença de extensão entre uma interação e outra.

\section{Formas de análise e discussão dos resultados}

O corpus será analisado com a finalidade de encontrar exemplos que estejam de acordo com os parâmetros desta pesquisa. Analisaremos como os elementos verbais e não-verbais são importantes na interação descortês, levando em consideração o contexto situacional da interação virtual. A nossa análise será embasada em Briz (2013), Kerbrat-Orecchioni (2006) e Díaz Pérez (2012), principalmente no que tange à classificação dos operadores pragmáticos de descortesia. Em alguns casos, os operadores deixam clara a descortesia implícita ou agravam a ofensa e o ataque. Levaremos em consideração o uso de um léxico disfemístico, os fatores contextuais e socioculturais, os implícitos, a indiferença ao interlocutor, além da pontuação e das marcações gráficas, como as maiúsculas presentes no suporte escrito da rede social digital.

Buscaremos responder às seguintes questões: 1) Quais são os elementos verbais e não-verbais empregados nas interações que suscitam a descortesia? 2) Quais são os atos de fala mais frequentes que desencadeiam a descortesia no mundo virtual? 3) É possível aplicar as máximas de (des)cortesia de Leech (2014) no mundo virtual? 


\section{CAPÍTULO 1: A (DES)CORTESIA LINGUÍSTICA}

\subsection{As contribuições dos Filósofos da Linguagem no estudo da cortesia linguística}

A conversação é uma atividade linguística rotineira e um ato de interação social. É por meio dela que construímos laços em sociedade, responsáveis pelo estabelecimento da boa convivência entre os seres humanos. Conforme Silva,

Por meio dela, os indivíduos se comportam como seres sociais, isto é,
relacionam-se com outras pessoas e procuram conseguir seus
propósitos, conversando; rompem relacionamentos, conversando ou
deixando de conversar. A conversação possibilita o trabalho
cooperativo e implementa as relações sociais. (SILVA, 2005, p.32)

Logo, a conversação se torna também objeto de estudo, em especial, pelos filósofos da linguagem. Neste sentido, um dos estudos precursores em relação à estrutura conversacional se dá em Grice (1982 [1975]). Ele propõe um modelo para explicar a conversação, sobretudo o tipo de contraste entre a lógica e a inferência.

Grice (1982 [1975]) desenvolveu o Princípio de Cooperação, defendendo que as contribuições conversacionais dos interactantes devem ser adaptadas ao tipo e ao objetivo da troca comunicativa. Ele sustenta que a conversação se estabelece como uma espécie de acordo pelo qual os interlocutores cooperam para que a troca comunicativa seja eficaz e satisfatória. Esse princípio engloba as categorias de quantidade, qualidade, relação e modo. Essas máximas podem ser respeitadas ou não, de forma que conduz a estratégias de cortesia. Cada falante ${ }^{2}$ deve ser consciente de sua posição nesse jogo interacional para que a troca comunicativa seja equilibrada. As máximas de Grice (1982 [1975]) são:

Quantidade: Faça com que a informação fornecida seja suficiente e que ela seja tão informativa quanto o necessário; a informação fornecida não deve ser mais informativa que o necessário.

Qualidade: Faça com que sua contribuição seja verdadeira; a informação fornecida não deve ser falsa; a informação fornecida pode ser provada.

\footnotetext{
${ }^{2}$ Nesta pesquisa, consideramos os termos "falante", "locutor" e "emissor" como sinônimos.
} 
Relação ou relevância: a informação fornecida deve ser coerente e pertinente ao assunto em questão.

Maneira ou modo: seja claro, evite a obscuridade; evite ambiguidade; seja breve; seja ordenado.

Grice (1982 [1975]) também prevê que o falante fará um esforço para responder ao que foi dito, o que ele denomina implicatura. A implicatura é a informação implicada ou inferida pelo interlocutor a partir de um proferimento em uma situação de fala. Seria o equivalente à sugestão e à insinuação na linguagem. A implicatura está na base de um subentendido e, sendo assim, ela é dependente do contexto, uma vez que o interlocutor ${ }^{3}$ deve ser capaz de compreender a informação implícita. De acordo com Armengaud:

A implicatura não tem vínculo nem com os valores de verdade, nem com a forma linguística. Ela não é nem lógica no sentido estrito, nem linguística. É discursiva e contextual. Reside naquilo que é "pensado" a partir, ao mesmo tempo, do que é dito e da situação em que é dito, situação que não é a do falante apenas, mas a situação comum a dois (ou a vários) interlocutores. (ARMENGAUD, 2006, p. 88)

Para Grice (1982 [1975]), há dois tipos de implicaturas, a primeira está restrita ao próprio texto e são denominadas de convencionais e, a segunda, ele denomina de conversacional e está ligada à boa compreensão da mensagem, o que pode mobilizar o conhecimento de mundo e do contexto por parte do receptor. Grice (1982 [1975]) desenvolve o conceito de implicatura pois, para ele, há diretrizes para tornar a conversação eficaz e cooperativa com o uso da língua. Ele estabelece, assim, máximas básicas da conversação para nortear o comportamento dos interactantes a fim de tornar a interação relevante e eficiente. Em relação ao princípio cooperativo, Grice afirma: "[...] faça sua contribuição conversacional tal como é requerida, no momento em que ocorre, pelo propósito ou direção do intercâmbio conversacional em que você está engajado." (GRICE, 1982 [1975]), p. 86).

Para poder interpretar um enunciado, é necessário compreender o efeito que o emissor quer causar em seu receptor. Assim, a decodificação de uma

\footnotetext{
${ }^{3}$ Nesta pesquisa, consideramos os termos "interlocutor", "receptor", "ouvinte" e "destinatário" como sinônimos. Não empregaremos, no entanto, os termos "falante" e "ouvinte" na interação virtual. Os termos "falante" e "ouvinte" são utilizados, neste trabalho, quando se referem aos estudos de interação face a face, pois são termos utilizados pelos principais teóricos abordados nesta pesquisa.
} 
mensagem será bem-sucedida caso o receptor considere toda a situação comunicativa, compartilhe das mesmas informações de seu interlocutor e de sua competência linguística, principalmente em casos em que ocorre o uso de ironia. Isso é muito frequente nas redes sociais digitais, pois, embora tenhamos aspectos da língua oral na escrita, os recursos oferecidos pela rede virtual não suprem totalmente ainda a dinâmica de uma interação face a face. Nesta, os interactantes podem fazer uso tanto de recursos verbais quanto não-verbais, como entonação, gestos faciais e corporais para chamar atenção de seu destinatário. Embora na escrita tenhamos vários recursos gráficos para substituir esses elementos extralinguísticos, em muitos casos, a interpretação de uma mensagem pode não ser bem-sucedida. Pode acontecer de um interlocutor se sentir ofendido mesmo sem que esta tenha sido a intenção do emissor. Neste sentido, Silva afirma:

Quando duas ou mais pessoas se reúnem, diversos podem ser os objetivos que justificam tal interação. Um dos aspectos fundamentais da conversação é a interação comunicativa entre seus participantes. Com esse propósito, os interactantes adotam uma diversidade de atitudes que apontam para diferentes perspectivas com as quais o locutor e interlocutor podem coincidir, aproximar-se ou distanciar-se. $\mathrm{O}$ êxito da comunicação depende da seleção de formas lingüísticas adequadas ao intento ou à situação do interlocutor. (SILVA, 2008, p. 157)

Para Grice (1982 [1975]), o princípio de cooperação consiste em dar sua contribuição de maneira solicitada na troca comunicativa. Nas redes sociais digitais, por sua vez, a cooperação acontece de maneira coletiva, mas, muitas vezes, de forma conflituosa, com desacordos e ameaças verbais. Tendo em vista as peculiaridades das redes sociais digitais, consideramos, nesta pesquisa, que a perspectiva de Grice (1982 [1975]) sobre a cooperação linguística deve ser pensada de outra maneira. Acreditamos que há um trabalho cooperativo entre os interactantes, que se realiza de duas maneiras neste ambiente virtual:

Cooperação positiva: os participantes contribuem na interação, informando ou respondendo às perguntas ou às solicitações dos (inter)locutores. Os participantes respeitam, assim, as máximas de Grice (1982 [1975]). Geralmente, a cortesia acontece em interações em que ocorrem a cooperação positiva.

Cooperação negativa: os participantes não contribuem com os (inter)locutores, esquivando-se do tópico principal das mensagens, muitas vezes, mudando o 
foco de uma pergunta ou de uma solicitação, ou contribuem com os (inter)locutores ao mesmo tempo em que usam a ironia e/ou o sarcasmo. São infrações das máximas estabelecidas por Grice (1982 [1975]). Geralmente, a descortesia acontece em interações cuja cooperação é negativa.

Os participantes que interpretam um enunciado reconstroem o sentido a partir de pistas presentes na interação, mas, em muitos casos, há um problema de mal-entendido na comunicação virtual devido à falta de elementos paralinguísticos no processo de enunciação. Sendo assim, muitos interactantes produzem enunciados com alguma intenção específica, porém, muitas vezes, não gera o efeito esperado no interlocutor. Como a conversação virtual também é cooperativa e coletiva, outros participantes podem colaborar para o bom entendimento da mensagem ou o emissor também pode editar ou reformular a sua publicação para que o processo da troca comunicativa seja bem-sucedida, uma vez que o suporte escrito permite isso.

Ainda em se tratando de elementos linguísticos relevantes nos processos de troca comunicativa, um dos principais estudiosos da intenção do falante foi o filósofo da linguagem, John Austin (1990 [1969]). Seu objetivo não era apresentar uma concepção teórica sobre a natureza e a função da linguagem, mas propor um método de análise de problemas filosóficos do uso da linguagem por ele entendida como forma de ação.

De acordo com Levinson (2007 [1983]), o surgimento da Teoria dos Atos de Fala, de Austin (1990 [1969]), se deve ao momento em que a preocupação da verificabilidade da linguagem estava em seu apogeu. Sendo assim, Austin (1990 [1969]) coloca em seu estudo central, as condições de verdade para a compreensão da linguagem. A publicação de How to do things with words (1969) é considerada um marco nos estudos linguísticos, uma vez que evidencia o valor de ação dos enunciados e elabora a teoria dos atos de fala, embora Austin não tenha sido o primeiro estudioso a afirmar que dizer é realizar uma ação.

Austin (1990 [1969]) sustenta que um grande número de enunciados escapa dessa problemática do verdadeiro e falso, já que há enunciados que realizam uma ação. Por exemplo, se alguém disser "Eu trabalho" e "Eu prometo trabalhar amanhã", temos aí dois sentidos distintos. O primeiro não realiza o ato de trabalhar pelo simples ato de dizer, enquanto o segundo pode ser sincero ou não, mas não pode ser verdadeiro ou falso. Austin (1990 [1969]) se preocupa 
em verificar em sua teoria se as condições de felicidade de um ato de fala foram preenchidas corretamente ou não para que se tenha sucesso nos atos de fala. Para ele, os atos de fala se organizam da seguinte maneira:

a) Ato locucionário - é o ato de dizer algo, produzir uma série de sons e usar morfemas, palavras, sintaxe, semântica, com significado, em uma determinada língua.

b) Ato ilocucionário - é o ato que se realiza ao dizer algo, ou seja, em uma ação há uma intenção.

c) Ato perlocucionário - é o ato que se realiza por dizer algo, ou seja, provocar efeitos na interação por meio do enunciado produzido. Para Austin (1990 [1969]), o perlocutório escapa do contexto essencialmente linguístico, visto que se presume que isso vai gerar uma reação por parte do interlocutor. Exemplos: ficar convencido, emocionado, irritado, emocionado.

Embora Austin (1990 [1969]) tenha feito o estudo de atos de fala em uma época em que não havia ainda a Internet, alguns de nossos exemplos para ilustrar a teoria considerarão o ambiente virtual, objeto de nosso estudo. No exemplo a seguir, nós temos o ato locucionário responsável pela realização do enunciado. $\mathrm{O}$ ato ilocucionário se dá por meio de uma afirmação da locutora $\mathbf{J}$ na rede social Facebook. Por fim, há o ato perlocucionário, onde a locutora $\mathbf{J}$ espera que os participantes da rede reajam à publicação, tal como ocorre. Além dos comentários na rede social digital, é possível mostrar a sua reação em relação ao que foi publicado por meio de símbolos, tais como "curtir", "amar", "dar risada", "ficar surpreso", "ficar triste" e "ficar com raiva", respectivamente.

Figura 1: Reações possíveis dos participantes na rede social digital Facebook
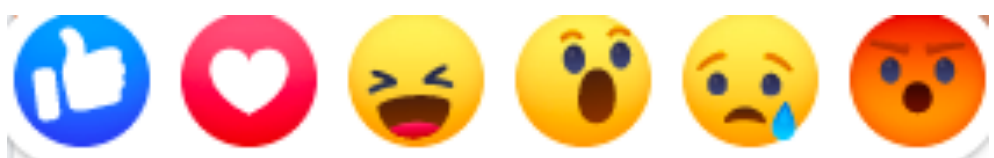

Fonte: Facebook (2019) 
Figura 2: Exemplos de atos ilocucionários e perlocucionários na rede social digital Facebook

$O$ ruim de assistir "A grande Família" depois de velho é que você deixa de achar o Lineu chato e começa a se identificar
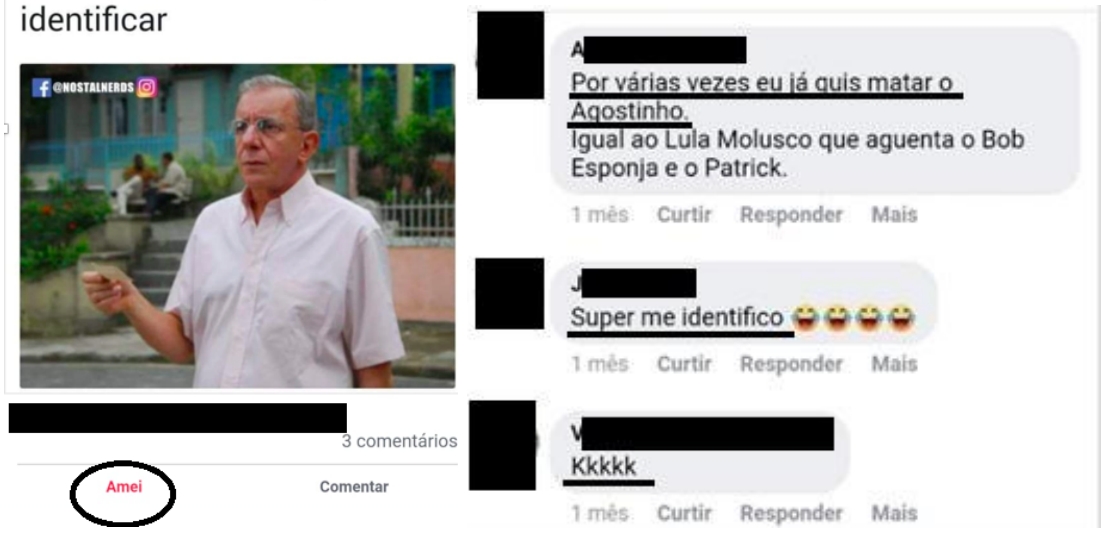

Fonte: Facebook (2018)

Percebe-se que a publicação de $\mathbf{J}$ gerou um efeito nos interactantes $\mathrm{e}$ mobilizou a interação, muitos se identificaram com a enunciação de $\mathbf{J}$.

Além da intenção e do efeito de um enunciado, Austin (1990 [1969]) observa que algumas sentenças não diziam simplesmente coisas, mas também faziam coisas ${ }^{4}$. Tais sentenças receberam a denominação de performativas enquanto declarações e asserções receberam o nome de constatativas, por exemplo. As performativas não podiam ser verdadeiras ou falsas, mas podiam ser felizes ou infelizes, ou seja, não serem bem-sucedidas.

Exemplos:

A) Eu abro a janela. (Constativo)

B) Eu declaro aberta a sessão. (Performativo)

O enunciado "A" descreve um tipo de ação e conforme a ação é executada ou não, podemos dizer se ela é verdadeira ou falsa, enquanto o enunciado "B" executa ou performa uma ação pela enunciação da frase. A ação se torna efetiva se as condições de felicidade estiverem reunidas para a realização do ato.

\footnotetext{
${ }^{4}$ O próprio título da obra de Austin nos dá uma pista sobre seu conteúdo: How to do things with words: Como fazer coisas com palavras, ao pé da letra.
} 
Austin (1990 [1969]) propõe, assim, uma classificação dos valores ilocutórios de uma enunciação, a qual listamos a seguir:

Veredictivos - consistem em pronunciar um julgamento em relação a um valor ou a um fato. São conhecidos também como atos judiciários. Exemplos: desculpar, considerar, calcular, descrever, analisar, classificar, avaliar.

Figura 3: Exemplo de ato veredictivo na rede social Facebook.

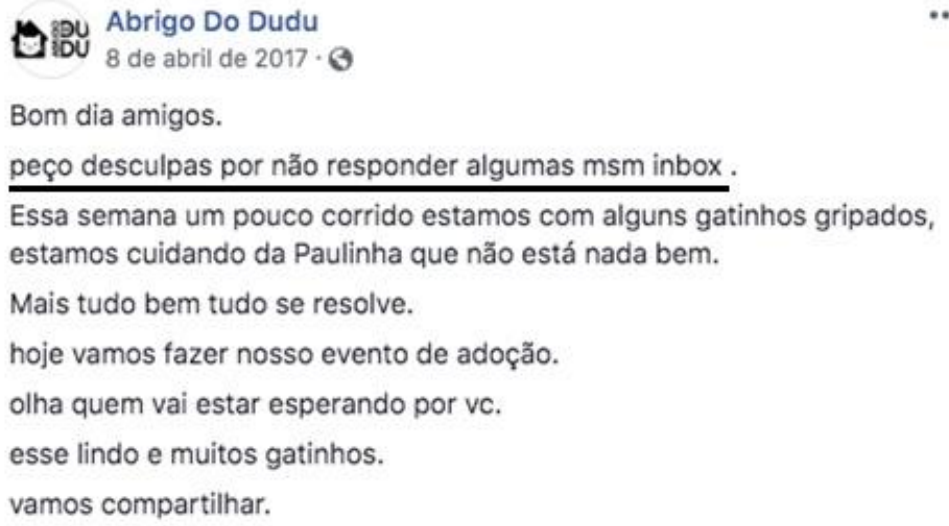

Fonte: Facebook (2017)

Exercitivos - são julgamentos favoráveis ou não. Exemplos: ordenar, condenar, perdoar, defender, suplicar, implorar, aconselhar.

Figura 4: Exemplo de ato exercitivo na rede social Facebook.

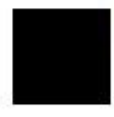

$$
\text { Dr. U }
$$

2 de julho às $19: 38 \cdot 6$

\section{EU CONDENO O USO DE QUALQUER TIPO DE COLÁGENO}

\section{Neste vídeo eu explico porque suplementar com colágeno não traz} nenhum benefício á sua saúde. Você entenderá a fisiologia da absorção intestinal do colágeno e entenderá porque nunca deve gastar dinheiro á toa suplementando colágeno

Fonte: Facebook (2017) 
Promissivos ou comissivos - obrigam o locutor a adotar uma conduta. Exemplos: prometer, garantir, jurar etc.

Figura 5: Exemplo de ato promissivo ou comissivos na rede social Facebook.

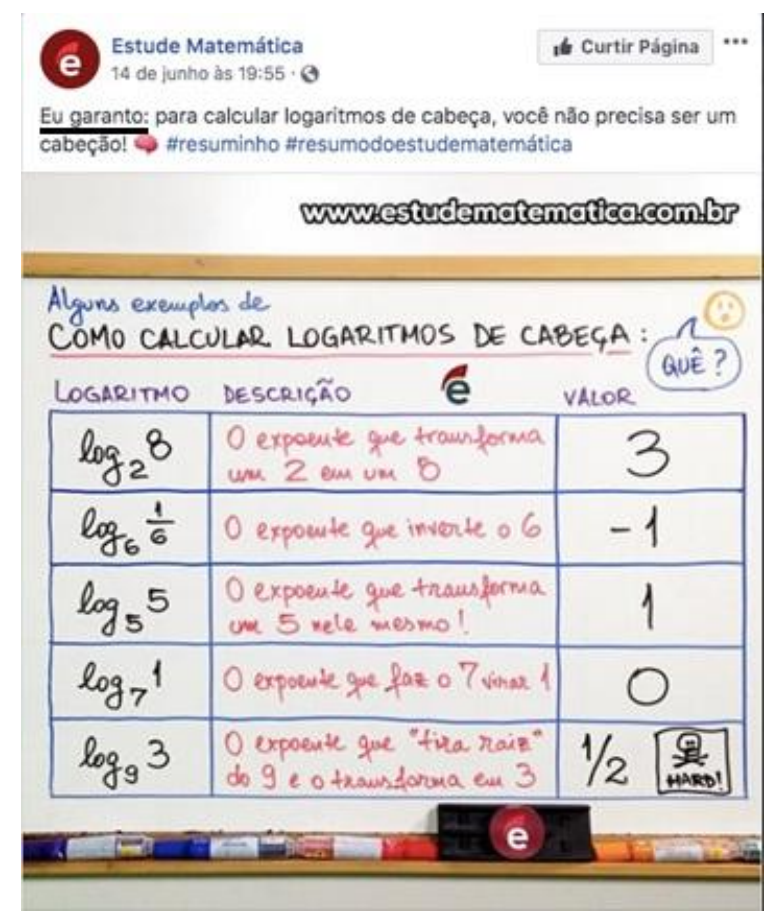

Fonte: Facebook (2018)

Comportativos - trata-se de reações ao comportamento dos outros e expressam uma atitude do locutor em relação à conduta anterior. Exemplos: desculpar, agradecer, deplorar, criticar, felicitar, exprimir condolências.

Figura 6: Exemplo de ato comportativo na rede social Facebook.

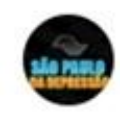

São Paulo da Depressão

29 de setembro de 2016 . 9

Pessoas lindas, perdão por incomodá-los com algo fora dos nossos assuntos porém, na noite passada, recebemos a triste notícia do falecimento de uma amiga do nosso grupo de WhatsApp. RAFAELA SANTOS realizou uma cirurgia delicada ontem pela manhã, ocorreram complicações e ela não resistiu. Nós, da São Paulo da Depressão, expressamos nossas condolências aos familiares e amigos $\mathrm{e}$ lembraremos sempre da Rafaela com esse sorriso alegre, sincero e o jeito brincalhão. Ela passou rápido por nossas vidas porém será sempre lembrada com muito carinho.

Fonte: Facebook (2016) 
Expositivos - expõem uma ideia, conduzem uma argumentação e esclarecem o emprego de termos. Exemplos: afirmar, negar, admitir, explicar etc.

Figura 7: Exemplo de ato expositivo na rede social Facebook.

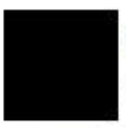

13 de novembro de $2012 \cdot$

Eu admito que na minha casa falta organização, porem tem certos lugares que isso é primodial.

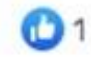

Fonte: Facebook (2012)

O enunciado tem sua Condição de Felicidade preenchida se $\mathrm{o}$ ato de fala é bem-sucedido quando o seu valor ilocutório se realiza perlocutoriamente. Para Austin (1990 [1969]), as condições de felicidade de um enunciado se devem a alguns fatores, tais como: a) as circunstâncias e as pessoas devem ser adequadas; b) o procedimento deve ser executado corretamente e completamente; c) as pessoas devem ter os pensamentos, sentimentos e intenções requeridos conforme especificado no procedimento, e se a conduta consequente é especificada.

Alguns estudiosos criticam a delimitação entre os atos ilocutórios e perlocutórios de Austin (1990 [1969]), visto que, muitas vezes, o perlocutório já se encontra em um enunciado. Leech (1983), por exemplo, propõe um teste como o uso da fórmula "try to" (tentar) para discriminar o que está no campo do ilocutório e do perlocutório.

Exemplos: A) Ela tentou me persuadir para acompanhá-la.

B) Ela tentou me pedir para acompanhá-la.

Em "A", o enunciado não alcançou o efeito perlocutório, enquanto, em "B", é o ato locutório que não ocorreu.

Anscombre (1981), por sua vez, sugere o teste do "talvez".

Exemplos: a) Talvez o que eu vou dizer vá te entristecer, mas João trabalha melhor que você.

b) Talvez eu vá te fazer uma crítica, mas João trabalha melhor que você.

Em "b", o valor da crítica está no ato ilocutório, enquanto, em "a", o fato de entristecer a outra pessoa parece ser mais um efeito secundário da afirmação 
de que "João trabalha melhor que você". Apesar dos testes serem bemsucedidos com alguns tipos de enunciados, o problema ainda permanece com os atos de fala indiretos.

Com base em Austin (1990 [1969]), Searle (2002 [1979]), outro filósofo da linguagem, apresenta outra abordagem das categorias dos atos de fala, em que ele tenta definir as Condições de Felicidade desses atos. Ele estuda também a intenção dos falantes em uma interação e como essa intenção tinha a possibilidade de modificar uma situação em curso. Porém, Searle (2002 [1979]) critica Austin pela classificação de atos ilocutórios e verbos ilocutórios. Ele afirma:

\begin{abstract}
Em resumo, a taxinomia de Austin depara-se com (no mínimo) seis dificuldades inter-relacionadas; em ordem crescente de importância: há uma confusão persistente entre verbos ilocucionários, há sobreposição demais entre as categorias, muitos dos verbos catalogados nas categorias não satisfazem a definição dada para a categoria, e, o que é mais importante, não há princípio consistente de classificação. (SEARLE, (2002 [1979]), p. 18)
\end{abstract}

Searle (2002 [1979]), por sua vez, sustenta que existem cinco classes de atos de fala que os falantes podem executar, tais como:

1) Assertivas - comprometem o falante com a verdade da proposição expressa, tais como afirmar e concluir, por exemplo.

Figura 8: Exemplo de ato assertivo na rede social Facebook.

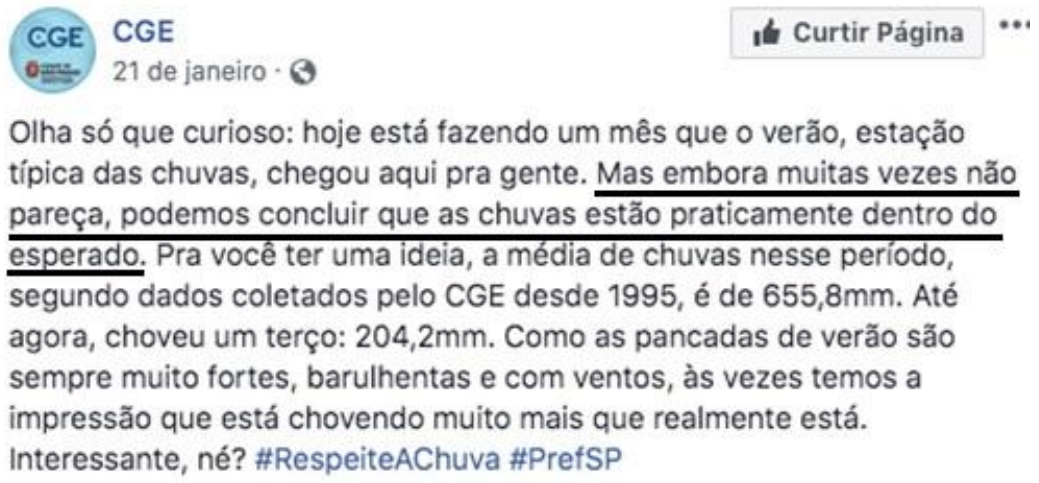

Fonte: Facebook (2019) 
2) Diretivas - tentativas do falante de fazer com que o destinatário faça algo, tais como o ato de pedir e perguntar.

Figura 9: Exemplo de ato diretivo na rede social Facebook.

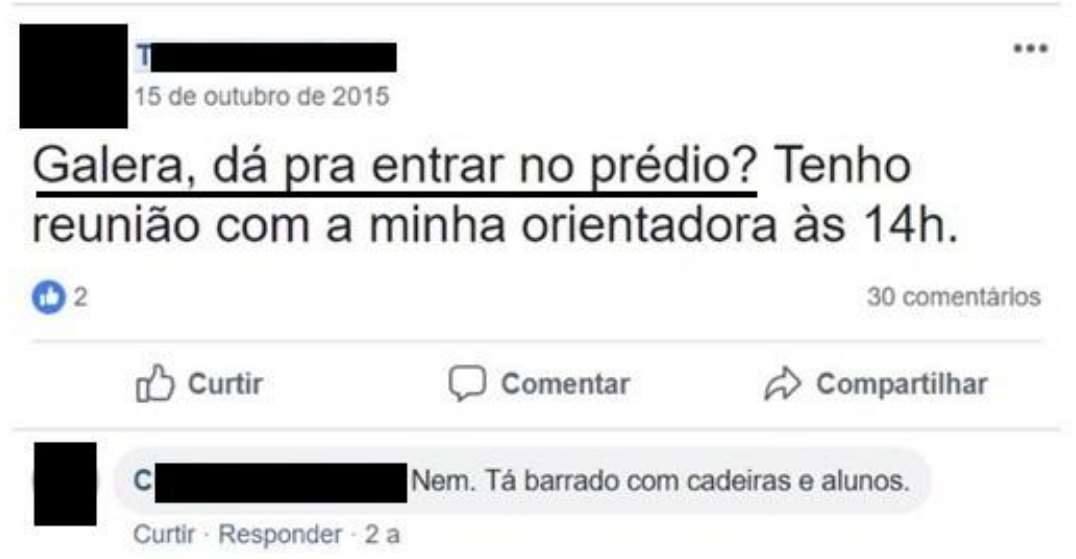

Fonte: Facebook (2015)

3) Comissivas - comprometem o falante com algum curso de ação futura, tais como a promessa, a ameaça e o oferecimento.

Figura 10: Exemplo de ato comissivo na rede social Facebook.

(São Paulo) (ofereço)
Boa tarde, me chamo Gabriella, mãe do Victor de 10 anos e do Pépe,
meu filho de 4 patas,
Sou educadora física e venho oferecer a vocês aulas especializadas sem
nem mesmo sair de casa!
Vou até você, com um preço justo e ótima qualidade!
gestantes, idosos, patologias em geral,
Aulas de pilates, musculação, treinamento funcional entre outras.
Não perca mais tempo e marque agora mesmo uma aula experimental
sem custo!

Fonte: Facebook (2017) 
4) Expressivas - expressam um estado psicológico, tais como os atos de agradecer, desculpar-se, dar as boas-vindas, parabenizar.

Figura 11: Exemplo de ato expressivo na rede social Facebook.

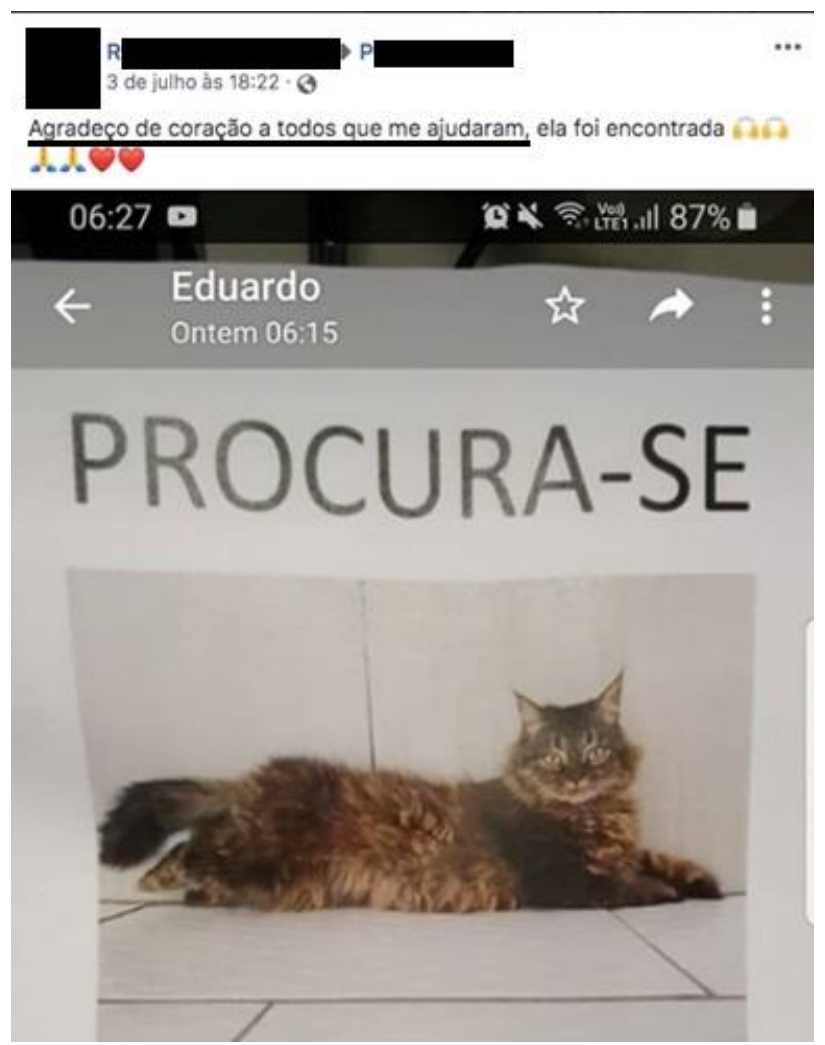

Fonte: Facebook (2018)

5) Declarações - as declarações suscitam mudanças imediatas no estado institucional de coisas e tendem a se valer de instituições extralinguísticas complexas, tais como o ato de excomungar, declarar guerra, batizar, demitir do emprego. Nas redes sociais digitais, devido ao tipo de suporte, não é realizado este tipo de ato de fala, pois ele se dá predominantemente em interações face a face.

Exemplo: Padre em uma cerimônia religiosa no ambiente da igreja: "Eu os declaro marido e mulher".

Além de Searle (2002 [1979]) ter realizado uma nova abordagem em relação ao estudo de Austin (1990 [1969]), ele acrescenta à sua teoria a possibilidade de um ato de fala se realizar de uma maneira indireta, isto é, são atos de fala realizados não mais diretamente, mas sim por outros atos. Uma aparente pergunta pode se comportar, em um determinado contexto interacional, 
como um pedido, ou seja, a intenção do locutor se dá de maneira velada. Segundo Searle (2002 [1979]), alusões, insinuações, ironias e metáforas não são tão simples de depreender. Neste sentido, o autor afirma:

\begin{abstract}
O problema levantado pelos atos de fala indiretos é o de saber como é possível para o falante dizer uma coisa, querer significá-la, mas também querer significar algo mais. E já que a significação consiste, em parte, na intenção de produzir no ouvinte a compreensão, grande parte desse problema é saber como é possível para o ouvinte compreender $\mathrm{o}$ ato de fala indireto quando a sentença que ouve e compreende significa algo mais. (Searle, 2002 [1979]), p. 49)
\end{abstract}

Os atos de fala considerados diretivos por Searle (2002 [1979]), por exemplo, invadem o território pessoal do interlocutor e nesta categoria encontram-se as ordens, proibições, conselhos, pedidos e perguntas. É por meio de um ato diretivo que o locutor espera que seu interlocutor faça coisas. Isso já coloca em jogo a imagem entre locutor-interlocutor, uma vez que o locutor coloca em risco sua autoestima, podendo receber críticas, insultos e discordâncias. A pergunta indireta soa, então, menos agressiva e mais polida que uma pergunta direta, uma vez que pressupõe que o interlocutor pode saber, ou não, respondêla. Daí a importância de um trabalho cooperativo na troca comunicativa, uma vez que o interlocutor deve ter a habilidade de fazer inferências a partir das pistas de contextualização que o locutor oferece na interação e ainda compartilhar informações prévias. Ainda para Searle:

(...) em atos de fala indiretos, o falante comunica ao ouvinte mais do que realmente diz, contando, com a informação de base, linguística e não linguística, que compartilhariam, e também com as capacidades gerais de racionalidade e inferência que teria o ouvinte. (SEARLE, 2002 [1979]), p. 50)

Com o advento dos estudos interacionistas, sustenta-se que a linguagem é um meio de influenciar a conduta do seu interlocutor na troca comunicativa, além de ser um trabalho cooperativo entre locutor e interlocutor, com a devida alternância de papéis entre eles. Por meio dos estudos dos atos da linguagem, percebe-se que muitos atos de fala são empregados de maneira indireta, a fim de se evitar um ataque à imagem do interlocutor e, consequentemente, um conflito na interação. Nossa tarefa será estudar essa abordagem dos atos indiretos em um contexto on-line, onde, muitas vezes, não há o suporte paralinguístico e extralinguístico entre os interactantes da rede e nem sempre os participantes das redes sociais digitais se conhecem entre si. Desta forma, os 
atos indiretos, em vez de serem uma estratégia de cortesia, tornam-se, em muitos casos, uma estratégia de ataque. Metáforas e ironias nem sempre são compreendidos de imediato na rede social digital e, em muitos casos, o interlocutor se encontra em uma posição vulnerável, dependente do emissor para o esclarecimento do enunciado ou de outros participantes da rede social digital que conseguiram inferir o significado do enunciado em questão.

Apesar da taxinomia ${ }^{5}$ defendida por Searle (2002 [1979]) já demonstrar um avanço nos estudos de Austin (1990 [1969]), ela ainda não é definitiva e deve ser repensada constantemente, ainda mais atualmente, em um contexto on-line. Reconhecemos a importância desses inventários de Austin (1990 [1969]) e Searle (2002 [1979]) e enfatizaremos, no nosso trabalho, que estamos cientes da grande diversidade que os atos de fala nos fornecem e que nem sempre é possível rotulá-los todos. É necessário sempre considerar-se o contexto em que um enunciado é inserido para que sua interpretação e seu efeito sejam bemsucedidos. Os atos de fala fazem parte, inclusive, do cotidiano das pessoas nas interações digitais. É recorrente, por exemplo, nas redes sociais digitais o emprego dos atos de fala indiretos. Nelas, por exemplo, um enunciado pode parecer uma pergunta como ato ilocucionário central, entretanto, pode possuir um outro valor ilocucionário principal, sendo a pergunta um ato de fala secundário. $O$ contexto pode ajudar na compreensão da interação, em casos como esse de indiretividade, mas, em outros, a falta de recursos paralinguísticos, como gestos e entonações no suporte escrito pode ser ainda um obstáculo para a compreensão efetiva de um enunciado. Percebeu-se, entretanto, que o caráter indireto de alguns enunciados na rede social digital Facebook suscitou, em muitos exemplos, manifestações descorteses devido a mal-entendidos e/ou provocações irônicas, tal como desenvolveremos nos capítulos a seguir.

Apesar de Austin (1990 [1969]) não ter se aprofundado nos atos perlocutórios, acreditamos que o efeito de um ato ilocutório é o mais marcante em atos de descortesia motivada e imotivada, ou seja, atos de descortesia propositais ou não. Mesmo alguns atos ilocutórios aparentemente desprovidos

\footnotetext{
${ }^{5}$ Neste trabalho, optou-se por usar o termo "taxinomia", em vez de "taxonomia", devido à tradução da obra de Searle (2002 [1979]), no Brasil, em que o termo "taxinomia" foi adotado.
} 
de força ${ }^{6}$, tais como interjeições, uso de formas de tratamento e saudações, cumprem um papel importante na interação, como atenuantes ou intensificadores da descortesia.

Apesar do inventário dos dois estudiosos, salientamos que o contexto no qual o enunciado se insere é extremamente importante para a correta interpretação do ato de fala, assim como seu efeito no interlocutor.

Enfatizaremos, no entanto, que os atos ilocutórios e perlocutórios, estudados no corpus deste trabalho, são analisados levando em consideração o contexto e destacaremos, sobretudo, a presença dos valores ilocutórios estabelecidos por Austin (1990 [1969]), tais como os comportativos. Ao longo do corpus, os atos indiretos também são revelados por meio da situação comunicativa na interação na rede social digital.

Assim, os estudos dos filósofos da linguagem conduziram a pesquisas referentes à cortesia, fenômeno social importante na boa interação entre as pessoas. No tópico a seguir, trataremos das abordagens interacionistas de Brown \& Levinson (1987 [1978]) e de Leech (1983, 2014), pesquisadores que tomaram Grice, Austin e Searle como base para reflexão do comportamento linguístico-social do ser humano na interação.

\subsection{A abordagem interacionista: Goffman (1967); Brown \& Levinson (1987 [1978]) e Leech $(1983 ; 2014)$}

As teorias que mais influenciaram outros estudos referentes à cortesia dizem respeito ao conceito de imagem de Goffman (1967) e ao conceito de face de.

Goffman foi um dos precursores no estudo da imagem pública do indivíduo na sociedade. A teoria de Goffman (2005 [1959]) se baseia em uma atuação teatral para o estudo da troca comunicativa entre interactantes. Sendo assim, cada indivíduo interage com uma máscara que muda, dependendo da audiência e das variantes sociais. Ele cunhou o termo face para designar essa

\footnotetext{
${ }^{6} \mathrm{~A}$ força ilocucionária seria o performativo propriamente dito, ou seja, o tipo de ato realizado.
} 
autoimagem pública dos indivíduos em suas relações interpessoais. De acordo com Goffman?:

\begin{abstract}
Pode-se definir o termo face como o valor social positivo que uma pessoa reclama efetivamente para si por meio da linha que os outros supõem que ela seguiu durante determinado contato. A face é a imagem da pessoa delineada em termos de atributos sociais aprovados. (GOFFMAN, 1967, p. 05, tradução nossa)
\end{abstract}

Em sua pesquisa, Goffman (1967) defende que o indivíduo espera que seus interlocutores respeitem esta autoimagem, assim como deve-se respeitar a imagem do outro. Os interactantes devem se esforçar para manter o equilíbrio interacional, porém quando há uma invasão ao território do outro, acontece o que Goffman (1967) denomina como perda de face. Quando isso ocorre, é necessário que os interactantes usem estratégias de trabalho da face (facework) para minimizar os efeitos de um conflito na troca comunicativa. Segundo o teórico, há três tipos de movimentos que podem preservar ou a manter a face em uma interação, tais como:

O distanciamento: realização de atos que evitam o contato com possíveis fontes de conflito, tais como evitar certos tópicos; ou mudar de tópicos; fazer brincadeiras; não ser direto. No mundo virtual, é frequente o uso de memes, por exemplo, para esse fim. Goffman (1967) considera a cortesia como uma forma de distanciamento.

A correção: o ofensor deve realizar uma ação de reparo para minimizar os custos do ofendido em uma situação conflituosa. É comum o pedido de desculpas para essa finalidade, por exemplo.

A aceitação: é o processo de intermudança, segundo Goffman (1967), pois só ocorre depois da realização do ritual do processo de correção da ofensa. Para ocorrer, é preciso que o ofensor e o ofendido aceitem o ocorrido, e que o ofensor repare o erro de modo que o ofendido lhe conceda perdão.

Com base nesses estudos de Goffman (1967) e dos filósofos da linguagem, Brown \& Levinson (1978; 1987) aprofundam o conceito de face, levando em consideração o comportamento social sob uma perspectiva de usos

\footnotetext{
${ }^{7}$ The term face may be defined as the positive social value a person effectively claims for himself by the line others assume he has taken during a particular contact. Face is an image of self delineated in terms of approved social attributes. (GOFFMAN, 1967, p. 5)
} 
universais da linguagem. Eles elaboram um modelo de cortesia tendo em vista uma pessoa modelo (Model Person), entendida como uma pessoa falante fluente de uma língua natural caracterizadas pela racionalidade e pela face.

Brown \& Levinson (1987 [1978]) sustentam que existem princípios reguladores da interação social. Ambos fizeram a distinção entre face negativa e face positiva e conceberam a noção de atos ameaçadores da face. O falante, assim, possui duas faces, a saber:

Negativa - é a proteção do território do eu que corresponde e compreende a dimensão corporal, espacial, temporal. Os atos ameaçadores de face negativa são as ordens, os pedidos, as sugestões, os conselhos, os lembretes, os avisos, as ameaças, as promessas e elogios exagerados. Em relação a tópicos que se deve evitar, minimiza-se a ameaça à face com desculpas, geralmente.

Positiva - corresponde às imagens valorizadas, construídas no decorrer da interação, ou seja, é a necessidade de ser apreciado pelos demais e que o outro compartilhe dos mesmos desejos. Os atos ameaçadores de face positiva são as críticas, a ridicularização, a repressão, acusação, a provocação e os insultos, as contradições, os desacordos e as dúvidas. Tenta-se, com ela, manter a aprovação social, a autoestima e reforça o desejo de ser admirado, querido e compreendido pela sociedade.

Alguns atos ameaçam tanto a face negativa quanta positiva do falante, tais como as expressões de violência; os temas constrangedores, como religião, política; e os temas tabus, comunicado de más notícias, uso de vocativos íntimos em situações que não convém.

Para os teóricos, o objetivo central de um evento interacional seria evitar a produção de atos ameaçadores à imagem do interlocutor ou atenuar esse tipo de realização. Em uma interação, preservar a face se torna, assim, uma tarefa importante. Para os pesquisadores, este tipo de ato foi nomeado como ato de ameaça às faces, do inglês FTAs, Face -Threatening Acts. É possível evitar um conflito na interação com atos atenuadores ou com elementos que valorizam o outro. Há algumas possibilidades de se efetuar um FTA:

Off record - trata-se de um ato indireto. $O$ ato indireto pode comportar mais de uma interpretação da intenção do locutor, por meio de ironias, metáforas ou insinuações. O locutor evita, assim, responsabilizar-se por seu enunciado e deixa a tarefa de interpretação da mensagem para o interlocutor. No exemplo a 
seguir, M faz uma insinuação e deixa a interpretação de sua mensagem a cargo dos outros participantes da rede social digital, enfatizando ainda mais a insinuação com o uso de reticências.

Exemplos:

Figura 12: Exemplo de insinuação na rede social Facebook

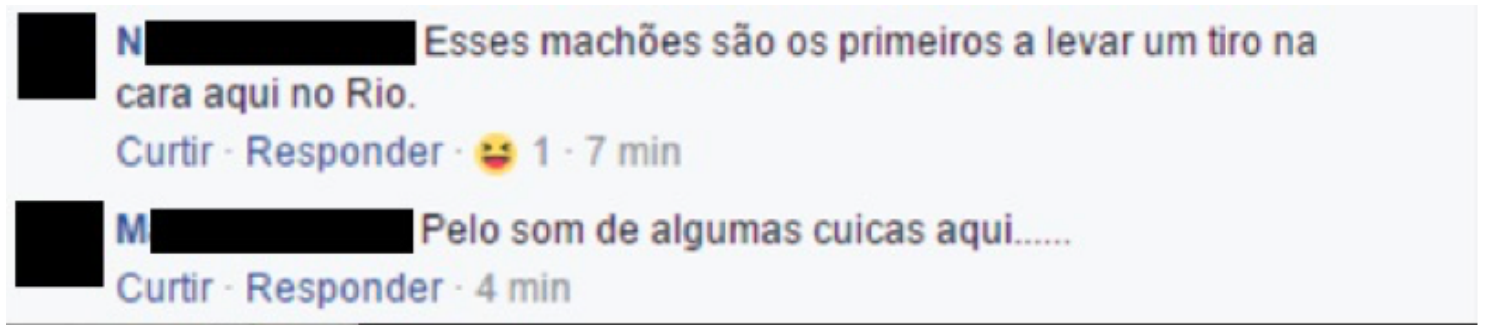

Fonte: Facebook (2017)

On record - trata-se de um ato direto. O locutor assume a sua posição comprometedora diante do que fala.

Bald on record - o locutor não se preocupa em como diz alguma coisa, mas sim no que diz. O objetivo é de comunicar algo sem dar atenção à forma. É comum o uso de verbos no imperativo. A seguir, dois exemplos da rede social Facebook, um exemplo on record e um bald on record respectivamente.

Figura 13: Exemplos de atos on record e bald on record no Facebook

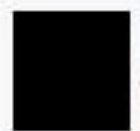

Bom, então as mulheres tem que sentar de pernas fechadas também? E isso não vai de encontro ao que elas ficam mimimizando que ninguém tem que falar como elas tem que se sentar? Agora elas bugam!!! kkkk

Curtir-Responder-OS: $57 \cdot 43 \mathrm{~min}$

^ Ocultar 22 respostas

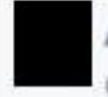
A Vai pra cozinha porra.

Curtir - Responder - 0 ग $\approx 3 \cdot 43 \mathrm{~min}$

Fonte: Facebook (2017)

A teoria de Brown \& Levinson (1987 [1978]) recebeu críticas de KerbratOrecchioni (2006) pelo fato de enfatizar somente o ato ameaçador da face. Para a pesquisadora, há também os atos valorizantes da face. Ela acrescenta a esses atos de valorização da face o conceito de FFA (Face Flattering Acts), ou AntiFTA. Alguns fatores contribuem tanto para os atos ameaçadores quanto para os 
valorizantes, tais como a cultura, a relação de poder, a distância social e o peso da imposição que orientam as escolhas linguísticas e o comportamento social.

Todos esses estudos culminam com o estudo da cortesia, visto que a cortesia se trata de um fenômeno social assim como a conversação em si. Tratase de uma estratégia conversacional inerente de trocas cooperativas entre os interactantes para manter uma imagem. É com base no trabalho de Brown \& Levinson (1987 [1978]) que outros teóricos desenvolvem os estudos de cortesia. Leech (1983; 2014), por exemplo, ancora-se nesses estudos dos Filósofos da Linguagem para elaborar um Princípio de Cortesia complementar ao princípio cooperativo estabelecido por Grice (1982 [1975]). Leech se aprofunda nas teorias para compreender a motivação do falante que não coopera com as máximas de Grice e, deste estudo, surge o Princípio de Cortesia em sua publicação Principles of Pragmatics, mais tarde rediscutida no livro The Pragmatics of Politeness. De acordo com Leech:

\begin{abstract}
O Princípio da Polidez ou Cortesia (PP) - análogo ao CP [Princípio de Cooperação] de Grice - é uma condição observada no comportamento comunicativo humano, influenciando-nos a evitar discórdia ou ofensa comunicativa, e manter ou reforçar a concordância comunicativa ou a cortesia. O que eu quero dizer com "discórdia comunicativa" é uma situação em que duas pessoas, x e y, podem ser assumidas, com base em quais significados foram comunicados, para entreter objetivos mutuamente incompatíveis. (Tal discórdia pode se espalhar em formas mais ameaçadoras de discórdia, como agressão verbal e conflito físico.) [...] A polidez também é um aspecto do comportamento orientado a objetivos; dizer que $S$ está sendo "educado" em usar um enunciado particular é dizer que o objetivo de $S$ em usar esse enunciado é, em algum grau, para transmitir uma impressão da polidez para $\mathrm{O}$. No entanto, a polidez preocupa-se em evitar discórdia e promover a concordância, apenas na medida em que estas se manifestam através da comunicação, especialmente através de quais significados são expressos ou implicados ${ }^{8}$. (LEECH, 2014, p. 87-88, tradução nossa).
\end{abstract}

Para Leech (1983), o falante se denomina S, self ou speaker, (doravante falante ou locutor) e é ele que ocupa o turno da fala; o ouvinte, $\mathrm{H}$, hearer

\footnotetext{
8 No original: The Principle of Politeness (PP)-analogous to Grice's CP-is a constraint observed in human communicative behavior, influencing us to avoid communicative discord or offence, and maintain or enhance communicative concord or comity. What I mean by "communicative discord" is a situation in which two people, $\mathrm{x}$ and $\mathrm{y}$, can be assumed, on the basis of what meanings have been communicated, to entertain mutually incompatible goals. (Such discord can spill over into more threatening forms of discord, such as verbal aggression and physical conflict.) [...] Politeness is also an aspect of goal-oriented behavior; to say that $S$ is being "polite" in using a particular utterance is to say that S's goal in using that utterance is, in some degree, to convey an impression of politeness toward O. However, politeness is concerned with avoiding discord and fostering concord, only insofar as these are manifested through communication, especially through what meanings are expressed or implicated.
} 
(doravante interlocutor) e $\mathrm{O}$, o Outro, que seria também um interlocutor, um interlocutor geral. O importante desta perspectiva é o fato de que esse "Outro" pode ser um destinatário direto ou indireto e isso vai ao encontro de nosso estudo, uma vez que no mundo virtual há vários "outros", um emissor pode ter um receptor direto a qual dirige à palavra e um receptor indireto que apenas acompanha a conversa e que pode, eventualmente, participar.

O Princípio de Cortesia de Leech (1983) acontece de acordo com uma escala de custo-benefício. Quando alguém deseja ser cortês, tentará beneficiar o interlocutor de alguma forma. O interactante deve demonstrar simpatia, tato e aprovação. Leech (1983) também faz um estudo semelhante a Brown \& Levinson, porém ele afirma que os conceitos de cortesia positiva e negativa dos dois teóricos são confusos. Para ele, há duas possibilidades de manifestação da cortesia, embora elas variem em grau e em intensidade:

Pos-Politeness ${ }^{9}$ (doravante Pos-Cortesia): é o ato de atribuir um valor positivo ao outro. Ofertas, convites, elogios e felicitações são exemplos de Pos-Cortesia; Neg-Politeness (doravante Neg-Cortesia): é a mais importante, segundo Leech $(1983 ; 2014)$, pois tem a função de atenuar ou reduzir o máximo possível as causas de ofensa ao outro. Geralmente, envolve recursos linguísticos como o eufemismo e mitigações de expressões negativas no geral.

Em sua taxinomia de atos ilocucionários, Leech (1983) estabelece as variedades ilocutórias características da cortesia (agradecer, saudar, oferecer, convidar) e as ações colaborativas, praticamente indiferentes à cortesia (afirmar, informar, anunciar). Leech também propõe que há ações que inviabilizam um bom relacionamento, tais como as ações competitivas (ordenar, perguntar, pedir) e ações descorteses, em muitos casos, conflitantes com o propósito social (ameaçar, acusar, blasfemar, insultar, maldizer). De acordo com Leech (1983, p.104-105), listamos a seguir um resumo de suas categorias relacionadas ou não com a cortesia:

\footnotetext{
9 Pos-Politeness faz referência à Positive Politeness assim como Neg-Politeness à Negative Politeness. Em nossa tradução, optou-se por utilizar o termo Pos-Cortesia e Neg-Cortesia, respectivamente.
} 
Competitivo: o objetivo ${ }^{10}$ ilocucionário compete com o objetivo social, por exemplo, ordenar, pedir, exigir, implorar. Os atos de fala competitivos estão sujeitos à Neg-Cortesia, pois o locutor faz o possível para reconciliar as metas ilocucionárias e sociais concorrentes;

Convivial: O objetivo ilocucionário coincide com o objetivo social, por exemplo, oferecer, convidar, saudar, agradecer, parabenizar. Os atos de fala convivial estão sujeitos à Pos-Cortesia, uma vez que os objetivos ilocucionários e sociais são idênticos.

Colaborativo: O objetivo ilocucionário é indiferente ao objetivo social, por exemplo, afirmar, relatar, anunciar, instruir. Os atos de fala colaborativos não têm nenhuma razão particular para envolver cortesia, pois os objetivos dos interactantes não competem nem contribuem para o objetivo social.

Conflitivo: O objetivo ilocucionário conflita com o objetivo social, por exemplo, ameaçar, acusar, xingar e repreender. Os atos de fala conflitivos normalmente não envolvem cortesia (exceto ironicamente), já que não há motivo para ser educado quando a natureza do ato de fala é causar ofensa deliberada.

Em 1983, Leech adotou a terminologia de cortesia relativa e cortesia absoluta em seu estudo. A cortesia relativa dependia da posição social do interlocutor e podia ser um fator determinante nas escolhas dos enunciados enquanto a cortesia absoluta associava alguns atos de fala à cortesia. Devido a interpretações errôneas e críticas a essa terminologia, Leech adota, em seu estudo posterior de 2014, a cortesia pragmalinguística e a cortesia sociopragmática em substituição aos termos usados em seu outro estudo. Para ele, a manifestação da cortesia se dá sob os dois domínios, um direcionado a realizações linguísticas e o outro orientado a determinantes culturais e sociais, ou seja, entre forma (contexto livre) e função (sensível ao contexto). O contexto sociopragmático orienta-se, sobretudo, em estudar as situações em que a cortesia deve ser apropriada ou normal em determinados contextos. Segundo ele:

Claramente, por razões socioculturais, a avaliação de uma situação em termos dessas escalas [linguísticas e sociais] afetará o grau de cortesia. Variações de idade, gênero, classe social e localidade terão um impacto potencial; e os julgamentos sobre o peso [da cortesia]

\footnotetext{
${ }^{10}$ Leech (2014) prefere o termo "objetivo ilocucionário" em vez de "intenção ilocucionária", pois considera o termo "intenção", problemático para os estudos da interação verbal.
} 
também dependerão de uma série de fatores culturais. [...] ambas as facetas da pragmática: uma voltada para a linguagem e outra para a sociedade. Uma parte fundamental do estudo da cortesia é investigar como elas se interconectam: como os recursos pragmalinguísticos de uma linguagem permitem que os valores culturais sejam expressos ${ }^{11}$. (LEECH, 2014, p. 14-15, tradução nossa)

Conforme Leech (1983), as Máximas ${ }^{12}$ de Cortesia podem variar de acordo com o objetivo ilocucionário e com os objetivos sociais do locutor. Em Principles of Pragmatics, ele estabelece seis máximas de cortesia, a saber:

1) Máxima do tato: $\mathrm{Na}$ interação, o falante deve amenizar qualquer ato que possibilite ao seu ouvinte algum tipo de custo na medida em que ele puder oferecer benefícios a este. A máxima do tato pode ser encontrada em diálogos, nos quais a negociação encontra-se em evidência, tais como os diálogos estabelecidos por atendentes de telemarketing, por exemplo. O princípio é minimizar o custo ao Outro ${ }^{13}$ e maximizar o benefício ao Outro.

2) Máxima da generosidade: A execução desta máxima compreende a construção da imagem que o ouvinte fará do falante, ou seja, quanto menos se beneficiar de um ato, mais considerado será pelo seu interlocutor. Deve-se minimizar o benefício para si próprio e maximizar o custo para si próprio.

3) Máxima de aprovação: Esta máxima requer do falante uma posição complementar à máxima anterior, pois favorece a construção de sua imagem perante o interlocutor. Ao enaltecer o Outro, evitando qualquer tipo de depreciação deste, o falante facilitará o engajamento dele, deixando-o confortável. Deve-se minimizar a depreciação do Outro e maximizar o enaltecimento do Outro.

4) Máxima da modéstia: Ao contrário da máxima anterior, esta tem como foco a imagem dos dois interlocutores, sendo o falante responsável por evitar

\footnotetext{
${ }^{11}$ No original: Clearly, for sociocultural reasons the evaluation of a situation in terms of these scales will affect the degree of politeness. Variation in age, gender, social class, and locality will all have a potential impact; and judgments about weightiness will also depend on a range of cultural factors. [...]both facets of pragmatics: one facing toward language and the other toward society. A key part of the study of politeness is to investigate how they interconnect: how the pragmalinguistic resources of a language enable cultural values to be expressed.

12 Leech critica o fato do termo "máximas" ser confundido como um ato prescritivo. Em seu estudo, a máxima é uma condição que visa alcançar um objetivo específico e que influencia o comportamento comunicativo dos falantes. Para ele, as máximas podem entrar em conflito ou competir entre elas mesmas em um contexto específico.

${ }^{13}$ No original, Leech (1983) usa o termo O, Other (Outro), que para ele pode ser tanto um destinatário direto quanto indireto. Por isso, optamos em colocar em maiúsculas a letra "O" nesses casos específicos.
} 
qualquer associação positiva com a própria imagem. Deve-se minimizar o enaltecimento de si mesmo e maximizar o enaltecimento do Outro.

5) Máxima de acordo: Em muitas situações comunicativas, a concordância é uma estratégia eficiente de cortesia, pois possibilita que os interlocutores se sintam mais à vontade para compartilhar informações e ideias afins. A atenuação de críticas corresponde às máximas de acordo, por exemplo. Deve-se maximizar a concordância entre si e o Outro e minimizar a discordância entre si e o Outro. 6) Máxima da simpatia: $O$ foco do falante é distanciar-se de uma imagem de si que não corresponda aos interesses do ouvinte, demonstrando-se simpático a esses. Deve-se minimizar a antipatia entre um interactante e outro e maximizar a simpatia entre si e o Outro.

Todas essas máximas contribuem para evitar ameaças contra a imagem social do interlocutor, embora elas não sejam exaustivas e possam variar de acordo com algumas culturas pelo mundo. Essas máximas também podem ocorrer concomitantemente uma com as outras. Uma atitude descortês perante o interlocutor provoca uma ruptura consciente deste Princípio da Cortesia e afeta a imagem de ambos, emissor e receptor. Quando a descortesia se manifesta, o princípio de cooperação positivo se quebra com a imposição de um locutor em relação ao seu interlocutor. A descortesia viola, assim, o contrato conversacional $^{14}$ outrora estabelecido no engajamento de uma troca comunicativa.

Posteriormente, Leech (2014) retoma sua teoria sob um enfoque mais crítico e aumenta de seis para dez as suas máximas na Estratégia Geral da Cortesia (General Strategy of Politeness (or GSP)):

Permitam-me começar com uma única supercondição, que compreende todas essas máximas, e que eu chamo de Estratégia Geral da Cortesia: para ser cortês, S [o locutor] expressa ou implica significados que associam um valor favorável com o que pertence a $\mathrm{O}$ [o interlocutor] ou associa um valor desfavorável com o que se refere a S [o locutor] ${ }^{15}$. (LEECH, 2014, p. 90, tradução nossa)

\footnotetext{
${ }^{14}$ A noção de contrato conversacional refere-se aos princípios que os participantes de uma interação devem aceitar e respeitar no que se refere aos direitos e deveres de cada um.

${ }^{15}$ No original: Let me begin with a single superconstraint, which comprehends all these maxims, and which I call the General Strategy of Politeness: In order to be polite, S expresses or implies meanings that associate a favorable value with what pertains to $O$ or associates an unfavorable value with what pertains to $S$ ( $S$ = self, speaker).
} 
Desta vez, ele prefere o uso do termo estratégias em vez de princípios, pois o fenômeno da cortesia deve ser estudado tanto no âmbito da pragmalinguística quanto na sociopragmática, já que deve ser levado em consideração o uso da linguagem na sociedade. Segundo Leech:

A cortesia, nesse sentido amplo, é uma forma de comportamento comunicativo geralmente encontrada nas linguagens humanas e entre as culturas humanas; de fato, tem sido reivindicada como um fenômeno universal da sociedade humana. O que significa ser cortês, eu argumentarei, é falar ou comportar-se de tal maneira a (parecer) dar benefício ou valor não a si mesmo, mas a outra pessoa (s), especialmente a (s) pessoa (s) com quem você está conversando ${ }^{16}$. (LEECH, 2014, p. 03, tradução nossa)

O uso da cortesia, no entanto, não é obrigatório. Para ele, as pessoas agirão com descortesia se houver, ao menos, algum motivo para tal, pois há diferentes tipos e situações em que a descortesia predominará mais que a cortesia, assim como haverá contextos em que a cortesia é esperada. Em sua Estratégia Geral da Cortesia, observa-se que, para ser cortês, o falante deve sempre evitar de colocar-se em uma posição privilegiada em relação ao outro, além de evitar depreciações. Dependendo da interação e do contexto, alguma máxima será priorizada em detrimento de outra ou mesmo podem ser realizadas combinadas com outras. Ele estabelece, então, algumas estratégias gerais do fenômeno da cortesia, ilustradas na tabela a seguir:

\footnotetext{
${ }^{16}$ No original: Politeness, in this broad sense, is a form of communicative behavior found very generally in human languages and among human cultures; indeed, it has been claimed as a universal phenomenon of human society. What it means to be polite, I will argue, is to speak or behave in such a way as to (appear to) give benefit or value not to yourself but to the other person(s), especially the person(s) you are conversing with.
} 
Tabela 1: As Estratégias Gerais da Cortesia de Leech (2014, p. 91), traduzidas e adaptadas.

\begin{tabular}{|c|c|c|c|}
\hline \multicolumn{4}{|c|}{ As máximas componentes da Estratégia Geral da Cortesia } \\
\hline $\begin{array}{l}\text { Violação da Máxima (expressa } \\
\text { de forma imperativa) }\end{array}$ & \begin{tabular}{|l|} 
Par de Máximas \\
relacionadas
\end{tabular} & $\begin{array}{c}\text { Categorias das } \\
\text { Máximas violadas }\end{array}$ & $\begin{array}{c}\text { Classes de atos } \\
\text { de fala }\end{array}$ \\
\hline $\begin{array}{l}\text { (M1) Atribuir um valor favorável } \\
\text { aos interesses do interlocutor. }\end{array}$ & & Generosidade & Comissivos \\
\hline $\begin{array}{l}\text { (M2) Atribuir um valor } \\
\text { desfavorável aos interesses do } \\
\text { locutor. }\end{array}$ & Tato & Tato & Diretivos \\
\hline $\begin{array}{l}\text { (M3) Atribuir um valor favorável } \\
\text { às qualidades do interlocutor. }\end{array}$ & & Aprovação & Elogios \\
\hline $\begin{array}{l}\text { (M4) Atribuir } \quad \text { um valor } \\
\text { desfavorável às } \\
\text { locutor. }\end{array}$ & Modéstia & Modéstia & $\begin{array}{c}\text { Autodesvaloriza } \\
\text { ção }\end{array}$ \\
\hline $\begin{array}{l}\text { (M5) Atribuir um valor favorável } \\
\text { às obrigações do locutor para } \\
\text { com o interlocutor. }\end{array}$ & & $\begin{array}{l}\text { Obrigação (de locutor } \\
\text { para interlocutor) }\end{array}$ & $\begin{array}{l}\text { Desculpas, } \\
\text { agradecimento }\end{array}$ \\
\hline $\begin{array}{l}\text { (M6) Atribuir um valor } \\
\text { desfavorável às } \\
\text { interlocutor para comõos do locutor. }\end{array}$ & 0 & $\begin{array}{l}\text { Obrigação (de } \\
\text { interlocutor para } \\
\text { locutor) }\end{array}$ & $\begin{array}{c}\text { Respostas a } \\
\text { desculpas/ } \\
\text { agradecimentos }\end{array}$ \\
\hline $\begin{array}{l}\text { (M7) Atribuir um valor favorável } \\
\text { às opiniões do interlocutor. }\end{array}$ & & Concordância & $\begin{array}{l}\text { Concordância, } \\
\text { discordância }\end{array}$ \\
\hline $\begin{array}{l}\text { (M8) Atribuir } \\
\text { desfavorável às } \\
\text { locutor. }\end{array}$ & Opinião & Opinião reticente & Dar opiniões \\
\hline $\begin{array}{l}\text { (M9) Atribuir um valor favorável } \\
\text { aos sentimentos do interlocutor. }\end{array}$ & & Simpatia & $\begin{array}{l}\text { Parabenizar, } \\
\text { simpatizar }\end{array}$ \\
\hline $\begin{array}{l}\text { (M10) Atribuir um valor } \\
\text { desfavorável aos sentimentos do } \\
\text { locutor. }\end{array}$ & Sentimento & Sentimento reticente & $\begin{array}{c}\text { Reprimir } \\
\text { sentimentos }\end{array}$ \\
\hline
\end{tabular}

Além das Estratégias Gerais da Cortesia, Leech não desconsidera outros princípios, tais como o Princípio da Ironia e do Banter (doravante "Gracejo" neste trabalho), que mais tarde também são estudados como estratégias; o princípio da lítotes e da hipérbole. Em especial nesta pesquisa, trabalharemos com as Estratégias Gerais da Cortesia e com as Estratégias da Ironia e do Gracejo, visto que, nessas situações específicas, o uso dos atenuadores e intensificadores linguísticos adquire uma significação mais descortês na interação. Como já mencionamos, os atos de fala adquirem uma nova dimensão em contextos específicos e não é possível categorizá-los como sendo corteses ou não. $A$ descortesia será objeto de estudo no tópico a seguir. Os elementos linguísticos empregados na (des)cortesia, por sua vez, serão objeto de estudo no capítulo 3 . 


\title{
1.3 A noção de descortesia
}

Assim como em uma interação face a face, é possível encontrar no mundo virtual conflitos entre os interactantes. Como já mencionamos anteriormente, uma maneira utilizada para manter a imagem positiva do interlocutor e minimizar a ação dos atos ameaçadores da face (FTA) é o emprego da cortesia. Tal como já vimos em Leech (2014), entendemos por cortesia a adequação linguística e social a um contexto determinado que preserva o caráter harmonioso de uma relação interpessoal. De acordo com Hilgert:

\begin{abstract}
A cortesia se manifesta por atos linguísticos e não linguísticos, seguramente com a prevalência dos primeiros, já que as relações humanas, em sua maioria, se realizam linguisticamente ou ao menos vêm acompanhadas de atos linguísticos. Portanto, a cortesia é uma atividade linguisticamente pertinente. A sua manifestação tanto ocorre por formulações cultural e socialmente definidas e consagradas, quanto por meio de recursos singulares e originais criados no aqui e agora dos atos enunciativos. (HILGERT, 2008, p.134)
\end{abstract}

Assim, a cortesia é um fenômeno pragmático que surge na interação comunicativa para assegurar a harmonia entre os interactantes, visto que há um objetivo comunicativo entre eles. Para Fuentes Rodríguez \& Brenes Peña (2013, p. 07), no entanto, a cortesia não é somente uma estratégia que faz com que a interação verbal se desenvolva de forma harmônica para conseguir acordo, mas que também a descortesia tem se convertido em um mecanismo útil para captar o receptor de alguma maneira nos últimos tempos. Segundo as duas pesquisadoras, há dois polos: um positivo (a cortesia), um negativo (a descortesia), entre os quais existe um continuum gradual. De acordo com Fuentes Rodríguez (2013), a cortesia emprega-se com três finalidades:

Coesiva: o locutor tenta manter o contato e a relação harmônica, para que o interlocutor não rompa a interação. É a cortesia ritual, empregada em saudações, agradecimentos e despedidas.

Argumentativa: Trata-se de uma cortesia estratégica. O falante a utiliza para conseguir atingir um objetivo. Ser cortês com o interlocutor coloca em posição favorável tanto o locutor quanto o interlocutor.

Social: o locutor projeta uma imagem de si mesmo como uma pessoa colaborativa, amável. 
Essas finalidades destacam o papel da cortesia na interação, ou seja, é uma estratégia para manter uma relação harmônica e colaborativa do ponto de vista pragmalinguístico e sociopragmático. Silva ainda destaca:

\begin{abstract}
O equilíbrio de uma interação pode depender da maneira como os participantes reagem diante dos conflitos que brotam durante a conversação. A partir do momento em que se inicia a interação, há um jogo de interesses diversos e, até de forma intuitiva, locutor e interlocutor negociam, a fim de conseguirem um determinado equilíbrio. É evidente que há ocasiões em que uma das partes, ou ambas, desejam o conflito, mas, no geral, é o equilíbrio que marca as interações. (SILVA, 2008, p.158)
\end{abstract}

Fraser (1980), por sua vez, sustenta que a cortesia verbal reside essencialmente no que se chama de contrato conversacional, isto é, os direitos e as obrigações mútuas das pessoas que engajam uma conversação. Desta forma, o uso da cortesia funciona como regras regulativas do comportamento humano. Assim:

Dada essa noção do contrato de conversação, podemos dizer que um enunciado é cortês, na medida em que o falante, na opinião do ouvinte, não violou os direitos ou obrigações [do contrato conversacional] vigentes naquele momento ${ }^{17}$. (FRASER, 1980, p. 343-344, tradução nossa)

Para Haverkate (1994), podemos falar de cortesia linguística e não linguística. Esta última se divide em duas subclasses: a paralinguística e a não paralinguística. A última se verifica exclusivamente por gestos que servem para proporcionar os mesmos efeitos perlocutivos que conseguem os atos puramente linguísticos. Uma inclinação de cabeça, por exemplo, dá a entender que estamos escutando com atenção as palavras de nosso interlocutor, sem estar indiferente. A cortesia paralinguística, por sua vez, expressa-se também mediante gestos, porém em conjunto com os signos verbais.

É importante salientar que a interpretação da cortesia ou da descortesia depende do interlocutor, pois é ele quem julga o efeito perlocutivo do ato de fala, independentemente do objetivo comunicativo do locutor. Diferentemente da cortesia, a interação descortês rompe com o contrato conversacional com o outro para dar espaço a um conflito na relação social. Neste sentido, Silva afirma:

Quando duas ou mais pessoas se reúnem, diversos podem ser os objetivos que justificam tal interação. Um dos aspectos fundamentais

\footnotetext{
${ }^{17}$ No original: Given this notion of the conversational contract, we can say that an utterance is polite, to the extend to which the speaker, in the hearer's opinion, has not violated the rights or obligations which are in effect at that moment. (Fraser, 1980, p. 343-344)
} 
da conversação é a interação comunicativa entre seus participantes. Com esse propósito, os interactantes adotam uma diversidade de atitudes que apontam para diferentes perspectivas com as quais 0 locutor e interlocutor podem coincidir, aproximar-se ou distanciar-se. $\mathrm{O}$ êxito da comunicação depende da seleção de formas lingüísticas adequadas ao intento ou à situação do interlocutor. (SILVA, 2008, p. 157)

De acordo com Haverkate (1994, p. 68), a cortesia pode se manifestar por meio de uma variedade de categorias linguísticas: seleção de pronomes de tratamento, uso do condicional ou imperfeito de cortesia e realização indireta de um ato ilocucionário no micronível ${ }^{18}$ do ato de fala. Ele ressalta, no entanto, que um comportamento não cortês não implica necessariamente em uma manifestação descortês. A descortesia surge, sobretudo, quando violamos as normas do considerado correto e atacamos a imagem do outro. Criamos, assim, um ambiente de conflito, que pode ser consciente ou inconsciente.

Culpeper (1996) é considerado um dos principais pesquisadores da descortesia linguística. Ele retoma, inicialmente, os estudos de Brown \& Levinson $(1978$; 1987) para criticar o fato de eles não contemplarem a problemática da descortesia em seus estudos. Inicialmente, ele retoma o conceito de face, mas ancorado em algumas categorias estabelecidas por ele, tais como: qualidade, relação, identidade social, normas sociais e moralidade. $O$ teórico sustenta que a descortesia é um campo multidisciplinar e que pode se relacionar com a psicologia e a sociologia, por exemplo. Com base em Brown \& Levinson (1978; 1987), ele propõe cinco estratégias da descortesia:

Descortesia direta - atos que ameaçam de forma clara e direta, com intenção de atacar o interlocutor.

Descortesia positiva - uso de estratégias para ferir a imagem positiva do interlocutor.

Descortesia negativa - uso de estratégias para ferir a imagem negativa do interlocutor.

Descortesia dissimulada - atos aparentemente corteses, mas que são falsos, como a ironia e o sarcasmo.

18 O micronível refere-se aos elementos internos do ato de fala, que constituem sua estrutura sintática, lexical, fonológica e prosódica. 
Não-cortesia - ausência de cortesia em situações em que ela é esperada.

Mais tarde, Culpeper retoma o seu estudo em 2011 e sustenta que a descortesia não é simplesmente um ataque à imagem do outro, mas sim que deveríamos considerar o conjunto de fatores que a desencadearam. Este ponto de vista converge com o propósito desta pesquisa e, sendo assim, adotamos a definição de descortesia dada por Culpeper:

\begin{abstract}
Descortesia é uma atitude negativa em relação a comportamentos específicos em contextos específicos. É sustentado por expectativas, desejos e/ou crenças sobre uma organização social, incluindo aí como a identidade de uma pessoa ou de um grupo são mediadas por outras interações. Alguns comportamentos são vistos negativamenteconsiderados mesmo descortês- quando há o conflito do que alguém espera que seja, como quer que seja e/ou como alguém pensa que deve ser em uma interação. Tais comportamentos sempre têm ou presumem ter consequências emocionais por pelo menos um participante da interação, ou seja, causam ou devem causar ofensa. Vários fatores podem desencadear $o$ quão ofensivo um comportamento descortês é interpretado, incluindo, por exemplo, se alguém entende que tal comportamento é intencional ou não ${ }^{19}$. (CULPEPER, 2011, p. 23, tradução nossa)
\end{abstract}

Leech (1983) retoma os estudos de Brown \& Levinson (1978;1987) e mais tarde, em The Pragmatics of Politeness (2014), ele discute os trabalhos de Culpeper (1996; 2011) para estudar os fenômenos da cortesia e da descortesia. Ele sustenta que é preciso se basear nas manifestações corteses para teorizar a descortesia, visto que se trata de um fenômeno intimamente relacionado à cortesia. Para Leech (2014), as Máximas da Cortesia se relacionam em oposição a outros fenômenos, tal como a não-cortesia, termo emprestado de Culpeper (1996; 2011), a descortesia, a ironia ou sarcasmo e o gracejo. Todos esses fenômenos, em certo sentido, contrastam com a cortesia de maneiras diferentes. No caso da ironia conversacional ou do sarcasmo, o contraste é entre o significado denotativo, que é cortês, e o significado conotativo ou implicado, que é o seu oposto. No caso de gracejos, o contraste é entre o significado denotativo,

\footnotetext{
${ }^{19}$ No original: Impoliteness is a negative attitude towards specific behaviours occurring in specific contexts. It is sustained by expectations, desires and /or beliefs about social organization, including, in particular, how one person's or a group's identities are mediated by others in interaction. Situated behaviours are viewed negatively - considered 'impolite' - when they conflict with how one expects them to be, how one wants them to be and/or how one thinks they ought to be. Such behaviours always have or are presumed to have emotional consequences for at least one participant, that is, they cause or are presumed to cause offence. Various factors can exacerbate how offensive an impolite behaviour is taken to be, including for example whether one understands a behaviour to be strongly intentional or not. (CULPEPER, 2011, p. 23)
} 
que é indelicado, e o significado implicado, que é o oposto. As violações das Máximas de Cortesia desencadeiam boa parte dos casos de descortesia, mas há outras manifestações de ataque verbal e não-verbal a serem consideradas. A seguir, temos uma tabela adaptada e traduzida de Leech (2014, p. 221), onde ele aponta as condições de infração da descortesia.

Tabela 2: As categorias de condições de infração da Estratégia Geral da Descortesia de Leech, traduzida e adaptada (2014, p. 221)

\begin{tabular}{|c|c|c|c|}
\hline \multicolumn{4}{|c|}{ As categorias de condições de infração da Estratégia Geral da Descortesia } \\
\hline $\begin{array}{l}\text { Violação da máxima (expressa } \\
\text { de forma imperativa) }\end{array}$ & $\begin{array}{l}\text { Par de máximas } \\
\text { relacionadas }\end{array}$ & $\begin{array}{c}\text { Categorias das } \\
\text { Máximas violadas }\end{array}$ & $\begin{array}{c}\text { Classes de atos } \\
\text { de fala }\end{array}$ \\
\hline $\begin{array}{l}\text { (M1) Atribuir um valor } \\
\text { desfavorável aos interesses do } \\
\text { interlocutor }\end{array}$ & \multirow{2}{*}{$\begin{array}{l}\text { Generosidade/ } \\
\text { Tato }\end{array}$} & Generosidade & $\begin{array}{l}\text { Recusar, } \\
\text { ameaçar }\end{array}$ \\
\hline $\begin{array}{l}\text { (M2) Atribuir um valor favorável } \\
\text { aos interesses do locutor }\end{array}$ & & Tato & $\begin{array}{l}\text { Ordem, } \\
\text { demanda }\end{array}$ \\
\hline $\begin{array}{l}\text { (M3) Atribuir um valor } \\
\text { desfavorável às qualidades do } \\
\text { interlocutor }\end{array}$ & \multirow{2}{*}{$\begin{array}{l}\text { Aprovação/ } \\
\text { Modéstia }\end{array}$} & Aprovação & $\begin{array}{l}\text { Insultar, } \\
\text { reclamar, falar } \\
\text { mal do outro }\end{array}$ \\
\hline $\begin{array}{l}\text { (M4) Atribuir um valor favorável } \\
\text { às qualidades do locutor }\end{array}$ & & Modéstia & $\begin{array}{l}\text { Gabar-se, ser } \\
\text { complacente }\end{array}$ \\
\hline $\begin{array}{l}\text { (M5) Atribuir um valor } \\
\text { desfavorável às obrigações do } \\
\text { locutor para com o interlocutor }\end{array}$ & \multirow{2}{*}{ Obrigação } & $\begin{array}{l}\text { Obrigação (ao } \\
\text { Outro) }\end{array}$ & $\begin{array}{c}\text { Recusar } \\
\text { agradecimentos } \\
\text { ou desculpas }\end{array}$ \\
\hline $\begin{array}{l}\text { (M6) Atribuir um valor favorável } \\
\text { às obrigações do interlocutor } \\
\text { para com o locutor }\end{array}$ & & $\begin{array}{l}\text { Obrigação (ao } \\
\text { Locutor) }\end{array}$ & $\begin{array}{c}\text { Pedir } \\
\text { agradecimentos } \\
\text { ou desculpas } \\
\end{array}$ \\
\hline $\begin{array}{l}\text { (M7) Atribuir um valor } \\
\text { desfavorável às opiniões do } \\
\text { interlocutor }\end{array}$ & \multirow[t]{2}{*}{ Opinião } & Concordância & $\begin{array}{l}\text { Discordar, } \\
\text { contradizer }\end{array}$ \\
\hline $\begin{array}{l}\text { (M8) Atribuir um valor favorável } \\
\text { às opiniões do locutor }\end{array}$ & & Opinião reticente & Ser opinativo \\
\hline $\begin{array}{l}\text { (M9) Atribuir um valor } \\
\text { desfavorável aos sentimentos do } \\
\text { interlocutor }\end{array}$ & \multirow[t]{2}{*}{ Sentimento } & Simpatia & $\begin{array}{l}\text { Expressar } \\
\text { antipatia ao } \\
\text { Outro } \\
\end{array}$ \\
\hline $\begin{array}{l}\text { (M10) Atribuir um valor favorável } \\
\text { aos sentimentos do locutor }\end{array}$ & & $\begin{array}{l}\text { Sentimento } \\
\text { reticente }\end{array}$ & $\begin{array}{l}\text { Reclamar, } \\
\text { resmungar }\end{array}$ \\
\hline
\end{tabular}

Apesar ainda de muitas críticas, outros teóricos ainda continuam fazendo uma releitura da teoria de face de Brown \& Levinson (1978;1987). Bravo (2005), por exemplo, substitui os conceitos de cortesia negativa e positiva pelos termos de autonomia e afiliação. Para Bravo (2005), a afiliação se caracteriza pelo desejo de uma pessoa de se ver e ser vista pelos demais, ou seja, trata-se de uma identificação com um grupo. Por outro lado, a autonomia é o desejo de uma pessoa de se ver e ser vista pelos demais como um indivíduo com características 
próprias dentro de um grupo. Neste sentido, outra estudiosa do fenômeno da descortesia, Kaul de Marlangeon, aproxima-se dos estudos da Pragmática Sociocultural sob a perspectiva de Diana Bravo e aborda a descortesia de fustigação e, posteriormente, o conceito de comunidades de práticas cortês e descortês. Para a pesquisadora, a cortesia e a descortesia estão relacionadas à presença ou à ausência de compromisso mútuo. Embora não trabalharemos com a terminologia adotada por Kaul de Marlangeon, a pesquisadora estabelece critérios de identificação da descortesia em que acreditamos ser úteis para nossa pesquisa em questão e, de certa forma, convergem com o ponto de vista de outros teóricos abordados aqui nesta pesquisa. Kaul de Marlangeon (2012) lista até onze comportamentos definidores do fenômeno. Para ela, há descortesia:

1) Quando o falante tenta ser cortês com o ouvinte, mas seu modo expressivo desperta no ouvinte uma reminiscência de linguagem imprópria ou indecorosa ou desrespeitosa;

2) Quando o falante ofende involuntariamente o ouvinte por causa de uma gafe;

3) Quando o falante ofende involuntariamente o ouvinte por causa da cortesia esperada pelo ouvinte;

4) Quando o falante ofende involuntariamente o ouvinte devido à falta de cortesia;

5) Quando o falante poupa deliberadamente a cortesia esperada pelo ouvinte;

6) Quando o falante ofende deliberadamente o ouvinte, com um propósito prejudicial à imagem do ouvinte;

7) Quando o falante ofende deliberadamente o ouvinte, com um propósito defensivo da imagem do falante;

8) Quando o ouvinte interpreta o comportamento do falante como um ataque intencional à sua imagem, o que o induz a aceitar o ataque;

9) Quando o ouvinte interpreta o comportamento do falante como um ataque intencional à sua imagem, o que o induz a rejeitar o ataque, na forma de defesa; 10) Quando o ouvinte interpreta o comportamento do falante como um ataque intencional à sua imagem, o que o induz a rejeitar o ataque, na forma de contraataque; $\mathrm{e}$,

11) Quando o ouvinte exerce deliberadamente seu silêncio para indicar desacordo com a enunciação do falante. 
Sob a perspectiva pragmalinguística e sociopragmática, assim como fez com o fenômeno da cortesia linguística, Fuentes Rodríguez (2013) atribui à descortesia algumas funções da linguagem na interação, tais como:

Coesiva: utiliza-se a descortesia para romper a relação social com o outro, terminar a conversação. Surge quando temos despedidas desagradáveis, respostas inoportunas, que rompem com a troca.

Argumentativa: o uso da descortesia busca conseguir certos fins. Por exemplo, enfadar o outro, projetar determinada imagem que apoie a argumentação. Isto ocorre em situações de grande conflito, tais como em brigas na conversa, em textos de cunho político etc.

Social: a descortesia projeta uma imagem agressiva do locutor. Assim, ela reforça a imagem de uma pessoa forte e destemida.

Modal: a descortesia surge como uma explosão emotiva, em situações de enfado ou tensão. É inconsciente e não contempla o efeito no receptor.

Ainda para Fuentes Rodríguez (2013, p.11), para se avaliar a presença da (des)cortesia na interação, torna-se necessário adotar uma metodologia variacionista, levando em consideração uma série de fatores:

1) Há elementos linguísticos marcados com um valor de cortesia ou descortesia pelo uso;

2) Os elementos do contexto atuam como potenciadores da cortesia ou da descortesia;

3) A situação social estabelece algumas normas de comportamento considerado adequado. A partir daí, se estabelecerá a avaliação de um ato positivo ou negativo. Isto inclui a situação socioeconômica, política, religiosa, física, etc; 4) A relação entre os interlocutores também é importante: a idade, o grau de familiaridade ou conhecimentos que compartilham, a distância social entre eles; 5) O tipo discursivo que se produz a comunicação é responsável por ditar algumas normas consideradas aceitáveis.

Kienpointner (1997) afirma que não se deve interpretar o fenômeno da descortesia como uma simples violação das regras da cortesia em sociedade, mas que é necessário analisar como uma interação cooperativa dá lugar a uma relação competitiva. Como já mencionamos neste trabalho, acreditamos que a descortesia não se dá somente em casos onde impera uma relação competitiva e, devido a isso, adotamos a terminologia de cooperação positiva e negativa, 
visto que muitas interações não deixam de ser cooperativas, mas mesmo assim usam a descortesia contra o interlocutor. Como já exposto, acreditamos que a descortesia deve ser analisada levando em consideração os aspectos pragmalinguísticos e sociopragmáticos, além dos fatores contextuais específicos em uma interação. Não deixaremos de considerar para a nossa análise as funções da descortesia na linguagem e os elementos extralinguísticos possíveis de recuperar nas redes sociais digitais, tal como faremos nos capítulos a seguir. 


\section{CAPÍTULO 2: A COMUNICAÇÃO VIRTUAL}

\subsection{A interação nas redes sociais digitais}

A interação social sofreu uma grande mudança no mundo atual com o advento das redes sociais na internet. As informações e as trocas comunicativas são instantâneas e romperam a barreira de distância do espaço físico. Por meio de publicações privadas ou públicas, há um intercâmbio de ideias e vivas discussões a respeito de um tema específico ou em voga nas mídias.

As mídias digitais comportam dados transformados em sequências de números interpretados por uma máquina. Assim, o compartilhamento, armazenamento e conversão de dados é possível com o uso de computadores, smartphones e tablets. Com a eliminação das fronteiras do espaço físico, a interação entre os usuários se dá no ciberespaço. De acordo com Martino, ciberespaço é um "[...] espaço de interação criado no fluxo de dados digitais em redes de computadores; virtual por não ser localizável no espaço, mas real em suas ações e efeitos" (MARTINO, 2014, p. 11, grifos do próprio autor).

Com a transição da Web 1.0 para a 2.0, o ambiente virtual se torna mais dinâmico em relação ao que se tinha anteriormente, tais como páginas estáveis de blogs, por exemplo. A Web 2.0 permitiu a constante interação de usuários, até então desconhecidos, por meio das redes sociais digitais e do Google. $\mathrm{O}$ estabelecimento de laços sociais entre os usuários neste ambiente acarretou na criação de comunidades on-line. De acordo com Martino, as comunidades online são:

\footnotetext{
Agrupamentos sociais construídos a partir de relações interpessoais mediadas por uma tela digital na qual estão informações sobre o grupo, as comunidades virtuais ganham força não por conta da tecnologia, mas pelas intenções, vontades, afetos e conhecimentos compartilhados - interação humana é o ponto de partida e a razão de ser das comunidades virtuais. (MARTINO, 2014, p. 45)
}

As comunidades virtuais se manifestam de várias formas na internet e uma delas se dá no ambiente das redes sociais digitais. A terminologia adotada neste trabalho levou em consideração as pesquisas recentes da área sobre mídias digitais e, diante disso, optou-se em usar o termo "redes sociais digitais", visto que o termo "redes sociais" já existia anteriormente na área de Sociologia. 
Martino afirma:

Redes sociais podem ser entendidas como um tipo de relação entre seres humanos pautada pela flexibilidade de sua estrutura e pela dinâmica entre seus participantes. Apesar de relativamente antiga nas ciências humanas, a ideia de rede ganhou mais força quando a tecnologia auxiliou a construção de redes sociais conectadas pela internet, definidas pela interação via mídias digitais. [...] Embora seja geralmente utilizada para falar de agrupamentos sociais online, a noção de "redes sociais" é um conceito desenvolvido pelas Ciências Sociais para explicar alguns tipos de relação entre pessoas. O uso da noção de "redes sociais" no ambiente da internet significa transpor um modelo de análise social para o espaço virtual, o que requer algumas mudanças no conceito. (MARTINO, 2014, p. 55)

Uma das redes sociais que se destacou nos últimos tempos, em termos de popularidade e uso, foi o Facebook. Ele foi criado por quatro alunos da Universidade de Harvard: Mark Zuckerberg, Dustin Moskovitz, Chris Hughes e o brasileiro Eduardo Saverin, no ano de 2004. O objetivo era reunir os alunos da universidade, mas tornou-se mundial ao longo do tempo. No Facebook, a interação pode ser pública ou privada, além de ser familiar ou institucional, representando uma empresa ou um grupo. Cada pessoa possui um perfil público ou privado e uma lista de amigos. É necessário o envio de convites para ser amigo de outra pessoa e isso possibilita o acesso às informações privadas de cada participante. A criação de um perfil com dados pessoais é a primeira etapa para se ter acesso à rede social. Santaella afirma que:

Ao criar um perfil nas redes sociais, as pessoas passam a responder e a atuar como se esse perfil fosse uma extensão sua, uma presença extra daquilo que constitui sua identidade. Esses perfis passam a ser como estandartes que representam as pessoas que os mantêm. [...]Hábitos e usos funcionam como pistas das silhuetas subjetivas de cada usuário. (SANTAELLA, 2016, p. 43)

Neste sentido, Recuero (2016) acrescenta que as redes sociais permitem aos participantes, criar e manter uma identidade que pode ser construída e legitimada pelos outros usuários, por meio da conversação. Assim como a conversação face a face, a conversação virtual também é regida por rituais que organizam as interações. Os elementos típicos das interações face a face, tais como a gestão de turnos e o contexto precisam ser reconstruídos na comunicação mediada pelo computador (doravante CMC). O discurso é coproduzido na interação virtual e tem alcance global. Recuero destaca que:

Quanto mais conectados estão essas redes, mais visíveis estão as mensagens que são publicadas pelos atores e mais capazes são de ser discutidas, buscadas, replicadas e reproduzidas pelos demais. E é 
essa capacidade da conversação de transcender o grupo que a iniciou, navegando pelas conexões dos sites de rede social e ampliando a audiência e a participação dos demais, que caracteriza as conversações em rede. (RECUERO, 2016, p. 55)

No Facebook, todas as postagens ou publicações ficam disponíveis na linha do tempo ou timeline, onde é possível interagir com e reagir nas publicações disponíveis com uma série de recursos para a interação, entre eles emoticons, Gifs e memes ${ }^{20}$. De acordo com Maingueneau:

Chamamos de postagens essas diversas categorias de enunciados.
Eles não se inscrevem em uma cadeia fechada de interações; podem
demorar certo tempo para encontrar seu(s) destinatário(s). Exceto
quando se trata de perguntas que exigem resposta imediata, autorizam
uma gama aberta de reações, mais ou menos rápidas, e,
eventualmente, até mesmo nenhuma reação. (MAINGUENEAU, 2015,
p. 171)

Nas publicações ou postagens há uma certa liberdade nos turnos de fala, uma vez que a relação entre os locutores pode ser síncrona e assíncrona. As conversações assíncronas são aquelas em que as interações acontecem quando os participantes não estão conectados ao mesmo tempo. Já as síncronas são aquelas em que as interações acontecem enquanto os interactantes estão conectados ao mesmo tempo. Apresentam, assim, características linguísticas híbridas entre a espontaneidade do oral e a estabilidade da escrita.

A relação entre os usuários nas redes sociais digitais costuma ser flexível e, em muitos casos, efêmera, uma vez que o vínculo entre os interactantes podem ser rompidos não importa o momento. Há uma categorização de vínculos na rede digital Facebook, por exemplo. É possível conectar com amigos, parentes e conhecidos, até mesmo desconhecidos. Muitas vezes, usuários que não se conhecem pessoalmente estabelecem amizade na rede pelo fato de terem interesses em comum. Desta forma, torna-se viável o contato entre os interactantes como seguidor ou amigo, caso tenha sido feito um pedido de amizade e ele ter sido aceito pelo outro. A rede social Facebook permite bloquear ou romper o contato de forma que não seja necessária uma justificativa, o que torna o processo de rompimento mais fácil se levarmos em consideração uma interação face a face em um evento interacional físico. Neste sentido, Martino

\footnotetext{
${ }^{20} \mathrm{O}$ estudo dos emoticons, memes e Gifs serão aprofundados no tópico 3.3 deste trabalho.
} 
acrescenta que "[...] o princípio de uma rede social é a natureza relacional de sua composição, definida por vínculos fluidos, flexíveis, e pelas várias dinâmicas dessas relações." (MARTINO, 2014, p. 58)

A internet, dessa forma, ganha espaço para trocas linguísticas. Castells (2003), por exemplo, defende o avanço da internet como forma de comunicação e como a grande responsável pela transformação da sociabilidade no mundo contemporâneo, com a substituição de comunidades espaciais por redes como formas de sociabilidade. Ainda de acordo com Martino,

\begin{abstract}
Embora a forma de ligação entre os indivíduos seja diferente, seres humanos transpõem para as comunidades virtuais seus desejos, vontades e aspirações, das mais sublimes às mais perversas. Suas características específicas - distâncias relativas, proximidades digitais, anonimato - podem criar um terreno fértil para o desenvolvimento das qualidades e problemas que já existem nos indivíduos e na sociedade. (MARTINO, 2014, p. 45-46)
\end{abstract}

São nessas trocas comunicativas que há espaço para a descortesia, principalmente quando o assunto das discussões é polêmico. Nas redes sociais digitais, os usuários gozam de certa liberdade de expressão e de uma grande espontaneidade, opinando sobre os mais diferentes assuntos da esfera pública e privada. Esse aparente anonimato e a possível efemeridade de publicações na internet contribuem para o uso de expressões mais agressivas na rede entre outros fatores, tais como sustenta Díaz Pérez²1:

Entre as características que favorecem os usos verbais descorteses na
rede são (1) anonimato: muitos usuários se sentem protegidos em uma
identidade oculta e exoneram ou pelo menos assim, de alguma forma,
sua responsabilidade pelas palavras transmitidas; (2) o
distanciamento, que favorece o descuido da forma e do tom da
mensagem, o que leva à desconsideração de fórmulas que atenuam e
desambiguam a possível interpretação ofensiva da mensagem; (3) a
distância espacial entre os participantes, o que torna sua relação

${ }^{21}$ No original: "Entre las características que favorecen los usos verbales descorteses en la red se encuentran (1) el anonimato: muchos usuarios se sienten amparados en una identidad oculta y exoneran o al menos difuminan así, de algún modo, su responsabilidad respecto de las palabras que emiten; 2) el distanciamiento, que favorece el escaso cuidado de la forma y el tono del mensaje, lo que lleva a prescindir de fórmulas mitigadoras y desambiguadoras de la posible interpretación ofensiva del mensaje; 3 ) la distancia espacial entre los participantes, que convierte su relación en virtual, de tal manera que el destinatario del ataque resulta invisible para el emisor y queda prácticamente deshumanizado como víctima de la agresión; 4) la rapidez en la transmisión; 5) el escaso esfuerzo de codificación que este tipo de comunicación exige al emisor; 6) la falta de normas y la desinhibición a la hora de abordar los contenidos groseros y agresivos, lo que permite que estos aparezcan de manera más extrema; y 7) el vasto alcance que logran los mensajes al propagarse por Internet tan fácilmente, ubicuidade que posibilita una gran exposición a los mensajes destructivos, a agredir y a ser agredido. (Díaz Pérez, 2012, p. 32) 
virtual, de modo que o receptor do ataque seja invisível ao emissor e seja virtualmente desumanizado como vítima de agressão; (4) velocidade de transmissão; (5) o esforço limitado de codificação exigido por este tipo de comunicação do emissor; (6) a falta de regras e desinibição ao lidar com conteúdo rude e agressivo, permitindo-lhes parecer ainda mais grosseiro; e 7) o vasto alcance das mensagens, espalhando-se pela Internet tão facilmente, de forma onipresente, o que permite uma grande exposição a mensagens destrutivas, atacar e ser atacado. (Díaz Pérez, 2012, p. 32, tradução nossa)

Predominam-se marcas de oralidade na linguagem, embora o suporte seja escrito. Crystal (2001) denominou esse tipo de linguagem de "ciberfala" graças à sua variedade linguística inovadora e sua capacidade de adaptar características gramaticais, semânticas, grafológicas e discursivas à tecnologia e às necessidades dos usuários. Embora o suporte seja predominantemente escrito, o Facebook também oferece inúmeros recursos de interação, tais como curtir ou reagir a uma publicação, comentar ou compartilhar o conteúdo publicado. Nas trocas comunicativas, os interactantes também podem mesclar diferentes tipos de linguagem na rede social digital, pois se trata de uma plataforma multimodal que conta com a presença de elementos verbais, vídeos e imagens de diferentes tipos, estáticas ou em movimento, tais como os Gifs e memes. Vários recursos complementam a comunicação escrita na rede, tais como os emoticons, que são representações tipográficas de expressões faciais, tais como um sorriso - - e os Stickers, figurinhas disponíveis no Facebook, por exemplo. Os memes, emoticons e os stickers são utilizados para expressar uma emoção ou indicar afeto, e também possuem a função de atenuadores e de intensificadores nos enunciados, para enfatizar uma emoção ou para atenuar uma opinião.

Graças ao alcance da rede no mundo inteiro e à dinamicidade das interações, deve-se considerar não só um emissor e receptor nas redes sociais digitais, mas também um receptor universal, já que uma mensagem pode ser vista por muitas pessoas de diferentes partes do mundo em um ambiente virtual. Assim, a interação humana, no mundo virtual, adquire uma dimensão diferente, uma vez que tempo e espaço podem aproximar e/ou afastar as pessoas. No tópico a seguir, trataremos das especificidades da enunciação na rede social digital. 


\subsection{A enunciação na rede social digital Facebook}

O conceito de enunciação promoveu inúmeras reflexões no campo da Linguística. Roman Jakobson (1974) foi um dos primeiros linguistas a pensar no processo enunciativo, uma vez que sua teoria das funções da linguagem sistematiza a questão do sujeito na língua. Mais tarde, Benveniste (1989) desenvolve um modelo de análise com base na enunciação. Com Benveniste (1989), a categoria de pessoa é concebida em termos de subjetividade, e o par "eu/tu" pertence ao nível pragmático da linguagem. Para o autor, a enunciação é entendida como o processo de "[...] colocar em funcionamento a língua por um ato individual de utilização". (BENVENISTE, 1989, p. 82)

Segundo Bakhtin [Volochinov] (2009 [1929-1930]), a compreensão de um texto implica uma responsividade e, logo, um juízo de valor. O ouvinte e o leitor adotam uma atitude responsiva diante de uma significação linguística de um texto, não importando a sua dimensão. Assim, o ato responsivo faz parte desta dinâmica das relações entre um "eu" com um "outro". De acordo com o teórico russo, a língua, em sua totalidade concreta, tem a propriedade de ser dialógica em seu uso real, isto é, o enunciador leva em consideração o enunciado de outro para construir o seu discurso, em que tempo, espaço e projeto discursivo são fundamentais. De acordo com Flores et alii:

Todo enunciado, segundo textos assinados por Voloshinov $(1926,1930)$, comporta duas faces indissociáveis: uma verbal e outra extraverbal (contexto mais amplo). Os enunciados não coincidem com sua constituição puramente verbal (em sentido estrito), pois são impregnados de não-ditos. A face extraverbal, situação e condição necessária do desenvolvimento ideológico do enunciado, corresponde ao espaço e tempo do acontecimento, ao objeto ou tema do enunciado $\mathrm{e}$ às posições assumidas pelos interlocutores. Os aspectos extraverbais não são a causa exterior do enunciado, não são uma força mecânica externa, mas sim se integram ao enunciado como um elemento indispensável a sua constituição semântica. Nessa perspectiva, o verbal e o extraverbal estão articulados no enunciado, indicando que toda a dimensão verbal é heterogênea e constitutivamente ideológica e social. Essas características, no entanto, não eliminam a possibilidade de o enunciado se materializar apenas por elementos não verbais (por exemplo, um gesto, uma expressão facial, uma obra de arte), desde que tenha sujeito, expressão avaliativa. (FLORES et alii, 2009, p. 99-100)

Considerando a pluralidade discursiva na Internet com a evolução das tecnologias, os novos meios de comunicação se distanciam do modelo conversacional prototípico, ou seja, o modelo falante e ouvinte face a face em 
um lugar físico específico. Destacamos que alguns elementos já presentes na obra de Bakhtin 2009 [1929-1930]), tal como a noção de que o enunciado não é manifestado apenas verbalmente, encontram-se também no mundo virtual. Desta forma, tornou-se necessário compreender a complexidade enunciativa em uma interação virtual, em especial, nas redes sociais. Neste sentido, Recuero afirma:

\begin{abstract}
Esses sites [Twitter e Facebook] não apenas modificaram as redes sociais mas, igualmente, estabeleceram formas de interação mais amplas (Primo, 2006), conversações mais abrangentes e públicas (Recuero, 2012) e novas convenções de linguagem (Hineycutt e Hering, 2009). Além desse conjunto de transformações nas próprias formas de interação, os sites de rede social também tornaram essas comunicações registradas e capazes de ser buscadas, gerando grandes conjuntos de dados até então inexistentes. (RECUERO, 2009, p. 18)
\end{abstract}

$\mathrm{Na}$ conversação prototípica, locutor e interlocutor asseguram a alternância de turnos e contam com a presença de diversos tipos de signos (verbais, gestuais, modos de vestir, prosódicos) para sustentar a conversação face a face. No mundo virtual, no entanto, oral e escrito se entrecruzam e a relação entre os locutores se dá de maneira distinta. Conforme Maingueneau:

\footnotetext{
Essa evolução [das tecnologias] põe em xeque a noção de endereço no duplo sentido de identificação de um destinatário bem específico e do lugar físico onde entregar a mensagem. Assiste-se, de fato, a uma des-localização da produção e da recepção dos enunciados: o destinador não tem a necessidade de perguntar onde se encontra $(\mathrm{m})$ seu(s) destinatário(s), nem este(s), onde se encontra o destinador. (MAINGUENEAU, 2015 p.171)
}

A respeito das redes sociais digitais, deve-se considerar não só um emissor e receptor, mas também um receptor universal, já que uma mensagem pode ser vista por muitas pessoas de diferentes partes do mundo devido ao fato de ser um ambiente virtual. A internet é, deste modo, de natureza polifônica.

Pretende-se abordar aqui as especificidades encontradas no ato enunciativo de uma interação virtual nas redes sociais digitais, visto que a relação entre emissor e receptor é diferente de uma interação face a face. Goffman (1967), por exemplo, concebeu uma estrutura de participação dos ouvintes em uma conversação face a face, ou seja, ele definiu os arranjos estruturais entre um falante e um ouvinte em uma interação presencial. No plano do ouvinte, ele defende que há dois tipos de participação em uma troca comunicativa: ouvintes ratificados e ouvintes não ratificados. Ele classifica como 
ouvinte endereçado, o participante ratificado a quem a fala é dirigida especificamente; enquanto o ouvinte não endereçado é aquele participante ratificado a quem a fala não é dirigida, porém ele tem um status participativo. Por outro lado, a plateia, ou audiência, é um conjunto de ouvintes que apreciam as observações feitas e não respondem diretamente, mesmo quando isso é possível. Os participantes não ratificados, por sua vez, são os ouvintes não reconhecidos como participantes diretos da interação. Com base neste estudo de Goffman (1967), levamos em consideração o ambiente virtual e os status dos participantes para conceber o plano enunciativo da interação na rede social Facebook no esquema a seguir:

Emissor ou locutor: é o responsável pelo ato comunicativo, publica a mensagem para os receptores interagirem. A mensagem pode ser publicada na própria linha do tempo, conhecida como Timeline, em grupos de discussão ou em publicações de outras pessoas. É ele o responsável em iniciar uma interação, porém ele pode ocupar uma posição de alternância, ser também um receptor ou destinatário de uma mensagem. O emissor pode escolher em deixar a publicação direcionada a amigos ou conhecidos, ou deixar de modo público ou personalizado, para pessoas específicas. No exemplo a seguir, o usuário publica a mensagem em sua linha do tempo de forma pública e espera o engajamento dos participantes da rede social digital.

Figura 14: Enunciado público no Facebook
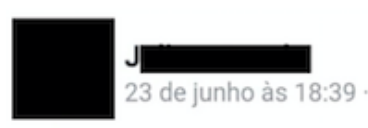

Não deu pras meninas, mas o Caio Ribeiro disse algo que é importante.

O futebol feminino nunca mais será o mesmo!

Precisou um monte de mulher em campo pra eu concordar com o Caio Ribeiro.

17

Curtir Comentar

Fonte: Facebook (2019)

Emissor ou locutor delegado: o emissor utiliza outros artifícios para interagir e publicar sua opinião, e a responsabilidade enunciativa é delegada para um ser real ou ficcional. Trata-se de um meio utilizado, sobretudo, para diminuir a 
responsabilidade do ato ilocutório, uma vez que a intenção comunicativa estará velada no discurso por meio de elementos verbais, não-verbais ou híbridos. $\mathrm{Na}$ imagem 1, o artifício utilizado pela usuária da rede foi fazer uma crítica ao comportamento dos colegas da faculdade por meio do discurso de seu cachorro. $\mathrm{Na}$ imagem 2, utilizou-se um meme de uma personagem popular de quadrinhos para expressar a própria opinião da pessoa.

Figura 15: Emissor delegado no grupo de Letras/FFLCH-USP

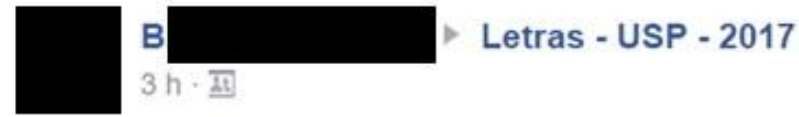

\section{MEU CACHORRO QUER SABER SE...}

Um humano postasse de forma educada que o barulho, gritos, risadas e etc na "entrada da Tia Bia" por vezes atrapalha o andamento da aula da sala 102 , vocês iam xingar esse humano e arranjar uma problematização muito louca sobre silenciamento na universidade.

Ele ta muito curioso então respondam por favor .

Bjs

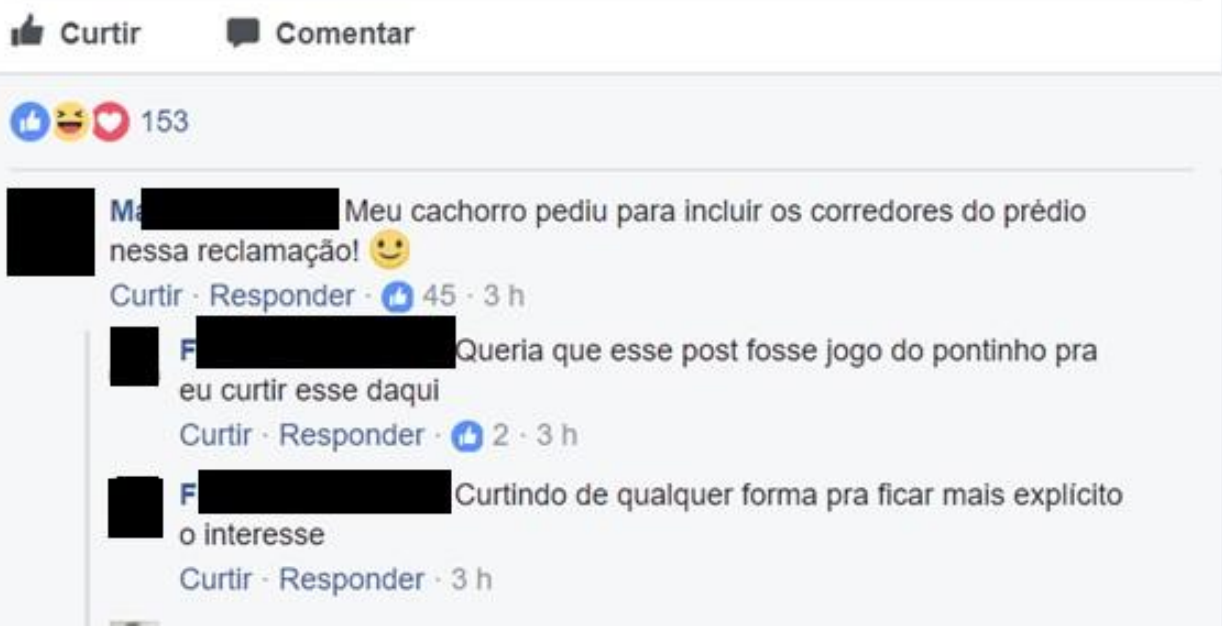

Fonte: Facebook (2017) 
Figura 16: Figura do meme da Turma da Mônica no grupo Novo Veneno, Facebook.

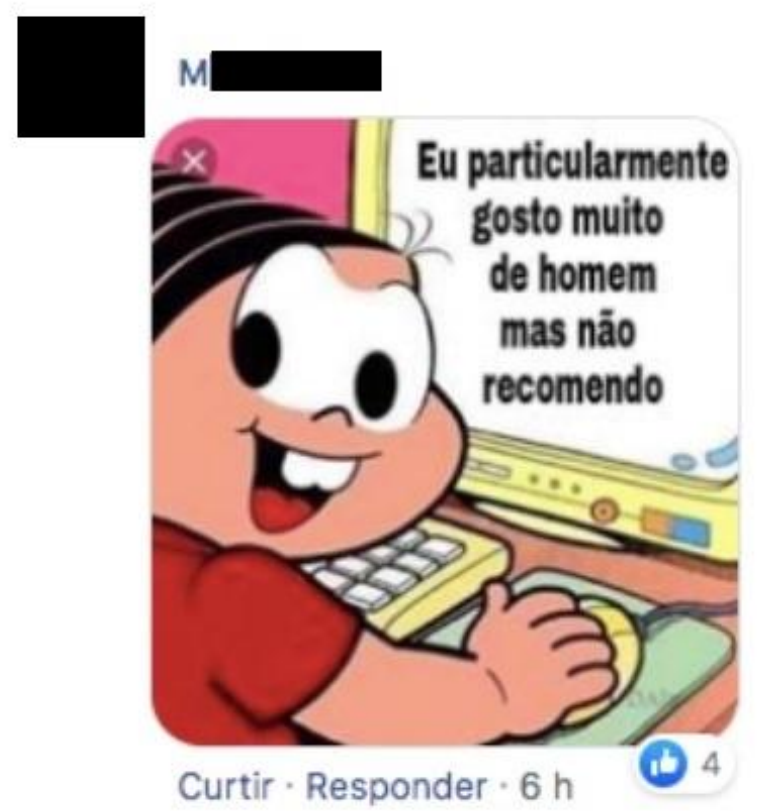

Fonte: Facebook (2018)

Receptor ou destinatário direto: aquele que o emissor considera explicitamente como seu parceiro na interação, ele recebe a mensagem do emissor e participa da troca comunicativa. No exemplo a seguir, a usuária $\mathbf{J}$ publica na linha do tempo de outra participante da rede, $\mathbf{R}$, parabenizando-a pelo aniversário. A mensagem foi direcionada especificamente a $\mathbf{R}$ e outros participantes não interagiram, embora todos os amigos de $\mathbf{R}$ pudessem ver a publicação. $\mathbf{R}$ é a receptora ou destinatária direta, enquanto seus amigos serviam apenas como testemunhas da interação, ou seja, receptores indiretos. 
Figura 17: Receptor ou destinatário direto no Facebook
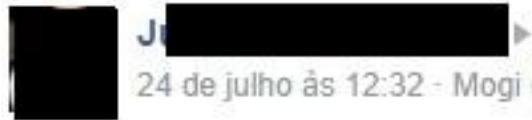

24 de julho às 12:32 - Mogi das Cruzes - $\mathbf{2 1}$

Rafinhaaaaa meu amor, hj é seu dia!

Quero Ihe desejar tudo de mais lindo, tudo de mais perfeito em sua vida !!

$\mathrm{Hj}$ posso dizer que ganhei uma outra familia com uma irmãzinha caçula e

com mesmo jeitinho que o meu $; \dot{\theta}=$ !

Que vc seja muito mais muito FELIZ, que seus caminhos seja sempre

iluminado por Deus !!!

Muita saúde, amor e fé

Amo vc princesa

Felicidades

It Curtir Comentar

R

1

Juuuu sua linda!!! Muito obrigadaa minha irma mais velha

(um pouco pior que eu vai! Kkkk)

Que tudo volte em dobro pra vc!

Amo vc chatonilda!!

Curtir-Responder

(1) 1.21h

J Pior nao है !!!

Somos igualzinhas sua fedô.

Curtir - Responder $-2 \mathrm{~h}$

Fonte: Facebook (2016)

Receptor ou destinatário indireto passivo: são todos os interactantes conectados nas redes sociais que presenciam a interação, são receptores universais, porém não participam da troca comunicativa. São os receptores universais e são testemunhas de toda a interação.

Receptor ou destinatário indireto ativo: recebem a mensagem de um emissor, porém a mensagem não foi dirigida a ele. Ele funciona como uma testemunha da troca verbal. Apesar de não ter a palavra dirigida a ele, ele participa da troca comunicativa.

$\mathrm{Na}$ imagem a seguir, $\mathbf{J}$ pede uma sugestão de leitura para todos os participantes do grupo. Ela se dirige a todos os destinatários indiretos do grupo e muitos participam ativamente, tornando-os destinatários indiretos ativos. A usuária Fer, até então destinatária indireta passiva, acompanha a discussão e 
também faz um pedido aos participantes do grupo, passando de uma destinatária indireta passiva à destinatária indireta ativa.

Figura 18: Receptor ou destinatário indireto dos tipos ativo e passivo.

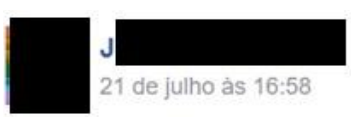

qual seria um primeiro bom livro pra começar a ler sobre crítica literária?

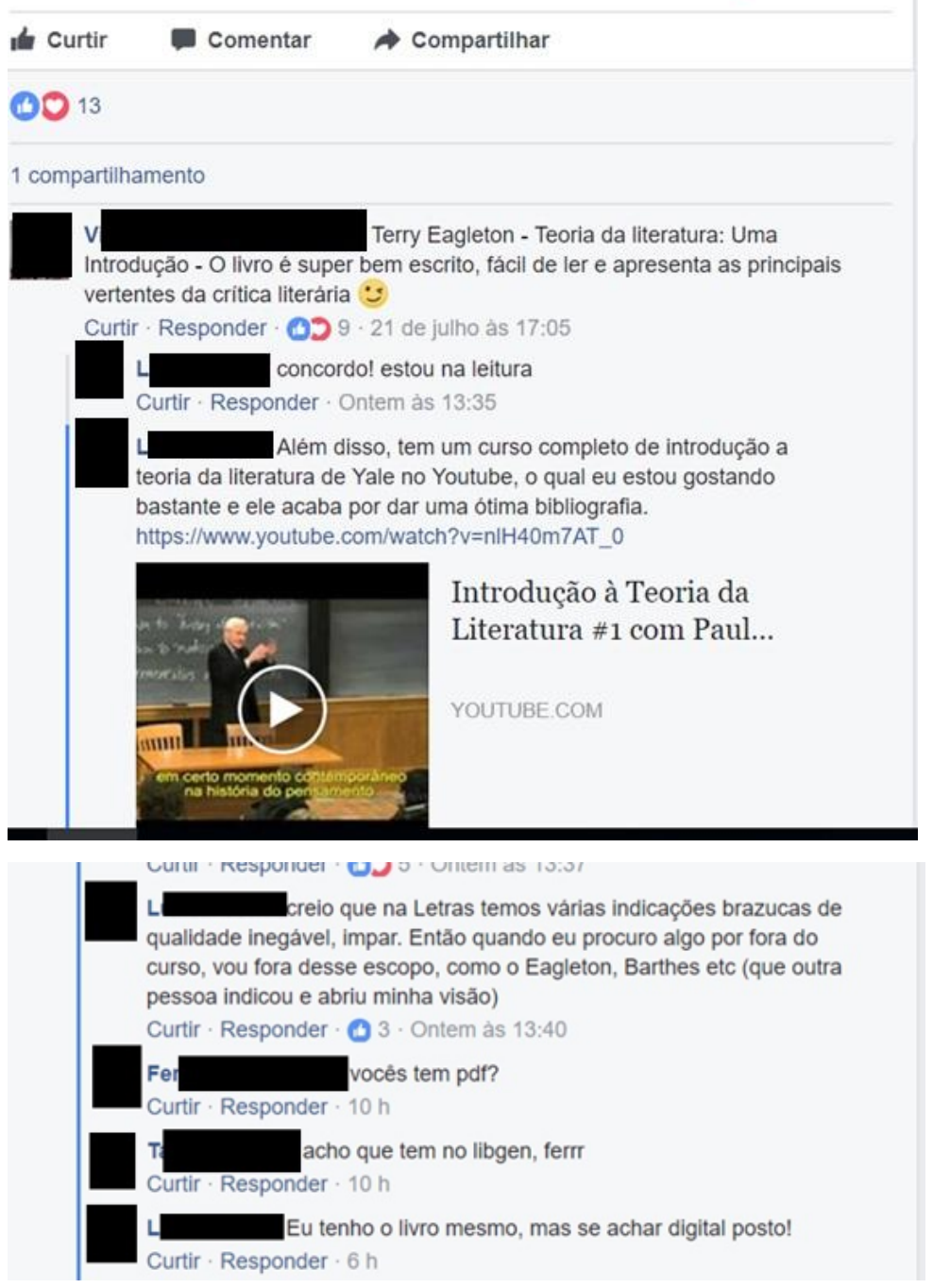

Fonte: Facebook (2016)

Receptor ou destinatário Voyeur: não participam da troca comunicativa diretamente como os demais interlocutores, porém sinalizam a sua presença por escrito ou por meio de memes e gifs. São receptores presentes em publicações polêmicas ou em interações conflituosas e demonstram o sentimento de satisfação em assistir a tais interações. A seguir, temos alguns memes usados 
para esse fim e um exemplo de uma publicação polêmica, onde se instaurou o conflito entre os participantes da rede e a página da publicação.

Figura 19: Memes do Receptor Voyeur comuns no Facebook
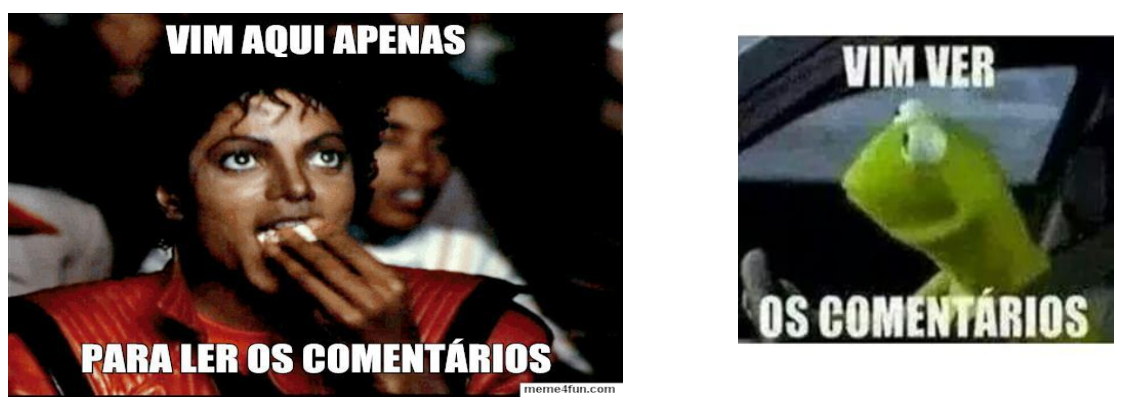

Fonte:

https://www.google.com/search?q=MEMES+VER+OS+COMENT\%C3\%81RIOS\&rlz=1C5CHFA enBR798BR799\&source=Inms\&tbm=isch\&sa=X\&ved=0ahUKEwja89eztijAhWBI7kGHT1zDKAQ AUIESgB\&biw=1440\&bih=699

Figura 20: Receptor Voyeur no Facebook

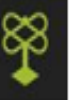

Catraca Livre

$10 \mathrm{~h} \cdot \mathrm{Q}$

Um detalhe está fazendo essa almofada ficar famosa nas redes sociais. Mãe comprou esse presente para filha, pensando que eram flores. A filha ficou com vergonha de colocar na sala.

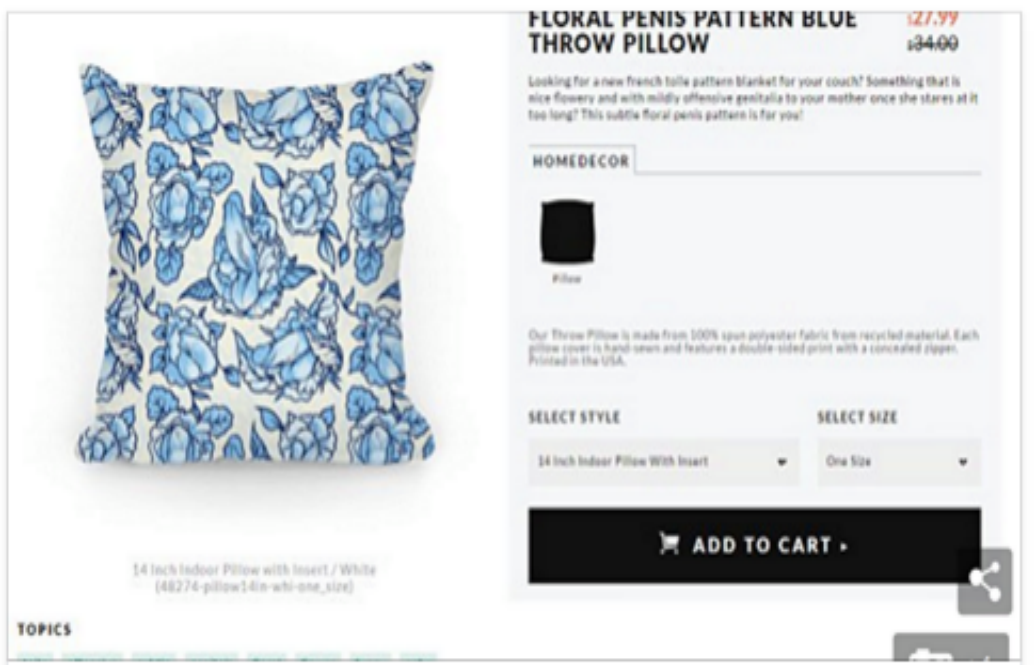

Mãe não viu um assustador detalhe ao comprar essa almofada na internet.

CATRACALIVRE.COM.BR

It Curtir $\quad \rightarrow$ Comentar $\Rightarrow$ Compartilhar 


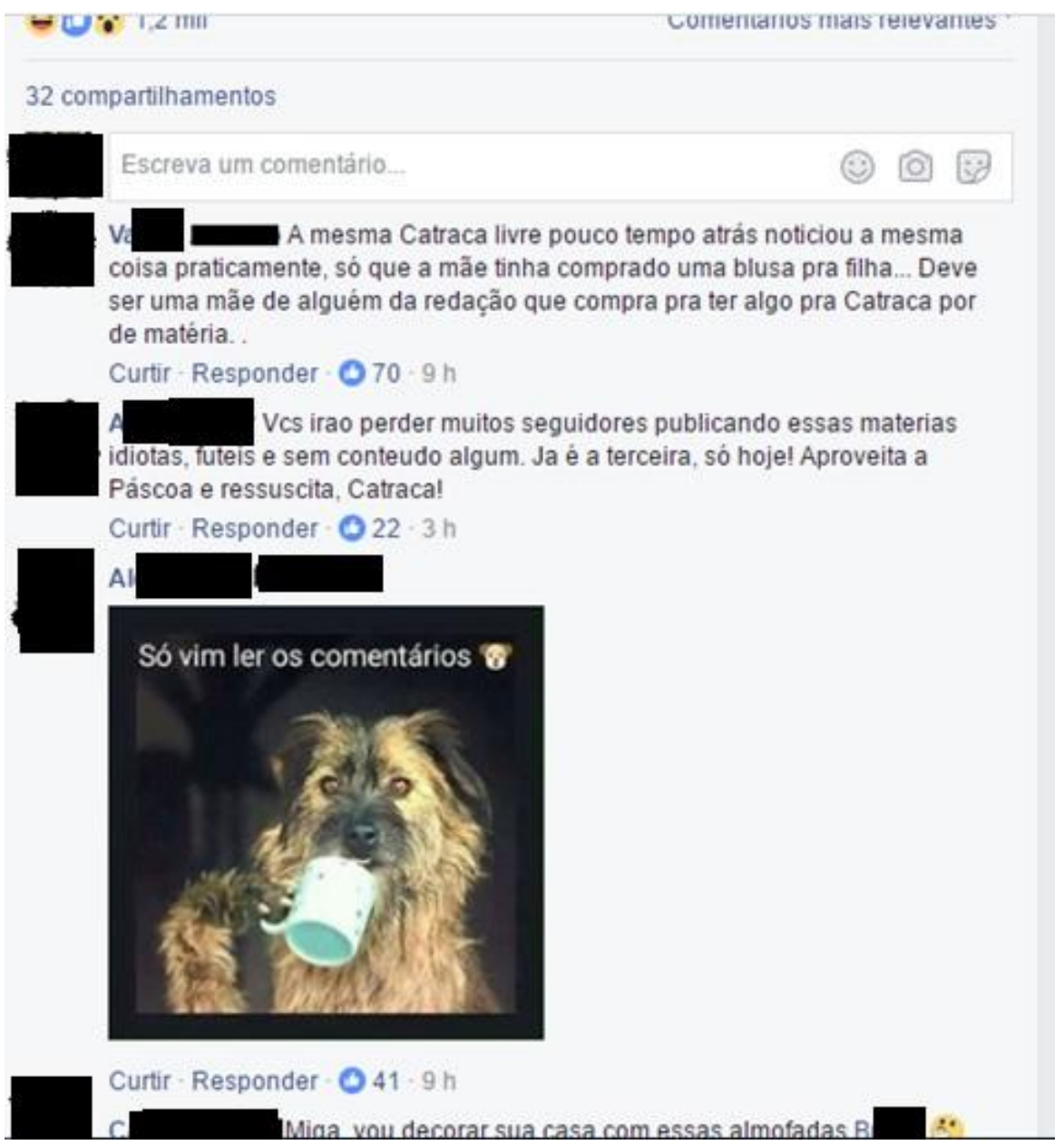

Fonte: Facebook (2015)

Emissor e o receptor robô: Nas redes sociais, e em outras plataformas de comunicação, tornou-se hábito também o uso de recursos tecnológicos na interação com um programa de computador, especialmente para que se tenha uma resposta imediata de empresas ou de celebridades. Trata-se do uso do Chatterbot ou chatbot, que tenta simular um ser humano na conversação com as pessoas. Seu objetivo é responder as perguntas de tal maneira que as pessoas pensem estar conversando realmente com uma pessoa real. O programa consulta uma base de conhecimento e fornece uma resposta que tenta imitar o comportamento humano. A seguir, os exemplos mostram o uso de Chatbot no perfil do político Geraldo Alckmin, que se tornaram virais pelas respostas inesperadas. 
Figura 21: Exemplos de chatbot na Internet

Zandro Zanfelice

@Zanfa

\section{O robô do Alckmin no Facebook é muito real}

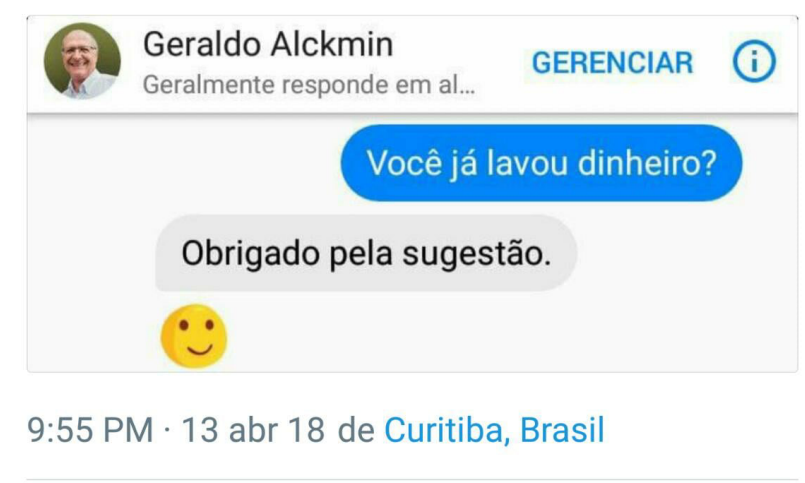

\subsection{Retweets 7.059 Curtidas}

Fonte: https://www.facebook.com/abaixoaredeGlobo/posts/894098890750760/

Figura 22: Exemplos de chatbot na Internet

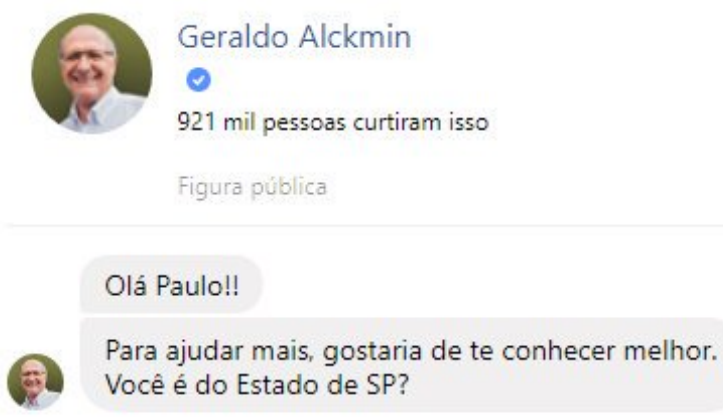

Legal! Vc tem alguma dúvida ou reclamação

relacionada ao Governo do Estado de São Paulo?

Boa noite, Geraldo. Gostaria de falar que vou votar em Jair Bolsonaro

\section{O que você me diz sobre isso?}

Estou trabalhando, depois marcamos um café, pode ser? 
Fonte: https://twitter.com/pauloap/status/984911243948552192

Além dos Chatbots, tornou-se frequente o uso de bots para dissipar mensagens nas redes sociais digitais. Os bots são aplicações autônomas que rodam na Internet enquanto desempenham algum tipo de tarefa prédeterminada. Chatbots, por sua vez, são programas que utilizam recursos de linguagem natural para interagir com os usuários via mensagens. Alguns chatbots utilizam inteligência artificial para descobrir a intenção na frase do usuário, lidar com ambiguidades, encontrar a melhor resposta e aprender com as interações. No exemplo a seguir, nota-se o uso de bots contra o jornal Folha de S.Paulo, na rede social digital Twitter:

Figura 23: Exemplos de bots na Internet

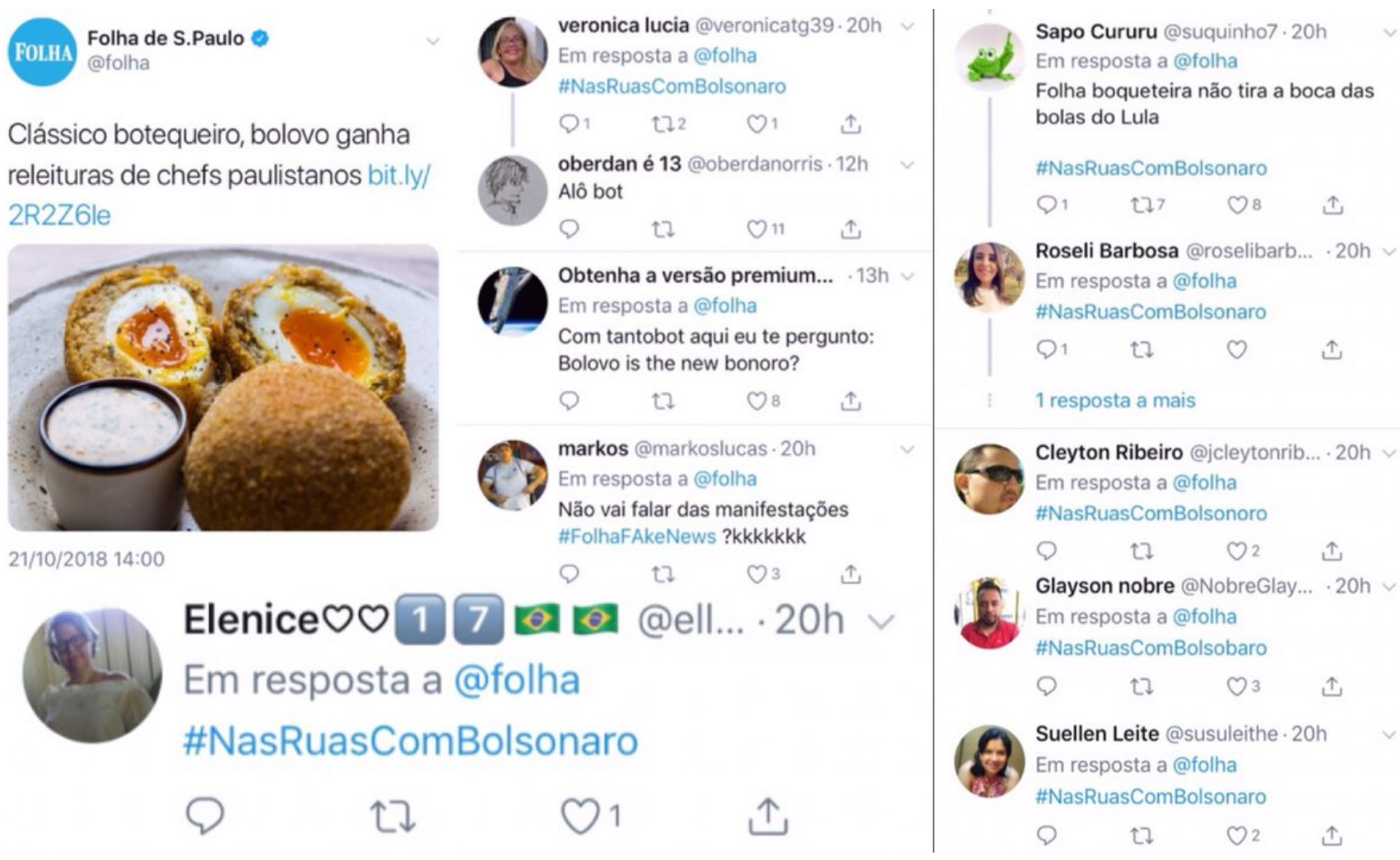

Fonte: https://www.buzzfeed.com/br/susanacristalli/bots-do-bolsonaro-xingando-bolovo

Com o exposto, salientamos que as funções de emissor e receptor podem ser mudadas ou alternadas a todo instante e ao longo da troca comunicativa nas redes sociais digitais. 


\subsection{A interação não-verbal ou híbrida: Memes, emoticons e Gifs}

Os recursos paralinguísticos na interação face a face, como já vimos, ajudam o interlocutor, em muitos casos, na decodificação de uma mensagem. Os gestos ou a entonação da voz, em determinados enunciados, podem ser um meio de demonstrar a descortesia na conversação face a face. Basta um interactante mostrar o "dedo do meio 22", por exemplo, para que o gesto se torne ofensivo. No mundo virtual, é possível utilizar representações gestuais ou fisionômicas por meio de recursos gráficos conhecidos como emoticons ou emojis. Os emoticons ou os emojis são muito utilizados, não só na internet, mas também em mensagens de texto de telefonia móvel. Graças à sua popularidade, é possível consultar, on-line, a Emojipédia, espécie de dicionário criado com o objeto específico de explicar o significado de cada figura utilizada, além de possibilitar a distribuição das figuras.

Figura 24: Exemplos de emoticons ou emojis

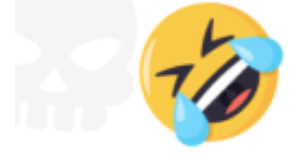

Rolando De Rir...

Copiar Detalhes

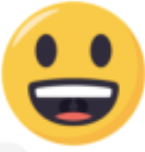

Sorrindo Carin...

Copiar Detalhes

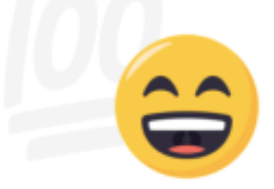

Sorrindo Carin...

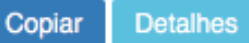

Fonte: Disponível em <http://emojipedia.com.br/z. Acessado em 05 de janeiro de 2019, às $12 \mathrm{~h}$

Além dos emoticons, com o desenvolvimento da Web 2.0, ganharam espaço outros tipos de interação gráficas, como os memes e os GIFs. Verificouse que, no corpus, esses elementos gráficos podem exercer também a função de atenuadores ou intensificadores da (des)cortesia.

Yus (2014) faz um importante estudo a respeito das funções pragmáticas que os emoticons desempenham na interação virtual e, acreditamos que o uso dos memes ou dos GIFs também desempenham o mesmo papel na interação.

\footnotetext{
${ }^{22}$ O gesto levantando o dedo do meio é considerado ofensivo e grosseiro para algumas culturas ocidentais.
} 
Adaptamos, assim, as funções listadas por Yus (2014) para todos os elementos gráficos mencionados neste trabalho:

1. Revelar a atitude proposicional que subjaz ao enunciado e que seria difícil de identificar sem a atitude do emoticon, do meme e do GIF;

2. Enfatizar uma atitude proposicional que já esteja verbalmente manifestada;

3. Intensificar ou atenuar a força ilocucionária de um ato de fala;

4. Contradizer o significado explícito de um enunciado com objetivos humorísticos;

5. Contradizer o significado explícito de um enunciado com o objetivo de ironizar os outros participantes da interação;

6. Acrescentar um sentimento ou emoção ao conteúdo proposicional do enunciado;

7. Exprimir um sentimento ou emoção no ato comunicativo; e,

8. Intensificar um sentimento ou emoção que se encontra verbalmente codificada.

Reações do interlocutor, como um riso sarcástico, podem ser representados por meio de GIFs, mesmo que este artifício não conte com recurso sonoro. Trata-se de uma ferramenta com a possibilidade de ser interpretada de diferentes maneiras, sobretudo devido ao fato do GIF ser retirado de seu contexto original. Em relação aos GIFs, Miltner \& Highfield afirmam que

\begin{abstract}
O Graphics Interchange Format (GIF) é um formato animado de arquivo digital com uma longa história em culturas da Internet e conteúdo digital. Emblemático da Web inicial, o GIF alcançou as graças do público no final dos anos 90, antes de experimentar um ressurgimento que viu o formato se tornar onipresente na comunicação digital. (...) os GIFs se tornaram uma ferramenta de comunicação fundamental nas culturas digitais contemporâneas, graças a uma combinação de suas características, restrições e capacidades. Os GIFs são polissêmicos, principalmente porque são trechos isolados de textos maiores. Isso, combinado com sua repetição loop infinita, permite que eles transmitam vários níveis de significado em um único GIF. Essa complexidade simbólica os torna uma ferramenta ideal para melhorar dois aspectos centrais da comunicação digital: o desempenho do afeto e a demonstração do conhecimento cultural ${ }^{23}$. (MILTNER \& HIGHFIELD, 2017, p. 01, tradução nossa)
\end{abstract}

\footnotetext{
${ }^{23}$ No original: The animated Graphics Interchange Format (GIF) is a digital file format with a long history within internet cultures and digital content. Emblematic of the early Web, the GIF fell from favor in the late 1990s before experiencing a resurgence that has seen the format become ubiquitous within digital communication. (...) GIFs have become a key communication tool in contemporary digital cultures thanks to a combination of their features, constraints, and
} 
Um dos GIFs mais populares na rede social digital Facebook é o de Miranda, personagem do filme $O$ diabo veste Prada. No filme, a personagem, interpretada por Meryl Streep, se destaca pela sua expressividade em relação ao seu entorno social. Geralmente, um dos GIFs mais utilizados é o de Miranda virando os olhos, demonstrando tédio e desaprovação, tal como nas figuras abaixo:

Figura 25: Exemplo de GIF

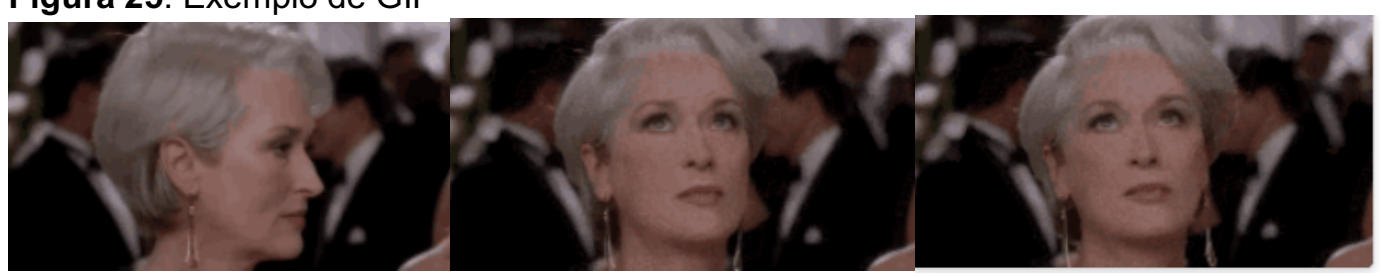

Fonte: http://tenor.com. Acesso em 05 de janeiro de 2019, às 23h

Atualmente, há sites de internet específicos para a escolha de GIFs, assim como os de memes ${ }^{24}$. Em relação aos memes, Dawkins (2001) foi o responsável em defini-los. Ele argumenta que as ideias, no âmbito da cultura, funcionam de maneira semelhante aos genes. Em vez de fitas de DNA, as ideias são replicadas por meio de veículos de comunicação. Ao equivalente cultural dos genes, Dawkins (2001) dá o nome de memes. Eles podem replicar-se por imitação e vários fatores podem colaborar com sua longevidade. Segundo Martino,

Os memes são transmitidos, primordialmente, entre indivíduos. No entanto, por conta da velocidade e alcance de sua disseminação, se tornam fenômenos culturais e sociais que ultrapassam a ligação entre as pessoas. Essa relação entre o nível micro do compartilhamento individual e o nível macro do alcance social tornam os memes particularmente importantes para se entender a cultura contemporânea. (MARTINO, 2014, p. 178)

affordances. GIFs are polysemic, largely because they are isolated snippets of larger texts. This, combined with their endless, looping repetition, allows them to relay multiple levels of meaning in a single GIF. This symbolic complexity makes them an ideal tool for enhancing two core aspects of digital communication: the performance of affect and the demonstration of cultural knowledge.

${ }^{24}$ Para conhecer um pouco mais dos GIFs, acesse $<$ https://tenor.com/ $>$ ou $<$ https://giphy.com/ $>$. Em relação aos memes, recomenda-se o site $<$ http://www.museudememes.com.br/ $>$, criado pela Universidade Federal Fluminense para catalogar o surgimento dos memes mais populares no Brasil. 
A criação e replicação dos memes nas redes sociais digitais possibilitam a distribuição rápida de mensagens entre os usuários, de maneira global. A propagação de um meme se dá de maneira coletiva, visto que é a quantidade de compartilhamentos que ajuda em sua popularidade. Os memes carregam consigo informações culturais e sociais, pois refletem, muitas vezes, um contexto específico de uma sociedade. Um meme estrangeiro, por exemplo, nem sempre será compreendido no ambiente socio-histórico brasileiro ou vice-versa. Destacamos, no entanto, que um meme originário de um determinado país pode sofrer adaptações em outros países e culturas. Foi o que aconteceu com o famoso meme Nazaré confusa, criado a partir de uma personagem da telenovela brasileira. O meme é utilizado em casos de dúvida e, devido à sua disseminação, alcançou a popularidade em vários países, tal como no exemplo abaixo, originário da Rússia:

Figura 26: Exemplo de meme brasileiro usado internacionalmente

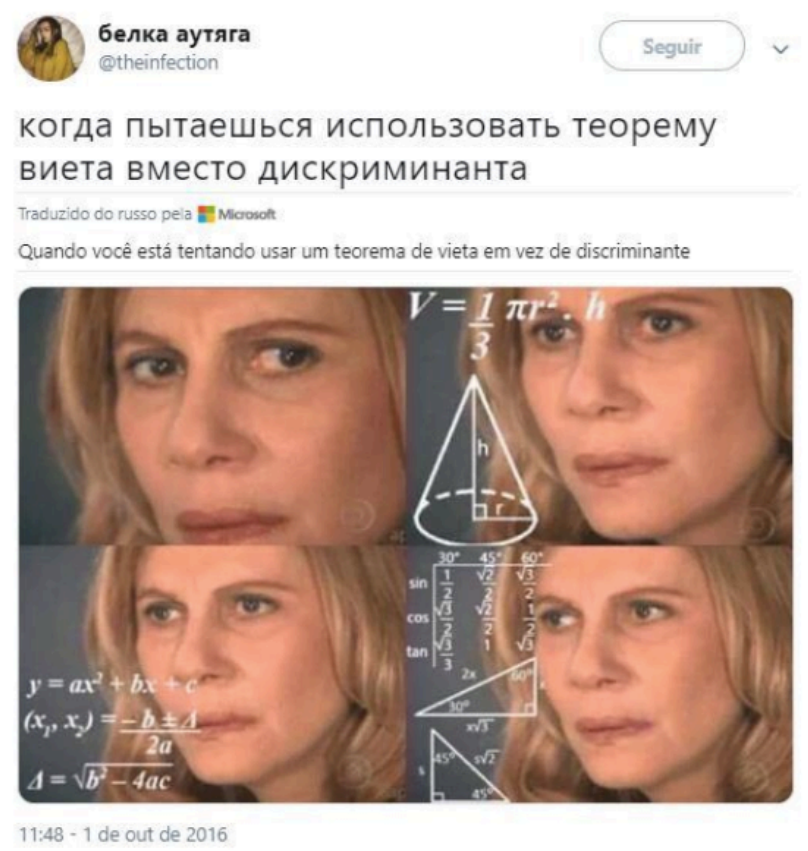

Fonte: Twitter (2016)

Como já mencionamos, nem sempre a história de um personagem que figura no meme é conhecida por todos. O meme da Nazaré confusa, por exemplo, é conhecido como math lady no exterior, já que nem todos conhecem a personagem da telenovela brasileira: 
Figura 27: Exemplo de meme brasileiro usado internacionalmente

\section{Counting in French be like}

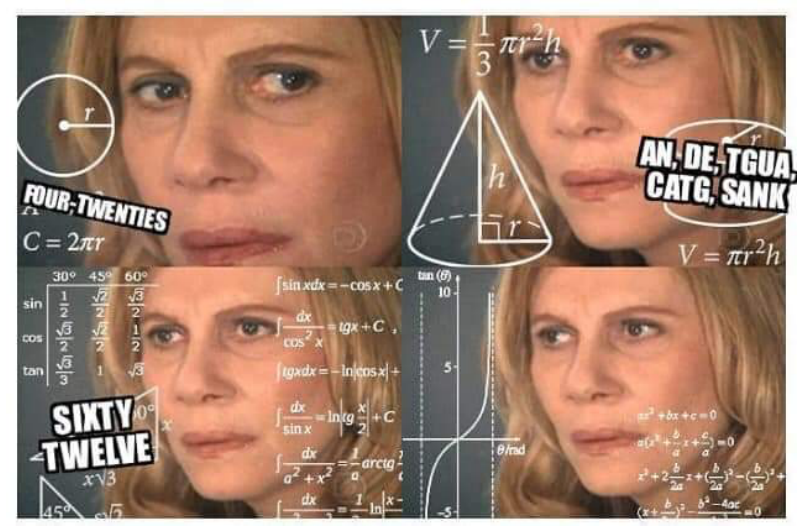

Fonte: Facebook (2018)

Graças à popularidade dos memes, eles estão adquirindo outras funções, além do humor contido neles, geralmente. Muitos são usados para fins de ensino, como no exemplo a seguir:

Figura 28: Exemplo de meme brasileiro usado para o estudo histórico de acontecimentos
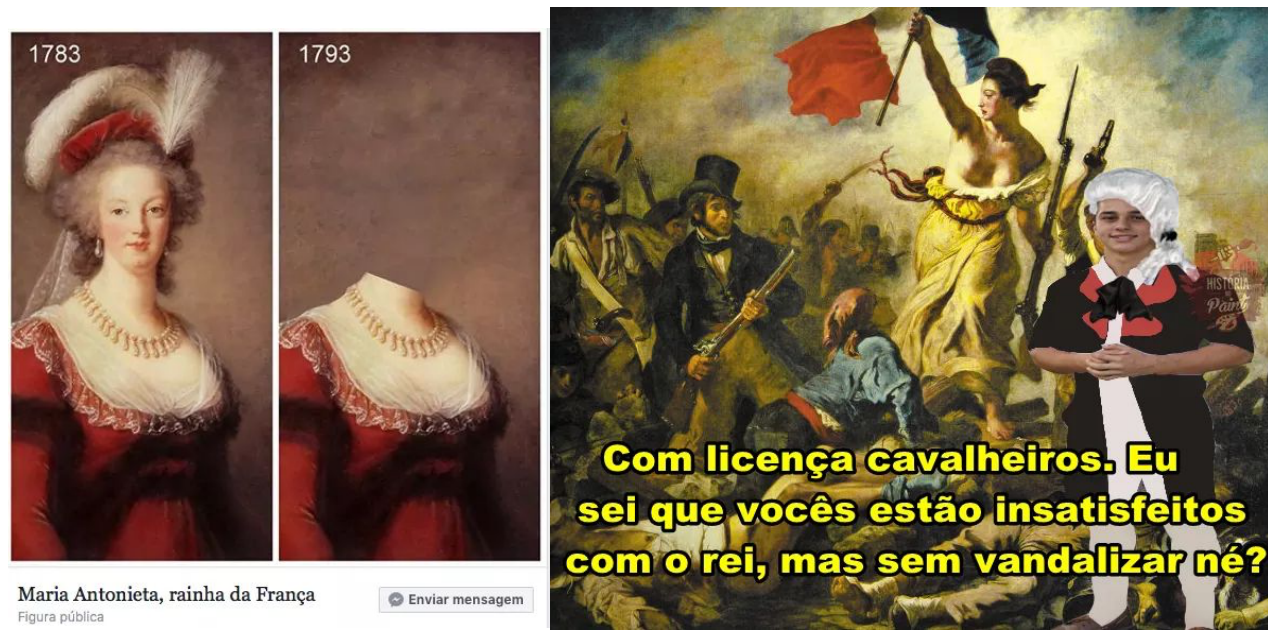

Fonte: Facebook (2018), página História no Paint

Nesses memes, retirados de páginas de estudo de história, é necessário que o usuário da internet conheça os acontecimentos relacionados à Revolução Francesa para que compreenda o humor contido nas figuras, ou seja, o usuário deve ter a competência pragmática para decodificá-los. A primeira figura faz alusão ao desafio dos 10 anos no Facebook, que se caracterizou com o compartilhamento de fotos dos participantes da rede para se comparar as 
diferenças ao decorrer do tempo. A segunda figura, por exemplo, além do conhecimento histórico, o usuário deve conhecer o famoso meme do playboy riquinho, ou seja, a representação de um garoto rico que não sabe o que acontece ao seu redor ${ }^{25}$. Além de memes usados para fins de ensino, muitos trabalham o humor com trocadilhos e, assim como nos exemplos anteriores, o usuário deve mobilizar sua competência pragmático-linguística para interpretálos com sucesso, como ilustra o exemplo a seguir.

Figura 29: Exemplo de meme brasileiro com trocadilho linguístico

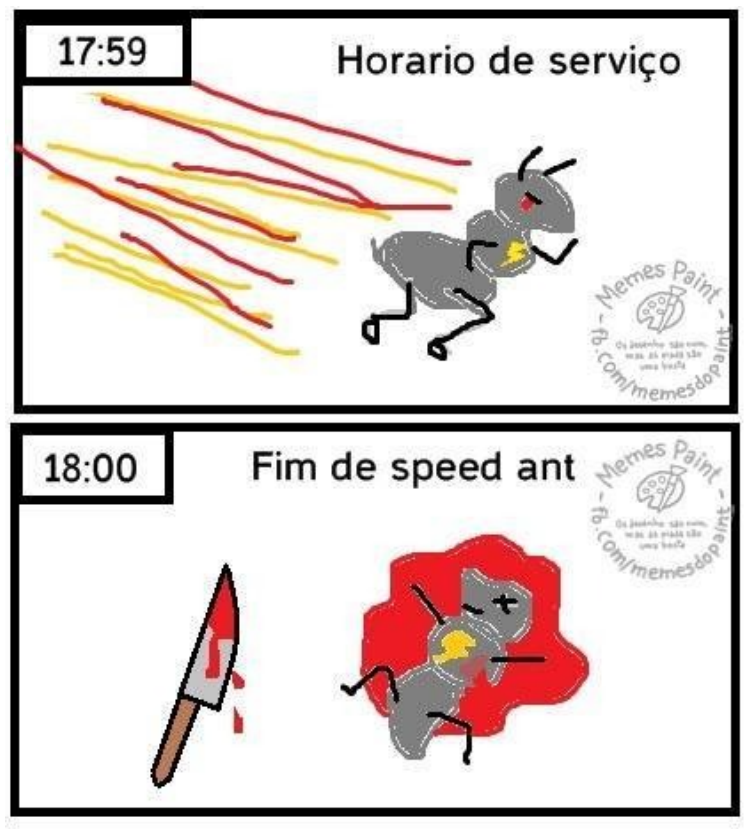

Fonte: Facebook (2019)

Nesse exemplo, é necessário que os participantes da rede social digital saibam reconhecer o humor contido na segunda tirinha mobilizando também o conhecimento de língua inglesa, em que temos a formiga correndo na primeira tirinha, formiga $=$ ant e velocidade $=$ speed, para, enfim, compreender 0 trabalho com o trocadilho sonoro, expediente $=$ speed ant. Tal como vimos, os memes trabalham, sobretudo, com o humor e, no Brasil, têm sido também usados como crítica política ou para ironizar falas de políticos, como nos exemplos a seguir:

25 Para mais informações a respeito do meme playboy riquinho, acesse: <https://www.dicionariopopular.com/meme-do-playboy-riquinho/> 
Figura 30: Exemplos de memes políticos

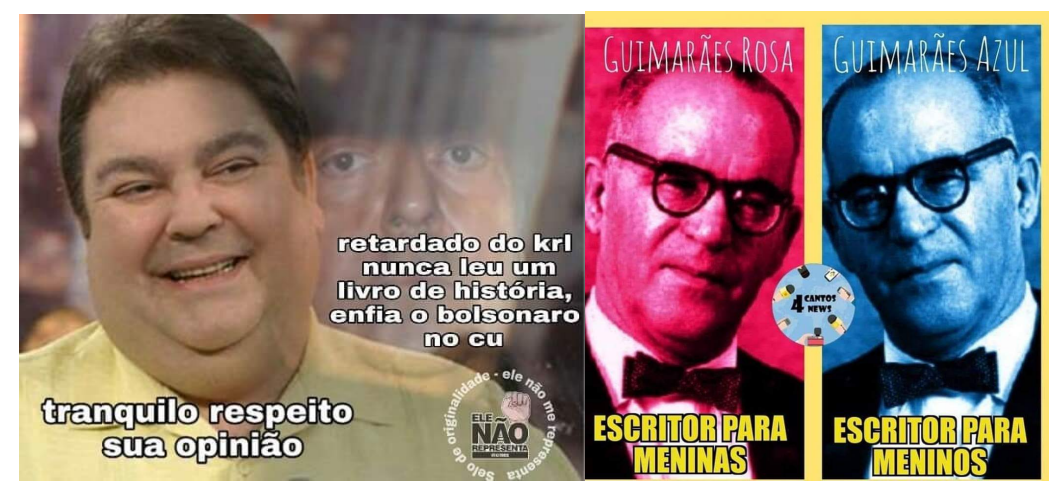

Fonte: Facebook (2019)

$\mathrm{Na}$ primeira figura, temos um apresentador brasileiro representando a discussão da polarização política entre as pessoas, enquanto na segunda, temos uma ironia relacionada à fala de uma ministra brasileira que afirmou que: "Meninas vestem rosa, meninos vestem azul.

Como exposto, consideramos esses elementos gráficos disponíveis nas redes sociais digitais como um suporte aos elementos linguísticos expressos verbalmente. Os emoticons e os GIFs tentam suprir a falta de recursos paralinguísticos no ambiente on-line, enquanto os memes funcionam como recursos híbridos, pois conjugam o verbal ao visual. Na análise do corpus, vamos verificar que esses elementos se fazem presente na interação e, embora possam funcionar como um mecanismo de descortesia, colaboram também para atenuar, com bom humor, possíveis conflitos, tal como veremos no capítulo 3 e 4 . 


\section{CAPÍTULO 3: AS MANIFESTAÇÕES DESCORTESES NA INTERAÇÃO}

\subsection{Tipos de descortesia na interação virtual}

Nas redes sociais, embora tenhamos aspectos da língua oral na escrita, ainda não se substitui completamente a dinâmica de uma interação face a face, especialmente no que diz respeito aos elementos paralinguísticos. Em uma interação face a face, os interactantes podem fazer uso tanto de recursos verbais como não verbais, como entonação, gestos faciais e corporais para chamar atenção de seu destinatário. Embora na escrita tenhamos vários recursos gráficos para substituir esses elementos extralinguísticos, em muitos casos a interpretação de uma mensagem não é bem-sucedida, em especial na interação virtual. De acordo com Kerbrat-Orecchioni (2006, p. 64), o mal-entendido é sempre uma defasagem entre o sentido intencional que o emissor deseja transmitir ao interlocutor e o sentido decodificado pelo receptor. Pode acontecer de um interlocutor se sentir ofendido mesmo sem que haja a intenção do emissor.

As manifestações descorteses acontecem em situações de conflito tanto reais quanto virtuais. Embora muitos participantes das redes sociais digitais não se conheçam, isso não é um obstáculo para os ataques, inclusive pessoais. Mesmo que a comunicação se dê em um ambiente on-line, a manifestação da descortesia também pode agrupar casos de violência verbal, ameaças e injúrias, principalmente em casos de discussões polêmicas. Amossy (2017) faz um estudo sobre a polêmica nas interações verbais, já que para ela a polêmica gera frequentemente casos de violência e descortesia verbal. Entende-se que a polêmica é "[...] um enfrentamento, uma forte oposição de discursos sobre uma questão controversa." (AMOSSY, 2017, p.167). Enfatizamos que a polêmica e a violência verbal não são uma condição necessária para a manifestação da descortesia, porém ambas podem desencadear uma interação onde imperam as manifestações descorteses.

Com base em Amossy (2017) e outros teóricos já mencionados neste trabalho, elaboramos os tipos recorrentes de descortesia no mundo virtual. 
Entendemos que a lista não é exaustiva e que muitos elementos apontados podem ocorrer concomitantemente em uma interação:

1) Descortesia coercitiva: neste tipo de descortesia, há violência verbal acompanhada de uma forte coerção a fim de impedir o outro de se exprimir. Neste caso, ocorre geralmente interrupções do turno de fala em uma conversação face a face ou o interactante impede o interlocutor de desenvolver seu ponto de vista. Na interação virtual, não há sobreposição nem interrupção de turnos, porém a interrupção do outro pode ser expressa por meio de recursos verbais, principalmente com o uso de insultos e formas de tratamento inadequados. O intuito é silenciar o interlocutor de modo coercitivo. $O$ interactante exprime sentimentos violentos por meio de marcas prosódicas, sintáticas ou lexicais. Na interação virtual, é recorrente também o uso de emoticons, Gifs ou memes com imagens ofensivas.

Figura 31: Exemplos de descortesia coercitiva na rede social digital Facebook

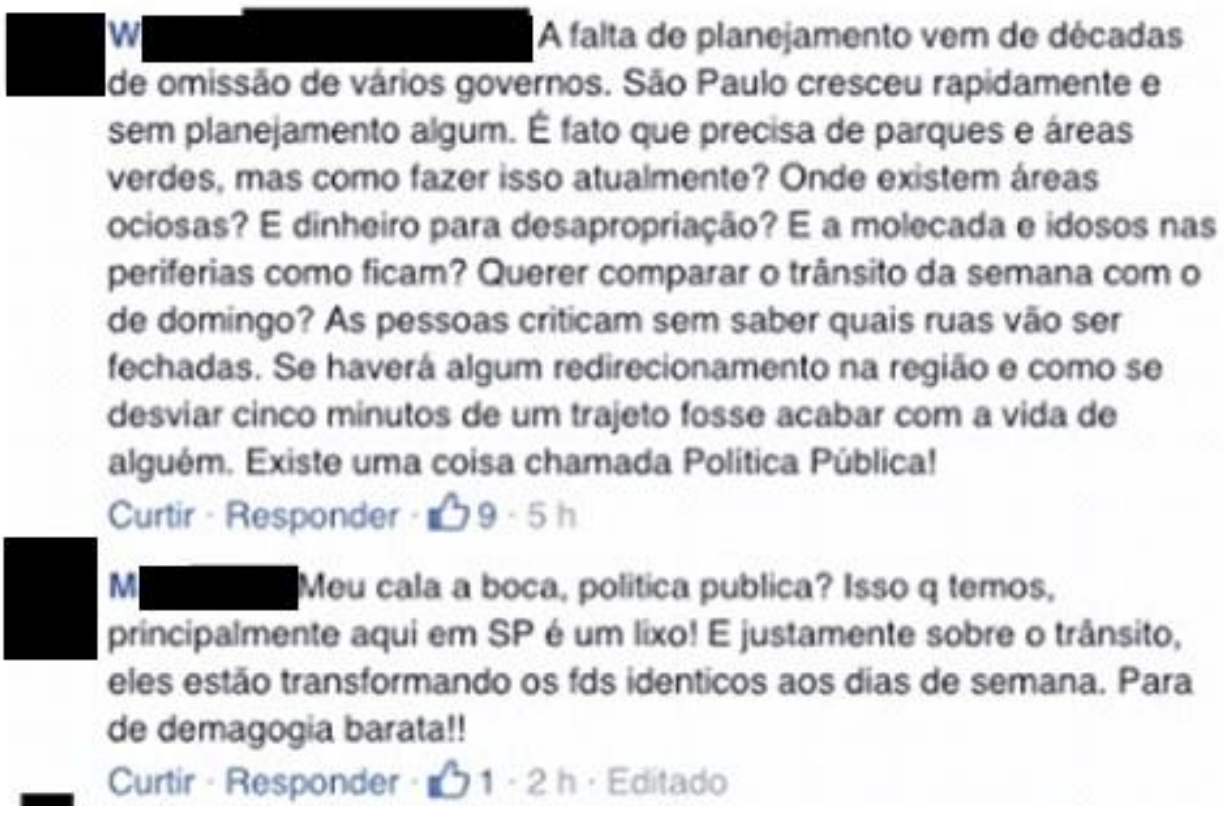

Fonte: Facebook (2015)

Figura 32: Exemplos de descortesia coercitiva na rede social digital Facebook

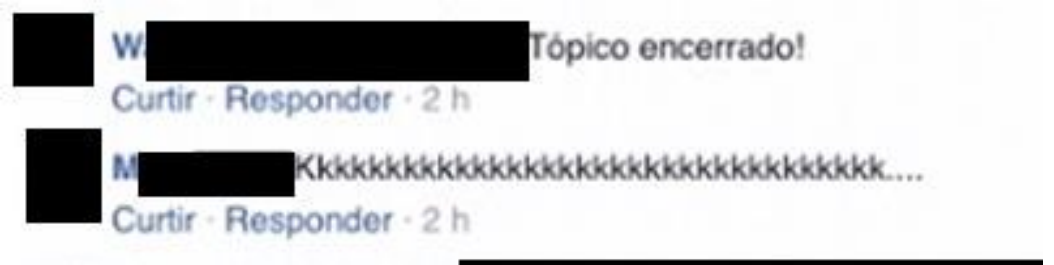




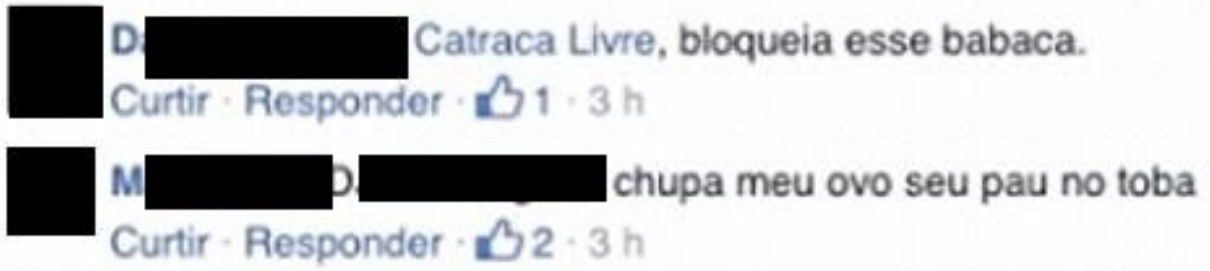

Fonte: Facebook (2015)

2) Descortesia ridicularizante: neste tipo de descortesia, o enunciado do locutor é totalmente desconsiderado ou ridicularizado pelo interlocutor.

Figura 33: Exemplos de descortesia ridicularizante na rede social digital Facebook

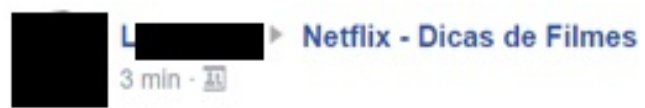

Mim recomenda um filme que passa homens lindos $\hat{\theta}$ 응 0 ?

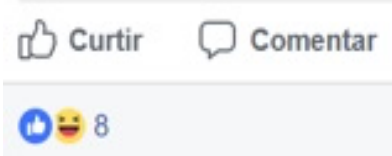




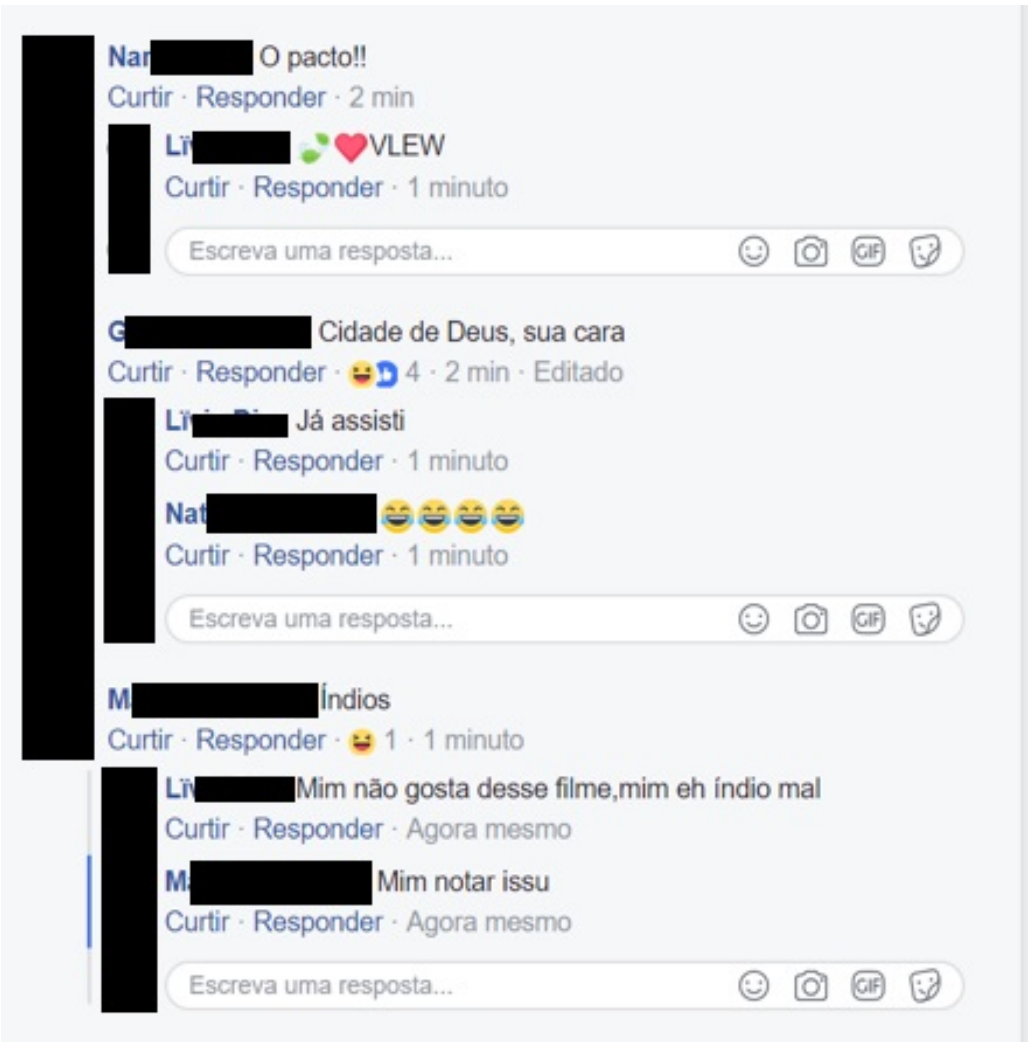

Fonte: Facebook (2017)

3) Descortesia Ad Hominem: Muitos ataques desviam o foco para os comentários dos usuários e atacam diretamente a pessoa responsável pela publicação. Esse tipo de ataque é conhecido como ad hominem. A discussão adquire ares pessoais. Caracteriza-se, assim, pelo ataque moral e de personalidade do outro no lugar de refutar os argumentos.

Figura 34: Exemplos de descortesia ad hominem na rede social digital Facebook curur - responaer - $\boldsymbol{U}^{4}$ - 5 mाп

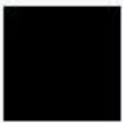

c G Grupo errado seu retardado doente.

Curtir-Responder - (1) $2 \cdot 2$ min

Fonte: Facebook (2018) 
Figura 35: Exemplos de descortesia ad hominem na rede social digital Facebook

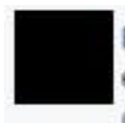

Elas pedem isso pq não tem nada entre as pernas pra ser esmagado quando se fecha!

Curtir-Responder -OP 9:1h

L Lulher não quer que o homem cruze as pernas, só năo abra a ponto de tomar o espaço dela.

Curtir - Responder - 15 - 55 min

J Do jeito q fala, parece $\mathrm{q}$ tem 2 bolas de basquete entre as pernas em vez de dois ovinhos de codorna. Ninguém quer bolas. machucadas, somente respeito pelo limite das poltronas.

Curtir-Responder - $9: 26 \cdot 50 \mathrm{~min}$

Fonte: Facebook (2017)

Figura 36: Exemplos de descortesia ad hominem na rede social digital Facebook

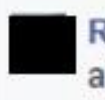

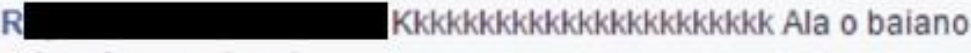

achando que eh gnt

Curtir- Responder- 4 min

Fonte: Facebook (2017)

4) Descortesia violenta: A incitação da violência contra os outros acompanhados de encorajamento para o uso de força, inclusive com uso de armas, ameaças de assassinato e agressões físicas marcadas para acontecer no ambiente on-line ou off-line.

Figura 37: Exemplos de descortesia violenta na rede social digital Facebook

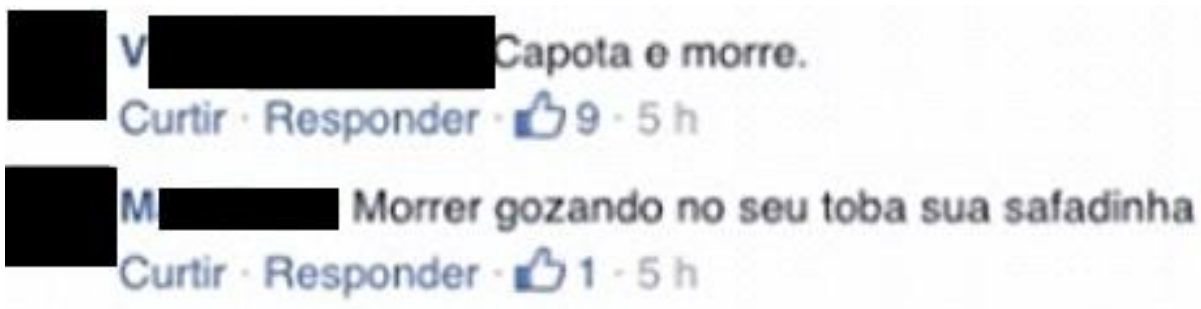

Fonte: Facebook (2015) 
Figura 38: Exemplos de descortesia violenta na rede social digital Facebook

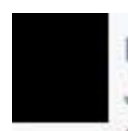

Bizarro que até lá tenha esses idiotas.

Já chego logo empurrando quando sento ao lado de um desses. Infelizmente a maioria das mulheres não podem se atrever a fazer o mesmo.

Curtir-Responder - $02 \mathrm{~S} 74 \cdot 40 \mathrm{~min}$

^ Ocultar 11 respostas

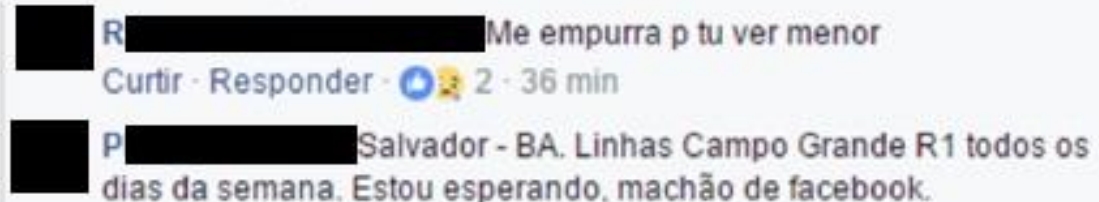

dias da semana. Estou esperando, machão de facebook.

Um abraço

Curtir-Responder-O: $55 \cdot 35 \mathrm{~min}$

Fonte: Facebook (2017)

5) Descortesia imagética: No mundo virtual, a falta de recursos paralinguísticos levam a má interpretação de um enunciado. É o caso das entonações das unidades linguísticas em casos de brincadeiras ou ironia ou de ênfase. $\mathrm{Na}$ comunicação face a face a presença deste suporte ao enunciado evita muitos mal-entendidos, por exemplo, pois a entonação, a velocidade e a intensidade da voz podem indicar alguma intenção específica do emissor. Devido à falta desses recursos no ambiente virtual, é comum o uso de memes, Gifs e emoticons para suprir esse recurso comunicativo. Muitos são escolhidos com o propósito de ser ofensivo e desencadeiam ou colaboram, assim, com a descortesia.

Figura 39: Exemplos de descortesia imagética na rede social digital Facebook

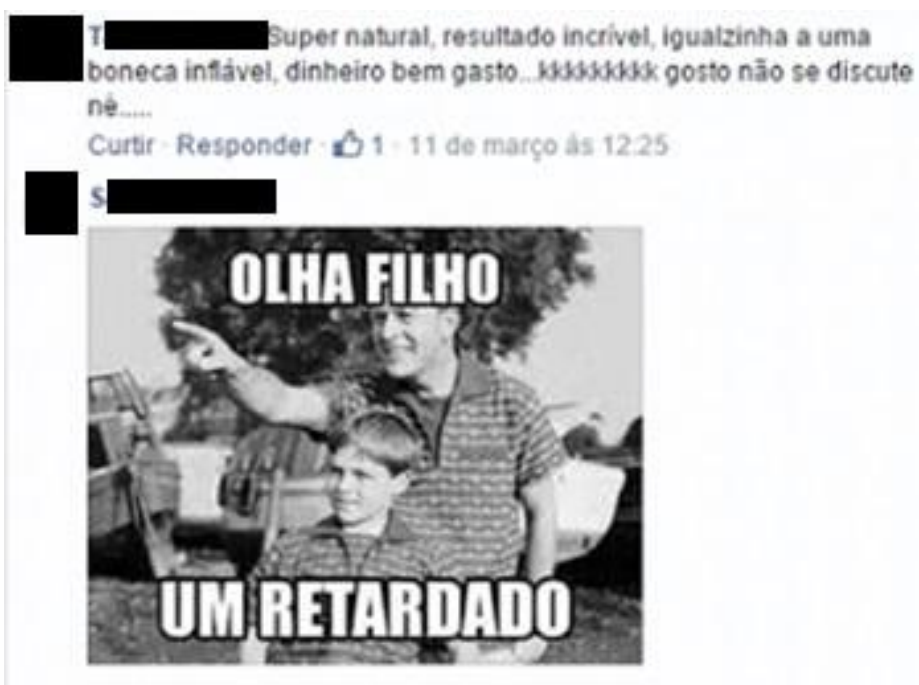

Curtir-Responder-11 de março ass 16.18

Fonte: Facebook (2015) 
Figura 40: Exemplos de descortesia imagética na rede social digital Facebook

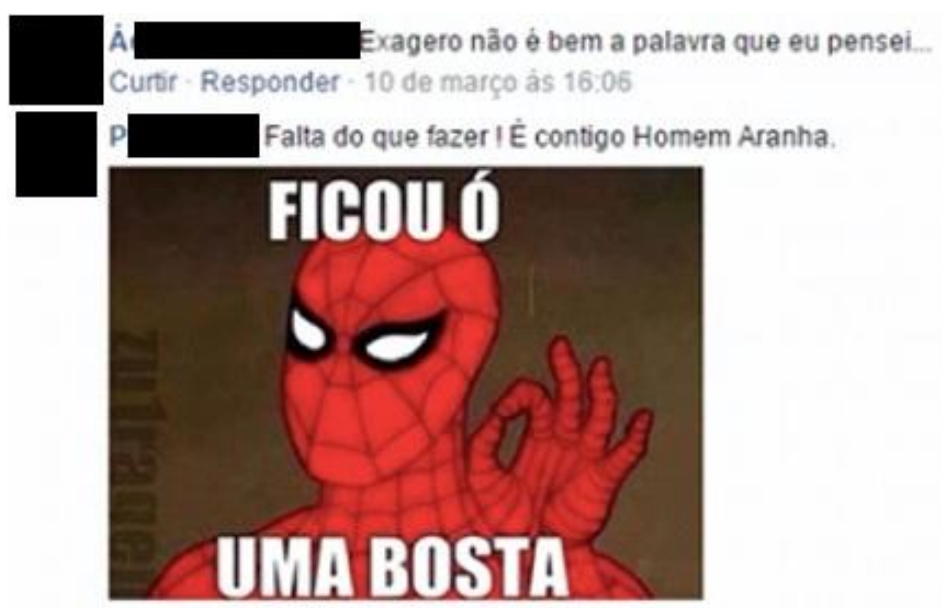

Curtir - Responder - 11 de março às 06:48

Fonte: Facebook (2015)

Figura 41: Exemplos de descortesia imagética na rede social digital Facebook

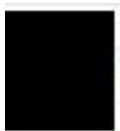

E

(Gramatica chata) Alguém me ajuda a entender o uso de Future perfect e future perfect continuous? Nã̃o entendo as diferenças

E eu fiquei com duvida nessa frase

Don't worry. By the time you get back, I (pick) will have picked up the living room and (finish) finished washing the dishes.

Por que usa o finished nessa frase?

It Curtir Comentar

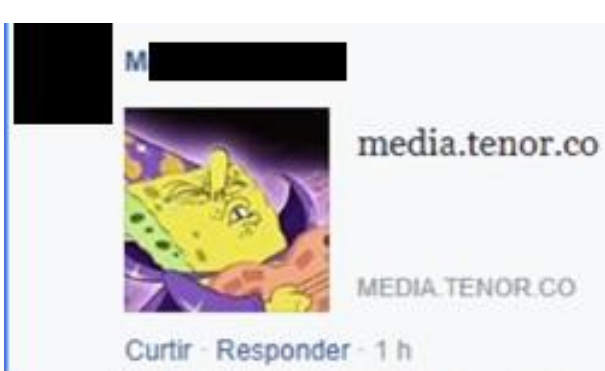

E Oh imbecil, quando vc perguntou aqui no grupo eu tentei te ajudar, então para de ser criança obrigado.

Se vc è um professor assim na vida real, não sei como alguém quer estudar com vc

Curtir-Responder - 45 min - Editado 


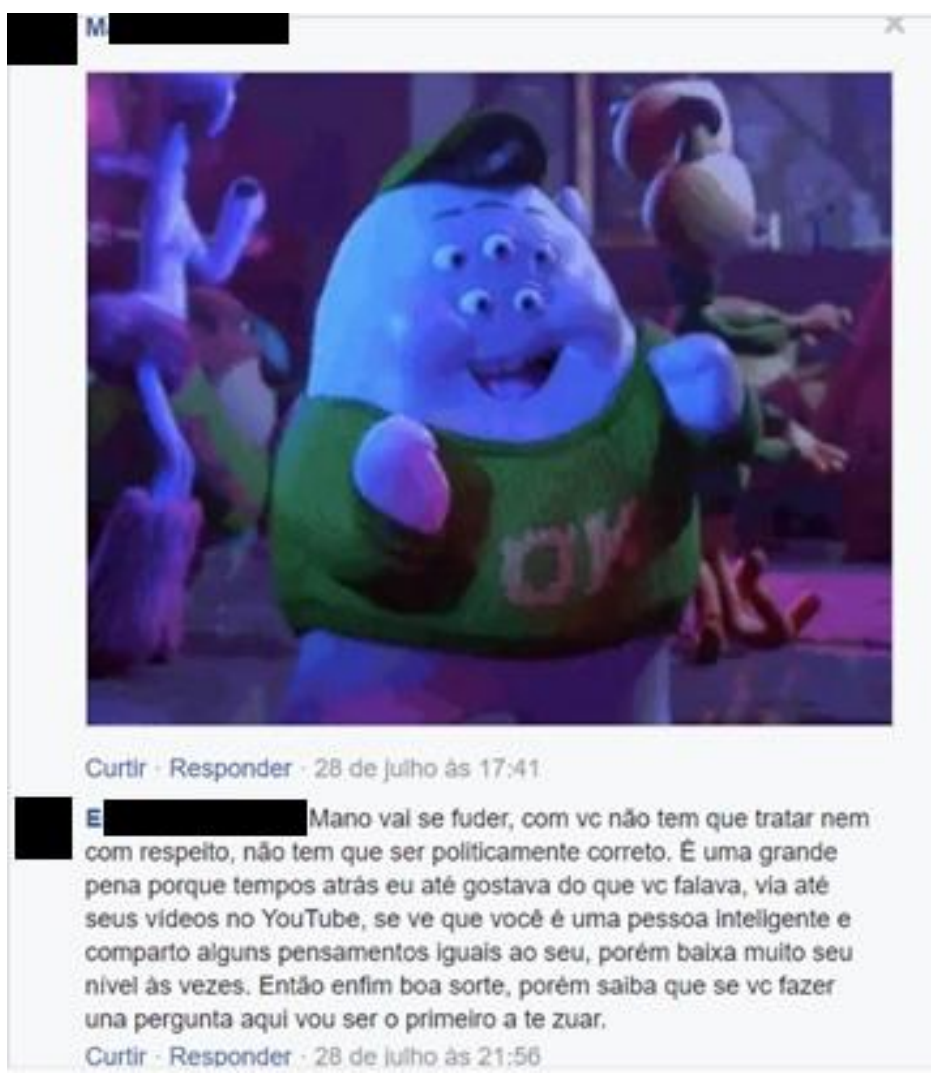

Fonte: Facebook (2015)

Figura 42: Exemplos de descortesia imagética na rede social digital Facebook

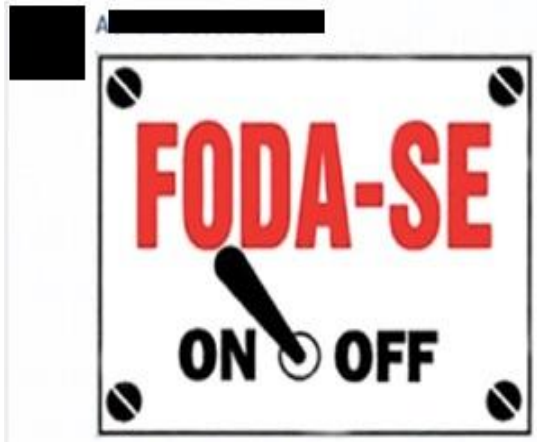

Curtir-Responder - B2 - 4 de dezembro de 2014 às 1401

Fonte: Facebook (2014) 
Figura 43: Exemplos de descortesia imagética na rede social digital Facebook

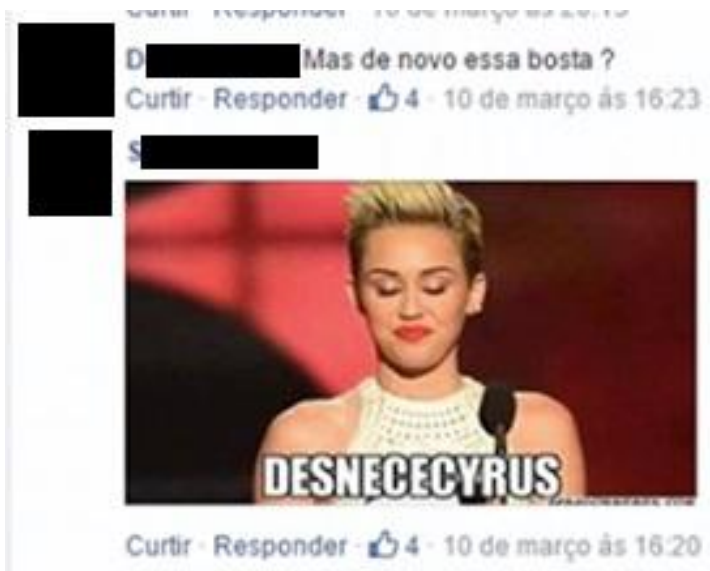

Fonte: Facebook (2014)

Figura 44: Exemplos de descortesia imagética na rede social digital Facebook

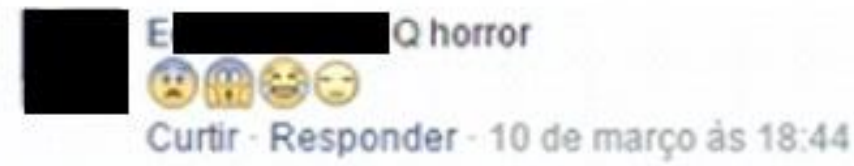

Fonte: Facebook (2014)

6) Pseudocortesia: a descortesia se dá de maneira velada. As expressões são usadas de maneira indireta, a decodificação pelo interlocutor é dependente do contexto e da competência linguística do interlocutor. Percebe-se o emprego das unidades linguísticas de maneira figurada, além do emprego da ironia e do sarcasmo. 
Figura 45: Exemplos de pseudocortesia na rede social digital Facebook

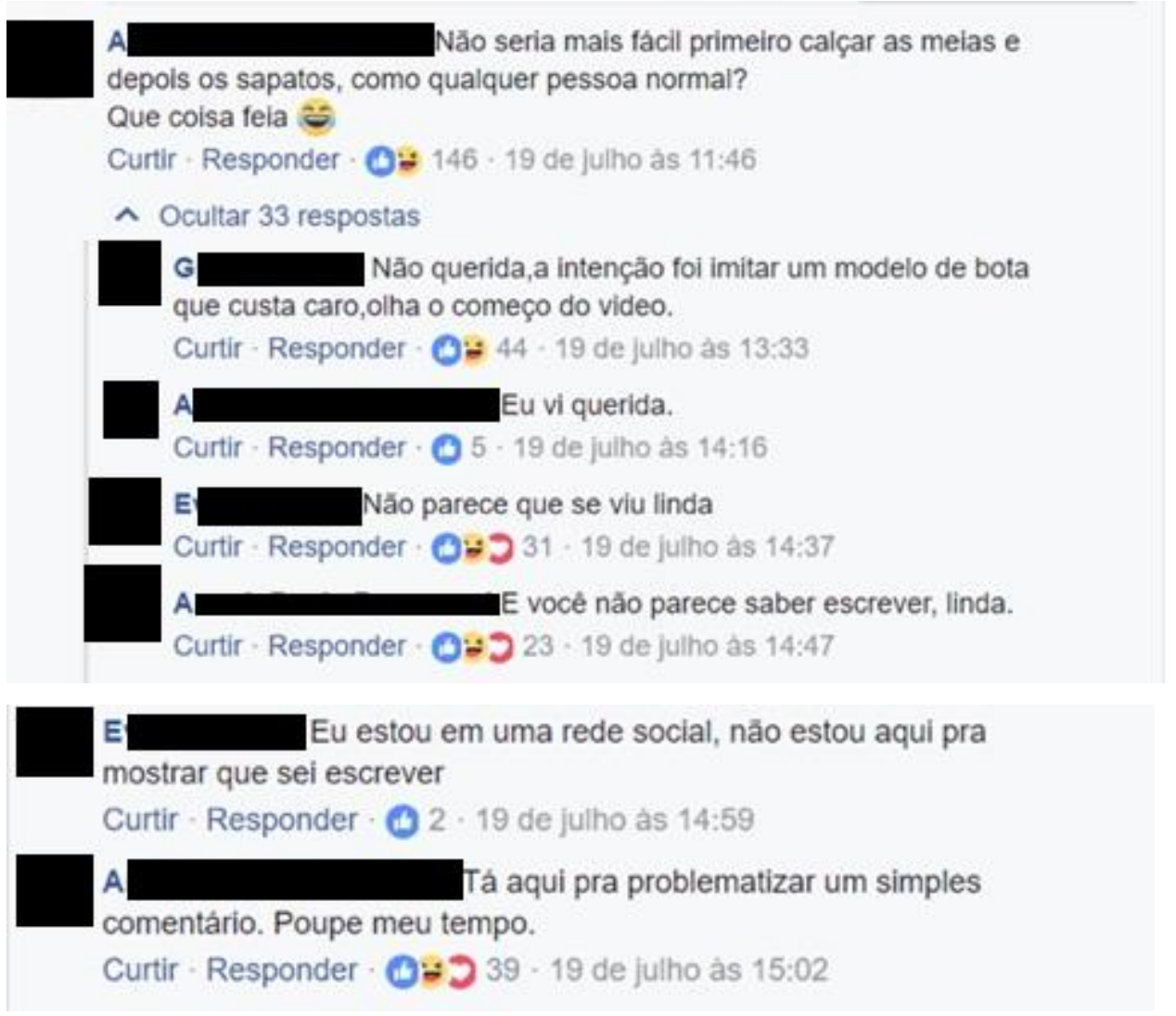

Fonte: Facebook (2017)

7) Pseudodescortesia: a pseudodescortesia acontece entre os interactantes que se conhecem e mantêm uma relação de intimidade. Palavras de baixo calão dão espaço para a cortesia em determinados contextos, fato oposto em situações corriqueiras. Os tratamentos indicam solidariedade, afetividade ou adesão a um grupo em vez de mostrar distanciamento ou ofensa. O receptor deve compartilhar da informação contextual de seu emissor para que compreenda a sua intenção comunicativa, pois isso é decisivo neste tipo interação. No exemplo da figura 30, retirado do Facebook, brinca-se com o fato de as mulheres terem fama de falsas, usando a pseudocortesia. Os homens, por sua vez, fazem uso da pseudodescortesia na figura, pois tratam uns aos outros com formas de tratamento injuriosos, demonstrando intimidade e amizade 
Figura 46: Exemplos de pseudodescortesia na rede social digital Facebook

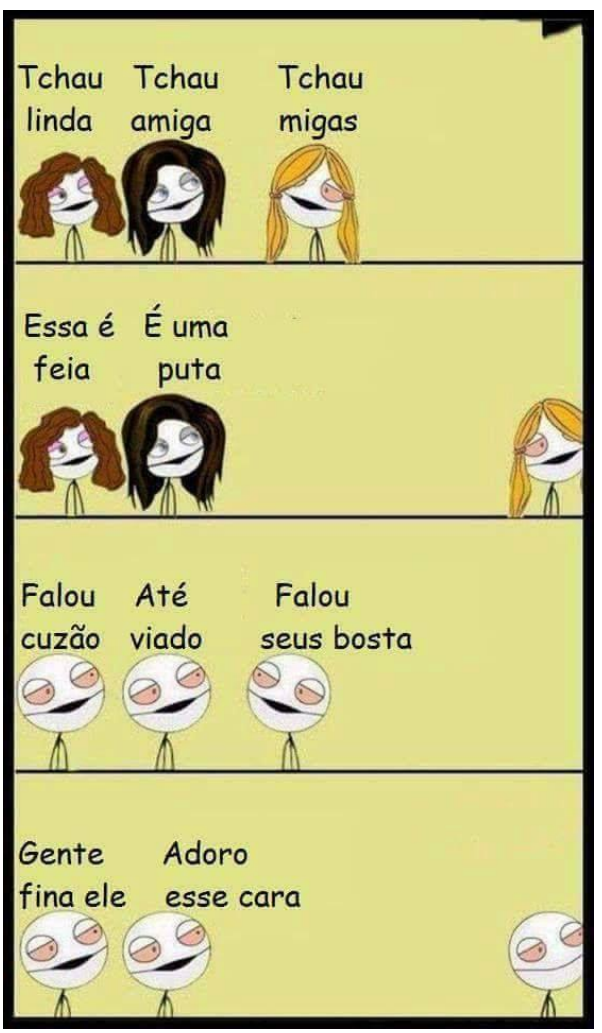

Fonte: Facebook (2016)

Figura 47: Exemplos de pseudodescortesia na rede social digital Facebook

Sobrou até para a Mercedes-Benz! Confira a lista. \#jornaldocarro

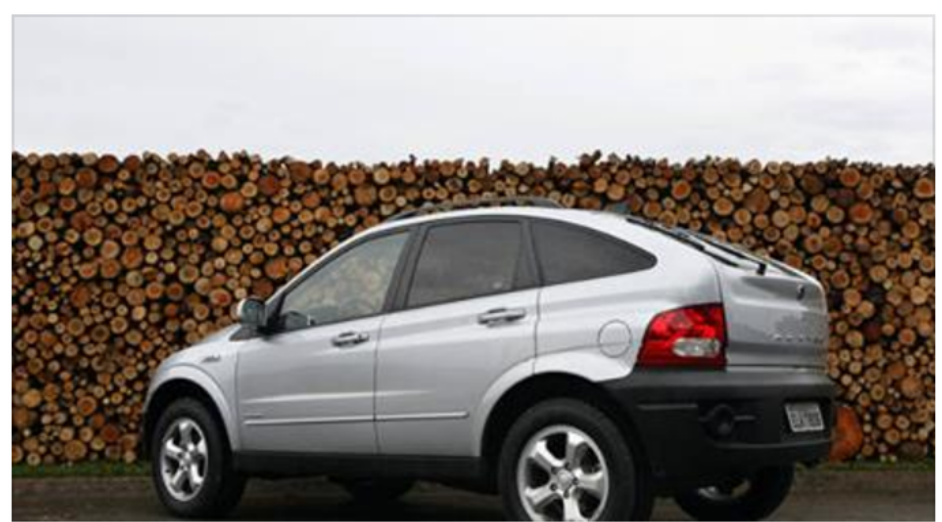

Os carros mais feios do Brasil 


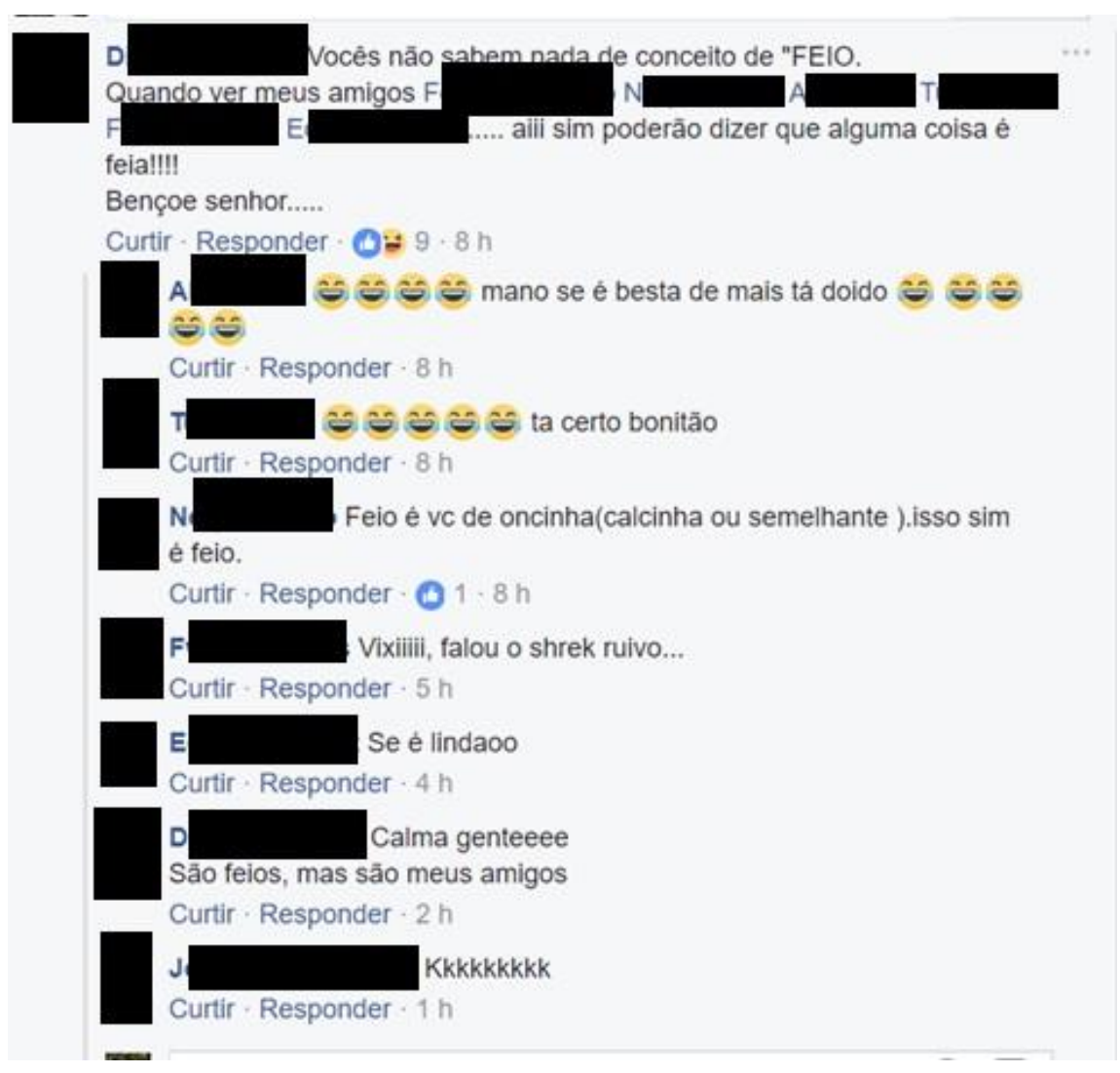

Fonte: Facebook (2018)

8) Descortesia tipográfica: $O$ tipo de letra e os sinais de pontuação também colaboram na interpretação da mensagem no texto escrito. $O$ uso de letras maiúsculas é considerado ofensivo na linguagem da internet, pois indica muitas vezes que o emissor está gritando e não enfatizando o seu discurso. O uso de sílabas longas também pode indicar grito ou alegria, dependendo do contexto.

Figura 48: Exemplos de descortesia tipográfica na rede social digital Facebook 
PARAMOS PARA PENSAR. EU NAO TO

CRITICANDO PARAMETROS DE BELEZA E SIM DE SAUDDE

MENTAL.

A PERGUNTA É ESSA MULHER SE AMA?

QUERER PARECER UMA BONECA INFLAVEL É SUBJULGAR A

EXISTENCIA DELA COMO SER HUMANO', BONECOS NAO TEM

VIDA, NAO TEM SENTIMENTO, SAO DESCARTAVEIS, NAO

ACHO QUE ELA SE AME.

Curtir - Responder - B1-10 de março às $17: 00$

Fonte: Facebook (2014)

9) Descortesia fática: iniciar uma conversa, geralmente marcada por uma saudação, indica disposição para participar de uma interação cooperativa com o outro. Porém, a falta de conversação ou resposta da outra pessoa, particularmente um conhecido, pode ser interpretada como uma descortesia, pois implica a falta de engajamento ou o não envolvimento na interação. A falta de uma resposta esperada a uma enunciação também pode ser considerada ofensiva, pois tal como afirma Leech (1983), o silêncio rompe com uma das máximas conversacionais relacionadas com a função fática da linguagem. Assim, um ato descortês pode gerar a ausência de resposta, como o silêncio, por exemplo.

Figura 49: Exemplos de descortesia fática na rede social digital Facebook

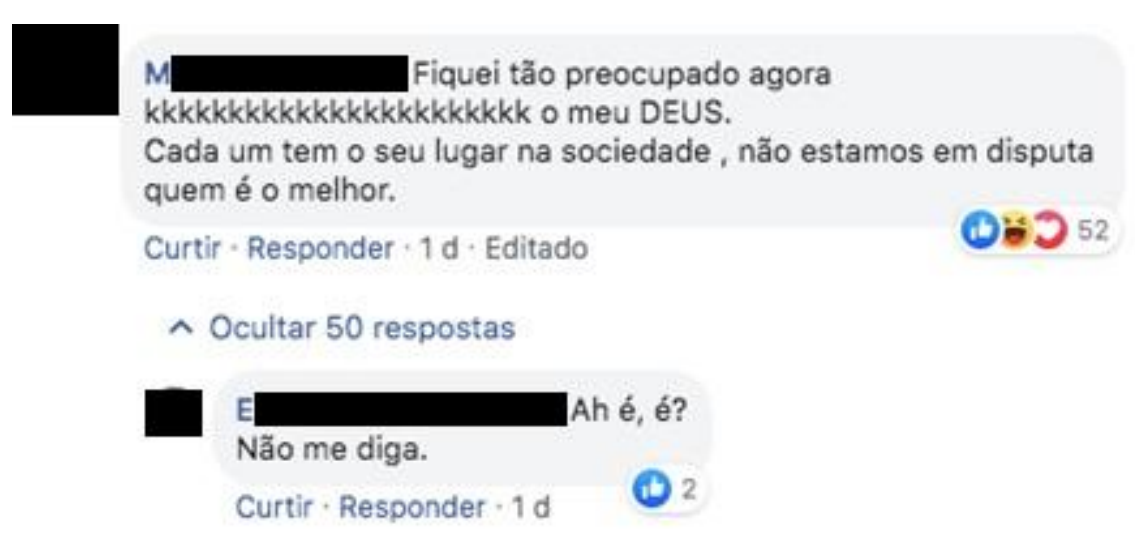

Fonte: Facebook (2018) 
Figura 50: Exemplos de descortesia fática na rede social digital Facebook

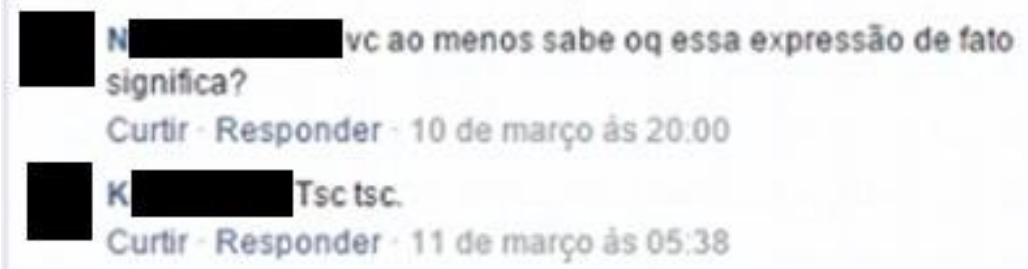

Fonte: Facebook (2014)

10) Descortesia coletiva: esta descortesia ocorre quando um grupo de participantes da rede social digital decide atacar a mesma pessoa, ou seja, temos um ataque coletivo.

Figura 51: Exemplos de descortesia coletiva na rede social digital Facebook

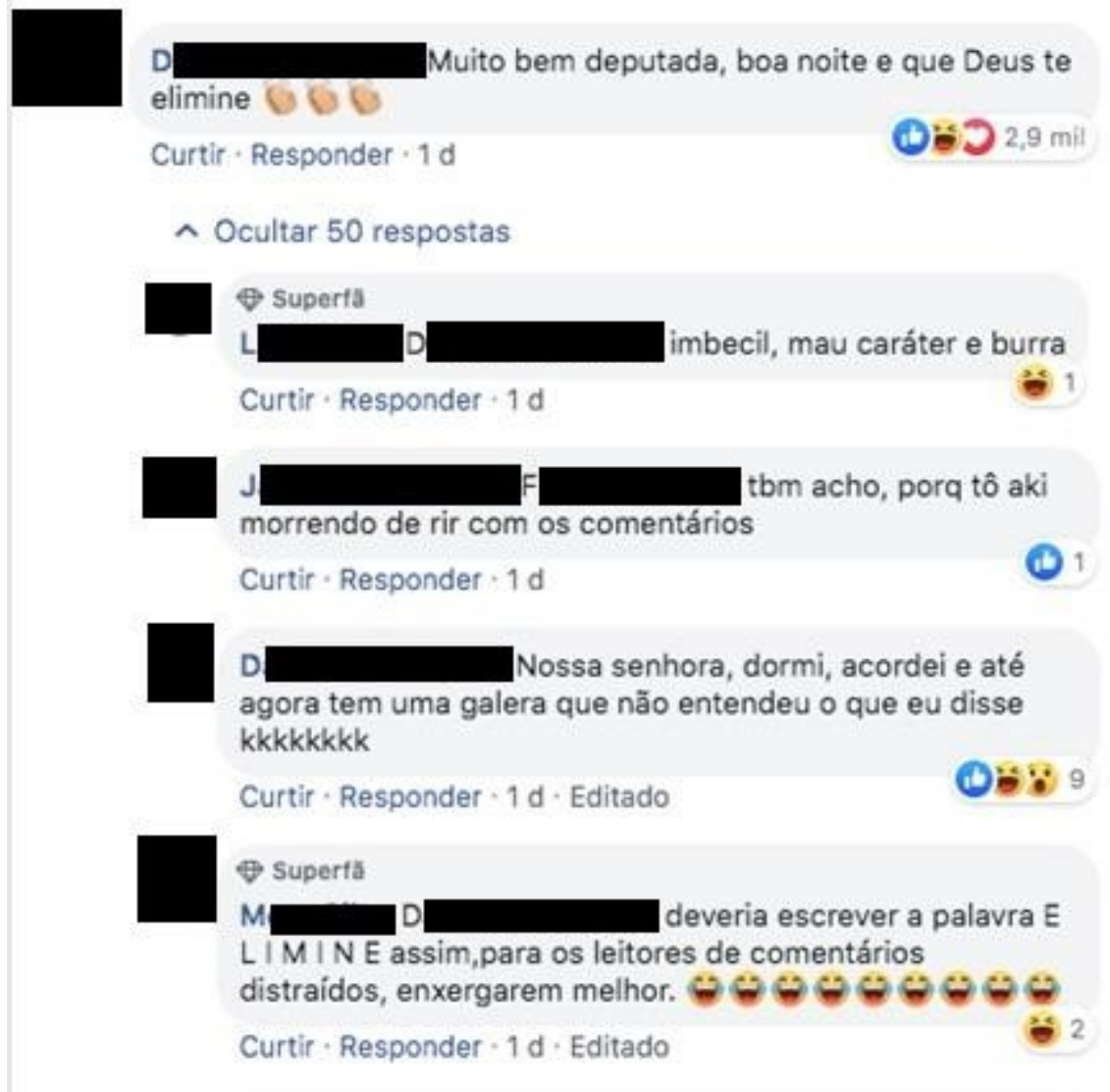


(9) Superfa

J $\mathrm{D}$ colocou Deus em

discurso preconceituoso e ainda de político oportunista, falso moralismo que chama.

Curtir-Responder-1 d

(9) Superta

$\mathrm{V}$

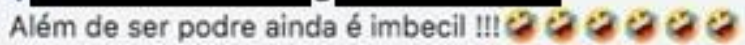

Curtir - Responder + $1 \mathrm{~d}$

M passar por burro mesmo pq não sou obrigadaaaaa e adoro ver uma vergonha alheia hahahahh deixa me xingarem. 0 problema do brasileiro é esse, falta de atenção e de interpretação de texto kkkk UM dos problemas né

Curtir-Responder-1d-Editado

6

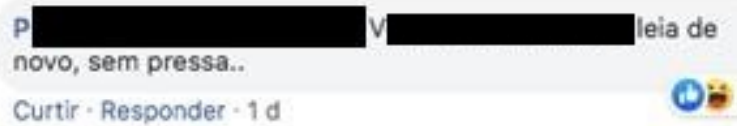

Curtir - Responder - 1d

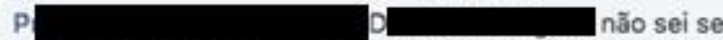

dou mais risada da sua sacada (ótima) ou dos comentários de qm nåo sabe ler $\Theta \Leftrightarrow \Leftrightarrow \Theta$

Curtir - Responder - $1 \mathrm{~d}$

๑ Superfa

A $D$ D

de elimine $\angle G C G$

Curtir - Responder -1d

o povo leu ilumine em vez
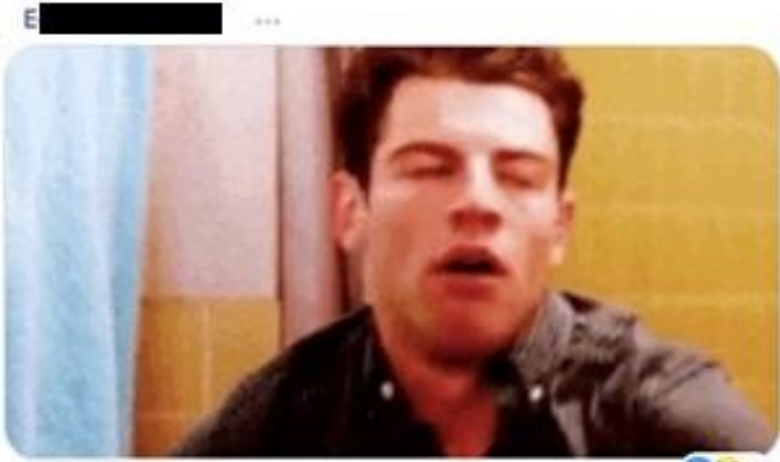


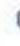

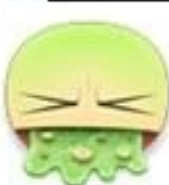

Curtir - Responder - $19 \mathrm{~h}$

$\mathrm{Ce}$ vergonha de gente igual vc ! Cada um é o que quiser! Lembre-se disso quando vc casar com seu macho alfa e ele tiver batendo em vc! Estaremos aqui de braços abertos e não depilados p dar apoio a vc !

Curtir-Responder - $18 \mathrm{~h}$

$\oplus$ Superta

Louca é a SRA sua progenitora III! $\cdots \ldots \ldots \ldots \ldots \ldots$

Curtir-Responder $+18 \mathrm{~h}$

๑) Superta

$\mathrm{V}$

Realmente os olhos é a raiva enganaram a minha mente e

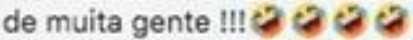

Porisso você ficou rindo o tempo todo como uma hiena !!! a 20 ca

Curtir-Responder $\cdot 18 \mathrm{~h}$

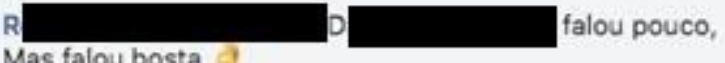

Curtir - Responder - $4 \mathrm{~h}$

M bom dia e q o capeta te ilumine, pq Cristo jamais estará perto de alguém como vc.. ele continua preferindo andar ao lado de qm prega o amor ao próximo

Curtir - Responder - $4 \mathrm{~h}$

A Vélhoooo a sociedade apodreceu e ficou Esclerosada kkkkkkkkk PUTA QUEO PARIOOOO

CARAIOOOO É UM MEME GENTE, UMA PIADA, UMA

ZUEIRA, UM IRONIAAAA, UM SARCASMO POXAAAAA VAO CARPIR UM LOTE E PAREM DE SE ACHAREM OS DONOS DA VERDADE E DA JUSTICCA A TOMA NO BURACOOO, GENTE CHATAAAA E OUTRA ESSA DOIDA DESSA MULHER MÁL AMADA TAMBEM, ESSA DEPUTADA QUE NAO TEM EMPATIA ALGUMA PELO PROXIMO, OUTRA SANGUE SUGA DO GOVERNO.

QUE DEUS ELIMINE ELA E TODOS VCS AMÉÉM.... is :S Uis

Curtir - Responder - 3 h 

mostra uma coisa, maioria da esquerda ou direita é a mesma coisa, não estudam, interpretam errado tudo quase, pouco sabem sobre maioria dos assuntos, e apenas sabem criticar ou chingar nas redes, você foi irônica e maioria não entendeu, triste!!

Curtir - Responder - $1 \mathrm{~d}$

Sério isso I? Você acha que Deus aprova esse tipo de atitude I? Onde está o amor ao próximo I?

Curtir - Responder - $23 \mathrm{~h}$

mas o diabo não mata ninguém, só pőe os filho dozotro nos tóchico, joga periguete no colo dos marido, faz a escumadeira trancar as gaveta e as coié cair atrás do fogão da temente a deus!!!

Curtir - Responder - $21 \mathrm{~h}$

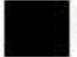

Curtir - Responder - $20 \mathrm{~h} \quad k k k k \mathrm{~B} \Theta \Theta \Theta$

-

BENTE ELA FALOU "ELIMINE"

Curtir - Responder - $20 \mathrm{~h}$

(9) Supert3

M ela quis escrever Elimine

mesmo kkk. E muitos confudiram com ilumine,e

massacraram a garota. A galera que é contra o governo não entendeu que ela está

do mesmo lado que eles.

Essa frase é um meme que cirlula na internet.

Curtir-Responder - $16 \mathrm{~h}$

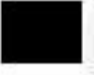

Fossa eu também li ilumine

no primeiro momento... afff kkkk

Curtir - Responder - $14 \mathrm{~h}$

(2) Superfa

Jumém

Curtif - Responder + $14 \mathrm{~h}$

C D teu comentário só vem corroborar a tese da internet sem lei. As pessoas têm preguiça de digitar um " eu te entendo" um "Deus te abençoe" mas, têm um prazer urgente, quase vital, em atacar quem já está sendo atacado, só porque não precisam se expor de verdade. Empatia nenhuma, humanidade menor ainda. Que vergonha.

Curtif - Responder - $12 \mathrm{~h}$

Fonte: Facebook (2019)

11) Descortesia motivada: trata-se de uma descortesia intencional, ou seja, a pessoa tinha o propósito de atacar a outra na interação. É comum neste tipo de 
descortesia a figura do "troll", ou seja, um usuário que desestabiliza o andamento de uma interação a fim de causar conflito.

Figura 52: Exemplos de descortesia motivada na rede social digital Facebook

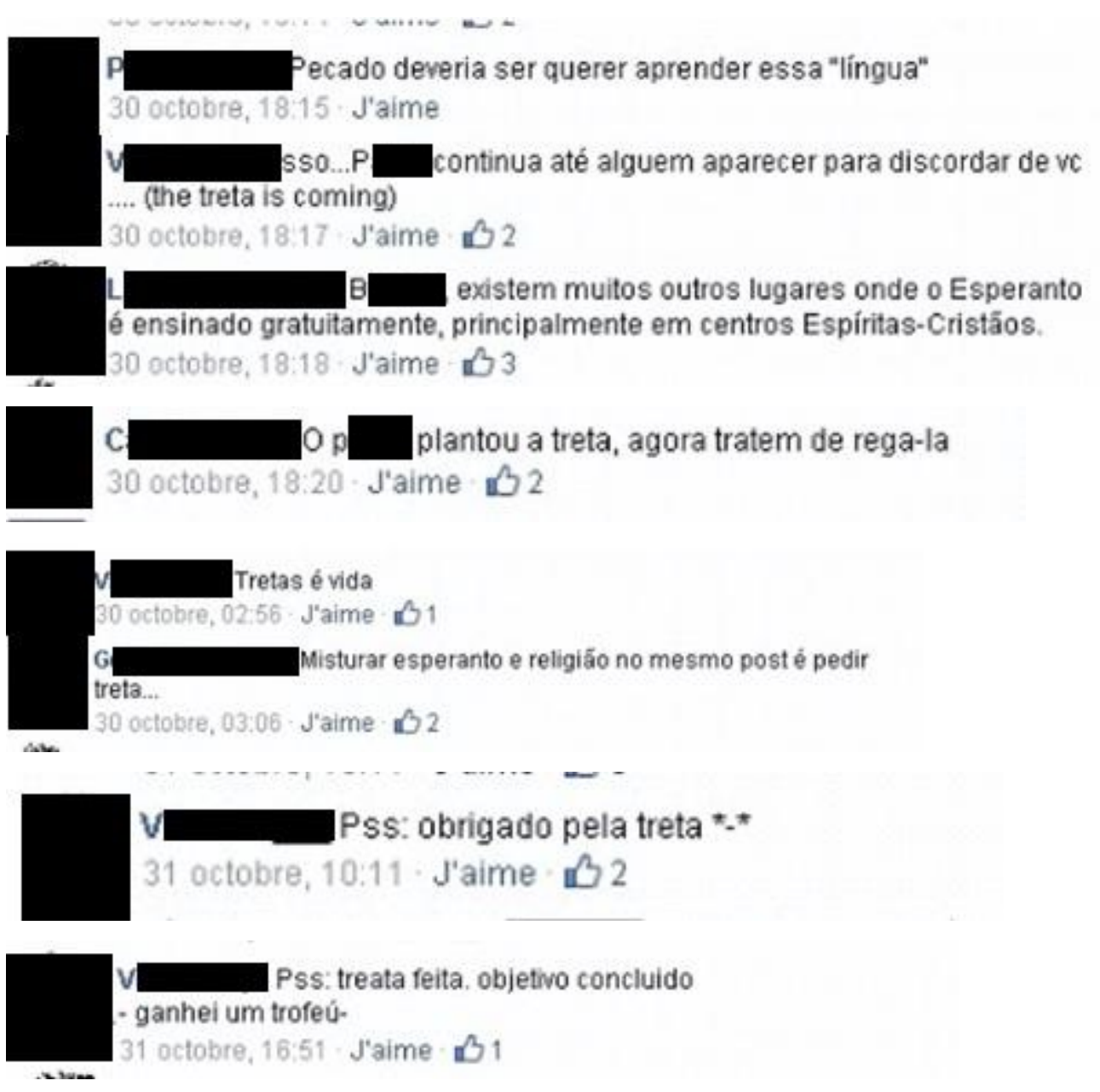

Fonte: Facebook (2015)

12) Descortesia imotivada: trata-se de uma ação descortês sem intenção, o locutor não teve o propósito de atacar a imagem do outro interlocutor. É frequente casos de descortesia deste tipo entre crianças, estrangeiros, em situações de gafes ou de má interpretação de um enunciado do locutor. 
Figura 53: Exemplos de descortesia imotivada na rede social digital Facebook

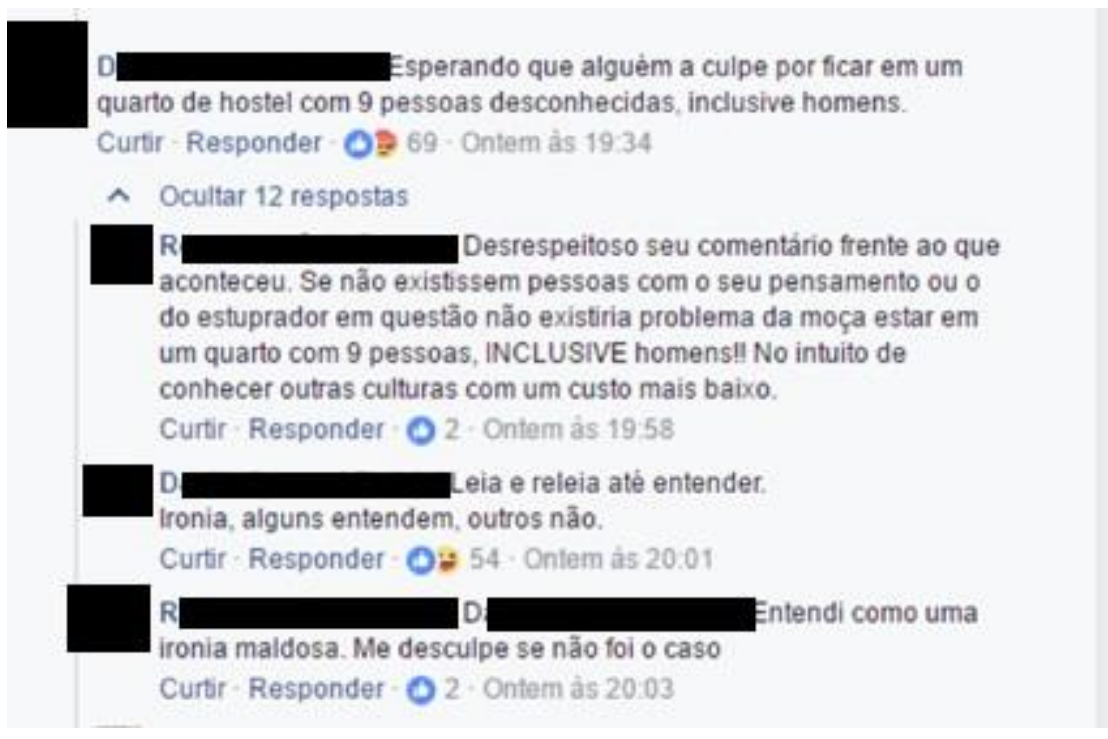

Fonte: Facebook (2018)

13) Descortesia reativa: trata-se de uma ação descortês após um ataque pessoal prévio, ou seja, a descortesia surge como resposta de uma manifestação descortês por parte de um locutor.

Figura 54: Exemplos de descortesia reativa na rede social digital Facebook

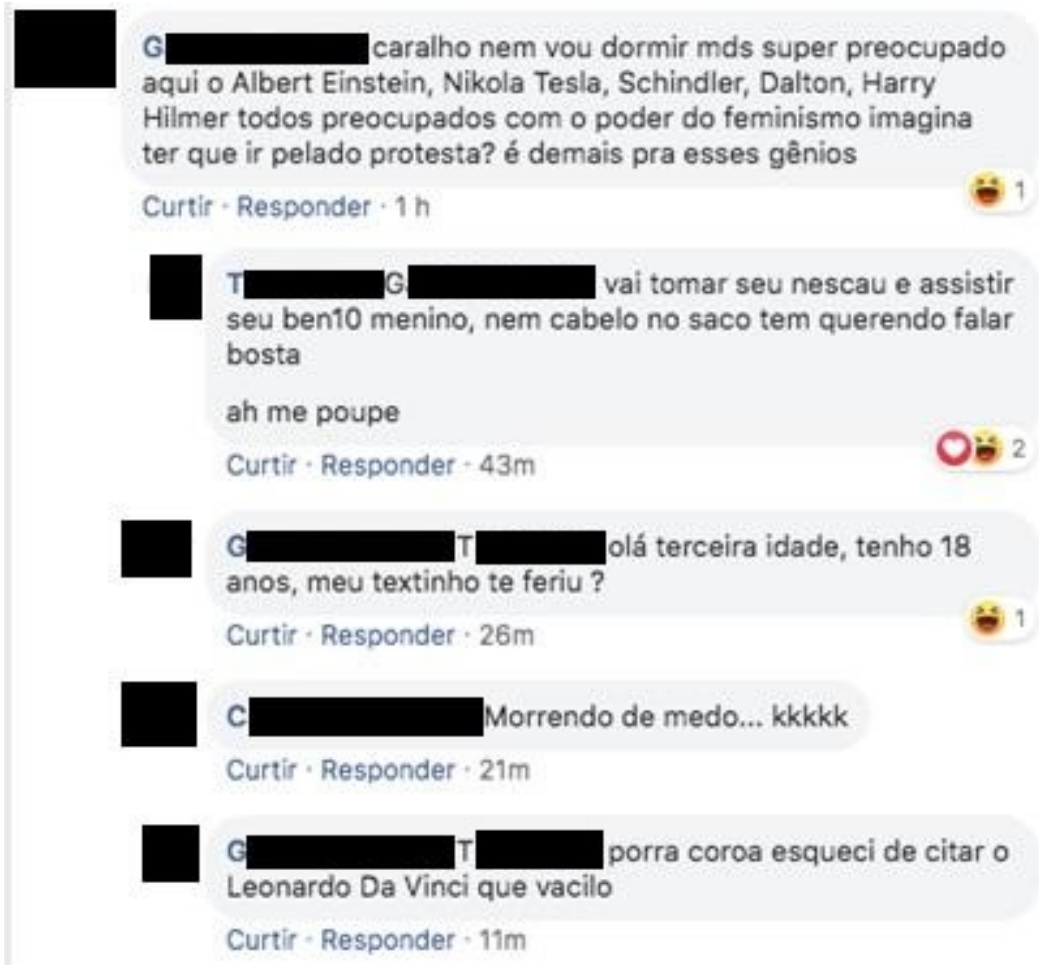

Fonte: Facebook (2018) 
No geral, independente do tipo de descortesia, é comum o uso recorrente de ofensas ou insultos para atacar o interlocutor. Neste trabalho, entendemos que insulto e ofensa são sinônimos. O conceito de insulto utilizado neste trabalho será o proposto por Colín Rodea ${ }^{26}$, segundo o qual

\begin{abstract}
O insulto é uma ação verbal/não verbal, considerada pelos estudos de cortesia como um ato de fala negativo, cuja força ilocucionária interfere e afeta a comunicação. Como ato de fala viola as normas sociais e ideais de cooperação, na medida em que o uso de um insulto se justifica apenas se ele responde a uma agressão óbvia e é realizado quando é reconhecido como tal pelo interlocutor (COLÍN RODEA, 2003, p. 183, tradução nossa).
\end{abstract}

Haverkate $(1994$, p.18; 79) considera o insulto como um ato descortês que requer uma desculpa a fim de restabelecer o equilíbrio interacional na troca comunicativa. Porém, como já vimos, nem sempre o ato descortês está relacionado com o equilíbrio interacional.

Goffman (1967) também já realizou um estudo da função social das ofensas na interação. Ele entende por ofensa o ato de deixar a si mesmo ou o outro em uma situação desconfortável, em termos de construção e manutenção da imagem de si mesmo. Para ele, há três categorias de ofensas:

Ofensas inocentes: $O$ falante pode parecer ter agido inocentemente, sua ofensa parece não ter intenção, mas também não constituem um tipo de brincadeira. Contudo, ele deveria prever as consequências ofensivas. São exemplos: gafes e erros que causam algum tipo de constrangimento tanto do falante quanto do ouvinte.

Ofensas maliciosas: Nesse caso, a ofensa ao ouvinte pode parecer ter sido feita maliciosamente e com o intuito de desaprovação, provocando insultos abertamente, tal como uma crítica.

Ofensas incidentais: Para o pesquisador, são ofensas incidentais aquelas que surgem de um modo não planejado, sem a intenção de ferir a imagem do interlocutor.

Há de se considerar, todavia, que a função agressiva do insulto muitas vezes pode conduzir ao término de uma conversação ou, em alguns casos,

\footnotetext{
${ }^{26}$ El insulto es una acción verbal / no verbal, considerado por los estudios sobre la cortesía como un acto de habla negativo, cuya fuerza ilocucionaria interfiere y afecta a la comunicación. Como acto de habla infringe las normas sociales y los ideales de cooperación, al grado que el uso de un insulto solo se justifica si este responde a una agresión evidente y se realiza cuando es reconocido como tal por el interlocutor. (COLÍN RODEA, 2003, p. 183)
} 
mobilizar outros interactantes para o ataque ou defesa do emissor/receptor que estavam apenas como meros espectadores da interação, ou seja, os destinatários indiretos. $\mathrm{Na}$ rede social digital, o insulto acontece quando o emissor se dirige a seu adversário sem este estar presente, pois geralmente, os participantes da rede social digital se sentem amparados pelo aparente anonimato do ambiente virtual.

Além disso, o insulto pode ser usado até mesmo como recurso argumentativo pelo fato de orientar a discussão para determinado fim ou como um marcador social, visto que pode indicar um sentimento de integração a uma comunidade, principalmente em casos de pseudodescortesia. De acordo com Amossy:

\begin{abstract}
Como ato de fala, o insulto combina o assertivo (atribuindo ao outro qualidades que o desqualificam), o expressivo (manifestando hostilidade contra ele) e o diretivo (solicitando uma reação de sua parte ou da parte do Terceiro) [apud] (Chevalier e Constantin, 2009, p. 46) (...) acrescentamos o fato de que o locutor se coloca como aquele que tem o direito de desqualificar o outro, colocando-o em uma posição inferior (...). Para Goffman (1967), o insulto é um ato agressivo que ameaça a face do receptor- mas que pode se voltar contra aquele que produz o ato. (AMOSSY, 2017, p. 172.)
\end{abstract}

Díaz Pérez (2012, p. 180-181) elenca alguns tipos de unidades léxicas implicadas no insulto. A partir de seu estudo, adaptamos para o português brasileiro algumas categorias nas quais complementamos e adicionamos exemplos:

1. Unidades léxicas e fraseológicas conhecidas socialmente como grosseiras, vulgares ou ofensivas: "viado", "filho da puta", "cuzão".

2. Unidades léxicas não marcadas socialmente como grosseiras, porém exercem essa função: "terrorista", "xenófobo", "racista".

3. Uso de ironia ou metáfora reveladas pelo contexto como grosseiras ou desqualificantes.

4. Insultos indiretos reportados no texto pelo interlocutor por meio de verbos como insultar e ofender.

Além de insultos, o uso do humor é utilizado como um recurso criativo para o ataque ao interlocutor em muitos casos na rede social digital. Assim como a ironia, o humor também depende do conhecimento de mundo e da competência linguística do receptor para a interpretação correta da mensagem. Em seu estudo sobre o humor com fins de insulto no Twitter, Díaz Pérez afirma: 
O tom humorístico de um comentário, além de ser capaz de adotar conotações dolorosas e ofender seriamente o destinatário, também desempenha uma função lúdica ao procurar risos em muitas ocasiões por meio da cumplicidade com o leitor. $\mathrm{Na}$ verdade, existem vários tweets que exigem que o destinatário decodifique a mensagem apelando para referências culturais ou sociais compartilhadas; a descoberta do que está oculto na mensagem criptografada produz surpresa e satisfação para o destinatário, mesmo que inclua uma crítica contundente contra alguém ou alguma coisa (...) O humor ajuda a resolver certos problemas politicamente incorretos e permite quebrar o tabu sem que a ofensa verbal pareça tão direta e explícita. Quando esses tabus são quebrados, comportamentos racistas, xenófobos, homofóbicos e classistas são expostos e constituem clichês sociais que normalmente tentam se evitar de uma posição politicamente correta ${ }^{27}$. (DÍAZ PÉREZ, 2012, p. 242-243, tradução nossa)

Com o exposto, verificamos que muitos elementos linguísticos, nãolinguísticos e extralinguísticos podem ser usados em uma troca comunicativa com uma função descortês. O insulto e o uso de formas de tratamento mais íntimas com interlocutores desconhecidos também cooperam para a manifestação da descortesia. Para interpretação adequada de uma enunciação, é importante também considerar os elementos socioculturais de uma interação, tais como o poder, a distância social e o grau de imposição do ato, principalmente para explicar um comportamento hostil por parte do interlocutor. A descortesia, assim, deve ser entendida como ações verbais e não verbais juntamente com os fenômenos linguísticos e comunicativos inseridos dentro de um contexto social.

Alguns elementos linguísticos e não-linguísticos intensificam ou atenuam o comportamento descortês dos interactantes e exercem um papel fundamental na restauração ou perda da imagem na interação, tal como veremos no tópico a seguir.

\footnotetext{
27 No original: El tono humorístico de un comentario, además de poder adoptar connotaciones hirientes y ofender gravemente al destinatario, cumple asimismo una función lúdica al buscar en muchas ocasiones la risa a través de la complicidad con el lector. De hecho, son numerosos los tuits que necesitan que el receptor descodifique el mensaje apelando a referencias culturales 0 sociales compartidas; el descubrimiento de lo que se esconde en el mensaje cifrado le produce sorpresa y satisfacción al receptor aunque incluya una crítica mordaz contra alguien o algo (...)El humor ayuda a abordar determinados temas políticamente incorrectos y permite romper el tabú sin que la ofensa verbal parezca tan directa y explícita. Al romper esos tabúes quedan al descubierto comportamientos racistas, xenófobos, homófobos y clasistas que constituyen clichés sociales que normalmente tratan de evitarse desde una postura políticamente correcta. (DÍAZ PÉREZ, 2012, p. 242-243)
} 


\subsection{Atenuadores e intensificadores da descortesia}

Geralmente, o ato de atenuar um enunciado tem objetivo de minimizar um conflito na interação, porém a atenuação não pode ser encarada como sinônimo de cortesia, tal como fazem alguns teóricos, mas frequentemente há cortesia quando há o emprego de recursos atenuantes. O uso de elementos atenuadores seria um princípio regulador das interações sociais tanto no contexto face a face quanto no contexto digital. Além da atenuação, é possível usar recursos intensificadores na interação. Para Briz (2013), a atenuação e a intensificação são estratégias complementares, e a intensificação seria um recurso para tornar o enunciado mais expressivo perante o interlocutor. Pretende-se, assim, acrescentar uma força argumentativa ao que é dito pelo locutor, por meio de elementos fonético-fonológicos, morfológicos, lexicais e sintáticos.

A cortesia verbal se manifesta, linguisticamente, por múltiplas estratégias, tais como as formas de tratamento, os agradecimentos, as desculpas e, muitas vezes, está ligada à concordância do ponto de vista do (inter)locutor. A descortesia, por sua vez, manifesta-se também pelas formas de tratamento, pelos insultos e pelo uso de sarcasmo e de ironia, entre outros recursos verbais e não-verbais. Tanto na cortesia quanto na descortesia, é possível encontrar elementos de atenuação ou de intensificação. De acordo com Carreira,

Globalmente, os processos de intensificação visam a valorização da zona do alocutário ${ }^{28}$ ( por ex. o elogio, os cumprimentos e saudações, o acordo) e os processos de atenuação - que se revelam particularmente complexos- visam a zona do locutor (ex. a oferta) e a zona do alocutário, no caso de restrição à liberdade ou à imagem positiva (ex. injunção, desacordo). Os processos de atenuação sugerem contornos esbatidos, a suspensão, a eventualidade. (CARREIRA, 2014, p. 39)

Para Briz (2013), o uso da atenuação é um procedimento estratégico intencional e retórico, uma vez que é por meio desse recurso pragmáticolinguístico que se busca alcançar um objetivo na interação, seja conseguir um acordo ou um benefício, seja para persuadir. No que concerne à atenuação, utilizamos o conceito de Briz, segundo o qual:

\footnotetext{
${ }^{28}$ Neste trabalho, optamos pelos termos 'interlocutor", "receptor" e "destinatário", em vez de "alocutário". O termo "alocutário" é utilizado, no entanto, por alguns teóricos citados neste trabalho.
} 


\begin{abstract}
A atenuação é uma atividade argumentativa (retórica) e estratégica de minimização da força ilocutória e do papel dos participantes na enunciação, para conseguir chegar-se com sucesso à meta prevista $\mathrm{e}$ que é utilizada em contextos situacionais, com menor caráter imediato ou que requerem ou se deseja que apresentem menos imediatez comunicativa. (BRIZ, 2013, p. 284)
\end{abstract}

As estratégias e os mecanismos atenuadores são utilizados quando o emissor ofende, mas ao mesmo tempo, não quer assumir totalmente a responsabilidade da descortesia. Kerbrat-Orecchioni (2006) retoma o conceito de suavizadores (softeners) de Brown \& Levinson (1987) para destacar que esses elementos podem ser de natureza paraverbal e não-verbal, visto que um sorriso ou uma entonação de voz mansa podem amenizar o que foi dito por um interactante. Além disso, segundo a teórica, há procedimentos também de natureza verbal, estes divididos em duas categorias, a saber: substitutivos e acompanhantes. Os primeiros consistem em substituir um enunciado mais direto por outro mais "suave" enquanto os segundos suavizam a realização de um FTA por meio de expressões especializadas, tais como o uso de "por favor", "se for possível".

Esses recursos atenuadores são usados tanto na fala quanto na escrita, mas nem sempre a atenuação e a intensificação serão usadas a fim de se evitar um conflito no mundo virtual. Apesar de Kerbrat-Orecchioni (2006) ter analisado conversações face a face, e Briz (2013) ter analisado conversações coloquiais e entrevistas semiformais, acreditamos que os mesmos elementos atenuantes e intensificadores se encontram na interação virtual. Para Briz (2013) existem três funções atenuadoras:

1) Autoproteção - é uma estratégia para não se responsabilizar ou para ser politicamente correto ao abordar alguns temas ou pessoas. Assim, tem a função de preservar a imagem do locutor. A impessoalização ('não sou eu, mas sim os outros que vão opinar'), o uso de perífrases e do advérbio de dúvida (possibilidades) são os mecanismos mais comuns que o locutor emprega para não se comprometer.

2) Prevenção - é uma estratégia para prevenir possíveis danos à imagem do outro, evitando tensões e conflitos. Geralmente, é no uso desta estratégia que o locutor se mostra mais cortês em relação ao outro. 
3) Reparação - é a reparação de uma ameaça à imagem do outro ou de uma intromissão no território de seu interlocutor, ou seja, o dano já foi realizado, mas o locutor que o produziu tentará atenuar o conflito na interação.

Nas redes sociais digitais, percebeu-se, sobretudo, o emprego dos atenuadores para minimizar a ação do enunciado e, consequentemente, seu efeito no interlocutor. Ainda de acordo com Briz:

(...) a atenuação afeta as relações interpessoais e, assim, além da
atividade linguística, participa de uma atividade social. Efetivamente, a
atenuação é um mecanismo estratégico de distanciamento linguístico
da mensagem e, por sua vez, de aproximação social: linguisticamente,
atenuação significa distância; socialmente, atenuação significa
aproximação. O locutor mitiga ou debilita a força ilocutória, de tal
maneira que consegue, assim, distanciar-se de sua mensagem para
se aproximar (social e afetivamente) ou não se afastar extremamente
do interlocutor ou de terceiros. Certamente, um indivíduo é
atenuadamente cortês para aproximar-se ou não se afastar
extremamente do outro e assim conseguir o objetivo, chegar com
sucesso à meta, uma meta local (obter algo em um momento dado) ou
global (conseguir o acordo ou minimizar o desacordo). (BRIZ, 2013, p.
286)

É necessário salientar que, na rede social digital, as práticas atenuadoras ou intensificadoras da (des)cortesia podem ser realizadas por meio de recursos verbais, não-verbais e híbridos. Com base em Briz (2013) e Kerbrat-Orecchioni (2006), listamos 43 elementos atenuadores e outros intensificadores comuns nas redes sociais digitais:

1) A impessoalização: Trata-se de uma alusão indireta ou vaguidade ao se referir ao destinatário. A estratégia de impessoalização é muito empregada para se dirigir a um interlocutor específico, visto que é uma maneira de incluí-lo em um coletivo criticado pelo locutor. Construções como nominalizações, passivas sem agente explícito ou passiva sintética e o emprego de eufemismos são os mais recorrentes. 
Figura 55: Exemplo de impessoalização na rede social digital Facebook

$\square$

Mais uma da série "Todos os homens são

agressores e todas as mulheres são coitadinhas oprimidas da sociedade e muito bem educadas".

Sua obsessão em xingar os outros já mostra que faz parte do grupo que agrediria quem pedisse pra tirar a bolsa.

Curtir-Responder - O 2-28 min - Editado

Fonte: Facebook (2017)

2) Atos indiretos de um ato de fala: os atos indiretos são formulados, geralmente, para se evitar manifestações descorteses. É comum esse uso para amenizar, principalmente, uma ordem. Perguntas com sentido de reprovação ou com sentido de críticas, tal como "Você não lavou a louça?", ou uma refutação, "Você acha mesmo que...?", são muito comuns.

Figura 56: Exemplo de atos indiretos na rede social digital Facebook
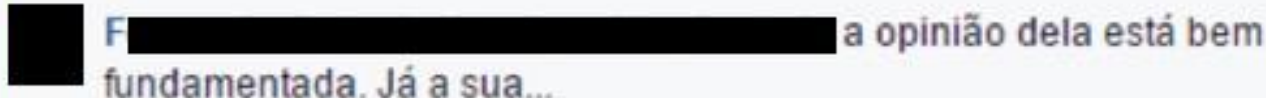

fundamentada. Já a sua.

Curtir - Responder - 1 1.1 minuto

Fonte: Facebook (2018)

Figura 57: Exemplo de atos indiretos na rede social digital Facebook

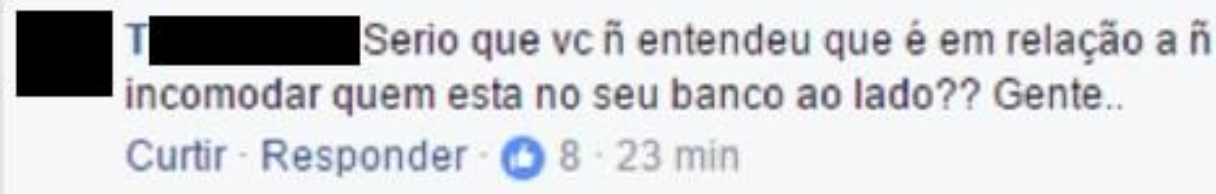

Fonte: Facebook (2017)

Figura 58: Exemplo de atos indiretos na rede social digital Facebook

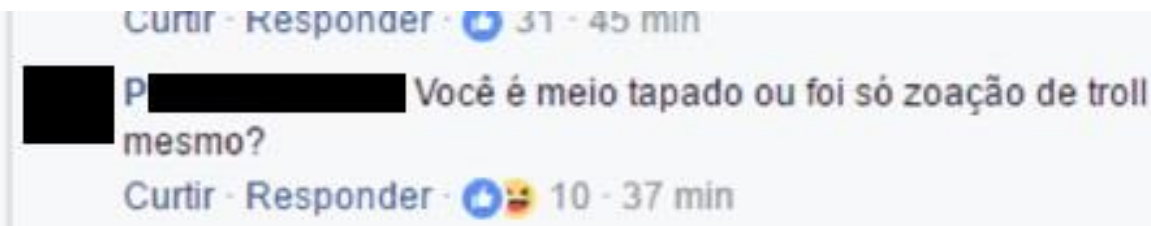

Fonte: Facebook (2017) 
Figura 59: Exemplo de atos indiretos na rede social digital Facebook

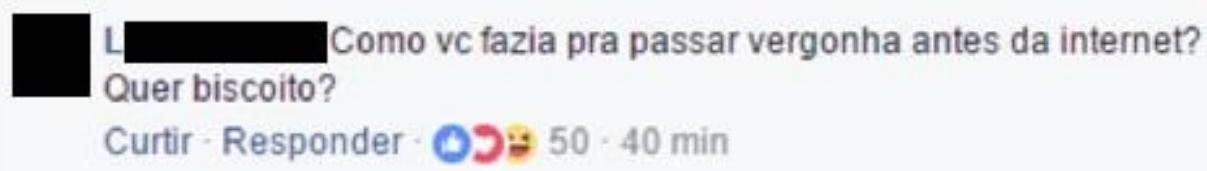

Fonte: Facebook (2017)

3) Uso de verbos performativos ou verbos que expressam valores modais epistêmicos e, inclusive, de evidência: o uso desses verbos é uma maneira de se manter uma distância em relação ao que é dito, de forma que o locutor se sinta protegido em relação à responsabilidade enunciativa. Exemplos: o uso de "não se sabe", "parecer", "pensar", "creio eu" etc;

Figura 60: Exemplo de uso de verbos performativos ou verbos com valores modais epistêmicos na rede social digital Facebook
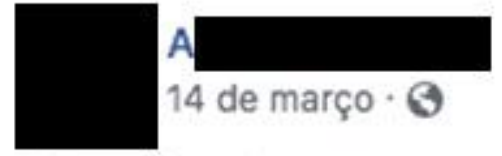

O que fazer?

Não se sabe quais foram as graves razões da irracionalidade que levaram dois rapazes a matar e a matar-se dentro de uma escola pública. $\mathrm{O}$ que me parece claro, pelos alucinados comentários que recolhemos da imprensa e da internet, é que essa barbárie é, sim, representativa, de forma radical, dos mais primários impulsos que estão movendo boa parte dos brasileiros. Representativa como é, já fez presidente um candidato desqualificado em todos os critérios possíveis - e mitificado exatamente pela violência obscena que encarna com sorriso na cara e dedos engatilhados. Pior: toda essa alucinação passa por restauração da moralidade e do patriotismo.

Fonte: Facebook (2019)

4) Confissões: apesar das confissões serem uma maneira de deixar o locutor em uma posição vulnerável, ao mesmo tempo, o locutor pode adquirir confiança do interlocutor em relação à essa posição sincera perante o outro. Dessa 
maneira, as confissões podem funcionar como um recurso atenuador em uma mensagem.

Figura 61: Exemplo de confissões na rede social digital Facebook

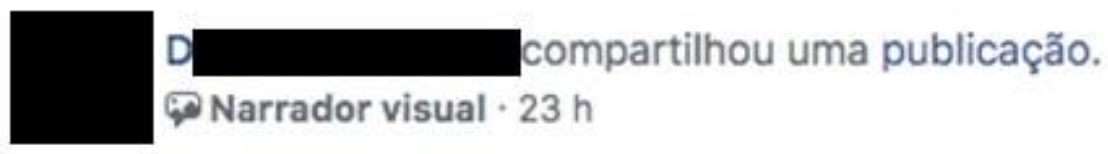

eia, ignorância minha - nem sabia que o leonardo tinha pintado um são jerônimo.

[como disse alguém, os gatíneos amiguinhos dos tradutores da época eram uns baitas de uns leões. de todo modo, a historieta do leão de jerônimo é bonitinha e compassiva.]

Fonte: Facebook (2018)

Figura 62: Exemplo de confissões na rede social digital Facebook

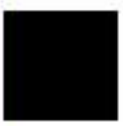

Nem sabia do que se tratava. Dei uma "guglada"

agora e, pelo pouco que li, "meu deus".

Curtir - Responder-1d

Fonte: Facebook (2017)

Figura 63: Exemplo de confissões na rede social digital Facebook
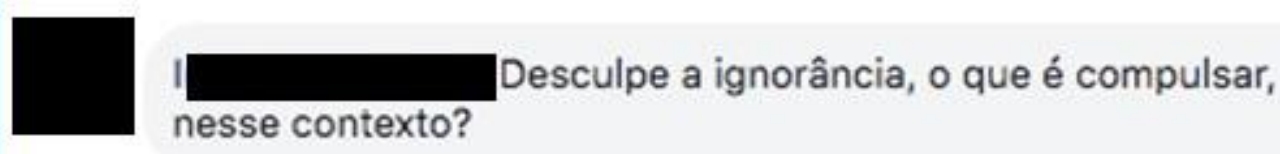

Curtir - Responder - $1 \mathrm{~d}$

Fonte: Facebook (2017)

5) Experiências pessoais: é recorrente usar a experiência pessoal para argumentar algo na rede social digital e, assim, reforçar o ponto de vista sem ser descortês com o outro, principalmente em casos de discordância. O exemplo de uma experiência pessoal valoriza mais a imagem do locutor e mostra que o locutor sabe do que fala. 
Figura 64: Exemplo de experiências pessoais na rede social digital Facebook

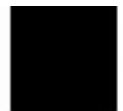

Minha experiência com este tipo de postagem mostra que não importa que se faça este post, as pessoas vão entrar e perguntar sem olhar planilha, e digo mais, irão responder no post em vez de indicar a planilha, e se disser que tem a planilha vão pedir o link, mesmo que ele esteja claramente indicado. Tão certo quanto 2 e 2 são... pera ai que to sem minha calculadora...

Curtir - Responder - 16 sem - Editado

Fonte: Facebook (2018)

Figura 65: Exemplo de experiências pessoais na rede social digital Facebook

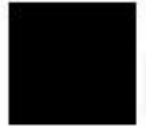

$\mathrm{J}$ Eu tive uma filha assassinada e os direitos
humanos não me assistiu

Curtir - Responder - $14 \mathrm{~h}$

Fonte: Facebook (2019)

6) Fatos históricos: o locutor se apoia em fatos históricos para sustentar o seu ponto de vista. Desta maneira, ele atenua um possível ataque de um interlocutor em casos de discordância da ideia defendida pelo locutor.

Figura 66: Exemplo de fatos históricos na rede social digital Facebook

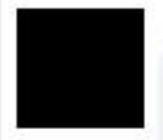

Os direitos humanos foram criados

por Ciro II, em 539 a.C. depois da conquista da Babilônia, para defender a humanidade da tortura, da fome, da insalubridade, da extinção. Ter uma regulamentação mundial que define parâmetros básicos para a qualidade de vida humana e respeita-la é um meio de evitar abusos que seres humanos praticam contra outros seres humanos.

Curtir - Responder - $2 \mathrm{~h}$

Fonte: Facebook (2019) 


\section{7) Modificações de verbos performativos nas formas temporais ou modais:}

Geralmente, são tempos verbais utilizados considerados corteses de acordo com a norma padrão do português brasileiro, tais como o uso do futuro do pretérito, do imperfeito do indicativo ou do subjuntivo.

Figura 67: Exemplo de modificações de verbos performativos nas formas temporais ou modais na rede social digital Facebook
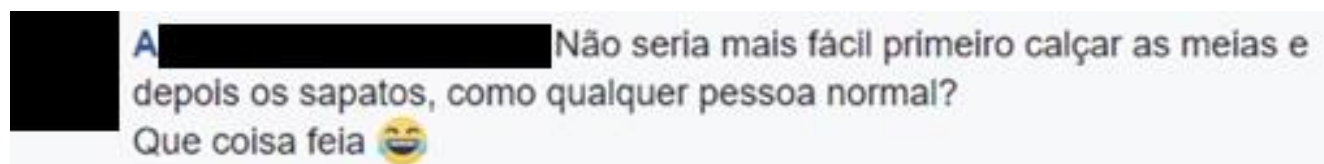

Fonte: Facebook (2018)

Figura 68:Exemplo de modificações de verbos performativos nas formas temporais ou modais na rede social digital Facebook
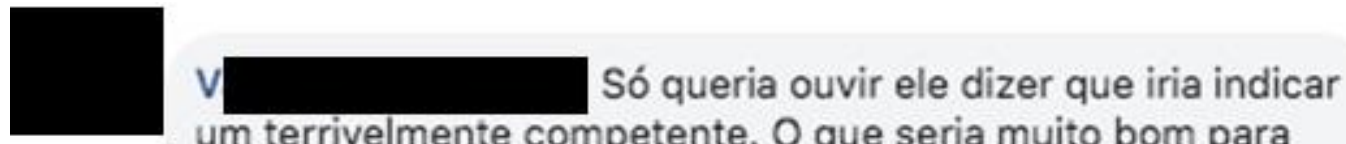
um terrivelmente competente. $O$ que seria muito bom para os Brasileiros, não é mesmo????

Curtir - Responder - $23 m$

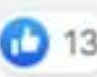

Fonte: Facebook (2019)

8) Marcadores discursivos modalizadores: instauram uma distância entre 0 sujeito da enunciação e o conteúdo do enunciado. São recorrentes expressões do tipo: "em minha opinião", "ao que parece", "para dizer a verdade", "talvez", "possivelmente".

Figura 69: Exemplo de Marcadores discursivos modalizadores na rede social digital Facebook
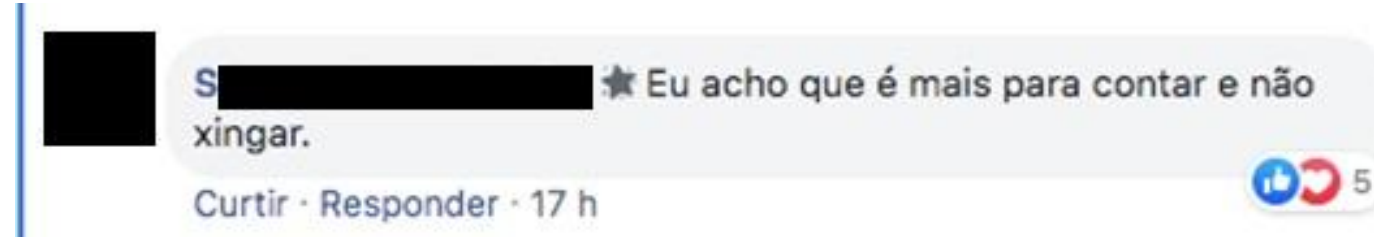

Fonte: Facebook (2019) 
Figura 70: Exemplo de Marcadores discursivos modalizadores na rede social digital Facebook

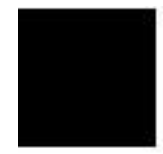

M Talvez, o melhor seja o pessoal colocar na planilha o par de idiomas e o link para o Linkedin. Assim, o contratante pode ver o currículo e decidir se vale a pena 0 contato.

Curtir-Responder - 16 sem

Fonte: Facebook (2018)

\section{9) Controladores de contato e outras formas apelativas como chamar pelo} nome do interlocutor: os controladores de contato buscam e solicitam o consentimento do interlocutor, além de ajudar a manter uma certa proximidade com o outro. Pode ser um elemento intensificador de descortesia, caso a forma de chamar o interlocutor seja inadequada. É comum o uso de "olhe", "mano", "moça", por exemplo.

Figura 71: Exemplo de controladores de contato e outras formas apelativas como chamar pelo nome do interlocutor na rede social digital Facebook

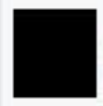
S Meu amor, o governo teve que fazer campanha para higiene levavam a amputação, e você está surpreso por precisar de campanha pra ensinar homem que tem que controlar as pernas pra não invadir o espaço dos outros?

Curtir - Responder - 31 min - Editado

Fonte: Facebook (2017)

Figura 72: Exemplo de controladores de contato e outras formas apelativas como chamar pelo nome do interlocutor na rede social digital Facebook

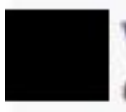

V】Mas, moça, não é machismo. É achismo mesmo. Achar que tá em casa kkkkk

Curtir-Responder - 13 - 136 min

Fonte: Facebook (2017)

10) Uso do diminutivo: pode servir como estratégia de atenuação, porém nem sempre ele será atenuador, uma vez que o sufixo qualificativo pode diminuir 
semanticamente, apenas. Podem ser um intensificador de descortesia em situações enunciativas irônicas.

Figura 73: Exemplo de uso do diminutivo na rede social digital Facebook

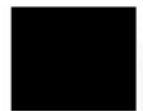

(-) Superfă

G Por favor, não venha me mostrar o exemplo de 1 (unzinho) moleque foi preso injustamente. Para cada UM, centenas de milhares são assassinos responsáveis por mais de 60 mil homicídios por ano, que põem a culpa de seus atos e de sua índole, em um sistema econômico.

Não normalize a justiça, por favor.

Curtir - Responder - $51 \mathrm{~m} \cdot$ Editado

Fonte: Facebook (2018)

11) Quantificadores e partículas que se aproximam do que é dito: é uma maneira de não comprometer o locutor quando este afirma algo. É comum os usos de "mais ou menos", "aproximadamente", "em alguns casos", etc.

Figura 74: Exemplo de quantificadores e partículas que se aproximam do que é dito na rede social digital Facebook

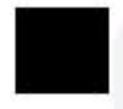

PLIsso já acontece em alguns casos, especialmente nos States. Em vez de chamar uma criança de 'Abigail', chamam de 'Aaabigail' para garantir a primeira posição em listas de benefícios, etc.

Curtir - Responder - 16 sem

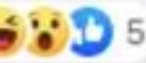

Fonte: Facebook (2018)

12) Expressões carinhosas: as expressões carinhosas servem como atenuadores quando empregados em um contexto adequado e quando o interlocutor não se sente ofendido com a forma de tratamento. É uma maneira de "quebrar o gelo" e atenuar a mensagem, especialmente quando o locutor ou interlocutor discorda do outro. Porém, é comum o uso de expressões carinhosas em um sentido irônico e, desta forma, podem funcionar como intensificadores de descortesia. 
Figura 75: Exemplo de expressões carinhosas na rede social digital Facebook

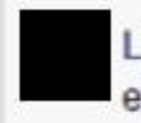

Então amor, mas para uma pessoa que conserta eletrodomésticos por exemplo, coisas sem funcionar são úteis para aproveitamento de peças. Vc não tem que ser conveniente ou deixar de ser com algo que não lhe diz respeito. Mas cansei de falar com quem não quer (ou finge não querer) entender. Bom caminho em sua vida...

Curtir-Responder - 9 - 4 - 17 min

Fonte: Facebook (2017)

13) Movimentos de justificação: englobam a categoria de estruturas com valor concessivo-opositivo que minimizam a desconformidade dialógica. Aparecem como reação de acordo em relação ao (inter)locutor para após mostrar um desacordo parcial ou não tão parcial.

Figura 76: Exemplo de movimentos de justificação na rede social digital Facebook

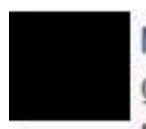
Mente boa! Li antes as regras do grupo e Pesquisei MUITO no
grupo antes de colocar e como a Lais bem colocou, encontrei gente que está
procurando sim. Tanto quem trabalha com eletrodomésticos os como quem
faz cenários, sei lá. Como não coloquei as fotos, entendo a reação, mas creio
que não teria sido tão intensa vendo que as coisas estão em estado de nova
e tem defeitos consertáveis. Curtir-Responder - 0 4-15 min

Fonte: Facebook (2017)

Figura 77: Exemplo de movimentos de justificação na rede social digital Facebook

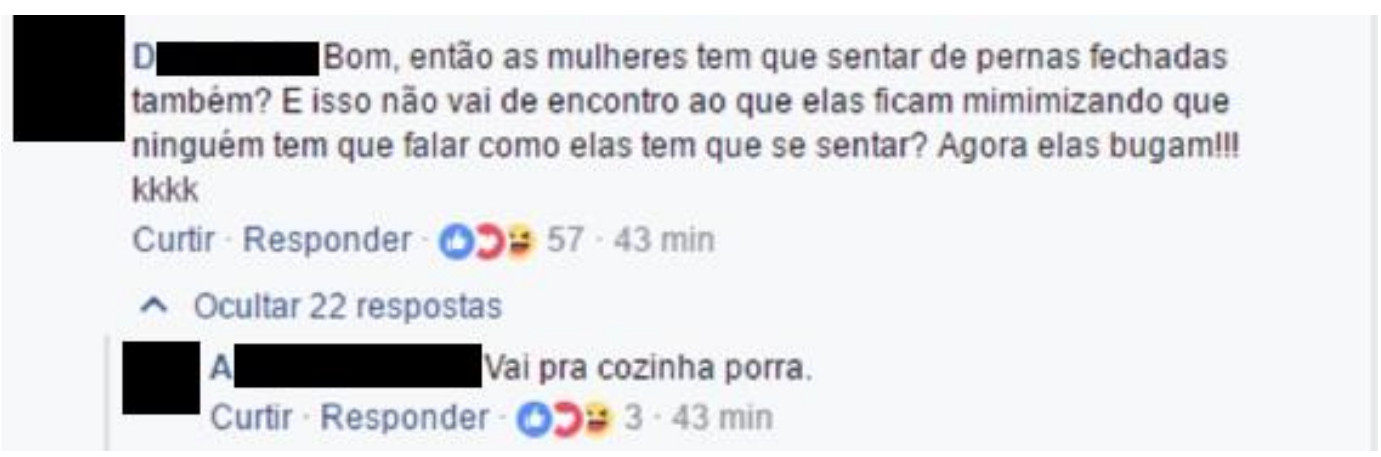

Fonte: Facebook (2017) 
14) Distanciamento do objetivo: Formas dêiticas como "ali", "aí", "algo assim", cujo significado vago evita a responsabilidade enunciativa e atenua, assim, o que é dito.

Figura 78: Exemplo de distanciamento do objetivo na rede social digital Facebook

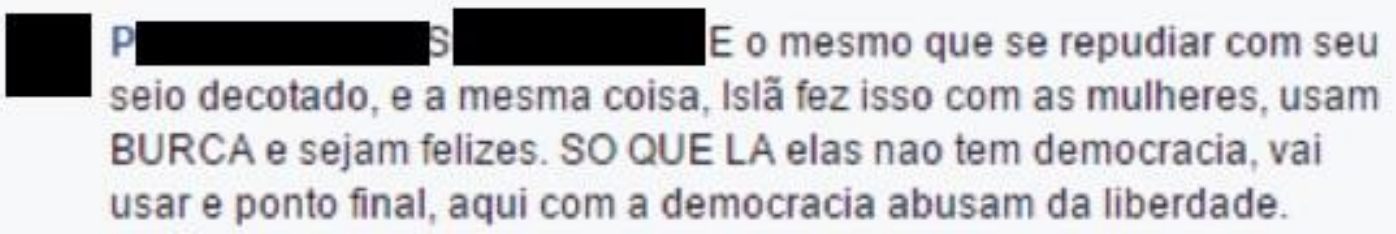

Fonte: Facebook (2017)

15) Uso da impessoalidade: ocorre por meio de formas impessoais, tais como o uso de "se", "nós". São recursos atenuadores empregados tanto na fala quanto na escrita.

Figura 79: Exemplo de impessoalidade na rede social digital Facebook

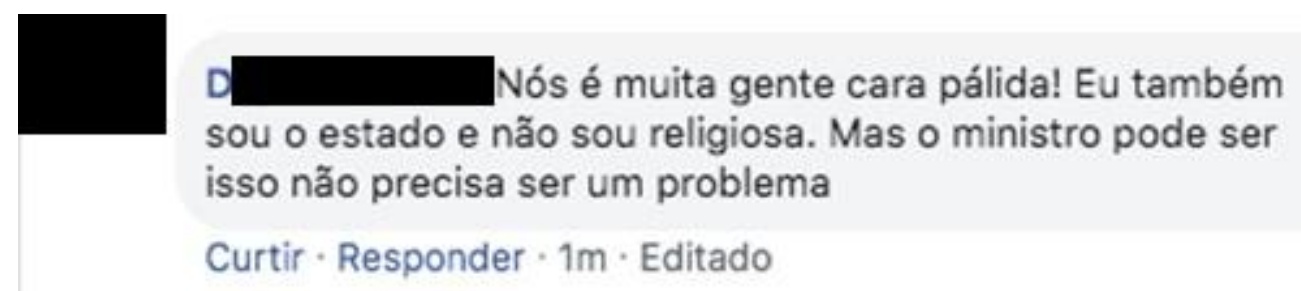

Fonte: Facebook (2019)

16) A generalização: relativização de um aspecto negativo através de uma generalização, tais como "todo o mundo", "segundo dizem", ou seja, é uma maneira de atacar um grupo mais do que o destinatário individual. Podem funcionar como atenuadores ou intensificadores da (des)cortesia, dependendo do contexto. 
Figura 80: Exemplo de generalização na rede social digital Facebook

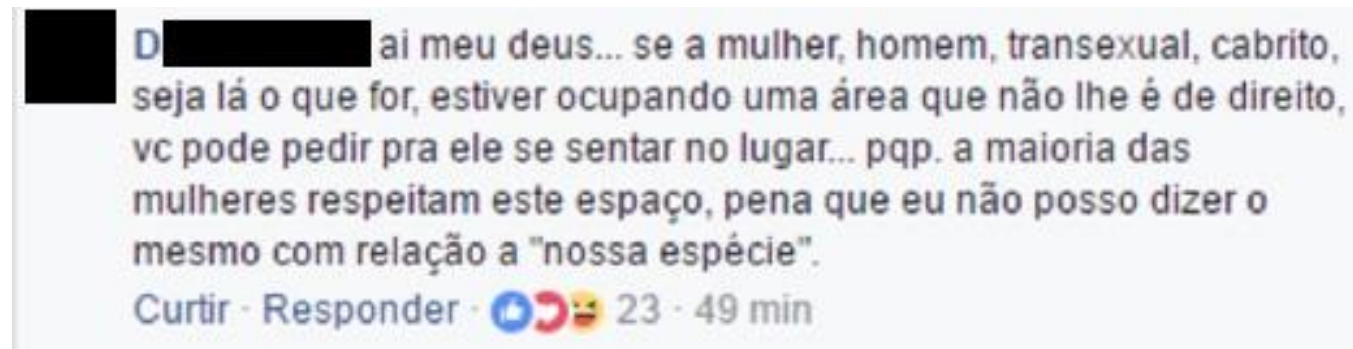

Fonte: Facebook (2017)

Figura 81: Exemplo de generalização na rede social digital Facebook

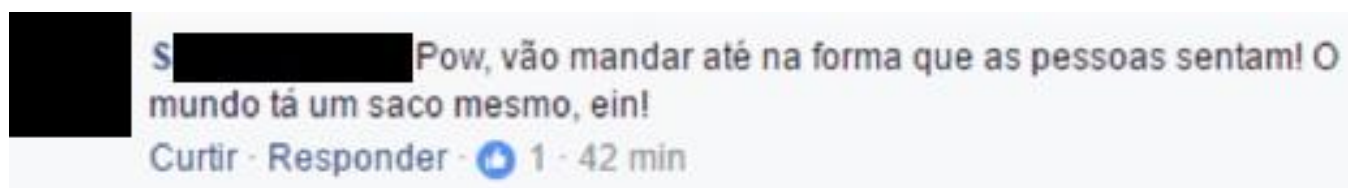

Fonte: Facebook (2017)

17) Uso das formas de tratamento: o uso das formas de tratamento pode indicar uma relação de solidariedade e de poder, dependendo do contexto. Além disso, pode aproximar o locutor e o interlocutor, mas também pode distanciá-los. Assim como os muitos exemplos já mencionados, também dependem do contexto para que se identifique se é um caso de atenuador ou intensificador na interação.

Figura 82: Exemplo de formas de tratamento na rede social digital Facebook

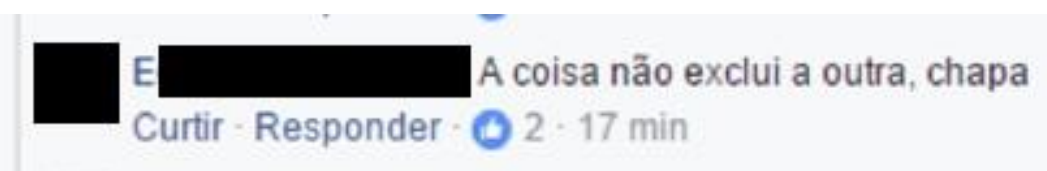

Fonte: Facebook (2017)

Figura 83: Exemplo de formas de tratamento na rede social digital Facebook

R Primeiro: que mulher fica de perna arreganhada?

Segundo: o que tem o feminismo com isso?

Terceiro: a senhora pode gostar e fazer oq a senhora quiser, desde

que seja a sua vontade, ta tudo certo. Isso è feminismo

Curtir - Responder - $0=33 \cdot 35 \mathrm{~min}$ 
Fonte: Facebook (2017)

18) Hipóteses: o uso de fórmulas hipotéticas atenua o ponto de vista do enunciador, uma vez que ele defende uma ideia, mas não se compromete ao afirmá-la.|

Figura 84: Exemplo de hipóteses na rede social digital Facebook

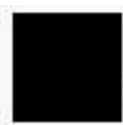

E se um homem pedisse pra uma mulher fechar as pernas? Não é meu corpo minhas regras? Ué.

Curtir-Responder - OS $40 \cdot 57 \mathrm{~min}$

^ Ocultar 18 respostas

$\square$ B Típico pensamento do rapaz revoltado de 12 anos Curtir-Responder - $050 \cdot 57$ min

L Aí que meda. Não usa argumentos, só esta atacar quem discorda não é mesmo?

Curtir-Responder - 0 8-56 min - Editado

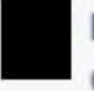

R Tipico escravoceta heueheueu

Curtir-Responder - $02-54$ min

Fonte: Facebook (2017)

19) Interjeições ou onomatopeias: As interjeições exprimem estados emocionais e sensações, e estados de espírito. É um recurso muito expressivo tanto na fala quanto na escrita, assim como nas redes sociais digitais. Elas não são vazias de sentido e colaboram tanto para atenuar quanto para intensificar o que é dito. As onomatopeias, por sua vez, reproduzem um som ou um fonema e assim como as interjeições, também podem atenuar ou intensificar o que é dito. 
Figura 85: Exemplo de interjeições ou onomatopeias na rede social digital Facebook

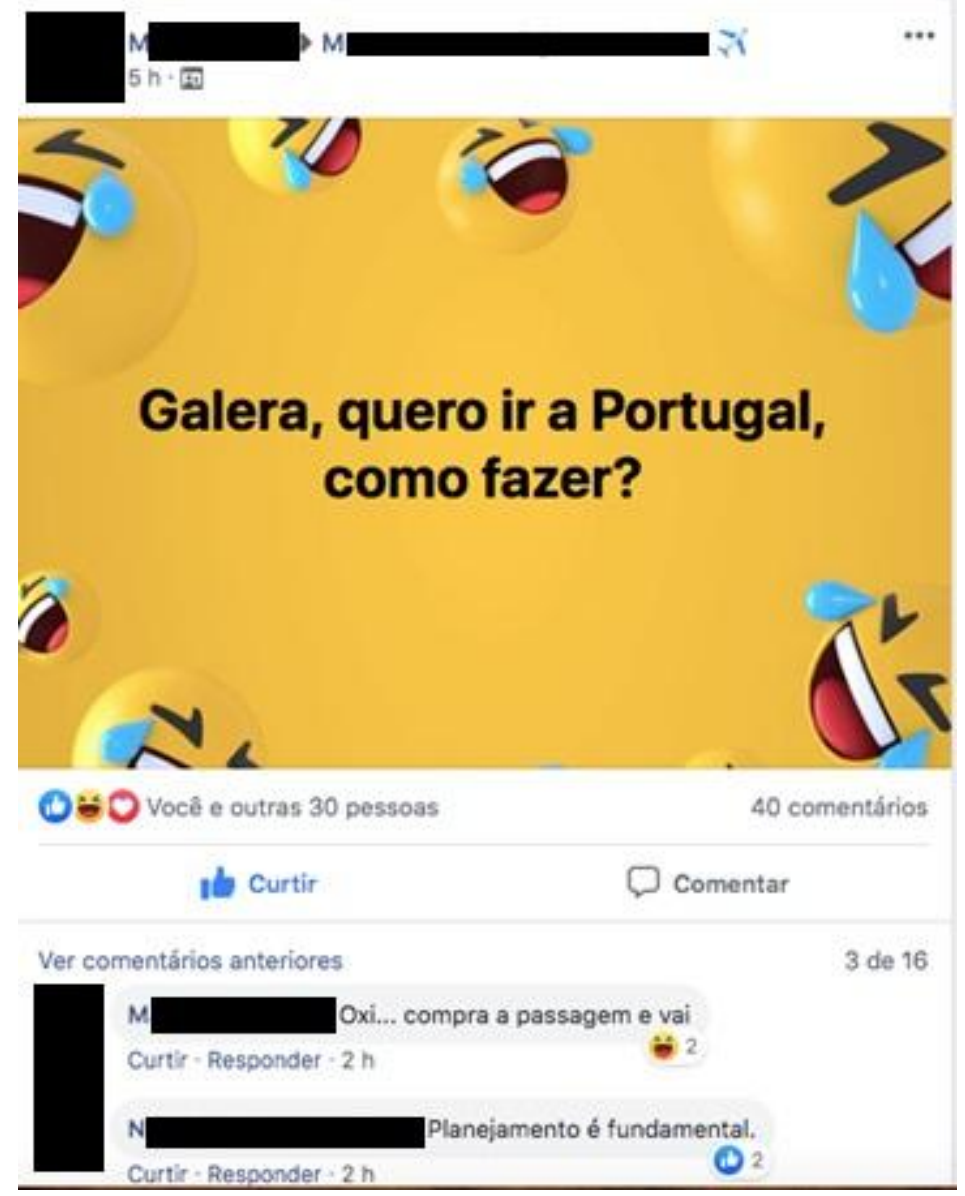

Fonte: Facebook (2017)

Figura 86: Exemplo de interjeições ou onomatopeias na rede social digital Facebook

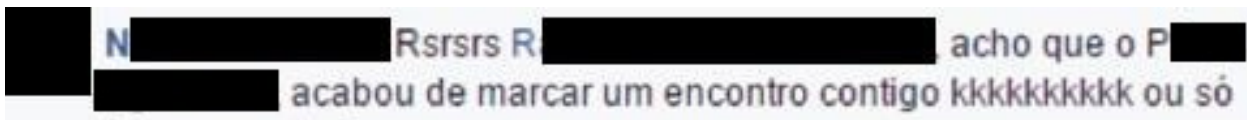
foi uma cantada mesmo.

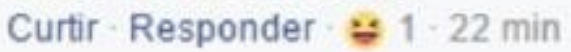
P. hur durrr... marcou encontro durrr...

Rapaz, adoro esse sentimento de nostalgia que esses moleques provocam quando, numa discussão na internet, me lembram de quando eu estava na $5^{3}$ série.

Curtir-Responder- $\mathbf{O} \cdot \mathbf{2} 11 \cdot 20 \mathrm{~min}$

Fonte: Facebook (2017)

20) Desqualificação ou concordância das palavras usadas pelo locutor ou interlocutor: É comum a retomada do enunciado, seja por meio de uma paráfrase ou da citação própria do locutor ou interlocutor para discordar ou 
concordar de seu ponto de vista. Assim, trata-se de um recurso intensificador da descortesia ou de atenuador em casos de concordância do ponto de vista do interlocutor.

Figura 87: Exemplo de desqualificação das palavras usadas pelo locutor ou interlocutor na rede social digital Facebook

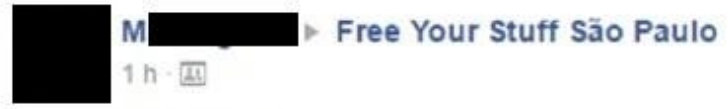

DOa-SP URGENTE:

- Microondas carrefour quebrado

- Ventilador de coluna quebrado

- Ferro de passar preto antigo quebrado

- Base de liquidificador quebrado

- Enciclopédias larrouse cultural coleção completa

Retirar até semana que vem na Freguesia do ó.

Amanhã posto fotos!

It Curtir Comentar

(1) 1

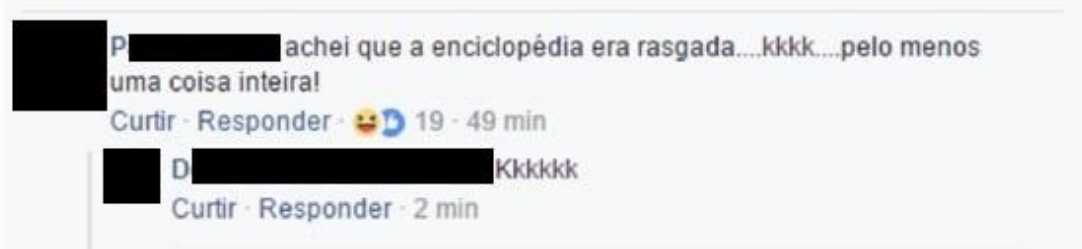

Fonte: Facebook (2017)

Figura 88: Exemplo de concordância das palavras usadas pelo locutor ou interlocutor na rede social digital Facebook

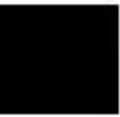

*) Superfas

E 10 que ele disse sobre muitas coisas é a mais pura verdade, o problema das penitenciárias é que virou um lugar sem lei, já que muitos agentes levam coisas para dentro dos presídios, celular, arma, faca, drogas não entram lá sozinho e sobre o que ele disse da polícia é muita verdade também, é tanta coisa errada sobre milícia e várias outras coisas e ela acaba não sendo respeitada e isso gera medo na população e outro ponto é sobre que as leis precisam ser mais duras $\mathrm{SIM}$, nem sempre é culpa das leis já que juizes também são da maioria culpados, o vídeo foi excelente $e$ muita coisa que ouvi nele eu concordo.

Curtir - Responder - $22 \mathrm{~m}$ - Editado

Fonte: Facebook (2019) 
21) Citação de declarações de uma terceira pessoa ou de palavras do próprio interlocutor: trata-se de um recurso de ataque sem assumir total responsabilidade do que foi dito e, assim, funciona como um intensificador de descortesia.

Figura 89: Exemplo de citação de declarações de uma terceira pessoa ou de palavras do próprio interlocutor na rede social digital Facebook

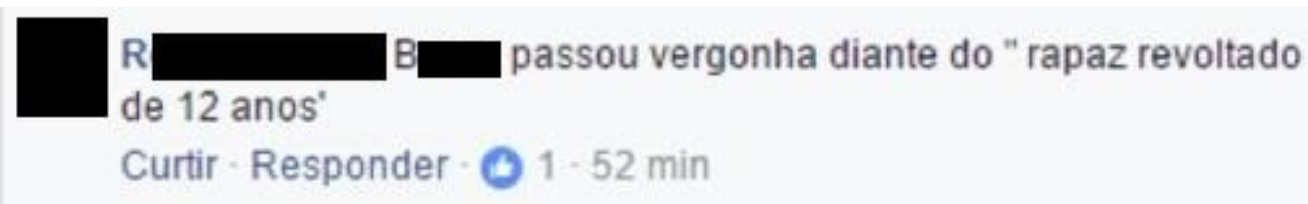

Fonte: Facebook (2017)

22) Argumentos de autoridade para respaldar as afirmações e impedir a refutação: trata-se de uma estratégia de se proteger de possíveis ataques do interlocutor e, assim, funciona como um recurso de atenuação na troca comunicativa.

Figura 90: Exemplo de uso de argumentos de autoridade para respaldar as afirmações e impedir a refutação na rede social digital Facebook
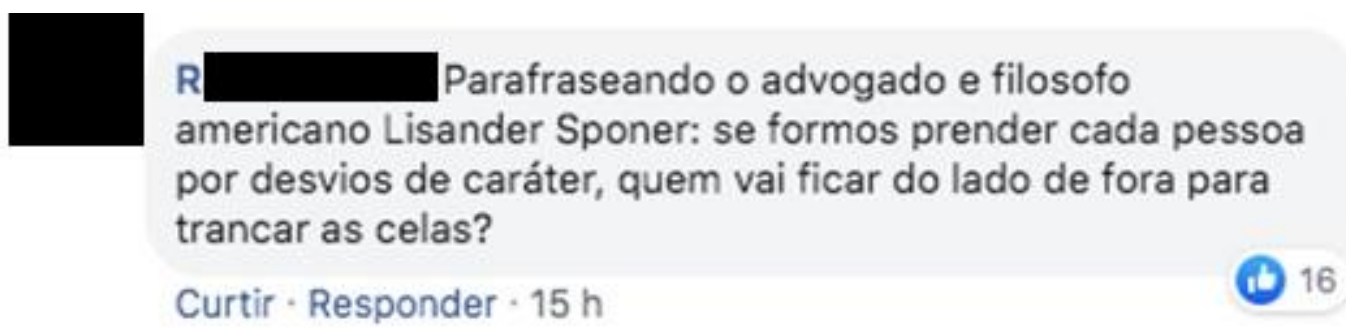

Fonte: Facebook (2018)

23) Uso de maiúsculas: na comunicação escrita, em especial na Internet, o uso de maiúsculas é condenado pelo fato de ser interpretado como um grito em relação a outro interlocutor. Em alguns casos, o uso de maiúsculas exprime um recurso de estilo empregado para dar ênfase ao que é dito, porém em muitos casos eles intensificam a descortesia na interação. 
Figura 91: Exemplo de uso de maiúsculas na rede social digital Facebook

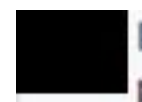

P $\quad$ vc nao leu, è uma campanha feita pela CAPITAL MADRI para colocar as placas, porem é o ESTADO CONTROLANDO SUA FORMA DE VIVER, porem nao vai ter multa é só um controle mesmo. Na verdade o problema é que nao dao educação as crianças ae cria-se adultos sem bom senso, como tem uma parcela gigantesca criada sem bom senso ae eles vao fazendo campanha, leis para moldar, agora é RIDícULO isso. Breve tera que mostrar um medidor de saco. Como vc vai julgar as pernas, no máximo vc tem que exigir um bom senso, pedindo dar licensa etc.. se o kara nao quiser Xinga o mesmo. isso é saber viver conviver. NAO PRECISA DE CAMPANHAS DO GOVERNO para te ensinar isso. é essa questão que as pessoas estão esquecendo, as pessoas estão escravas do estado.

Curtir - Responder - 45 min

Fonte: Facebook (2017)

24)Alongamentos de vogais: os alongamentos de vogais são um recurso estilístico na escrita para mimetizar a língua falada. Funcionam como um recurso expressivo de ênfase, porém, na rede social digital, notou-se que o uso das vogais alongadas funciona tanto como atenuadores quanto intensificadores.

Figura 92: Exemplo de alongamentos de vogais na rede social digital Facebook
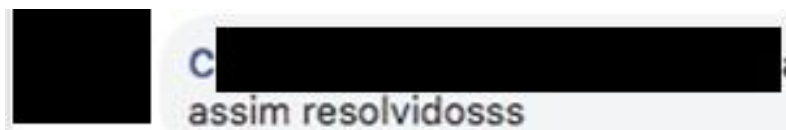
aaaah pq meus profs não são assim resolvidosss

Curtir - Responder - 2 a

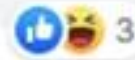

Fonte: Facebook (2017)

25) Expressões faciais: como na linguagem da internet não há os recursos paraverbais, é possível usar recursos que suprem essa necessidade em uma interação virtual, tais como o uso de emojis, Gifs ou memes. No exemplo a seguir, os emojis complementam a enunciação de $\mathbf{T}$ e podem servir tanto como atenuadores quanto intensificadores a depender do contexto. 
Figura 93: Exemplo de expressões faciais na rede social digital Facebook
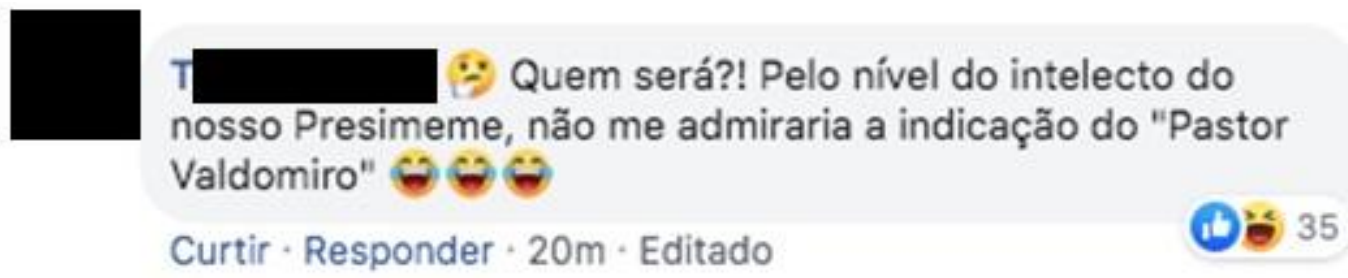

Fonte: Facebook (2019)

26) Verbos modais: os usos dos verbos "poder", 'dever", "desejar" protegem a imagem do enunciador em relação ao que é dito. Assim, funcionam muitas vezes como atenuadores na interação.

Figura 94: Exemplo de verbos modais na rede social digital Facebook
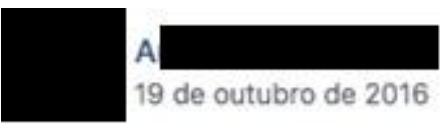

Eu sei que reclamações săo super chatas. Mas mais chato ainda é passar por certas situações. Todo mundo sabe que năo é fácil levar uma graduação com tantos desafios, muitos deles vindos da própria universidade. Então espero sempre poder contar com os colegas, já que estamos no mesmo barco. Gente, é no mínimo uma atitude egoista esconder um livro da biblioteca. Principalmente se ele é o único exemplar. Ainda mais se ele está na coleção didática, justamente pra todos poderem consultá-lo. Vamos ter um pouquinho mais de empatia uns com os outros, sim?

Em tempo: por favor, quem tiver escondido o livro "Cabo Verde: Literatura em Chão de Cultura", por favor disponibiliza pros colegas - são quase 240 alunos matriculados com a Simone precisando desse livro.

(1) 8.89

8 comentários

Fonte Facebook (2016)

27) Elogios: O elogio, por exemplo, pode ser intensificado de maneira negativa quando se trata de uma ironia. Neste caso, o contexto específico da interação deve ser analisado, visto que o elogio pode ser um elemento atenuador quando a apreciação for positiva e intensificador de descortesia quando tiver a apreciação negativa. 
Figura 95: Exemplo de elogios na rede social digital Facebook

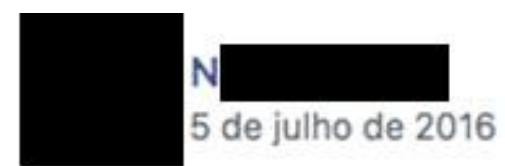

Gentxs, temos que fazer uma campanha" Alcides no te amamos", esse professor é maravilhoso, ele é um daqueles professores que realmente gostam de dar aula, que transmite conhecimento com inspiração. ele é tão fofooo, queria que ele fosse meu avô !!!!! precisamos falar para ele que as aulas dele são MARAVILHOSAS e que ele é "sussa" na avaliação o que significa que ele é justo, acho que ele confundio "sussa" com picareta..

Fonte: Facebook (2016)

28) Insultos: os insultos são elementos intensificadores de descortesia, uma vez que possuem uma carga de significação negativa quando usado em sociedade. Não são necessariamente de baixo calão, mas as expressões de baixo calão também são insultos.

Figura 96: Exemplo de insultos na rede social digital Facebook

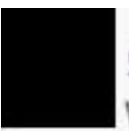

S Taquepariu! !!

Você anda de ônibus e metrô escrota?

Sabe o que é ficar imprensada num canto porque um macho não pode fechar as pernas tomando o espaço de duas pessoas?

Curtir-Responder- $\boldsymbol{\Theta} \equiv 12 \cdot 32 \mathrm{~min}$

Fonte: Facebook (2017)

29) Expressões de baixo calão: assim como os insultos, são palavras dotadas de uma significação negativa e podem ser intensificadores de descortesia, entretanto, é necessário ter atenção ao contexto, pois podem ser usados para exprimir uma surpresa positiva ou pseudodescortesia. 
Figura 97: Exemplo de expressões de baixo calão na rede social digital Facebook

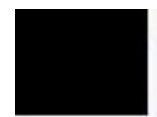

J Pqp mas dai já estão exagerando. Querer controlar como eu me sento já é de mais...

Curtir-Responder-@ 1.1 h

Fonte: Facebook (2017)

30) Anúncio: trata-se de um meio utilizado para atenuar um ato ameaçador, utilizando-se de um enunciado preliminar, tal como na expressão "se me permite vou te dizer uma coisa", do exemplo a seguir:

Figura 98: Exemplo de anúncio na rede social digital Facebook

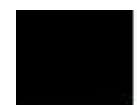

H Em primeiro lugar você não tem intimidade comigo para me chamar de amor e depois se me permite vou te dizer uma coisa: Você não tem direito a dar a sua opinião,você tem direito de dar a sua opinião fundamentada,ninguém tem o direito de ser ignorante!

Curtir - Responder - O 3 3-17 min

Fonte: Facebook (2017)

31) Minimizadores: a função dos minimizadores é parecer reduzir um FTA. Alguns exemplos são "Eu queria simplesmente perguntar...", "Você poderia me arrumar um pouquinho de açúcar?", "Pode me dar uma ajudinha?". No exemplo a seguir, temos o uso da expressão "Perguntinha de..." para atenuar a posição vulnerável na interação.

Figura 99: Exemplo de minimizadores na rede social digital Facebook
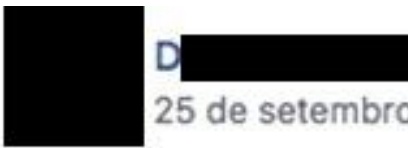

25 de setembro de 2017

Perguntinha de uma aluna quase terminando o curso de letras: gostaria de saber quanto tempo temos para terminar a graduação de bacharel junto com a licenciatura, alguém sabe me dizer?

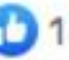

5 comentários

Fonte: Facebook (2017) 
32) Desarmadores: antecipa uma possível reação negativa por parte do interlocutor e tenta neutralizar este efeito por meio de algumas expressões, tais como: "Não queria te incomodar, mas..." Espero que você não me leve a mal, mas...". No exemplo a seguir, temos um uso do desarmador "nada contra, mas...". Este recurso visa, então, atenuar um possível conflito.

Figura 100: Exemplo de desarmadores na rede social digital Facebook

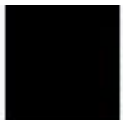

Sério isso? Nada contra um objeto usado mas no minimo precisa estar em condições de uso! Dar lixo para os outros e querer estar certo é complicado demais.

Curtir-Responder - $3 \cdot 29$ min

Fonte: Facebook (2017)

Figura 101: Exemplo de desarmadores na rede social digital Facebook
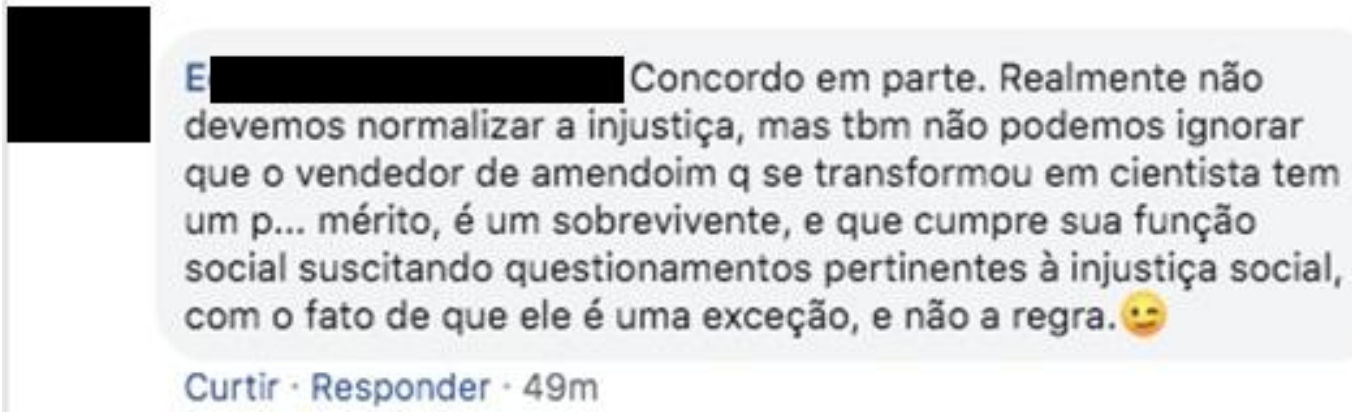

Fonte: Facebook (2019)

33) Moderadores: são atenuadores que amenizam o efeito de um FTA. Expressões como "por gentileza", "você que sabe das coisas, poderia...", "algum anjo para responder..." etc. 
Figura 102: Exemplo de uso de moderadores na rede social digital Facebook

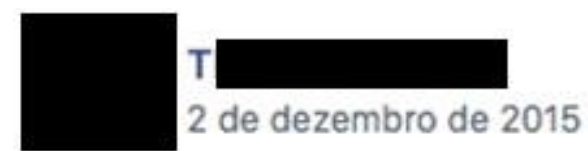

Oi, gente!

Alguém fala Tcheco ou conhece alguém que fale? Tenho uma amiga que vai fazer intercâmbio e precisa traduzir uns papéis com urgência. Se alguém souber, por gentileza, me avise.

Muito obrigada!

(b) 4

Fonte: Facebook (2015)

Figura 103: Exemplo de uso de moderadores na rede social digital Facebook

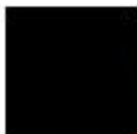

G1 de outubro de 2015

[Teatro Latino ] [Robson Cesila ]

Ooi gente. Eu perdi algumas aulas e quase não tenho anotações das Troianas, alguém poderia me passar? Tb estou sem os handouts quatro $\mathrm{e}$ cinco, se algum anjo puder me ajudar... pode ser por foto mesmo, to tentando estudar pra prova dessa semana.

6 comentários

Fonte: Facebook (2015)

Figura 104: Exemplo de uso de moderadores na rede social digital Facebook

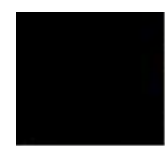

Mo de janeiro de 2015

Pessoas, gostaria de saber qual é o nível necessário de inglês para acompanhar a habilitaçăo de acordo com quadro europeu comum. Algum anjo do inglês para responder?

6 comentários

Fonte: Facebook (2015) 
34) Comparações: é comum o uso de comparações para defender um ponto de vista e evitar refutações. Assim, geralmente, elas atenuam críticas, mas nem sempre podem funcionar como recurso argumentativo nas redes sociais digitais.

Figura 105: Exemplo de comparações na rede social digital Facebook

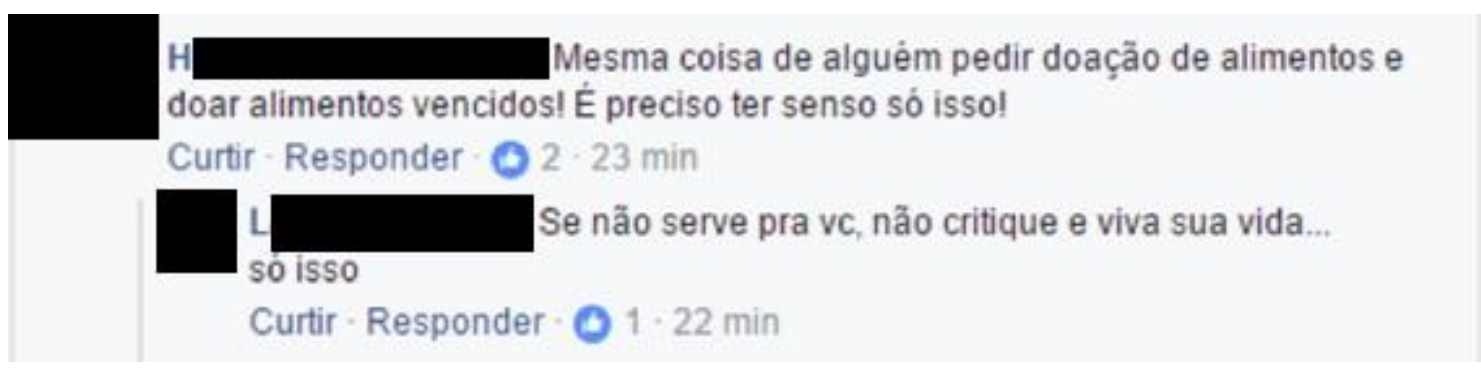

Fonte: Facebook (2017)

Figura 106: Exemplo de comparações na rede social digital Facebook

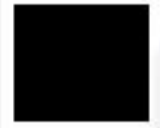

ELAte anos atrás a gente ouvia falar em direitos

e deveres do cidadão, mas hoje vivemos uma época que a maioria só pensa em direitos e não pensam em dever nenhum.

Curtir-Responder - $9 \mathrm{~h}$

(1) 30

Fonte: Facebook (2018)

35) Conselhos: os conselhos são utilizados como recursos atenuadores ou intensificadores da (des)cortesia. Também são dependentes do contexto para que sejam bem interpretados. Nas redes sociais digitais, no entanto, percebeuse o uso predominantemente de conselhos para fazer uma crítica indireta e assim, intensificar a descortesia.

Figura 107: Exemplo de conselhos na rede social digital Facebook

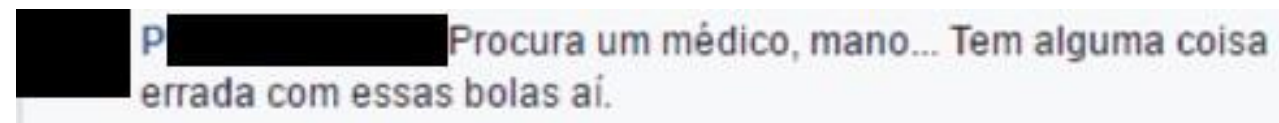

Boa sorte.

Curtir-Responder - $\% 13 \cdot 45 \mathrm{~min}$

Fonte: Facebook (2017) 
Figura 108: Exemplo de conselhos na rede social digital Facebook

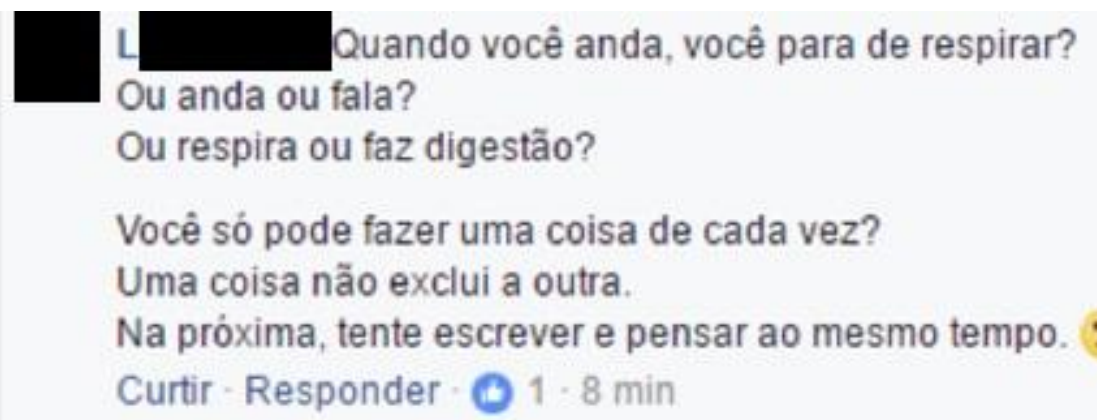

Fonte: Facebook (2017)

36) Conclusões: as conclusões são usadas para exprimir um ponto de vista por parte de um participante da rede social digital. São usadas para concordar ou discordar de um ponto de vista, funcionando assim como um procedimento de defesa na interação virtual. Funcionam como atenuadores em caso de concordância ou intensificadores em casos de discordância.

Figura 109: Exemplo de conclusões na rede social digital Facebook

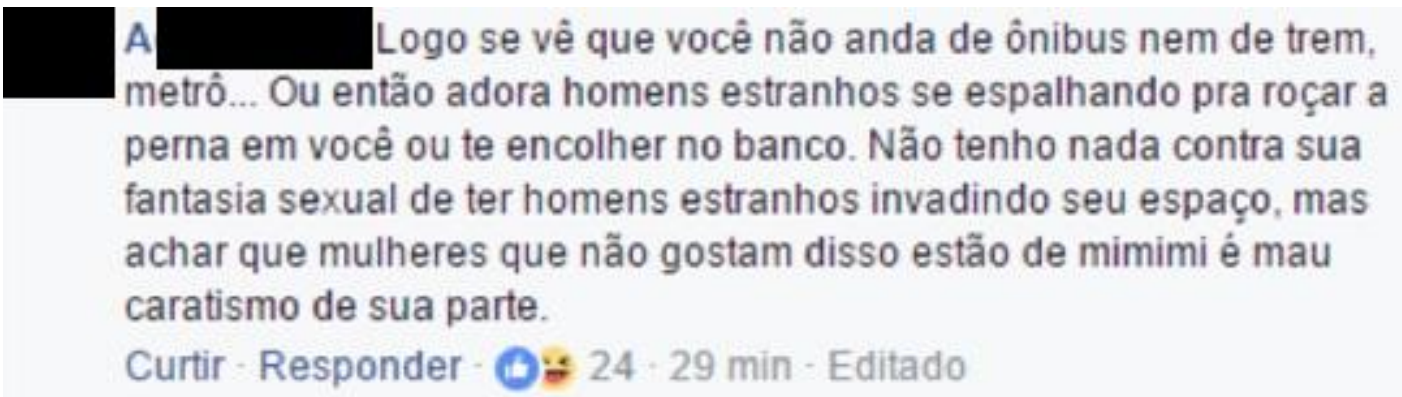

Fonte: Facebook (2017)

37) Críticas: as críticas, assim como os insultos, deixam o interlocutor vulnerável e são intensificadores de descortesia. Podem ocorrer de forma direta ou indireta.

Figura 110: Exemplo de críticas na rede social digital Facebook A Que comentário ridiculo. Você anda de transporte homens achando que podem ocupar o banco dele e o ao lado, como se estivessem no sofá de casa Curtir-Responder - $5 \cdot 22 \mathrm{~min}$ 
Fonte: Facebook (2017)

38) Ameaças: nas redes sociais digitais, é comum o uso de ameaças verbais ou físicas, apesar de ser um ambiente virtual. São intensificadores da descortesia na interação.

Figura 111: Exemplo de ameaças na rede social digital Facebook

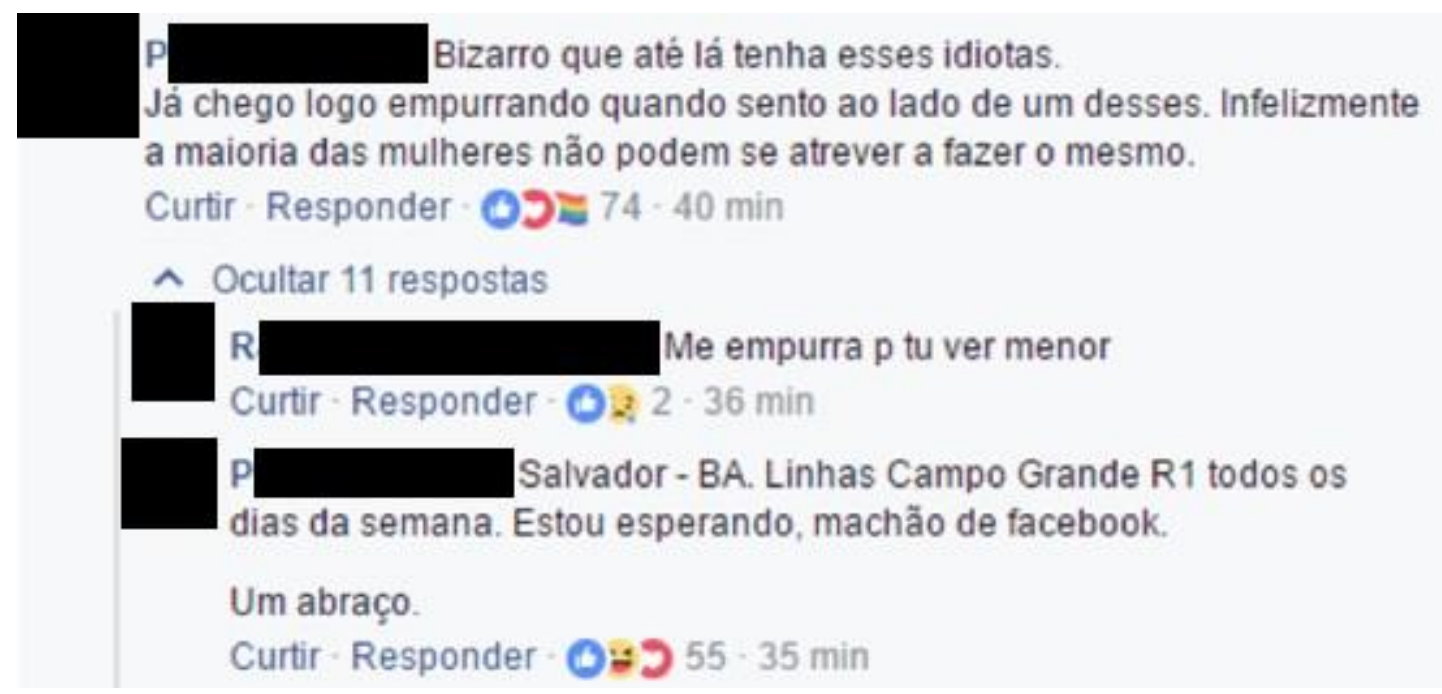

Fonte: Facebook (2017)

39) Argumentos Ad Hominem: é comum o ataque pessoal na Internet a fim de intensificar a descortesia.

Figura 112: Exemplo de argumentos ad hominem na rede social digital Facebook

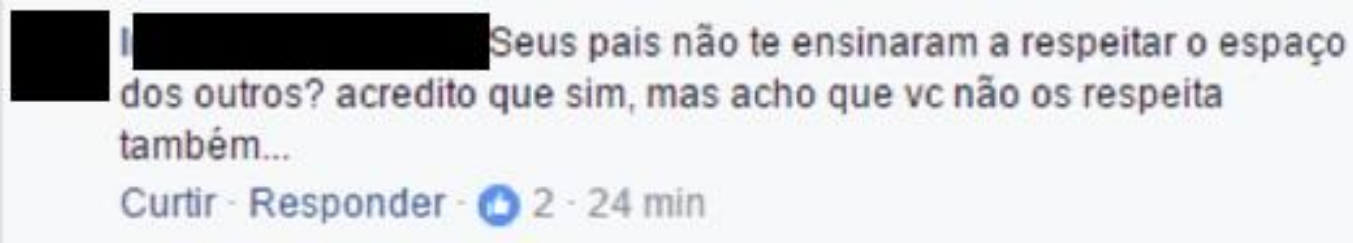

Fonte: Facebook (2017)

Figura 113: Exemplo de argumentos ad hominem na rede social digital Facebook

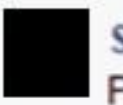

Meu filho querem controlar quem se a noticia é de Paris e vc não tem dinheiro nem pra ir pra padaria?

Curtir-Responder - 92.58 min 
Fonte: Facebook (2017)

40) Agradecimentos: os agradecimentos atenuam um pedido ou uma pergunta na rede social digital. É um recurso muito usado em ordens e pedidos. No entanto, é possível que os agradecimentos sejam usados de maneira irônica e, sendo assim, podem intensificar um ato de fala descortês.

Figura 114: Exemplo de agradecimentos na rede social digital Facebook
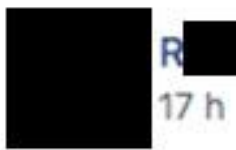

Boa noite caros colegas!

Como eu poderia traduzir de forma natural e contundente:

Discussão entre militantes opostos nunca dá certo.

Pra isso existem os diplomatas.

Desde já, muito obrigado!

Fonte: Facebook (2018)

41) Uso dos parênteses: $O$ uso de parênteses pode sugerir, enfatizar ou exemplificar algo que foi dito e podem funcionar como atenuadores e intensificadores da (des)cortesia dependendo do contexto.

Figura 115: Exemplo de parênteses na rede social digital Facebook
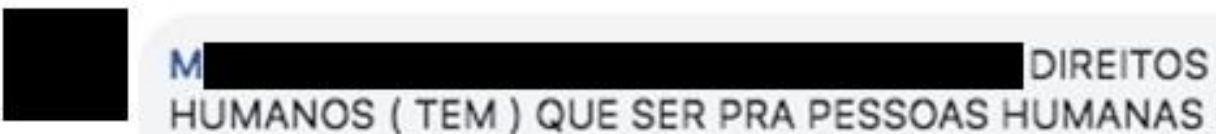

HUMANOS ( TEM ) QUE SER PRA PESSOAS HUMANAS E NAO BANDIDOS (as ) (MONSTRUS ) NAO HUMANOS !!!

Curtir - Responder $\cdot 8 \mathrm{~h}$

Fonte: Facebook (2019)

42) Uso de aspas: o uso de aspas pode funcionar como um atenuador ou intensificador da (des)cortesia a depender do contexto. As aspas podem ser usadas para destacar uma ironia ou para retomar a palavra de alguém. 
Figura 116: Exemplo de uso de aspas na rede social digital Facebook
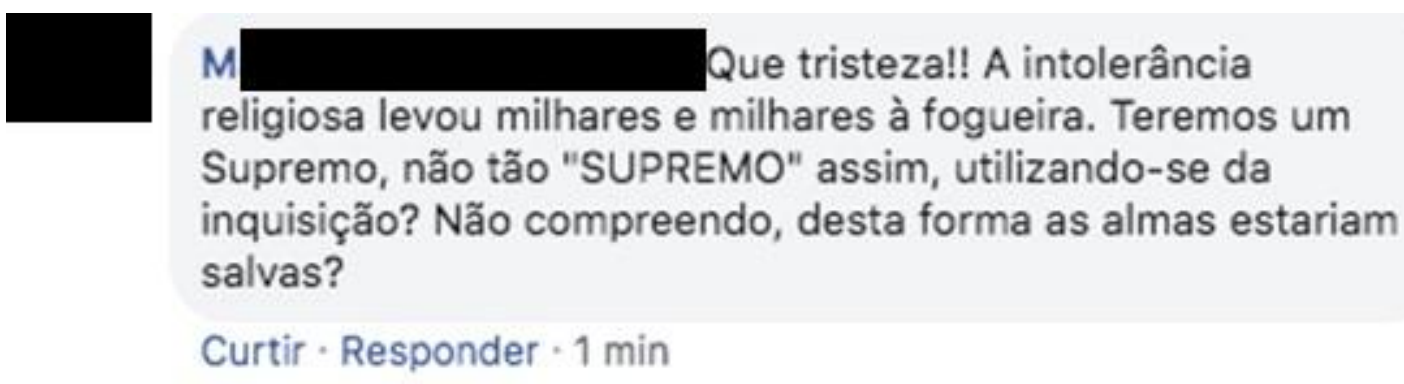

Fonte: Facebook (2019)

43) Uso de expressões preconceituosas ou de estereótipos: o uso de expressões preconceituosas ou de estereótipos intensificam a descortesia na interação, tal como no exemplo a seguir:

Figura 117: Exemplo de uso de expressões preconceituosas ou de estereótipos na rede social digital Facebook
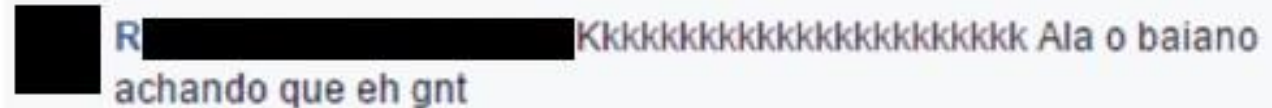

achando que eh gnt

Curtir-Responder - 4 min

Fonte: Facebook (2017) 
Figura 118: Exemplo de uso de expressões preconceituosas ou de estereótipos na rede social digital Facebook

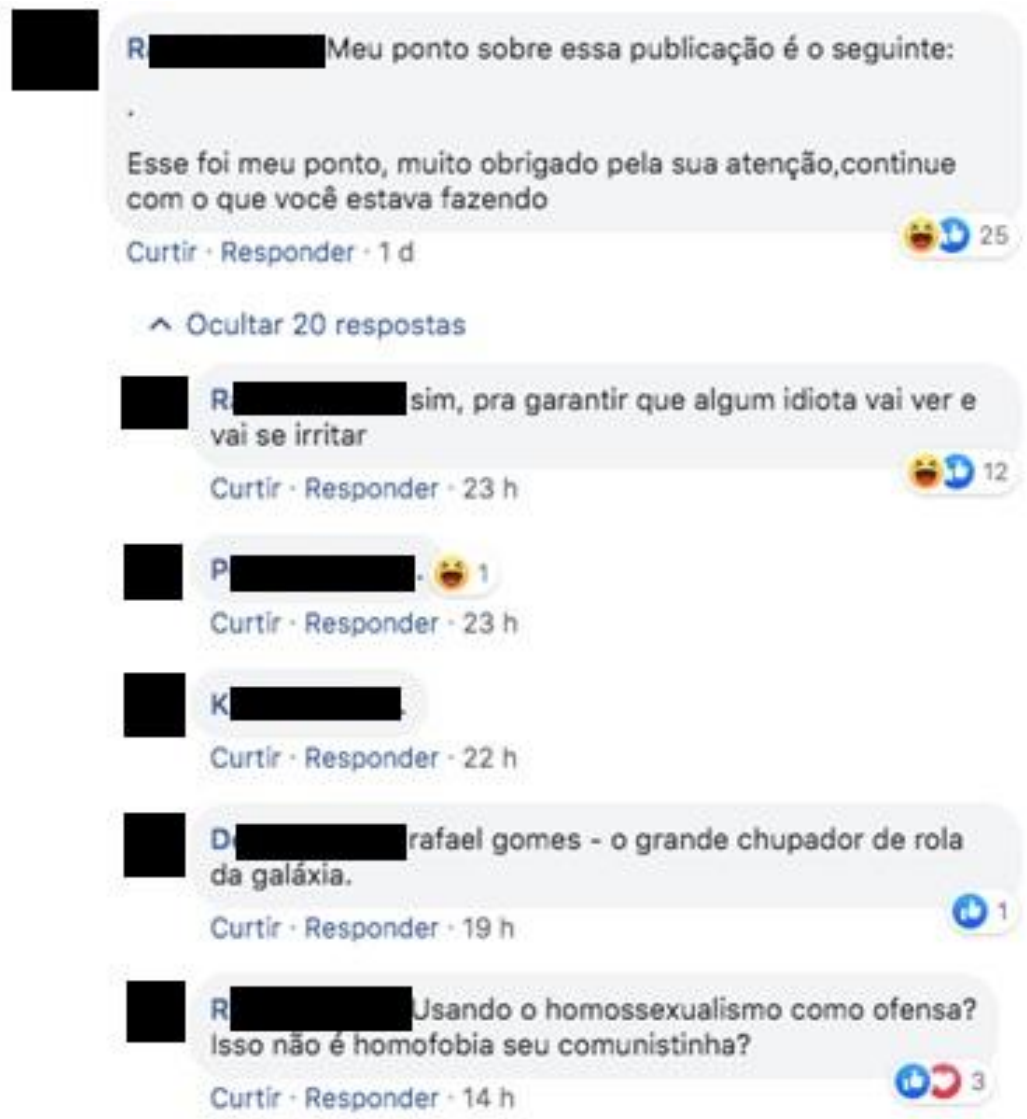

Fonte: Facebook (2019)

Além dos elementos linguísticos já mencionados, salientamos que as escolhas lexicais também funcionam como atenuadores e intensificadores, podendo amenizar e intensificar tanto a cortesia quanto a descortesia, tal como ilustra também o exemplo a seguir:

Figura 119: Exemplo de escolhas lexicais na rede social digital Facebook

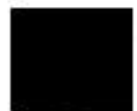

R As palavras TERRÍVEL e CRISTÃo não cabem na mesma frase $\because$

Curtir - Responder $\cdot 22 m$

Fonte: Facebook (2019)

Salientamos ainda que vários elementos que poderiam ser caracterizados como corteses adquirem outro viés quando usados de maneira oposta ao pretendido. Agradecimentos e elogios são alguns desses casos. O FTA 
acompanha, geralmente, um atenuador, mas, muitas vezes, se mostra ineficaz, assim como um FFA que se contradiz.

Percebeu-se no corpus, todavia, ataques feitos de maneira direta ou indireta, com o uso de atenuadores e intensificadores. Assim, nota-se que a descortesia se manifesta de diferentes modos na interação, tal como veremos no tópico a seguir.

\subsection{0 fenômeno da ironia e do gracejo na interação}

A ironia é um fenômeno linguístico complexo, uma vez que depende da situação comunicativa para a sua interpretação e compreensão. A primeira acepção de ironia no dicionário Houaiss destaca que se trata de uma "[...] figura por meio da qual se passa uma mensagem diferente, muitas vezes contrária, à mensagem literal, geralmente com objetivo de criticar ou promover humor [A ironia ressalta do contexto.] $]^{29 " .}$

Desde a Grécia Antiga, a ironia já se fazia presente no discurso socrático, porém tinha uma dimensão diferente do que nós a conhecemos hoje. Naquela época, a ironia era empregada de modo a fazer as pessoas julgarem, elas mesmas, e para que elas tivessem consciência da ignorância delas. É frequente o uso de humor na ironia, mas nem sempre o humor terá um sentido irônico, assim como o sarcasmo. Muitas vezes, a ironia e o sarcasmo possuem uma fronteira ambígua entre um e outro, tanto que Leech (1983; 2014) considera ambos como sinônimos, entretanto o sarcasmo funciona como instrumento de crítica e pretende magoar e ferir o interlocutor, de acordo com Guimarães (2001). $\mathrm{Na}$ interação face a face, a ironia pode ser codificada mais facilmente por gestos e entonações, enquanto, na escrita, podemos algumas vezes identificá-la com o uso de aspas ou parênteses, mas nem sempre os participantes da interação na rede social digital possuem competência pragmática para identificá-la, tal como ilustra a interação a seguir:

${ }^{29}$ Disponível em<http://houaiss.uol.com.br>. Acesso em 05 de abril de 2017, às 15 h. 
Figura 120: Exemplo de ironia na rede social digital Facebook

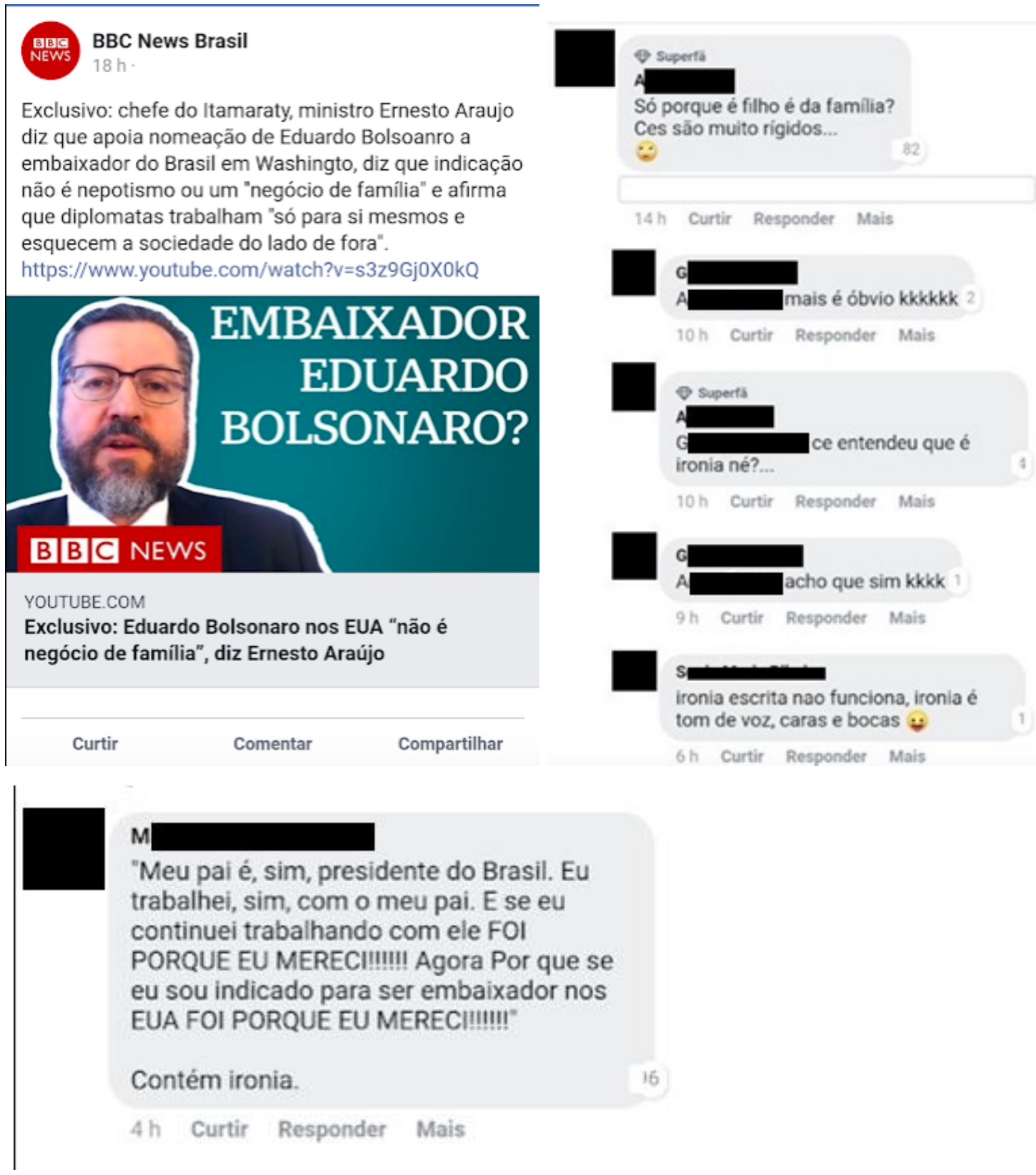

Fonte: Facebook (2019)

A ironia, em geral, pode ser determinada no nível lexical ou no nível sintático, tal como a inversão do uso de algumas palavras na frase. Sobre a interpretação correta da ironia por parte do interlocutor, Guimarães sustenta:

Se é certo que um ouvinte tem determinadas expectativas, não será menos correcto afirmar que o emissor de uma mensagem, aquele que a codifica, possui também à partida algumas expectativas quanto à capacidade de descodificação do seu interlocutor. Ele de certa forma joga com a capacidade de descodificação do destinatário(...) ao emissor é exigida uma grande capacidade de diferenciação, no 
momento da escolha das estratégias, dos veículos em que vai fazer transportar a sua ironia. Para que o emissor seja bem sucedido, não basta que ele próprio fique satisfeito com as formulações por que optou. Os seus esforços só serão coroados de êxito, se conseguir que o receptor chegue às conclusões que ele próprio tinha antecipado como sendo as correctas, e para que isso aconteça ele tem, por vezes, de "impedir" o acesso a conclusões erradas, reduzindo assim as possibilidades de fracasso para o seu interlocutor e, de certa forma, também para si mesmo. (GUIMARÃES, 2001, p. 416)

Grice (1982 [1975]) não faz muitas referências à ironia em suas máximas, no entanto, consideramos que a ironia é uma violação à máxima da qualidade e do princípio de cooperação, uma vez que não há uma contribuição da verdade por parte do locutor. Searle (2002 [1979]) defende que a enunciação irônica é aquela cujo falante pretende significar o oposto do que diz e, neste sentido, vai ao encontro ao pensamento de Grice, já que o locutor não contribui com a verdade dizendo o oposto do que se pretende.

De acordo com a linha interacionista de Brown \& Levinson (1987), a ironia estaria inserida na categoria off-record, pois é uma estratégia de indireção que possibilita uma margem de negociação de sentido. Como a ironia veicula uma crítica de forma implícita, ela é essencialmente um ato de fala descortês, já que exige um esforço interpretativo maior e nem sempre o interlocutor entende de imediato. Muitas vezes, ela representa uma estratégia para desconstruir o discurso do outro, desvalorizando-o. Outros teóricos, como Kerbrat-Orecchioni (1986), destacam que a ironia faz parte de um procedimento retórico baseado na antífrase e salienta seu efeito ilocutório.

Para Braz (2014), a ironia pode ser empregada para fins argumentativos e persuasivos e depende de fatores contextuais para que o enunciado seja inadequado em seu sentido literal. Díaz Pérez (2012) considera a ironia como uma descortesia indireta devido ao fato de ser um recurso que esconde a ofensa mas que não a elimina. Neste sentido,

A descortesia indireta é considerada, em geral, mais ofensiva que [a
descortesia] direta (Fuentes Rodríguez e Alcaide Lara 2008: 25) e,
portanto, entende-se que o ofensor direto é mais favorável à sua vítima
do que aquele que o faz de uma maneira indireta e, portanto,
distorcida $^{30}$. (DÍAZ PÉREZ, 2012, p. 154, tradução nossa)

\footnotetext{
30 No original: La descortesía indirecta es considerada, en general, más ofensiva que la directa (Fuentes Rodríguez y Alcaide Lara 2008: 25) y, por lo tanto, se entiende que el ofensor directo es más solidario con su víctima que el que lo hace de una manera indirecta $y$, por lo tanto, retorcida. (DÍAZ PÉREZ, 2012, p. 154)
} 
Braz (2014) defende a ambivalência da ironia, pois segundo a interpretação da pesquisadora, a ironia permite mitigar o ataque à imagem positiva do interlocutor, uma vez que a apreciação negativa se dá de forma indireta. Assim como os demais teóricos, ela também dá destaque ao contexto:

A ironia é então entendida como um fenômeno semântico fortemente dependente de fatores contextuais, sendo assinalada pela inadequação entre o sentido literal da frase e o seu contexto de produção. Possui uma dimensão avaliativa intrínseca a que não é estranho o seu emprego com fins argumentativos e persuasivos. (BRAZ, 2014, p.175)

Alvarado \& Padilla (2007) sustentam que é necessário considerar vários aspectos para se compreender a ironia, como a situação comunicativa e o uso das máximas conversacionais. Para os pesquisadores, há marcas e indicadores que ajudam a interpretar se um enunciado é irônico ou não, tais como: indicadores linguísticos (ordem das palavras, uso de superlativos, diminutivos, etc.); indicadores cinésicos (gestos, piscadelas, caretas, etc.); indicadores paralinguísticos (sorrisos, risos, etc.); e indicadores acústico-melódicos (entonação, pausas, alongamentos vocálicos, etc.).

Leech $(1983 ;$ 2014) também é um dos teóricos que defendem a importância do contexto para a correta interpretação da ironia. Do Princípio da Cortesia de sua publicação de 1983, Leech desenvolve o Princípio da Ironia:

Se você tiver que ofender, pelo menos faça isso de uma forma que não conflite de forma evidente com a PP, mas permita que o ouvinte chegue ao ponto ofensivo da sua observação indiretamente, por meio de implicatura. (LEECH,1983, p. 82)

Conforme Leech $(1983 ; 2014)$, a ironia faz com que a máxima de tato seja violada e, desta forma, o locutor deve fornecer pistas ao interlocutor sobre o caráter irônico de seu enunciado. O IP (Princípio da Ironia) permite ao falante ser descortês quando parece ser cortês. De acordo com Leech, há uma quebra superficial do Princípio de Cooperação (CP), para finalmente mantê-lo. Ele acrescenta:

Aparentemente, o Princípio da Ironia é disfuncional em relação ao PP [Princípio da Cortesia], pois o Princípio da Cortesia promove preferencialmente a comunhão em vez do conflito nas relações sociais. O Princípio da Ironia nos capacita a promover o uso anti-social da língua. Nós somos irônicos, mentindo para os outros por meio de uma 
cortesia que obviamente é insincera, como um substituto para a descortesia. (LEECH, 1983, p.142, tradução nossa) $)^{31}$

Leech também observou que havia enunciados ofensivos que pareciam simpáticos e corteses, no entanto, o contexto indicava o contrário. Ele denominou esse fenômeno de mock-politeness, termo utilizado neste trabalho como pseudocortesia. Para ele, a ironia pode ser uma forma de pseudocortesia, pois permite ao locutor ser indelicado aparentando delicadeza e não age, assim, de maneira sincera. Por outro lado, o pesquisador também identificou situações em que o comportamento verbal era ofensivo, mas era coerente ao contexto, muitas vezes situações de amizade e intimidade. Para este fenômeno, ele denominou de mock-impoliteness, ou seja, a pseudodescortesia. Leech (1983) descreve a ironia e o gracejo como "princípios" e, portanto, fazem parte da mesma natureza geral que o Princípio de Cooperação (CP) e o Princípio da Cortesia (PP).

Em seu trabalho posterior, no entanto, ele sustenta que ambos não têm a mesma generalidade de aplicação que $\mathrm{C} C P$ e $\mathrm{O} P \mathrm{P}$, e que devem ser considerados estratégias, mais ou menos como a Estratégia Geral de Cortesia (GSP), embora eles explorem o GSP para fins e efeitos contrastantes. Para ele, o Princípio da Ironia foi um ponto de partida, mas que é necessário ainda considerar a função da ironia na troca comunicativa e os efeitos que ela pode ter. De acordo com Leech:

Para ser irônico, $S$ [o falante] expressa ou implica um significado
(vamos chamá-lo de Significado I) que associa um valor favorável com
o que pertence a O (O = outra pessoa (s), principalmente o
destinatário) ou associa um valor desfavorável com o que é pertinente
para $S$ (o falante). Ao mesmo tempo, por meio do Significado I e do
contexto, S [o falante] implica indiretamente um segundo significado
mais profundo (Significado II) que cancela o Significado I associando
um valor desfavorável ao que pertence a O, ou associando um
significado favorável com o que pertence a S [o falante]. A derivação
do Sentido II do Significado I é por meio de dois caminhos de
inferência: primeiro, o Significado I é infeliz (ou seja, pragmaticamente
insustentável no contexto, muitas vezes por causa da violação do
Princípio Cooperativo) e portanto ser rejeitado; e segundo, dado que o
significado é infeliz e de acordo com o PP, a maneira óbvia de dar
sentido a ele é procurar uma interpretação relacionada que seja feliz e
que não esteja de acordo com o PP [ o Princípio da Cortesia] - que é o

\footnotetext{
${ }^{31}$ No original: Apparently, then, the IP is dysfunctional: If PP promotes a bias towards comity rather than conflict in social relations, the IP, by enabling us to bypass politeness promoting antisocial use of language. We are ironic at someone's expense, scoring off others by politeness that is obviously insincere, as a substitute for impoliteness. (LEECH, 1983, p.142)
} 
que o Princípio da Ironia fornece ${ }^{32}$. (LEECH, 2014, p. 233, tradução nossa)

Para evitar qualquer mal-entendido, a ironia (assim como o gracejo) é frequentemente associada a um comportamento amistoso com a finalidade de reforçar ou alcançar a solidariedade dentro de um grupo, incluindo risadas e marcação prosódica. A ironia está associada a um comportamento hostil e a interpretação ocorre devido ao contexto em que é claro que a enunciação não se destina a ser séria.

A ironia é uma estratégia linguística usada para fins descorteses proveniente de uma grande competência linguística por parte do emissor, pois muitas vezes não é necessário usar um léxico ou uma unidade linguística socialmente marcada como grosseira ou pejorativa para marcá-la, ou seja, a descortesia se dá de forma velada. Para Leech (2014), a ironia tende a ser mais complexa, engenhosa, espirituosa e / ou divertida do que um enunciado cortês realizado de forma direta. De acordo com Kerbrat-Orecchioni:

\begin{abstract}
A ironia pode também vir alojar-se nos reguladores tais como "ah", "pois bem", "certo", "muito bem", "ah é ?"e suas diversas combinações (exemplo; "ah certo porque - pois é pois é certo"); ou ainda nas fórmulas de polidez (desculpas ou agradecimento: "eu lhe agradeço por essa estrelinha"...). (KERBRAT-ORECCHIONI, 2014, p. 75)
\end{abstract}

Assim, é possível perceber as várias possibilidades de manifestação da ironia em diferentes contextos de interação. Tal como visto no tópico 3.2 deste trabalho, a identificação de um enunciado irônico será de extrema importância na verificação dos atos atenuadores ou intensificadores da descortesia, em especial nas redes sociais digitais.

\footnotetext{
${ }^{32}$ No original: In order to be ironic, $S$ expresses or implies a meaning (let's call it Meaning I) that associates a favorable value with what pertains to $\mathrm{O}(\mathrm{O}=$ other person(s), mainly the addressee $)$ or associates an unfavorable value with what pertains to $S(S=$ self, speaker). At the same time, by means of Meaning I and the context, $S$ more indirectly implies a second, deeper meaning (Meaning II) that cancels out Meaning I by associating an unfavorable value with what pertains to $\mathrm{O}$, or associating a favorable meaning with what pertains to $\mathrm{S}$. The derivation of Meaning II from Meaning I is by means of two paths of inference: first, Meaning I is in- felicitous (i.e., pragmatically untenable in context, often because of violation of the Cooperative Principle) and therefore to be rejected; and second, given that the meaning is infelicitous and in accordance with the PP, the obvious way to make sense of it is to look for a related interpretation that is felicitous and not in accordance with the PP—which is what the Irony Principle provides. (LEECH, 2014, p. 233)
} 


\section{CAPÍTULO 4: ANÁLISE DO CORPUS}

\subsection{Apresentação do corpus}

A interação e o engajamento dos interactantes nos grupos da rede social digital Facebook acontecem, predominantemente, por meio de um pedido ou de uma pergunta. Essas realizações, muitas vezes, ocorrem de maneira direta ou indireta, e isso gera, também, uma resposta adequada ou inadequada ao gênero de pergunta e/ou solicitação. Ressalta-se, assim, o valor iniciativo deste tipo de ato desencadeador de uma reação por parte dos membros do grupo. É por meio da ação pedido-resposta que a interação na rede social digital toma forma.

De acordo com Kerbrat-Orecchioni (2005), existem enunciados iniciativos, ou seja, aqueles que trazem consequências na continuidade do discurso e os enunciados reativos, ou seja, desencadeados pelo enunciado anterior e pela situação interacional. Nos grupos do Facebook, em especial em nosso corpus, observou-se a predominância dos atos iniciativos como as perguntas e solicitações para dar início à troca comunicacional na rede social digital. É a partir do ato iniciativo que os participantes da rede social digital estabelecem uma relação de distância ou proximidade, e/ou conflito e boa convivência.

O uso das formas de tratamento exerce importância dentro do contexto interacional da rede social digital, pois é por meio delas ou pela ausência delas que a relação entre locutor e interlocutor será evidenciada no tocante à familiaridade entre os participantes do grupo na rede virtual. O uso ou a ausência de atenuadores indicarão a intenção e a preocupação do locutor e interlocutor de ser cortês ou não. De acordo com Benveniste (1989), a pergunta constitui um dos elementos comportamentais de grande importância do ser humano, pois é um ato que faz parte da sociabilidade. Entendemos por pergunta "[...] todo enunciado que se apresentar com a finalidade principal de obter do destinatário um aporte de informação" (KERBRAT-ORECCHIONI, 2005, p. 101). Sendo assim, a pergunta solicita uma informação, mas também comporta outras variáveis na interação na rede social digital, tal como um pedido, de acordo com a análise do corpus. As perguntas e solicitações podem ser realizadas de maneira direta, com o uso de marcadores específicos de natureza lexical, 
morfológica ou sintática na interação mediada pelo computador. Em uma interação face a face, é possível também que uma pergunta se manifeste pela natureza prosódica do enunciado, fato que não é possível de se realizar na rede social digital. Além de ser produzida de maneira direta, a pergunta pode ser expressa de maneira indireta, geralmente acompanhada por modalizadores de dúvida ou incerteza ou asserções. Como a pergunta gerará um ato reativo nem sempre satisfatório e esperado, vamos observar no corpus como se dá esse processo. A solicitação, por si só, já possui um caráter ameaçador da imagem do locutor, uma vez que ele fica vulnerável diante de seu interlocutor, pois a formulação escolhida no processo iniciativo trará consequências na interação.

O corpus desta pesquisa é composto de quinhentos comentários provenientes de um grupo, no Facebook, do curso de Letras da Faculdade de Filosofia, Letras e Ciências Humanas da Universidade de São Paulo. Em 2018, o grupo contava com quinze mil duzentos e dois integrantes e era (e ainda é) um espaço público, ou seja, todos integrantes podem visualizar, comentar e publicar nele. Assim, como todos os grupos no Facebook, ele possui regras para a publicação e interação: "Arma virumque cano... Pede-se civilidade, este é um grupo de estudantes". Percebe-se, já na regra do grupo, a importância da cortesia com o termo utilizado, "civilidade".

De acordo com o Dicionário Houaiss ${ }^{33}$, civilidade tem dois significados: 1) conjunto de formalidades, de palavras e atos que os cidadãos adotam entre si para demonstrar mútuo respeito e consideração; boas maneiras, cortesia, polidez. 2) o fato e a maneira de observar essas formalidades. Todo o grupo criado no Facebook possui administradores, isto é, integrantes responsáveis pela moderação do conteúdo publicado, o que inclui a análise de uma publicação que pode ferir alguma regra do grupo. Caso uma delas seja desrespeitada, o administrador pode bloquear ou mesmo expulsar um integrante que a tenha desobedecido. No grupo escolhido para o corpus, muitos participantes podem ou não se conhecer pessoalmente, visto que se trata de uma comunidade da Universidade de São Paulo. Os alunos têm o hábito de publicar todos os dias, os do período matutino, noturno e, inclusive, os ex-alunos. Eventualmente,

\footnotetext{
${ }^{33}$ Disponível em < https://houaiss.uol.com.br/>. Acesso em 22/01/2019, às 12:00.
} 
professores da unidade de ensino também publicam, já que o grupo é aberto e não há a exigência de que só discentes participem.

As publicações se caracterizam por perguntas, pedidos e, eventualmente, oferecimento de serviços. A seguir, analisaremos os comentários de acordo com os pressupostos teóricos já mencionados.

\subsection{Análise do corpus}

\section{INQUÉRITO 1}

No curso de Letras da USP, há um espaço denominado 'Pró-Aluno', onde os alunos podem ter acesso a computadores para fazer e imprimir trabalhos. Como já mencionado neste trabalho, o grupo de Letras reúne alunos e exalunos, e muitas publicações no grupo do Facebook dizem respeito às suas rotinas na faculdade. Eles podem ou não se conhecer pessoalmente, além das publicações levantarem alguns problemas que acontecem no prédio. Neste Inquérito 1, $\mathbf{Z}$ faz uma publicação no grupo de Letras da Faculdade de Filosofia, Letras e Ciências Humanas da Universidade de São Paulo. Ele faz uma pergunta que se configura como uma crítica ao barulho dos alunos na sala Pró-Aluno.

Figura 122: Exemplo de descortesia no grupo de Letras/USP no Inquérito 1
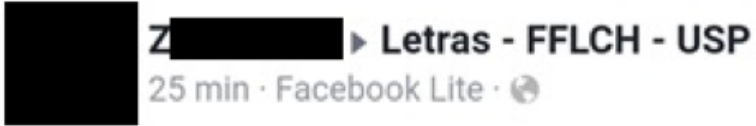

Cacete, mano, qual é o problema dessa galera que bate papo na pró aluno como se tivesse na porra do Starbucks? Vai lá fora, toma um café, faz qualquer merda mas cala boca, cacete! As pessoas vem nessa porra pra estudar e trabalhar. Puta molecada tosca, dá vontade de chamar a supernanny pra dar com a régua na boca.

Curtir Comentar Compartilhar

\section{(1) $=48$}

Fonte: Facebook (2017) 
Z faz a crítica em forma de pergunta a todos os participantes do grupo, além de fazer um pedido sob a forma de uma ordem: "Vai lá fora, toma um café, faz qualquer merda mas cala boca, cacete!". Por meio de sua intervenção, $\mathbf{Z}$ quer mobilizar os outros alunos a fazerem o que ele pede, mas a maneira como ele solicita se dá de uma maneira autoritária. Trata-se de uma forma de intimação e, portanto, a publicação de $\mathbf{Z}$ é potencialmente ameaçadora para os participantes do grupo.

Em seguida, ele justifica o motivo de sua reclamação e de seu pedido: "As pessoas vem nessa porra pra estudar e trabalhar". Para finalizar o seu enunciado, ele ainda acrescenta críticas ao comportamento dos alunos, sob a forma de insulto, reforçando ainda mais o seu nervosismo com a vontade de partir para a agressão física: "Puta molecada tosca, dá vontade de chamar a supernanny pra dar com a régua na boca." A escolha lexical de $\mathbf{Z}$ reforça ainda mais a ameaça à imagem dos alunos barulhentos, frequentadores do curso de Letras da USP. Apesar disso, a publicação de $\mathbf{Z}$ tem 48 reações, entre curtidas, risos e surpresa por parte de alguns alunos. $\mathbf{Z}$ faz uso de uma enunciação iniciativa e, espera, assim, respostas e engajamento por parte dos participantes do grupo que viram a publicação no Facebook. Apesar de $\mathbf{Z}$ abordar o assunto com o uso de um léxico cuja carga de sentido é negativa (e que se dá através de palavras de baixo calão, tais como "cacete", "merda" , "porra", "molecada tosca"), ele tem o cuidado de usar termos mais vagos para se referir aos alunos específicos que fazem parte da "galera que bate papo na pró-aluno", para se prevenir de possíveis ataques daqueles que não fazem parte do grupo mencionado por $\mathbf{Z}$. Os termos empregados por $\mathbf{Z}$ passam de "galera que bate papo" para "molecada tosca", enfatizando o seu descontentamento com a situação e insultando os alunos barulhentos. Percebe-se que $\mathbf{Z}$ usa muito o recurso dos atos indiretos, visto que ele reclama e insulta pessoas da faculdade, ao mesmo tempo que não generaliza a todos os alunos. Seu ato ilocutório já fica expresso antes mesmo de fazer a pergunta, pois $\mathbf{Z}$ já usa uma expressão de raiva, "cacete" e o vocativo "mano" para se dirigir a todos do grupo. Com esses elementos, nota-se a indignação de $\mathbf{Z}$ com o problema e o emprego da descortesia para com os alunos barulhentos que frequentam a Pró-Aluno.

A primeira receptora da mensagem, G, usa um meme para brincar com o nervosismo de $\mathbf{Z}$ e, assim, tentar atenuar a situação em que há a ameaça à 
imagem de Z. No meme, existe a frase "Parece que usted está pistolito", com a figura de uma pistola com um chapéu e bigode. "Pistola" é uma gíria usada na internet para pessoas nervosas ou com raiva. A partir da reação de $\mathbf{G}, \mathbf{Z}$ e $\mathbf{G}$ conversam entre eles. Na rede social digital, é possível comentar diretamente com uma pessoa específica, e é isso que $\mathbf{G}$ faz com $\mathbf{Z}$, reforça a sua vontade de partir para a agressão física nos "adolescentes cacarejantes", pois $\mathbf{G}$ concorda com Z. Entre os dois, o diálogo transcorre normalmente, sem uso de descortesia em relação a $\mathbf{G}$, pois $\mathbf{G}$ está de acordo com a reclamação de $\mathbf{Z}$. Apesar de não ocorrer um ato descortês em relação a $\mathbf{G}, \mathbf{Z}$ ainda usa um léxico ameaçador em relação aos alunos barulhentos, a quem ele chama de "adolescentes cacarejantes".

Figura 123: Exemplo de descortesia no grupo de Letras/USP no Inquérito 1

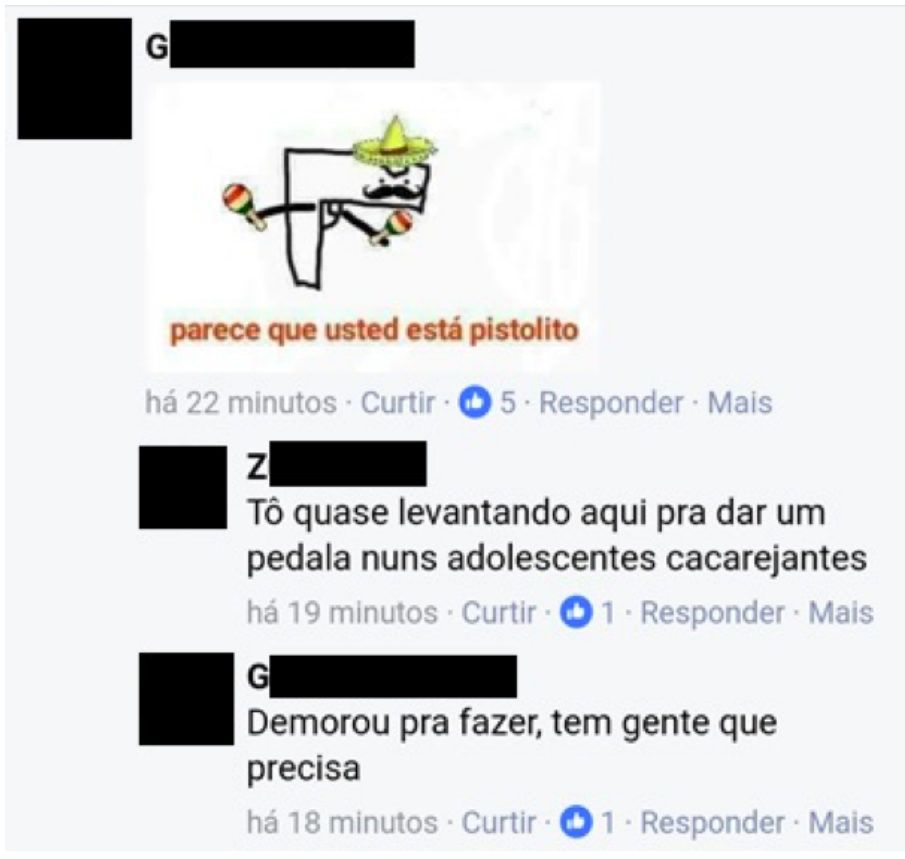

Fonte: Facebook (2017)

Logo em seguida, outros alunos reagem. $\mathbf{M}$, por meio de uma pergunta retórica, ironiza o fato de ter adolescentes no curso de Letras: "Molecada na letras? Nunca vi". A ironia de $\mathbf{M}$ é entendida por alguns alunos, visto que seu comentário tem curtidas e risos. Mi, outra participante da rede social, também concorda com a reclamação de $\mathbf{Z}$ e igualmente usa termos vagos para se referir aos alunos, com o uso de "galera" e "eles". No comentário de Mi, fica clara a distinção entre dois tipos de alunos no curso de Letras: "galera [os barulhentos] não tem a menor noção de que muita gente [os alunos necessitados] usa a pró- 
aluno para fazer aquele trabalho que eles [os alunos barulhentos] puderam fazer em casa no Mac deles [os alunos barulhentos]". Mi faz um processo de distanciamento entre os dois tipos de alunos, aqueles que necessitam de recursos da faculdade, "muita gente" e aqueles com boas condições de se manter na faculdade, "eles", "no Mac deles".

Figura 124: Exemplo de descortesia no grupo de Letras/USP no Inquérito 1

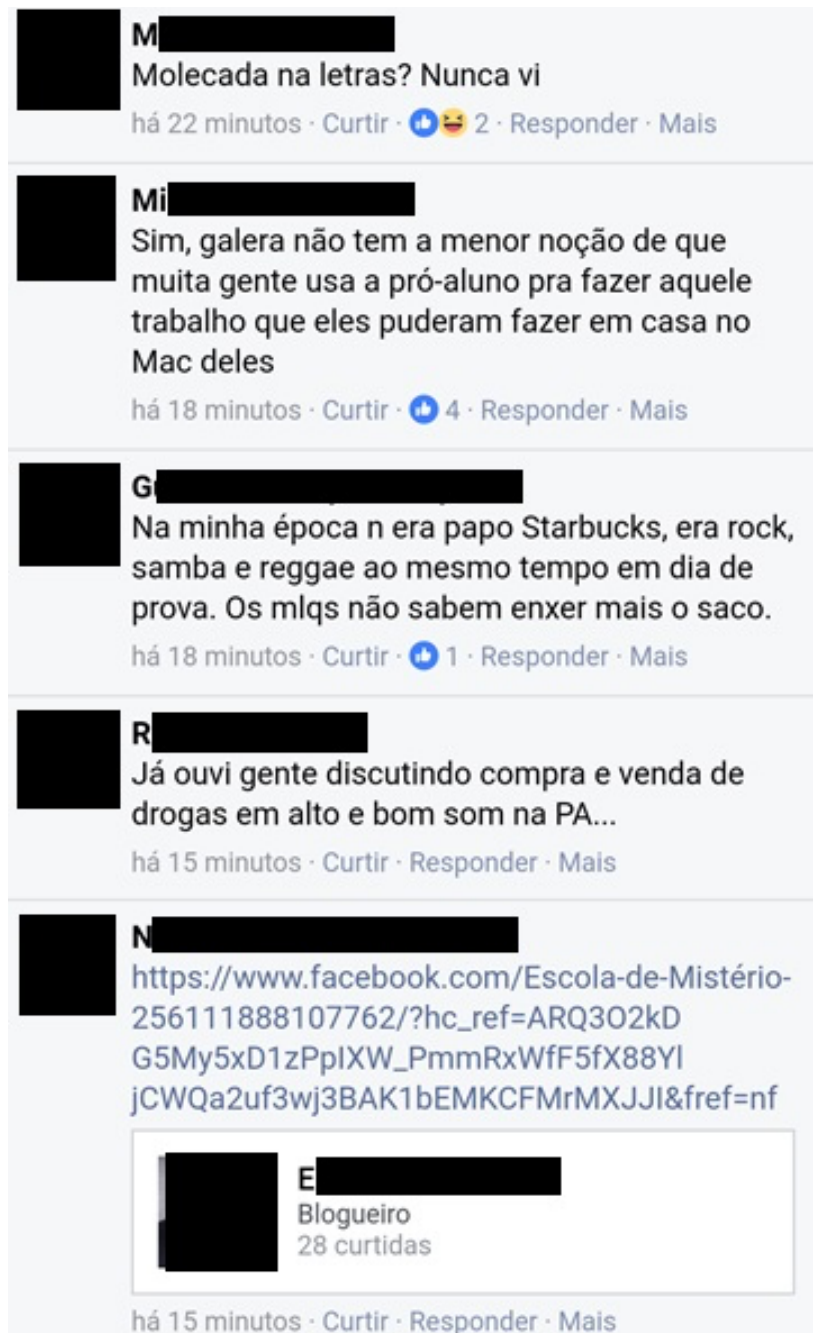

Fonte: Facebook (2017)

Mi usa a mesma estratégia de $\mathbf{Z}$, pois faz uma alusão indireta aos destinatários do grupo para se dirigir aos interlocutores específicos, ou seja, aqueles alunos que fazem barulho. Assim, tanto $\mathbf{Z}$ quanto $\mathbf{M i}$ incluem esses alunos, alvo de críticas, no conjunto daqueles frequentadores do curso. $\mathbf{G}$ e $\mathbf{R}$ também comentam na publicação de $\mathbf{Z}$, ambos relatam as experiências pessoais na faculdade com o barulho. G usa também o termo "moleques" abreviado na rede social como "mlqs". Observa-se, até então, o uso de um vocabulário 
ameaçador para se referir aos estudantes que causam o problema que, por sua vez, ainda não se manifestaram na publicação de $\mathbf{Z}$. $\mathbf{R}$, por sua vez, denuncia a compra e venda de drogas por parte de alguns alunos no ambiente da Pró-Aluno. $\mathbf{R}$ também tem o cuidado de se referir aos alunos com um termo vago, "já ouvi gente". Além das reações de concordância $\operatorname{com} \mathbf{Z}, \mathbf{N}$ aparece na publicação e desvia o assunto dos comentários. $\mathbf{N}$ publica o endereço do seu blog para que os participantes do grupo na rede social digital possam curtir. $\mathbf{N}$ não contribui com a discussão, apenas defende o seu interesse e tenta desviar o assunto em questão. Assim, enquanto os outros participantes cooperam positivamente com $\mathbf{Z}$, o participante $\mathbf{N}$, por sua vez, coopera negativamente, pois não acrescenta seu comentário a fim de sugerir uma solução ou para concordar com $\mathbf{Z}$, apenas defende seu interesse pessoal de conseguir seguidores para o blog. A publicação de $\mathbf{N}$ não gera reações por parte dos participantes e a interação dos alunos em relação à postagem de $\mathbf{Z}$ continua. $\mathbf{L}$ pede calma para $\mathbf{Z}$, fato reforçado e intensificado por meio de uso de maiúsculas "CALMA MEU".

Figura 125: Exemplo de descortesia no grupo de Letras/USP no Inquérito 1

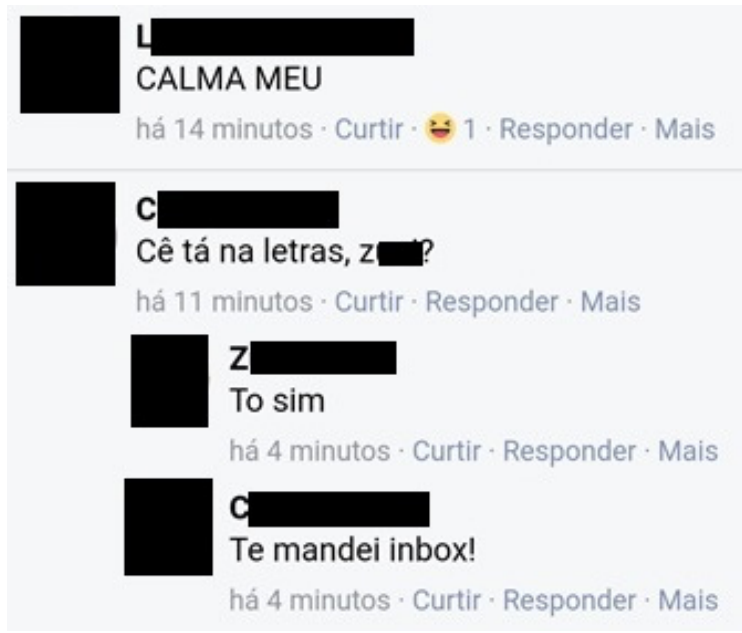

Fonte: Facebook (2017)

$\mathbf{C}$ pergunta se $\mathbf{Z}$ está na Letras e, pela resposta positiva de $\mathbf{Z}$, $\mathbf{C}$ manda uma mensagem privada para $\mathbf{Z}$. Nota-se, por meio disso, que $\mathbf{C}$ e $\mathbf{Z}$ se conhecem pessoalmente, mas $\mathbf{C}$ prefere escrever de forma privada a $\mathbf{Z}$. Não é possível saber, por isso, se $\mathbf{C}$ concorda ou discorda de $\mathbf{Z}$, pois preferiu enviar uma mensagem privada e, assim, $\mathbf{C}$ também se previne de ataques na rede social digital, sem deixar seu comentário público para outros participantes. E, outra participante do grupo, aparece e também reforça a reclamação de $\mathbf{Z}$. 
Figura 126: Exemplo de descortesia no grupo de Letras/USP no Inquérito 1

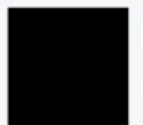

E

o pior são os fudido que vão na pro aluno pra ver CLIPE DE MÚSICA, enquanto tem fila de gente pra fazer/imprimir coisas importantes há 10 minutos · Curtir · 8 8 Responder - Mais
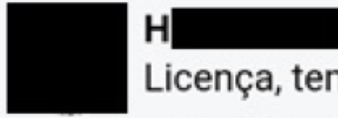

Licença, tem impressão?

há 9 minutos - Curtir - Responder - Mais

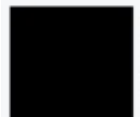

mete a faca

Fonte: Facebook (2017)

E usa termos também de baixo calão para se referir aos alunos que atrapalham as atividades na sala Pró-Aluno: "o pior são os fudido que vão na pro aluno ver CLIPE DE MÚSICA". E reforça sua crítica com o uso de maiúsculas, visto que ver clipe de música não é uma atividade para ser feita no ambiente em questão. E, assim como $\mathbf{M i}$, também reforça a diferença entre os alunos frequentadores do espaço "o pior são os fudido [os alunos que atrapalham] que vão na pro aluno pra ver CLIPE DE MÚSICA, enquanto tem fila de gente [alunos que necessitam do espaço] pra fazer/imprimir coisas importantes". O comentário de $\mathrm{E}$ recebe 8 curtidas, ou seja, muitos alunos concordam com o ponto de vista de E. H, por sua vez, comenta logo em seguida, mas, também, desvia o tópico de $\mathbf{Z}$. Como $\mathbf{Z}$ se encontra na Pró-Aluno, $\mathbf{H}$ faz a pergunta se há impressão "Licença, tem impressão?". Consciente de seu desvio do tópico abordado por $\mathbf{Z}$, H faz uso de um moderador "licença" antes de efetuar a pergunta, porém sem sucesso, pois não obtém a resposta esperada por parte de $\mathbf{Z}$ e dos alunos que estão discutindo na interação. Assim, tanto $\mathbf{H}$ quanto $\mathbf{N}$ não são bem sucedidos em seus comentários, pois desviam o tópico abordado por $\mathbf{Z}$ e são ignorados pelos demais participantes que interagem com $\mathbf{Z}$. Embora $\mathbf{H}$ e $\mathbf{N}$ respondam à publicação de $\mathbf{Z}, \mathbf{H}$ e $\mathbf{N}$ cooperam negativamente com a continuidade da interação, pois fazem um desvio do tópico principal para outros assuntos.

Logo em seguida, E, que já havia participado antes com um comentário, sugere partir para a violência física "mete a faca". $\mathbf{S}$ também reforça os 
comentários já realizados por outros participantes e enfatiza o uso do termo "adolescente" para se referir aos alunos que não se comportam bem na PróAluno.

Figura 127: Exemplo de descortesia no grupo de Letras/USP no Inquérito 1

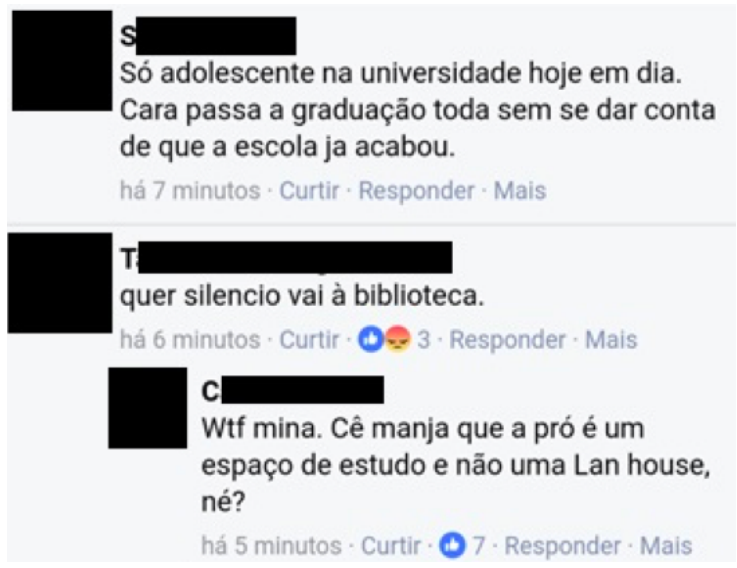

Fonte: Facebook (2017)

Depois de vários comentários concordando $\operatorname{com} \mathbf{Z}$, aparece um comentário de $\mathbf{T}$, que discorda da situação e sugere que $\mathbf{Z}$ e os outros alunos incomodados com o barulho se dirijam à biblioteca em busca de silêncio: "quer silencio vai à biblioteca".

Figura 128: Exemplo de descortesia no grupo de Letras/USP no Inquérito 1

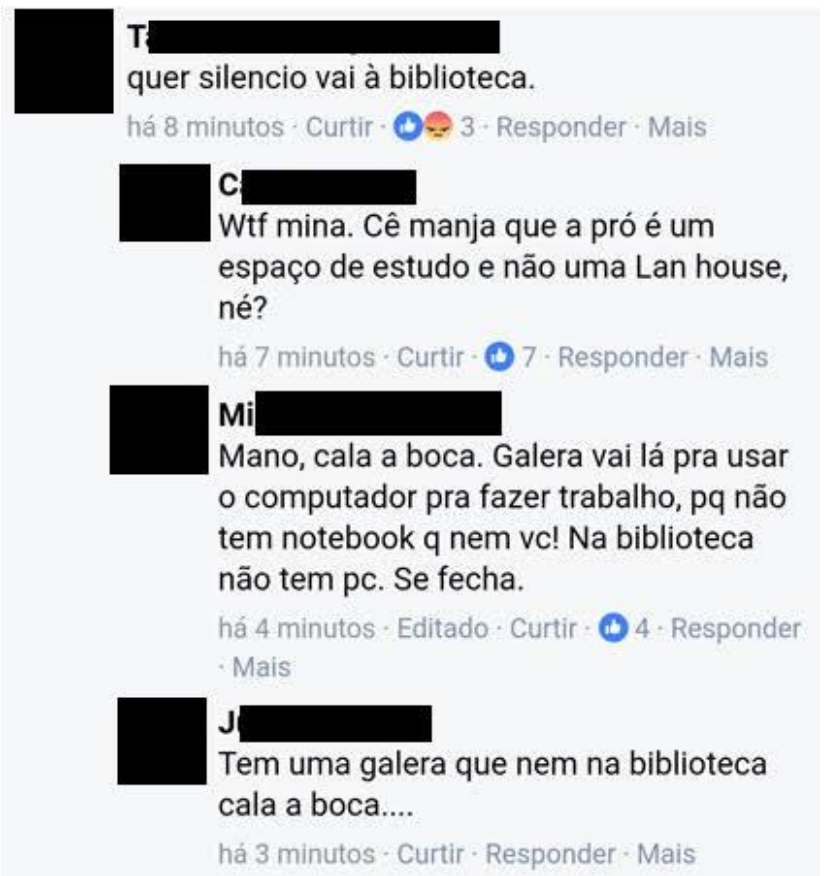

Fonte: Facebook (2017) 
Até então, todos os comentários dos participantes estavam de acordo com $\mathbf{Z}$ e reforçavam a reclamação e crítica ao comportamento dos alunos barulhentos. É a partir do comentário reativo de $\mathbf{T}$ que a descortesia é desencadeada por parte dos alunos que já comentaram na publicação. $O$ comentário de $\mathbf{T}$ possui curtidas e reações de raiva. $\mathbf{C}$, ao responder, dirige-se diretamente a T por meio de um palavrão em inglês e um vocativo "Wtf mina" e pergunta se $\mathbf{T}$ sabe que aquele espaço é um lugar de estudo: "Wtf mina. Cê manja que a pró é um espaço de estudo e não uma Lan house, né?". A pergunta de $\mathbf{C}$ também se configura como uma crítica indireta a $\mathbf{T}$. É possível notar que se trata de uma crítica devido à reação de $\mathbf{C}$ com o uso de um palavrão para o comentário de $\mathbf{T}$. A resposta de $\mathbf{C}$ para $\mathbf{T}$ recebe 7 curtidas e, logo em seguida, Mi, também responde a $\mathbf{T}$. Mi usa também uma ordem sob a forma de insulto "Mano, cala a boca" e "se fecha". Novamente, Mi compara os alunos que necessitam do espaço "Galera vai lá pra usar o computador pra fazer trabalho" e coloca T entre os que não precisam do espaço "pq não tem notebook q nem vc". O comentário de Mi rende 4 curtidas. Por meio das curtidas nos comentários de Mi e C, observa-se que muitos estudantes estão de acordo com a opinião de ambas, porém, não participam comentando na interação. As curtidas ou reações na rede social digital também é uma estratégia para preservar a imagem dos interactantes, visto que é possível participar da discussão sem fazer um comentário verbal público.

$\mathbf{J}$, por sua vez, não concorda com a sugestão de $\mathbf{T}$, pois para $\mathbf{J}$, a biblioteca também tem problemas com barulho: "Tem uma galera que nem na biblioteca cala a boca...". J também usa um termo vago para se dirigir com crítica àqueles que fazem barulho no espaço por meio da expressão "uma galera".

Z, o responsável pela publicação que gerou todos os comentários, retoma o turno para responder diretamente a T. Ele não concorda com a colocação de $\mathbf{T}$, retomando o comentário de $\mathbf{T}$, invocando-a diretamente em seu comentário: "Vai na biblioteca coisa nenhuma, moça" e $\mathbf{Z}$ se justifica: "Pró-aluno não é Lan house. Tem um milhão de espaços de interação social na universidade. Se não conseguem aprender minimamente a respeitar espaços coletivos, que dirá então aprender as merdas que a universidade ensina pra fazer essa galera mimada se achar a elite intelectual de bambuluá. Vamos ter noção e educação, faz favor". 
A publicação de $\mathbf{Z}$ tem 56 curtidas, entre elas a reação "Amei". Novamente, é comum o uso de recursos de impessoalização como " Se não conseguem aprender minimamente a respeitar espaços coletivos" e do léxico que gera ironia sob a forma de insulto para se referir aos alunos barulhentos, "essa galera mimada" e "elite intelectual de bambuluá". $\mathbf{Z}$ usa de uma ironia em "elite intelectual de bambuluá", pois ele se refere a uma telenovela infantil produzida pela rede Globo, com a apresentadora Angélica. É necessário que outros participantes do grupo compartilhem dessa informação para entender a crítica de $\mathbf{Z}$ em relação aos alunos que fazem barulho. Tal como os comentários anteriores dos outros participantes, $\mathbf{Z}$ infantiliza os estudantes causadores de problema no espaço. $\mathbf{H}$, que antes havia desviado do tópico principal com o seu comentário, retoma o turno e, por sua vez, faz uma crítica a T, ou seja, H coopera positivamente com a discussão desta vez, pois interage de forma a complementar os comentários do tópico abordado: "Deve ser das que fazem baderna também." 
Figura 129: Exemplo de descortesia no grupo de Letras/USP no Inquérito 1

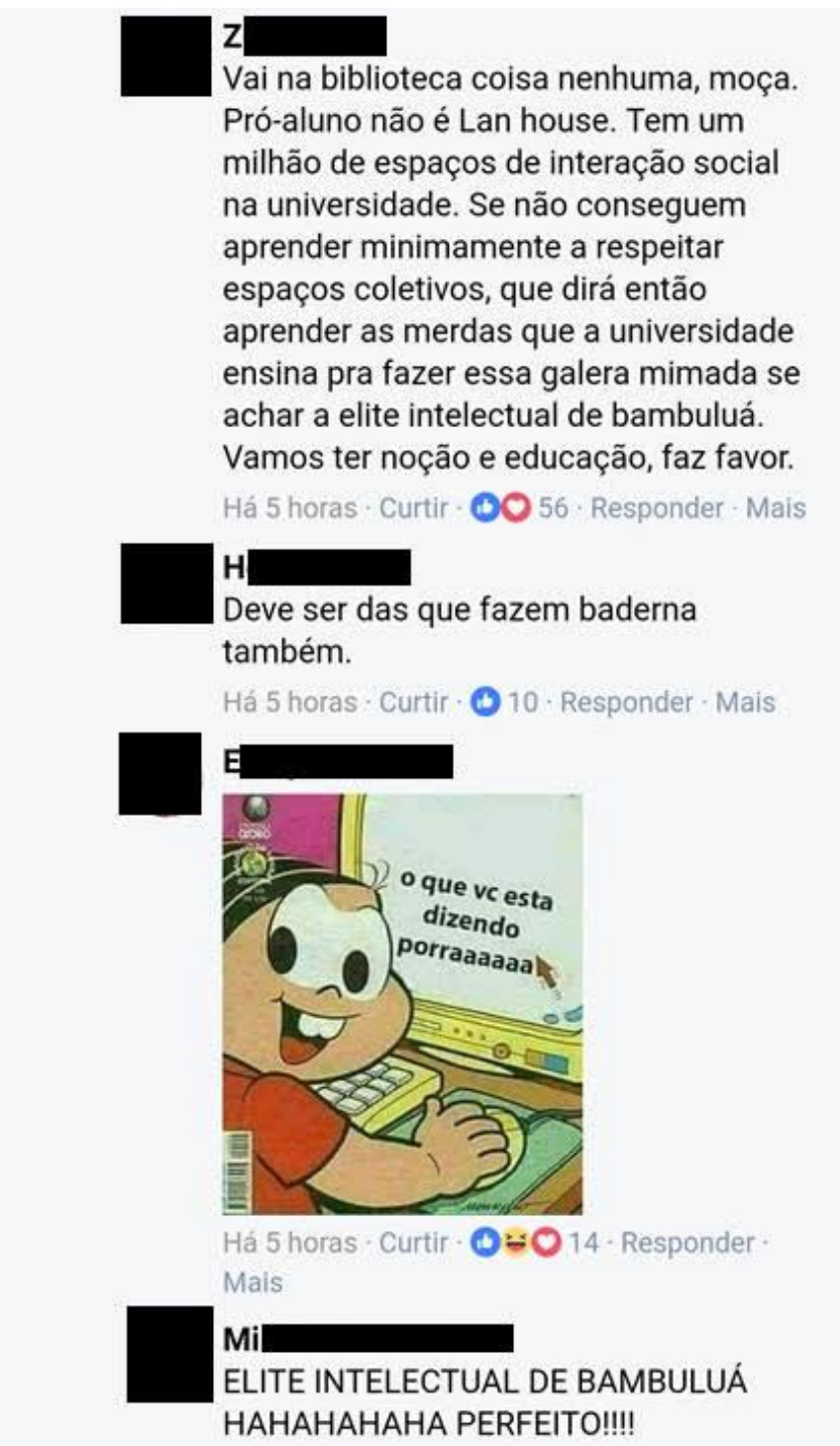

Fonte: Facebook (2017)

Assim, por meio do comentário de $\mathbf{T}, \mathbf{H}$ faz uma insinuação que $\mathbf{T}$ seria um dos alunos que fazem parte do grupo barulhento da faculdade. O comentário com a insinuação de $\mathbf{H}$ possui 10 curtidas e não recebe resposta de $\mathbf{T}$. Apesar de ter feito uma insinuação, $\mathbf{H}$ faz uso dos verbos "deve ser", ou seja, é uma estratégia para manter uma distância em relação ao que foi dito, de forma a se prevenir de sua responsabilidade enunciativa. Logo em seguida, E retoma o turno com um meme da turma da Mônica, meme muito comum nas redes sociais. Por meio da imagem, percebe-se a indignação de E para com T: "o que vc esta dizendo porraaaaa", com o uso de uma palavra de baixo calão intensificada com o alongamento da vogal 'a' ("porraaaaa"). O uso do meme também atenua o comentário de $\mathbf{E}$ para $\mathbf{T}$, pois $\mathbf{E}$ utiliza uma forma bem humorada para se 
distanciar também de um conflito direto com $\mathbf{T}$. A reação de $\mathbf{E}$ gera 14 curtidas, entre risos e reações de "Amei". Mi também retoma o turno e reage ao comentário de $\mathbf{Z}$, usando as próprias palavras de $\mathbf{Z}$, porém com o uso de maiúsculas, seguido de sua reação com risos e comentário pessoal: "ELITE INTELECTUAL DE BAMBULUÁ HAHAHAHAHA PERFEITO!!!!".

A aparece pela primeira vez na interação e também reage ao comentário de T por meio de um meme com cara de espanto: "Não cara, que loucura! Como vc é burro!".

Figura 130: Exemplo de descortesia no grupo de Letras/USP no Inquérito 1
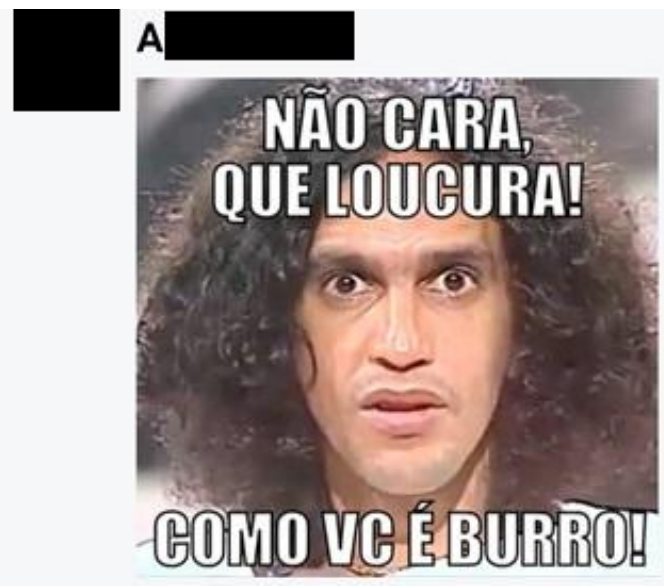

Fonte: Facebook (2017)

A faz uma ofensa direta à $\mathbf{T}$, uma descortesia ad hominem, porém tenta atenuar a ameaça usando o recurso humorístico do meme. Ed também aparece, pela primeira vez na interação, para reagir ao comentário de T. Também por meio de um meme, mostra sua reação diante do comentário de T: "Tá tranquilo, respira", pois no meme, demonstra falta de paciência em relação ao comentário de T. Ed, novamente, publica um meme em que é possível ver, na figura vários emoticons representando expressões bravas e um emoticon maior com uma cara brava, que vai ser jogado por um personagem de um desenho. A reação de Ed gera risos, curtidas e amei. 
Figura 131: Exemplo de descortesia no grupo de Letras/USP no Inquérito 1

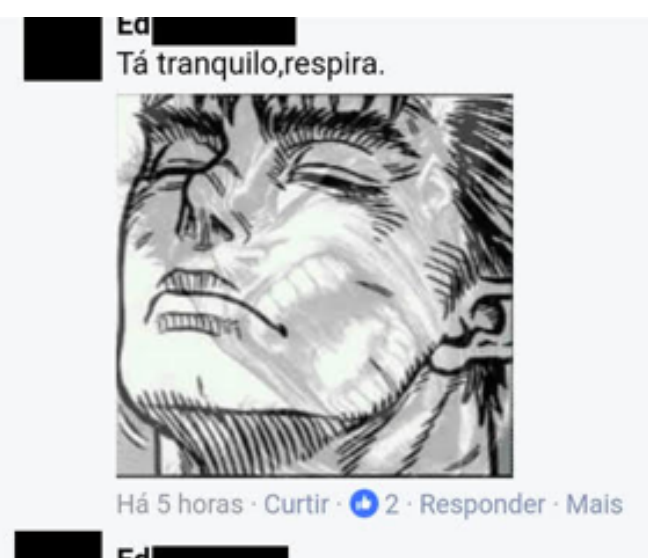

Respira uma @! Galerinha, levantem as mãos.

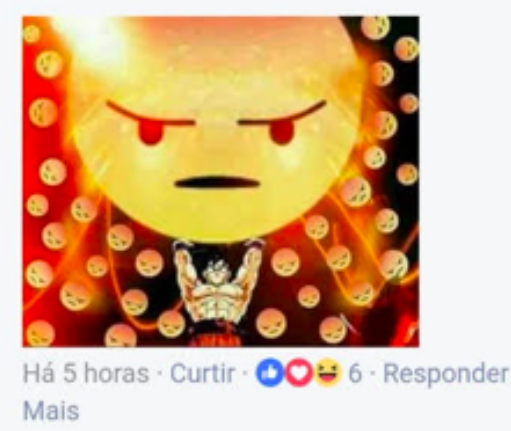

Fonte: Facebook (2017)

Mi retoma o turno para se dirigir a T. Relatando a sua experiência pessoal, Mi tenta justificar a sua crítica para $\mathbf{T}$, ao mesmo tempo que reforça o seu argumento, demonstrando que sabe do que ela, Mi, está falando. Th, aparentemente amigo de T, marca-a no Facebook para rir das reações causadas por $\mathbf{T}$, deixando $\mathbf{T}$ em situação vulnerável. $\mathbf{D}$ também responde à $\mathbf{T}$, usando um vocabulário típico de crianças, "recreio", para a pausa entre as aulas: "Quer papear vai pro recreio", e Mi retoma as palavras de D, porém reformula o comentário, referindo-se à novela adolescente Malhação, da rede Globo, que tinha como um dos lugares de cena, a lanchonete Giga Byte: "Quer papear vai pro GIGA BYTE". 
Figura 132: Exemplo de descortesia no grupo de Letras/USP no Inquérito 1

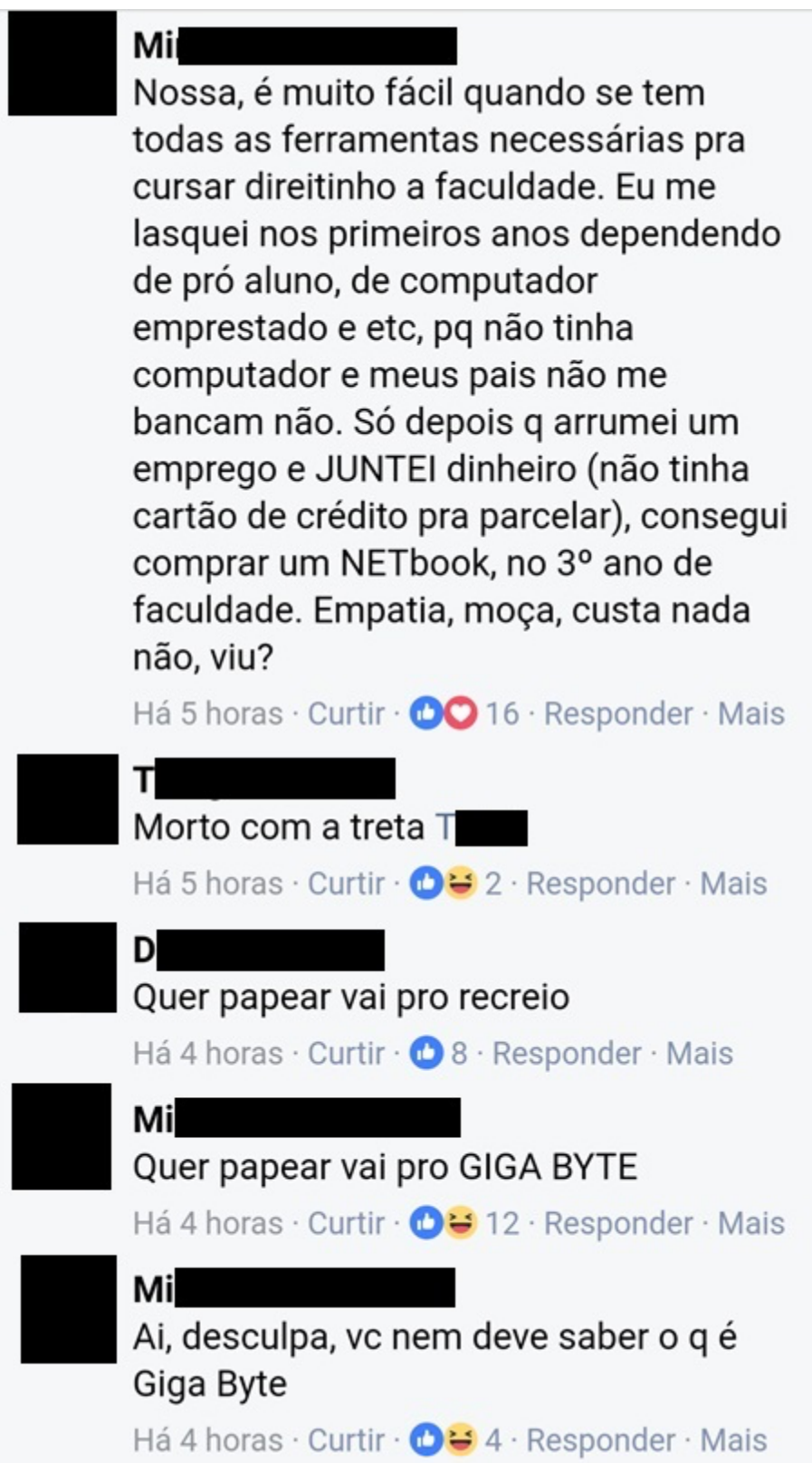

Fonte: Facebook (2017)

Logo em seguida, Mi retoma o seu turno para ironizar o seu próprio comentário: "Ai, desculpa, vc nem deve saber o q é Giga Byte". Mi insinua, por meio de sua ironia, que $\mathbf{T}$ seria uma criança, pois nem saberia o que era Giga Byte. Mi intensifica a sua ironia com um pedido de desculpa, ato que, fora desse contexto de conflito, seria um ato reparador de um FTA para equilibrar o ritual interativo. Usando de modo irônico, o pedido de desculpas intensifica o ato descortês. 
Depois de várias críticas, $\mathbf{T}$ finalmente reaparece e responde aos comentários dos demais participantes, reformulando a sua intervenção.

Figura 133: Exemplo de descortesia no grupo de Letras/USP no Inquérito 1

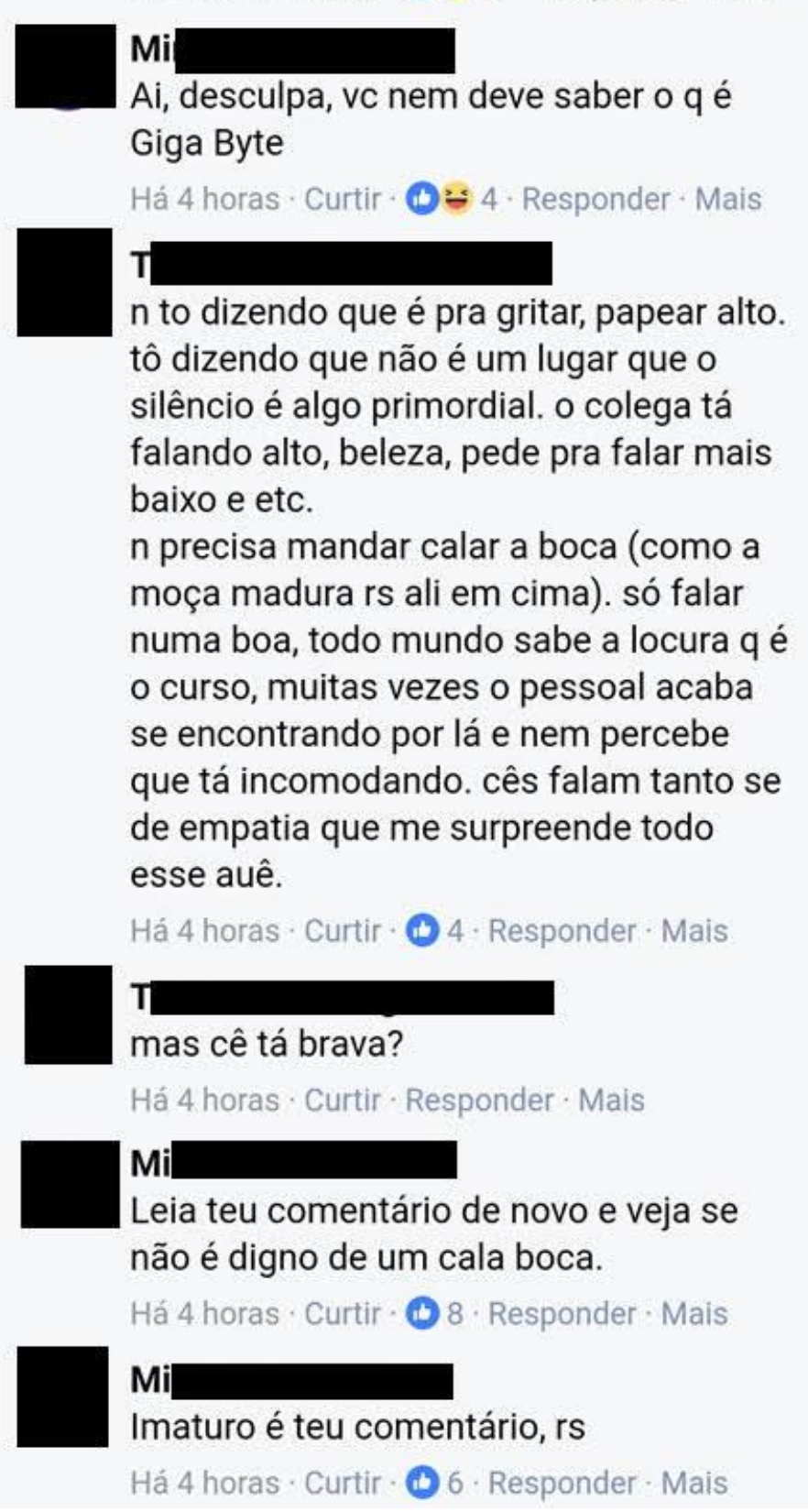

Fonte: Facebook (2017)

T se dirige a Mi de maneira indireta e irônica, entre parênteses, "n [não] precisa mandar calar a boca (como a moça madura rs [risos] ali em cima)", e também se dirige aos demais de forma geral: "cês falam tanto se de empatia que me surpreende todo esse auê". Depois, T faz outra intervenção, ironizando a 
reação de Mi "mas cê tá brava?". A expressão "mas cê tá brava?" é recorrente no mundo virtual, principalmente para ironizar o outro interlocutor que se mostra nervoso com um comentário feito. Mi retoma a discussão com $\mathbf{T}$ e pede que $\mathbf{T}$ reveja o comentário e entenda a reação de $\mathbf{M i}$. Mi ainda critica, diretamente, o comentário de $\mathbf{T}$, pois entende que a indireta de "moça madura" foi direcionada a ela e intensifica a descortesia com risos no final: "Imaturo é teu comentário, rs".

Mi ainda responde à ironia salientando que ficou brava e reforça a crítica a T, chamando-a de infantil e criança de modo direto, sem atenuadores.

Figura 134: Exemplo de descortesia no grupo de Letras/USP no Inquérito 1

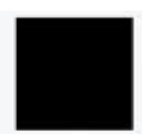

Mi

Sim, fiquei bastante brava. E esse "mas

cê tá brava?" é tão infantil que nossa... to

de boa de discutir com criança q nem vc.

Há 4 horas - Editado · Curtir - 3. Responder

Mais

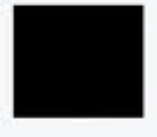

T:(-))))

Há 4 horas · Curtir · Responder · Mais

Fonte: Facebook (2017)

T não responde com palavras, apenas com imagens, por meio de um emoticon sorrindo. No comentário T digita :))))), mas a rede social transforma :) em $:())))$ ) automaticamente. A reação de $\mathbf{T}$, com muitos sorrisos, é totalmente irônica em relação à $\mathbf{M i}$. D retoma o turno para sugerir um espaço socializador dentro do prédio e Ma, por sua vez, retoma as palavras de T para criticá-la: "Nem percebe que tá incomodando...empatia". 
Figura 135: Exemplo de descortesia no grupo de Letras/USP no Inquérito 1

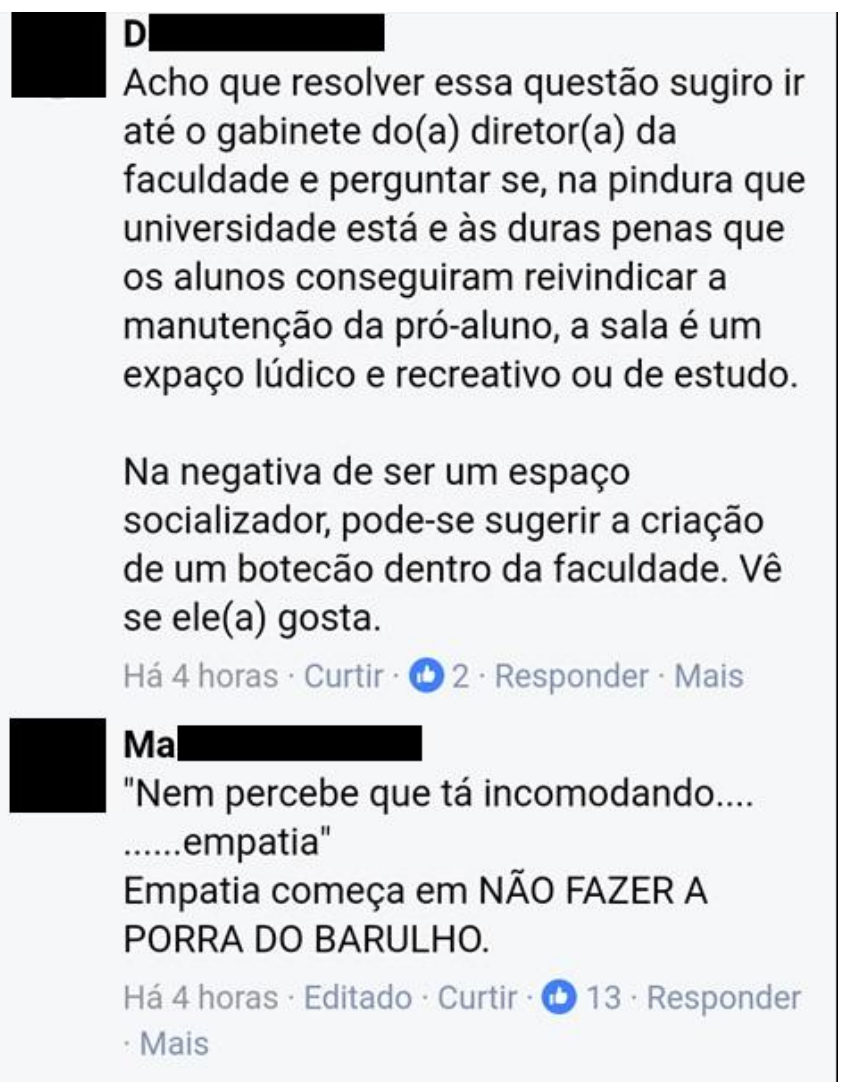

Fonte: Facebook (2017)

Ma retoma as palavras de $\mathbf{T}$ para criticar, inclusive com 0 uso de maiúsculas, que a "empatia" seria "NÃO FAZER A PORRA DO BARULHO". Desta maneira, a retomada do enunciado de $\mathbf{T}$ por Ma atenua a sua responsabilidade enunciativa, mas não deixa de ameaçar a imagem de $\mathbf{T}$, visto que não é Ma que está dizendo, mas sim T. Ao mesmo tempo que Ma atenua o seu comentário na rede social digital em relação aos demais participantes, Ma deixa $\mathbf{T}$ em situação vulnerável ao usar as palavras de $\mathbf{T}$ para desqualificá-la. $\mathbf{Z}$ também retoma o termo "empatia" usado por $\mathbf{T}$ e explica que "existem certos códigos sociais, protocolos básicos de convivência, que se pressupõe que pessoas adultas são capazes de interpretar e incorporar por conta própria". Novamente, T é colocada no patamar "infantil, adolescente" de maneira indireta, pois $\mathbf{Z}$ reforça que "pessoas adultas são capazes de interpretar e incorporar por conta própria", fato que $\mathbf{T}$ não o fez. $O$ comentário de $\mathbf{Z}$ tem, novamente, muitas reações, entre curtidas e amei dos participantes do grupo, 19 no total. 
Figura 136: Exemplo de descortesia no grupo de Letras/USP no Inquérito 1

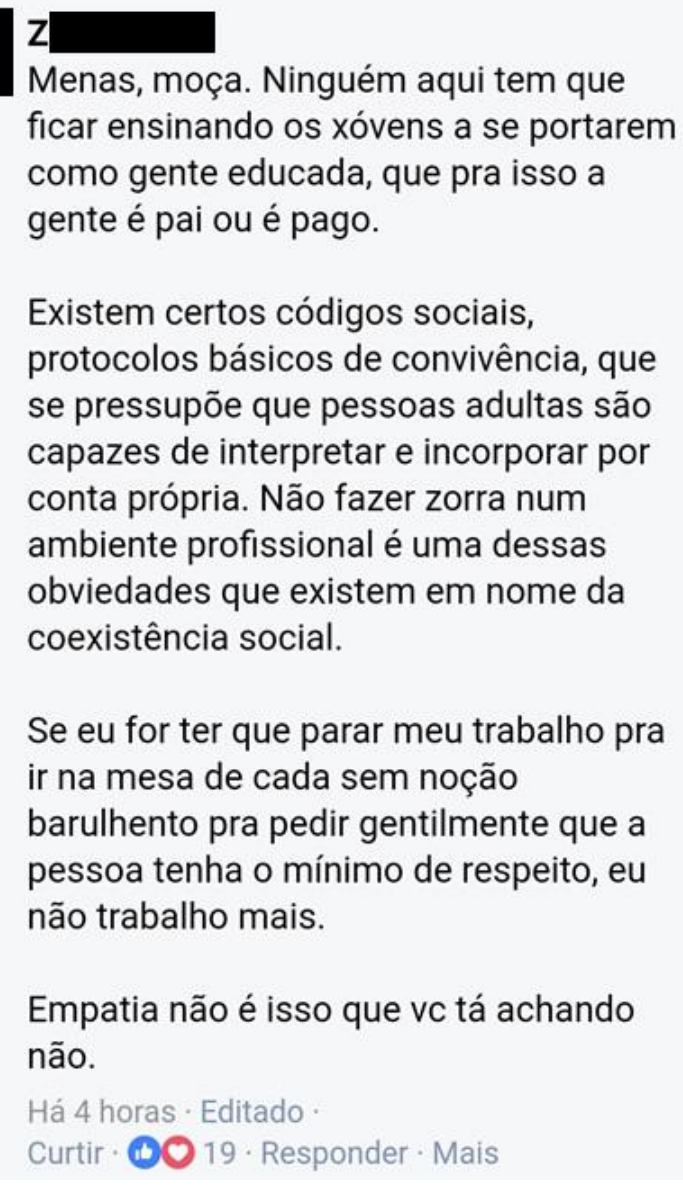

Fonte: Facebook (2017)

Mi retoma o turno para justificar que a sugestão de avisar as pessoas que estão incomodando na Pró-Aluno não funciona e, novamente, Mi argumenta seu ponto de vista, usando uma experiência pessoal para justificar a crítica: "Pior q já rolou de eu pedir pra maneirarem na conversa, abaixar o tom de voz, e a pivetada ainda tirar da minha cara. É muita falta de respeito, de noção, de empatia e de maturidade". 
Figura 137: Exemplo de descortesia no grupo de Letras/USP no Inquérito 1

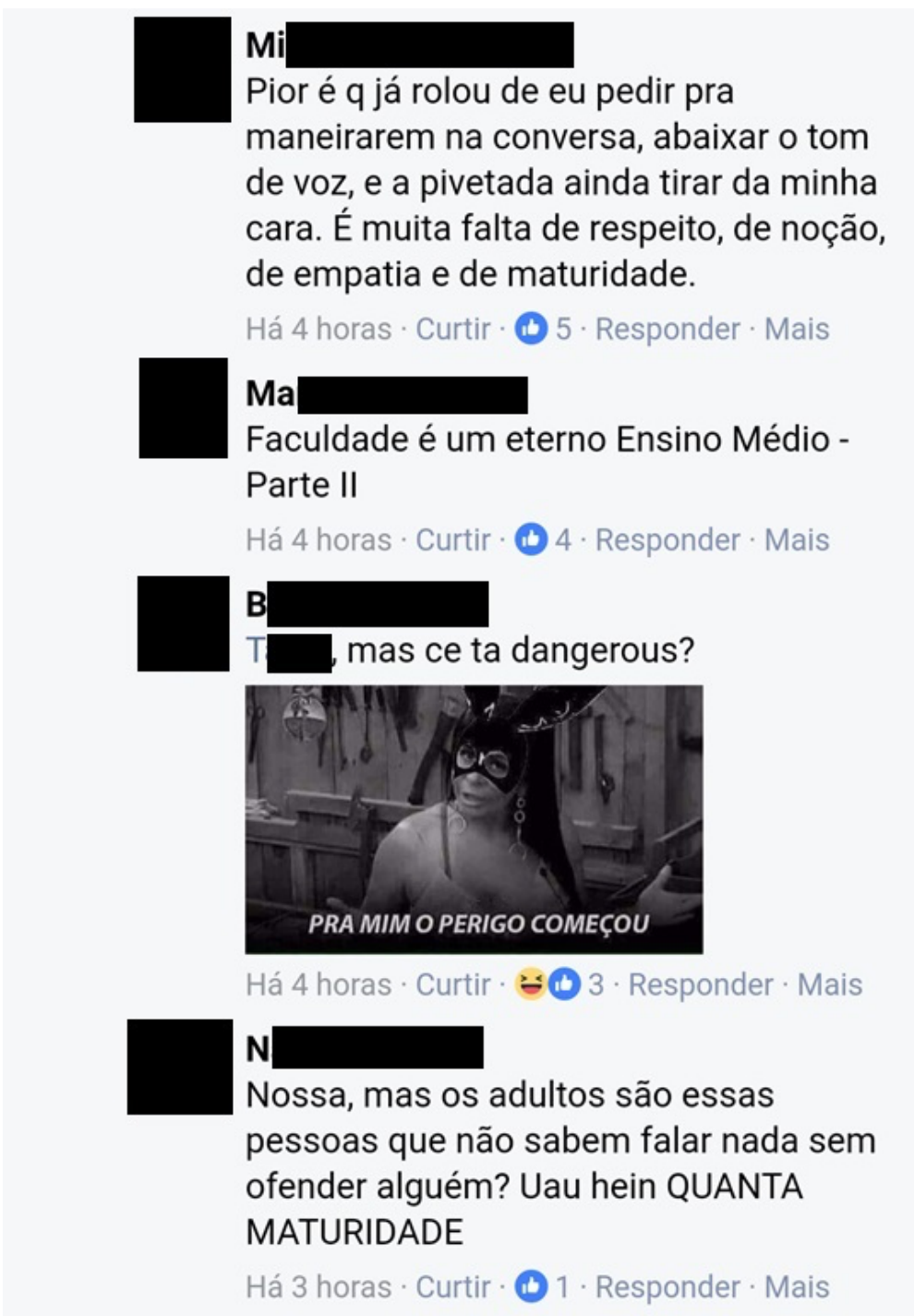

Fonte: Facebook (2017)

Novamente, Mi faz uso de um léxico referente a "crianças" de uma maneira pejorativa. Ma também retoma o turno e reforça a ideia da presença de adolescentes imaturos na faculdade: "Faculdade é um eterno Ensino Médio Parte II". B aparece entre os comentários e, pelo fato de marcar T na rede social digital, indica que $\mathbf{T}$ faz parte de seu grupo de amigos. B brinca com a situação por meio de um meme e sugere que $\mathbf{T}$ está perigosa, ao provocar os demais colegas no grupo. $\mathbf{N}$, por sua vez, aparece pela primeira vez na interação para refutar a ideia de que os adultos da faculdade são maduros e critica as ofensas de todos contra $\mathbf{T}$. Pela primeira vez na interação, surge alguém para defender $\mathbf{T}$ e, consequentemente, discordar da reclamação de $\mathbf{Z}$. 
Figura 138: Exemplo de descortesia no grupo de Letras/USP no Inquérito 1

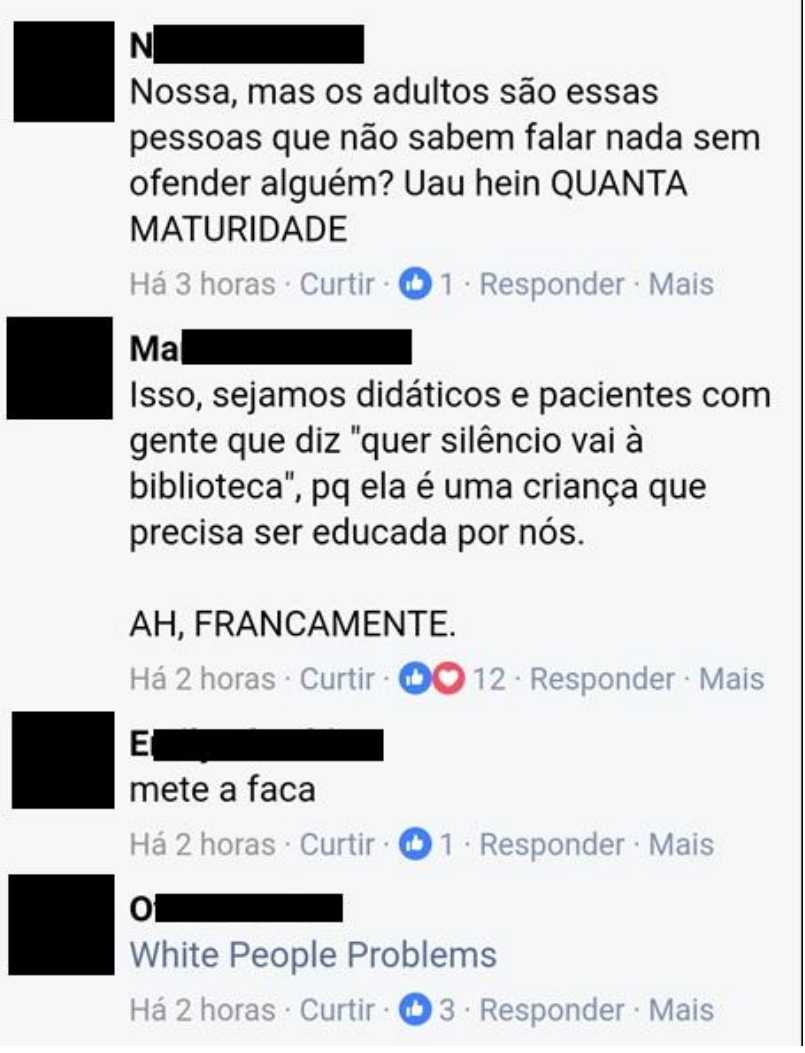

Fonte: Facebook (2017)

$\mathbf{N}$ também faz uso de um ato de fala indireto por meio de uma pergunta para criticar todos "Nossa, mas os adultos são essas pessoas que não sabem falar nada sem ofender alguém? e ainda ironiza e enfatiza, por meio de maiúsculas, a maturidade dos adultos no grupo: "Uau hein QUANTA MATURIDADE". Ma responde a $\mathbf{N}$ de forma a criticá-la por meio da impessoalização e também faz uma crítica indireta à fala de $\mathbf{T}$, que novamente é criticada pelo comportamento considerado infantil: "Isso, sejamos didáticos e pacientes com gente que diz "quer silêncio vai à biblioteca", pq ela é uma criança que precisa ser educada por nós." Depois Ma faz uma pequena pausa em sua própria fala, pausa identificada por meio do espaço de seu texto e, em maiúsculas, ironiza e reforça a sua própria fala para refutá-la: "AH, FRANCAMENTE". E, retoma o turno e reforça a ideia de violência física que ela já havia mencionado antes na interação: "mete a faca". 0, por sua vez, marca uma página famosa na rede social digital, White people problems, página na rede social digital que trata de problemas banais de pessoas ricas na sociedade. Por meio dessa publicação, infere-se que $\mathbf{O}$ parece achar a discussão de todos 
irrelevante no grupo e, por isso, marca a página. F fica surpresa com a reação de $\mathbf{N}$ em defesa de $\mathbf{T}$. O uso de expressão de baixo calão reforça a sua surpresa: "Puta que o pariu, eu não li isso."

Figura 139: Exemplo de descortesia no grupo de Letras/USP no Inquérito 1

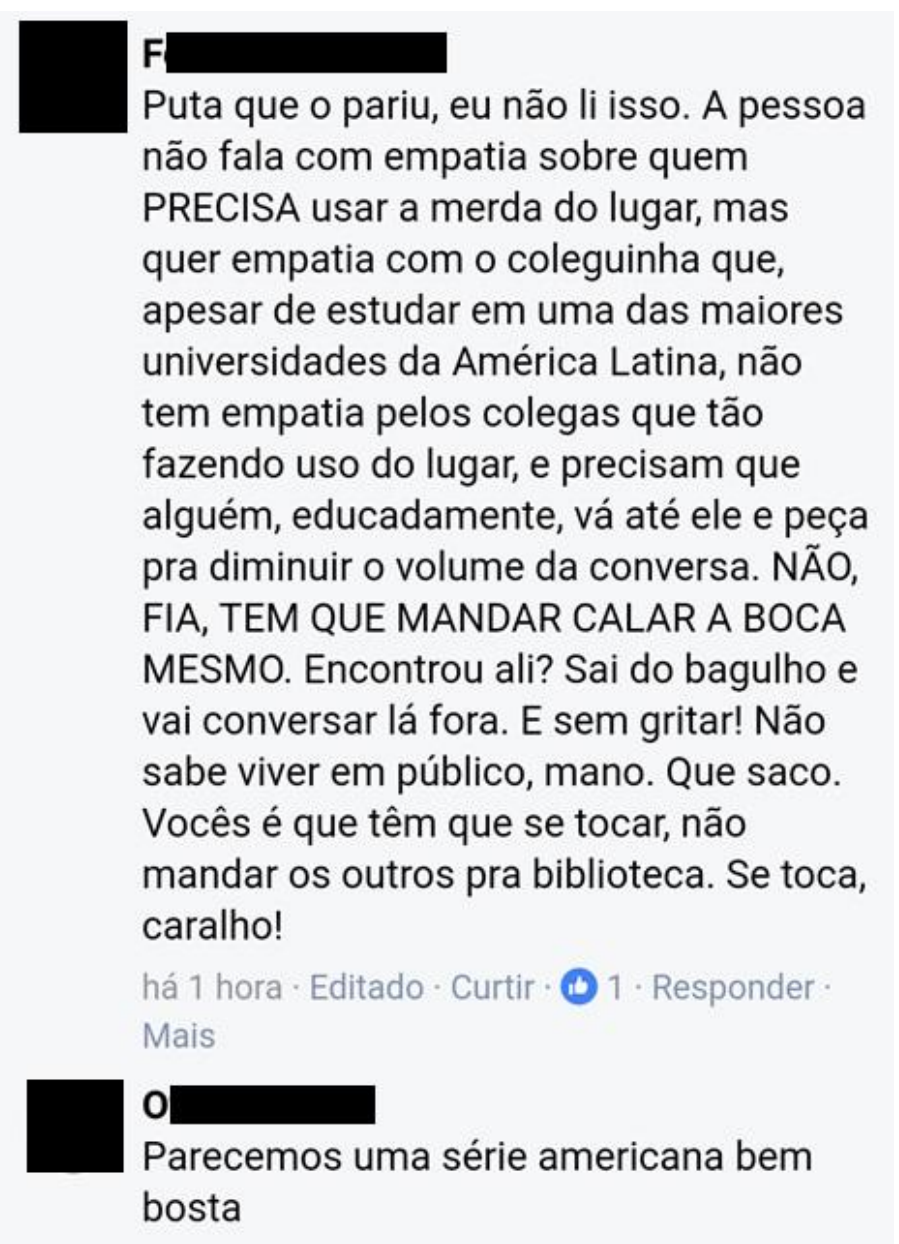

Fonte: Facebook (2017)

$\mathbf{F}$ também critica $\mathbf{T}$ de maneira indireta, por meio de uma forma impessoal, "a pessoa". Depois, por meio do uso de maiúsculas, $\mathbf{F}$ intensifica a descortesia em relação a $\mathbf{N}$ por meio de um vocativo irônico "NÃO, FIA, TEM QUE MANDAR CALAR A BOCA MESMO", e depois, $\mathbf{F}$ continua o seu comentário de maneira indireta àqueles que não respeitam os colegas na Pró-Aluno: "Vocês é que têm que se tocar, não mandar os outros pra biblioteca. Se toca, caralho!". Por meio de uma ordem em relação a todos que fazem barulho na Pró-Aluno para que "se toquem", $\mathbf{F}$ intensifica a descortesia por meio de uma palavra de baixo calão. $\mathbf{O}$ retoma o turno e compara a situação como "uma série americana bem bosta". 
Ca aparece pela primeira vez na discussão, e esclarece, com uma comparação, que, em seu tempo, já era assim, com os mesmos problemas, e ri da situação.

Figura 140: Exemplo de descortesia no grupo de Letras/USP no Inquérito 1

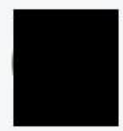

Cal

Estudei aí de 97 a 2001: isso já era assim kkkkk

há 7 minutos · Curtir · Responder · Mais

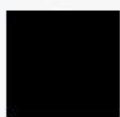

Jubilar essa molecada toda

há 5 minutos · Curtir · Responder · Mais

Fonte: Facebook (2017)

S sugere jubilar os alunos que fazem barulho, a quem trata de "molecada". Ga surge na troca comunicativa para fazer uma reclamação referente a outro tipo de comportamento, "gente escrota que leva o computador ou o livro pra ler e fica ocupando a mesa na lanchonete enquanto geral como em pé sem ter como nem encostar no balcão". Assim como foi recorrente nesta troca comunicativa entre $\mathbf{Z}$ e os demais participantes, Ga faz uso de um termo geral "gente" para se referir a algumas pessoas específicas que agem da maneira descrita na faculdade. E concorda com Ga e Hi marca um amigo, seguido de risos. Por meio desta intervenção de $\mathbf{H i}$, infere-se que o amigo marcado deve fazer o que foi criticado, ou seja, Hi também deixa um amigo em posição vulnerável, porém o amigo marcado não se manifesta na interação. 
Figura 141: Exemplo de descortesia no grupo de Letras/USP no Inquérito 1

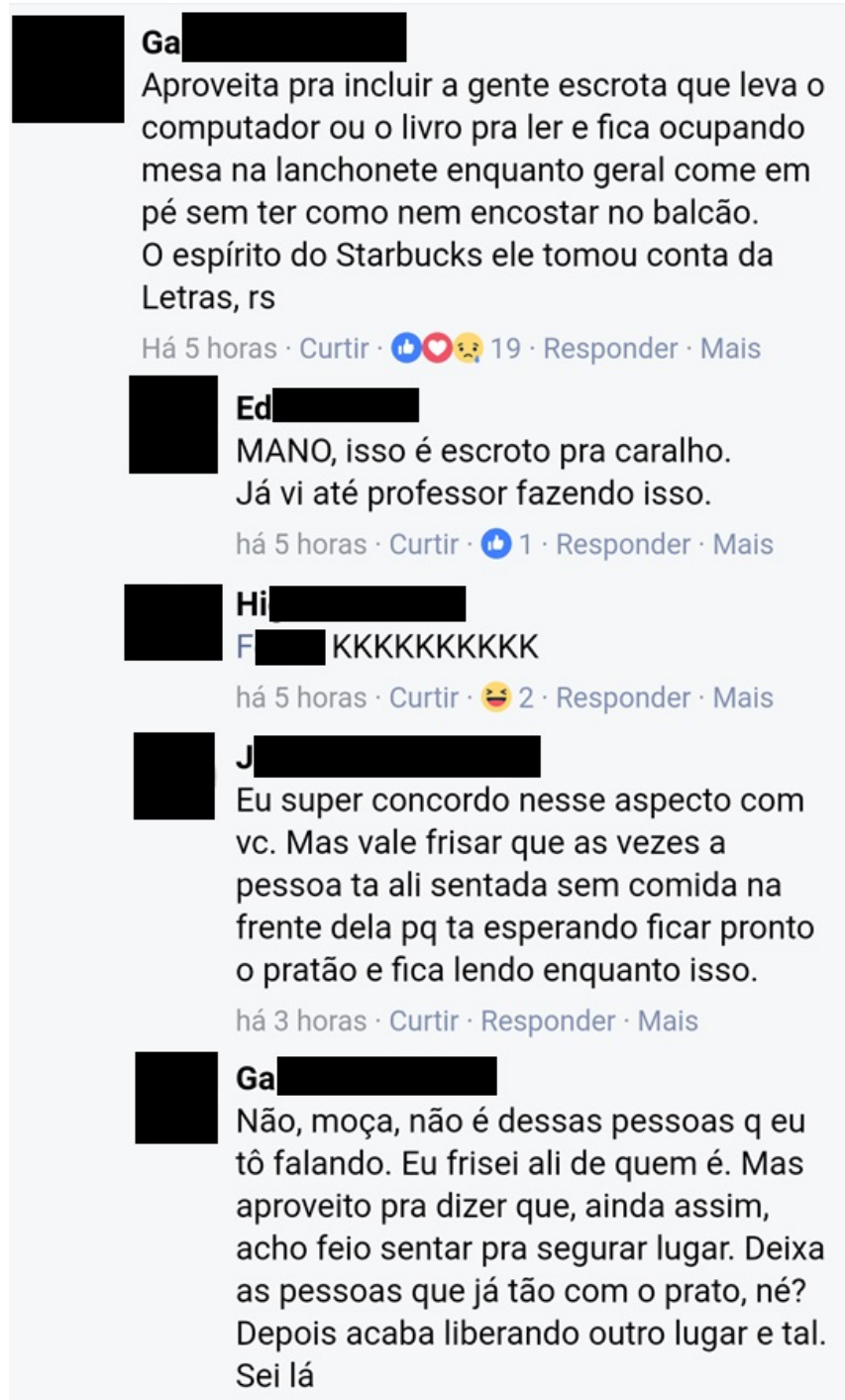

Fonte: Facebook (2017)

Jo concorda parcialmente com Ga, mas justifica que "as vezes a pessoa ta ali sentada sem comida na frente dela pq tá esperando ficar pronto o pratão e fica lendo enquanto isso." Jo concorda parcialmente com Ga, para,depois, discordar, como estratégia para se antecipar de uma possível reação negativa, visto que ela defende as pessoas criticadas por Ga. Esta, por sua vez, retoma seu turno para reformulá-lo: "Não, moça, não é dessas pessoas q eu tô falando. Eu frisei ali de quem é." Assim, o objetivo é fazer uma reparação de seu comentário para evitar mal-entendido, tal como aconteceu com a resposta de Jo. Ao mesmo tempo que $\mathbf{G a}$ tenta explicar o mal-entendido, $\mathbf{G a}$ aproveita para reforçar a sua crítica "Mas aproveito para dizer que, ainda assim, acho feio sentar para segurar lugar. Deixa as pessoas que já tão com o prato, né? Depois acaba 
liberando outro lugar e tal. Sei lá." Mar também aproveita a crítica de Ga e igualmente reforça outro problema recorrente de barulho, não só no espaço da Pró-Aluno. Mar pede para os alunos, em geral: "Falar mais baixo perto da sala de estudos também seria bacana com os coleguinhas".

Figura 142: Exemplo de descortesia no grupo de Letras/USP no Inquérito 1

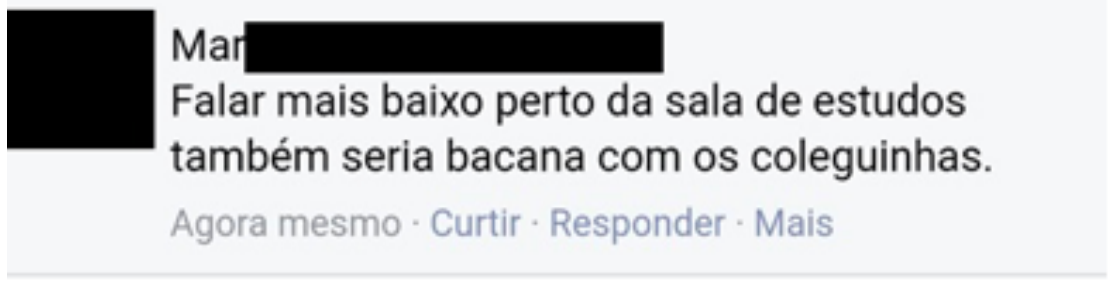

Fonte: Facebook (2017)

O pedido de Mar, do mesmo modo, conta com atenuadores linguísticos, principalmente com o uso do futuro do pretérito, "seria bacana", e o uso do diminutivo, "com os coleguinhas". J também aproveita a série de críticas, não só referente a barulho, para criticar também "as festas tocando uns funk e rihanna às $14 \mathrm{~h}$ e foda-se quem está na biblioteca estudando."

Figura 143: Exemplo de descortesia no grupo de Letras/USP no Inquérito 1

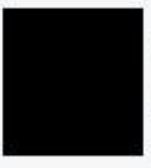

$\sqrt{ }$

Aproveita pra incluir sobre as festas tocando

uns funk e rihanna às 14:00 $\mathrm{h}$ e foda-se quem está na biblioteca estudando.

Agora mesmo $\cdot$ Curtir $\cdot$ Responder $\cdot$ Mais

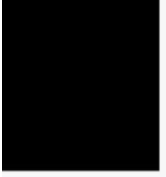

$\mathrm{R}$

Até desisti. Agora só acompanho as tretas.

Agora mesmo · Curtir · Responder · Mais

Fonte: Facebook (2017)

$\mathbf{R}$ também retoma o turno e, diante de tantos problemas encontrados no prédio, salienta que já desistiu: "Até desisti. Agora só acompanho as tretas". Ra igualmente entra na discussão para reforçar que não adianta reclamar, pois já sofreu "cyberbullying", ou seja, embora o grupo seja um espaço para sugestões e críticas, muitos alunos entram em conflito uns com os outros. 
Figura 144: Exemplo de descortesia no grupo de Letras/USP no Inquérito 1

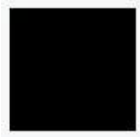

$\mathrm{Ra}$

eu ja reclamei disso e sofri um cyberbullying

hahaha

Há 5 horas · Curtir · (1) $\because 10 \cdot$ Responder - Mais

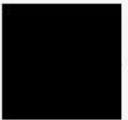

$\mathrm{Fe}$

Também acho

Há 5 horas · Curtir · Responder · Mais

Fonte: Facebook (2017)

Fe concorda com o posicionamento dos colegas e C reaparece na discussão para dizer que ela tem pedido, pessoalmente, para os alunos barulhentos pararem e tem tido resultado. Ma também concorda com $\mathbf{C}$ e reforça que houve resultados.

Figura 145: Exemplo de descortesia no grupo de Letras/USP no Inquérito 1

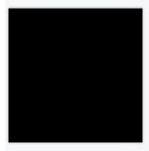

C

Eu tenho começado a falar pra galera quando tá incomodando, principalmente no corredor perto das salas de estudo. Tem gente que nem percebe que tá falando alto e acaba pedindo desculpas e parando.

Há 5 horas · Curtir · $10 \cdot$ Responder · Mais

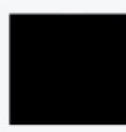

Mar

Já rolou comigo também. Pedi e pararam. Mas é uma coisa boa pra se ligarem.

Há 5 horas · Curtir - (t) 1 - Responder · Mais

Fonte: Facebook (2017)

Por meio dos comentários de $\mathbf{C}$ e $\mathbf{M a}$, as interactantes reforçam que as críticas para os colegas não funcionam no mundo virtual, mas sim com ações face a face. Ol surge na interação e retoma o comentário irônico de T, "mas ce ta brava", porém os outros participantes não interagem verbalmente com OI, apenas reagem com risos ou curtidas. 
Figura 146: Exemplo de descortesia no grupo de Letras/USP no Inquérito 1

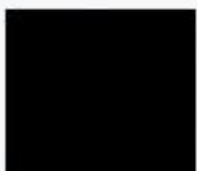

이

mas ce ta brava

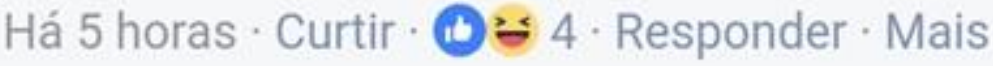

Fonte: Facebook (2017)

Na dirige a palavra a Z, por quem trata pelo uso do vocativo "Migo", indicando uma relação de proximidade. Na relata que não frequenta mais o curso, mas tem acompanhado os problemas. Na deseja, "Boa sorte", seguido de um emoticon triste. Re concorda com $\mathbf{N a}$ e $\mathbf{Z}$ se dirige a $\mathbf{N a}$ para relatar algo de sua vida pessoal: "Foi eu voltar pra Letras que votou minha gastrite". Na responde a Z, para criticar novamente as pessoas e o lugar: " Eu tô tentando me manter longe desse lugar pq é pesado d+. É uma glr muito cabeça oca". Na generaliza que os estudantes de Letras da faculdade são "uma glr [galera] muito cabeça oca". Por meio da forma de tratamento e do diálogo estabelecido entre os dois, infere-se que ambos se conhecem pessoalmente.

Figura 147: Exemplo de descortesia no grupo de Letras/USP no Inquérito 1

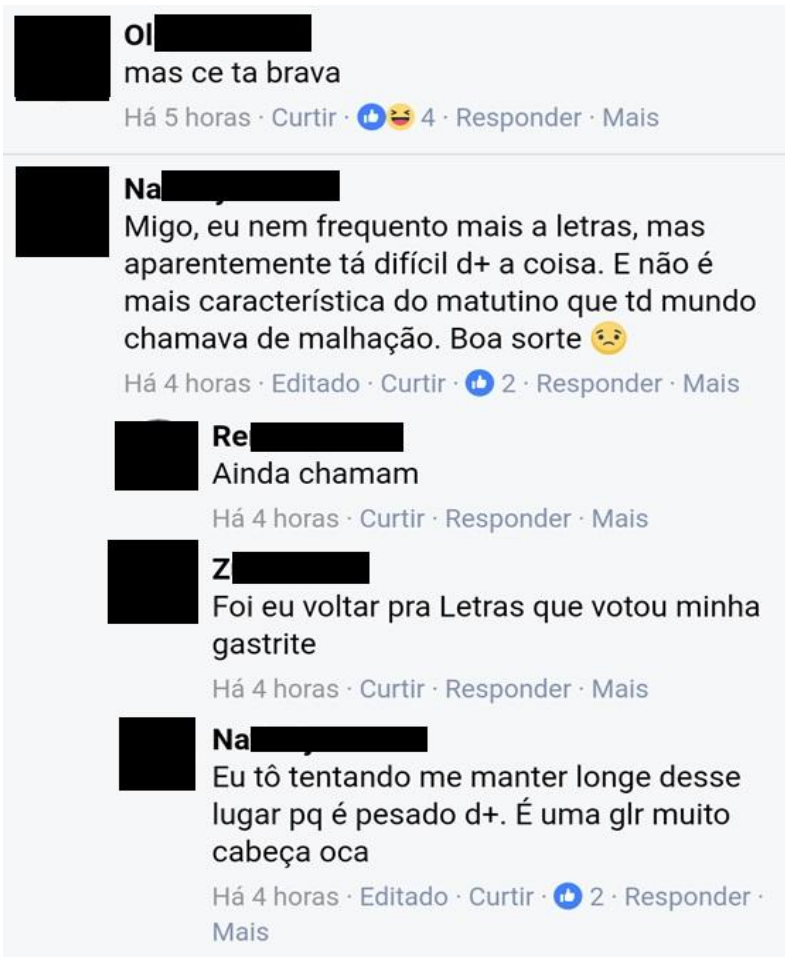

Fonte: Facebook (2017) 
Al aparece na interação para perguntar se era ele quem estava fazendo barulho na Pró-Aluno.

Figura 148: Exemplo de descortesia no grupo de Letras/USP no Inquérito 1

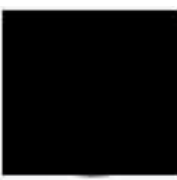

Al

Ixi z...., era eu? Podia colar ali e pedir que eu me retirava numa boa.

\section{há 1 hora · Curtir · Responder · Mais}

Fonte: Facebook (2017)

Al defende que $\mathbf{Z}$ poderia abordá-lo para reclamar que não teria problemas: " Ixi $\mathbf{Z}$, era eu? Podia colar ali e pedir que eu me retirava numa boa.". $\mathbf{Z}$ responde dizendo que não sabia se era $\mathbf{A l}$, mas ameniza a situação dizendo que a sua crítica não era uma pessoa específica: "Não é o caso de uma pessoa específica, e sim uma questão bastante geral, que acontece muito frequentemente."

Figura 149: Exemplo de descortesia no grupo de Letras/USP no Inquérito 1

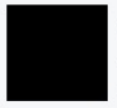

$\mathrm{z}$

Não sei se vc era uma das pessoas hj não, cara. Não é o caso de uma pessoa específica, e sim uma questão bastante geral, que acontece muito frequentemente.

No caso, eu realmente náo iria até quem quer que fosse pra pedir pra se retirar nem pra parar pq, como expliquei num outro comentário, se eu for levantar e conversar com cada pessoa que passa dos limites, vou virar monitor da pró aluno.

Fonte: Facebook (2017)

Apesar de amenizar a situação dizendo que não era $\mathbf{A l}, \mathbf{Z}$ se dirige diretamente a Al para aconselhar para prestar mais atenção em seus atos caso tenha pensado que a mensagem dele era para Al: "Se vc sentiu que passou do limite hj, e que por isso eu estivesse me referindo a vc, então recomendo que vc simplesmente seja mais atencioso a isso no futuro." 
Figura 150: Exemplo de descortesia no grupo de Letras/USP no Inquérito 1

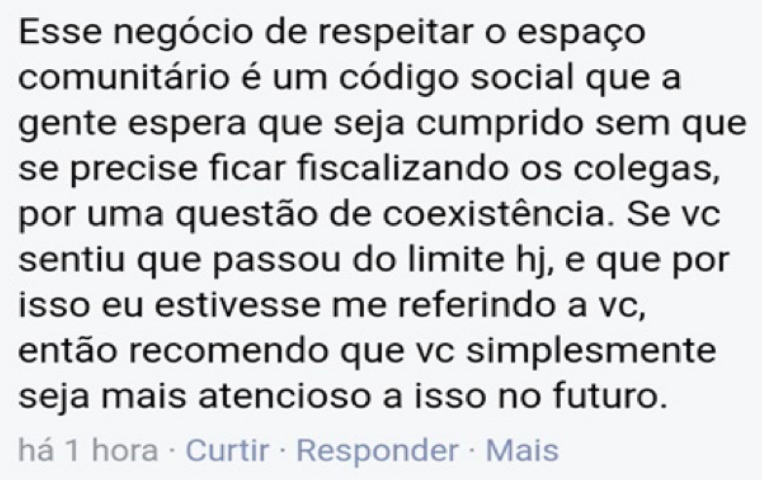

Fonte: Facebook (2017)

Al responde entendendo o posicionamento de $\mathbf{Z}$, porém ele defende também o seu ponto de vista: "Não sei, eu entendo mas ao mesmo tempo acho que a gente devia pelo menos tentar investir mais em diálogo. Muita coisa aqui seria resolvida com um pouquinho de cordialidade. Eu, por exemplo, passo praticamente o dia todo na pró-aluno, e não é incomum que apareça alguém que eu conheço para conversar." Al faz uso de um desarmador para também tentar neutralizar a situação conflituosa, "eu entendo mas", em relação ao comentário de $\mathbf{Z}$. Al, a partir de sua experiência pessoal, justifica a possível causa de outros alunos fazerem barulho na Pró-Aluno : "Nisso é muito fácil de perder o tom de voz e acabar incomodando os outros sem querer. Não duvido que seja o caso de muita gente." 
Figura 151: Exemplo de descortesia no grupo de Letras/USP no Inquérito 1

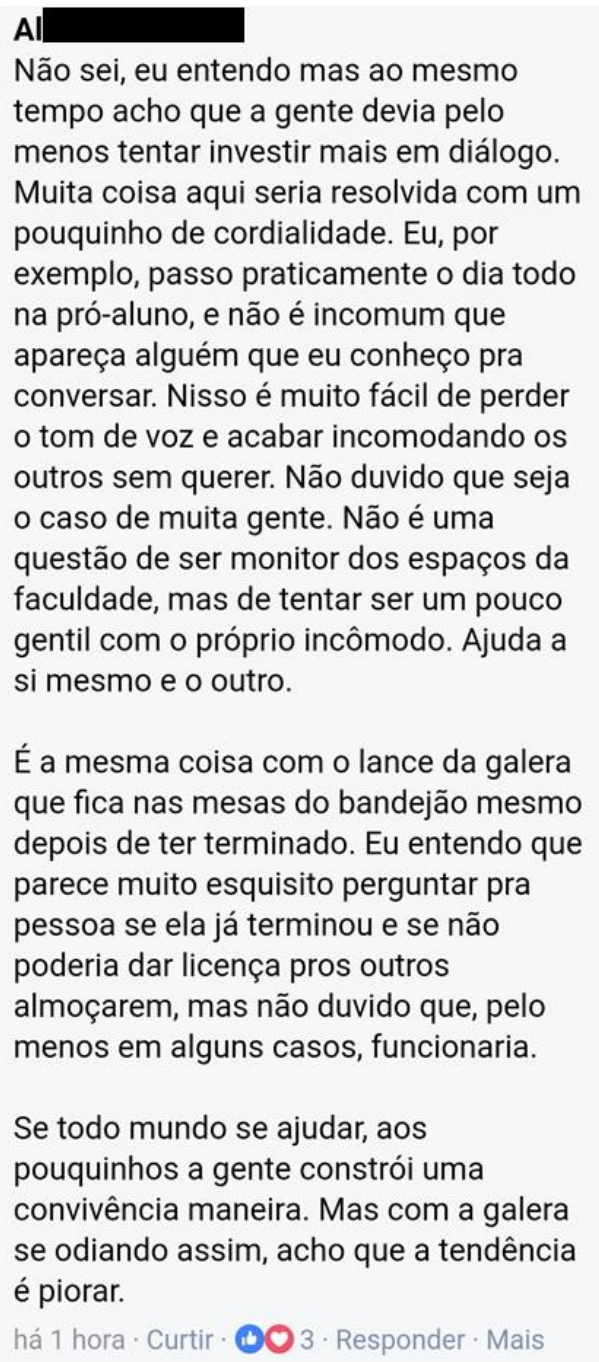

Fonte: Facebook (2017)

Al, para terminar, acredita que o diálogo resolve os problemas, em vez de partir para o ódio: "Se todo mundo se ajudar, aos pouquinhos a gente constrói uma convivência maneira. Mas com a galera se odiando assim, acho que a tendência é piorar."

$\mathbf{Z}$ retoma o seu turno para responder a $\mathbf{A l}$ e, também, entende o lado $\mathbf{A l}$ : "Então, eu entendo, mas é que isso deveria partir prioritariamente do outro lado, né?". 
Figura 152: Exemplo de descortesia no grupo de Letras/USP no Inquérito 1

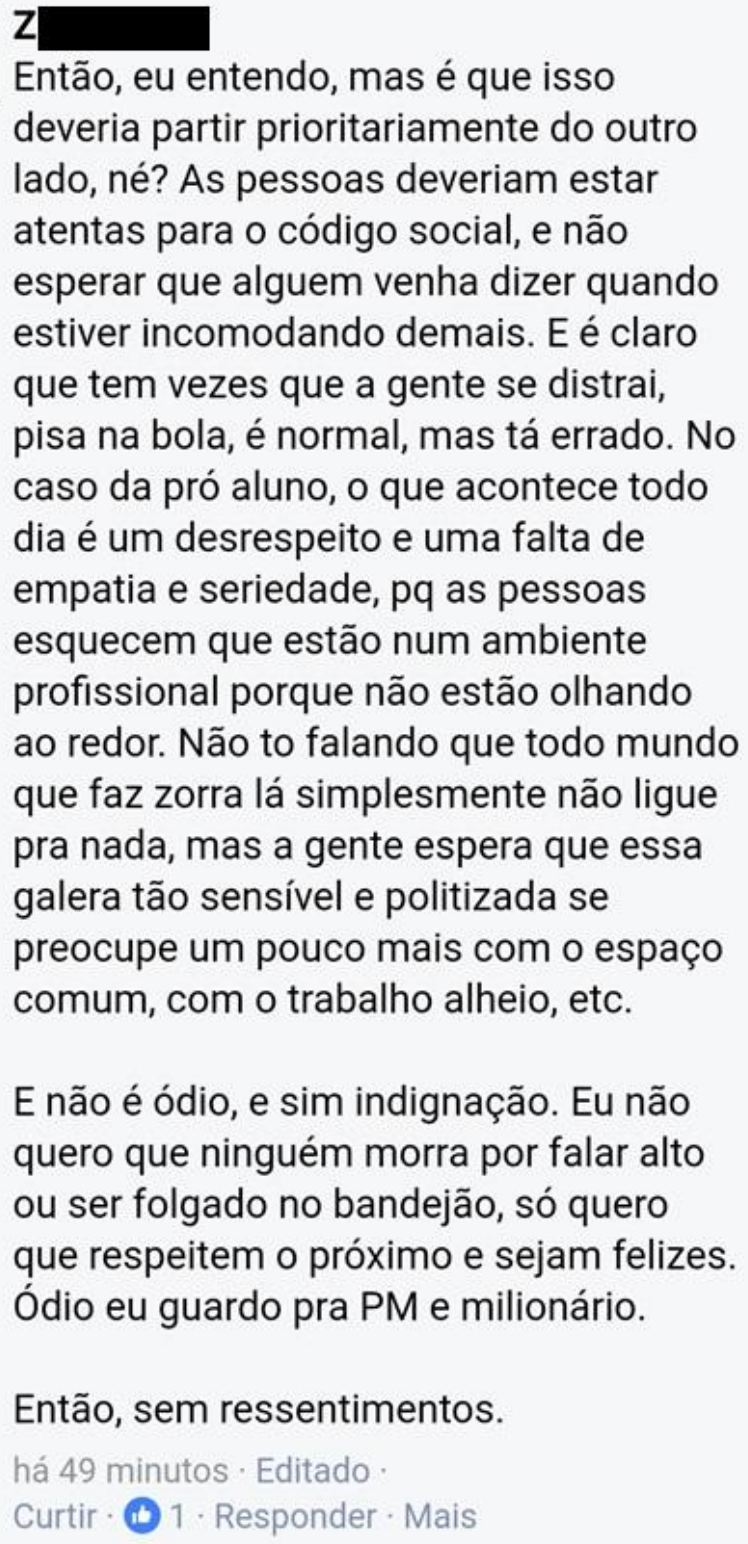

Fonte: Facebook (2017)

$\mathbf{Z}$ ainda enfatiza que não está generalizando para todos os alunos que frequentam o local: "Não to falando que todo mundo que faz zorra lá simplesmente não ligue pra nada, mas a gente espera que essa galera tão sensível e politizada se preocupe um pouco mais com o espaço comum, com o trabalho alheio, etc.", e ainda defende que não sente ódio nem ressentimento: "E não é ódio, e sim indignação. Eu não quero que ninguém morra por falar alto ou ser folgado no bandejão, só quero que respeitem o próximo e sejam felizes. Ódio eu guardo pra PM e milionário. Então sem ressentimentos." Outros alunos 
continuam a publicar na postagem, sobretudo de maneira irônica, tal como fazem K, Ad e El.

Figura 153: Exemplo de descortesia no grupo de Letras/USP no Inquérito 1

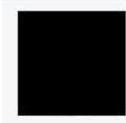

Deixa os menino brinca

há 47 minutos · Curtir · Responder · Mais

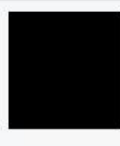

Ad

Faça ciranda e contação de histórias para os colegas " da empatia", e também chama os psicólogos e assistentes sociais vai que ficam com trauma "pós chamado de atenção"

há 43 minutos · Editado · Curtir · Responder · Mais
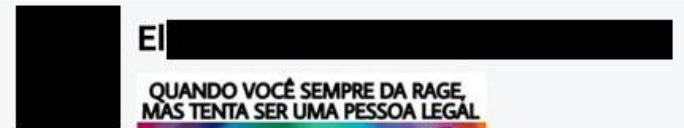

QUANDO VOCE SEMPRE DA RAGE,

MAS TENTA SER UMA PESSOA LEGAL

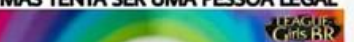
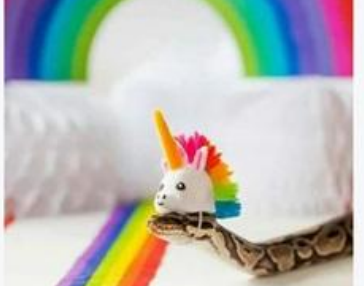

há 23 minutos · Curtir · Responder · Mais

Fonte: Facebook (2017)

K e Ad ironizam ainda o comportamento infantil dos colegas: "Deixa os menino brinca" e "Faça ciranda e contação de histórias para os colegas "da empatia", e também chama os psicólogos e assistentes sociais vai que ficam com trauma "pós chamado de atenção". EI, por sua vez, usa o humor para se dirigir a $\mathbf{Z}$ por meio de um meme, ironizando o fato de $\mathbf{Z}$ ser nervoso, mas ao mesmo tempo tentar ser uma pessoa legal com os demais. A discussão continua com os demais alunos. $\mathbf{G}$ faz o pedido para que todos calem a boca para sempre e generaliza para todos os alunos da faculdade, sem distinção: "vamo fazer um favor e calar a boca geral pra sempre, que tal?". 
Figura 154: Exemplo de descortesia no grupo de Letras/USP no Inquérito 1

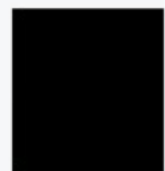

G

vamo fazer um favor e calar a boca geral pra sempre, que tal?

\section{Há 3 horas · Curtir · (1) 2 - Responder · Mais}

Fonte: Facebook (2017)

Ca retoma o turno e deduz que, pelo relato de todos, está pior que sua época e reforça, por meio dos parênteses, sua experiência pessoal: "(Véia falando)". Cl marca um amigo para dizer que poderia ter sido ela na situação exposta pelo colega. 
Figura 155: Exemplo de descortesia no grupo de Letras/USP no Inquérito 1
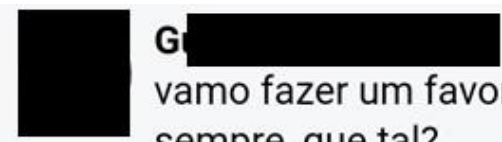

vamo fazer um favor e calar a boca geral pra

sempre, que tal?

Há 3 horas · Curtir - (1) 2. Responder - Mais

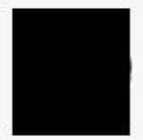

\section{$\mathrm{Ca}$}

Nossa, pelos relatos, tá tudo bem pior que na minha época... (Véia falando)

Há 2 horas · Curtir · Responder · Mais

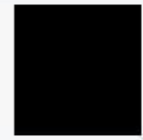

$\mathrm{cl}$

V nao fui eu mas poderia

há 1 hora · Curtir · Responder · Mais

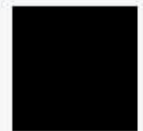

\section{Mi}

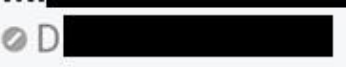

há 1 hora $\cdot$ Curtir $\cdot$ Responder $\cdot$ Mais
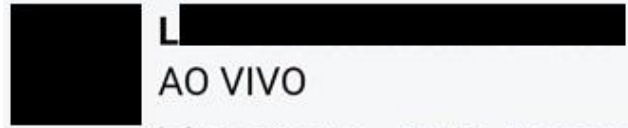

AO VIVO

há 51 minutos · Curtir - Responder - Mais

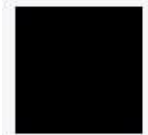

$\mathrm{Hi}$

Ta ficando fresco o estudante de Letras, ein

há 48 minutos · Curtir - (1) 2. Responder - Mais

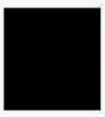

\section{Mi}

Esse post não é sobre aquele cochicho com o colega que tá do lado, fazendo trabalho ou distraindo a mente com um vídeo, com uma música, etc. É sobre pessoas que vão na pró e ficam conversando em voz alta, dando aaraalhadas. obriaando a todos a ouvir

Fonte: Facebook (2017)

Hi, por sua vez, entra na discussão para reclamar que "Tá ficando fresco o estudante de Letras, ein". Hi generaliza que o estudante de Letras é fresco e, Mi retoma o seu turno para reformular o que está sendo discutido e justificar a crítica de Z: "Esse post não é sobre aquele cochicho com o colega que tá do lado, fazendo trabalho ou distraindo a mente com um vídeo, com uma música, etc. É sobre pessoas que vão na pró e ficam conversando em voz alta, dando 
gargalhadas, obrigando a todos a ouvir sua conversa. É sobre isso. E se pedem para ela falar baixo, ela tira sarro, assim como muitos aqui nesse post."

Figura 156: Exemplo de descortesia no grupo de Letras/USP no Inquérito 1

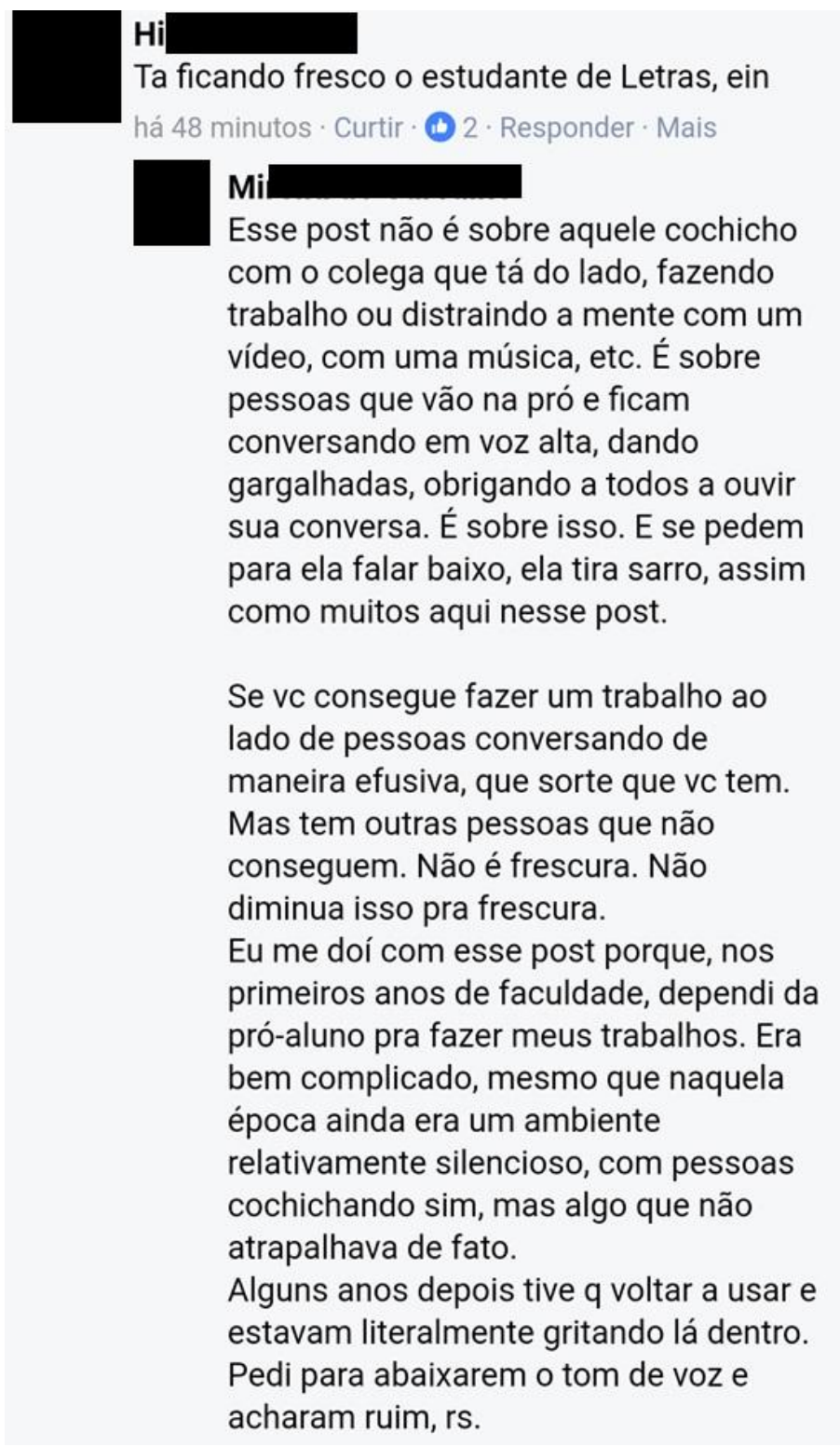

Fonte: Facebook (2017)

Depois Mi se dirige a $\mathrm{Hi}$ de forma direta "Se vc consegue fazer um trabalho ao lado de pessoas conversando de maneira efusiva, que sorte que vc tem. Mas tem outras pessoas que não conseguem. Não é frescura. Não diminua isso pra frescura.". El retoma o seu turno para usar uma expressão conhecida pelos internautas em casos de brigas on-line: "the treta has been planted". 
Figura 157: Exemplo de descortesia no grupo de Letras/USP no Inquérito 1

Se vc consegue fazer um trabalho ao
lado de pessoas conversando de
maneira efusiva, que sorte que vc tem.
Mas tem outras pessoas que não
conseguem. Não é frescura. Não
diminua isso pra frescura.
Eu me doí com esse post porque, nos
primeiros anos de faculdade, dependi da
pró-aluno pra fazer meus trabalhos. Era
bem complicado, mesmo que naquela
época ainda era um ambiente
relativamente silencioso, com pessoas
cochichando sim, mas algo que não
atrapalhava de fato.
Alguns anos depois tive q voltar a usar e
estavam literalmente gritando lá dentro.
Pedi para abaixarem o tom de voz e
acharam ruim, rs.
Ao meu ver, estamos em uma
universidade e um ambiente voltado
para o uso de computadores não é um
local feito para a socialização
exacerbada. Tem gente ali na pró que
não tem a escolha de escrever o trabalho
em casa, simplesmente pq ela não tem
computador. Frescura pedir o mínimo de
silêncio?
há 22 minutos · Editado · curtir · Responder
Mais
El
the treta has been planted
há 23 minutos · Curtir · Responder · Mais

Fonte: Facebook (2017)

Hi retoma o turno para responder a $\mathbf{M i}$, mas de forma indireta, pois generaliza a resposta para todos: "mas gnt [gente] vcs $n$ [não] acha q [que] esse eh [é] literalmente o menor dos problemas????? kkkk", e minimiza o problema de forma geral, com o uso de risos: "é chato sim e é difícil de concentrar sim mas menos né brasil". 
Figura 158: Exemplo de descortesia no grupo de Letras/USP no Inquérito 1

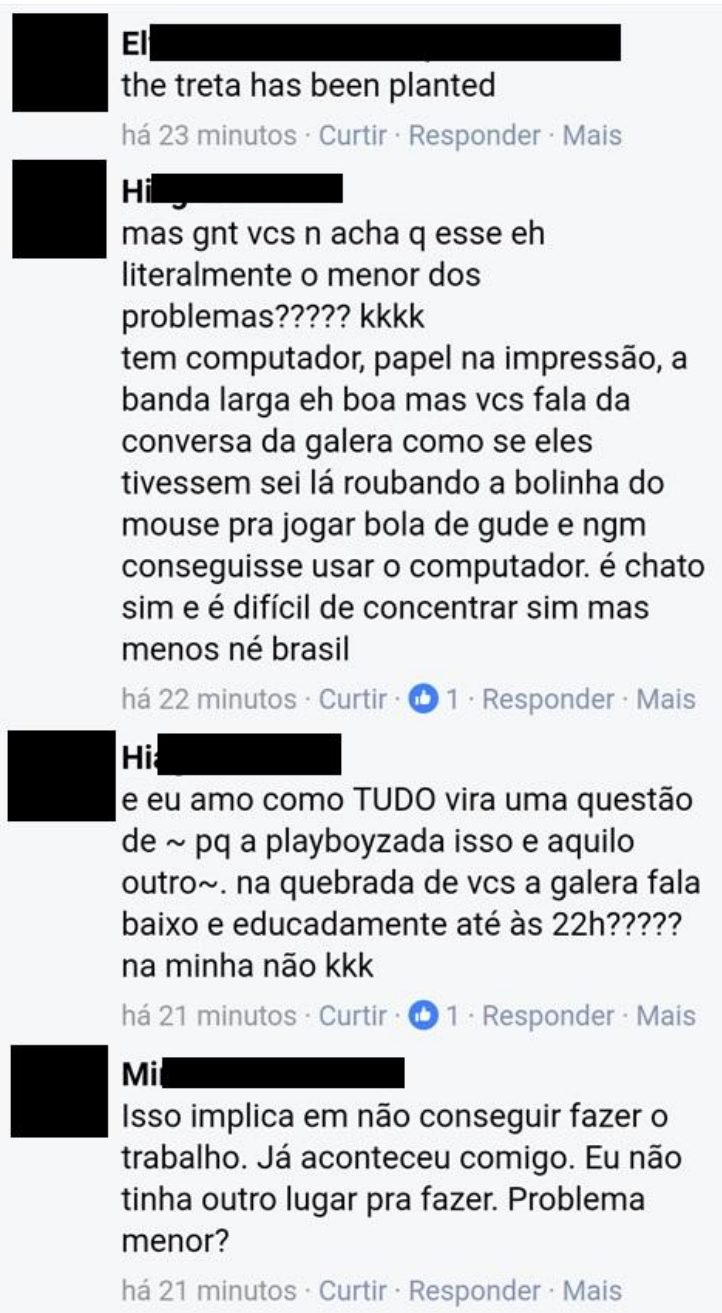

Fonte: Facebook (2017)

Hi ainda continua: "e eu amo como TUDO vira uma questão de $\sim p q$ a playbozada isso e aquilo outro . na quebrada de vcs a galera fala baixo e educadamente até às $22 \mathrm{~h}$ ????? na minha não kkk." Mi refuta que não se trata de um problema menor, uma vez que já foi impedida de conseguir fazer um trabalho, ou seja, novamente Mi usa de sua experiência pessoal para atenuar a situação e mostrar que tem autoridade no assunto: "Isso implica em não conseguir fazer o trabalho. Já aconteceu comigo. Eu não tinha outro lugar pra fazer. Problema menor?" 
Figura 159: Exemplo de descortesia no grupo de Letras/USP no Inquérito 1

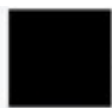

Mi

Isso implica em não conseguir fazer o trabalho. Já aconteceu comigo. Eu não tinha outro lugar pra fazer. Problema menor?

há 21 minutos - Curtir - Responder - Mais

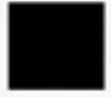

$\mathrm{Mi}$

Nossa, vc tá mudando completamente o foco. Na quebrada onde eu moro não é uma universidade e muito menos um ambiente de estudo.

há 21 minutos · Curtir · 1 1 Responder · Mais

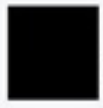

$\mathrm{Hi}$

tô retomando um comentário seu lá de cima, mi que vc diz q isso é pq a galera faz os trabalhos no Mac, como se isso fosse uma questao de alunos ricos $x$ alunos pobres. isso não é $p q o$ estudante da letras é playboy, é pq ele é mau educado mesmo $\because \cdot)$ )

há 18 minutos - Curtir - Responder - Mais

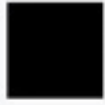

Mi

Pode ser, rs. Mas aposto q quem faz barulho na pró, tem computador pra fazer trabalho fora dali. Eu não tive durante mto tempo. Ou seja, ela tá numa condição melhor q a minha.

há 12 minutos - Curtir - Responder - Mais

Fonte: Facebook (2017)

Mi reclama de Hi mudar o foco da discussão, "Nossa, vc tá mudando completamente o foco", e Hi se defende: "to retomando um comentário seu lá de cima, mi, que vc diz q isso é pq a galera faz os trabalhos no Mac, como se isso fosse uma questão de alunos ricos $x$ alunos pobres. isso não é pq o estudante de letras é playboy, é pq ele é mau educado mesmo :)).

Mi concorda parcialmente com Hi por meio de um modalizador, para, depois, refutá-lo: "Pode ser, rs. Mas aposto q quem faz barulho na pró, tem computador pra fazer trabalho fora dali. Eu não tive durante mto tempo. Ou seja, ela tá numa condição melhor q a minha." 
Figura 160: Exemplo de descortesia no grupo de Letras/USP no Inquérito 1

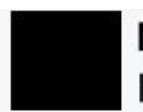

\section{Mi}

Independente da condição social, o que se discute aqui é o respeito com o outro, cara. Vc é contra isso?

há 12 minutos · Curtir · Responder · Mais

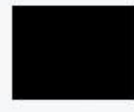

$\mathrm{Hi}$

sim eu acho que todo mundo tem q pegar um dia e sair no soco

há 11 minutos · Curtir · Responder · Mais

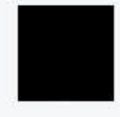

\section{C}

Seria meu sonho sair no soco com a galera da letras

há 9 minutos · Curtir · Responder · Mais

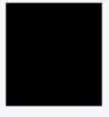

\section{Mi}

A questão maior é essa. Agora vir se apegar a um desvio no discurso pra invalidar a questão do silêncio na próaluno é reduzir o problema todo.

há 8 minutos · Curtir · Responder · Mais

Fonte: Facebook (2017)

Mi ainda acrescenta, "Independente da condição social, o que se discute aqui é o respeito com o outro, cara. Vc é contra isso?". Mi faz uma pergunta direta a Hi, de forma a deixá-lo também vulnerável diante de outros participantes. Hi sugere que todos deveriam, um dia, partir para a violência física: "sim, eu acho que todo mundo tem q pegar um dia e sair no soco." C reaparece e concorda com Hi: "Seria meu sonho sair no soco com a galera de letras". Mi retoma o discurso de Hi para reclamar que Hi desviou o discurso para invalidar a reclamação do silêncio: "A questão maior é essa. Agora vir se apegar a um desvio no discurso pra invalidar a questão do silêncio na pró-aluno é reduzir o problema todo." Mi encerra a discussão com Hi desaprovando a sugestão de partir para a violência física. Mi usa uma estratégia de generalização para atacar Hi, para depois atacá-lo diretamente de forma irônica : "Eu não vou discutir com gente q não tem mais argumento e vem falar de soco. Na boa. E espero um dia te encontrar estudando pra poder conversar bem alto do teu lado. Abraços." 
Figura 161: Exemplo de descortesia no grupo de Letras/USP no Inquérito 1

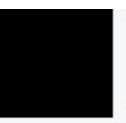

Mi

Eu não vou discutir com gente q não tem mais argumento e vem falar de soco. $\mathrm{Na}$ boa. E espero um dia te encontrar estudando pra poder conversar bem alto do teu lado. Abraços.

há 9 minutos · Curtir · Responder · Mais

Fonte: Facebook (2017)

Mi encerra o seu comentário com uma fórmula de despedida, "Abraços", para $\mathbf{H i}$, o que reforça ainda mais a descortesia com o emprego da ironia, ou seja, configura-se em uma pseudocortesia.

Observa-se, por meio desta interação, que os alunos tentam criticar uns aos outros de maneira indireta ou generalizante para evitar o confronto direto. É recorrente o uso de estratégias atenuadoras para, depois, fazer um ataque descortês em relação aos outros participantes. Neste Inquérito 1, notou-se que, enquanto todos estavam em uma posição de concordância uns com os outros, em especial com a publicação de $\mathbf{Z}$, não houve manifestações de descortesia. Quando T surge na interação discordando da posição de $\mathbf{Z}$, a descortesia se manifesta, sobretudo, em relação a $\mathbf{T}$ e a $\mathbf{N}$, que defende $\mathbf{T}$. Contra $\mathbf{T}$, houve casos de descortesia coercitiva, descortesia Ad hominem combinada com a descortesia imagética, descortesia violenta e a descortesia tipográfica. É importante salientar que a descortesia se deu devido ao comentário irônico de T e, por isso, foi uma descortesia reativa e coletiva contra T. $\mathbf{N}$ e $\mathbf{H}$ fazem uso da descortesia fática, pois desviam o tópico de $\mathbf{Z}$, sem respondê-lo de forma esperada, entretanto, $\mathbf{H}$ depois coopera positivamente para participar $\mathrm{da}$ discussão, sem o desvio do foco. Mais tarde, Mi e Hi entram em conflito na interação, em especial pelo fato de $\mathbf{H i}$ minimizar o problema de $\mathbf{M i}$. Mi, por sua vez, encerra o tópico principal com o uso de pseudocortesia contra $\mathrm{Hi} \mathrm{e}$, depois deste comentário, o assunto no grupo se encerra. Percebe-se, além dos recursos linguísticos estratégicos para atenuar ou intensificar a descortesia, o uso de um léxico com carga negativa para reforçar o ataque entre os participantes. Por meio das categorias de condições de infração da cortesia de Leech (2014), resumiremos como se deu a manifestação da descortesia no

\section{Inquérito 1:}


Tabela 3: As categorias de condições de infração da estratégia geral da descortesia no Inquérito 1

\begin{tabular}{|c|c|c|c|c|c|}
\hline \multicolumn{6}{|c|}{ As categorias de condições de infração da estratégia geral da descortesia } \\
\hline $\begin{array}{c}\text { Violação da } \\
\text { máxima } \\
\text { (expressa de } \\
\text { forma } \\
\text { imperativa) }\end{array}$ & $\begin{array}{l}\text { Participantes } \\
\text { do grupo }\end{array}$ & $\begin{array}{c}\text { Par de } \\
\text { máximas } \\
\text { relacionadas }\end{array}$ & $\begin{array}{c}\text { Categorias das máximas } \\
\text { violadas }\end{array}$ & $\begin{array}{c}\text { Classes de atos de } \\
\text { fala }\end{array}$ & $\begin{array}{c}\text { Estratégias } \\
\text { linguísticas e } \\
\text { não- } \\
\text { linguísticas } \\
\text { /híbridas }\end{array}$ \\
\hline $\begin{array}{c}\text { (M1) Atribuir um } \\
\text { valor } \\
\text { desfavorável } \\
\text { aos interesses } \\
\text { do interlocutor } \\
\text { (Outro) }\end{array}$ & $\begin{array}{c}\text { T em relação a } \mathbf{Z} \\
\text { Hi em relação a } \\
\text { Mi }\end{array}$ & \multirow[t]{2}{*}{$\begin{array}{l}\text { Generosidade/T } \\
\text { ato }\end{array}$} & Generosidade & Recusar, ameaçar & Uso de ironia \\
\hline $\begin{array}{l}\text { (M2) Atribuir um } \\
\text { valor favorável } \\
\text { aos interesses } \\
\text { do EU (Locutor) }\end{array}$ & Z e Mi & & Tato & Ordem, demanda & $\begin{array}{c}\text { Uso do verbo } \\
\text { no imperativo } \\
\text { ou atos de } \\
\text { fala indireto }\end{array}$ \\
\hline $\begin{array}{l}\text { (M3) Atribuir um } \\
\text { valor } \\
\text { desfavorável às } \\
\text { qualidades do } \\
\text { interlocutor } \\
\text { (Outro) }\end{array}$ & $\begin{array}{c}\text { C, Mi, J, Z, H, E, } \\
\text { A, Ed, D, Ma, F, } \\
\text { S, contra T } \\
\text { Hi contra Mi } \\
\text { Mi contra Hi }\end{array}$ & \multirow[t]{2}{*}{$\begin{array}{l}\text { Aprovação/ } \\
\text { Modéstia }\end{array}$} & Aprovação & $\begin{array}{l}\text { Insultar, reclamar, } \\
\text { falar mal do } \\
\text { interlocutor }\end{array}$ & $\begin{array}{c}\text { Uso de léxico } \\
\text { com } \\
\text { significado } \\
\text { negativo, } \\
\text { palavras de } \\
\text { baixo calão } \\
\end{array}$ \\
\hline $\begin{array}{l}\text { (M4) Atribuir um } \\
\text { valor favorável } \\
\text { às qualidades } \\
\text { do EU (Locutor) }\end{array}$ & $\begin{array}{l}\text { Nenhum } \\
\text { participante }\end{array}$ & & Modéstia & $\begin{array}{l}\text { Gabar-se, ser } \\
\text { complacente }\end{array}$ & $\begin{array}{c}\text { Sem } \\
\text { ocorrências }\end{array}$ \\
\hline $\begin{array}{c}\text { (M5) Atribuir um } \\
\text { valor } \\
\text { desfavorável às } \\
\text { obrigações do } \\
\text { EU (Locutor) } \\
\text { para com o } \\
\text { interlocutor } \\
\text { (Outro) }\end{array}$ & $\begin{array}{l}\text { Nenhum } \\
\text { participante }\end{array}$ & \multirow[t]{2}{*}{ Obrigação } & Obrigação (ao interlocutor) & $\begin{array}{c}\text { Recusar } \\
\text { agradecimentos ou } \\
\text { desculpas }\end{array}$ & $\begin{array}{c}\text { Sem } \\
\text { ocorrências }\end{array}$ \\
\hline $\begin{array}{c}\text { (M6) Atribuir um } \\
\text { valor favorável } \\
\text { às obrigações } \\
\text { do interlocutor } \\
\text { para com o } \\
\text { Locutor }\end{array}$ & $\begin{array}{c}\text { Al em relação a } \\
\mathbf{Z}\end{array}$ & & Obrigação (ao Locutor) & $\begin{array}{l}\text { Agradecer ou } \\
\text { desculpar-se }\end{array}$ & $\begin{array}{c}\text { Uso do } \\
\text { pretérito } \\
\text { imperfeito, } \\
\text { sugestão, ato } \\
\text { de fala } \\
\text { indireto } \\
\end{array}$ \\
\hline $\begin{array}{c}\text { (M7) Atribuir um } \\
\text { valor } \\
\text { desfavorável às } \\
\text { opiniões do } \\
\text { interlocutor } \\
\text { (Outro) }\end{array}$ & $\begin{array}{c}\text { C, Mi, J, Z, H, E, } \\
\text { A, Ed, D, Ma, F, } \\
\text { S, contra T } \\
\text { Hi contra Mi } \\
\text { Mi contra Hi }\end{array}$ & \multirow[t]{2}{*}{ Opinião } & Concordância & $\begin{array}{l}\text { Discordar, } \\
\text { contradizer }\end{array}$ & $\begin{array}{c}\text { Uso de ironia, } \\
\text { uso dos atos } \\
\text { de fala } \\
\text { indiretos, Uso } \\
\text { de léxico com } \\
\text { significado } \\
\text { negativo, } \\
\text { palavras de } \\
\text { baixo calão }\end{array}$ \\
\hline $\begin{array}{l}\text { (M8) Atribuir um } \\
\text { valor favorável } \\
\text { às opiniões do } \\
\text { Locutor (EU) }\end{array}$ & $\begin{array}{c}\text { Todos os } \\
\text { participantes, } \\
\text { exceto } \mathbf{T}, \mathbf{N} \text { e } \mathbf{H i}\end{array}$ & & Opinião reticente & Ser opinativo & Asserções \\
\hline $\begin{array}{c}\text { (M9) Atribuir um } \\
\text { valor } \\
\text { desfavorável } \\
\text { aos sentimentos } \\
\text { do interlocutor } \\
\text { (Outro) }\end{array}$ & $\begin{array}{l}\text { Hi contra } \mathbf{M i} \\
\text { T contra Z } \\
\mathbf{N} \text { contra Z }\end{array}$ & \multirow{2}{*}{ Sentimento } & Simpatia & $\begin{array}{l}\text { Expressar antipatia } \\
\text { ao interlocutor }\end{array}$ & $\begin{array}{c}\text { Uso de ironia, } \\
\text { uso dos atos } \\
\text { de fala } \\
\text { indiretos, Uso } \\
\text { de léxico com } \\
\text { significado } \\
\text { negativo, } \\
\text { palavras de } \\
\text { baixo calão }\end{array}$ \\
\hline $\begin{array}{l}\text { (M10) Atribuir } \\
\text { um valor } \\
\text { favorável aos } \\
\text { sentimentos do } \\
\text { Locutor (EU) }\end{array}$ & $\begin{array}{l}\text { Todos os } \\
\text { participantes em } \\
\text { relação a Z, } \\
\text { exceto } \mathbf{T}, \mathbf{N} \text { e Hi }\end{array}$ & & Sentimento reticente & $\begin{array}{l}\text { Reclamar, } \\
\text { resmungar }\end{array}$ & $\begin{array}{c}\text { Uso de ironia, } \\
\text { uso dos atos } \\
\text { de fala } \\
\text { indiretos, Uso } \\
\text { de léxico com } \\
\text { significado } \\
\text { negativo, } \\
\text { palavras de } \\
\text { baixo calão }\end{array}$ \\
\hline
\end{tabular}




\section{INQUÉRITO 2}

O Inquérito 2 deste trabalho também diz respeito à mesma reclamação do Inquérito 1: o barulho dos alunos no prédio de Letras. O barulho, no entanto, seria em outro local do prédio, na "entrada da Tia Bia"

Figura 162: Exemplo de descortesia no grupo de Letras/USP no Inquérito 2
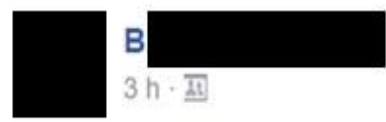

Letras - USP - 2017

\section{MEU CACHORRO QUER SABER SE...}

Um humano postasse de forma educada que o barulho, gritos, risadas e etc na "entrada da Tia Bia" por vezes atrapalha o andamento da aula da sala 102 , vocês iam xingar esse humano e arranjar uma problematização muito louca sobre silenciamento na universidade.

Ele ta muito curioso então respondam por favor .

Bjs

It Curtir Comentar

$0=0153$

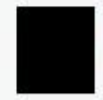

Meu cachorro pediu para incluir os corredores do prédio

nessa reclamação! $\because \cdot$

Curtir - Responder - $45 \cdot 3 \mathrm{~h}$

F_Queria que esse post fosse jogo do pontinho pra

eu curtir esse daqui

Curtir-Responder - (1) $2 \cdot 3 \mathrm{~h}$

\begin{tabular}{l|l}
$\mathrm{F}$ & Curtindo de qualquer forma pra ficar mais explicito \\
$\mathrm{o}$ interesse &
\end{tabular}

Curtir - Responder - $3 \mathrm{~h}$

Fonte: Facebook (2017)

$\mathbf{B}$ faz a reclamação, mas usa uma estratégia diferente de $\mathbf{Z}$ no Inquérito 1: o pedido é realizado por meio de um emissor delegado "MEU CACHORRO QUER SABER SE...", ou seja, B tenta escapar da responsabilidade enunciativa de fazer uma crítica aos alunos barulhentos, ao mesmo tempo que está consciente que o seu pedido pode ser recebido de forma ameaçadora por parte dos alunos e, assim, gerar conflitos. Com esse recurso, B se autoprotege e se previne de possíveis danos à imagem dela mesma e à imagem dos outros. Além de usar o recurso de um emissor delegado, B tem o cuidado usar uma generalização "vocês" para relativizar a crítica aos alunos específicos 
barulhentos e mais o moderador, "por favor", para que os alunos respondam à sua postagem. A publicação de B tem 153 reações de alunos, entre curtidas, risos e amei. Logo em seguida, B recebe respostas dos alunos da faculdade e, no geral, os alunos cooperam positivamente na publicação de $\mathbf{B}$, uma vez que os alunos também reclamam dos problemas da faculdade, mas usam a mesma estratégia de $\mathbf{B}$, ou seja, o uso de animais para fazer a reclamação. $\mathbf{M}$, por exemplo, pede para incluir o barulho dos "corredores do prédio" e F curte a publicação de B e de $\mathbf{M}$ para mostrar interesse, tal como F comenta. Outros alunos aparecem para comentar a publicação, concordando com a reclamação de B.

G e Ma concordam e, esta última, por sua vez, ainda usa maiúsculas para dar ênfase ao local do problema e reticências em sua crítica.

Figura 163: Exemplo de descortesia no grupo de Letras/USP no Inquérito 2

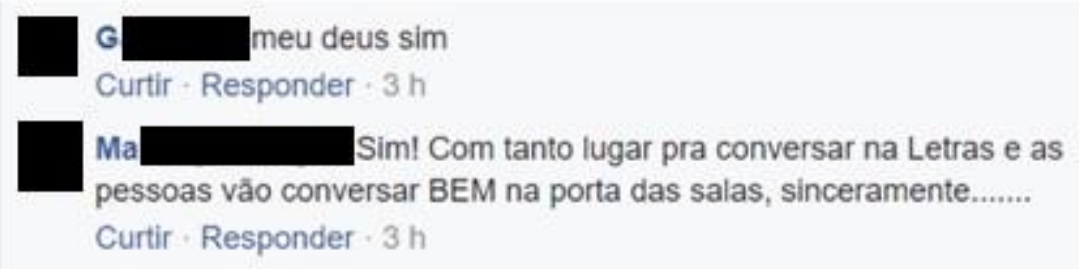

Fonte: Facebook (2017)

C concorda com a crítica " Eu acharia de boa", mas, logo em seguida, também usa um animal para afirmar que a crítica de $\mathbf{B}$ seria ameaçadora para alguns alunos "mas meu gato disse que provavelmente teria gente xingando". 
Figura 164: Exemplo de descortesia no grupo de Letras/USP no Inquérito 2

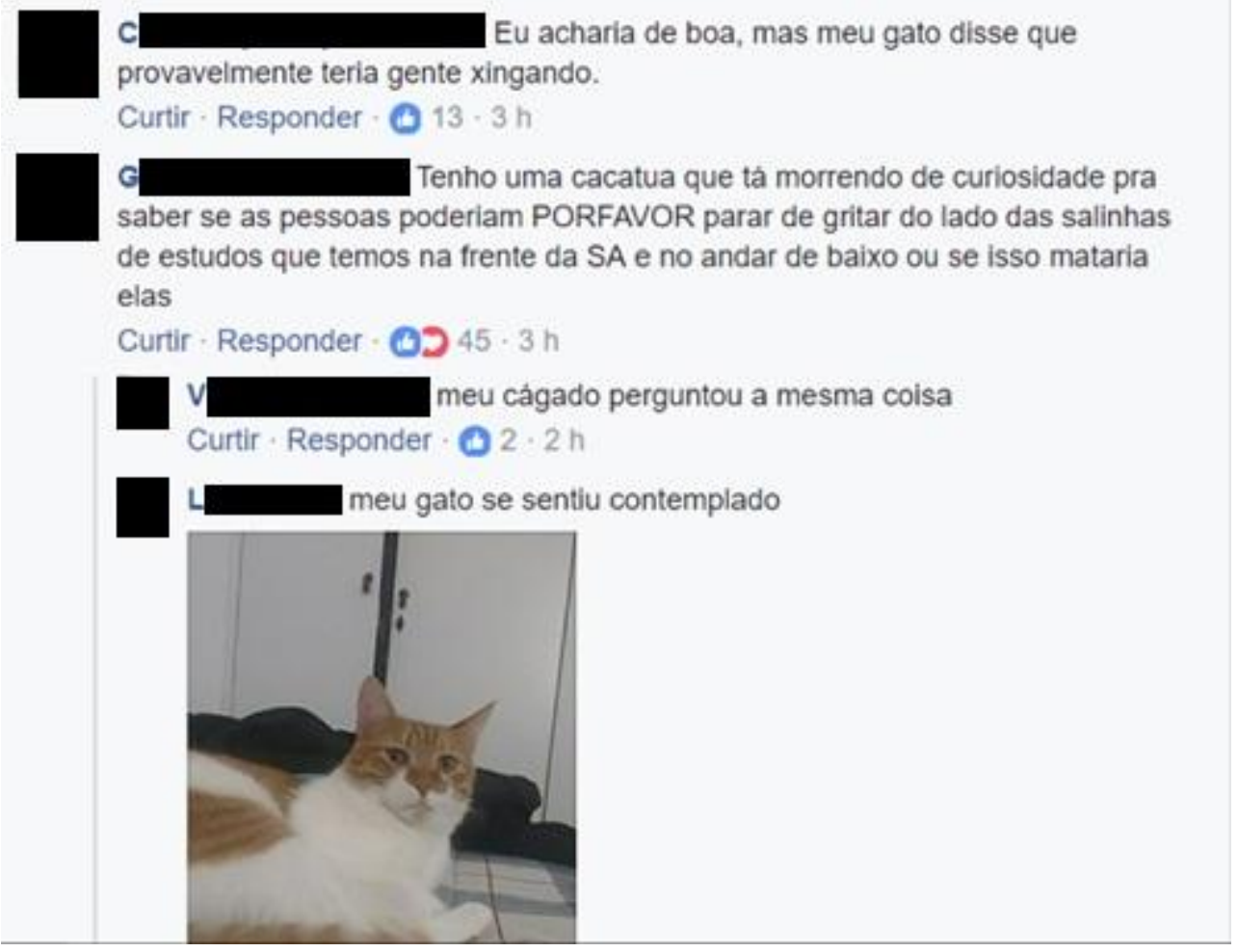

Fonte: Facebook (2017)

C, além de usar o animal para fazer a afirmação e delegar sua responsabilidade enunciativa, do mesmo modo usa o advérbio "provavelmente", também para se prevenir de possíveis danos à sua imagem. Gi também aproveita a publicação de B para fazer uma crítica, mas assim como fez os demais participantes, $\mathbf{G i}$ igualmente usa um animal para se proteger e criticar os colegas: "Tenho uma cacatua que tá morrendo de curiosidade pra saber se as pessoas poderiam PORFAVOR parar de gritar do lado das salinhas de estudos que temos na frente da SA e no andar de baixo ou se isso mataria elas". Gi tenta escapar de sua responsabilidade enunciativa e se distanciar da crítica, porém, usa um moderador em maiúsculas "PORFAVOR". Na linguagem virtual, o uso de maiúsculas também pode ser interpretado como uma representação de um grito e, apesar de Gi ter usado um moderador para amenizar um efeito de um FTA, Gi intensifica seu ato descortês com o uso das maiúsculas. Apesar da publicação de $\mathbf{G i}$ ser potencialmente ameaçadora, $\mathbf{V}$ e $\mathbf{L}$ concordam e, da mesma maneira, fazem uso de um animal para delegar a responsabilidade enunciativa da afirmação. L, inclusive, publica a foto de um gato parecendo estar 
desanimado com a situação. Assim, L reforça a sua crítica, mas ao mesmo tempo, tenta atenuá-la com outros recursos.

Mu comenta elogiando os estudantes de Letras do grupo e sua publicação tem 6 curtidas.

Figura 165: Exemplo de descortesia no grupo de Letras/USP no Inquérito 2

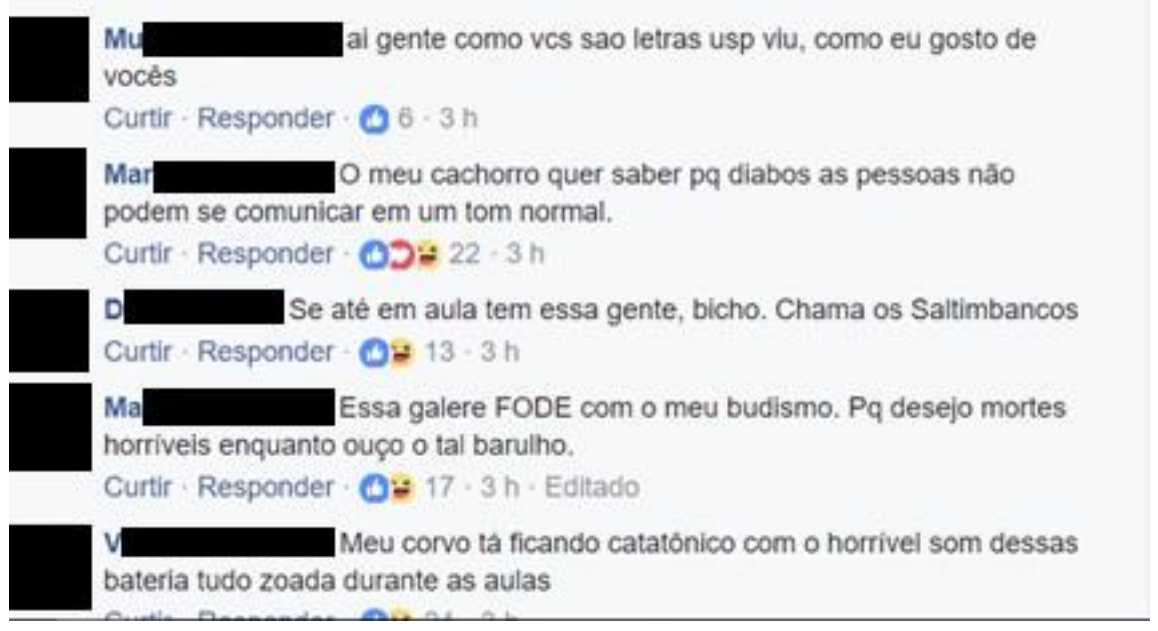

Fonte: Facebook (2017)

Mar também usa um emissor delegado para criticar as pessoas que não se comunicam em um tom normal e ainda comenta, depois, seu desejo de morte em relação aos alunos barulhentos, porém, Mar faz o comentário em um tom bem-humorado "Essa galere FODE com o meu budismo. Pq desejo mortes horríveis enquanto ouço o tal barulho". Mar também faz o uso de maiúsculas para enfatizar o seu descontentamento, no entanto, não há reações negativas ao seu comentário, apenas curtidas e risos. Os demais participantes do grupo começam a responder e usando outros animais para complementar a crítica de B.

Bi, em resposta a Fe, comete um erro "Meu ratinho te odeia". Bi percebe que usou "te" em vez de "também" e tenta reparar o erro para evitar um malentendido de Fe. 
Figura 166: Exemplo de descortesia no grupo de Letras/USP no Inquérito 2

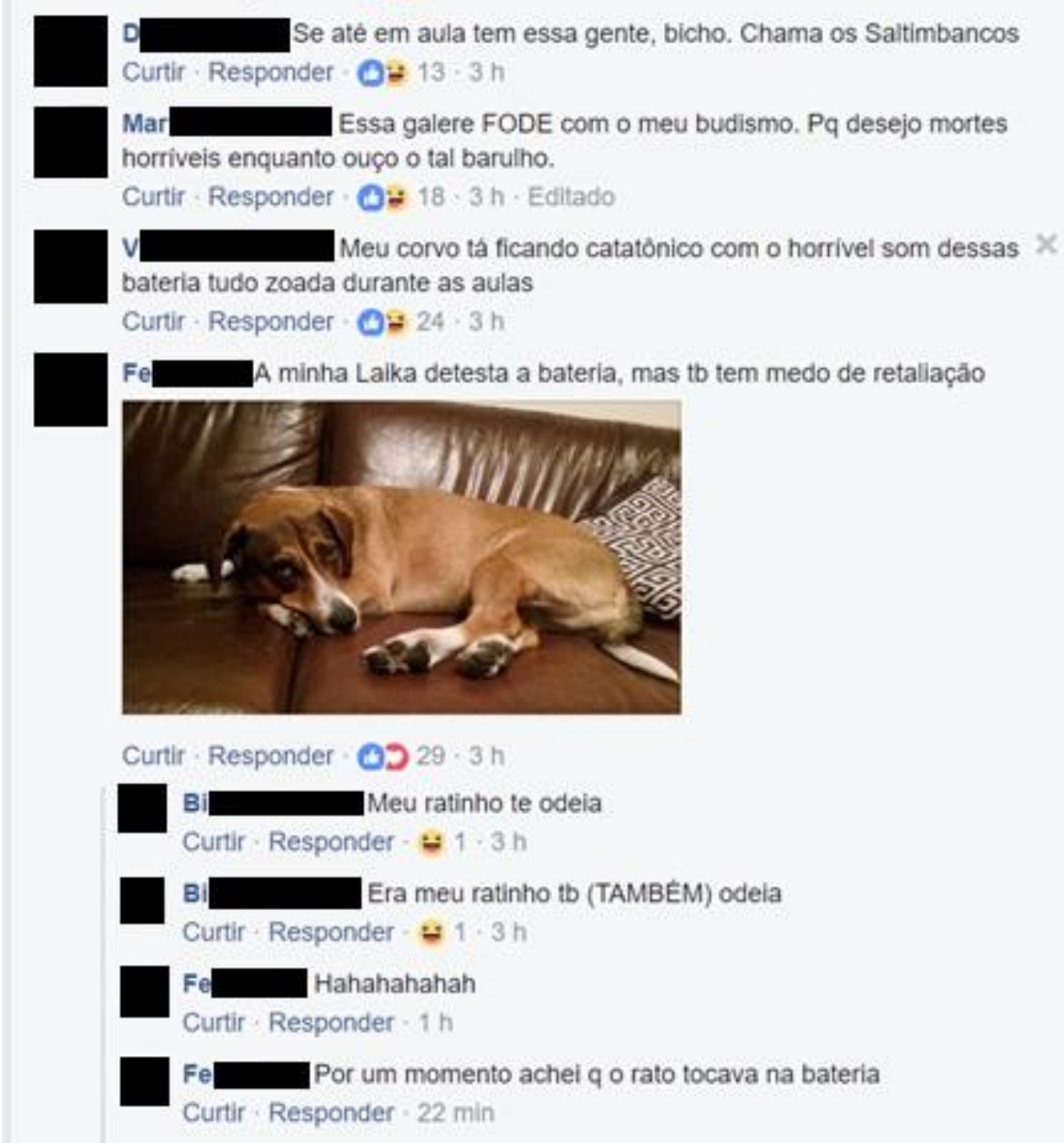

Fonte: Facebook (2017)

Bi reformula o seu comentário e acrescenta o "também" entre parênteses e maiúsculas para evitar um possível dano à sua imagem: "Era meu ratinho tb (TAMBÉM) odeia". Fe ri do comentário de Bi e igualmente comenta o malentendido: "Por um momento achei q [que] o rato tocava na bateria".

As reclamações continuam e Gab comenta sobre o barulho do corredor da sala 160. B, a responsável pela publicação principal, pergunta a Gab qual é o animal que reclama do barulho. B ainda usa a forma de tratamento "senhor" e o moderador "favor" para fazer o pedido para que Gab inserisse um animal. Ma insere um animal para Gab, que demora um pouco para responder ao pedido de B. 
Figura 167: Exemplo de descortesia no grupo de Letras/USP no Inquérito 2

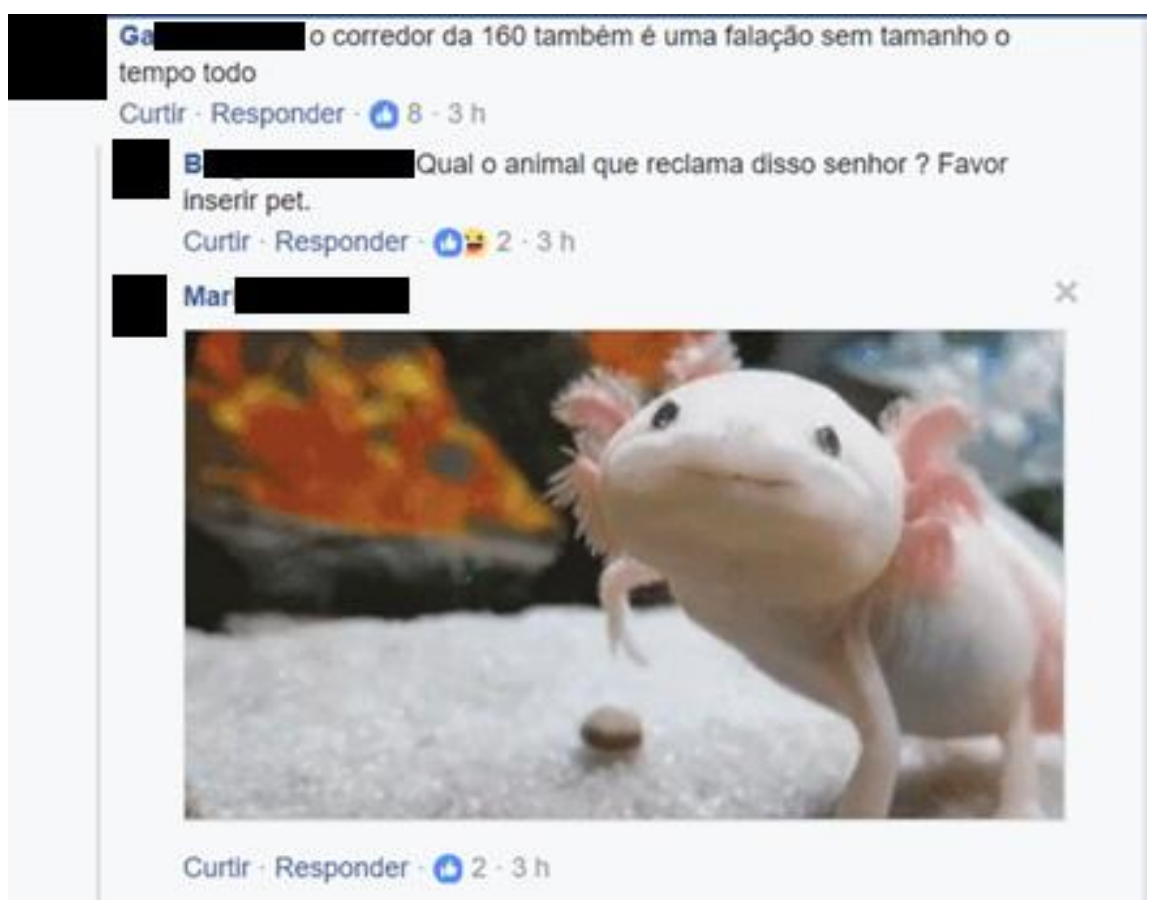

Fonte: Facebook (2017)

Ma coopera positivamente com a interação, pois sabe que o papel de cada um era reclamar ao mesmo tempo em que se deveria publicar um animal, tal como B, a responsável pelo enunciado iniciativo, fez desde o início com a publicação na rede social digital.

Figura 168: Exemplo de descortesia no grupo de Letras/USP no Inquérito 2

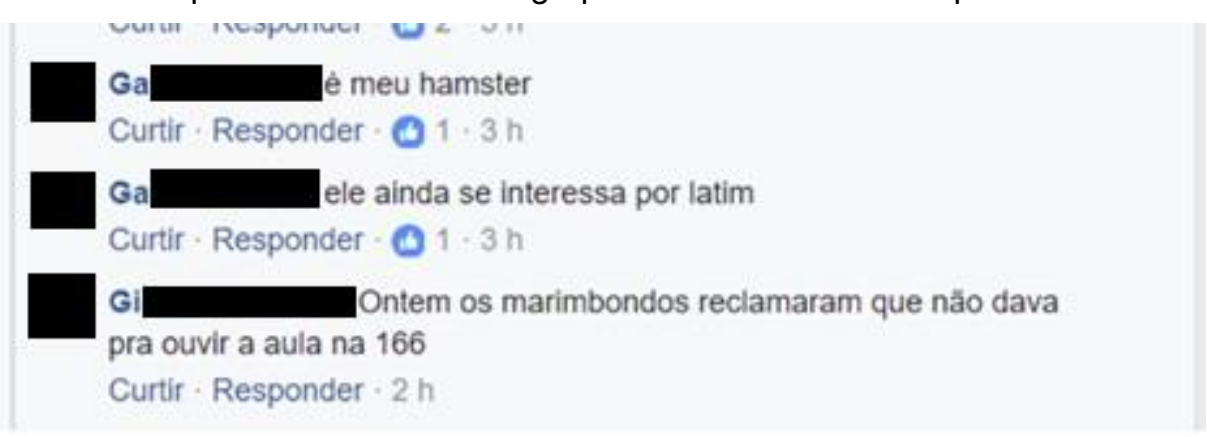

Fonte: Facebook (2017)

A discussão entre os alunos continua e outro participante, I , também insere a foto de seu animal de estimação e como o animal, reage diante da situação dos alunos barulhentos. Após a publicação da foto do cachorro de I, os demais participantes começam a discutir sobre o cachorro. 
Figura 169: Exemplo de descortesia no grupo de Letras/USP no Inquérito 2

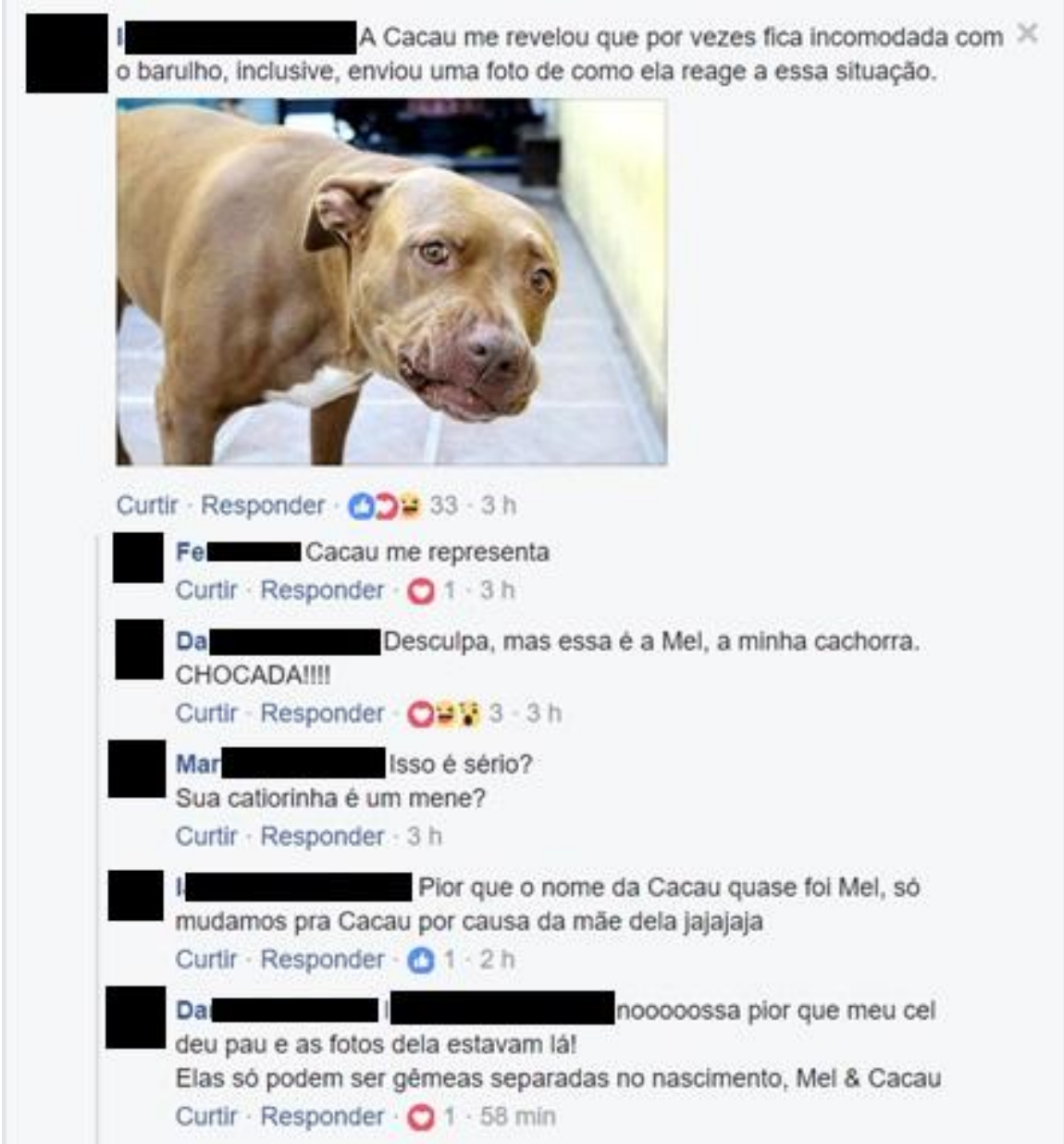

Giu Meu cachorro quer saber por que fazer silêncio na sala $X$ de leitura pra năo atrapalhar os coleguinhas se tem gente literaimente GRITANDO bem na porta

Curtif - Responder - $0213 \cdot 3 \mathrm{~h}$

$\mathrm{Fe}$ A calopsita da minha vizinha sempre se perguntou qual a lógica psicodélica dissi Curtir-Responder - 1 - $3 \mathrm{~h}$

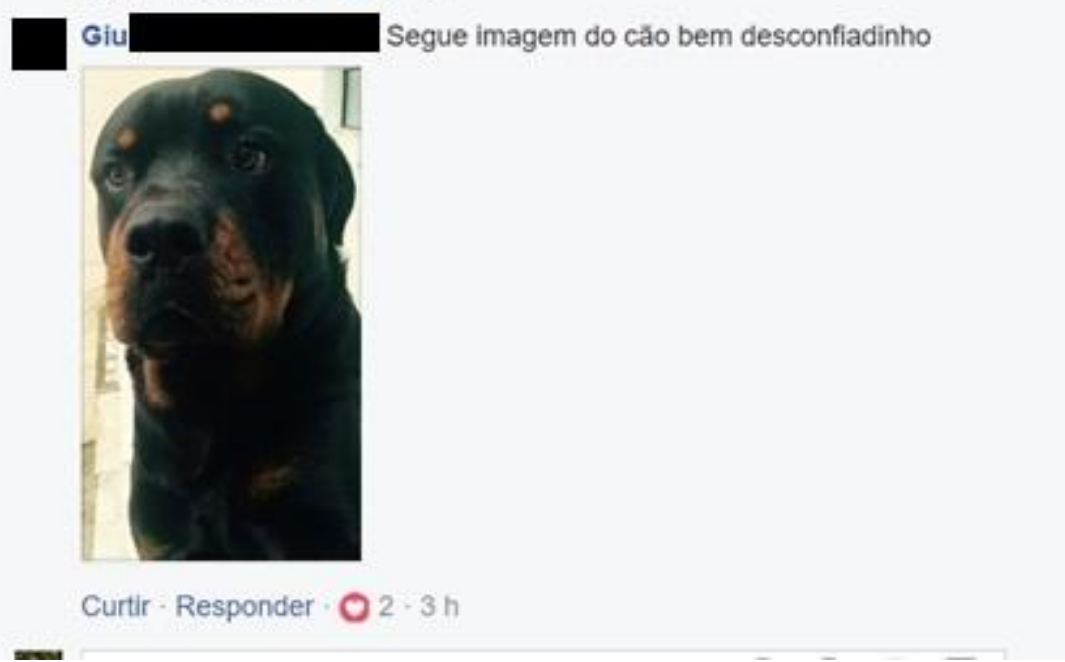

Fonte: Facebook (2017) 
As reclamações dos alunos continuam e seguem o mesmo padrão, com um emissor delegado representado por um animal e mais as críticas aos alunos barulhentos. Alguns estudantes enfatizam a crítica com o uso de maiúsculas, mas, mesmo assim, a discussão entre os discentes segue sem conflitos. Todos continuam seguindo o padrão de reclamações, mas com emissores delegados, com vários animais. Da, por exemplo, usa o seu animal de estimação, Luck, para se dirigir aos alunos de Letras que fazem barulho, com palavras de baixo-calão.

Figura 170: Exemplo de descortesia no grupo de Letras/USP no Inquérito 2

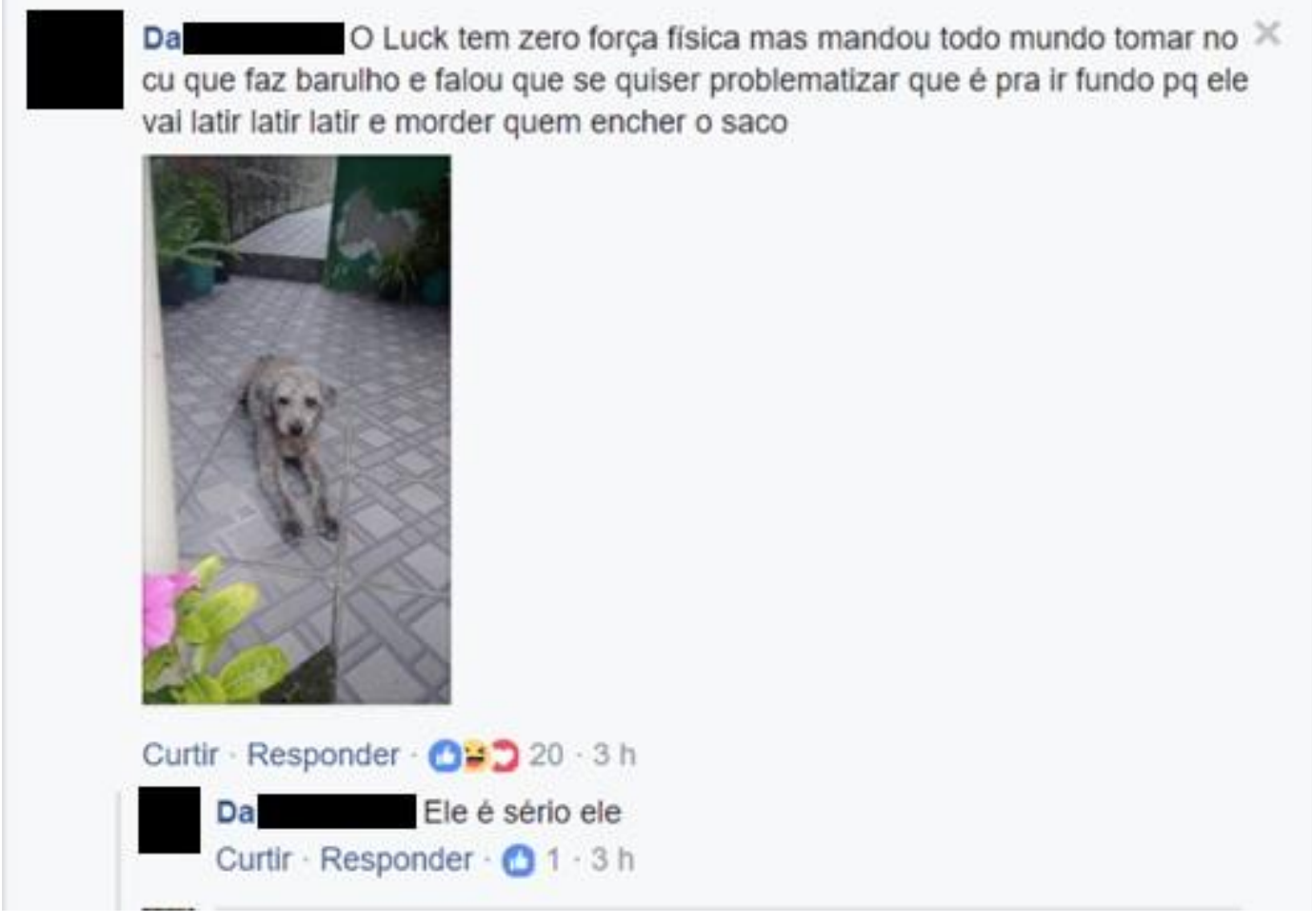

Fonte: Facebook (2017)

Da generaliza sua crítica a todos os alunos "O Luck tem zero força física mas mandou todo mundo tomar no cu", mas depois ameniza a ameaça dizendo que são aqueles que "faz barulho": "mas mandou todo mundo tomar no cu que faz barulho". Mesmo com um tom mais agressivo, ninguém entra em conflito com Da, apenas reagem com risos, curtidas e amei à sua postagem.

Ra reitera o problema apontado por $\mathbf{B}$, a responsável pela publicação, e, entre parênteses, afirma que, de fato, já presenciou ocorrências com barulho no local em que $\mathbf{B}$ reclama na publicação. 
Figura 171: Exemplo de descortesia no grupo de Letras/USP no Inquérito 2

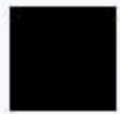

$\mathrm{Ra}$ minhas 2 gatas e 1 cachorra queria saber se è possivel os alunos da letras usp pararem de gritar tb e tocar violao na frente da tia bia em horario de aula (sim isso ja ocorreu na 102, professor tendo que dar aula com charlie brown ji de fundo)

tb seria bom se vcs $\mathrm{n}$ irritassem a prof maria celia de morfo de novo pq fiquei assustada

Curtir - Responder - 23 - 3 h - Editado

Fonte: Facebook (2017)

$\mathbf{R a}$, assim, também preserva a imagem de $\mathbf{B}$, ao afirmar que de fato $\mathbf{0}$ problema relatado existe e já atrapalhou professores. Em seu comentário, Ra ainda pede para os alunos não irritarem uma docente da faculdade, pois já ficou assustada com a reação da professora, em classe. A publicação de Ra recebe 23 curtidas, ou seja, os alunos estão cientes da situação relatada ou estão de acordo com a publicação de $\mathbf{R a}$. Após a postagem de Ra, Dan aparece para perguntar o que houve com a professora mencionada, pois suscitou a sua curiosidade.

Figura 172: Exemplo de descortesia no grupo de Letras/USP no Inquérito 2

Ra minhas 2 gatas e 1 cachorra queria saber se é possivel os alunos da letras usp pararem de gritar tb e tocar violao na frente da tia bia em horario de aula (sim isso ja ocorreu na 102, professor tendo que dar aula com charlie brown jr de fundo)

th seria bom se vcs $n$ irritassem a prof maria celia de morfo de novo pq fiquei assustada

Curtir-Responder - 23:3 h-Editado

Dan Minha cachorra Mel pediu pra vo contar qual foi a treta da Maria Celia assustada porque ela quer rir (a nāo ser que tenha sido sério)

Curtir-Responder - $2 \cdot 3 \mathrm{~h}$

Ra menina foram perguntar pra ela sobre os requerimentos ne, q tem vaga na turma etc, ai ela falou q nao ia aceitar. ai começaram a insistir pra ela aceitar e ela começou a ficar nervosa e falando alto $q$ ano passado ela fez isso pra resolver o problema dos alunos mas arranjou problema pra ela pq ela nao arrumava sala $p$ caber todo mundo em dia de prova ( $q$ ela deixa uma carteira de distancia entre os alunos), ela pedia emprestado pros outros professores mas eles nao emprestavam sala, que ela arranjou um problema enorme pra ela tentando ser boazinha com a gente...... mas no final das contas ela so ia aceitar quem ja tinha mandado requerimento e tava com o nome na lista de presença ja. dps ainda interromperam ela no meio da aula pra falar de algo do tipo, q nao tinha a ver com o conteudo, quando a aula tava fluindo e eu so pude ver o brilho de odio nos olhos dela

Curtir-Responder - $\mathbf{0}=5 \cdot 3 \mathrm{~h}$ 
Fonte: Facebook (2017)

Como se trata de uma pergunta invasiva, Dan tem o cuidado de também usar um emissor delegado "Minha cachorra Mel" e usar o recurso dos parênteses para deixar claro para Ra que não precisava ser obrigada a dizer o que tinha acontecido, caso tivesse sido algo sério em classe: "(a não ser que tenha sido sério)." Ra conta o que aconteceu. Ambas as publicações recebem curtidas e risos. Os comentários prosseguem seguindo o mesmo padrão de usar um emissor delegado, um animal, para fazer reclamações da faculdade e, até mesmo, na universidade, tal como acontece com a publicação de Mar: "Meu dog quer saber pq o pessoal que corta grama foi indicado a fazer isso as 8am"e Ra logo em seguida responde: "amifa isso pq vc nao viu no crusp". Figura 173: Exemplo de descortesia no grupo de Letras/USP no Inquérito 2

Mari Meu dog quer saber pq o pessoal que corta grama fol indicado a fazer isso as 8 am, sendo que a faculdade năo tem aula no periodo da tarde e eles poderiam cortar a grama sem atrapalhar a aula.

Curtir-Responder - $14 \cdot 3 \mathrm{~h}$

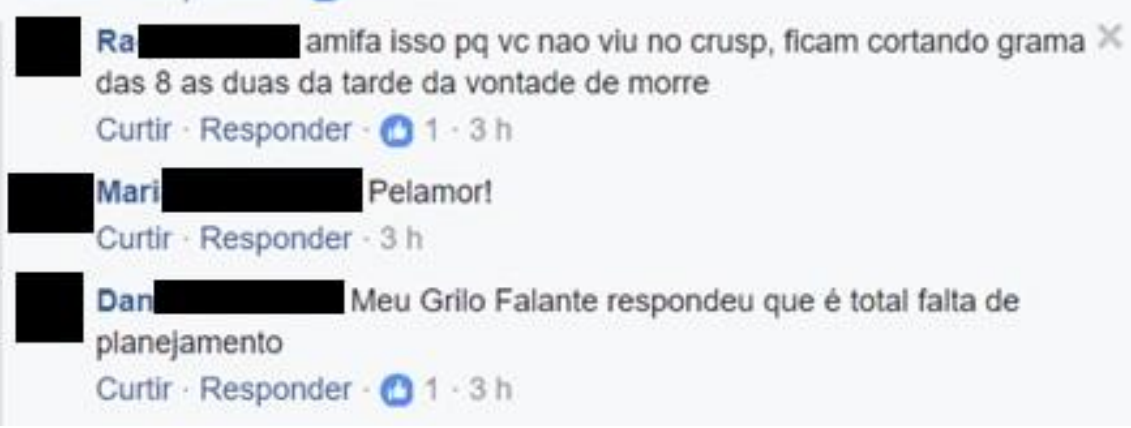

Fonte: Facebook (2017)

Os comentários prosseguem dando razão uns aos outros. Ar aparece na interação para fazer uma pergunta indireta: "Aproveitando a deixa, o meu capiroto queria saber se já pode matar geral essas pessoas".

Figura 174: Exemplo de descortesia no grupo de Letras/USP no Inquérito 2

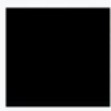

Ar Aproveitando a deixa, o meu capiroto queria saber se já pode matar geral essas pessoas.

Curtir-Responder- $3.3 \mathrm{~h}$

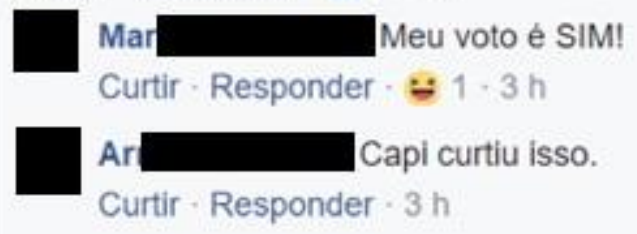

Fonte: Facebook (2017) 
Mar responde afirmativamente e Ar gosta da resposta, porém também usa um emissor delegado, "Capi [capiroto] curtiu isso". Logo em seguida, os participantes do grupo continuam interagindo como emissores delegados até que Ta aparece para reclamar.

Figura 175: Exemplo de descortesia no grupo de Letras/USP no Inquérito 2

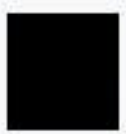

Ta_Leria lindo se as pessoas prestassem atenção pra não

bloquear a passagem dos corredores quando estão em grupinhos (no caso o animal encrenqueiro sou eu mesma, bj)

Curtir - Responder - OS $14 \cdot 3 \mathrm{~h}$

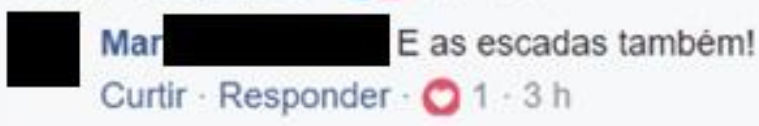

Fonte: Facebook (2017)

Desta vez, Ta não usa o recurso de emissor delegado para escapar de sua responsabilidade enunciativa, porém Ta, consciente de sua posição ameaçadora em relação aos demais, usa recursos atenuadores, tais como o uso do futuro do pretérito e do diminutivo: "Seria lindo se as pessoas prestassem atenção pra não bloquear a passagem dos corredores quando estão em grupinhos" e Ta se justifica, por meio dos parênteses, que o animal encrenqueiro seria ela mesma e ainda manda beijos para os demais participantes: "(no caso o animal encrenqueiro sou eu mesma, bj)". Apesar de Ta ter feito a crítica de modo mais direta, sem emissor delegado, ainda assim, a publicação recebe curtidas e reações de amei entre os participantes do grupo. Ma, inclusive, também colabora com a colocação de Ta. Neste sentido, Ju, igualmente, faz a mesma reclamação de Ta, porém usa um animal como emissor delegado e faz uso de maiúsculas para reforçar a sua crítica aos grupos que fazem barulho ou se aglomeram nas portas e corredores. 
Figura 176: Exemplo de descortesia no grupo de Letras/USP no Inquérito 2

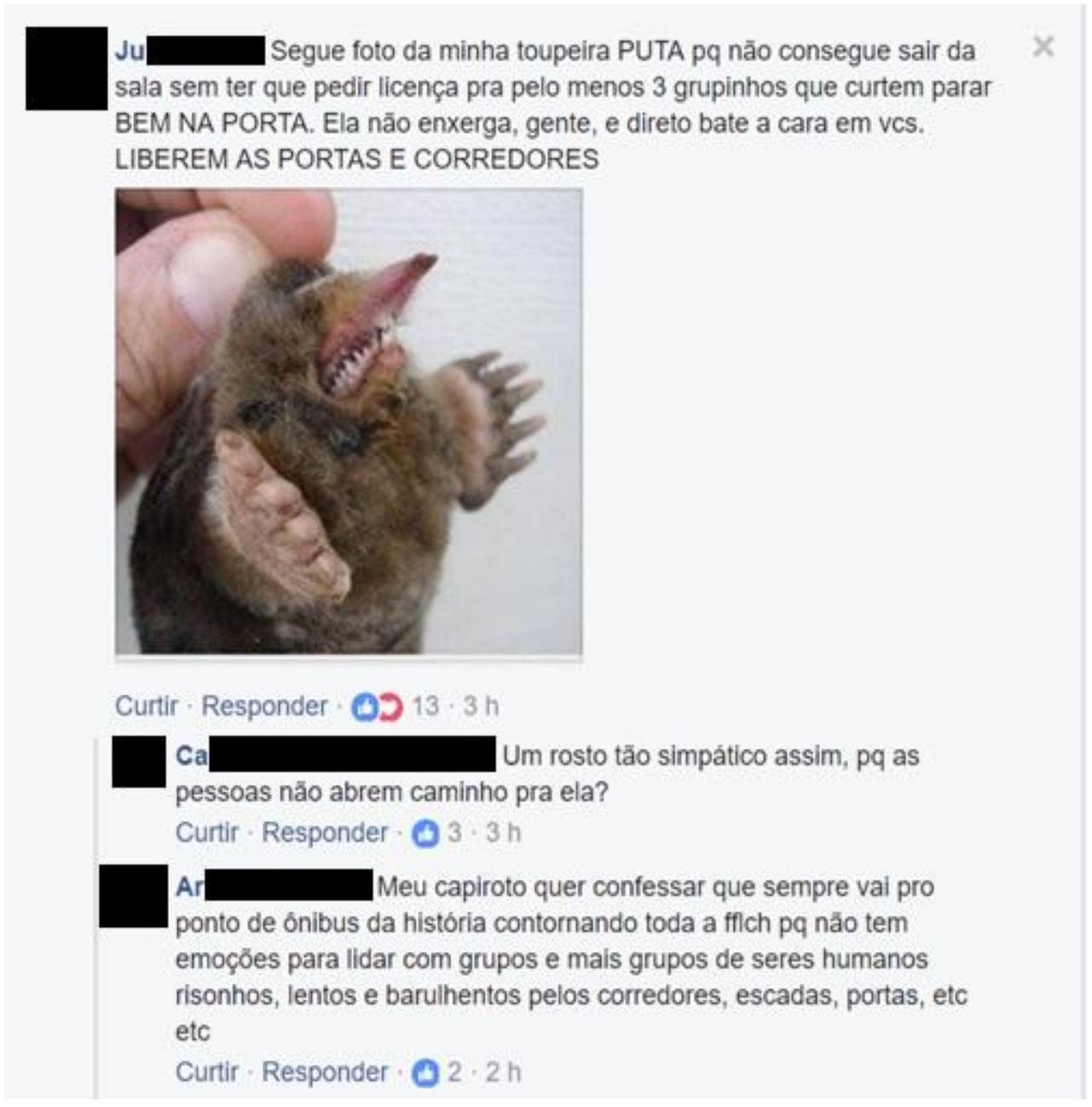

Fonte: Facebook (2017)

Apesar de usar como atenuador um emissor delegado, ela reforça a sua crítica por meio de maiúsculas, o que costuma ser mal visto nas redes sociais digitais. Apesar disso, o comentário de Ju recebe curtidas e reações de amei. Outros alunos comentam e dão razão a Ju.

Depois da continuidade de comentários do mesmo tipo, Bru aparece na publicação para se retratar, pois entende que já cometeu alguns erros apontados pelos colegas da faculdade. 
Figura 177: Exemplo de descortesia no grupo de Letras/USP no Inquérito 2

Bru minha cachorra queria dizer que ela já deu altos vacilos pelos corredores, mas ela sabe que vacilou e já ta tentando ser mais cuidadosa, ela pede desculpas sinceras aos colegas se ela já atrapalhou alguma vez

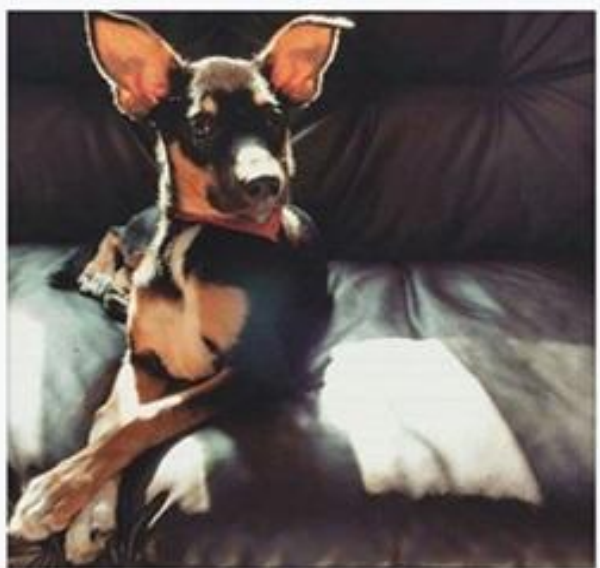

Fonte: Facebook (2017)

Por meio de um emissor delegado, Bru fica em posição vulnerável ao se confessar como uma das culpadas pelo problema "minha cachorra queria dizer que ela já deu altos vacilos pelos corredores", mas Bru pede desculpas aos participantes do grupo: " ela [a cachorra] pede desculpas sinceras aos colegas se ela já atrapalhou alguma vez". Depois do comentário de Bru, os participantes respondem, aceitando as desculpas e elogiam a iniciativa dela de se desculpar. O tópico é, assim, encerrado sem conflitos.

Figura 178: Exemplo de descortesia no grupo de Letras/USP no Inquérito 2

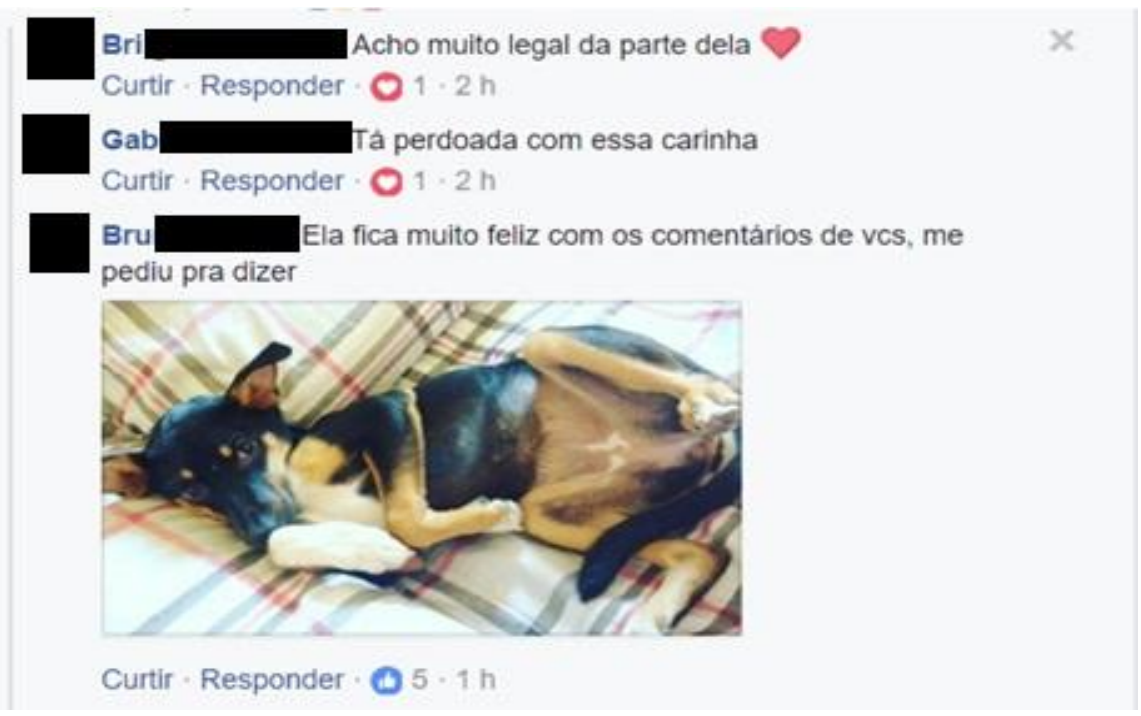

Fonte: Facebook (2017)

Diferentemente do Inquérito 1, os diálogos no Inquérito 2 acontecem sem conflitos, mesmo com críticas e reclamações. A estratégia de usar um emissor 
delegado, em especial um animal de estimação, e mais as estratégias linguísticas empregadas para atenuar ou intensificar um ato ameaçador à imagem dos locutores e interlocutores, funciona bem para se evitar manifestações descorteses. Não houve ataque direto entre os interactantes e o tópico foi encerrado com os alunos querendo participar ativamente, com críticas e com brincadeiras a respeito do comportamento dos alunos no curso. Por meio das categorias de condições de infração da cortesia de Leech (2014), resumiremos como se deu a manifestação da descortesia no Inquérito 2: 
Tabela 4: As categorias de condições de infração da estratégia geral da descortesia no Inquérito 2

\begin{tabular}{|c|c|c|c|c|c|}
\hline \multicolumn{6}{|c|}{ As categorias de condições de infração da estratégia geral da descortesia } \\
\hline $\begin{array}{l}\text { Violação da } \\
\text { máxima } \\
\text { (expressa de } \\
\text { forma } \\
\text { imperativa) }\end{array}$ & $\begin{array}{l}\text { Participantes } \\
\text { do grupo }\end{array}$ & $\begin{array}{c}\text { Par de } \\
\text { máximas } \\
\text { relacionadas }\end{array}$ & $\begin{array}{c}\text { Categorias das máximas } \\
\text { violadas }\end{array}$ & $\begin{array}{l}\text { Classes de atos de } \\
\text { fala }\end{array}$ & $\begin{array}{c}\text { Estratégias } \\
\text { linguísticas e } \\
\text { não- } \\
\text { linguísticas } \\
\text { /híbridas }\end{array}$ \\
\hline $\begin{array}{c}\text { (M1) Atribuir um } \\
\text { valor } \\
\text { desfavorável } \\
\text { aos interesses } \\
\text { do interlocutor } \\
\text { (Outro) } \\
\end{array}$ & Nenhum & \multirow[t]{2}{*}{$\begin{array}{l}\text { Generosidade/T } \\
\text { ato }\end{array}$} & Generosidade & Recusar, ameaçar & $\begin{array}{c}\text { Sem } \\
\text { ocorrências }\end{array}$ \\
\hline $\begin{array}{l}\text { (M2) Atribuir um } \\
\text { valor favorável } \\
\text { aos interesses } \\
\text { do EU (Locutor) }\end{array}$ & $\begin{array}{l}\text { Todos os } \\
\text { interactantes }\end{array}$ & & Tato & Ordem, demanda & $\begin{array}{c}\text { Emissor } \\
\text { delegado, uso } \\
\text { da } \\
\text { impessoalização }\end{array}$ \\
\hline $\begin{array}{l}\text { (M3) Atribuir um } \\
\text { valor } \\
\text { desfavorável às } \\
\text { qualidades do } \\
\text { interlocutor } \\
\text { (Outro) }\end{array}$ & $\begin{array}{c}\text { Todos os } \\
\text { interactantes }\end{array}$ & \multirow[t]{2}{*}{$\begin{array}{l}\text { Aprovação/ } \\
\text { Modéstia }\end{array}$} & Aprovação & $\begin{array}{l}\text { Insultar, reclamar, } \\
\text { falar mal do } \\
\text { interlocutor }\end{array}$ & $\begin{array}{c}\text { Emissor } \\
\text { delegado, uso } \\
\text { da } \\
\text { impessoalização } \\
\end{array}$ \\
\hline $\begin{array}{l}\text { (M4)Atribuir um } \\
\text { valor favorável } \\
\text { às qualidades } \\
\text { do EU (Locutor) }\end{array}$ & Sem ocorrências & & Modéstia & $\begin{array}{l}\text { Gabar-se, ser } \\
\text { complacente }\end{array}$ & $\begin{array}{c}\text { Sem } \\
\text { ocorrências }\end{array}$ \\
\hline $\begin{array}{l}\text { (M5) Atribuir um } \\
\text { valor } \\
\text { desfavorável às } \\
\text { obrigações do } \\
\text { EU (Locutor) } \\
\text { para com o } \\
\text { interlocutor } \\
\text { (Outro) }\end{array}$ & Sem ocorrências & \multirow[t]{2}{*}{ Obrigação } & Obrigação (ao interlocutor) & $\begin{array}{c}\text { Recusar } \\
\text { agradecimentos ou } \\
\text { desculpas }\end{array}$ & $\begin{array}{c}\text { Sem } \\
\text { ocorrências }\end{array}$ \\
\hline $\begin{array}{l}\text { (M6) Atribuir um } \\
\text { valor favorável } \\
\text { às obrigações } \\
\text { do interlocutor } \\
\text { para com o } \\
\text { Locutor } \\
\end{array}$ & Bru & & Obrigação (ao Locutor) & $\begin{array}{l}\text { Agradecer ou } \\
\text { desculpar-se }\end{array}$ & $\begin{array}{l}\text { Pedido de } \\
\text { desculpas por } \\
\text { meio de um } \\
\text { emissor } \\
\text { delegado } \\
\end{array}$ \\
\hline $\begin{array}{l}\text { (M7) Atribuir um } \\
\text { valor } \\
\text { desfavorável às } \\
\text { opiniões do } \\
\text { interlocutor } \\
\text { (Outro) }\end{array}$ & Sem ocorrências & \multirow{2}{*}{ Opinião } & Concordância & $\begin{array}{l}\text { Discordar, } \\
\text { contradizer }\end{array}$ & $\begin{array}{c}\text { Sem } \\
\text { ocorrências }\end{array}$ \\
\hline $\begin{array}{l}\text { (M8) Atribuir um } \\
\text { valor favorável } \\
\text { às opiniões do } \\
\text { Locutor (EU) }\end{array}$ & $\begin{array}{c}\text { Todos os } \\
\text { interactantes }\end{array}$ & & Opinião reticente & Ser opinativo & $\begin{array}{c}\text { Uso de } \\
\text { emissor } \\
\text { delegado para } \\
\text { expressar a } \\
\text { opinião } \\
\end{array}$ \\
\hline $\begin{array}{c}\text { (M9) Atribuir um } \\
\text { valor } \\
\text { desfavorável } \\
\text { aos sentimentos } \\
\text { do interlocutor } \\
\text { (Outro) }\end{array}$ & Sem ocorrências & \multirow[t]{2}{*}{ Sentimento } & Simpatia & $\begin{array}{l}\text { Expressar antipatia } \\
\text { ao interlocutor }\end{array}$ & $\begin{array}{c}\text { Sem } \\
\text { ocorrências }\end{array}$ \\
\hline $\begin{array}{c}\text { (M10) Atribuir } \\
\text { um valor } \\
\text { favorável aos } \\
\text { sentimentos do } \\
\text { Locutor (EU) }\end{array}$ & $\begin{array}{l}\text { Todos os } \\
\text { interactantes }\end{array}$ & & Sentimento reticente & $\begin{array}{l}\text { Reclamar, } \\
\text { resmungar }\end{array}$ & $\begin{array}{c}\text { Uso de } \\
\text { emissor } \\
\text { delegado para } \\
\text { reclamar } \\
\end{array}$ \\
\hline
\end{tabular}




\section{INQUÉRITO 3}

$\mathrm{O}$ assunto a ser abordado neste Inquérito 3 diz respeito a outro assunto polêmico no curso de Letras: greves e paralisações de docentes e discentes. J faz uma publicação no grupo de Letras no Facebook apoiando-se, provavelmente, em um documento oficial da faculdade. Percebe-se a sua preocupação em preservar a sua imagem no que diz respeito à veracidade da informação dada aos demais alunos e, assim, manter uma imagem pessoal engajada nas causas estudantis. Isso fica expresso, sobretudo, quando $\mathbf{J}$ salienta que os dados são "direto da Diretoria". Para não deixar margem de dúvidas, ela passa a fonte da informação, ou seja, o e-mail oficial da faculdade.

Figura 179: Exemplo de descortesia no grupo de Letras/USP no Inquérito 3

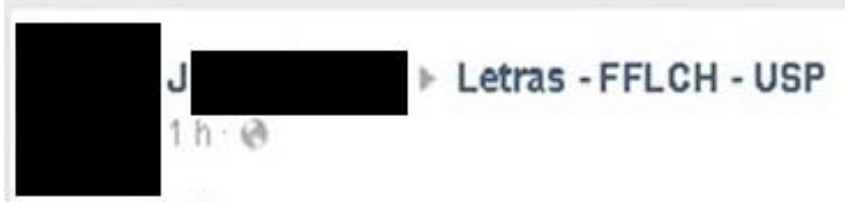

Informaçōes direto da Diretoria - para confirmar, escreva para ffich [arroba] usp [ponto] br: se NÓS, ESTUDANTES, entrarmos outubro em greve, 0 semestre 20142 (o presente) será obrigatoriamente cancelado e a Direçăo da Unidade vai ter que se virar nos 30 pra resolver a situaçăo (como? Năo sei. Problema deles).

Se NÓS, ESTUDANTES, sairmos de greve antes de outubro, a burocracia pode dar um mês de aulinhas de mentirinha, com conteúdo de mentininha e o método de avaliaçăo que bem entender, com o prazo que bem entender (provavelmente urna correna louca do cu, afinal, os professores querem mesmo é sair de férias). Neste caso, a Diretoria fica suave no rolê e não tem que se responsabilizar por nada.

Opçẵo 1: possivel dignidade e conteúdo de verdade para os alunos. \#Comovaiser? \#MaseoCicloBásico? Nẵo sei, problema da Diretoria, mas 0 direito fica garantido para os estudantes e ninguérn vai sair reprovando os alunos em atitude de gracinha da docência fascista. 
Opçã̃o 2: burocracia rindo da nossa cara e indo passar férias nas Bahamas + dois semestres de fachada para os alunos (20141 e 20142) = ano letivo perdido em conteúdo, decência e dignidade, ou seja, professores de boae você, que passou na FUVEST, no ranqueamento etc. e luta para se manter em SP, com um ano da sua vida perdido nas costas - no sentido da sua formação em Letras.

Escolham. Segunda-feira tem Assembleia da Letras. Compareçam e façam valer a voz de vocês.

J'aime : Commenter Partager

B 11 personnes aiment ça.

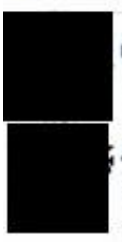

C opção 2 pq eu me formo com ela

h-Modifié-J'aime - B 5

Parabéns pela sua consideração à coletividade,

é por causa de gente como você que essa porra está sucateada do jeito que

está. Vai lá, pega seu papetzinho diploma e cai no mundão com ele, depois

vem contar aqui pra gente 0 que foi que deu. Boa sorte.

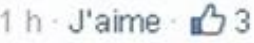

Fonte: Facebook (2015)

Apesar das informações serem da Diretoria, a estudante repassa os dados com suas próprias palavras, dando destaque, em letras maiúsculas, aos estudantes, grupo do qual também faz parte: "se, NÓS, ESTUDANTES, entrarmos outubro em greve (...)". O uso das maiúsculas funciona, sobretudo, para destacar o papel dos estudantes e $\mathbf{J}$, inclui-se neste discurso, "NÓS, ESTUDANTES". A possibilidade de se incluir em seu próprio discurso é um recurso atenuador para a realização do pedido que $\mathbf{J}$ fará ao final de sua publicação, pois $\mathbf{J}$ se insere no mesmo grupo que deve fazer o que ela pede.: "Escolham. Segunda-feira tem Assembleia da Letras. Compareçam e façam valer a voz de vocês.".

$\mathrm{Na}$ publicação, nota-se que $\mathbf{J}$ mantém seu discurso em um registro coloquial, ironizando a burocracia com o uso de diminutivos, tais como "aulinhas de mentirinha", "conteúdo de mentirinha", "atitude de gracinha"; de palavras de baixo calão, tal como "uma correria louca do cu"; e de expressões populares, como "ficar suave no rolê". J contrapõe, em seu discurso, a situação dos estudantes versus a burocracia da universidade, incluindo os professores, ou seja, restringe o seu discurso a um embate entre "nós" e "eles"

Em seguida, $\mathbf{J}$ oferece duas opções de escolha aos alunos. A primeira opção seria a continuidade da greve para uma "possível dignidade e conteúdo 
de verdade" e a segunda opção seria o fim da greve, com "dois semestres de fachada para os alunos", "ano letivo perdido em conteúdo, decência e dignidade". Percebe-se que $\mathbf{J}$ espera que os alunos escolham a primeira opção por meio de seu discurso, inclusive garante que, com a primeira opção, os alunos não serão prejudicados: “(...) mas o direito fica garantido para os estudantes e ninguém vai sair reprovando os alunos em atitude de gracinha da docência fascista".

Geralmente, a convergência de interesses faz que com que uma interação seja bem-sucedida, no entanto, percebe-se uma divergência de objetivos por parte dos interactantes durante o evento comunicativo em questão. Dessa forma, a interação entre os participantes do grupo on-line se torna conflituosa e abre espaço para a descortesia.

$\mathbf{J}$ espera convencer os demais participantes do grupo a se engajarem ao movimento de greve e, como não obtém a reação esperada, reage com descortesia, muitas vezes, com uma pseudocortesia expressa pela ironia. Isso fica evidente quando ela responde à intervenção ${ }^{34}$ do aluno C, que prefere a segunda opção porque necessita de seu diploma. A pseudocortesia se expressa, sobretudo, quando $\mathbf{J}$ faz um falso elogio a $\mathbf{C}$ : "Parabéns pela sua consideração à coletividade, C." Embora $\mathbf{J}$ faça um elogio a $\mathbf{C}$ com o uso de "parabéns", percebe-se, pelo contexto, que ela o ironiza, pois, logo em seguida, ela o critica, colocando-o como um dos responsáveis pela atual situação da faculdade: "é por causa de gente como você que essa porra está sucateada do jeito que está. " $A$ ironia continua com o uso do diminutivo "papelzinho", em vez do uso da palavra "diploma", ao qual ela mesma faz referência " diploma ", e desejando-o "Boa sorte". Pelo contexto, observa-se que se trata de uma pseudocortesia, pois não é boa sorte que ela deseja de fato para $\mathbf{C}$. A ofensa se torna um ato ameaçador à imagem de $\mathbf{C}$, o que o faz reagir com descortesia, pois ele percebe o tom irônico de J. Ela não modaliza o seu discurso para defender a sua opinião, recurso considerado como estratégia linguística cortês nas interações cotidianas e que atenuaria a imposição de seu ponto de vista.

\footnotetext{
${ }^{34}$ Neste trabalho, optamos por utilizar os termos "turno" e "intervenção" como sinônimos.
} 
Figura 180: Exemplo de descortesia no grupo de Letras/USP no Inquérito 3

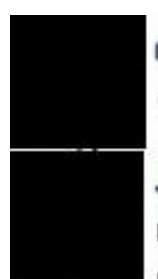

c opçăo 2 pq eu me formo com ela

h. Modifíé J'aime : B5

J Parabéns pela sua consideração à coletividade,

é por causa de gente como você que essa porra está sucateada do jeito que

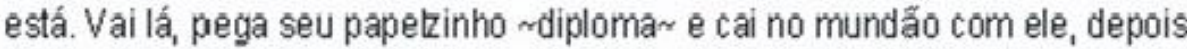
vem contar aqui pra gente o que foi que deu. Boa sorte.

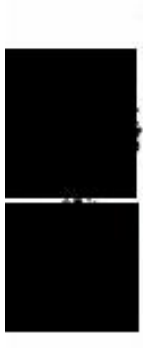

h. J'aime $B_{3}$

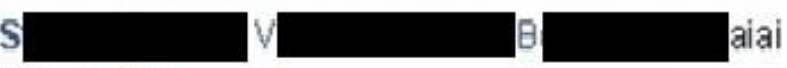

$1 \mathrm{~h}$ - J'aime

C moça, sabe 2007, 60 dias na reitoria?

sabe 2009 , bombas na usp?

săbe 2011, trétá côma a pm ná história?

nẵo venha me falar de coletividade... eu já participei mto do coletwo, agora eu preciso do meu "papelzinho"... lamento

$1 \mathrm{~h} \cdot \mathrm{J}$ 'aime $\cdot \mathrm{B}^{3}$

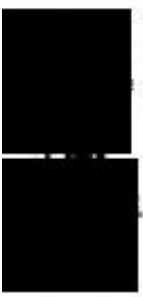

C e estou bem resolvido com isso, acredite...

$1 \mathrm{~h} \cdot \mathrm{J}$ 'aime

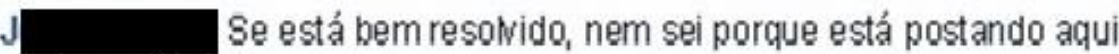

ainda, entẫo. Bjs

h. J'aime

Fonte: Facebook (2015)

A interação continua entre os dois e mais integrantes do grupo entram para participar da discussão. $\mathbf{S}$ aparece no diálogo entre $\mathbf{C}$ e $\mathbf{J}$, mas não se dirige diretamente a eles. A participante $\mathbf{S}$ marca e chama duas amigas pelo nome. $\mathrm{Na}$ rede social em questão, o fato de marcar o nome das pessoas faz com que elas consigam acompanhar o andamento da conversa e interagir também. $\mathbf{S}$ esboça a sua reação com uma interjeição apenas "aiai", prevendo, provavelmente, um possível conflito entre os participantes no grupo. $\mathbf{C}$ retoma o seu turno e se dirige diretamente a J pelo vocativo "moça". Aparentemente, ele se mostra descontente com a resposta de $\mathbf{J}$ e igualmente responde com ironia. Nota-se que a interpretação de um enunciado irônico também depende do interlocutor, o que desencadeia um trabalho cooperativo conversacional. Ele se defende da acusação de $\mathbf{J}$ sobre o fato de não pensar na coletividade e demonstra, por meio de seu turno, todo o seu histórico de participações dos movimentos de greve na instituição por meio de perguntas direcionadas a J. Além disso, C retoma o termo 
utilizado antes por J, "papelzinho", para se referir ao seu diploma. Logo em seguida, após o uso de reticências, pede desculpas: "lamento". Assim, C também tenta salvar a sua imagem, mostrando-se ativo nos atos estudantis da faculdade, fazendo uso também da ironia. Nota-se aqui, um caso de descortesia reativa, pois $\mathbf{C}$ não foi descortês com $\mathbf{J}$ em seu primeiro comentário, apenas discordou de J. Após o comentário irônico de J, C começa a se manifestar de maneira descortês. $\mathbf{C}$ rejeita a opinião de $\mathbf{J}$ e faz outra intervenção, mostrandose autoconfiante em relação à sua participação no movimento estudantil: "e estou bem resolvido com isso, acredite". J aparenta não gostar da intervenção de $\mathbf{C}$ e diz não saber o porquê ele ainda insiste em publicar uma resposta. Em seguida, ela encerra o seu turno com uma fórmula de despedida que seria gentil, se não fosse considerada o contexto da discussão dos dois: "Bjs", abreviação de "beijos". Dessa forma, percebe-se que ela pretende encerrar a participação de C na conversa de forma abrupta e autoritária, o que se configura como uma descortesia coercitiva. A discussão, no entanto, continua.

Figura 181: Exemplo de descortesia no grupo de Letras/USP no Inquérito 3

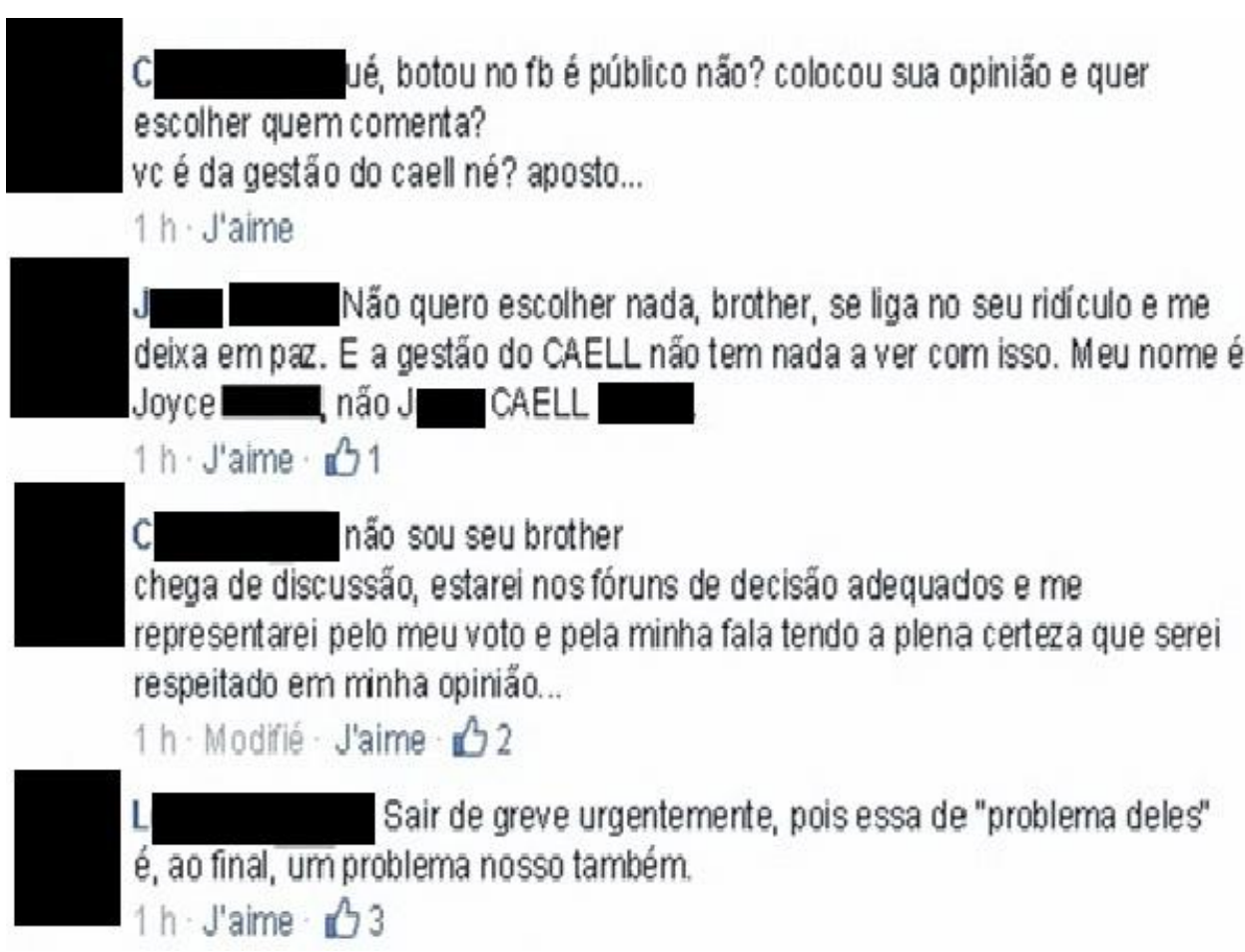

Fonte: Facebook (2015)

A discussão entre os dois se torna cada vez mais conflituosa. $\mathbf{C}$ não aceita o fato de $\mathbf{J}$ querer controlar quem participa da interação e a acusa de ser 
integrante do CA, Centro Acadêmico do curso de Letras. J responde se dirigindo a C com uma forma de tratamento, "brother". Ela o acusa de "ridículo" e pede para deixá-la em paz. Ela salienta que não faz parte do CA e se mostra como a única responsável pelo que é dito nas publicações. Em outro contexto, a forma de tratamento "brother" indicaria proximidade e intimidade com o interlocutor, mas, na interação em análise, ela adquire uma conotação negativa, irônica. C rejeita a proximidade do tratamento, pois prefere manter distância em relação à J: "não sou seu brother". Fica claro, em seu turno, que ele quer encerrar o conflito entre eles, ao dizer, "chega de discussão", mas, mesmo que ele queira o fim da interação, provoca $\mathbf{J}$, criticando-a de forma indireta, acusando-a de não respeitar a sua opinião: “ (...) me representarei pelo meu voto e pela minha fala tendo a plena certeza que serei respeitado em minha opinião...”. O uso das reticências ao final da frase também dá espaço para a interpretação de que se trata de uma forma indireta e, do mesmo modo, representa uma deixa para que a interação continue, ou seja, ele intensifica o conflito ao deixar em aberto a discussão e a crítica em relação à J. A partir desse momento, entra outro aluno na interação, $\mathbf{L}$, e, embora ele não faça uma defesa direta a $\mathbf{C}$, também é partidário da ideia de $\mathbf{C}$ de encerrar a greve o mais rápido possível: "Sair de greve urgentemente (...)". L, inclusive, retoma a fala de $\mathbf{J}$ em seu discurso em prol da greve, pois é contra a ideia de que esse é um problema apenas da Diretoria “(...) pois essa de "problema deles" é, ao final, um problema nosso também". J inicia, assim, um outro turno, agora dirigido a $\mathbf{L}$. Ela ignora, momentaneamente, o turno de $\mathbf{C}$. 
Figura 182: Exemplo de descortesia no grupo de Letras/USP no Inquérito 3
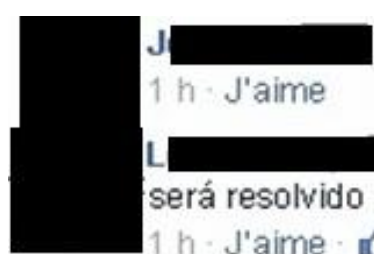

cê sabe ler?

Enqto existir esse pensamento de "nós versus eles" nada será resolvido e construído de verdade.

J'aime $B_{3}$

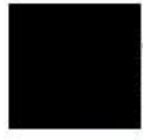

considera o Facebook um fórum de decisăo ou foi só má interpretação minha?

De repente no meu post eu estou sugerindo justamente que todos vão à

Assembleia na segunda, você está com analfabetismo funcional?

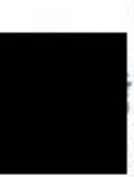

$1 \mathrm{~h}$ - J'aime

c c c tá entrevendo coisa demais heim moça.... ahuahauah

fo é pra falar merda, vc vem aqui, fala merda, eu venho aqui, respondo merda e

a gente fica nesse chorume.... hahahahaha

h. J'aime $\mathbb{2} 2$

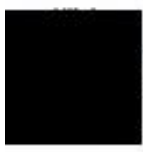

você já foi lá na ADM FFLCH alguma vez na

sua vida como aluno de Letras corversar com os Diretores sobre essa questấo do "nós versus eles" pra dizer pra eles LARGAREM MÃO dessa palhaçada, pois isso, precisamente, năo leva a nada? Eu fui.

$1 \mathrm{~h} \cdot \mathrm{J}$ 'aime $\mathbb{B} 2$

Fonte: Facebook (2015)

Para se dirigir ao outro aluno, $\mathbf{J}$ marca o nome de $\mathbf{L}$, usando o recurso da rede social para que ele veja de fato a sua resposta, ou seja, $\mathbf{J}$ especifica o seu interlocutor, já que na rede social digital há vários receptores indiretos. J mantém a sua descortesia com esse participante, fato que até então se restringia a $\mathbf{C}$. Ela interage com L, fazendo uma pergunta direta e agressiva "cê sabe ler?", ameaçando a imagem pública de $\mathbf{L}$. Diferentemente de $\mathbf{C}$, o turno de $\mathbf{J}$ com $\mathbf{L}$ se caracteriza majoritariamente pela descortesia, ao passo que a interação entre $\mathbf{C}$ e $\mathbf{J}$ combinava a descortesia com a pseudocortesia. A descortesia de $\mathbf{J}$, no entanto, é ignorada em um primeiro momento por L. Ele continua em defesa de seu ponto de vista e retoma mais uma vez as palavras de $\mathbf{J}$, que se baseia sobretudo na relação "nós versus eles", ou seja, os estudantes contra a Diretoria da faculdade. $\mathbf{J}$ retoma o seu turno, mas se dirige a $\mathbf{C}$, participante com quem ela havia interagido anteriormente, perguntando-lhe se está sendo mal interpretada, agora, no entanto, ela finaliza o seu turno com uma pergunta direta, tal como havia feito com L. A pergunta também é ofensiva, a descortesia é evidente: “(...) você está com analfabetismo funcional?”. C responde com humor, retomando os termos utilizados por $\mathbf{J}$ e reagindo com risos: "c tá entrevendo coisa demais heim moça...ahuahauah". Apesar do humor, $\mathbf{C}$ não deixa de marcar 
seu discurso com ironia a $\mathbf{J}$, a quem se dirige novamente com o termo "moça." Termina assim a discussão entre os dois. $\mathbf{J}$ não retoma mais a discussão com C, mas se dirige novamente a L, perguntando se ele já tentou diálogo com a Diretoria. Mesmo que ele ainda não responda, $\mathbf{J}$ afirma que já fez isso e, dessa forma, retoma sua imagem de engajada no movimento estudantil que já havia demonstrado em seu discurso, como se $\mathbf{J}$ tivesse autoridade no assunto. Essa estratégia de se mostrar ativa no movimento estudantil seria uma maneira de ressaltar as suas qualidades em oposição aos demais, que seriam alunos passivos e, dessa forma, seria um modo de recuperar a sua imagem de aluna engajada diante dos demais participantes, uma vez que ela havia se mostrado descortês na interação. Os conflitos, no entanto, não cessam.

Figura 183: Exemplo de descortesia no grupo de Letras/USP no Inquérito 3

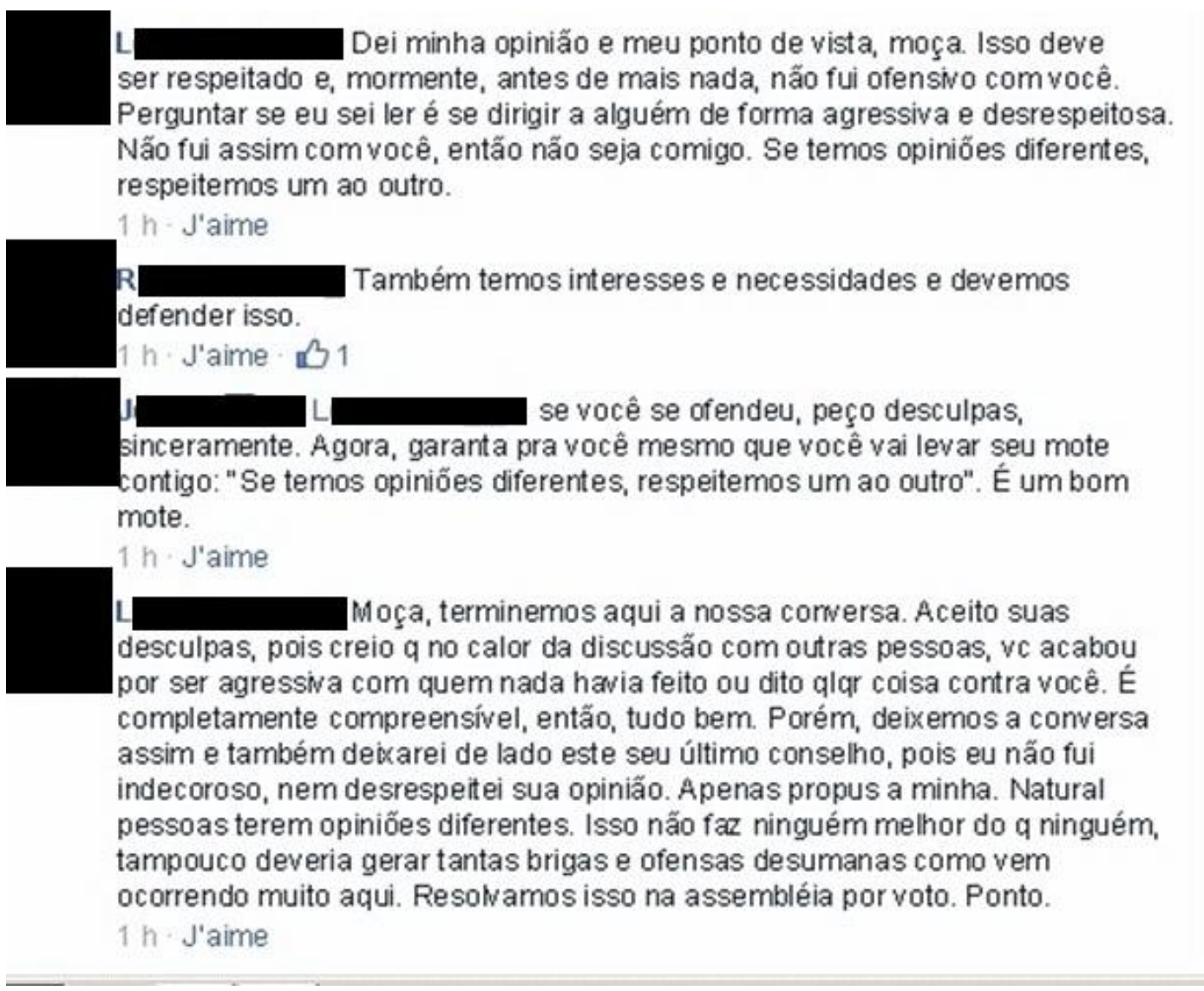

Fonte: Facebook (2015)

L retoma o seu turno com o termo antes utilizado por $\mathbf{C}$, "moça" e demonstra impaciência em relação à descortesia de J. Ele a acusa diretamente de ser ofensiva e desrespeitosa e afirma que deve ser respeitado mesmo que 
tenha ponto de vista diferente do dela: "Dei minha opinião e meu ponto de vista, moça. Isso deve ser respeitado e, mormente, antes de mais nada, não fui ofensivo com você. Perguntar se eu sei ler é se dirigir a alguém de forma agressiva e desrespeitosa. Não fui assim com você, então não seja comigo. Se temos opiniões diferentes, respeitemos um ao outro." $\mathbf{R}$, outro aluno, entra na discussão e não toma partido da discussão dos dois, apenas destaca que os estudantes devem defender os seus interesses e necessidades. J, por sua vez, dirige-se a $\mathbf{L}$ marcando-o em seu turno e, embora ela peça desculpas pela descortesia para reparar a imagem dela, $\mathbf{J}$ o provoca ironizando o que ele havia falado: “ (...) garanta pra você mesmo que você vai levar o seu mote contigo: 'Se temos opiniões diferentes, respeitemos um ao outro'. É um bom mote". Ele retoma o turno, acusando-a mais uma vez de ser desrespeitosa e encerra a conversa "Moça, terminemos aqui a nossa conversa. Aceito suas desculpas, pois creio q no calor da discussão com outras pessoas, vc acabou por ser agressiva (...) Resolvamos isso na assembleia por voto. Ponto”. J responde novamente com ironia, mas L ignora e abandona a discussão.

Figura 184: Exemplo de descortesia no grupo de Letras/USP no Inquérito 3

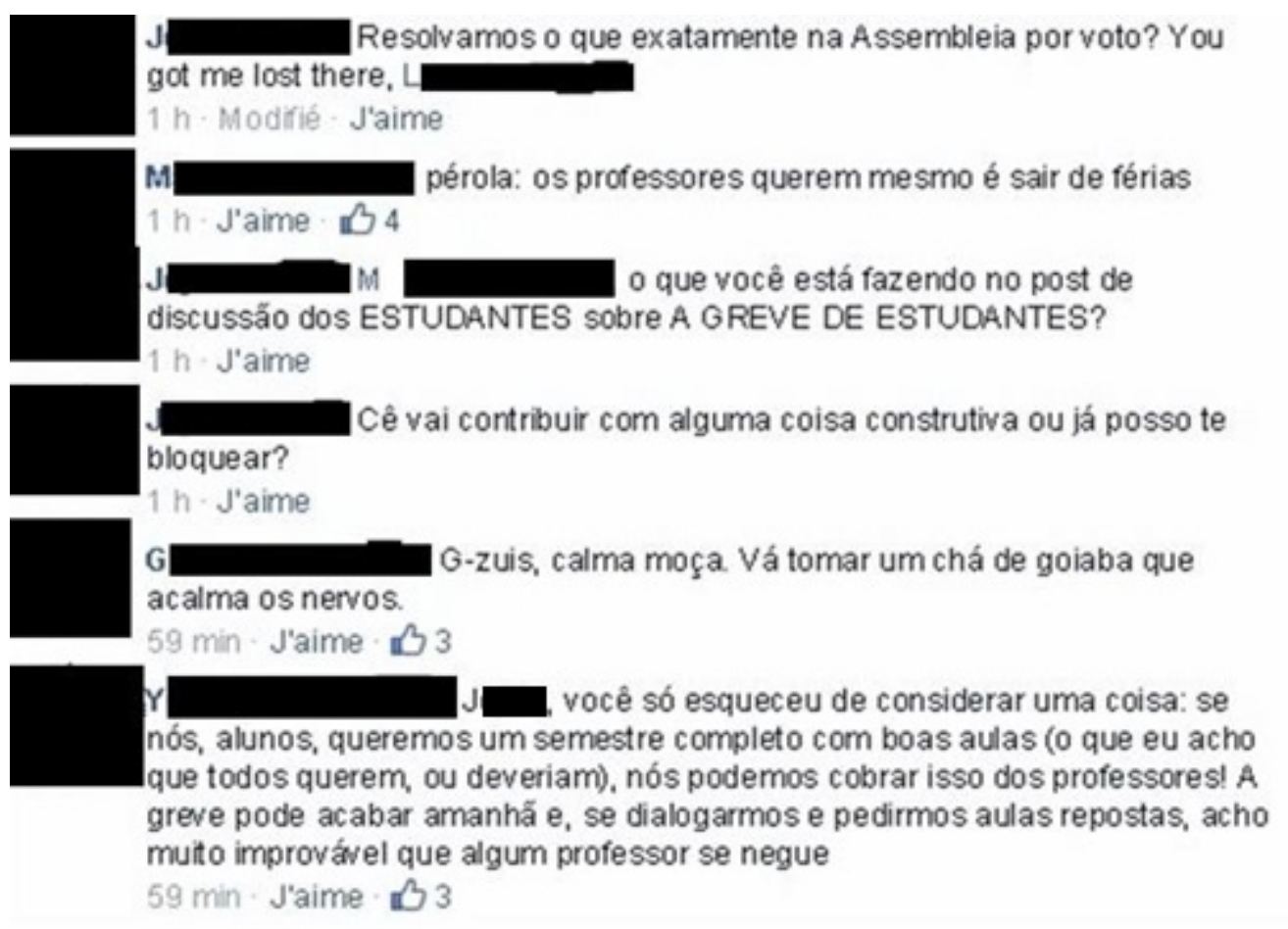

Fonte: Facebook (2015) 
É interessante observar a entrada de um professor da universidade na discussão. O professor, identificado por $\mathbf{M}$ no corpus, satiriza o discurso de $\mathbf{J}$ em relação ao que ela havia afirmado sobre os professores da instituição "pérola: os professores querem mesmo é sair de férias" e recebe a resposta imediata da aluna $\mathbf{J}$. A hierarquia professor-aluno é ignorada na rede social digital por $\mathbf{J}$, que não se sente intimidada em ameaçar a imagem do professor. Com o uso de maiúsculas, ela pede explicação ao professor pelo fato de ele participar da discussão, em uma publicação que, segundo ela, é dirigida aos estudantes: "M, o que você está fazendo no post de discussão dos ESTUDANTES sobre A GREVE DE ESTUDANTES?" Na linguagem virtual, o recurso das maiúsculas indica, geralmente, uma entonação de voz maior, um grito. $\mathbf{J}$ continua o seu turno ameaçando de bloqueá-lo na discussão, ou seja, embora ela não se sinta intimidada em ameaçar a face do professor, ela se sente incomodada com a participação dele na interação agindo com a descortesia coercitiva. J quer manter o seu poder e imagem de representante dos interesses estudantis e faz questão de marcar isso em seu discurso com a ameaça de interromper a participação do professor. A atitude, no entanto, não é bem vista pelos demais participantes do grupo. Começam, assim, várias intervenções de diferentes alunos preocupados em defender a face do professor. G, por exemplo, expressase com humor, pedindo calma e sugerindo que $\mathbf{J}$ tome "um chá de goiaba para acalmar os nervos". Com o tom de brincadeira, ele tenta apaziguar o conflito na interação. $\mathbf{Y}$, outra aluna, dirige-se diretamente a $\mathbf{J}$ e reclama do fato de ela não respeitar a presença do professor na discussão, uma vez que ele também é responsável pelo andamento das aulas. Outra participante, F, dirige-se também a $\mathbf{J}$, acusando-a de ser desrespeitosa com quem não compartilha a ideia de continuar a greve, seja aluno, seja professor. Observa-se que a imposição autoritária do ponto de vista de $\mathbf{J}$ não a leva a persuadir os alunos, e seu discurso em favor da greve tem um efeito contrário ao esperado. Isso se deve, sobretudo, aos atos descorteses e pseudocorteses expressos nas falas de $\mathbf{J}$. Os integrantes do grupo, que até então não estavam participando da interação, assumem uma posição preponderante contra $\mathbf{J}$.

Figura 185: Exemplo de descortesia no grupo de Letras/USP no Inquérito 3 


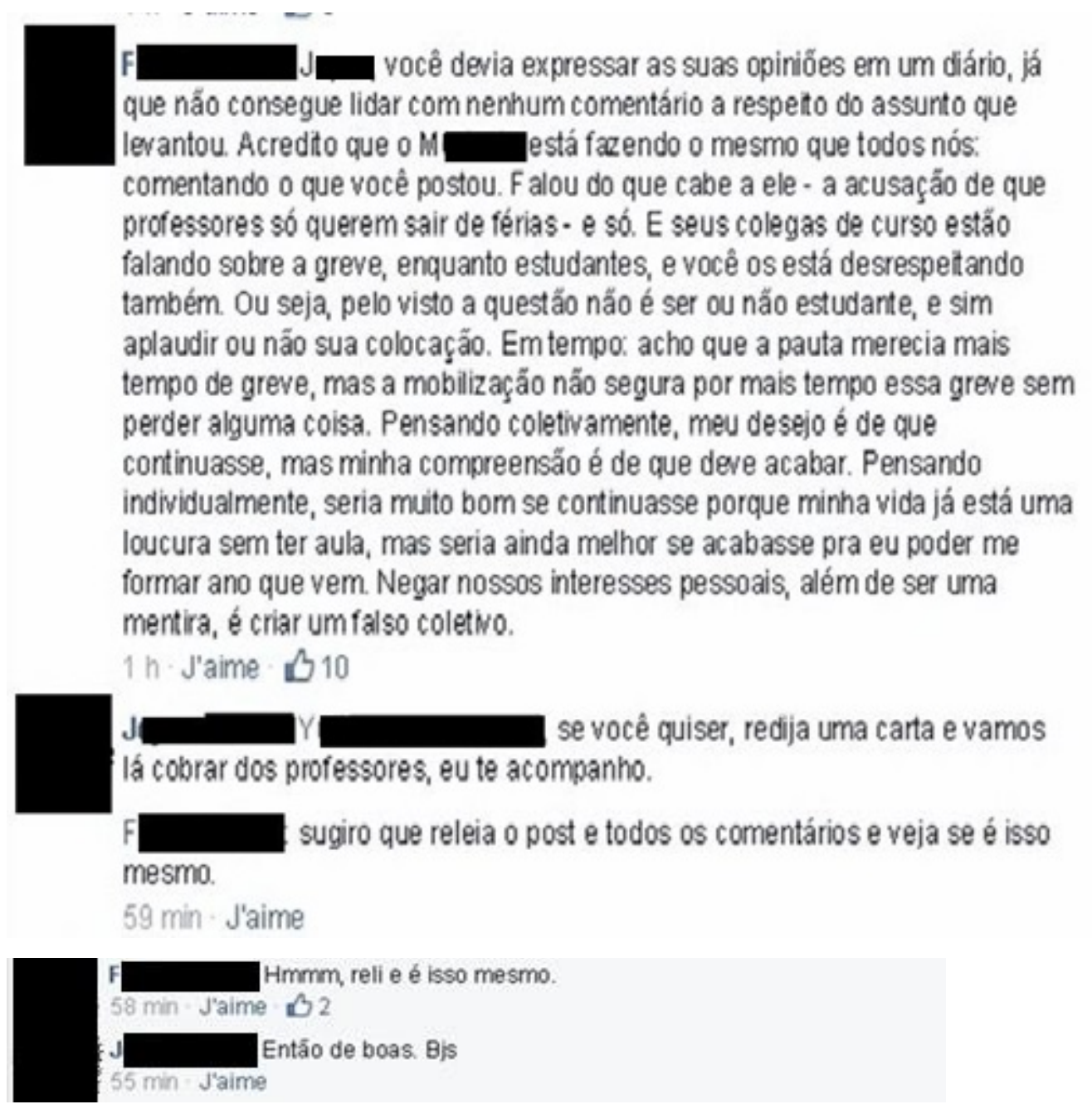

Fonte: Facebook (2015)

J retoma o turno e se dirige a $\mathbf{Y}$ e $\mathbf{F}$, agora de uma maneira menos agressiva. Ela pede, inclusive, para $\mathbf{F}$ reler a publicação para ver se não foi má interpretação do que ela havia afirmado. J adota, assim, outra estratégia na interação, diferente das acusações agressivas de "analfabetismo funcional" que havia feito com os outros participantes. Possivelmente, essa mudança de comportamento se deve ao número maior de participantes que estão contra o comportamento hostil que ela apresentou com os integrantes do grupo. $\mathbf{F}$ retoma o turno, demonstrando que leu bem a publicação e que não interpretou de maneira errônea. J responde aceitando, aparentemente, a intervenção de $\mathbf{F}$ e não se mostra disposta a discutir: "Então de boas. Bjs." Ela encerra o turno da mesma maneira que fez com os outros participantes, com "beijos" expressos pela abreviação "Bjs", forma que foi inserida de maneira irônica nas demais intervenções. Mesmo que ela não tenha sido descortês tal como o foi com os 
demais participantes, percebe-se que $\mathbf{J}$ ainda tenta manter 0 mesmo comportamento que havia apresentado antes, com o uso da pseudocortesia, uma vez que ela aparenta não ter intimidade o bastante para encerrar a conversa com "beijos" junto às participantes da discussão. $\mathbf{Y}$ também se mostra engajada no movimento estudantil, mas demonstra uma postura diferente de $\mathbf{J}$, preocupada com os dois lados, a questão burocrática e a questão estudantil. Outra aluna, $\mathbf{M i}$, também defende a figura do professor e reprova a atitude de $\mathbf{J}$ em querer excluí-lo.

Figura 186: Exemplo de descortesia no grupo de Letras/USP no Inquérito 3

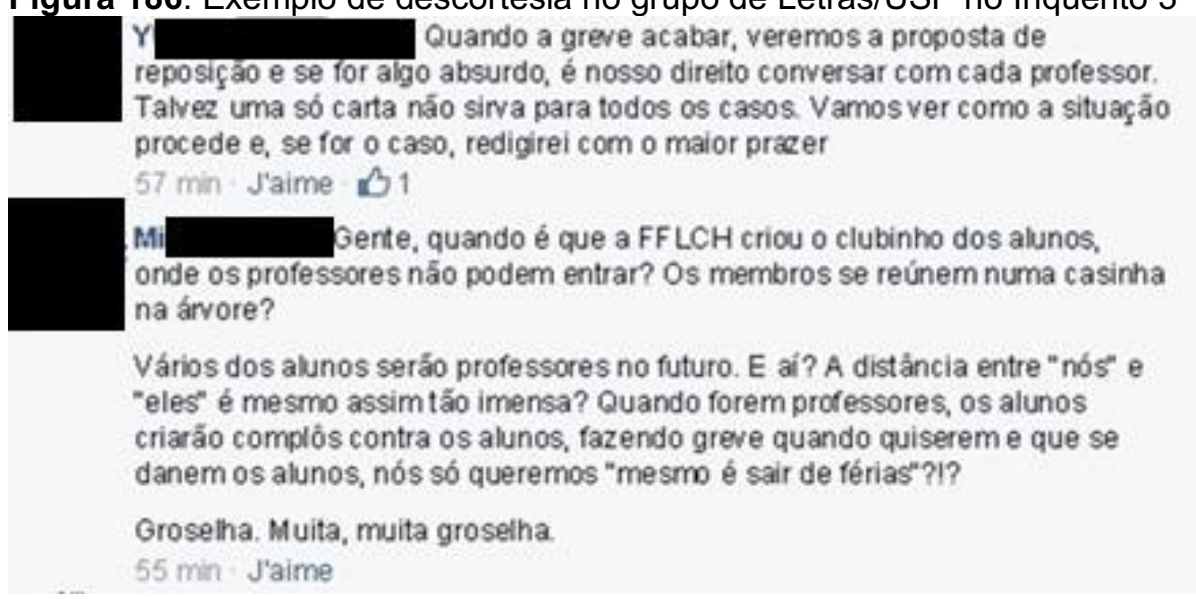

Fonte: Facebook (2015)

J, mais uma vez, tenta manter sua imagem engajada no movimento, querendo se mostrar experiente no assunto para $Y$ nas próximas interações. $A$ seguir, outro aluno, $\mathbf{G u}$, também entra na discussão apontando que prefere a opção dois, pois precisa também de seu diploma. J retoma a ironia e manda "beijos" e "boa sorte", expressões que ela já havia utilizado com C e L, com quem foi descortês. Além disso, ela intensifica a ironia com um tratamento carinhoso, "chérie". Gu entende a ironia, mas opta por não responder de maneira descortês e sim com uma pseudocortesia, agradecendo-lhe e, logo em seguida, usa um emoticon sorrindo. O uso do emoticon, na linguagem virtual, substitui, muitas vezes, os gestos ou as expressões faciais que faríamos em uma interação face a face. Mesmo sendo alvo de ironia, Gu tira proveito da situação, fingindo não compreender o tom irônico, anulando assim o efeito ameaçador de sua imagem pública. $\mathbf{J}$ também responde com o uso de um emoticon piscando, pois, ambos 
entendem a ironia de um e de outro. A tensão no evento comunicativo é anulada entre os dois e a conversação entre eles se encerra.

Figura 187: Exemplo de descortesia no grupo de Letras/USP no Inquérito 3

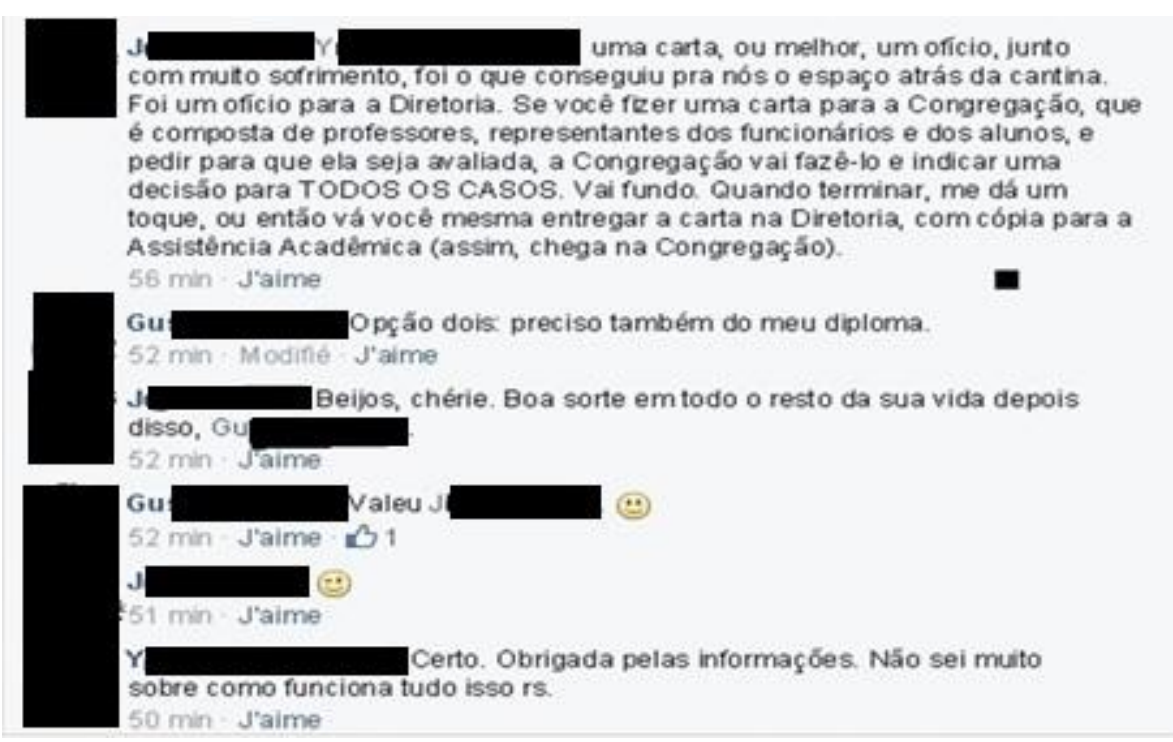

Fonte: Facebook (2015)

A interação continua com $\mathbf{Y}$, que também responde com a pseudocortesia, agradecendo J pelas informações, mas termina o seu turno com "rs", abreviação de "risos". Assim, o indicador paralinguístico típico da interação face a face é expresso também na conversação virtual e exerce a mesma função de uma interação de rotina, ou seja, depende do contexto para interpretarmos como deboche ou como um riso resultante de uma interação engraçada. No corpus em questão, percebe-se o uso de "risos" como deboche, pois $\mathbf{J}$ não é levada a sério no grupo devido às suas reações descorteses com os estudantes. Os alunos participantes do grupo conseguem inverter a posição de poder que até então era exercida por $\mathbf{J}$, utilizando-se dos mesmos recursos linguísticos empregados pela aluna para impor o seu ponto de vista. Dessa forma, a descortesia e a pseudocortesia na interação são responsáveis pela construção negativa da imagem de $\mathbf{J}$ e leva o discurso da aluna ao fracasso, pois ela não consegue convencer os demais estudantes a aceitarem o seu ponto de vista. 


\section{INQUÉRITO 3}

Tabela 5: As categorias de condições de infração da estratégia geral da descortesia no Inquérito 3

\begin{tabular}{|c|c|c|c|c|c|}
\hline \multicolumn{6}{|c|}{ As categorias de condições de infração da estratégia geral da descortesia } \\
\hline $\begin{array}{l}\text { Violação da } \\
\text { máxima } \\
\text { (expressa de } \\
\text { forma } \\
\text { imperativa) }\end{array}$ & $\begin{array}{l}\text { Participantes } \\
\text { do grupo }\end{array}$ & $\begin{array}{c}\text { Par de } \\
\text { máximas } \\
\text { relacionadas }\end{array}$ & $\begin{array}{c}\text { Categorias das máximas } \\
\text { violadas }\end{array}$ & $\begin{array}{c}\text { Classes de atos de } \\
\text { fala }\end{array}$ & $\begin{array}{c}\text { Estratégias } \\
\text { linguísticas e } \\
\text { não- } \\
\text { linguísticas } \\
\text { /híbridas }\end{array}$ \\
\hline $\begin{array}{c}\text { (M1) Atribuir um } \\
\text { valor } \\
\text { desfavorável } \\
\text { aos interesses } \\
\text { do interlocutor } \\
\text { (Outro) }\end{array}$ & $\mathbf{J}$ & \multirow[t]{2}{*}{$\begin{array}{l}\text { Generosidade/T } \\
\text { ato }\end{array}$} & Generosidade & Recusar, ameaçar & $\begin{array}{l}\text { Ironia, uso de } \\
\text { maiúsculas, } \\
\text { uso de } \\
\text { pseudcortesia }\end{array}$ \\
\hline $\begin{array}{l}\text { (M2) Atribuir um } \\
\text { valor favorável } \\
\text { aos interesses } \\
\text { do EU (Locutor) }\end{array}$ & $\mathbf{J}$ & & Tato & Ordem, demanda & $\begin{array}{c}\text { Uso de } \\
\text { perguntas, } \\
\text { uso do } \\
\text { imperativo }\end{array}$ \\
\hline $\begin{array}{l}\text { (M3) Atribuir um } \\
\text { valor } \\
\text { desfavorável às } \\
\text { qualidades do } \\
\text { interlocutor } \\
\text { (Outro) }\end{array}$ & $\begin{array}{c}\text { Todos os } \\
\text { interactantes }\end{array}$ & \multirow{2}{*}{$\begin{array}{l}\text { Aprovação/ } \\
\text { Modéstia }\end{array}$} & Aprovação & $\begin{array}{l}\text { Insultar, reclamar, } \\
\text { falar mal do } \\
\text { interlocutor }\end{array}$ & $\begin{array}{l}\text { Ironia, uso de } \\
\text { maiúsculas, } \\
\text { uso de } \\
\text { perguntas }\end{array}$ \\
\hline $\begin{array}{l}\text { (M4) Atribuir um } \\
\text { valor favorável } \\
\text { às qualidades } \\
\text { do EU (Locutor) }\end{array}$ & $\mathbf{J}$ & & Modéstia & $\begin{array}{l}\text { Gabar-se, ser } \\
\text { complacente }\end{array}$ & $\begin{array}{l}\text { Uso de } \\
\text { perguntas, } \\
\text { experiência } \\
\text { pessoal como } \\
\text { argumento }\end{array}$ \\
\hline $\begin{array}{c}\text { (M5) Atribuir um } \\
\text { valor } \\
\text { desfavorável às } \\
\text { obrigações do } \\
\text { EU (Locutor) } \\
\text { para com o } \\
\text { interlocutor } \\
\text { (Outro) }\end{array}$ & Sem ocorrências & \multirow[t]{2}{*}{ Obrigação } & Obrigação (ao interlocutor) & $\begin{array}{c}\text { Recusar } \\
\text { agradecimentos ou } \\
\text { desculpas }\end{array}$ & $\begin{array}{c}\text { Sem } \\
\text { ocorrências }\end{array}$ \\
\hline $\begin{array}{l}\text { (M6) Atribuir um } \\
\text { valor favorável } \\
\text { às obrigações } \\
\text { do interlocutor } \\
\text { para com o } \\
\text { Locutor }\end{array}$ & $\mathbf{J}$ e $\mathbf{L}$ & & Obrigação (ao Locutor) & $\begin{array}{l}\text { Agradecer ou } \\
\text { desculpar-se }\end{array}$ & $\begin{array}{c}\text { Uso de } \\
\text { moderadores }\end{array}$ \\
\hline $\begin{array}{l}\text { (M7) Atribuir um } \\
\text { valor } \\
\text { desfavorável às } \\
\text { opiniões do } \\
\text { interlocutor } \\
\text { (Outro) } \\
\end{array}$ & $\begin{array}{c}\text { Todos os } \\
\text { interactantes }\end{array}$ & \multirow[t]{2}{*}{ Opinião } & Concordância & $\begin{array}{l}\text { Discordar, } \\
\text { contradizer }\end{array}$ & $\begin{array}{c}\text { Uso de ironia, } \\
\text { pseudocortesi } \\
\text { a }\end{array}$ \\
\hline $\begin{array}{l}\text { (M8) Atribuir um } \\
\text { valor favorável } \\
\text { às opiniões do } \\
\text { Locutor (EU) }\end{array}$ & Sem ocorrências & & Opinião reticente & Ser opinativo & $\begin{array}{c}\text { Sem } \\
\text { ocorrências }\end{array}$ \\
\hline $\begin{array}{l}\text { (M9) Atribuir um } \\
\text { valor } \\
\text { desfavorável } \\
\text { aos sentimentos } \\
\text { do interlocutor } \\
\text { (Outro) }\end{array}$ & Todos contra $\mathbf{J}$ & \multirow[t]{2}{*}{ Sentimento } & Simpatia & $\begin{array}{l}\text { Expressar antipatia } \\
\text { ao interlocutor }\end{array}$ & Uso de ironia \\
\hline $\begin{array}{l}\text { (M10) Atribuir } \\
\text { um valor } \\
\text { favorável aos } \\
\text { sentimentos do } \\
\text { Locutor (EU) }\end{array}$ & Sem ocorrências & & Sentimento reticente & $\begin{array}{l}\text { Reclamar, } \\
\text { resmungar }\end{array}$ & $\begin{array}{c}\text { Sem } \\
\text { ocorrências }\end{array}$ \\
\hline
\end{tabular}




\section{INQUÉRITO 4}

Figura 188: Exemplo de descortesia no grupo de Letras/USP no Inquérito 4
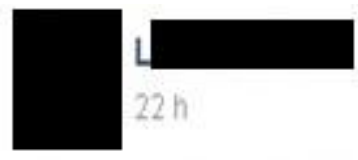

Pessoal, vocês poderiam nos ajudar com 3 minutinhos para responder a uma pesquisa da facu? Valeu!

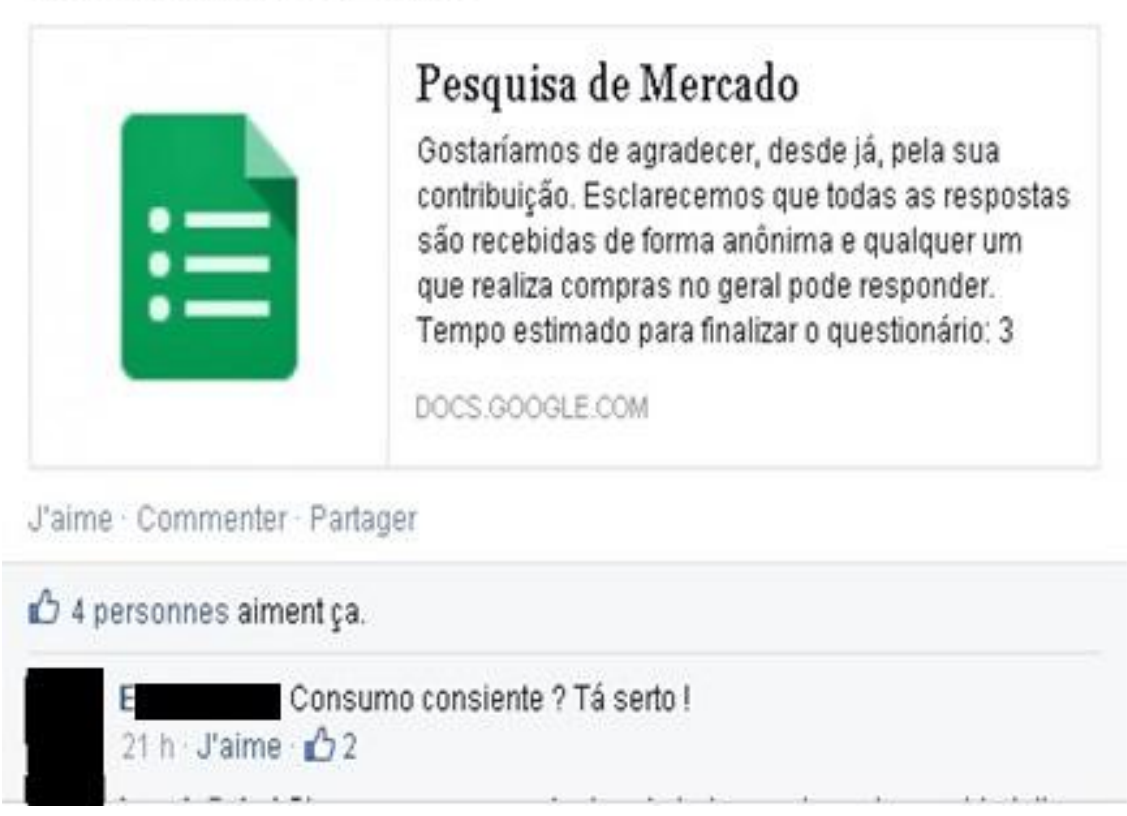

Fonte: Facebook (2015)

L faz um pedido de ajuda no grupo do curso de Letras para que os alunos do grupo respondam um questionário para uma pesquisa da faculdade. Para realizar a sua solicitação, $\mathbf{L}$ aborda os alunos do grupo com o uso do futuro do pretérito e agradece antecipadamente, atenuando assim um possível risco de ameaça à sua imagem e à imagem dos participantes do grupo: "Pessoal, vocês poderiam nos ajudar com 3 minutinhos para responder a uma pesquisa da facu? Valeu!". L também enfatiza o tempo a ser gasto para responder a pesquisa com o uso do diminutivo "3 minutinhos" e, recebe, logo em seguida, a primeira resposta, feita por meio de uma pergunta do interlocutor E: "Consumo consiente? Tá serto!"

A pergunta de $\mathbf{E}$ ironiza o erro presente no questionário enviado no link por L, no qual estava escrito "consiente". E usa uma expressão recorrente no mundo virtual, quando os interactantes percebem um erro em alguma 
publicação. A expressão "Tá serto", escrita com "s" em vez de "c", escrita de forma errada propositalmente para criticar quem cometeu o erro.

Figura 189: Exemplo de descortesia no grupo de Letras/USP no Inquérito 4

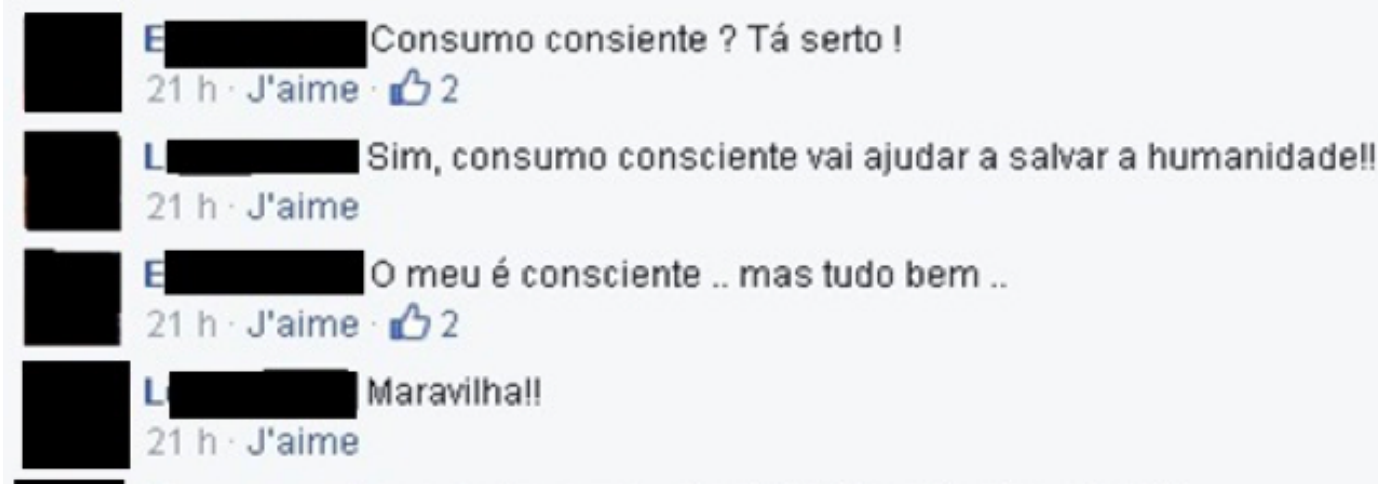

Fonte: Facebook (2015)

L parece não entender a crítica, defendendo o seu ponto de vista de que o consumo consciente ajudará a salvar a humanidade e retoma as palavras de E para reafirmá-la.

E percebe que $\mathbf{L}$ não entendeu a crítica e insiste, escrevendo a palavra "consciente" de forma correta e com uso de reticências. Seria uma outra tentativa de $\mathbf{E}$ de ter seu comentário compreendido por $\mathbf{L}, \mathbf{E}$ insiste em criticar $\mathbf{L}$ de forma indireta, porém reformula o comentário de outra maneira. Diante da resposta inesperada de L para E, com o elogio "Maravilha!!", E faz outra pergunta, pois está ciente que seus comentários seriam ameaçadores em relação a $\mathbf{L}$ e estranha o comportamento cortês de L: "Consiente ou Consciente? Não entendeu ainda?". A estratégia de $\mathrm{E}$, dessa vez, é reformular uma outra pergunta com os termos "consiente" e "consciente" utilizados por $\mathbf{L}$ e por $\mathbf{E}$, respectivamente, para se fazer entender em sua crítica e ter, assim, sua mensagem decodificada por $\mathbf{L}$, complementando com outra pergunta "Não entendeu ainda?" e, esperando assim, uma resposta de L. Durante esta interação entre $\mathbf{E}$ e $\mathbf{L}, \mathbf{F}$ responde o questionário de $\mathbf{L}$, porém não critica $\mathbf{L}$ em relação ao erro contido no questionário: "Feito". $\mathbf{F}$ faz somente a ação que foi pedida. E, como ainda não obtém resposta de L, usa um sticker com as mãos no rosto para expressar vergonha de $\mathbf{L}$, que não entendeu ainda a crítica. Depois da insistência de $E$, L percebe o problema, admite o erro e mantém a cortesia com $\mathbf{E}$ e os demais interactantes. L agradece a correção de $\mathbf{E}$ de forma 
generalizante "Valeu pessoal. Logo no grupo de letras. Valeu!". E, por sua vez, não se dirige mais a $\mathbf{L}$, mas marca um amigo no comentário, $\mathbf{A}$, para que ele pudesse ajudar L. Apesar de $\mathbf{E}$ mobilizar um amigo para ajudar L, E ainda assim usa um tratamento descortês para se referir a $\mathbf{L}$, "japa". Neste Inquérito 4 , $\mathbf{L}$ faz um pedido no grupo de Letras e consegue o feito dos alunos participarem da pesquisa. L, no entanto, teve a imagem ameaçada algumas vezes, sobretudo pelo erro do questionário exposto no grupo por $\mathbf{E}$, além de $\mathbf{L}$ não ter percebido a crítica de $\mathbf{E}$ de imediato e ser, assim, ridicularizada diante dos demais participantes. Apesar de $\mathbf{L}$ ter ficado com sua imagem vulnerável na interação, L manteve a cortesia mesmo com sua face ameaçada e obteve sucesso em seu pedido, pois teve seu questionário respondido, inclusive por $\mathbf{E}$, que a criticou. $\mathbf{E}$ coopera positiva e negativamente na interação, visto que realiza o ato pedido por $\mathbf{L}$, porém não deixa de criticar $\mathbf{L}$.

Figura 190: Exemplo de descortesia no grupo de Letras/USP no Inquérito 4

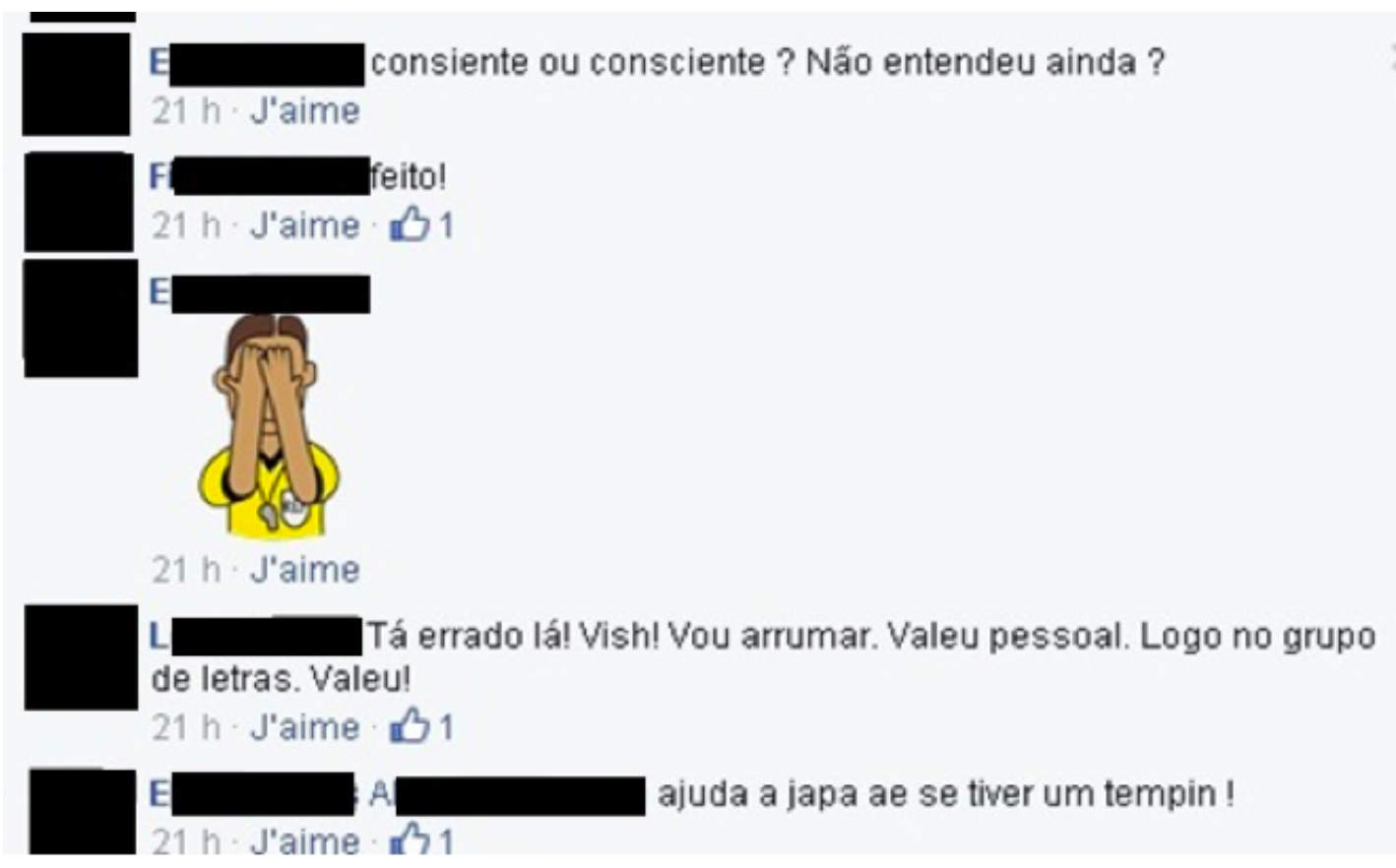

Fonte: Facebook (2015)

Percebe-se, então, um problema de mal-entendido entre os interlocutores, sobretudo entre o sentido intencional que $\mathbf{E}$ desejou transmitir e o sentido decodificado pelo receptor. O sentido só foi decodificado depois da insistência de $\mathbf{E}$. L teve sua face ameaçada ao fazer um pedido, ao mesmo tempo em que foi criticada pelo erro de português presente no questionário. 
Criticada com uma ironia, que não foi percebida por L, E não obteve sucesso em sua crítica e igualmente ameaçou sua própria imagem.

\section{INQUÉRITO 4}

Tabela 6: As categorias de condições de infração da estratégia geral da descortesia no Inquérito 4

\begin{tabular}{|c|c|c|c|c|c|}
\hline \multicolumn{6}{|c|}{ As categorias de condições de infração da estratégia geral da descortesia } \\
\hline $\begin{array}{l}\text { Violação da } \\
\text { máxima } \\
\text { (expressa de } \\
\text { forma } \\
\text { imperativa) }\end{array}$ & $\begin{array}{l}\text { Participantes } \\
\text { do grupo }\end{array}$ & $\begin{array}{l}\text { Par de } \\
\text { máximas } \\
\text { relacionadas }\end{array}$ & $\begin{array}{c}\text { Categorias das máximas } \\
\text { violadas }\end{array}$ & $\begin{array}{l}\text { Classes de atos de } \\
\text { fala }\end{array}$ & $\begin{array}{c}\text { Estratégias } \\
\text { linguísticas e } \\
\text { não- } \\
\text { linguísticas } \\
\text { /híbridas }\end{array}$ \\
\hline $\begin{array}{c}\text { (M1) Atribuir um } \\
\text { valor } \\
\text { desfavorável } \\
\text { aos interesses } \\
\text { do interlocutor } \\
\text { (Outro) }\end{array}$ & $\mathbf{E}$ & \multirow[t]{2}{*}{$\begin{array}{l}\text { Generosidade/T } \\
\text { ato }\end{array}$} & Generosidade & Recusar, ameaçar & Uso da ironia \\
\hline $\begin{array}{l}\text { (M2) Atribuir um } \\
\text { valor favorável } \\
\text { aos interesses } \\
\text { do EU (Locutor) }\end{array}$ & $\mathbf{E}$ & & Tato & Ordem, demanda & $\begin{array}{c}\text { Uso do } \\
\text { imperativo }\end{array}$ \\
\hline $\begin{array}{l}\text { (M3) Atribuir um } \\
\text { valor } \\
\text { desfavorável às } \\
\text { qualidades do } \\
\text { interlocutor } \\
\text { (Outro) }\end{array}$ & $\mathbf{E}$ & \multirow[t]{2}{*}{$\begin{array}{l}\text { Aprovação/ } \\
\text { Modéstia }\end{array}$} & Aprovação & $\begin{array}{l}\text { Insultar, reclamar, } \\
\text { falar mal do } \\
\text { interlocutor }\end{array}$ & Uso de ironia \\
\hline $\begin{array}{l}\text { (M4)Atribuir um } \\
\text { valor favorável } \\
\text { às qualidades } \\
\text { do EU (Locutor) }\end{array}$ & Sem ocorrências & & Modéstia & $\begin{array}{l}\text { Gabar-se, ser } \\
\text { complacente }\end{array}$ & $\begin{array}{c}\text { Sem } \\
\text { ocorrências }\end{array}$ \\
\hline $\begin{array}{c}\text { (M5) Atribuir um } \\
\text { valor } \\
\text { desfavorável às } \\
\text { obrigações do } \\
\text { EU (Locutor) } \\
\text { para com o } \\
\text { interlocutor } \\
\text { (Outro) }\end{array}$ & Sem ocorrências & \multirow[t]{2}{*}{ Obrigação } & Obrigação (ao interlocutor) & $\begin{array}{c}\text { Recusar } \\
\text { agradecimentos ou } \\
\text { desculpas }\end{array}$ & $\begin{array}{c}\text { Sem } \\
\text { ocorrências }\end{array}$ \\
\hline $\begin{array}{l}\text { (M6) Atribuir um } \\
\text { valor favorável } \\
\text { às obrigações } \\
\text { do interlocutor } \\
\text { para com o } \\
\text { Locutor }\end{array}$ & $\mathbf{L}$ & & Obrigação (ao Locutor) & $\begin{array}{l}\text { Agradecer ou } \\
\text { desculpar-se }\end{array}$ & $\begin{array}{c}\mathrm{L} \text { agradece e } \\
\text { se desculpa } \\
\text { verbalmente }\end{array}$ \\
\hline $\begin{array}{l}\text { (M7) Atribuir um } \\
\text { valor } \\
\text { desfavorável às } \\
\text { opiniões do } \\
\text { interlocutor } \\
\text { (Outro) }\end{array}$ & Sem ocorrências & \multirow[t]{2}{*}{ Opinião } & Concordância & $\begin{array}{l}\text { Discordar, } \\
\text { contradizer }\end{array}$ & $\begin{array}{c}\text { Sem } \\
\text { ocorrências }\end{array}$ \\
\hline $\begin{array}{l}\text { (M8) Atribuir um } \\
\text { valor favorável } \\
\text { às opiniões do } \\
\text { Locutor (EU) }\end{array}$ & Sem ocorrências & & Opinião reticente & Ser opinativo & $\begin{array}{c}\text { Sem } \\
\text { ocorrências }\end{array}$ \\
\hline $\begin{array}{l}\text { (M9) Atribuir um } \\
\text { valor } \\
\text { desfavorável } \\
\text { aos sentimentos } \\
\text { do interlocutor } \\
\text { (Outro) }\end{array}$ & Sem ocorrências & \multirow[t]{2}{*}{ Sentimento } & Simpatia & $\begin{array}{l}\text { Expressar antipatia } \\
\text { ao interlocutor }\end{array}$ & $\begin{array}{c}\text { Sem } \\
\text { ocorrências }\end{array}$ \\
\hline $\begin{array}{l}\text { (M10) Atribuir } \\
\text { um valor } \\
\text { favorável aos } \\
\text { sentimentos do } \\
\text { Locutor (EU) }\end{array}$ & Sem ocorrências & & Sentimento reticente & $\begin{array}{l}\text { Reclamar, } \\
\text { resmungar }\end{array}$ & $\begin{array}{c}\text { Sem } \\
\text { ocorrências }\end{array}$ \\
\hline
\end{tabular}




\section{INQUÉRITO 5}

Assim como o Inquérito 4, o Inquérito 5 se configura como um pedido de ajuda aos participantes do grupo do curso de Letras.

Figura 191: Exemplo de descortesia no grupo de Letras/USP no Inquérito 5

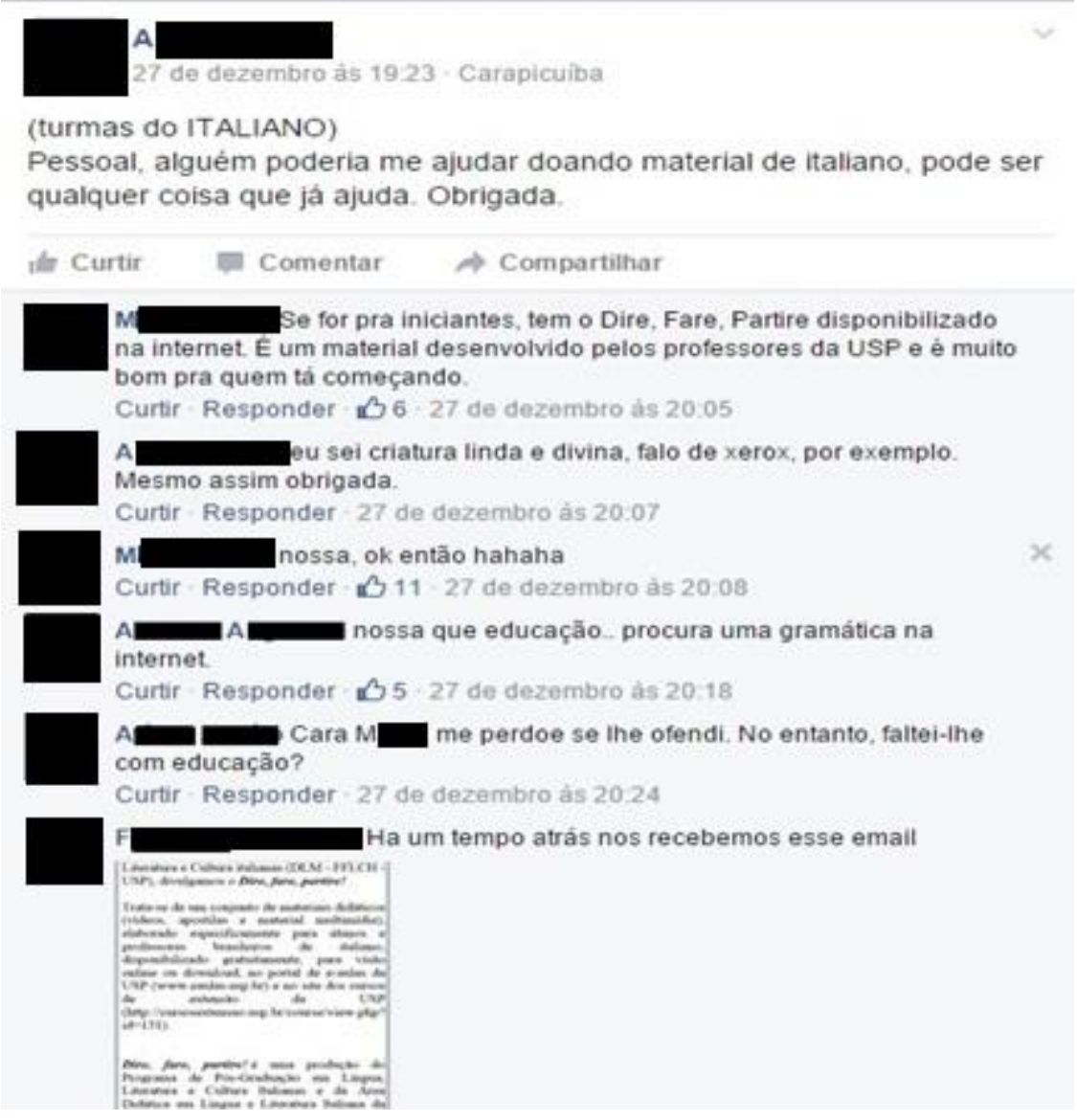

Fonte: Facebook (2015)

A faz um pedido de ajuda no grupo, pois precisa de doação de material de língua italiana para estudo: "Pessoal, alguém poderia me ajudar doando material de italiano, pode ser qualquer coisa que já ajuda. Obrigada". A é clara em sua publicação, visto que coloca entre parênteses quais são os alunos a quem ela se dirige: "(turmas do ITALIANO)". Ao realizar o pedido, A usa também o futuro do pretérito e agradece antecipadamente, recursos esses que preservam sua imagem pessoal diante de uma ameaça de se fazer um pedido. $\mathbf{M}$, imediatamente, responde e sugere o material disponibilizado na internet pela Universidade de São Paulo: "Se for pra iniciantes, tem o Dire, Fare, Partire disponibilizado na internet. É um material desenvolvido pelos professores da 
USP e é muito bom pra quem tá começando". A resposta de $\mathbf{M}$ obtém 6 curtidas, ou seja, alguns participantes não escrevem o comentário, porém estão de acordo com a sugestão de $\mathbf{M}$.

A, no entanto, recusa a ajuda de $\mathbf{M}$ e responde: "Eu sei criatura linda e divina, falo de xerox, por exemplo. Mesmo assim obrigada." Apesar do contexto virtual não permitir verificar o tom desse enunciado, o elogio "linda e divina" foi interpretado como ironia por $\mathbf{M}$ e pelos demais participantes, pois a palavra "criatura" costuma exercer uma carga negativa de sentido. O elogio, em si, tratase de um ato de alto risco tanto para quem elogia quanto para quem é elogiado. Apesar da recusa da oferta de $\mathbf{M}, \mathbf{A}$ atenua a ameaça agradecendo: "Mesmo assim obrigada". M fica surpresa e espantada com a resposta e a expressa por meio da interjeição "nossa" e ri da situação: "nossa, ok então hahaha". Outro interactante, AA, critica a falta de educação de A de maneira indireta, por meio de ironia, reforçada pelas reticências "nossa que educação..." e a manda procurar uma gramática na internet. AA, desta forma, além de criticar $\mathbf{A}$, também se recusa a ajudar. Após a reação negativa dos interactantes, $\mathbf{A}$ se dirige a $\mathbf{M}$, marcando-a no comentário e se desculpa, perguntando se a ofendeu "Cara $M$, me perdoe se lhe ofendi. No entanto, faltei-lhe com educação?". A tenta recuperar sua imagem entre os participantes do grupo atenuando a recusa ao se desculpar, ao mesmo tempo em que $\mathbf{A}$ reitera que não foi intencional a ameaça contra M: "No entanto, faltei-lhe com educação?". M não participa mais da interação e não responde A. F, por sua vez, participa da interação, sugerindo o mesmo material da internet já citado por $\mathbf{M}$ anteriormente. Percebe-se, assim, que F não leu os comentários anteriores da publicação. 
Figura 192: Exemplo de descortesia no grupo de Letras/USP no Inquérito 5

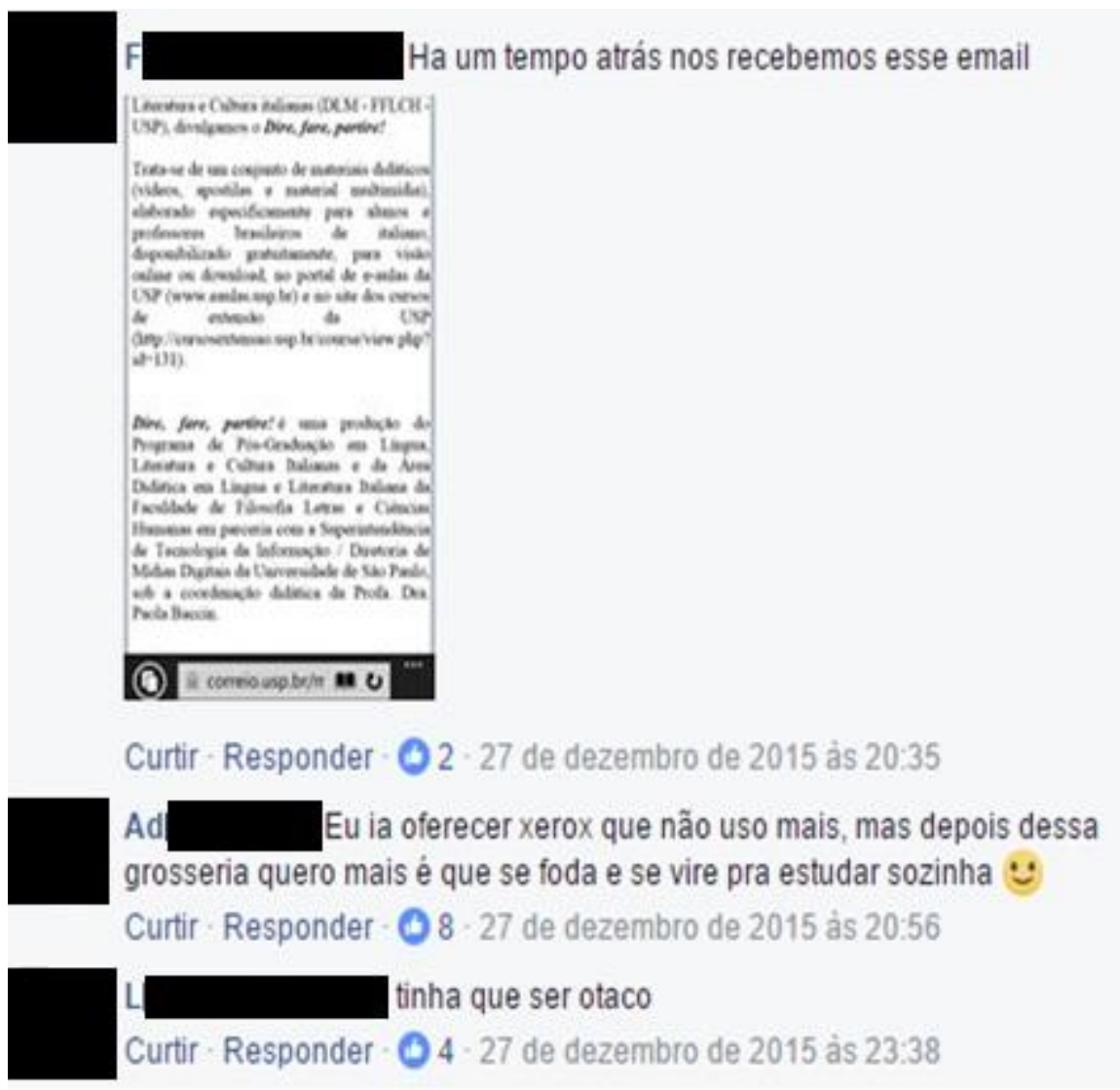

Fonte: Facebook (2015)

Ad também interage, comentando que poderia ajudar se não fosse a grosseria demonstrada por $\mathbf{A}$ : "Eu ia oferecer xerox que não uso mais, mas depois dessa grosseria quero mais é que se foda e se vire pra estudar sozinha". Por meio de seu comentário, $\mathbf{A d}$ iria ajudar $\mathbf{A}$, porém como a intervenção de $\mathbf{A}$ contra $\mathbf{M}$ foi considerada descortês, $\mathbf{A d}$ recusa a ajuda e intensifica a descortesia desejando que A "se foda" sendo irônica com um emoticon sorrindo após o insulto contra A. O comentário de Ad obtém 8 curtidas, ou seja, mesmo que os outros participantes não comentem na publicação de $\mathbf{A}$, eles estão de acordo com o que Ad defende. $\mathbf{L}$, por sua vez, faz um insulto indireto a $\mathbf{A}$, ao usar a expressão "tinha que ser otaco". Subentende-se que $\mathbf{L}$ não gosta do comportamento de otacos, ou seja, fãs de desenhos japoneses. No perfil de $\mathbf{A}$, em vez de ter sua fotografia de perfil, $\mathbf{A}$ tinha uma figura de uma personagem de desenho japonês.

Nota-se, assim, que A não obteve sucesso em seu pedido, principalmente devido a dois fatores: a falta de clareza no pedido, uma vez que $\mathbf{A}$ teve que 
esclarecer na resposta a $\mathbf{M}$ que se tratava de xerox e não era qualquer material como havia mencionado antes; e porque A recusa a oferta dos participantes, reforçada com o uso de ironia das escolhas lexicais.

\section{INQUÉRITO 5}

Tabela 7: As categorias de condições de infração da estratégia geral da descortesia no Inquérito 5

\begin{tabular}{|c|c|c|c|c|c|}
\hline \multicolumn{6}{|c|}{ As categorias de condições de infração da estratégia geral da descortesia } \\
\hline $\begin{array}{c}\text { Violação da } \\
\text { máxima } \\
\text { (expressa de } \\
\text { forma } \\
\text { imperativa) }\end{array}$ & $\begin{array}{l}\text { Participantes } \\
\text { do grupo }\end{array}$ & $\begin{array}{l}\text { Par de } \\
\text { máximas } \\
\text { relacionadas }\end{array}$ & $\begin{array}{c}\text { Categorias das máximas } \\
\text { violadas }\end{array}$ & $\begin{array}{c}\text { Classes de atos de } \\
\text { fala }\end{array}$ & \begin{tabular}{|c|} 
Estratégias \\
linguísticas e \\
não- \\
linguísticas \\
/híbridas
\end{tabular} \\
\hline $\begin{array}{c}\text { (M1) Atribuir um } \\
\text { valor } \\
\text { desfavorável } \\
\text { aos interesses } \\
\text { do interlocutor } \\
\text { (Outro) }\end{array}$ & A & \multirow{2}{*}{$\begin{array}{c}\text { Generosidade/T } \\
\text { ato }\end{array}$} & Generosidade & Recusar, ameaçar & $\begin{array}{l}\text { Uso de ironia, } \\
\text { escolha } \\
\text { lexical com } \\
\text { carga } \\
\text { negativa }\end{array}$ \\
\hline $\begin{array}{l}\text { (M2) Atribuir um } \\
\text { valor favorável } \\
\text { aos interesses } \\
\text { do EU (Locutor) }\end{array}$ & A & & Tato & Ordem, demanda & \begin{tabular}{|c|} 
Pedido de \\
ajuda, futuro \\
do \\
pretérito,uso \\
de moderador
\end{tabular} \\
\hline $\begin{array}{c}\text { (M3) Atribuir um } \\
\text { valor } \\
\text { desfavorável às } \\
\text { qualidades do } \\
\text { interlocutor } \\
\text { (Outro) }\end{array}$ & A & \multirow[t]{2}{*}{$\begin{array}{l}\text { Aprovação/ } \\
\text { Modéstia }\end{array}$} & Aprovação & $\begin{array}{l}\text { Insultar, reclamar, } \\
\text { falar mal do } \\
\text { interlocutor }\end{array}$ & $\begin{array}{c}\text { Uso de ironia, } \\
\text { escolha } \\
\text { lexical com } \\
\text { carga } \\
\text { negativa } \\
\end{array}$ \\
\hline $\begin{array}{l}\text { (M4)Atribuir um } \\
\text { valor favorável } \\
\text { às qualidades } \\
\text { do EU (Locutor) }\end{array}$ & Sem ocorrências & & Modéstia & $\begin{array}{l}\text { Gabar-se, ser } \\
\text { complacente }\end{array}$ & $\begin{array}{l}\text { Sem } \\
\text { ocorrências }\end{array}$ \\
\hline $\begin{array}{c}\text { (M5) Atribuir um } \\
\text { valor } \\
\text { desfavorável às } \\
\text { obrigações do } \\
\text { EU (Locutor) } \\
\text { para com o } \\
\text { interlocutor } \\
\text { (Outro) }\end{array}$ & Sem ocorrências & \multirow[t]{2}{*}{ Obrigação } & Obrigação (ao interlocutor) & $\begin{array}{c}\text { Recusar } \\
\text { agradecimentos ou } \\
\text { desculpas }\end{array}$ & $\begin{array}{c}\text { Sem } \\
\text { ocorrências }\end{array}$ \\
\hline $\begin{array}{l}\text { (M6) Atribuir um } \\
\text { valor favorável } \\
\text { às obrigações } \\
\text { do interlocutor } \\
\text { para com o } \\
\text { Locutor }\end{array}$ & A & & Obrigação (ao Locutor) & $\begin{array}{l}\text { Agradecer ou } \\
\text { desculpar-se }\end{array}$ & $\begin{array}{c}\text { Uso de } \\
\text { desarmadores }\end{array}$ \\
\hline $\begin{array}{l}\text { (M7) Atribuir um } \\
\text { valor } \\
\text { desfavorável às } \\
\text { opiniões do } \\
\text { interlocutor } \\
\text { (Outro) }\end{array}$ & Sem ocorrências & \multirow[t]{2}{*}{ Opinião } & Concordância & $\begin{array}{l}\text { Discordar, } \\
\text { contradizer }\end{array}$ & $\begin{array}{l}\text { Sem } \\
\text { ocorrências }\end{array}$ \\
\hline $\begin{array}{l}\text { (M8) Atribuir um } \\
\text { valor favorável } \\
\text { às opiniões do } \\
\text { Locutor (EU) }\end{array}$ & Sem ocorrências & & Opinião reticente & Ser opinativo & $\begin{array}{c}\text { Sem } \\
\text { ocorrências }\end{array}$ \\
\hline $\begin{array}{l}\text { (M9) Atribuir um } \\
\text { valor } \\
\text { desfavorável } \\
\text { aos sentimentos } \\
\text { do interlocutor } \\
\text { (Outro) }\end{array}$ & $\begin{array}{l}\text { Todos os } \\
\text { interactantes } \\
\text { contra A }\end{array}$ & \multirow[t]{2}{*}{ Sentimento } & Simpatia & $\begin{array}{l}\text { Expressar antipatia } \\
\text { ao interlocutor }\end{array}$ & $\begin{array}{c}\text { Uso de } \\
\text { insultos, ironia }\end{array}$ \\
\hline $\begin{array}{l}\text { (M10) Atribuir } \\
\text { um valor } \\
\text { favorável aos } \\
\text { sentimentos do } \\
\text { Locutor (EU) }\end{array}$ & Sem ocorrências & & Sentimento reticente & $\begin{array}{l}\text { Reclamar, } \\
\text { resmungar }\end{array}$ & $\begin{array}{c}\text { Sem } \\
\text { ocorrências }\end{array}$ \\
\hline
\end{tabular}




\section{INQUÉRITO 6}

O Inquérito 6, diferente dos demais, configura-se como um oferecimento, primeiramente, por meio de uma pergunta de $\mathbf{L}$ no grupo de Letras da USP: "Alguém tem interesse em um grupo de estudos sobre o pensamento liberal?". L, ao realizar a pergunta, apresenta-se na publicação e explica como seria a realização da atividade do grupo de estudos. Ao encerrar a publicação, $\mathbf{L}$ pede para que os interessados mandem mensagens privadas: "Me mande via inbox, qual seria o melhor dia e horário para você ou escreve aí embaixo". L usa o verbo no imperativo, mas usa o futuro do pretérito para atenuar a ordem feita aos participantes interessados. A publicação de $\mathbf{L}$ recebe 11 curtidas e 143 comentários no grupo.

Figura 193: Exemplo de descortesia no grupo de Letras/USP no Inquérito 6

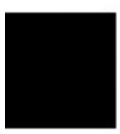

L 23 de março de 2015

Alguém tem interesse em um grupo de estudos sobre o pensamento liberal? Sou da filosofia e fiz uma parceria com um colega da economia, para estudarmos esses autores da Escola Austriaca de Economia e Filosofia. No caso, estudariamos Frederic Bastiat, Ludwig Von Mises e Hayek. Seria uma introdução sobre o Estado, a lei, a economia, a liberdade $e$ a individualidade na perspectiva liberal. Os livros que usaremos para essa parte introdutiva são: A lei do Bastiat, As Seis Liçöes do Mises e O Caminho da Servidão de Hayek. As aulas aconteceriam no próprio Mackenzie.

Me mande via inbox, qual seria o melhor dia e horário para você ou escreve aí embaixo

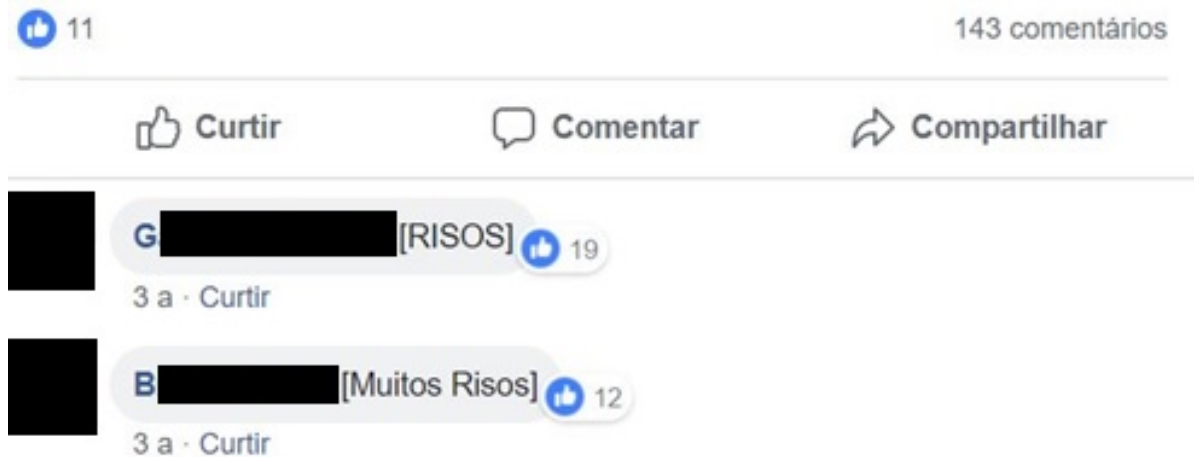

Fonte: Facebook (2015)

Com a realização do oferecimento, $\mathbf{L}$ espera receber respostas dos alunos interessados, entretanto, os alunos reagem de maneira inesperada, 
ameaçando a imagem pessoal de L. G, o primeiro aluno a responder, coloca entre colchetes a sua reação ao oferecimento de L, "[RISOS]". Com a falta de recursos paralinguísticos no suporte escrito, $\mathbf{G}$ não deixa de representar a sua reação verbalmente, intensificada pelo uso de maiúsculas. A publicação de $\mathbf{G}$ recebe 19 curtidas e suscita comentários parecidos, logo em seguida. B e F complementam com "[Muitos Risos]"e "[risos $d+]$ ", respectivamente, e também recebem muitas curtidas. Com essas reações, $\mathbf{L}$ fica em posição vulnerável em relação aos demais, sobretudo por ser ridicularizado no grupo público. $\mathbf{G i}$, diferentemente dos demais, comenta parabenizando a iniciativa de $\mathbf{L}$. $\mathbf{G i}$, inclusive, sugere pessoas que podem ajudar com a proposta de $\mathbf{L}$.

Figura 194: Exemplo de descortesia no grupo de Letras/USP no Inquérito 6

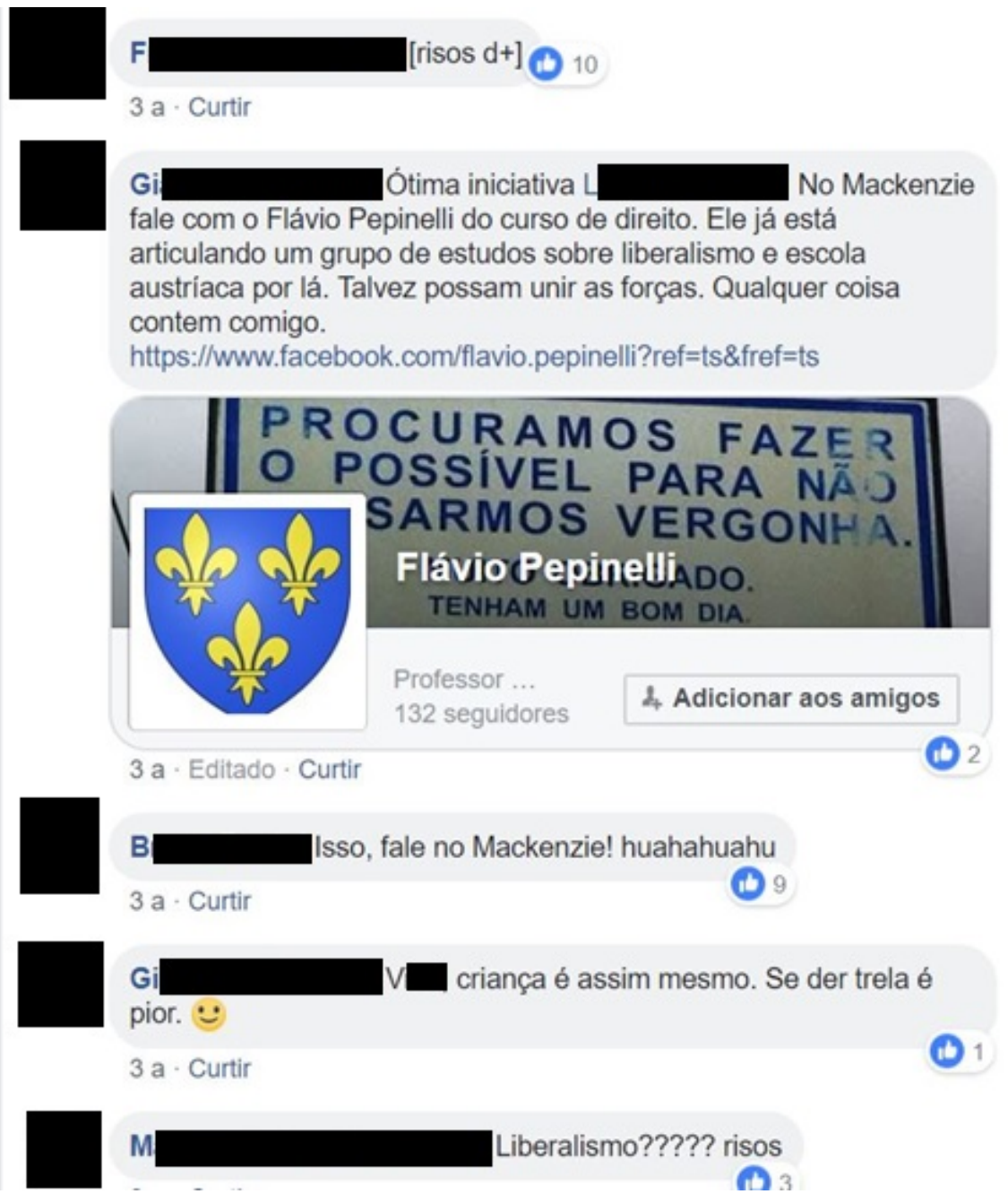

Fonte: Facebook (2015) 
Enquanto G, B e $\mathbf{F}$ cooperam negativamente ao ridicularizar $\mathbf{L}$, Gi tenta amenizar o ataque à imagem de $\mathbf{L}$ parabenizando-o. B retoma o seu turno $\mathrm{e}$ continua atacando a imagem de $\mathbf{L}$ e intensificando com a representação de risos no final: "Isso, fale no Mackenzie! huahahuahu". Por meio do comentário de B, infere-se que o grupo da faculdade de Letras da FFLCH/USP não seria o local adequado para tal proposta, mas sim o Mackenzie, especialmente porque a proposta de $\mathbf{L}$ se refere aos estudos do pensamento liberal, algo que não é recorrente pelos partidários de esquerda da FFLCH/USP. Gi retoma o seu turno para fazer uma crítica indireta. Ele marca o participante $\mathbf{V}$, que havia comentado, criticando a postura ridicularizante dos colegas, mas $\mathbf{V}$ acaba apagando 0 comentário feito. Mesmo assim, na rede social, as marcas ficam, pois Gi se refere especificamente a $\mathbf{V}$. Gi, por meio do comentário a $\mathbf{V}$, chama os participantes de "criança": "V, criança é assim mesmo. Se der trela é pior", ao comentário, segue um emoticon sorrindo. $\mathbf{M}$, outro participante, responde logo em seguida, e assume a posição também de ataque à imagem de $\mathbf{L}$ por meio de uma pergunta, seguida de risos: "Liberalismo????? risos". A intervenção de M também ridiculariza $\mathbf{L}$ e, assim como os outros participantes fizeram, intensifica a descortesia por meio da representação de risos. A aparece para comentar em defesa de $\mathbf{L}$ e critica o fato de os participantes terem ridicularizado $\mathbf{L}$ por meio de risos: "Cada um faz o que quer, estuda o que quer e acredita no que achar melhor! Acho bizarro colocar "risos" num post completamente simples no qual uma pessoa convida outras a estudar!".

Figura 195: Exemplo de descortesia no grupo de Letras/USP no Inquérito 6

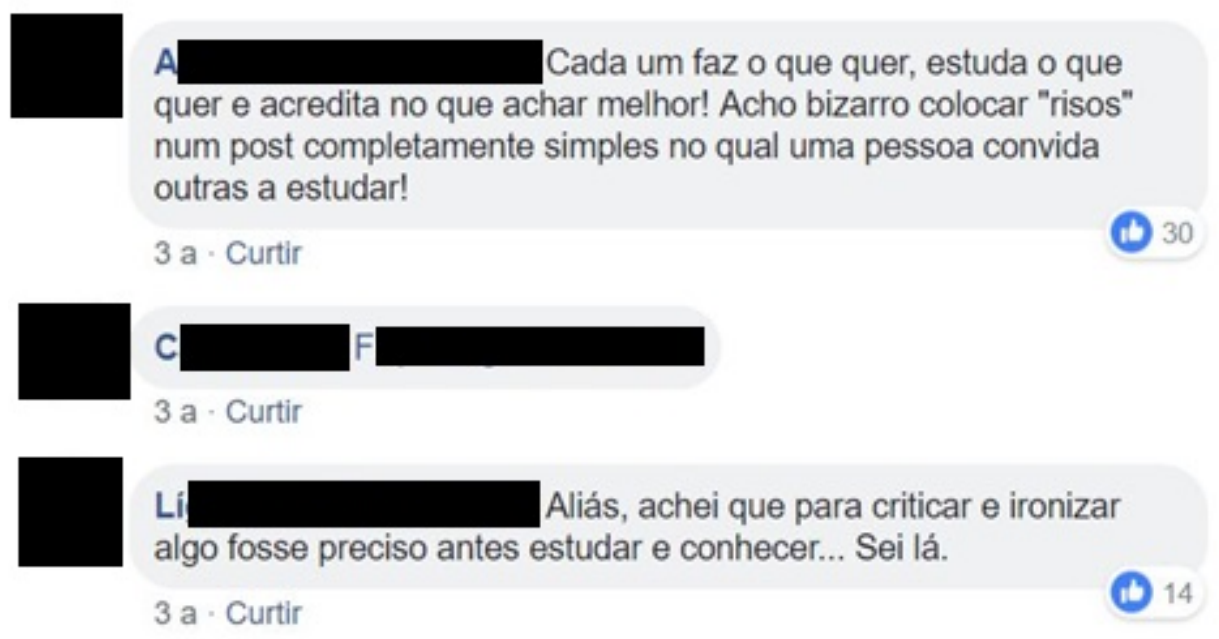


Fonte: Facebook (2015)

C, por sua vez, não expressa a sua opinião a respeito, mas marca um amigo, F. Lí também aparece em defesa de L e critica, indiretamente, a ação dos participantes contra $\mathbf{L}$, ao mesmo tempo que modaliza o seu discurso: "Aliás, achei que para criticar e ironizar algo fosse preciso antes estudar e conhecer...Sei lá." O comentário de Lí rende 14 curtidas, ou seja, recebe muitas curtidas, tal como aconteceu com os participantes que ameaçaram a imagem de L. Assim, percebe-se que dentro do grupo há a oposição entre os defensores de L e os participantes que o ridicularizam. Le também faz um comentário logo após Lí, em defesa de L. Le critica o uso de ironia por parte dos participantes e elogia o comportamento de $\mathbf{L}$, que apenas faz um convite para um grupo de estudo. Le se mostra engajada em participar, mas se justifica dizendo que não é possível por morar longe. Logo em seguida, Le parabeniza L "Parabéns pela iniciativa, que mais grupos de estudo apareçam."

Figura 196: Exemplo de descortesia no grupo de Letras/USP no Inquérito 6

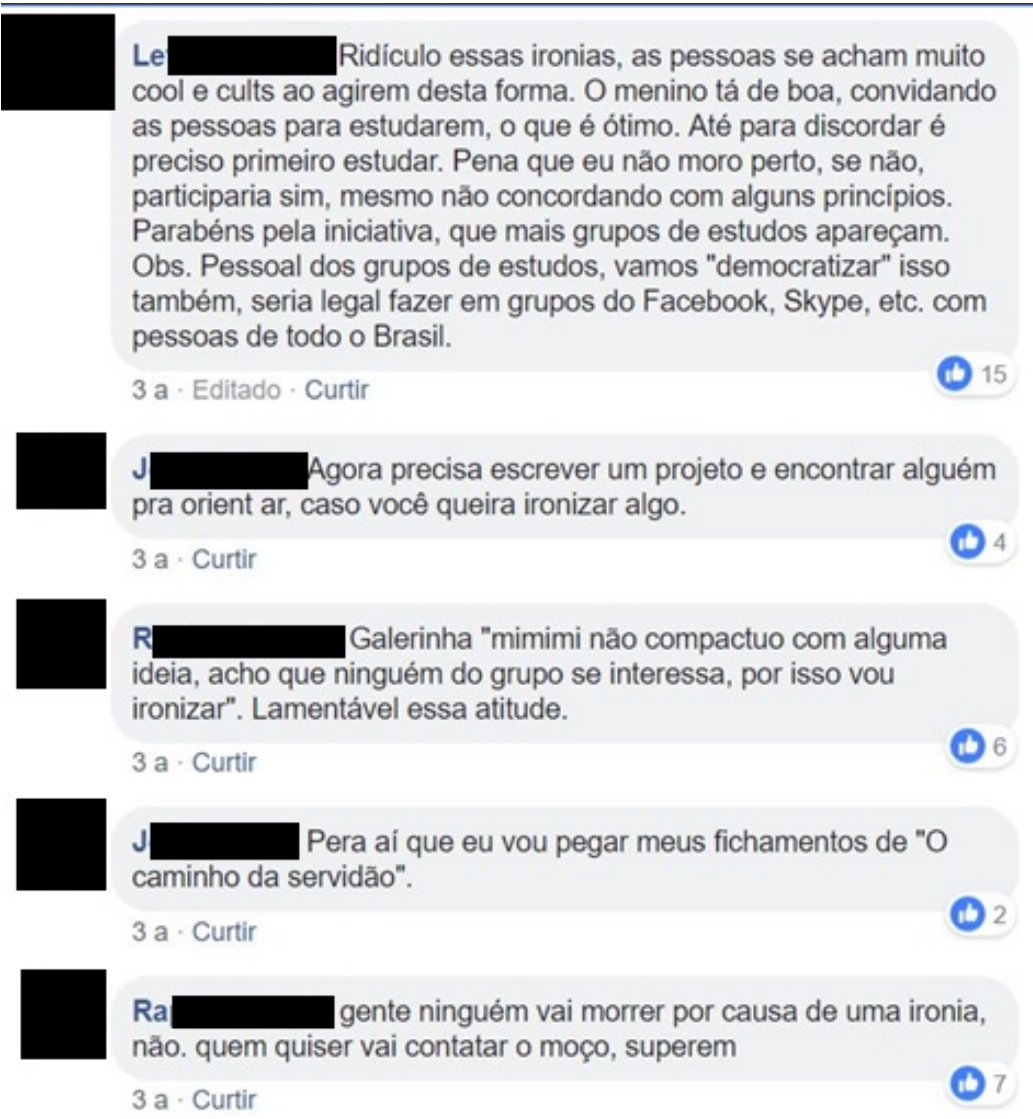


Fonte: Facebook (2015)

Assim, Le ameaça as imagens dos participantes que ridicularizaram $\mathbf{L}$, ao mesmo tempo que valoriza a imagem de $\mathbf{L}$. $\mathbf{R}$ também aparece em defesa de $\mathbf{L}$, sobretudo criticando o uso de ironia por parte dos participantes. $\mathbf{R}$ usa o termo irônico, "Galerinha", no diminutivo para se referir aos participantes que ameaçaram a imagem de $\mathbf{L}$. $\mathbf{R}$ também usa aspas, mas para imitar um possível discurso dos participantes contra $\mathbf{L}$. Por meio do uso de aspas, $\mathbf{R}$ quer proteger a sua imagem, pois seria um enunciado não pertencente a ele: "mimimi não compactuo com alguma ideia, acho que ninguém do grupo se interessa, por isso vou ironizar". Logo em seguida, $\mathbf{R}$ ainda reforça a sua crítica: "Lamentável essa atitude." $\mathbf{J}$ comenta que iria pegar seus fichamentos, porém não fica claro pelo contexto se $\mathbf{J}$ comentou de maneira irônica ou não. $\mathbf{R a}$, por sua vez, minimiza o efeito da ironia dos comentários e se dirige a todos os interactantes de maneira generalizante: "gente ninguém vai morrer por causa de uma ironia, não. quem quiser vai contatar o moço, superem". O comentário de Ra também recebe muitas curtidas, o total de 7 . Nota-se que o grupo está dividido, entre os partidários de $\mathbf{L}$ e aqueles que $\mathrm{O}$ atacam. B dirige-se a $\mathbf{J}$ para sugerir a comparação dos fichamentos e o comentário também termina com risos: "Tb tenho os meus $\mathbf{J}$, vamos comparar! hahaha". 
Figura 197: Exemplo de descortesia no grupo de Letras/USP no Inquérito 6

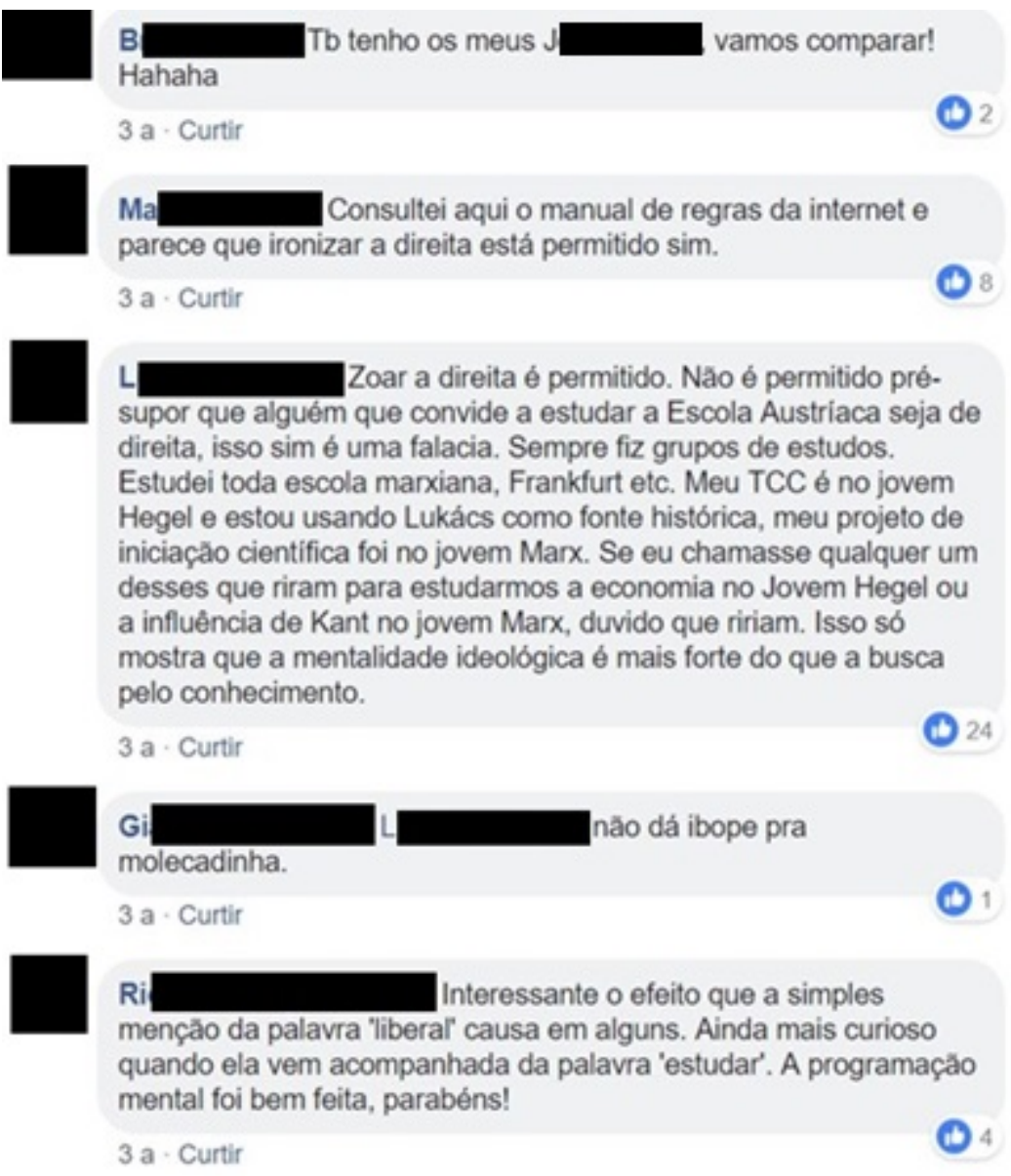

Fonte: Facebook (2015)

Apesar da crítica por parte de alguns participantes do grupo, o uso da ironia ainda persiste contra L, assim como faz Ma: "Consultei aqui o manual de regras da internet e parece que ironizar a direita está permitido sim." 0 comentário de Ma recebe 8 curtidas e também usa de ironia para defender sua própria imagem nos comentários. Pela primeira vez, após vários ataques, L aparece para se defender: "Zoar a direita é permitido. Não é permitido pré-supor que alguém que convide a estudar a Escola Austríaca seja de direita, isso sim é uma falacia." L se refere a ele mesmo usando uma impessoalização, "alguém". Assim, ele se inclui no grupo daqueles que estudam a "Escola Austríaca" e, ao mesmo tempo, generaliza ao se referir a outras pessoas que estudam o mesmo tema que ele. Em seguida, $\mathbf{L}$ valoriza a sua imagem em primeira pessoa, de modo a sustentar que é uma pessoa que conhece bem do assunto, tanto no espectro político de direita quanto de esquerda: " Sempre fiz grupos de estudos. 
Estudei toda escola marxiana, Frankfurt etc. Meu TCC é no jovem Hegel e estou usando Lukács como fonte histórica, meu projeto de iniciação científica foi no jovem Marx.". L termina seu comentário criticando os participantes do grupo que ameaçaram a sua imagem e os trata como "qualquer um": "Se eu chamasse qualquer um desses que riram para estudarmos a economia no Jovem Hegel ou a influência de Kant no jovem Marx, duvido que ririam. Isso só mostra que a mentalidade ideológica é mais forte do que a busca pelo conhecimento." Assim, nota-se que $\mathbf{L}$ se respalda em seu conhecimento pessoal, mostrando-se ser uma autoridade no assunto e, assim, valoriza e defende sua própria imagem. Depois do comentário de $\mathbf{L}, \mathbf{G i}$, pede para que $\mathbf{L}$ ignore os participantes: "L não dá ibope pra molecadinha". Novamente, Gi usa um termo irônico para se referir aos participantes que ridicularizaram L, "molecadinha", criticando-os pelo comportamento infantil com o uso do diminutivo. Ri também aparece na interação e faz uma crítica irônica aos participantes que ameaçaram a imagem de L, para, logo em seguida, parabenizá-los de forma igualmente irônica, ou seja, de forma pseudocortês: "Interessante o efeito que a simples menção da palavra "liberal" causa em alguns. Ainda mais curioso quando ela vem acompanhada da palavra "estudar". A programação mental foi bem feita, parabéns!". Gi, por sua vez, retoma o turno para criticar os participantes, a quem ele chama de "idiotas": "Causar a fúria dos idiotas é uma delícia. Isso é medinho pela perda da hegemonia. Enquanto eles brincam de panelinha do toddynho a gente estuda". O comentário de Gi se segue de forma irônica, colocando os participantes críticos de $\mathbf{L}$ no mesmo patamar que crianças, ao contrário daqueles que estudam. A descortesia de Gi contra aos participantes que ameaçaram $\mathbf{L}$ é intensificada com o uso de diminutivo e do emoticon piscando. B reage ao comentário de $\mathbf{G i}$ criticando de forma generalizante: "Tão sabendo bem essa galera confederadista!". 
Figura 198: Exemplo de descortesia no grupo de Letras/USP no Inquérito 6

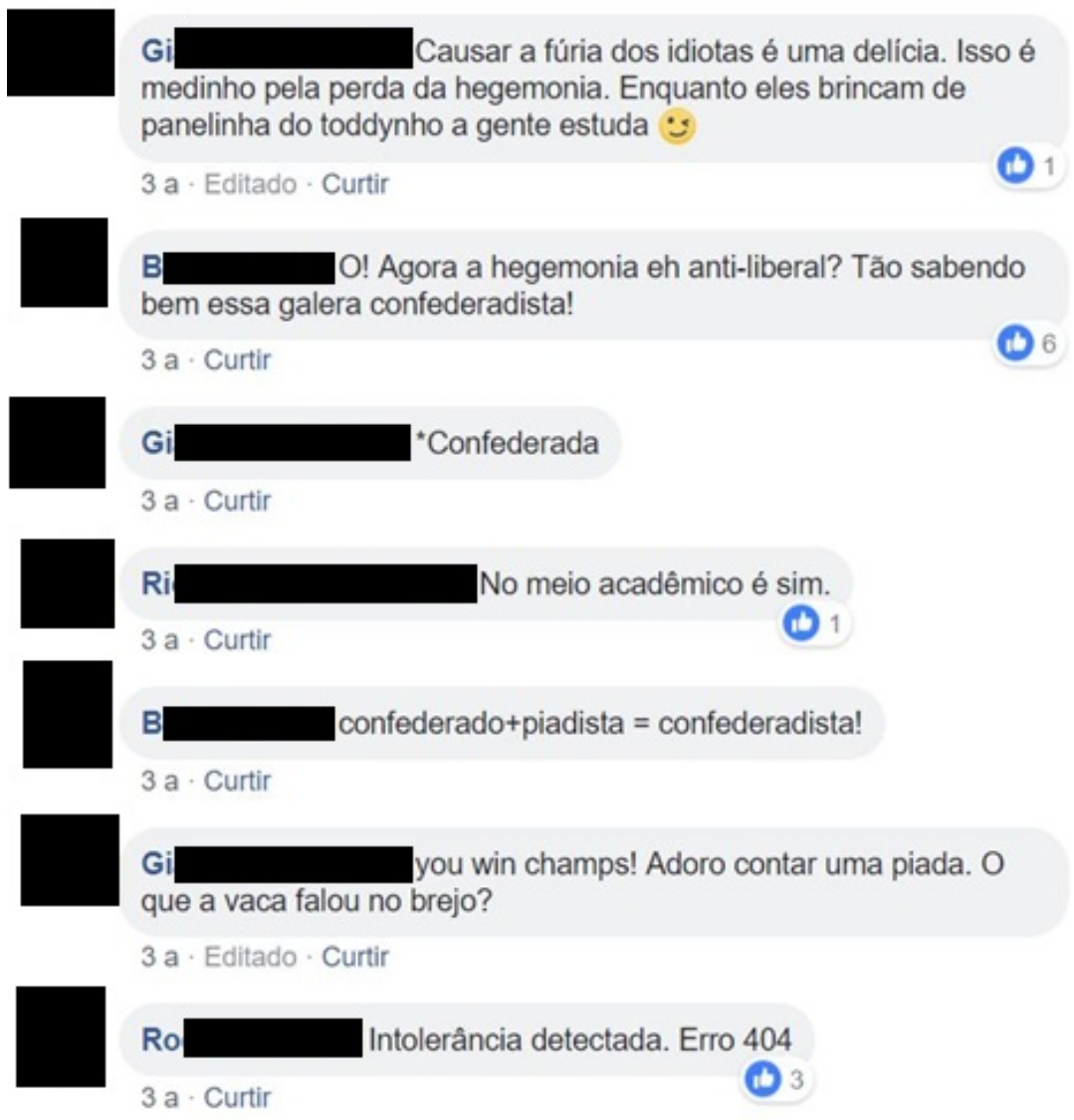

Fonte: Facebook (2015)

Gi, por sua vez, rebate a crítica, sob a forma de correção do termo utilizado por B, intensificando a descortesia: "*Confederada". O uso do asterisco na linguagem virtual é comum quando alguém quer corrigir algum erro cometido. Assim, ambos têm a imagem ameaçada, pois Gi fica em posição vulnerável ao corrigir B e, ao mesmo tempo, B se vê corrigido publicamente no grupo. Ri concorda com a colocação de $\mathbf{G i}$ e $\mathbf{B}$, por sua vez, retoma seu turno para se defender do erro cometido: "confederado+piadista= confederadista!". B se defende com um neologismo e Gi retoma o seu turno de forma irônica em relação a B: "you win champs! Adoro contar uma piada. O que a vaca falou no brejo?". Ro também critica novamente os comentários de $\mathbf{B}$ de forma irônica: "Intolerância detectada. Erro 404." D aparece pela primeira vez e parabeniza o convite de $\mathbf{L}$, assim como $\mathbf{F e}$, que lamenta e critica a posição de ataque contra L, pelos participantes: "triste essa soberba da esquerdalha, hein". 
Figura 199: Exemplo de descortesia no grupo de Letras/USP no Inquérito 6

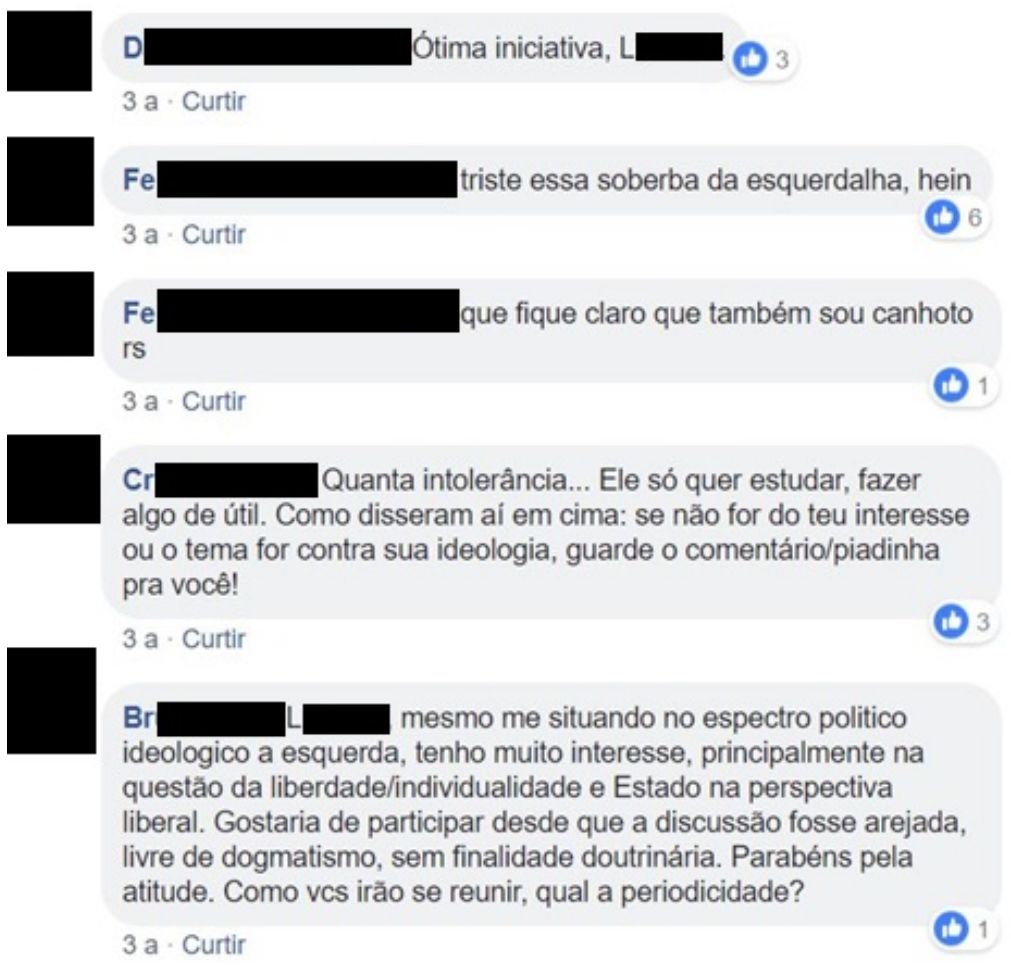

Fonte: Facebook (2015)

Apesar da crítica, Fe se defende logo em seguida se colocando também entre os participantes partidários da esquerda: "que fique claro que também sou canhoto rs". Cr também critica a intolerância e defende L: "Ele só quer estudar, fazer algo de útil.", e retoma as palavras de outro interactante: "Como disseram aí em cima: se não for do teu interesse ou o tema for contra sua ideologia, guarde o comentário/piadinha pra você!". Br também participa na interação, para defender $\mathbf{L}$, salientando também que é partidário da esquerda, porém, tem interesse e pergunta a $\mathbf{L}$ mais informações a respeito. Além disso, parabeniza $\mathbf{L}$ pela iniciativa: "Parabéns pela atitude". $\mathbf{L}$ marca $\mathrm{Br}$ na conversação para respondê-lo diretamente. $\mathbf{L}$ envia as informações solicitadas por $\mathbf{B r}$ de forma privada, assim, se previne também de possíveis ataques dos outros interactantes: "Br, respondi via Inbox". 
Figura 200: Exemplo de descortesia no grupo de Letras/USP no Inquérito 6

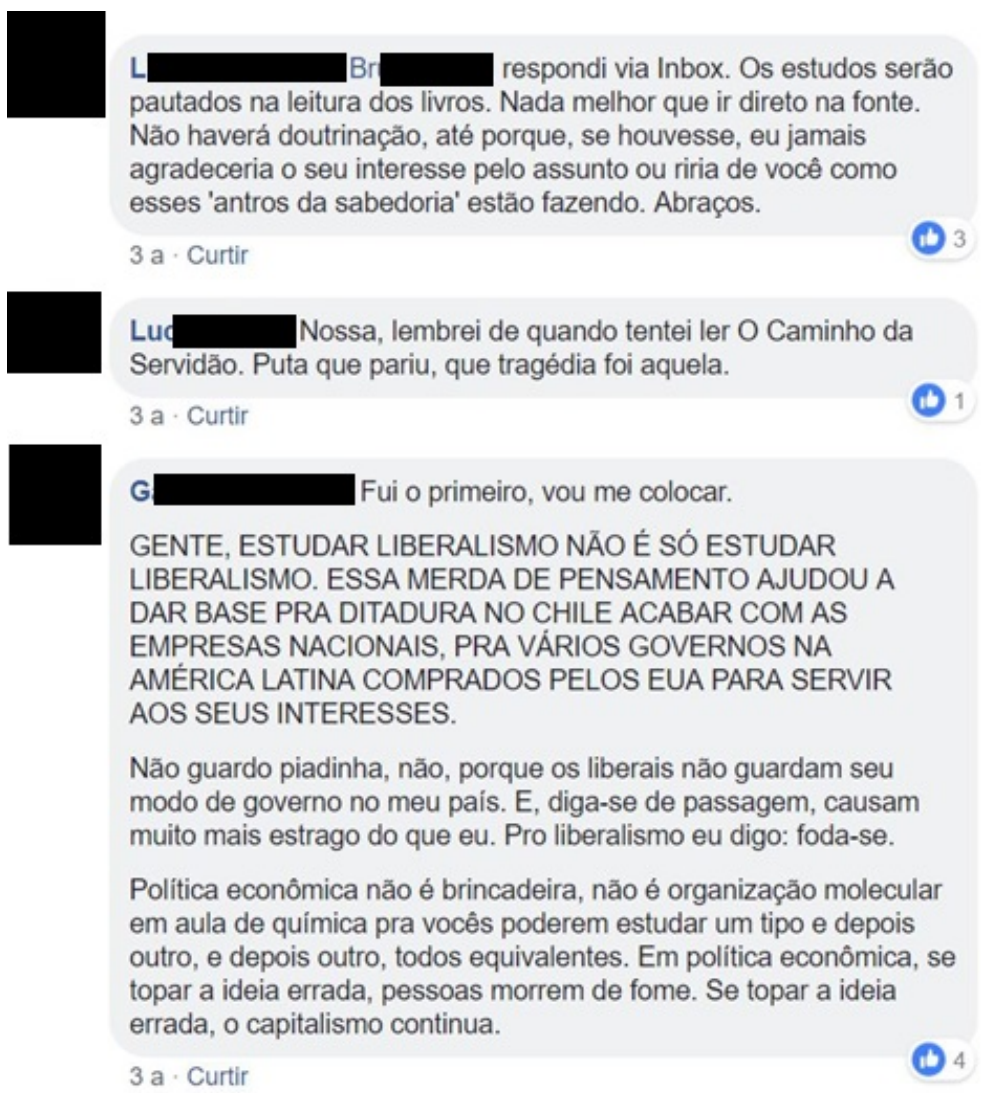

Fonte: Facebook (2015)

L também faz uma crítica indireta aos participantes que o ameaçaram por meia de uma ironia e com o uso das aspas: "Os estudos serão pautados na leitura dos livros. Nada melhor que ir direto na fonte. Não haverá doutrinação, até porque, se houvesse, eu jamais agradeceria o seu interesse pelo assunto ou riria de você como esses 'antros da sabedoria' estão fazendo. Abraços". L finaliza a sua resposta para Br usando uma expressão cortês de despedida, "Abraços". Apesar das críticas e ironias em relação aos participantes que ameaçam a imagem de $\mathbf{L}$, o ataque continua. Lu critica um dos textos sugeridos para estudo e $\mathbf{G}$, o primeiro a interagir na publicação de $\mathbf{L}$, reaparece na interação para defender sua imagem. G faz uso das maiúsculas para chamar atenção para o seu comentário: "GENTE, ESTUDAR LIBERALISMO NÃO É SÓ ESTUDAR LIBERALISMO. ESSA MERDA DE PENSAMENTO AJUDOU A DAR BASE PRA DITADURA NO CHILE ACABAR COM AS EMPRESAS NACIONAIS, PRA VÁRIOS GOVERNOS NA AMÉRICA LATINA COMPRADOS PELOS EUA 
PARA SERVIR AOS SEUS INTERESSES". Por meio do seu comentário, G tenta justificar seu ponto de vista apoiado em acontecimentos históricos que prejudicaram pessoas, além de comparar o estudo da política econômica com algo banal para tentar convencer os participantes do seu pensamento contra o liberalismo : "Política econômica não é brincadeira, não é organização molecular em aula de química pra vocês poderem estudar um tipo e depois outro, todos equivalentes. Em política econômica, se topar a ideia errada, pessoas morrem de fome. Se topar a ideia errada, o capitalismo continua." Após a longa justificativa de $\mathbf{G}$, os participantes que defenderam $\mathbf{L}$, os participantes $\mathbf{F e}, \mathbf{G i}, \mathbf{C r}$ e Ro usam de ironia a respeito do comentário de G, pois o acharam inconsistente: "Vamos queimar os livros do pensamento liberal.", "Índex já", "Índex Librorum - FFLCH edition".

Figura 201: Exemplo de descortesia no grupo de Letras/USP no Inquérito 6

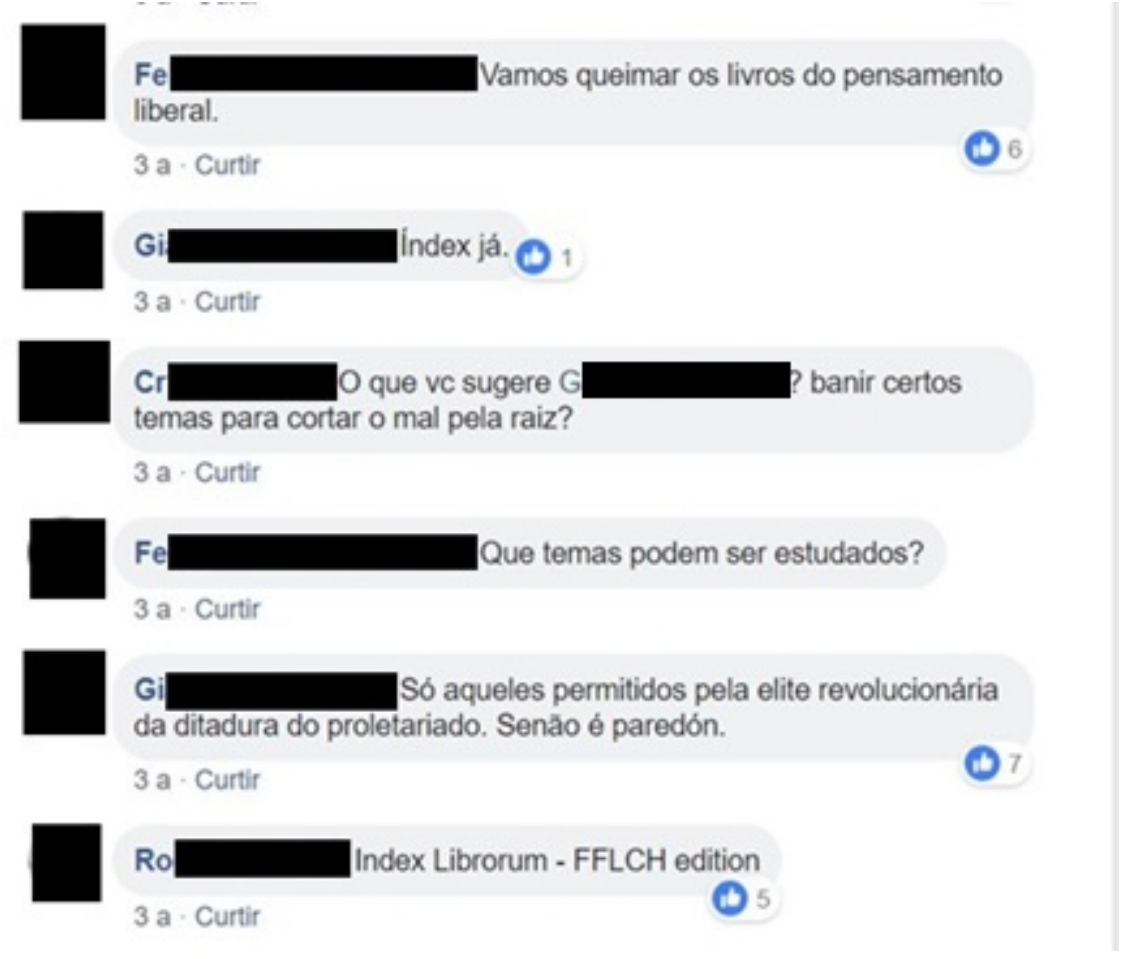

Fonte: Facebook (2015)

Cr e Fe fazem, respectivamente, um pedido para $\mathbf{G}$ sob a forma de pergunta: "O que vc sugere G? banir certos temas para cortar o mal pela raiz?" "Que temas podem ser estudados?". Como G não responde às perguntas, Gi 
responde de maneira irônica: "Só aqueles permitidos pela elite revolucionária da ditadura do proletariado. Senão é paredón.". O comentário de $\mathbf{G i}$ recebe mais curtidas que o de $\mathbf{G}$. B, o segundo interactante a responder a L, logo após $\mathbf{G}$, na publicação principal, também aparece para se defender. B minimiza o seu ataque usando um modalizador: "Acho super valido qualquer tipo de estudo e, realmente, todos são livres - e eh bom que sejam - para escolher o que estudar ou do que rir." e continua a usar a mesma fórmula: "Acho, particularmente, engraçado propor um grupo de estudo sobre um modelo altamente utilizado quando a meu ver guiaria meus esforços intelectuais pra sair dessa merda de modelo.".

Figura 202: Exemplo de descortesia no grupo de Letras/USP no Inquérito 6

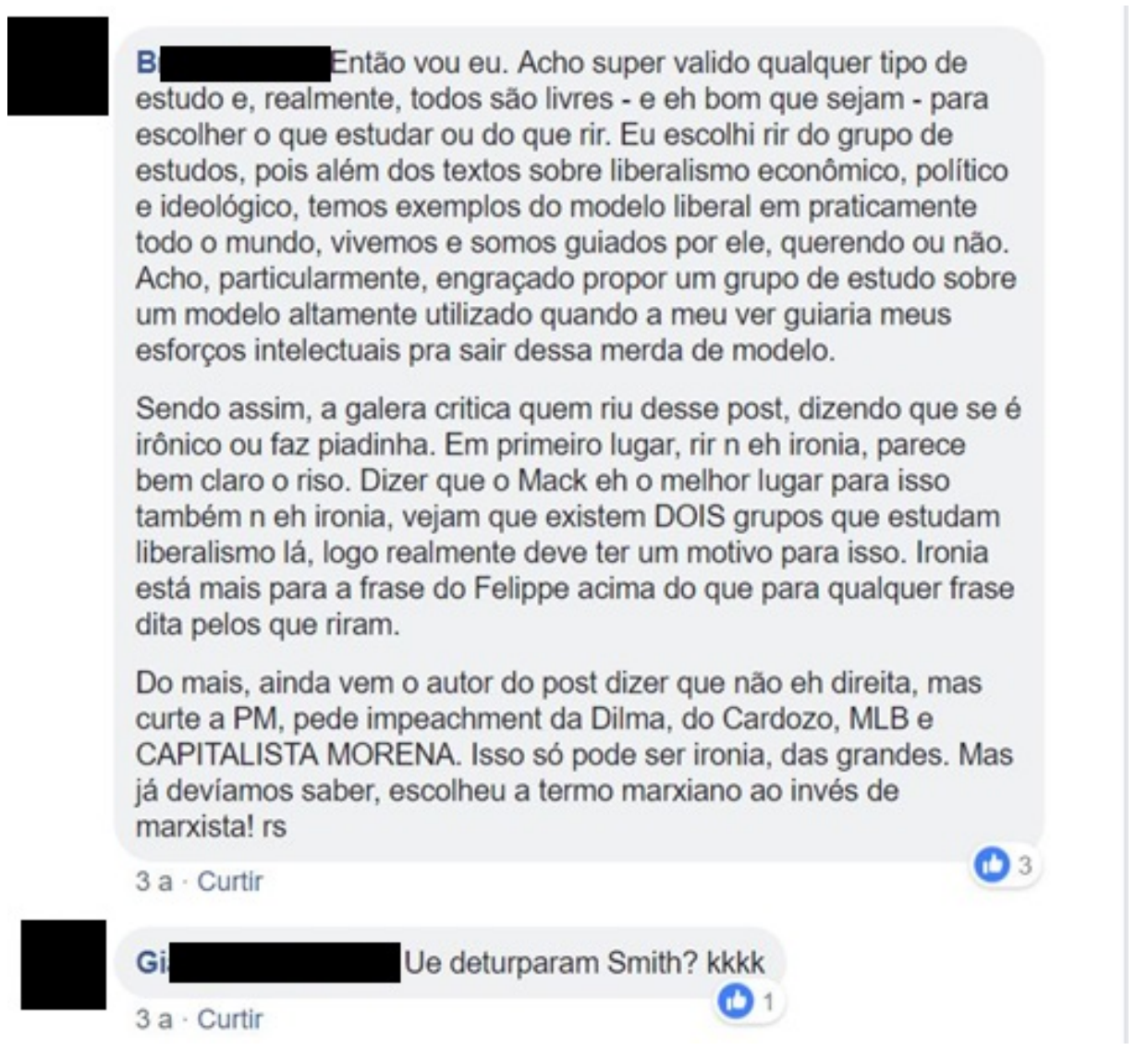

Fonte: Facebook (2015)

B também defende que não fez uso de ironia ao rir da publicação de $\mathbf{L}$ e, também ataca a imagem de Fe: "Sendo assim, a galera critica quem riu desse post, dizendo que se é irônico ou faz piadinha. Em primeiro lugar, rir $n$ eh ironia, 
parece bem claro o riso. Dizer que o Mack eh o melhor lugar para isso também n eh ironia, vejam que existem DOIS grupos que estudam liberalismo lá, logo realmente deve ter um motivo para isso. Ironia está mais para a frase do Fe acima do que para qualquer frase dita pelos que riram". Para terminar o seu comentário, B ainda faz um ataque à imagem de $\mathbf{L}$ por meio das informações acessadas em seu perfil pessoal no Facebook para ridicularizá-lo outra vez, usando a descortesia ad hominem: "Do mais, ainda vem o autor do post dizer que não eh direita, mas curte a PM, pede impeachment da Dilma, do Cardozo, MLB e CAPITALISTA MORENA. Isso só pode ser ironia, das grandes. Mas já devíamos saber, escolheu a termo marxiano ao invés de marxista!". Gi, por sua vez, faz uso da ironia de novo para criticar os comentários contra L: "Ue deturparam Smith? kkkk". G faz um ataque indireto a $\mathbf{G i}$, de forma generalizante: "Tem gente que não entende mesmo como as coisas funcionam no macro...".

Figura 203: Exemplo de descortesia no grupo de Letras/USP no Inquérito 6

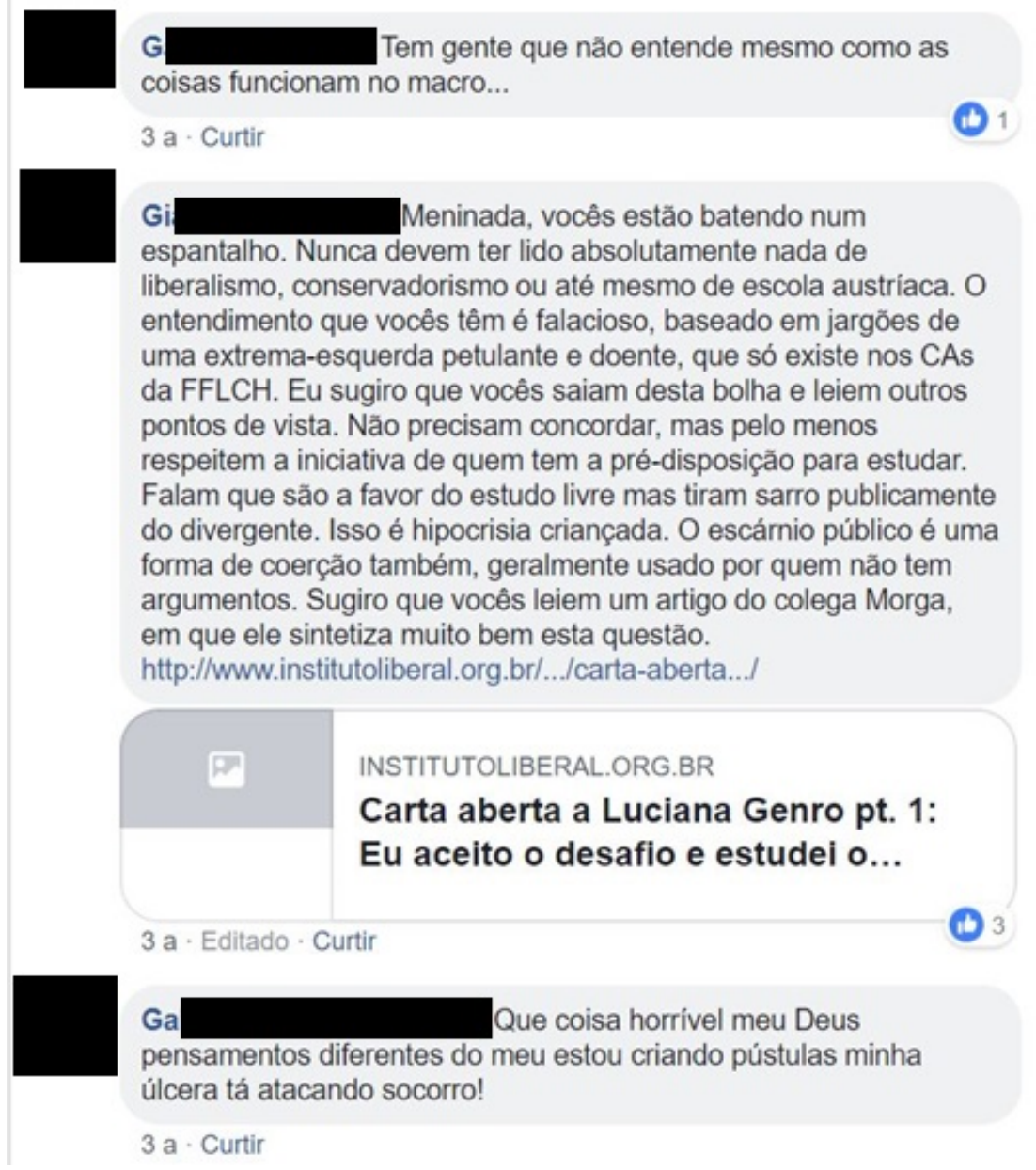

Fonte: Facebook (2015) 
Gi novamente comenta e responde os adversários de L. Gi usa termos depreciativos e irônicos para se referir aos participantes, tais como "meninada" e "criançada", e se refere a eles de modo generalizante ou de forma impessoal: "vocês estão batendo em um espantalho", "nunca devem ter lido (...)", "O entendimento que vocês têm é falacioso", e ainda aconselha: "Eu sugiro que vocês saiam desta bolha e leiem outros pontos de vista.", e pede mais respeito : "Não precisam concordar, mas pelo menos respeitem a iniciativa de quem tem a pré-disposição para estudar.", além de, novamente, criticar a ação dos participantes contra L: "Falam que são a favor do estudo livre mas tiram sarro publicamente do divergente. Isso é hipocrisia criançada. O escárnio público é uma forma de coerção também, geralmente usado por quem não tem argumentos." Ga também concorda com o posicionamento crítico de Gi e faz uma ironia contra os adversários de L: "Que coisa horrível meu Deus pensamentos diferentes do meu estou criando pústulas minha úlcera tá atacando socorro!". Logo em seguida, Ga também ironiza os adversários de L para colocálos também no mesmo patamar referido por $\mathbf{G i}$, referindo-se a eles como crianças: "Rapaziada, vocês não saíram da 5 série, na moralzinha. Deixa o cara estudar e chamar quem quiser estudar o que QUISER". 
Figura 204: Exemplo de descortesia no grupo de Letras/USP no Inquérito 6

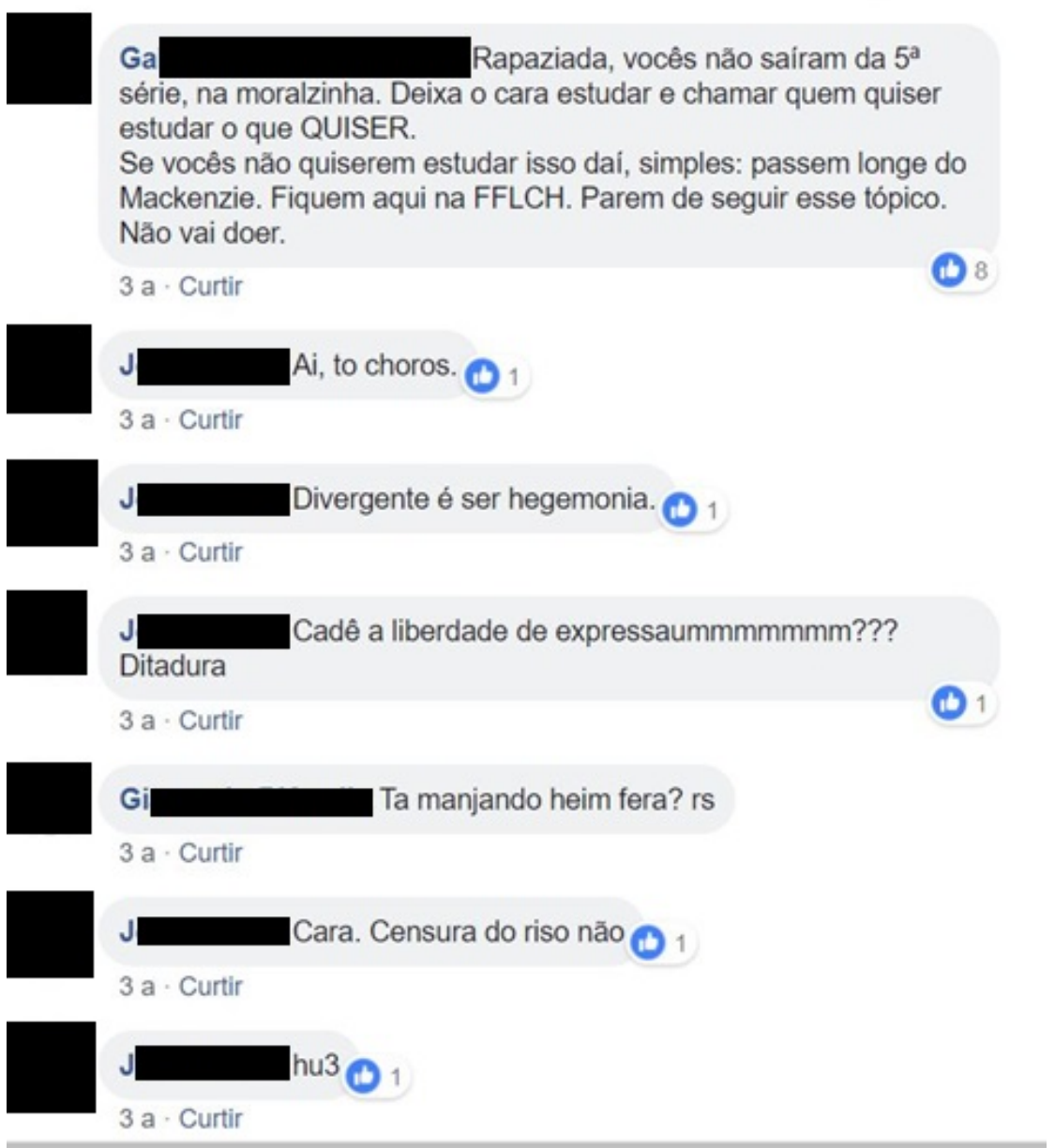

Fonte: Facebook (2015)

J faz uma série de comentários irônicos ridicularizando todo o conflito entre os partidários e adversários de $\mathbf{L}$ na interação. Gi reage contra os comentários de $\mathbf{J}$ também de forma irônica por meio de uma pergunta e usando de ironia, seguida de risos. $\mathbf{G}$ volta para comentar que o liberalismo impede muita gente de comer e Fe retoma o seu turno logo após, também criticando o comportamento dos adversários de $\mathbf{L}$. 
Figura 205: Exemplo de descortesia no grupo de Letras/USP no Inquérito 6

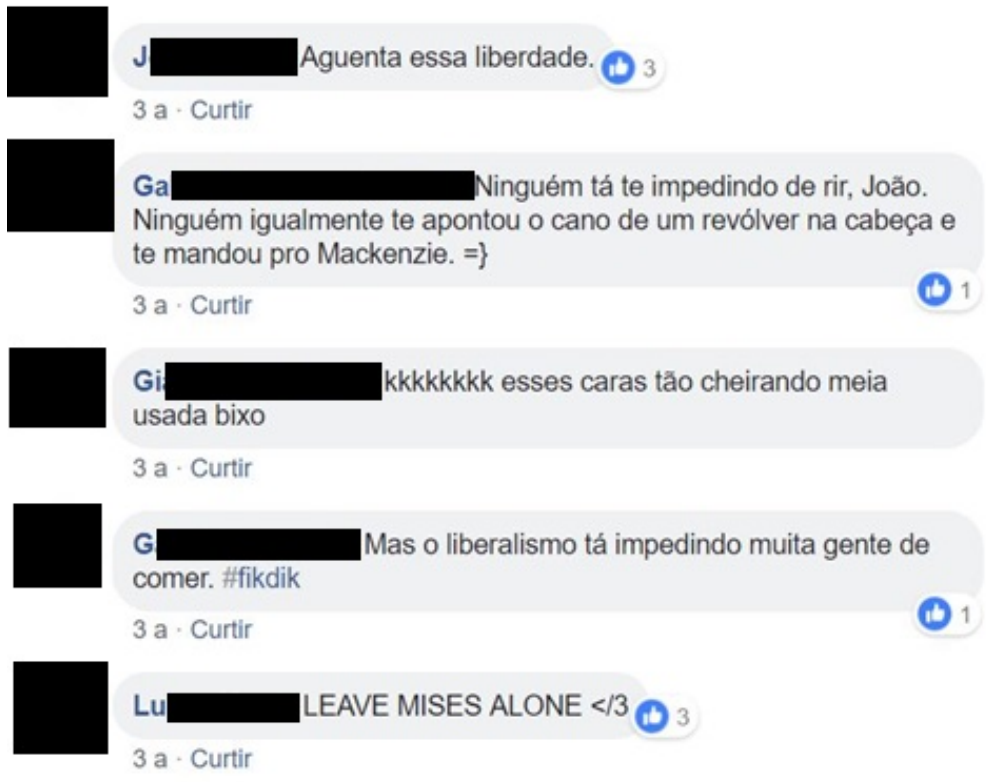

Fonte: Facebook (2015)

Fe sempre se coloca como partidário da esquerda, porém defende sua imagem oposta a esses participantes que foram descorteses com L: "Não é por brincadeira, mas por essa postura completamente infantil e arrogante de quem do alto dos seus 20 anos acha que tem as moral de dizer o que deve ou não ser estudado pelas pessoas. E mais: a incapacidade de lidar com o outro". 
Figura 206: Exemplo de descortesia no grupo de Letras/USP no Inquérito 6

$\mathrm{Fe} \longrightarrow$ Não é por brincadeira, mas por essa postura completamente infantil e arrogante de quem do alto dos seus 20 anos acha que tem as moral de dizer o que deve ou não ser estudado pelas pessoas. E mais: a incapacidade de lidar com o outro.

Eu não simpatizo nem um pouco com liberalismo mas acho válido ir atrás de teoria pra conhecer melhor e poder argumentar com mais propriedade. Acho isso mais válido do que ironizar o tempo todo kkkkk zuera sem limites Huehue lobão. Porra, o cara que fez Arquitetura da Destruiçăo, por exemplo, teve de ler muita do nazismo, investigar a fundo sua história e ideologia, e nem por isso era nazi. Interessar-se por uma teoria não significa necessariamente concordar ou ser adepto dela.

Mas também, problema nenhum se o cara que postou aqui se identifica com liberalismo, problema dele. Ele veio de boa, sem causar e fez o anúncio. Se fosse uma figura tipo CESAR TIOSSI, eu era a favor de bullying vitalicio; mas, com eSse cara anunciando na dele e A ESQUERDA vindo zoar, a piada foi a gente, mesmo tendo bandeiras confederadas do lado de lá.

3 a $\cdot$ Editado $\cdot$ Curtir

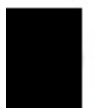

Só vejo argumentum ad ignorantiam. Tenho

interesse. Que tal incluírem Locke e Adam Smith?

2 a $\cdot$ Curtir

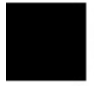

Ri Tenho interesse.

$2 \mathrm{a} \cdot$ Curtir

Fonte: Facebook (2015)

Ao fazer a crítica, Fe se previne de possíveis ataques reforçando a sua imagem como pertencente ao mesmo grupo adversário de L: "Eu não simpatizo nem um pouco com liberalismo mas acho válido ir atrás da teoria pra conhecer melhor e poder argumentar com mais propriedade." Fe também é contra o ataque ad hominem: " Mas também, problema nenhum se o cara que postou aqui se identifica com liberalismo, problema dele. Ele veio de boa, sem causar e fez o anúncio." C e Ri encerram o tópico da discussão demonstrando interesse ao grupo de L e, assim, toda a interação chega ao fim. 


\section{INQUÉRITO 6}

Tabela 8: As categorias de condições de infração da estratégia geral da descortesia no Inquérito 6

\begin{tabular}{|c|c|c|c|c|c|}
\hline \multicolumn{6}{|c|}{ As categorias de condições de infração da estratégia geral da descortesia } \\
\hline $\begin{array}{c}\text { Violação da } \\
\text { máxima } \\
\text { (expressa de } \\
\text { forma } \\
\text { imperativa) }\end{array}$ & $\begin{array}{l}\text { Participantes } \\
\text { do grupo }\end{array}$ & $\begin{array}{l}\text { Par de } \\
\text { máximas } \\
\text { relacionadas }\end{array}$ & $\begin{array}{c}\text { Categorias das máximas } \\
\text { violadas }\end{array}$ & $\begin{array}{l}\text { Classes de atos } \\
\text { de fala }\end{array}$ & $\begin{array}{c}\text { Estratégias } \\
\text { linguísticas } \\
\text { e não- } \\
\text { linguísticas } \\
\text { /híbridas }\end{array}$ \\
\hline $\begin{array}{c}\text { (M1) Atribuir } \\
\text { um valor } \\
\text { desfavorável } \\
\text { aos interesses } \\
\text { do interlocutor } \\
\text { (Outro) }\end{array}$ & G, B,F, M & \multirow{2}{*}{$\begin{array}{c}\text { Generosidade/ } \\
\text { Tato }\end{array}$} & Generosidade & Recusar, ameaçar & Uso de ironia \\
\hline $\begin{array}{c}\text { (M2) Atribuir } \\
\text { um valor } \\
\text { favorável aos } \\
\text { interesses do } \\
\text { EU (Locutor) }\end{array}$ & $\mathbf{L}$ & & Tato & Ordem, demanda & $\begin{array}{l}\text { Uso do } \\
\text { imperativo, } \\
\text { futuro do } \\
\text { pretérito }\end{array}$ \\
\hline $\begin{array}{c}\text { (M3) Atribuir } \\
\text { um valor } \\
\text { desfavorável } \\
\text { às qualidades } \\
\text { do interlocutor } \\
\text { (Outro) }\end{array}$ & $\begin{array}{l}\text { Todos os } \\
\text { participantes }\end{array}$ & \multirow{2}{*}{$\begin{array}{l}\text { Aprovação/ } \\
\text { Modéstia }\end{array}$} & Aprovação & $\begin{array}{l}\text { Insultar, reclamar, } \\
\text { falar mal do } \\
\text { interlocutor }\end{array}$ & $\begin{array}{l}\text { Uso de } \\
\text { ironia, atos } \\
\text { de fala } \\
\text { indireto } \\
\text { (crítica) }\end{array}$ \\
\hline $\begin{array}{l}\text { (M4)Atribuir } \\
\text { um valor } \\
\text { favorável às } \\
\text { qualidades do } \\
\text { EU (Locutor) }\end{array}$ & $\mathbf{L}$ & & Modéstia & $\begin{array}{l}\text { Gabar-se, ser } \\
\text { complacente }\end{array}$ & $\begin{array}{l}\text { Experiência } \\
\text { pessoal, } \\
\text { nível de } \\
\text { estudo }\end{array}$ \\
\hline $\begin{array}{l}\text { (M5) Atribuir } \\
\text { um valor } \\
\text { desfavorável } \\
\text { às obrigações } \\
\text { do EU } \\
\text { (Locutor) para } \\
\text { com o } \\
\text { interlocutor } \\
\text { (Outro) }\end{array}$ & $\begin{array}{c}\text { Sem } \\
\text { ocorrências }\end{array}$ & \multirow[t]{2}{*}{ Obrigação } & Obrigação (ao interlocutor) & $\begin{array}{c}\text { Recusar } \\
\text { agradecimentos ou } \\
\text { desculpas }\end{array}$ & $\begin{array}{c}\text { Sem } \\
\text { ocorrências }\end{array}$ \\
\hline $\begin{array}{l}\text { (M6) Atribuir } \\
\text { um valor } \\
\text { favorável às } \\
\text { obrigações do } \\
\text { interlocutor } \\
\text { para com o } \\
\text { Locutor }\end{array}$ & $\begin{array}{c}\text { Sem } \\
\text { ocorrências }\end{array}$ & & Obrigação (ao Locutor) & $\begin{array}{l}\text { Agradecer ou } \\
\text { desculpar-se }\end{array}$ & $\begin{array}{c}\text { Sem } \\
\text { ocorrências }\end{array}$ \\
\hline $\begin{array}{l}\text { (M7) Atribuir } \\
\text { um valor } \\
\text { desfavorável } \\
\text { às opiniões do } \\
\text { interlocutor } \\
\text { (Outro) }\end{array}$ & $\begin{array}{l}\text { Todos os } \\
\text { participantes }\end{array}$ & \multirow[b]{2}{*}{ Opinião } & Concordância & $\begin{array}{l}\text { Discordar, } \\
\text { contradizer }\end{array}$ & $\begin{array}{l}\text { Uso de } \\
\text { ironia, atos } \\
\text { de fala } \\
\text { indireto } \\
\text { (crítica) }\end{array}$ \\
\hline $\begin{array}{l}\text { (M8) Atribuir } \\
\text { um valor } \\
\text { favorável às } \\
\text { opiniões do } \\
\text { Locutor (EU) }\end{array}$ & $\begin{array}{c}\text { Gi, A, Lí, Le, R, } \\
\text { Ri, Ro, Fe, Cr, } \\
\text { Br }\end{array}$ & & Opinião reticente & Ser opinativo & $\begin{array}{l}\text { Defesa da } \\
\text { opinião } \\
\text { contrária por } \\
\text { meio de } \\
\text { críticas } \\
\text { indiretas ou } \\
\text { ironia em } \\
\text { defesa do } \\
\text { locutor }\end{array}$ \\
\hline $\begin{array}{l}\text { (M9) Atribuir } \\
\text { um valor } \\
\text { desfavorável } \\
\text { aos } \\
\text { sentimentos do } \\
\text { interlocutor } \\
\text { (Outro) }\end{array}$ & $\begin{array}{l}\text { Todos os } \\
\text { participantes }\end{array}$ & \multirow[t]{2}{*}{ Sentimento } & Simpatia & $\begin{array}{l}\text { Expressar antipatia } \\
\text { ao interlocutor }\end{array}$ & $\begin{array}{l}\text { Uso de } \\
\text { insultos, } \\
\text { ironia }\end{array}$ \\
\hline $\begin{array}{l}\text { (M10) Atribuir } \\
\text { um valor } \\
\text { favorável aos } \\
\text { sentimentos do } \\
\text { Locutor (EU) }\end{array}$ & $\begin{array}{c}\text { Gi, A, Lí, Le, R, } \\
\text { Ri, Ro, Fe, Cr, } \\
\text { Br }\end{array}$ & & Sentimento reticente & $\begin{array}{l}\text { Reclamar, } \\
\text { resmungar }\end{array}$ & $\begin{array}{l}\text { Uso de } \\
\text { ironia, atos } \\
\text { de fala } \\
\text { indireto } \\
\text { (crítica) }\end{array}$ \\
\hline
\end{tabular}




\section{INQUÉRITO 7}

M faz uma postagem no grupo de Letras para fazer um pedido sob forma de ordem. Antes de publicar, coloca, inclusive, o seu sentimento em relação ao problema, seguido por um emoticon: "se sentindo desrespeitada". De modo impositivo, $\mathbf{M}$ se refere aos integrantes do grupo como "colegas" e, em maiúsculas, usa um moderador antes acrescentar a ordem: "POR FAVOR, NÃO tirem seus sapatos/sapatilhas na sala. É confortável SÓ pra vc".

Figura 207: Exemplo de descortesia no grupo de Letras/USP no Inquérito 7

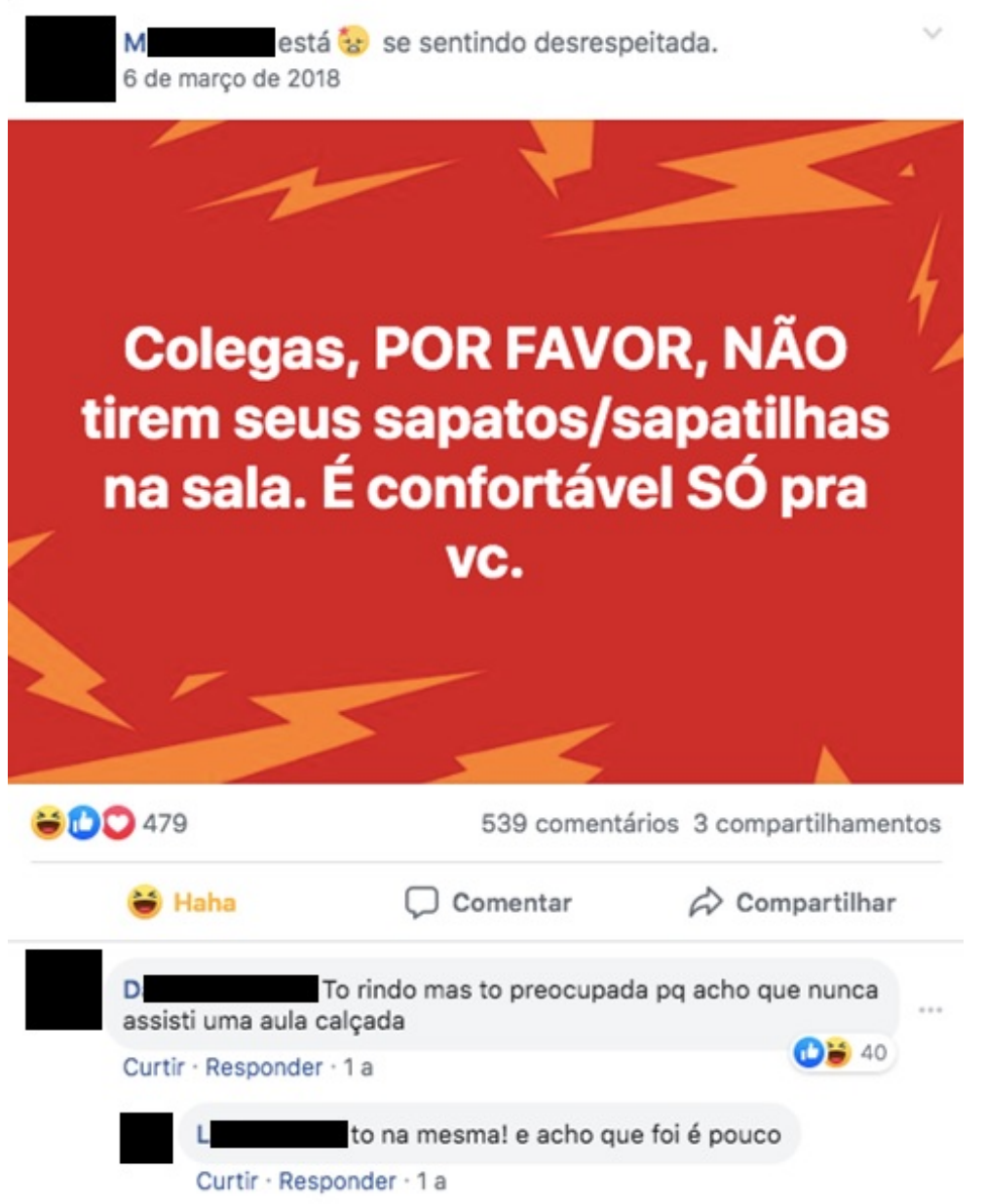

Fonte: Facebook (2018)

A publicação de $\mathbf{M}$ recebe 539 comentários, 3 compartilhamentos e reações de curtidas, risadas e amei. D é a primeira a comentar, explicando que riu, mas ao mesmo tempo se preocupou pelo fato de nunca assistir uma aula 
calçada. Mesmo que a postagem de $\mathbf{M}$ não tenha sido direcionada à $\mathbf{D}$, esta se sentiu ameaçada em sua imagem pelo fato de agir da maneira como $\mathbf{M}$ critica. $\mathbf{L}$ responde, logo em seguida, à $\mathbf{D}$, para explicar que também costuma ficar descalça e que também sentiu sua imagem ameaçada: "to na mesma! e acho que foi é pouco". Ma reage com uma interjeição, "Oxi" e recebe 3 curtidas. A interjeição "Oxi" é muito utilizada na internet para demonstrar espanto em relação à alguma coisa. $\mathbf{A}$ e $\mathbf{A l}$ também se expressam com a mesma interjeição e A, inclusive, coloca logo após a interjeição o número 2 entre parênteses, recurso usado na rede social digital para intensificar o comentário.

Figura 208: Exemplo de descortesia no grupo de Letras/USP no Inquérito 7

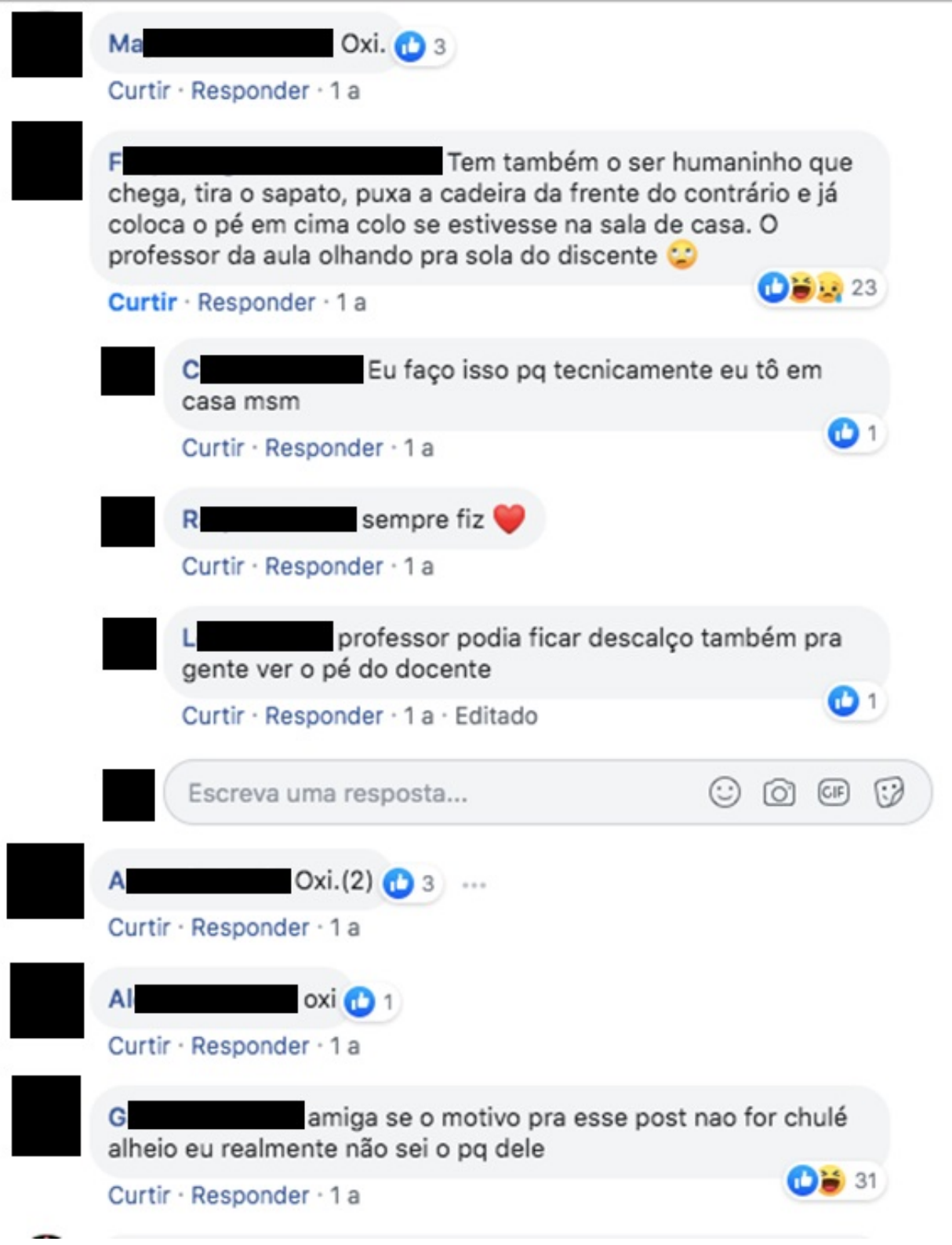


Fonte: Facebook (2018)

F aproveita a reclamação de $\mathbf{M}$ para também criticar os alunos que tiram o sapato e colocam os pés em outra cadeira: "Tem também o ser humaninho que chega, tira o sapato, puxa a cadeira da frente do contrário e já coloca o pé em cima colo se estivesse na sala de casa". $\mathbf{F}$ faz a crítica aos alunos que agem dessa forma e se refere a eles como "ser humaninho", usando o diminutivo para depreciar, de forma mais generalizante, os alunos, embora $\mathbf{F}$ se refira a esses alunos específicos que colocam os pés nas cadeiras. $\mathbf{O}$ comentário de $\mathbf{F}$ ainda finaliza com um emoticon com os olhos virados para o lado, representando desconforto e tédio com a situação. $\mathrm{O}$ comentário de $\mathbf{F}$ recebe curtidas, risos e choros. $\mathbf{C}$ responde a $\mathbf{F}$ e ameaça ambas as imagens, pois $\mathbf{C}$ se inclui no grupo que se comporta, tal como $\mathbf{F}$ reclamou. Em posição de crítica, $\mathbf{F}$ também tem sua própria imagem ameaçada e, $\mathbf{C}$ retoma, inclusive, as palavras de $\mathbf{F}$, ao defender que o problema era o fato de os alunos agirem como se estivessem em casa: "Eu faço isso pq tecnicamente eu tô em casa msm". $\mathbf{R}$ também concorda com $\mathbf{C}$ : "sempre fiz" e o seu comentário finaliza com um coração. $\mathbf{L}$ também concorda com o posicionamento de $\mathbf{C}$ e $\mathbf{R}$ e ainda sugere que os professores também deveriam fazer o mesmo. Percebe-se, assim, que $\mathbf{F}$ ataca a imagem dos alunos, mas ao mesmo tempo é atacado por aqueles que colocam os pés nas cadeiras em sala de aula. G, por sua vez, critica a publicação de $\mathbf{M}$ devido à ambiguidade de sua mensagem. G parece não saber ao certo se $\mathbf{M}$ se refere ao comportamento dos alunos de simplesmente tirarem os sapatos em aula ou se M se refere ao "chulé alheio". G se dirige a $\mathbf{M}$ com uma forma de tratamento próxima, mas ao mesmo tempo ameaça a imagem de seu interlocutor ao discutir o motivo da publicação: "amiga se o motivo pra esse post nao for chulé alheio eu realmente não sei o pq dele". O comentário de $\mathbf{G}$ recebe 31 reações, entre curtidas e risos. $\mathbf{G i}$, a partir da publicação de $\mathbf{G}$, também se refere à ambiguidade da postagem de M: "Sem chulé acho que sem problemas, né?!"e atenua a situação de forma humorada, com risos ao se referir aos alunos com chulé: "Agora se largar aquela bomba atômica, fica complicado.Rsrsrs". 
Figura 209: Exemplo de descortesia no grupo de Letras/USP no Inquérito 7

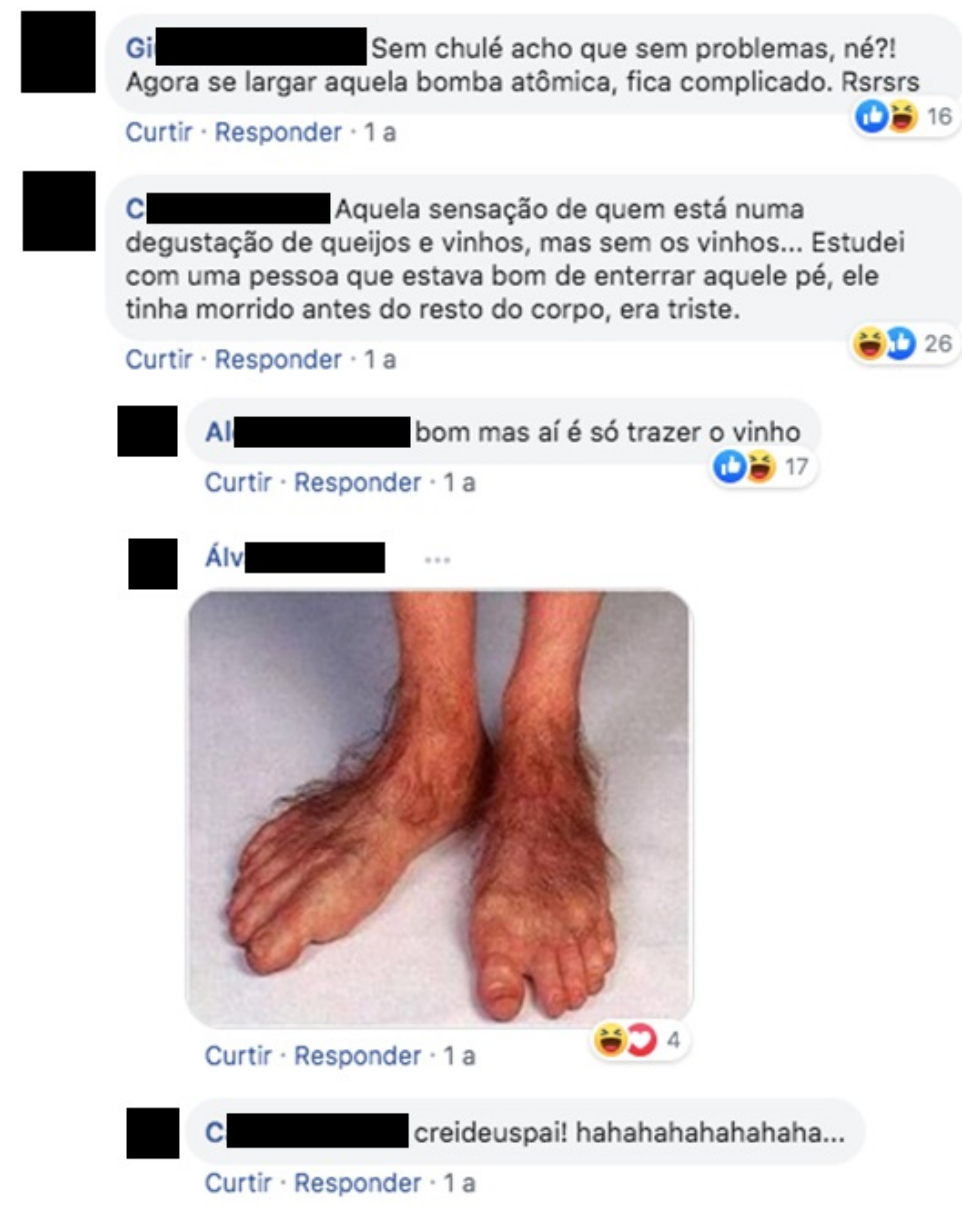

Fonte: Facebook (2018)

A discussão dos alunos começa a tomar outra direção, ao discutir sobre chulé. C critica os alunos com chulé e se refere a uma pessoa com o problema, usando a indeterminação "uma pessoa": "Estudei com uma pessoa que estava bom de enterrar aquele pé, ele tinha morrido antes do resto do corpo, era triste." A publicação de $\mathbf{C}$ recebe 26 reações entre curtidas e risos. Ao receber curtidas, infere-se que alguns alunos concordam com o comentário de $\mathbf{C}$ e já vivenciaram o problema. Al reage com humor ao comentário de $\mathbf{C}$, esta que se sentia em uma degustação de queijos e vinhos, mas sem o vinho devido ao chulé alheio: "bom mas aí é só trazer o vinho". O comentário recebe 17 reações, entre curtidas e risadas. Logo em seguida, outro aluno, Álv, coloca a figura de um pé feio e peludo no grupo, o que suscita risos e amei como reações. $\mathbf{C}$ responde a Álv com humor também: "creideuspai! hahahahahahaha..." 
Ma entende que $\mathbf{M}$, a responsável pela publicação, critica o fato dos alunos estarem descalços e reclama de maneira indireta da imposição de $\mathbf{M}$, referindo-se às pessoas de modo geral e restringindo o hábito de estar calçado aos alunos da FEA, Faculdade de Economia e Administração da USP: "Tao querendo impedir as pessoas de ficarem descalças agora? Sorry people, não somos da FEA".

Figura 210: Exemplo de descortesia no grupo de Letras/USP no Inquérito 7

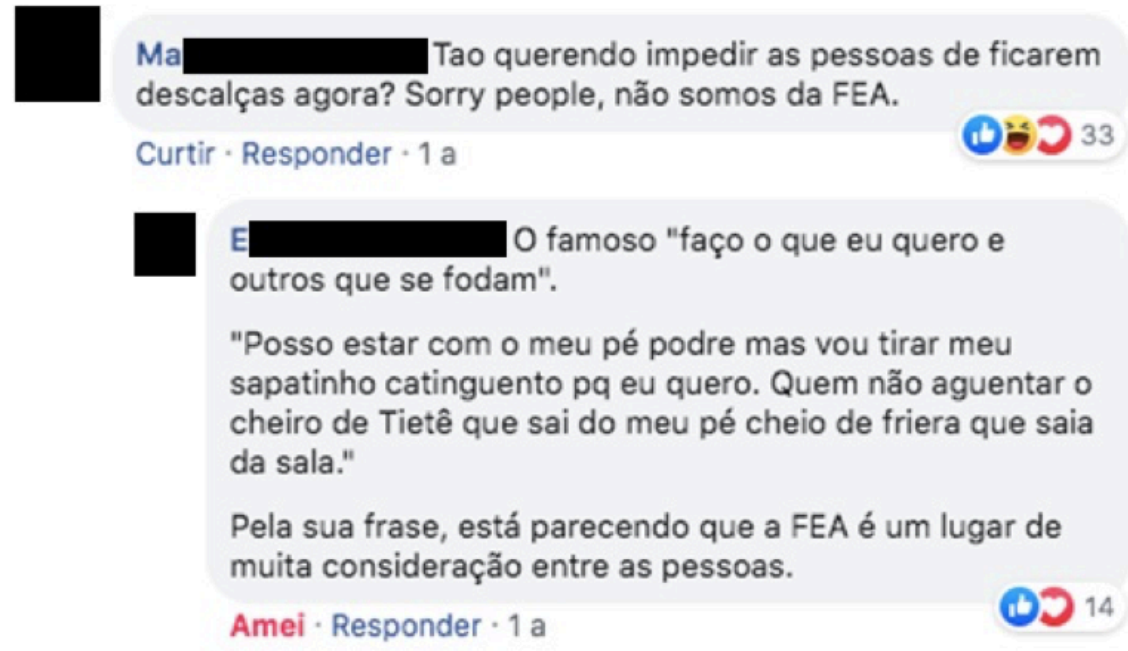

Fonte: Facebook (2018)

A publicação de Ma recebe 33 curtidas, porém $\mathbf{E}$ lhe responde, criticandoa: "O famoso "faço o que eu quero e outros que se fodam." "Posso estar com o meu pé podre mas vou tirar meu sapatinho catinguento pq eu quero. Quem não aguentar o cheiro de Tietê que sai do meu pé cheio de friera que saia da sala". A marcação das aspas no comentário de $\mathbf{E}$ foi usada, sobretudo, como forma de defesa para destacar que as palavras usadas em seu comentário são de outra voz, provenientes de outras pessoas e não pertencentes a ele mesmo, mas E se apropria delas para fazer a crítica à Ma e, assim, proteger sua imagem.

Al se refere a $\mathbf{E}$ para retomar as palavras de Ma e defendê-la: "é um lugar de sapatos e [E, o interlocutor]". E, por sua vez, responde a Al: "do que vc tá falando, cara?" Ma retoma o turno para se explicar: "A FEA é lugar de roupa e sapato social.". E responde de forma irônica e ameaçadora, esperando a complementação do comentário: "e?". 
Figura 211: Exemplo de descortesia no grupo de Letras/USP no Inquérito 7

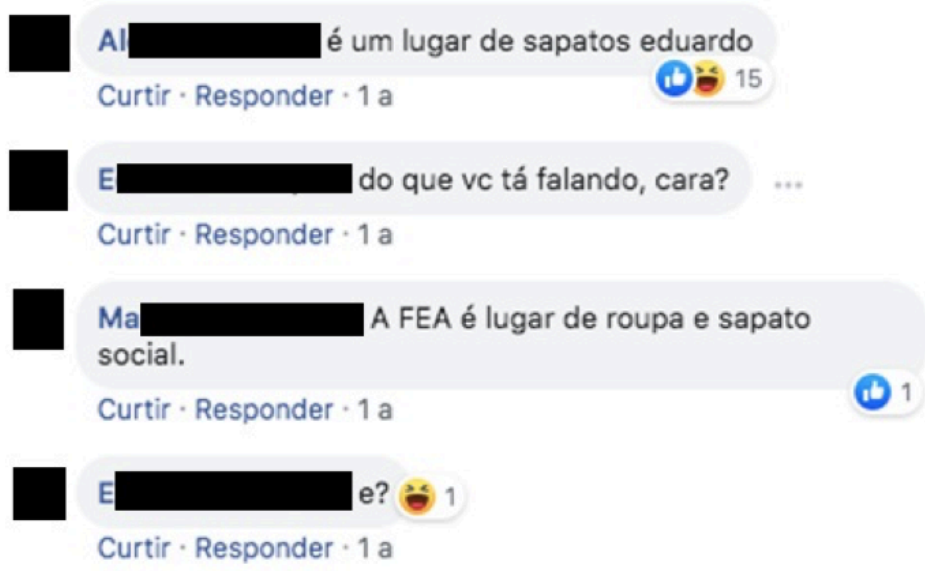

Fonte: Facebook (2018)

E retoma o turno e, novamente, usa o recurso das aspas para se defender e proteger a sua imagem, mas desta vez, usa as aspas para se referir aos comentários já feitos pelos colegas no grupo, além de se referir às pessoas que são obrigadas a aguentar o problema: "pq a fflch não é um lugar de "roupa e sapato social" as pessoas são obrigadas a aguentar a catinga de chulé de quem quer tirar o seu sapatinho e abrir as portas das catacumbas?". Al responde ironizando o comentário de $\mathbf{E}$, defendendo que seria necessário colocar a polícia para revistar o pé das pessoas para prender quem tivesse chulé. Al tenta minimizar o problema e coloca a figura da polícia em seu comentário para ironizar, pois interpreta que o pedido de $\mathbf{M}$ é uma ordem: 
Figura 212: Exemplo de descortesia no grupo de Letras/USP no Inquérito 7

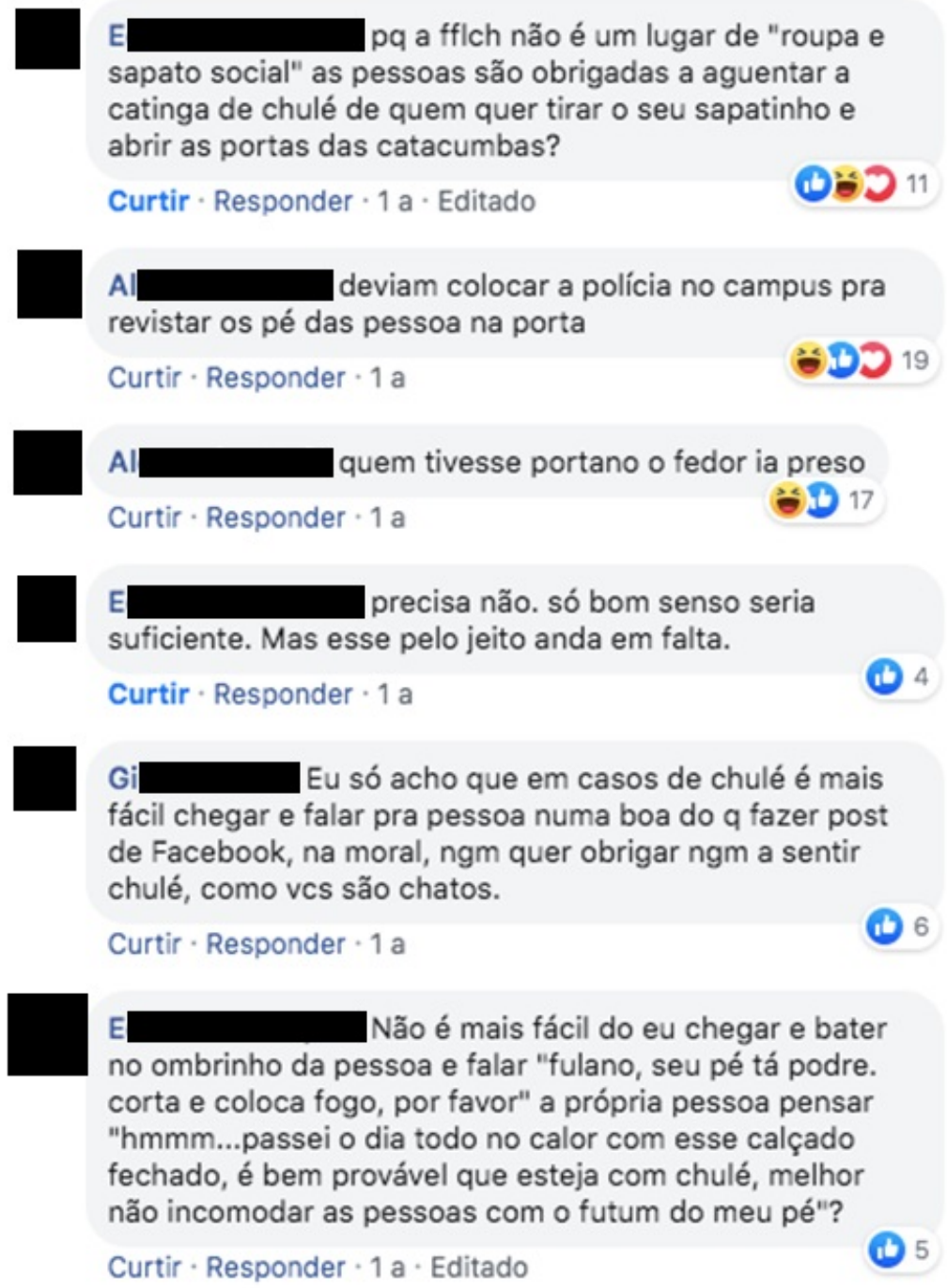

Fonte: Facebook (2018)

$\mathbf{E}$, por sua vez, retoma o turno refutando a ironia de $\mathbf{A l}$, defendendo que não é necessário polícia, mas sim bom senso. E critica de forma indireta a falta de bom senso dos colegas: "Mas esse [o bom senso] pelo jeito anda em falta."

Outro interactante, $\mathbf{G i}$, critica a publicação de $\mathbf{M}$, usando um marcador discursivo modalizador. Gi acredita que não se deve fazer uma publicação no Facebook, mas sim reclamar pessoalmente com a pessoa que causa o problema: "Eu só acho que em casos de chulé é mais fácil chegar e falar pra pessoa numa boa do q fazer post de Facebook, na moral, ngm quer obrigar ngm a sentir chulé, como vcs são chatos". Ao usar um modalizador, Gi instaura uma distância entre o sujeito da enunciação e o conteúdo de seu enunciado e, assim, previne-se de possíveis ataques à sua imagem. Gi, logo em seguida, reclama 
de todos os participantes do grupo de forma generalizante: "como vcs são chatos."

E defende que abordar a pessoa não seria a maneira mais fácil e, com aspas, coloca uma fala hipotética de como seria sua abordagem em relação à pessoa: "Não é mais fácil do eu chegar e bater no ombrinho da pessoa e falar: "fulano, seu pé tá podre. corta e coloca fogo, por favor" a própria pessoa pensar "hmmm... passei o dia todo no calor com esse calçado fechado, é bem provável que esteja com chulé, melhor não incomodar as pessoas com o futum do meu pé"? E sustenta que as pessoas é que deveriam estar cientes do problema e não incomodar as demais, respeitando o próximo com o uso do bom senso e intensifica com o alongamento de vogais o seu posicionamento: "sei lá, a lógica do bom senso não parece ser tããão complicada assim"

Gi retoma o seu turno e reclama da abordagem hipotética de E:" Se vc chegasse falando desse jeito, chamando o meu pé de podre, eu, por exemplo, esfregaria meu pé hipoteticamente fedido na sua cara".

Figura 213: Exemplo de descortesia no grupo de Letras/USP no Inquérito 7

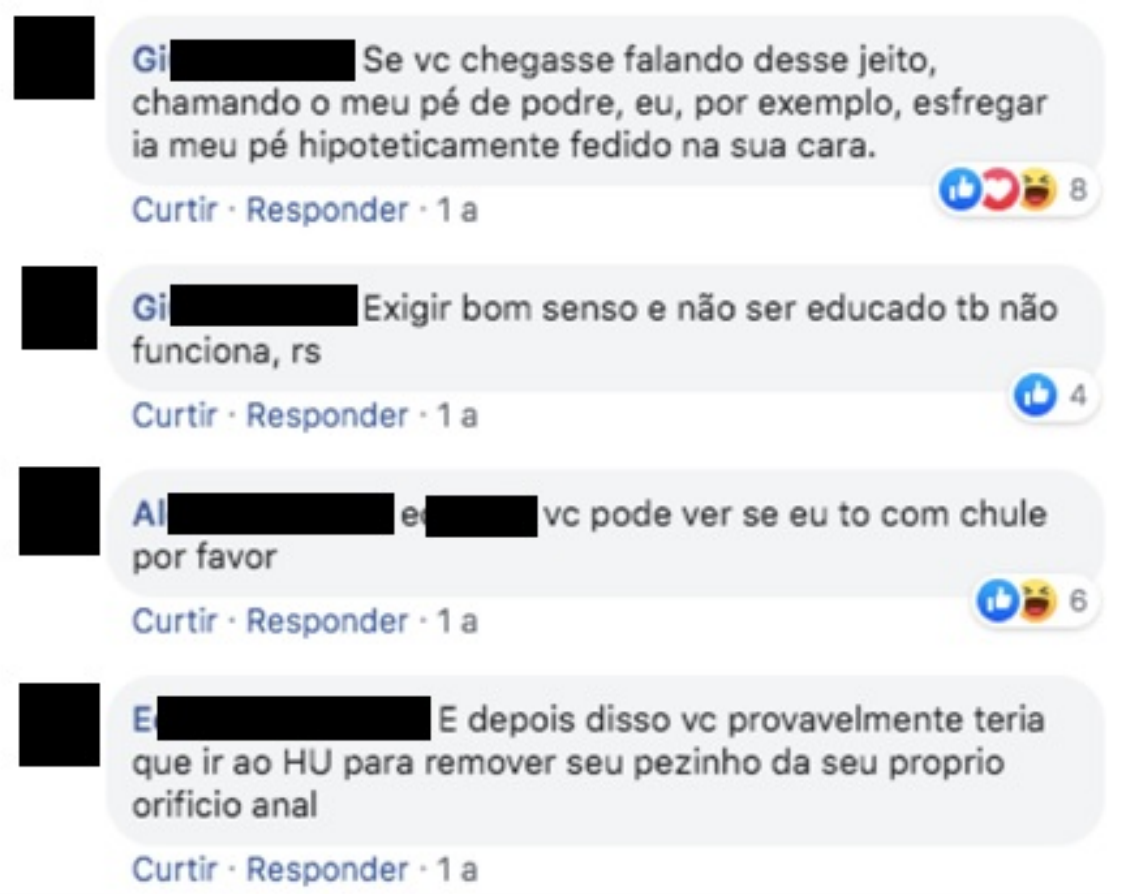

Fonte: Facebook (2018) 
Sendo assim, Gi defende resolver o problema pessoalmente, mas, de forma cortês para que o pedido funcione com o interlocutor: "Exigir bom senso e também não ser educado tb não funciona, rs". Em seguida, Al pede para que $\mathbf{E}$ verifique se ele está com chulé ou não e, assim, E tem sua imagem atacada: "e, vc pode ver se eu to com chule por favor". Diante da ameaça à sua imagem, E faz uma ameaça física a Al " E depois disso vc provavelmente teria que ir ao HU para remover seu pezinho da seu proprio orificio anal". Al responde usando palavras de baixo calão: "Vc cheira com meu cu?"e a descortesia entre ambos continua.

Figura 214: Exemplo de descortesia no grupo de Letras/USP no Inquérito 7

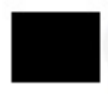

vc cheira com meu cu?

Curtir - Responder - 1 a

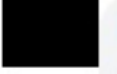

E

não ter bom senso. Minha úlcera simplesmente não

suporta.

Curtir - Responder - 1 a

Fonte: Facebook (2018)

E faz uma crítica indireta a Gi e Al "E pior ainda, é querer exigir educação e não ter bom senso. Minha úlcera simplesmente não suporta". Gi, por sua vez, retoma o turno para se defender: "Acho que exigir educação não é coisa de quem tem bom senso, pra começar. Eu sou educada por escolha minha, não exijo coisas, posso pedir, mas exigir não me parece legal, me fede aos ouvidos. Agora, me conta mais sobre esse fetiche de pé no cu, tinha uma galera aqui nos comentários nessa vibe tb, mas eu não sou tão flexível. Ainda bem que úlceras não têm chulé". 
Figura 215: Exemplo de descortesia no grupo de Letras/USP no Inquérito 7

Acho que exigir educação não é coisa de quem tem bom senso, pra começar. Eu sou educada por escolha minha, não exijo coisas, posso pedir, mas exigir não me parece legal, me fede aos ouvidos.

Agora, me conta mais sobre esse fetiche de pé no cu, tinha uma galera aqui nos comentários nessa vibe tb, mas eu não sou tão flexível.

Ainda bem que úlceras não têm chulé.

Curtir - Responder - 1 a

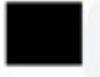

B Esse E $\square$ é uma mumia mesmo. Se o pé não fede, de tanta bosta que sai, da boca não há dúvidas! Curtir - Responder - 1 a

Du Eu não tô entendendo. Pessoas pedindo de forma mal educada pras outras serem educadas? É isso mesmo? Vamos refletir, pessoal.

Curtir - Responder - 1 a

Fonte: Facebook (2018)

B surge na interação para criticar o comportamento de $\mathbf{E}$ de forma direta, marcando-o no comentário e o insultando: "Esse $\mathbf{E}$ é uma mumia mesmo. Se o pé não fede, de tanta bosta que sai, da boca não há dúvidas!". Du também participa da interação para criticar $\mathbf{E}$ de forma indireta, no entanto, generalizando o direcionamento de sua crítica para "pessoas" em vez de se referir a $\mathbf{E}$ de forma direta: "Eu não tô entendendo. Pessoas pedindo de forma mal educada pras outras serem educadas? É isso mesmo? Vamos refletir, pessoal".

Logo em seguida, Mar critica a ambiguidade da publicação de $\mathbf{M}$, reclamando da proibição de se tirar os sapatos em sala de aula. Mar inclusive complementa o seu comentário de forma a atenuar a crítica em relação a $\mathbf{M}$, mostrando-se solidária à reclamação caso $\mathbf{M}$ tenha criticado casos de chulé : "A pessoa trabalhou $12 \mathrm{~h}$ o dia inteiro e não pode tirar o sapato? (Só entendo a proibição em caso de chulé)" 
Figura 216: Exemplo de descortesia no grupo de Letras/USP no Inquérito 7

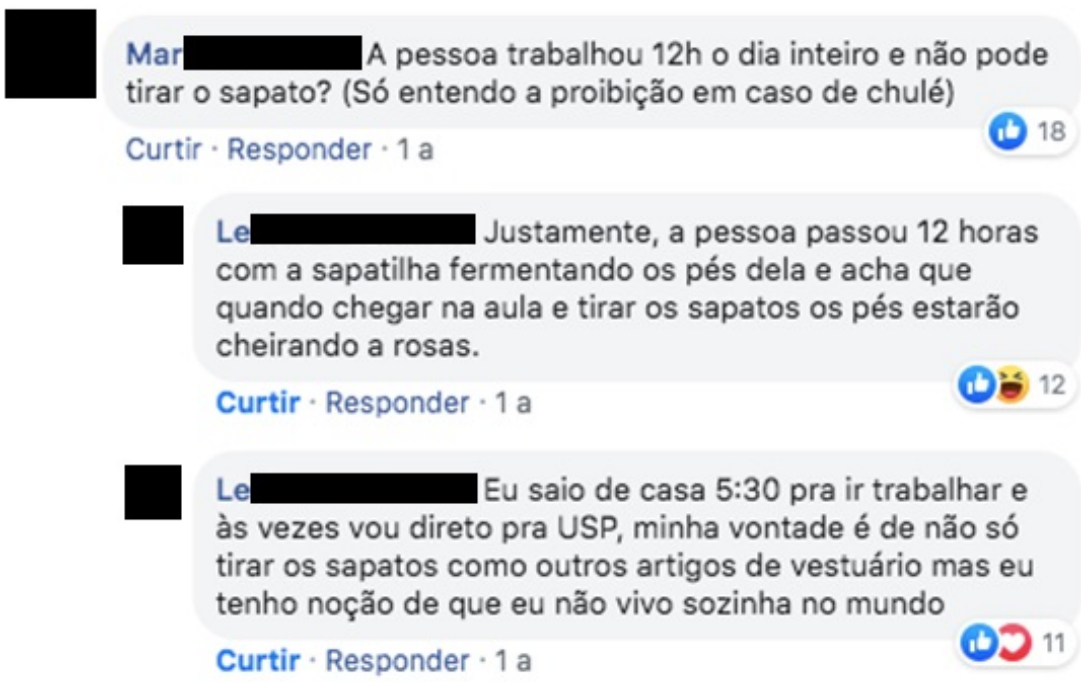

Fonte: Facebook (2018)

Le desqualifica o enunciado de Mar para justificar o seu posicionamento em relação ao problema: "Justamente, a pessoa passou 12 horas com a sapatilha fermentando os pés dela e acha que quando chegar na aula e tirar os sapatos os pés estarão cheirando a rosas". Depois de discordar com Mar, Le se apóia em sua experiência pessoal para justificar o seu ponto de vista e, assim, atenuar a ameaça à sua imagem: "Eu saio de casa 5:30 pra ir trabalhar e às vezes vou direto pra USP, minha vontade é de não só tirar os sapatos como outros artigos de vestuário mas eu tenho noção de que eu não vivo sozinha no mundo". Além de atenuar a sua crítica mostrando-se como uma pessoa que também fica muito tempo com sapato, Le valoriza também a sua própria imagem, mostrando-se uma pessoa consciente de seus atos em relação ao outro. Mar retoma o turno e não se sente ofendida e, concorda que as pessoas sofrem com o problema de chulé, mas usa o quantificador "alguns" para não generalizar o problema "Alguns pés são mais fedidos mesmo". 
Figura 217: Exemplo de descortesia no grupo de Letras/USP no Inquérito 7

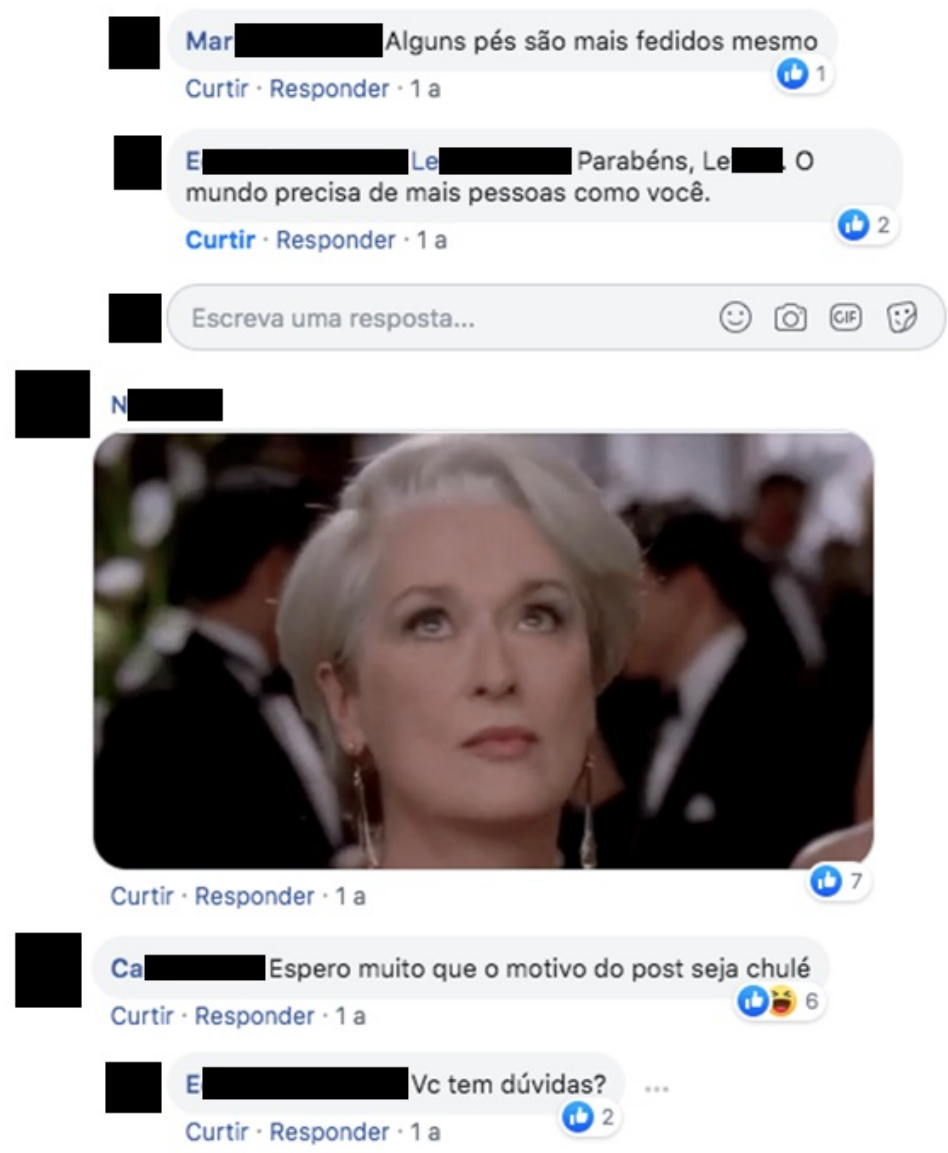

Fonte: Facebook (2018)

A tentativa de valorizar a própria imagem funciona com Le, uma vez que E a valoriza também: "Parabéns, Le. O mundo precisa de mais pessoas como você". Ao valorizar Le em detrimento dos demais, E ameaça a imagem dos outros alunos. $\mathbf{N}$ reage com um GIF com uma personagem virando os olhos", ou seja, $\mathbf{N}$ não faz o comentário verbalmente, mas mostra a sua desaprovação em relação à postagem e aos comentários. Ca também parece não entender o objetivo da publicação de $\mathbf{M}$ e diz: "Espero muito que o motivo do post seja chulé". E responde com uma pergunta retórica "Vc tem dúvidas?", pois para $\mathbf{E}$ está bem claro que $\mathbf{M}$ se refere ao problema do chulé, apenas não quis explícitálo de forma direta. $\mathrm{Ca}$ se defende valorizando a sua imagem como questionadora, pois para $\mathbf{C a}$ a ordem de $\mathbf{M}$ era passível de ambiguidade: "Vindo de um grupo em que brigam por causa de ecobag, quem não duvida é muito inocente" 
Figura 218: Exemplo de descortesia no grupo de Letras/USP no Inquérito 7

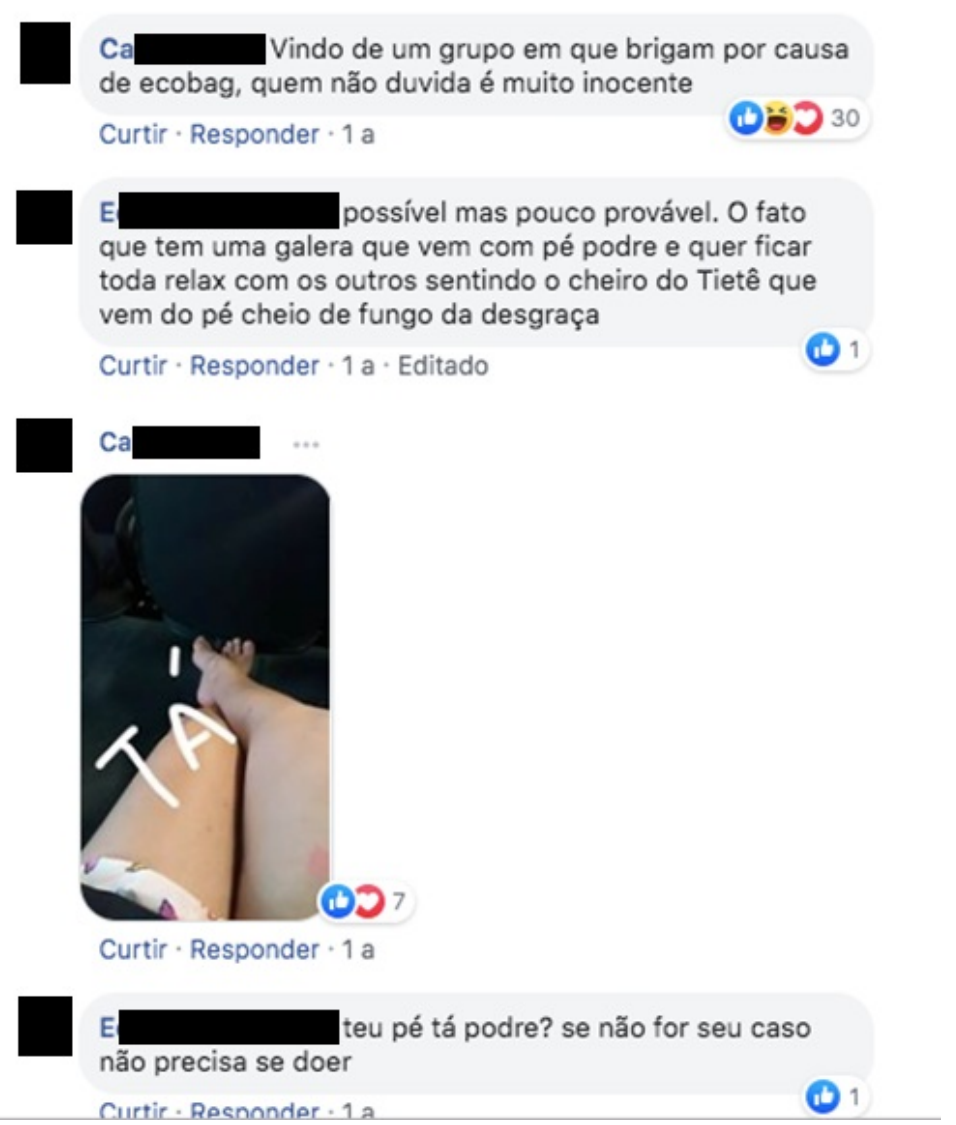

Fonte: Facebook (2018)

E complementa e minimiza a dúvida de $\mathbf{C a}$ : "possível mas pouco provável. O fato que tem uma galera que vem com pé podre e quer ficar toda relax com os outros sentindo o cheiro do Tietê que vem do pé cheio de fungo da desgraça". Ca se sente ofendida com o comentário de $\mathbf{E}$ e responde com uma foto de pés descalços, onde Ca escreve "Tá", ironizando o comentário de E. Ao ter a imagem ameaçada por $\mathbf{C a}$, E se irrita e pergunta: "teu pé tá podre? se não for seu caso não precisa se doer". Ca se refere a E usando a forma de tratamento "Migo", porém se dirige a ele de forma cortês: "Migo, quem tá falando de fungos é vc. Eu estou apenas questionando as motivações da colega.Ps. Meu pé é lindo e cheiroso". 
Figura 219: Exemplo de descortesia no grupo de Letras/USP no Inquérito 7

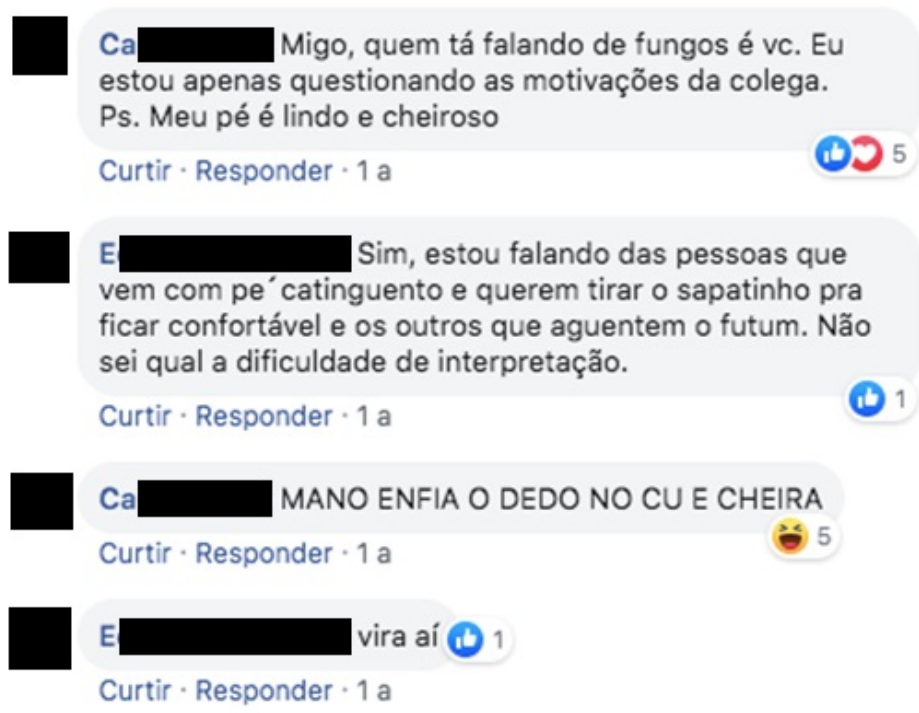

Fonte: Facebook (2018)

E retoma o turno para ironizar as capacidades de interpretação de $\mathbf{C a}$ : "Sim, estou falando das pessoas que vem com pé catinguento e querem tirar o sapatinho pra ficar confortável e os outros que aguentem o futum. Não sei qual a dificuldade de interpretação". Ca, ao ter a imagem pessoal atacada, responde de maneira descortês, enfatizada pelas maiúsculas e pelo léxico de baixo calão, insultando-o: "MANO ENFIA O DEDO NO CU E CHEIRA". E, por sua vez, aproveita a resposta de Ca para atacá-la ainda mais e atingi-la, também, fisicamente, mesmo que de forma verbal: "vira aí".

Em aparece na publicação para fazer uma crítica à comunidade da FFLCH no geral:"mais um post de "parem de fazer isso, parem de fazer aquilo" vindo de alguém da fflch... típico". 
Figura 220: Exemplo de descortesia no grupo de Letras/USP no Inquérito 7

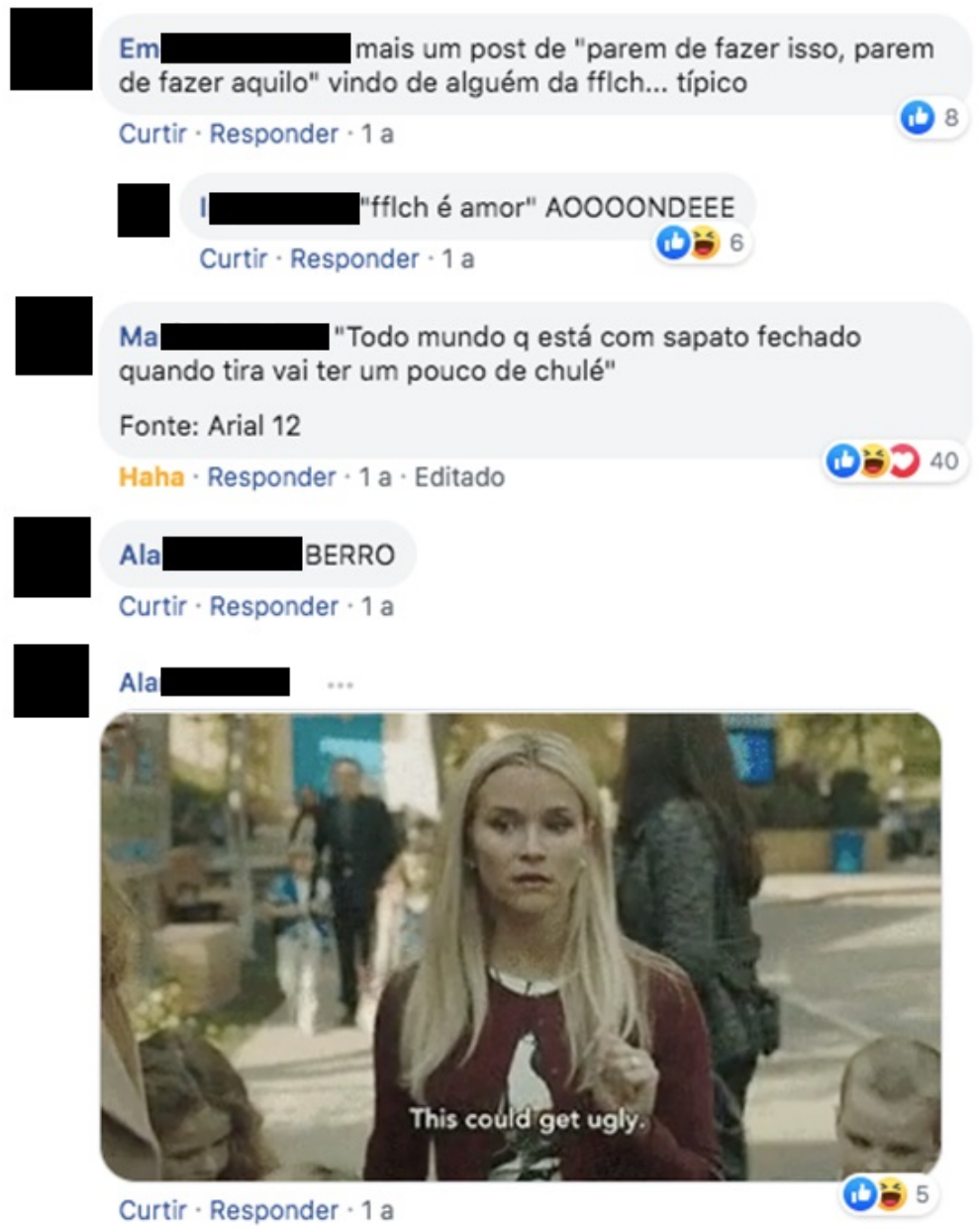

Fonte: Facebook (2018)

Em também usa o recurso das aspas para se proteger em seu comentário, pois as aspas atenuam as palavras que não foram ditas por ele, mas sim por pessoas frequentadoras da FFLCH. I complementa sua crítica à comunidade do curso também com o uso de aspas e, rebate o próprio comentário das aspas, com uso de maiúsculas: "fflch é amor" AOOOONDEEE" Mar usa o humor ao comentar, novamente, com o recurso das aspas, os enunciados de outros alunos: "Todo mundo q está com sapato fechado quando tira vai ter um pouco de chulé" Fonte: Arial 12". Ala reage com "BERRO", expressão usada em maiúsculas para representar gargalhadas. Ala ainda complementa com um GIF de um filme, onde é possível ver a frase "This could get ugly", ou seja, "Pode ficar feio". Ala entende que a discussão entre os alunos pode piorar, visto o ataque frequente contra uns aos outros. 
D retoma o seu turno para comparar a situação de chulé ao bafo, pois entende que as pessoas não percebem o problema e, tenta assim, minimizar a discussão entre os alunos: "Ninguém acha que tem chulé, é tipo bafo".

Figura 221: Exemplo de descortesia no grupo de Letras/USP no Inquérito 7
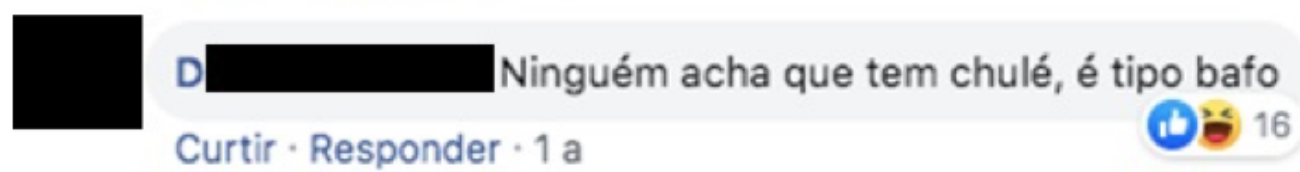

Fonte: Facebook (2018)

L se preocupa com sua própria imagem ao se questionar se já agiu de maneira impositiva em relação aos outros alunos e usa, novamente, o recurso das aspas para fazer menção às palavras dos outros e, assim, proteger sua própria imagem: "Será que eu já fui o "tinha que ser proibido tirar sapato na aula" de alguém?".

Figura 222: Exemplo de descortesia no grupo de Letras/USP no Inquérito 7

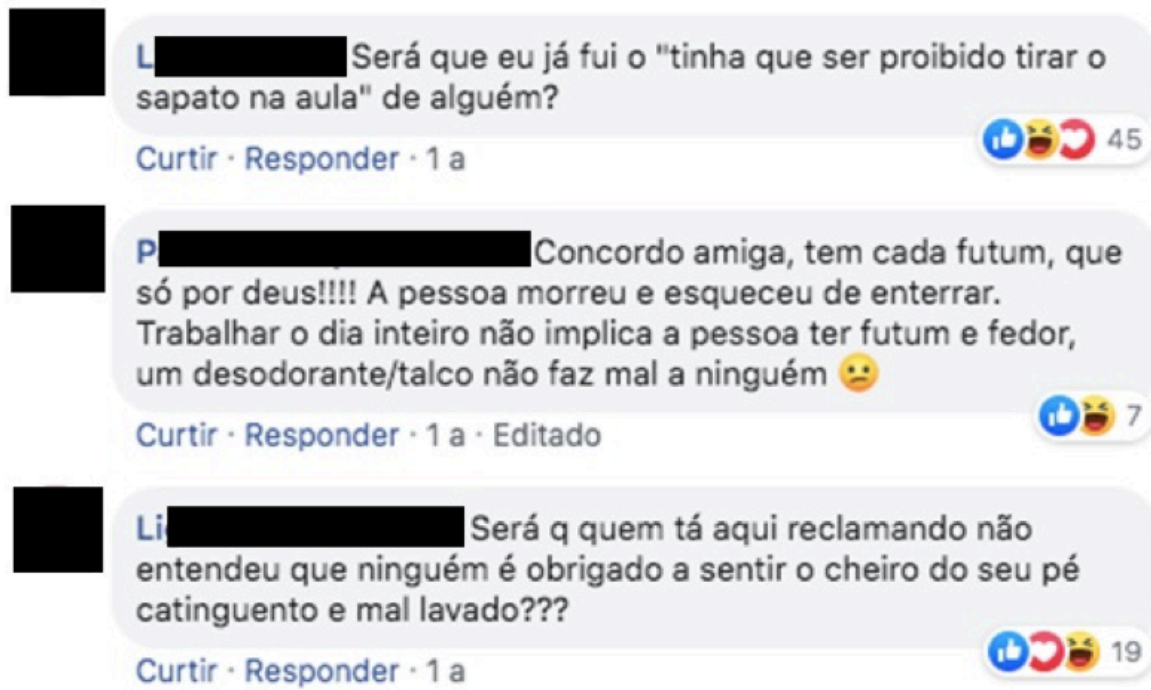

Fonte: Facebook (2018)

$\mathbf{P}$ concorda com o comentário de $\mathbf{M}$, referindo-se a ela com uma forma de tratamento íntima, "amiga" : "Concordo amiga, tem cada futum, que só por 
deus!!!! A pessoa morreu e esqueceu de enterrar. Trabalhar o dia inteiro não implica a pessoa ter futum e fedor,um desodorante/talco não faz mal a ninguém." P sugere o uso de talco ou desodorante para os pés aos alunos que precisam ficar com sapatos o dia inteiro. Apesar de $\mathbf{P}$ atacá-los com a crítica, ele quer ao mesmo tempo aconselhar para que o problema seja resolvido e, assim, atenuar a sua ameaça aos demais.

Li critica a reação dos alunos do curso: "Será q quem tá aqui reclamando não entendeu que ninguém é obrigado a sentir o cheiro do seu pé catinguento e mal lavado???" H critica a ordem de $\mathbf{M}$ e, assim, como fez $\mathbf{A l}$, ironizando o fato de ser um crime estar descalço: "infelizmente viro crime por o pe no chao gelado"

Figura 223: Exemplo de descortesia no grupo de Letras/USP no Inquérito 7

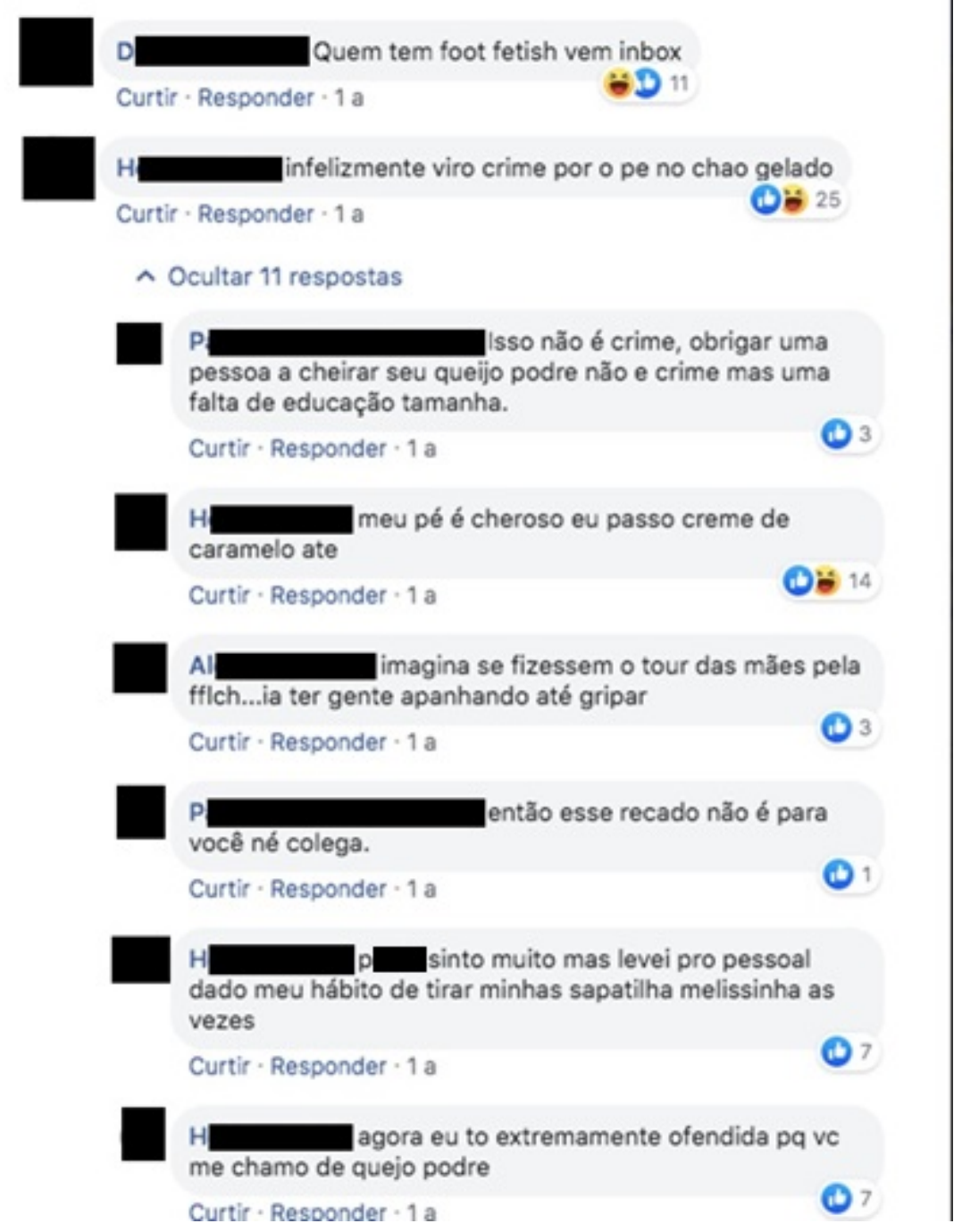

Fonte: Facebook (2018) 
$\mathbf{P}$, por sua vez, defende a diferença entre estar descalço e o fato de se ter chulé, amenizando a crítica: "Isso não é crime, obrigar uma pessoa a cheirar seu queijo podre não e crime mas uma falta de educação tamanha". H defende que seu pé é cheiroso e valoriza sua própria imagem: "meu pé é cheroso eu passo creme de caramelo ate". P se refere a $\mathbf{H}$ usando uma forma de tratamento de proximidade, "colega", afirmando que não foi uma crítica pessoal a H: "então esse recado não é para você né colega". $\mathbf{H}$ se dirige a $\mathbf{P}$, explicando que entendeu a crítica como um ataque à sua imagem: "p sinto muito mas levei pro pessoal dado meu hábito de tirar minhas sapatilha melissinha as vezes". E H ainda acrescenta: "agora eu to extremamente ofendida pq vc me chamo de quejo podre"

Figura 224: Exemplo de descortesia no grupo de Letras/USP no Inquérito 7

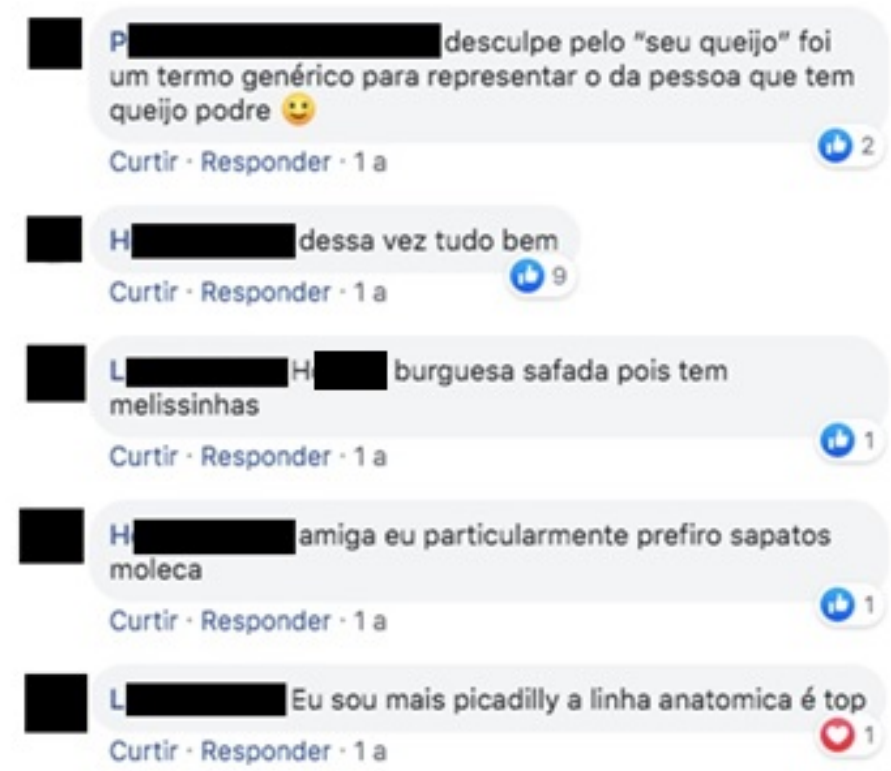

Fonte: Facebook (2018)

$\mathbf{P}$ pede desculpas a $\mathbf{H}$, amenizando o ataque de ambas as partes, $\mathbf{0}$ ofendido e o ofensor: "desculpe pelo "seu queijo" foi um termo genérico para representar o da pessoa que tem queijo podre". P explica que quis usar um termo genérico e que não era seu objetivo atacar a imagem de $\mathbf{H}$. $\mathbf{H}$ aceita as desculpas de P: "dessa vez tudo bem". L aproveita o comentário de $\mathbf{H}$ para atacá-la "burguesa safada pois tem melissinhas", porém percebe-se pelo contexto que $\mathbf{L}$ 
e $\mathbf{H}$ são amigas, pela forma de tratamento íntimo de $\mathbf{H}$ em relação à $\mathbf{L}$ após a ofensa: "amiga eu particularmente prefiro sapatos moleca". $\mathbf{L}$ responde a $\mathbf{H}$ comentando qual é a marca de sapatos que ela prefere. Trata-se, então, de um caso de pseudodescortesia entre as interactantes.

Da retoma as palavras de $\mathbf{M}$ para ironizá-la em sua ordem e, assim, também atacar a imagem de ambos: POR FAVOR não respirem na sala, é necessário só pra vc". Apesar do ataque, Da usa um moderador para fazer o pedido, mas de forma descortês, com maiúsculas. Outros alunos retomam o recurso de ataque empregado por $\mathbf{D a}$ e continuam a ironizar a ordem de $\mathbf{M}$, tal como faz R: "POR FABOR nao sente na cadeira da sala, é confortavel so pra vc". Assim, começa um ataque coletivo à imagem de $\mathbf{M}$, configurando-se como uma descortesia coletiva. Cam reclama do ato indireto da publicação de $\mathbf{M ~ e}$ sugere que $\mathbf{M}$ o faça de outra maneira: "Se o problema é o chulé, ataca o problema colega. Muda o pedido: mantenham seus pés limpos, secos e arejados". Álv reage com humor para atenuar todo o conflito que está acontecendo com os alunos por meio de um meme: 
Figura 225: Exemplo de descortesia no grupo de Letras/USP no Inquérito 7

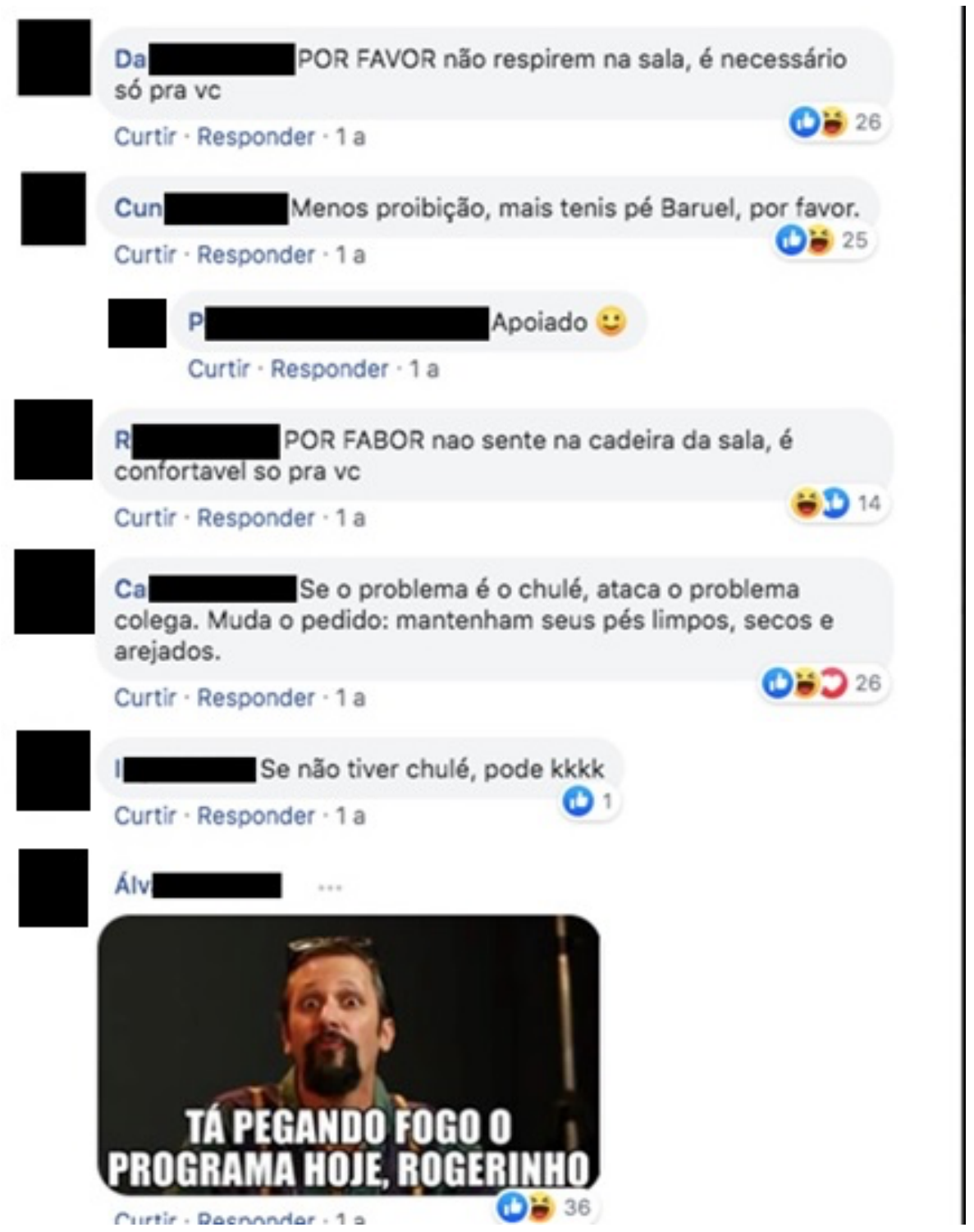

Fonte: Facebook (2018)

$\mathbf{H}$ retoma o turno para também se utilizar do humor para atenuar o conflito entre os interactantes. $\mathbf{H}$ filosofa sobre o tema "acho um absurdo que ngm tenha problematizado o higienismo dessa publicação... o que é "pé fedido"? quem define se um cheiro é agradável? O que é pé? e $\mathbf{R}$ complementa "eu acho q o conceito de pé fedido é muito subjetivo. se o pé se identifica como fedido, temos q respeita-lo". Al também ironiza a situação de conflito entre os interactantes com humor: 
Figura 226: Exemplo de descortesia no grupo de Letras/USP no Inquérito 7

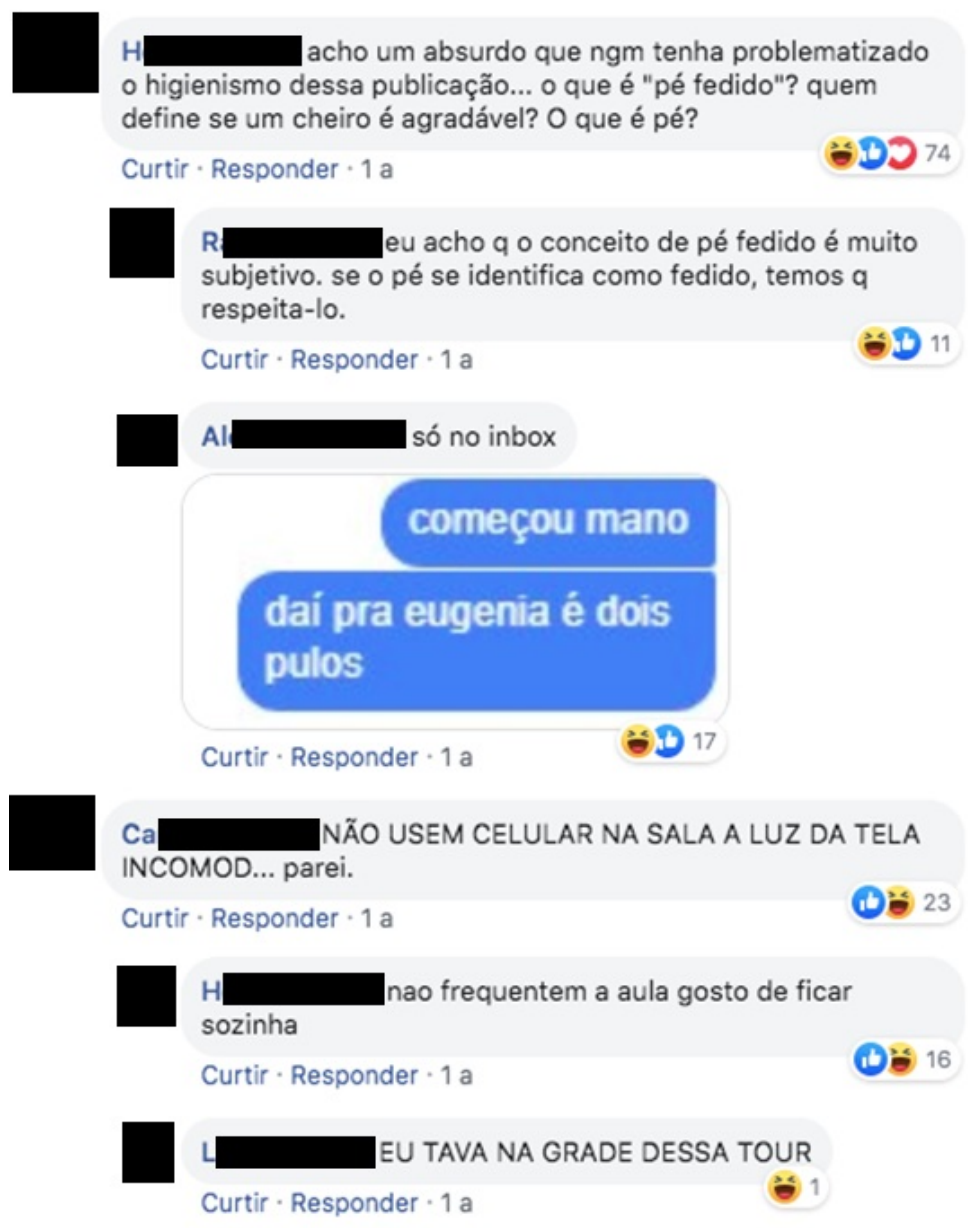

Fonte: Facebook (2018)

Outros alunos, tal como Cam também ironiza a ordem de $\mathbf{M}$, sugerindo uma ordem aos alunos de forma debochada, intensificada com maiúsculas e reticências: "NÃO USEM CELULAR NA SALA A LUZ DA TELA INCOMOD... parei". D também continua a brincadeira: "POR FAVOR não façam Letras, não é bom nem pra vcs". 
Figura 192: Exemplo de descortesia no grupo de Letras/USP no Inquérito 7

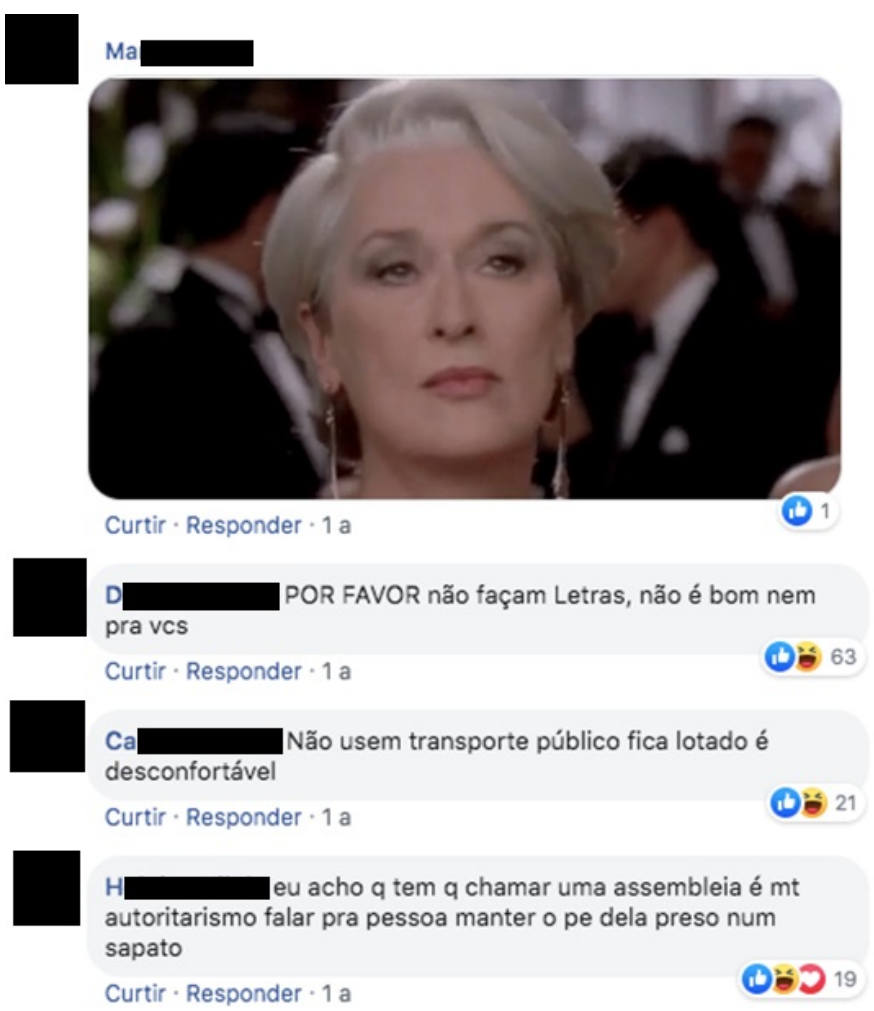

Fonte: Facebook (2018)

Outros alunos continuam a ironizar a ordem, mas com elementos da rotina com quem vive em sociedade, tal como faz Cam: "Não usem transporte público fica lotado é desconfortável". Sendo assim, o ataque coletivo à imagem de $\mathbf{M}$ continua. $\mathbf{Y}$ também reage com humor, atenuando o conflito com os alunos. $\mathbf{Y}$ coloca a figura de um pé em movimento por meio de um GIF, levantando o dedo do meio. 
Figura 227: Exemplo de descortesia no grupo de Letras/USP no Inquérito 7

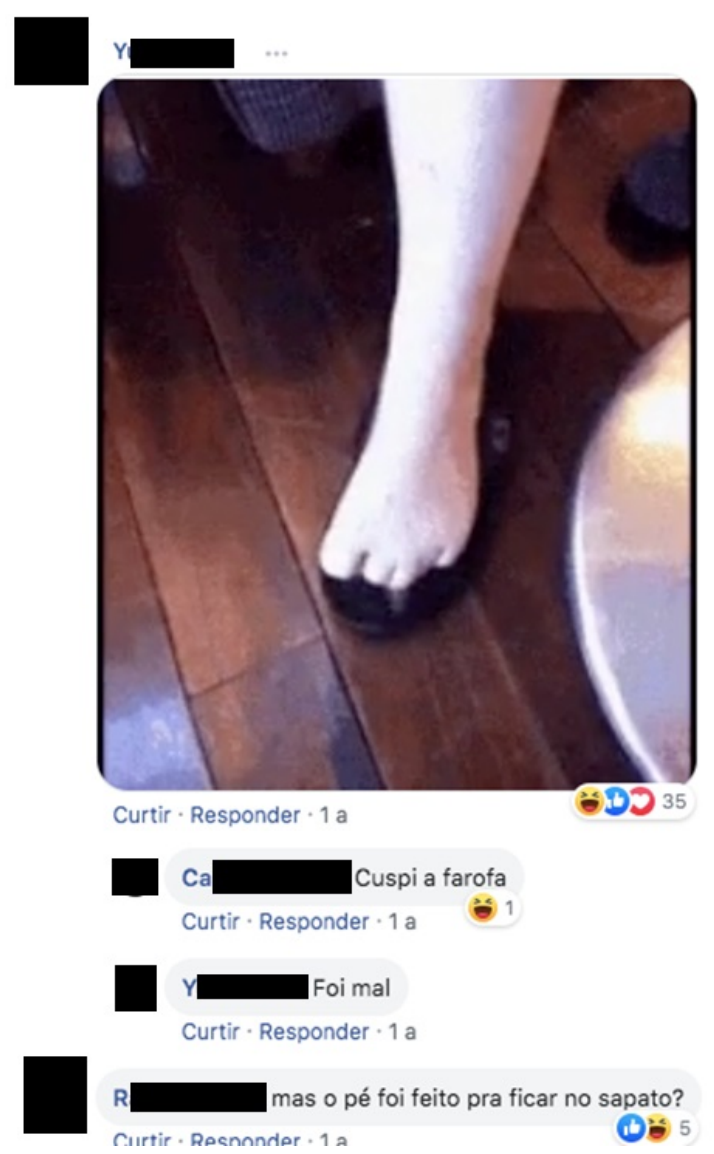

Fonte: Facebook (2018)

$\mathbf{L}$ critica o fato dos alunos imporem regras uns aos outros e faz a crítica generalizando para "as pessoas": "Ah, pronto... Fico surpreso de como as pessoas gostam de cagar regra. Ontem foi a segunda fila do Circular, hoje são os pés... Deixa os pé do povo, deixa o povo fazer fila, eu hein!"

Figura 228: Exemplo de descortesia no grupo de Letras/USP no Inquérito 7

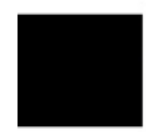

Ah, pronto... Fico surpreso de como as pessoas gostam de cagar regra. Ontem foi a segunda fila do Circular, hoje são os pés... Deixa os pé do povo, deixa o povo fazer fila, eu hein!

\section{Curtir - Responder - 1 a}

Fonte: Facebook (2018) 
$\mathbf{R}$ continua com a crítica, retomando o modelo de ordem utilizado por $\mathbf{M}$ : "por favor se possivel nao tenha um pé, é confortavel SO pra vc".

Figura 229: Exemplo de descortesia no grupo de Letras/USP no Inquérito 7

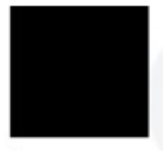

R_por favor se possivel nao tenha um pé, é confortavel SO pra vc.

Curtir - Responder - 1 a

Fonte: Facebook (2018)

Álv desvia o foco da discussão entre os alunos e faz um anúncio de venda:

Figura 230: Exemplo de descortesia no grupo de Letras/USP no Inquérito 7

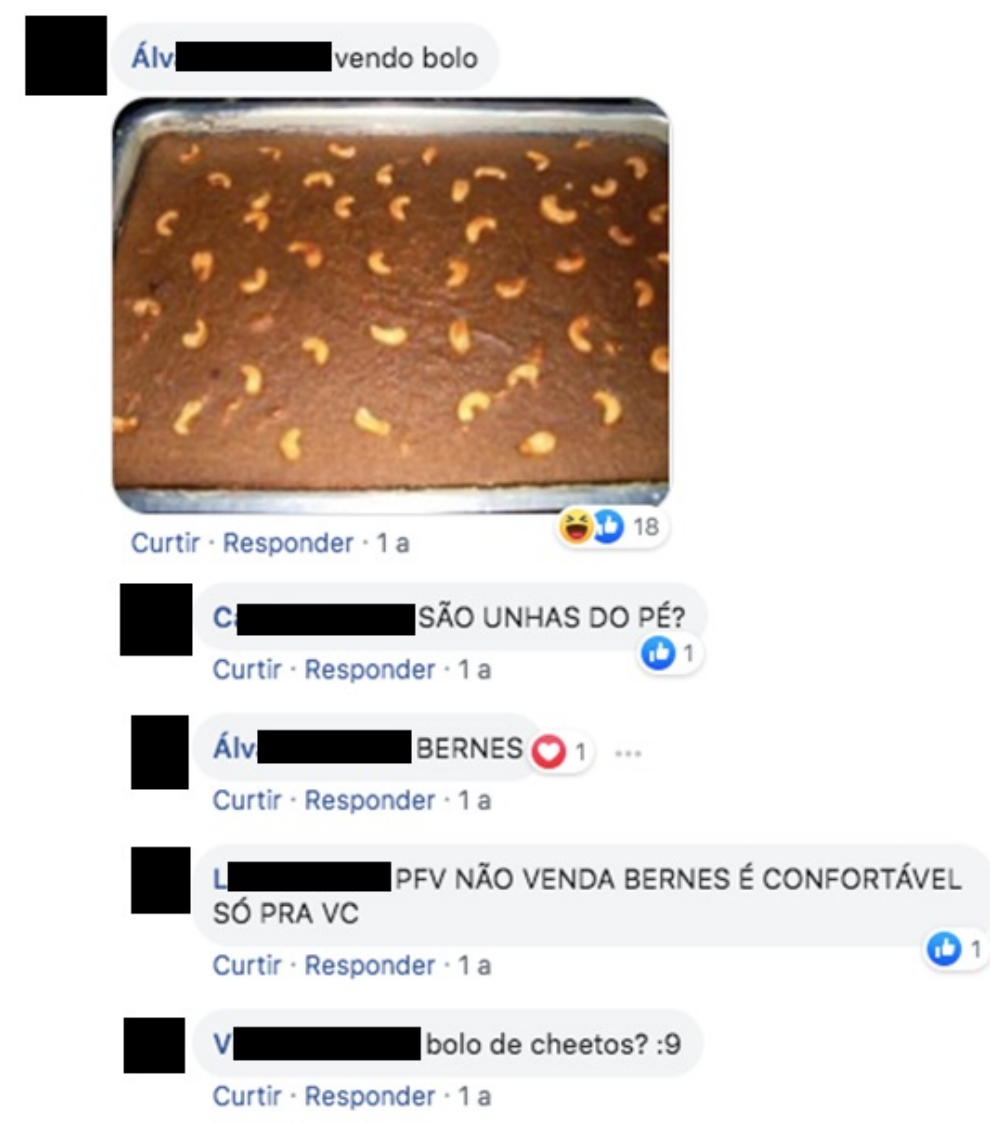

Fonte: Facebook (2018) 
Geralmente, este tipo de postagem de Álv é comum em casos de discussões ou publicações consideradas inúteis, pois desviam para um assunto totalmente diferente do tópico. C pergunta para Álv se "SÃO UNHAS DO PÉ?", referindo-se ao tema "pé" discutido no grupo. Álv responde que são "BERNES" e $\mathbf{L}$ retoma a "brincadeira" de criticar $\mathbf{M}$ usando-se do modelo de sua ordem: "PFV NÃO VENDA BERNES É CONFORTÁVEL SO PRA VC"

$\mathbf{N}$ marca uma amiga, $\mathbf{U}$, em seu comentário: "Passou o talquinho nos pés hoje ne? Se não nem vai pra aula". Apesar de $\mathbf{N}$ brincar na discussão, $\mathbf{N}$ expõe a imagem de $\mathbf{U}$, pois infere-se que $\mathbf{U}$ tenha o hábito de ficar descalça nas aulas e, assim, precisaria de "talquinho". U reage ao comentário com bom humor, ao usar um meme para mostrar seu espanto, apesar de ter tido sua imagem ameaçada:

Figura 231: Exemplo de descortesia no grupo de Letras/USP no Inquérito 7

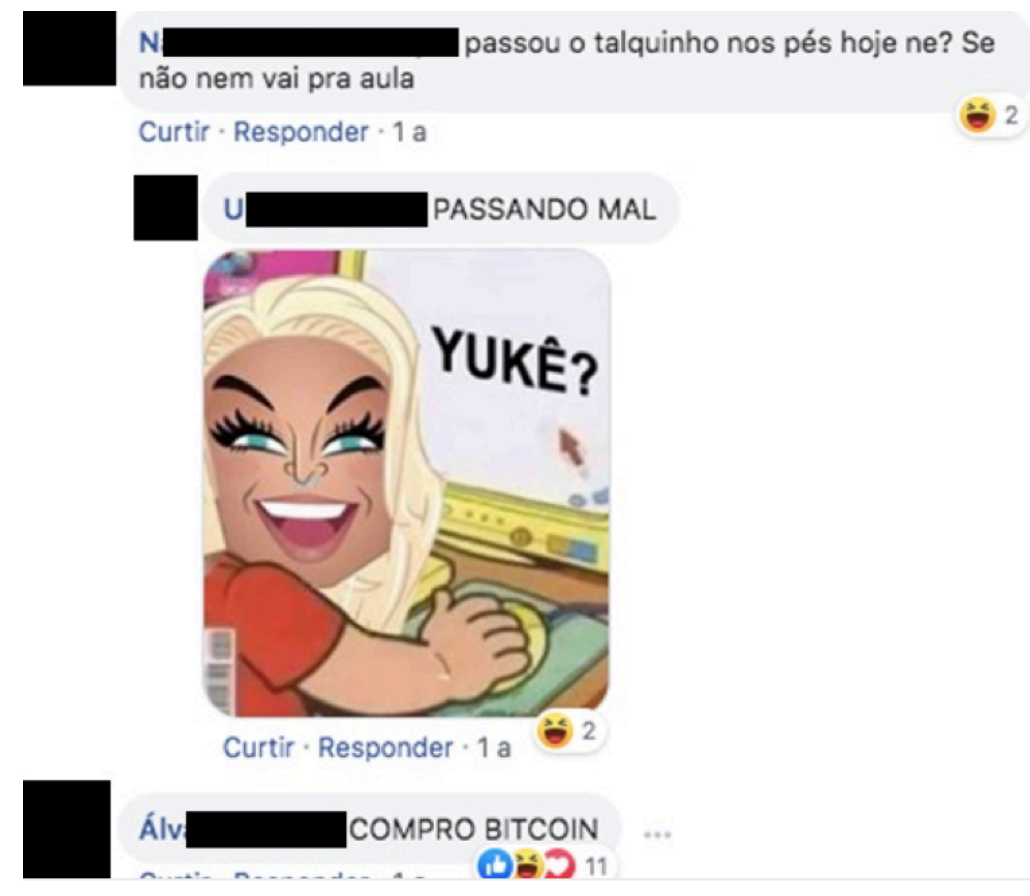

Fonte: Facebook (2018)

Álv tenta desviar o foco da discussão para outro assunto novamente: "COMPRO BITCOIN", assim como faz $\mathbf{R}$, que publica uma receita de rondelli: 
Figura 232: Exemplo de descortesia no grupo de Letras/USP no Inquérito 7

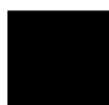

Receita de Rondelli de Quatro Queijos; vinho a

gosto.

\section{MODO DE PREPARO}

1 - Rale a mussarela, a ricota e o gorgonzola misturando 0 requeijão até obter uma pasta

2 - Abra a massa de pastel

3- Coloque a pasta de queijos em cerca de $60 \mathrm{~cm}$ de massa (essa quantidade da receita é suficiente pra 2 ou 3 rocamboles, dependendo a quantidade de recheio)

4 - Enrole e pincele água no final para não abrir

6 - Corte o rocambole em fatias de cerca de $2 \mathrm{~cm}$

7 - Coloque o molho em uma assadeira, deixando cerca de 0,5 $\mathrm{cm}$ de massa pra cima do molho

8 - Cubra com papel alumínio e leve ao forno médio $\left(180^{\circ} \mathrm{C}\right)$ por 40 minutos

9 - Retire o papel alumínio, polvilhe queijo parmesão e volte ao forno por mais 10 minutos

Curtir - Responder - 1 a

Fonte: Facebook (2018)

Mar critica novamente a publicação de $\mathbf{M}$ e intensifica 0 descontentamento com o uso de maiúsculas: "O post é sobre CAGAR REGRA". Li responde em defesa de $\mathbf{M}$, atacando a imagem pessoal de Mar : "vc deveria ler o post outra vez pq vc tem um serio problema de interpretação de texto". Apesar da crítica direta à imagem pessoal de Mar, Li tenta atenuar a crítica com o uso do futuro do pretérito. Mar ironiza o comentário de Li : "Me obrigue". M, a responsável pela publicação, aparece depois de muitas críticas e reformula o seu pedido, de modo explicativo: "O post é sobre não incomodar os outros com chulé...". 
Figura 233: Exemplo de descortesia no grupo de Letras/USP no Inquérito 7
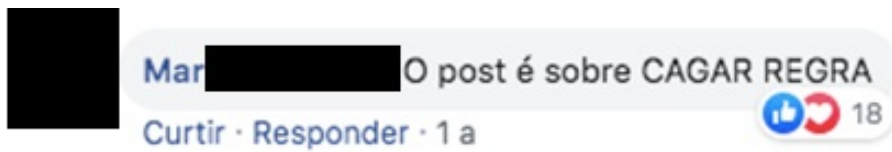

Curtir - Responder - 1 a

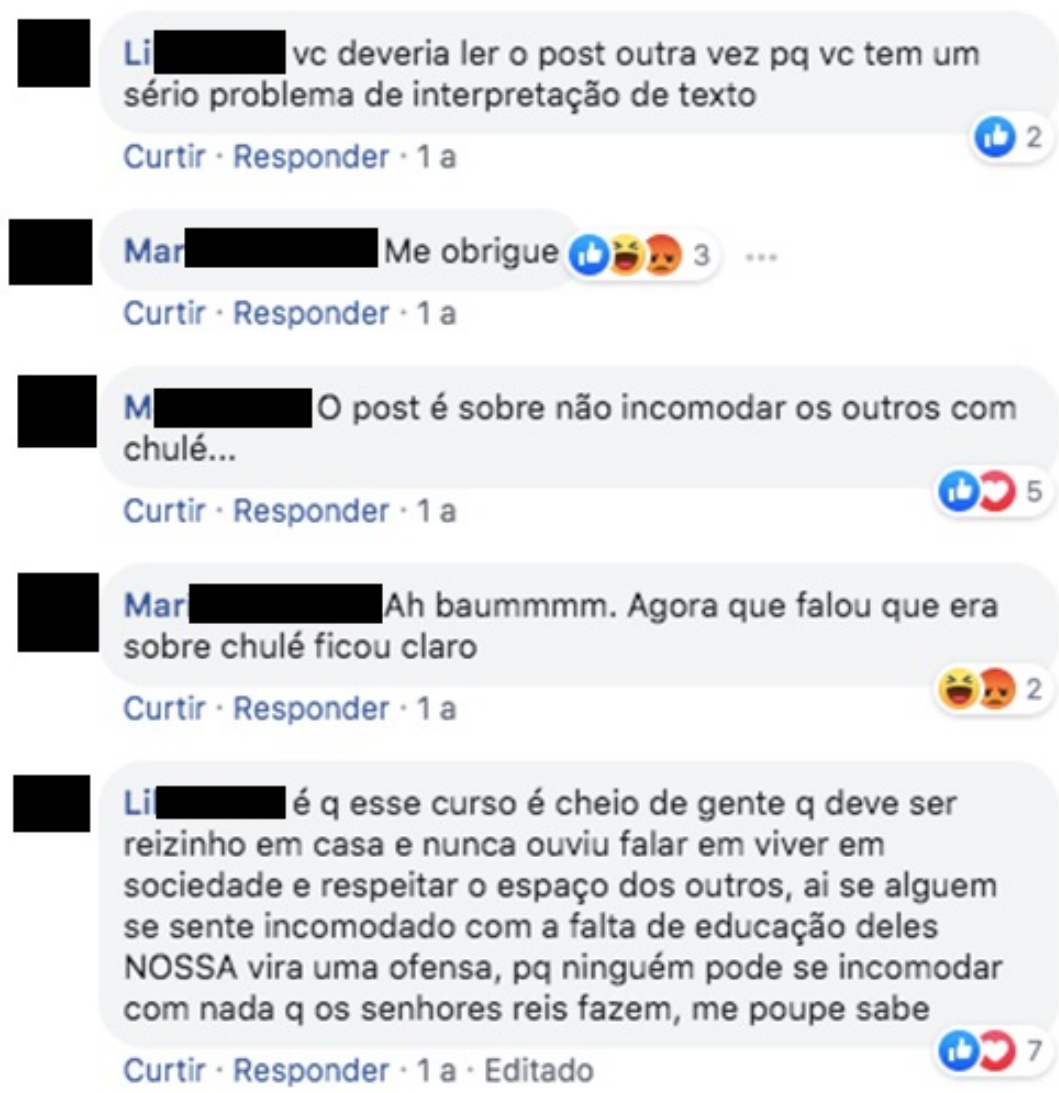

Fonte: Facebook (2018)

Mar novamente ironiza $\mathbf{M}$, sobretudo por $\mathbf{M}$ não ter sido mais clara em sua publicação antes. Mar usa como recurso atenuador o alongamento de letras em sua frase: "Ah baummmm. Agora que falou que era sobre chulé ficou claro". Li, novamente, faz um ataque aos alunos do curso, sobretudo para criticá-los pelo fato deles não aceitarem opiniões diferentes ou críticas: "é q esse curso é cheio de gente q deve ser reizinho em casa e nunca ouviu falar em viver em sociedade e respeitar o espaço dos outros, ai se alguem se sente incomodado com a falta de educação deles NOSSA vira uma ofensa, pq ninguém pode se incomodar com nada q os senhores reis fazem, me poupe sabe". Li usa formas de tratamento de forma irônica "reizinho", "senhores reis", além de se referir a todos 
de maneira impessoal: "cheio de gente". Am defende a publicação de $\mathbf{M}$ ao explicar que $\mathbf{M}$ se refere ao chulé "Gente, com ctz ela está falando do chulé!" e $\mathbf{M}$ reaparece, dirigindo-se a todos os participantes do grupo para concordar com Am e demonstra sua falta de paciência com o alongamento de letras: "Amig@s, é óbvio que tô falando do chulé...Pelamooorrrr".

Figura 234: Exemplo de descortesia no grupo de Letras/USP no Inquérito 7

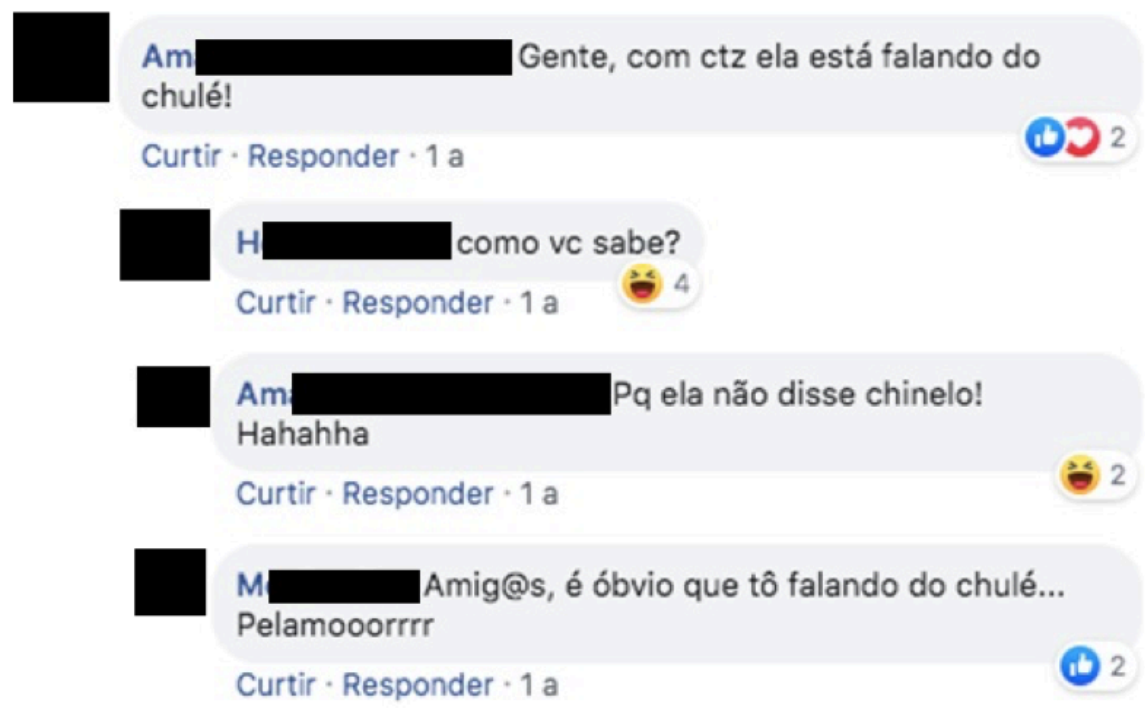

Fonte: Facebook (2018)

Diante de mais críticas sobre a ambiguidade de seu pedido, $\mathbf{M}$ se explica se dirigindo aos demais alunos com uma forma de tratamento carinhosa, em maiúsculas e com alongamentos de letras: "AMOOOOREEESSSSS, não tenho nada contra PES, por favor, só não acho legal ficar a aula inteira inalando chulé..." $\mathbf{N}$ responde a $\mathbf{M}$ de forma a acalmá-la, usando uma forma de tratamento íntimo: "Mana, tudo bem, isso já foi além da treta e virou diversão, não esquenta que apenas o meme vai ficar marcado na história". 
Figura 235: Exemplo de descortesia no grupo de Letras/USP no Inquérito 7

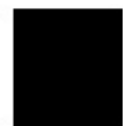

AMOOOOREEESSSSS, não tenho nada contra PÉS,

por favor, só não acho legal ficar a aula inteira inalando chulé...

Curtir - Responder - 1 a

(1) 21

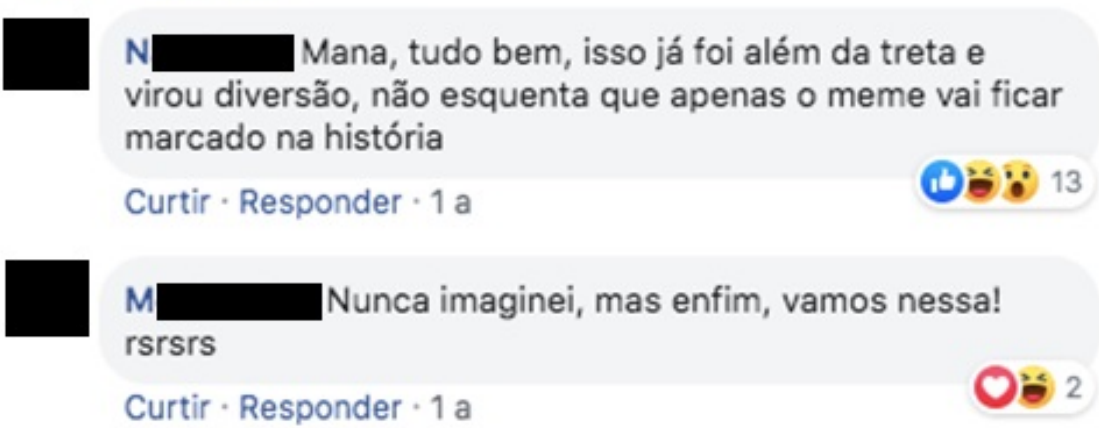

Fonte: Facebook (2018)

$\mathbf{M}$, por sua vez, fica surpresa com a resposta de $\mathbf{N}$ e reage com risos: "Nunca imaginei, mas enfim, vamos nessa!". Am defende a imagem pessoal de $\mathbf{M}$, ao criticar como os alunos do curso reagem às oposições de opinião, tranquilizando-a: "M, você fez certo de comentar, mas é teste de resistência mesmo, mais nojento que chulé, a forma que a galera da Letras reage a qqr coisa que difere do que eles gostam. Não precisa se sentir mal pela forma que isso virou piada, eu tenho pra mim que eles não gostarem é sinal de que eu estou certa kkkk". M, por sua vez, responde usando uma forma de tratamento carinhosa, indicando proximidade: "Obrigada, querida. Pois é, fiquei meio chocada com tanta repercussão, mas enfim...Pelo menos acho que contribui pra pensarmos um pouco sobre como nossas atitudes podem chegar até 0 outro.Não deixa de ser um ótimo exercício, no final" e finaliza sua mensagem com um emoticon sorrindo. 
Figura 236: Exemplo de descortesia no grupo de Letras/USP no Inquérito 7

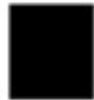

- Am $\square$ você fez certo de comentar, mas é teste de resistência mesmo, mais nojento que chulé, a forma que a galera da Letras reage a qqr coisa que difere do que eles gostam. Não precisa se sentir mal pela forma que isso virou piada, eu tenho pra mim que eles não gostarem é sinal de que eu estou certa kkkk

Amei - Responder - 1 a
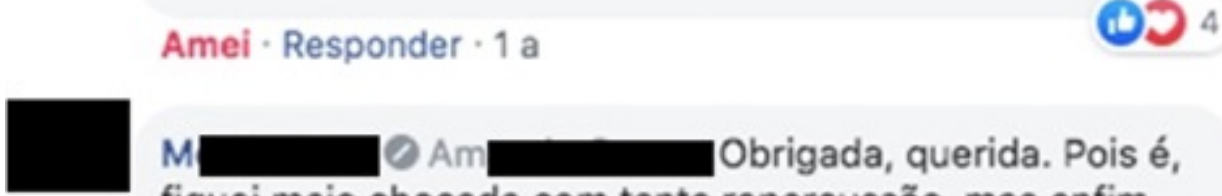

M Am Obrigada, querida. Pois é, fiquei meio chocada com tanta repercussão, mas enfim... Pelo menos acho que contribui pra pensarmos um pouco sobre como nossas atitudes podem chegar até o outro. Não deixa de ser um ótimo exercício, no final $\because$

Curtir - Responder - 1 a

Fonte: Facebook (2018) 
Tabela 9: As categorias de condições de infração da estratégia geral da descortesia no Inquérito 7

\begin{tabular}{|c|c|c|c|c|c|}
\hline \multicolumn{6}{|c|}{ As categorias de condições de infração da estratégia geral da descortesia } \\
\hline $\begin{array}{c}\text { Violação da } \\
\text { máxima } \\
\text { (expressa de } \\
\text { forma } \\
\text { imperativa) }\end{array}$ & $\begin{array}{l}\text { Participantes } \\
\text { do grupo }\end{array}$ & $\begin{array}{c}\text { Par de } \\
\text { máximas } \\
\text { relacionadas }\end{array}$ & $\begin{array}{c}\text { Categorias das máximas } \\
\text { violadas }\end{array}$ & $\begin{array}{l}\text { Classes de atos } \\
\text { de fala }\end{array}$ & $\begin{array}{c}\text { Estratégias } \\
\text { linguísticas } \\
\text { e não- } \\
\text { linguísticas } \\
\text { /híbridas }\end{array}$ \\
\hline $\begin{array}{c}\text { (M1) Atribuir } \\
\text { um valor } \\
\text { desfavorável } \\
\text { aos interesses } \\
\text { do interlocutor } \\
\text { (Outro) } \\
\end{array}$ & $\begin{array}{l}\text { Todos os } \\
\text { participantes }\end{array}$ & \multirow{2}{*}{$\begin{array}{l}\text { Generosidade/ } \\
\text { Tato }\end{array}$} & Generosidade & Recusar, ameaçar & $\begin{array}{c}\text { Uso de } \\
\text { ironia, uso } \\
\text { do } \\
\text { imperativo } \\
\end{array}$ \\
\hline $\begin{array}{l}\text { (M2) Atribuir } \\
\text { um valor } \\
\text { favorável aos } \\
\text { interesses do } \\
\text { EU (Locutor) }\end{array}$ & M & & Tato & Ordem, demanda & $\begin{array}{c}\text { Uso do } \\
\text { imperativo }\end{array}$ \\
\hline $\begin{array}{c}\text { (M3) Atribuir } \\
\text { um valor } \\
\text { desfavorável } \\
\text { às qualidades } \\
\text { do interlocutor } \\
\text { (Outro) }\end{array}$ & $\begin{array}{l}\text { Todos os } \\
\text { participantes }\end{array}$ & \multirow{2}{*}{$\begin{array}{l}\text { Aprovação/ } \\
\text { Modéstia }\end{array}$} & Aprovação & $\begin{array}{l}\text { Insultar, reclamar, } \\
\text { falar mal do } \\
\text { interlocutor }\end{array}$ & Uso de ironia \\
\hline $\begin{array}{l}\text { (M4)Atribuir } \\
\text { um valor } \\
\text { favorável às } \\
\text { qualidades do } \\
\text { EU (Locutor) }\end{array}$ & $\mathrm{N}, \mathrm{H}, \mathrm{Ca}$ & & Modéstia & $\begin{array}{l}\text { Gabar-se, ser } \\
\text { complacente }\end{array}$ & $\begin{array}{c}\text { Autovaloriza } \\
\text { ção ou } \\
\text { valorização } \\
\text { da imagem } \\
\text { do outro } \\
\end{array}$ \\
\hline $\begin{array}{l}\text { (M5) Atribuir } \\
\text { um valor } \\
\text { desfavorável } \\
\text { às obrigações } \\
\text { do EU } \\
\text { (Locutor) para } \\
\text { com o } \\
\text { interlocutor } \\
\text { (Outro) }\end{array}$ & $\begin{array}{l}\text { Sem } \\
\text { ocorrências }\end{array}$ & \multirow[t]{2}{*}{ Obrigação } & Obrigação (ao interlocutor) & $\begin{array}{c}\text { Recusar } \\
\text { agradecimentos ou } \\
\text { desculpas }\end{array}$ & $\begin{array}{c}\text { Sem } \\
\text { ocorrências }\end{array}$ \\
\hline $\begin{array}{l}\text { (M6) Atribuir } \\
\text { um valor } \\
\text { favorável às } \\
\text { obrigações do } \\
\text { interlocutor } \\
\text { para com o } \\
\text { Locutor }\end{array}$ & P para H & & Obrigação (ao Locutor) & $\begin{array}{l}\text { Agradecer ou } \\
\text { desculpar-se }\end{array}$ & $\begin{array}{l}\text { Pedido direto } \\
\text { de desculpas }\end{array}$ \\
\hline $\begin{array}{c}\text { (M7) Atribuir } \\
\text { um valor } \\
\text { desfavorável } \\
\text { às opiniões do } \\
\text { interlocutor } \\
\text { (Outro) }\end{array}$ & $\begin{array}{l}\text { Todos os } \\
\text { participantes }\end{array}$ & \multirow[t]{2}{*}{ Opinião } & Concordância & $\begin{array}{l}\text { Discordar, } \\
\text { contradizer }\end{array}$ & $\begin{array}{l}\text { Uso de } \\
\text { humor, } \\
\text { ironia, } \\
\text { memes e } \\
\text { GIFs }\end{array}$ \\
\hline $\begin{array}{l}\text { (M8) Atribuir } \\
\text { um valor } \\
\text { favorável às } \\
\text { opiniões do } \\
\text { Locutor (EU) }\end{array}$ & $\begin{array}{c}\mathbf{E} \text { em defesa de } \\
\mathbf{M}\end{array}$ & & Opinião reticente & Ser opinativo & $\begin{array}{l}\text { Uso de } \\
\text { ironia, } \\
\text { críticas } \\
\text { indiretas }\end{array}$ \\
\hline $\begin{array}{l}\text { (M9) Atribuir } \\
\text { um valor } \\
\text { desfavorável } \\
\text { aos } \\
\text { sentimentos do } \\
\text { interlocutor } \\
\text { (Outro) }\end{array}$ & $\begin{array}{l}\text { Todos os } \\
\text { participantes }\end{array}$ & \multirow[t]{2}{*}{ Sentimento } & Simpatia & $\begin{array}{l}\text { Expressar antipatia } \\
\text { ao interlocutor }\end{array}$ & $\begin{array}{c}\text { Uso de } \\
\text { insultos, } \\
\text { ironia, humor }\end{array}$ \\
\hline $\begin{array}{l}\text { (M10) Atribuir } \\
\text { um valor } \\
\text { favorável aos } \\
\text { sentimentos do } \\
\text { Locutor (EU) }\end{array}$ & E & & Sentimento reticente & $\begin{array}{l}\text { Reclamar, } \\
\text { resmungar }\end{array}$ & $\begin{array}{c}\text { Uso de } \\
\text { insultos, } \\
\text { ironia, humor }\end{array}$ \\
\hline
\end{tabular}




\title{
INQUÉRITO 8
}

Figura 237: Exemplo de descortesia no grupo de Letras/USP no Inquérito 8

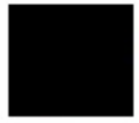

27 de outubro às $18: 12$

\begin{abstract}
Galere, alguém por acaso encontrou agora a tarde no banheiro de deficientes masculino do segundo andar (ao lado do elevador) um bilhete único e um cartão do Santander? Se sim, por favor, eles são meus, e se puderem me devolver vou ficar rios mais feliz! Obrigada
\end{abstract}

\section{It Curtir $\quad \Rightarrow$ Comentar $\Rightarrow$ Compartilhar}

5 pessoas curtiram isso.

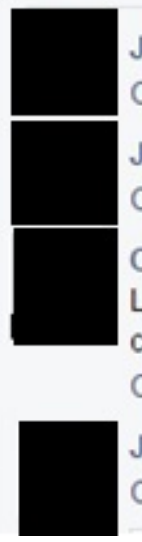

Jo putz.

Curtir - Responder - 27 de outubro às 18:35

Jo vc frequenta o banheiro de deficientes?

Curtir-Responder - B1.27 de outubro às 18:35

C $\quad$ Oi J achei e deixei com o segurança do segundo andar da

Letras ontem (pelo que entendi eles iam mandar pro p1). Tinha também 50

centavos que também deixei lá.

Curtir - Responder - B 2-28 de outubro às 09:39

Curtir - Responder - 28 de outubro às 16:41

Fonte: Facebook (2015)

J faz uma pergunta no grupo de Letras, trata-se de um pedido de informação: "Galere, alguém por acaso encontrou agora a tarde no banheiro de deficientes masculino do segundo andar (ao lado do elevador) um bilhete único e o cartão do Santander?", pois J espera que os seus pertences sejam devolvidos: "Se sim, por favor, eles são meus, e se puderem me devolver ficarei rios mais feliz. Obrigada". J faz o pedido com o uso de um moderador "por favor" e agradece antecipadamente, atenuando assim a sua atitude ameaçadora ao fazer um pedido aos estudantes de Letras.

J é surpreendido com uma resposta crítica ao fato de ele frequentar o banheiro de deficiente masculino. Jo reage com a interjeição "putz...", que demonstra espanto e intensifica uma ameaça a imagem de J. Logo em seguida, Jo faz uma pergunta: "vc frequenta o banheiro de deficientes?", mas é ignorada por J. A pergunta de Jo se configura como um ato indireto, uma vez que se trata de uma crítica. C, outro interactante, aparece e responde que achou os pertences de $\mathbf{J}$ e que deixou com o segurança do prédio. Assim, $\mathbf{J}$ obteve 
sucesso em seu pedido, mesmo com a sua imagem ameaçada. Jo também teve sua imagem ameaçada, ao fazer a crítica a $\mathbf{J}$ e de não ter sua pergunta respondida e, consequentemente, ser ignorado na interação.

Tabela 10: As categorias de condições de infração da estratégia geral da descortesia no Inquérito 8

\begin{tabular}{|c|c|c|c|c|c|}
\hline \multicolumn{6}{|c|}{ As categorias de condições de infração da estratégia geral da descortesia } \\
\hline $\begin{array}{c}\text { Violação da } \\
\text { máxima } \\
\text { (expressa de } \\
\text { forma } \\
\text { imperativa) }\end{array}$ & $\begin{array}{l}\text { Participantes } \\
\text { do grupo }\end{array}$ & $\begin{array}{l}\text { Par de } \\
\text { máximas } \\
\text { relacionadas }\end{array}$ & $\begin{array}{c}\text { Categorias das máximas } \\
\text { violadas }\end{array}$ & $\begin{array}{l}\text { Classes de atos } \\
\text { de fala }\end{array}$ & $\begin{array}{c}\text { Estratégias } \\
\text { linguísticas } \\
\text { e não- } \\
\text { linguísticas } \\
\text { /híbridas }\end{array}$ \\
\hline $\begin{array}{c}\text { (M1) Atribuir } \\
\text { um valor } \\
\text { desfavorável } \\
\text { aos interesses } \\
\text { do interlocutor } \\
\text { (Outro) }\end{array}$ & Jo & \multirow{2}{*}{$\begin{array}{c}\text { Generosidade/ } \\
\text { Tato }\end{array}$} & Generosidade & Recusar, ameaçar & $\begin{array}{l}\text { Pergunta, } \\
\text { crítica } \\
\text { indireta }\end{array}$ \\
\hline $\begin{array}{c}\text { (M2) Atribuir } \\
\text { um valor } \\
\text { favorável aos } \\
\text { interesses do } \\
\text { EU (Locutor) }\end{array}$ & $\mathbf{J}$ & & Tato & Ordem, demanda & Pedido direto \\
\hline $\begin{array}{c}\text { (M3) Atribuir } \\
\text { um valor } \\
\text { desfavorável } \\
\text { às qualidades } \\
\text { do interlocutor } \\
\text { (Outro) }\end{array}$ & J para Jo & \multirow{2}{*}{$\begin{array}{l}\text { Aprovação/ } \\
\text { Modéstia }\end{array}$} & Aprovação & $\begin{array}{l}\text { Insultar, reclamar, } \\
\text { falar mal do } \\
\text { interlocutor }\end{array}$ & $\begin{array}{l}\text { Uso do } \\
\text { silêncio, sem } \\
\text { resposta }\end{array}$ \\
\hline $\begin{array}{l}\text { (M4)Atribuir } \\
\text { um valor } \\
\text { favorável às } \\
\text { qualidades do } \\
\text { EU (Locutor) }\end{array}$ & $\begin{array}{c}\text { Sem } \\
\text { ocorrências }\end{array}$ & & Modéstia & $\begin{array}{l}\text { Gabar-se, ser } \\
\text { complacente }\end{array}$ & $\begin{array}{c}\text { Sem } \\
\text { ocorrências }\end{array}$ \\
\hline $\begin{array}{l}\text { (M5) Atribuir } \\
\text { um valor } \\
\text { desfavorável } \\
\text { às obrigações } \\
\text { do EU } \\
\text { (Locutor) para } \\
\text { com o } \\
\text { interlocutor } \\
\text { (Outro) }\end{array}$ & $\begin{array}{c}\text { Sem } \\
\text { ocorrências }\end{array}$ & \multirow[t]{2}{*}{ Obrigação } & Obrigação (ao interlocutor) & $\begin{array}{c}\text { Recusar } \\
\text { agradecimentos ou } \\
\text { desculpas }\end{array}$ & $\begin{array}{c}\text { Sem } \\
\text { ocorrências }\end{array}$ \\
\hline $\begin{array}{l}\text { (M6) Atribuir } \\
\text { um valor } \\
\text { favorável às } \\
\text { obrigações do } \\
\text { interlocutor } \\
\text { para com o } \\
\text { Locutor }\end{array}$ & $\mathbf{J}$ & & Obrigação (ao Locutor) & $\begin{array}{l}\text { Agradecer ou } \\
\text { desculpar-se }\end{array}$ & $\begin{array}{l}\text { Uso de } \\
\text { moderadores }\end{array}$ \\
\hline $\begin{array}{l}\text { (M7) Atribuir } \\
\text { um valor } \\
\text { desfavorável } \\
\text { às opiniões do } \\
\text { interlocutor } \\
\text { (Outro) }\end{array}$ & $\begin{array}{c}\text { Sem } \\
\text { ocorrências }\end{array}$ & \multirow[t]{2}{*}{ Opinião } & Concordância & $\begin{array}{l}\text { Discordar, } \\
\text { contradizer }\end{array}$ & $\begin{array}{c}\text { Sem } \\
\text { ocorrências }\end{array}$ \\
\hline $\begin{array}{l}\text { (M8) Atribuir } \\
\text { um valor } \\
\text { favorável às } \\
\text { opiniões do } \\
\text { Locutor (EU) }\end{array}$ & $\begin{array}{c}\text { Sem } \\
\text { ocorrências }\end{array}$ & & Opinião reticente & Ser opinativo & $\begin{array}{c}\text { Sem } \\
\text { ocorrências }\end{array}$ \\
\hline $\begin{array}{c}\text { (M9) Atribuir } \\
\text { um valor } \\
\text { desfavorável } \\
\text { aos } \\
\text { sentimentos do } \\
\text { interlocutor } \\
\text { (Outro) }\end{array}$ & Jo & \multirow[t]{2}{*}{ Sentimento } & Simpatia & $\begin{array}{l}\text { Expressar antipatia } \\
\text { ao interlocutor }\end{array}$ & $\begin{array}{c}\text { uso de } \\
\text { interjeição, } \\
\text { crítica } \\
\text { indireta } \\
\end{array}$ \\
\hline $\begin{array}{l}\text { (M10) Atribuir } \\
\text { um valor } \\
\text { favorável aos } \\
\text { sentimentos do } \\
\text { Locutor (EU) }\end{array}$ & $\begin{array}{c}\text { Sem } \\
\text { ocorrências }\end{array}$ & & Sentimento reticente & $\begin{array}{l}\text { Reclamar, } \\
\text { resmungar }\end{array}$ & $\begin{array}{c}\text { Sem } \\
\text { ocorrências }\end{array}$ \\
\hline
\end{tabular}




\section{CONSIDERAÇÕES FINAIS}

$\mathrm{Na}$ introdução deste trabalho, discutimos como os avanços tecnológicos mudaram a maneira pela qual os seres humanos se socializam. Por meio de novas tecnologias de sociabilidade, a fronteira da distância adquire uma dimensão global na interação entre os participantes das redes sociais digitais. Partindo do pressuposto de que a linguagem virtual apresenta características semelhantes à conversação face a face, observamos que os interactantes recorrem a artifícios gráficos para ter a mensagem bem compreendida pelos demais participantes, mas, nem sempre a interação virtual se dá de forma harmoniosa, tal como ocorre também em uma interação face a face. Observamos que os recursos verbais, não-verbais e híbridos são explorados pelos participantes da rede social digital para suprir os elementos paralinguísticos de uma interação presencial, entretanto, a enunciação dos participantes da rede social digital nem sempre é bem sucedida, uma vez que alguns interlocutores podem não compreender uma ironia ou o objetivo de uma mensagem de uma publicação na rede social digital, fato que pode gerar a descortesia entre os interactantes.

O conflito, assim como na interação presencial, desencadeia manifestações descorteses e, a rápida difusão de comentários nas redes sociais digitais abre espaço para expressões ofensivas como os insultos, visto que muitos usuários não se encontram em presença física com os demais participantes. A tensão provocada por um comentário depende do contexto do ato comunicativo, especialmente de como o receptor da mensagem vai agir diante de um comentário hostil. Deve-se considerar em que medida o interlocutor mostra seu desacordo em relação ao ataque recebido e em que grau realiza suas atividades de ameaça à imagem do interlocutor.

Inicialmente, apresentamos os pressupostos teóricos que colaboraram com o desenvolvimento de teorias acerca da cortesia, ou seja, os estudos dos Filósofos da Linguagem. A partir da discussão das teorias de Grice, Austin e Searle, pesquisadores de linha interacionista se apoiaram na Sociologia para compreender a dinâmica de uma interação harmoniosa. Brown \& Levinson foram um dos pioneiros no estudo da cortesia linguística e, influenciam os demais pesquisadores a pensar sobre o tema. Apesar da teoria ser criticada pela sua 
universalidade, Leech pondera que, ainda assim, é possível pensar na interação entre os interactantes sob a perspectiva de Brown \& Levinson. Leech desenvolve, em um primeiro momento, o Princípio da Cortesia em sua obra, Principles of Pragmatics, embora, mais tarde, o teórico retome o estudo do fenômeno da cortesia de maneira mais descritiva, pensando em diferentes culturas, em Pragmatics of Politeness.

Os capítulos 1 e 2 foram destinados à apresentação das teorias que nortearam a análise deste trabalho. O capítulo 2 enfatiza as várias estratégias linguísticas ou os fatores sociais recorrentes no emprego da descortesia.

A partir da discussão sobre as estratégias de cortesia na interação, discorremos sobre o fenômeno da descortesia. Devemos prestar atenção na intencionalidade do emissor e na avaliação da mensagem por parte do receptor, visto que muitas vezes a descortesia se manifesta de forma motivada ou imotivada. A complexidade enunciativa na rede social digital foi exposta no capítulo 3, assim como foram observadas as várias estratégias linguísticas, nãolinguísticas e híbridas em uma interação virtual.

Com base nessas discussões, procuramos verificar, por meio de um vasto corpus do Facebook, as principais características da descortesia virtual e quais seriam os elementos linguísticos, não-linguísticos e híbridos responsáveis para atenuar ou intensificar uma ameaça em relação aos demais participantes da rede social digital. No Inquérito 1, o locutor responsável pela publicação no grupo de Letras-USP engaja os demais participantes a interagir a respeito do problema levantado: o barulho na sala Pró-Aluno, local onde os estudantes podem imprimir e fazer trabalhos da faculdade. $\mathbf{Z}$, o locutor principal, dirige-se aos demais usuários da rede de forma descortês, com uso de insultos para mostrar sua indignação. Apesar da abordagem, muitos estudantes se identificam com a crítica e defendem o ponto de vista de Z. Em um determinado momento da interação, no entanto, $\mathbf{T}$ responde discordando de $\mathbf{Z}$ e o conflito na interação começa a surgir entre os demais interactantes.Percebe-se nesta interação que atribuir um valor desfavorável aos interesses do interlocutor pode desencadear uma descortesia coletiva, visto que $\mathbf{T}$ tem sua imagem atacada pelos demais justamente por discordar de $\mathbf{Z}$ e, consequentemente, dos demais usuários em defesa da crítica de $\mathbf{Z}$. A maioria atribui um valor favorável aos sentimentos e à opinião do locutor $\mathbf{Z}$ e, quando $\mathbf{T}$ atribui um valor desfavorável às opiniões do 
locutor $\mathbf{Z}$, rompe o contrato conversacional estabelecido na interação e a descortesia entra em cena.

O Inquérito 2 se destaca pela mesma crítica do Inquérito 1, porém faz uso de um artifício para proteger a imagem da locutora, com o uso de um emissor delegado, no caso específico, o cachorro da locutora da publicação, B. Todos os usuários do grupo utilizam o mesmo recurso para reclamar ou criticar os problemas e a interação se dá de maneira harmoniosa. Nota-se que, embora os Inquéritos 1 e 2 tenham tratado sobre o mesmo tópico, a abordagem dos locutores em relação aos interlocutores fez a diferença para suscitar ou não conflitos na interação e, por conseguinte, a descortesia.

O Inquérito 3 se destaca pelo uso da ironia e da pseudocortesia em uma publicação com assunto polêmico na faculdade: paralisações e greves. J, a responsável pela publicação, faz um apelo aos estudantes para aderir à greve, entretanto, os alunos discordam. $\mathbf{J}$ responde os usuários de forma pseudocortês a todo instante e os participantes do grupo retribuem com o uso de descortesia também. Desta forma, J não é bem-sucedida em seu pedido, principalmente pelo fato de usar a ironia constantemente em sua interação. Assim como o Inquérito 1 , nota-se que atribuir um sentimento desfavorável ao sentimento e à opinião do outro pode desencadear a descortesia.

O Inquérito 4 é diferente dos demais, visto que se trata de um pedido de ajuda para uma pesquisa. Os estudantes cooperam positivamente para a realização da pesquisa, respondendo as perguntas da enquete, entretanto o interlocutor $\mathbf{E}$ faz uma crítica em forma de ironia em relação a um erro da língua portuguesa presente na ficha. L, a locutora responsável pela publicação, não entende a ironia e continua sendo cortês com E. Após a insistência de $\mathbf{E}, \mathbf{L}$ percebe o erro, porém agradece e não entra em conflito com $\mathbf{E}$, mesmo tendo a sua imagem prejudicada. Assim como o Inquérito 4, o Inquérito 5 se destaca por um pedido de ajuda. Nesse caso específico, trata-se de um pedido de material de língua italiana para estudo. Os alunos participantes do grupo demonstram interesse em ajudar, porém A recusa a ajuda da primeira participante a responder no grupo. Com a recusa, os demais usuários interpretam como uma ação descortês e param de contribuir com sugestões. Percebe-se, novamente, que a abordagem do locutor e a interação deste com os demais interlocutores são fundamentais para uma interação harmoniosa. 
O Inquérito 6 se distingue dos demais por se tratar de um oferecimento aos usuários do grupo. Trata-se de um grupo de pesquisa sobre o pensamento liberal e, como muitos participantes não são adeptos ao pensamento em questão, alguns usuários respondem de maneira irônica e descortês a publicação de L. Muitos participantes, no entanto, discordam do comportamento desses alunos irônicos e saem em defesa de L.Novamente, a relação de concordância e/ou discordância se mostra como um fator de (des)cortesia.

O Inquérito 7, por sua vez, destaca-se por um pedido sob forma de ordem: não tirar os sapatos/sapatilhas a sala. Muitos usuários usam a ironia e o humor para justificar o fato de não usar sapatos em aula, criticam e brincam a respeito da ordem da responsável pela publicação no grupo. Como $\mathbf{M}$, a locutora principal, não entra em conflito com os demais, os usuários interagem entre eles mesmos a respeito das situações frequentes em sala de aula.

Finalmente, o Inquérito 8 se destaca por um pedido de informação de $\mathbf{J}$. Como $\mathbf{J}$ perdeu os documentos no banheiro de deficientes, Jo, o primeiro interlocutor a responder, faz uma crítica indireta questionando o uso do banheiro por $\mathbf{J}$. J não responde o interlocutor Jo, somente ao outro que encontrou os documentos.

Pelo fato das redes sociais digitais darem uma ideia de distância física e de um aparente anonimato, a descortesia mostra-se recorrente nas interações e, isto, como revela o corpus estudado, deve-se, sobretudo, à discordância de opiniões entre os interactantes. Notamos, também, casos em que a descortesia é empregada para chamar a atenção do receptor e demonstrar intimidade, tal como ocorre no fenômeno da pseudodescortesia. Em muitos casos, no entanto, observamos o emprego de uma cortesia aparente, mas falsa, a partir de pistas fornecidas pelo contexto de interação. Defendemos, assim, que o contexto se revela de fundamental importância para compreender a dinâmica deste tipo de interação, sobretudo no emprego de estratégias linguísticas e não-linguísticas para atenuar ou intensificar o ataque ao interlocutor.

Assim, a troca comunicativa na rede social digital se dá de maneira cooperativa, inter-relacionando os vários recursos linguísticos e tecnológicos presentes na era virtual. Percebe-se que o comportamento dos participantes do Facebook espelha suas atividades na sociedade, por meio de publicações públicas e privadas, restritas, muitas vezes, a um grupo de amigos ou a grupos 
específicos. Apesar da distância temporal entre as teorias de Austin, Searle, Grice, e Brown \& Levinson em relação ao advento da Internet, os estudos se mostram ainda eficazes para compreender a dinâmica de uma interação, seja real ou virtual e continuam influenciando outros pesquisadores.

Embora não tenham sido concebidas para a interação on-line, as máximas de Cortesia de Leech, adotadas neste trabalho, mostram-se como um bom fio condutor nas análises das conversações virtuais, visto que muitos fatores, tal como o desacordo, suscitam a descortesia. Consideramos que a teoria de Leech, embora seja simplificada diante da complexidade de interação no ambiente on-line, fornece elementos para que o fenômeno da descortesia seja desenvolvido por outros teóricos. Nas primeiras análises, verificamos que todo ato de imposição em relação ao interlocutor costuma suscitar a descortesia, mas esta pode ser atenuada ou intensificada com o uso de alguns elementos linguísticos. Observaram-se, predominantemente, relações de conflito entre os interactantes em casos de ordem ou de ironia. Muitos pedidos que ameaçavam a imagem do outro também foram responsáveis pelas manifestações descorteses, mas alguns foram bem-sucedidos ao atenuarem a imposição de forma cortês ou com humor, tal como ocorreu no Inquérito 2, com o uso de um emissor delegado. Tal como previsto, a discussão de temas polêmicos, tais como a polarização política ou a greve na universidade, desencadeou vivas discussões entre os interactantes e, percebe-se que, em um ambiente virtual o ataque ao outro também pode se dar de maneira coletiva, causando a divisão entre os participantes do grupo. Observamos que o acordo ou as reações de curtidas entre os interactantes acontecem conforme a identificação do sujeito em um grupo específico, do qual é partidário.

Salientamos que nossa pesquisa não é exaustiva, sobretudo considerando a complexidade de um discurso on-line, esperamos, no entanto, que este trabalho propicie a outros pesquisadores pensarem a respeito das manifestações descorteses não só em interações face a face, mas também no ambiente da Internet. 


\section{Referências bibliográficas}

ALVARADO, Belén; PADILLA, Xose A. La ironia o como enmascarar um acto supuestamente amenazante. In: Actas del Congreso de EDICE en Valencia, 2007.

AMOSSY, Ruth. Apologia da polêmica. Tradução Rosalice Botelho Wakim Souza Pinto. São Paulo: Contexto, 2017.

ANSCOMBRE, J-C. Marqueurs et hypermarqueurs de dérivation illocutoire: notions et problèmes. In: Cahiers de Linguistique française, Genève, n.3, p.75124, 1981.

ARAÚJO, Júlio; LEFFA, Vilson. (Orgs.) Redes sociais e ensino de línguas: o que temos de aprender?, São Paulo: Parábola, 2016.

ARMENGAUD, Françoise. A pragmática. São Paulo: Parábola, 2006.

AUSTIN, John L. Quando dizer é fazer: palavras e ação. Porto Alegre: Artes Médicas, 1990 [1969].

BAKHTIN, Mikhail M. Marxismo e Filosofia da Linguagem. São Paulo: Hucitec, 2009 [1929-1930].

BENVENISTE, Émile Problemas de linguística geral II. Campinas: Pontes, 1989.

BRAVO, Diana. Estudios de la (des)cortesia en español. Buenos Aires: Dunken, 2005.

BRAZ, Ana Cristina Pereira. A ironia no debate parlamentar português: veículo de (des) cortesia verbal. In: SEARA, Isabel Roboredo (Org.) Cortesia: olhares e (re) invenções. Lisboa: Chiado, p.173-190, 2014.

BRENES PEÑA, Ester. Descortesía verbal y tertúlia televisiva. Bern: Peter Lang, 2011.

BRIZ, Antonio. A atenuação e os atenuadores: estratégias e táticas/ The attenuation and the attenuators: strategies and tactics. Tradução de Luiz Antônio da Silva, Adriana Marcelle de Andrade, Ramiro Carlos Humberto Caggiano Blanco. In: Linha d'Água, n.26 (2), p. 281-314, 2013.

BROWN, Penélope; LEVINSON, Stephen C. Politeness: some universals in language use. Cambridge: Cambridge University Press, 1987.

CARREIRA, Maria Helena A. Cortesia e proxémica: abordagem semânticopragmática. In: SEARA, Isabel Roboredo (Org.) Cortesia: olhares e (re) invenções. Lisboa: Chiado, p.27-46, 2014.

CASTELLS, Manuel. A galáxia da internet: reflexões sobre a internet, os negócios e a sociedade. Rio de Janeiro: Jorge Zahar, 2003.

CHARAUDEAU, Patrick. A conquista da opinião pública: como o discurso manipula as escolhas políticas. Tradução: Ângela M. S. Corrêa. São Paulo: Contexto, 2016

COLÍN RODEA, M. El insulto: Estudio pragmático textual y representación lexicográfica. Barcelona: Universitat Pompeu Fabra. Tese de doutoramento, 2003.

CRYSTAL, David. Language and the Internet. Cambridge: Cambridge University Press, 2001.

CULPEPER, Jonathan. Towards an anatomy of impoliteness. Journal of Pragmatics 25 (3), 349-367.

J. Impoliteness: using language to cause offence. Londres:

Cambridge University Press, 2011.

DAWKINS, Richard. O Gene Egoísta. Belo Horizonte: Itatiaia, 2001. 
DÍAZ PÉREZ, Juan Carlos. Pragmalingüística del disfemismo y la descortesía: los actos de habla hostiles en los medios de comunicación virtual. Tese de doutoramento. Universidad Carlos III de Madrid, 2012.

FLORES, Valdir do Nascimento; TEIXEIRA, Marlene. Introdução à Linguística da Enunciação. São Paulo: Contexto, 2008.

FLORES et alii. Dicionário de Linguística da Enunciação. São Paulo: Contexto, 2009.

FRASER, B. Conversacional mitigation. In: Journal of Pragmatics 4 (4), 341 350, 1980.

FUENTES RODRÍGUEZ, Catalina; BRENES PEÑA, Ester. Comentarios de textos corteses y descorteses. Madrid: Arco/ Libros, 2013.

GALEMBECK, Paulo de Tarso. Polidez e preservação da face na fala de universitários. In: PRETI, Dino. (Org.) Cortesia verbal. São Paulo: Humanitas, p.323-353, 2008.

GOFFMAN, Erving. Interaction ritual: essays in face-to-face behavior. New Brunswick, N.J: Aldine Transaction, 1967.

Vozes, 2005 [1959].

A representação do eu na vida cotidiana. Petrópolis:

GRICE, Herbert P. Lógica e Conversação. In: DASCAL, Marcelo (Org.).

Fundamentos metodológicos da Linguística. Campinas: Ed.Particula, vol IV, p.81-103, 1982 [1975].

GUIMARÃES, Maria Joana. Ironia: uma primeira abordagem. In: Revista da

Faculdade de Letras "Línguas e Literaturas", Porto, XVIII, p. 411-422, 2001.

HAVERKATE, Henk. La cortesía verbal. Madrid: Gredos, 1994.

HILGERT, José Gaston. A cortesia no monitoramento de problemas de compreensão da fala. In: PRETI, Dino. (Org.) Cortesia verbal. São Paulo: Humanitas, p.125-155, 2008.

JAKOBSON, R. Linguística e comunicação. São Paulo: Cultrix, 1974.

KAUL de MARLANGEON, Silvia; ALBA-JUEZ, Laura. A typology of verbal impoliteness behaviour for the English and Spanish cultures. In: Revista Española de Linguistica Aplicada, Janeiro, p.69-92, 2012.

KERBRAT-ORECCHIONI, Catherine. L'implicite. Paris: Armand Colin, 1986.

, Catherine. Os atos de linguagem no discurso: teoria e funcionamento. Tradução de Fernando Alonso de Almeida. Niterói: EdUFF, 2005.

métodos. São Paulo: Parábola, 2006.

Catherine. Análise da conversação: princípios e Catherine. L'énonciation: de la subjectivité dans le langage. Paris: Armand Colin, 2009.

Catherine. Polidez e impolidez nos debates políticos televisivos: o caso dos debates entre dois turnos dos presidentes franceses. In: SEARA, Isabel Roboredo (Org.) Cortesia: olhares e (re) invenções. Lisboa: Chiado p.47-79, 2014.

KIENPOINTNER, M. Varieties of Rudeness. Types and Functions of Impolite Utterances, In: Functions of Language 4 (2), 251-287, 1997.

LEECH, Geoffrey N. Principles of Pragmatics. Londres: Longman, 1983. Rioja, 1997. Geoffrey N. Principios de pragmática. Logroño: Universidad de La , Geoffrey N. The Pragmatics of Politeness. Nova York: Oxford University Press, 2014. 
LEVINSON, Stephen C. Pragmática. São Paulo: Martins Fontes, 2007 [1983]. MAINGUENEAU, Dominique. Discurso e análise do discurso. São Paulo: Parábola, 2015.

MARTINO, Luis Mauro Sá. Teoria das Mídias Digitais: linguagens, ambientes, redes. Petrópolis: Vozes, 2014.

MILTNER, Kate M; HIGHFIELD, Tim. Never gonna GIF you up: analyzing the cultural significance of the animated GIF. In: Social Media+ Society, JulySeptember, 2017, p.1-11

RECUERO, Raquel. Redes sociais na internet. Porto Alegre: Sulina, 2009 Raquel. A conversação em rede: Comunicação mediada pelo computador e Redes Sociais na Internet. Porto Alegre : Sulina, 2014.

, Raquel. Atos de ameaça à face e à conversação em redes sociais na internet. In: PRIMO, Alex. (Org.) Interações em rede. Porto Alegre: Sulina, 2016.

SANTAELLA, Lúcia. Intersubjetividade nas redes digitais: repercussões na educação. In: PRIMO, Alex. (Org.) Interações em rede. Porto Alegre: Sulina, 2016.

SEARLE, John R. Expressão e significado: estudo da teoria dos atos de fala. Tradução: Ana Cecília G.A. de Camargo, Ana Luiza Marcondes Garcia. $2^{\mathrm{a}}$ edição. São Paulo: Martins Fontes, 2002. [1979]

SILVA, Luiz Antônio da. Conversação: modelos de análise. In: SILVA, Luiz Antônio da. (Org.) A língua que falamos. São Paulo: Globo, 2005.

, Luiz Antônio da. Cortesia e formas de tratamento. In: PRETI, Dino (Org.)

Cortesia verbal. São Paulo: Humanitas, 2008.

YUS, Francisco. Not all emoticons are created equal. In: Linguagem em (Dis)curso, Tubarão, SC, v. 14, n.3, p.511-529, set/dez 2014.

, Francisco. Ciberpragmática: el uso del linguaje en Internet. Barcelona: Ariel, 2001. 